\title{
Universiteit
}

Leiden

The Netherlands

\section{Een kolonie van Duitsers. Groepsvorming onder Duitse immigranten in Utrecht in de negentiende eeuw}

Schrover, Marlou

\section{Citation}

Schrover, M. (2002). Een kolonie van Duitsers. Groepsvorming onder Duitse immigranten in Utrecht in de negentiende eeuw. Amsterdam: Aksant. Retrieved from https://hdl.handle.net/1887/19349

Version: $\quad$ Not Applicable (or Unknown)

License: $\quad$ Leiden University Non-exclusive license

Downloaded from: $\quad$ https://hdl.handle.net/1887/19349

Note: To cite this publication please use the final published version (if applicable). 
EEN KOLONIE VAN DUITSERS 



\title{
EEN KOLONIE VAN DUITSERS
}

Groepsvorming onder Duitse immigranten in Utrecht in de negentiende eeuw

\author{
MARLOU SCHROVER
}

aksant Amsterdam, 2002 
IS B N 90-5260-066-X

() 2002 Marlou Schrover/Aksant, Utrecht/Amsterdam

Niets van deze uitgave mag worden vermenigvuldigd en/of openbaar gemaakt door middel van druk, fotokopie of op welke andere wijze dan ook, zonder voorafgaande schriftelijke toestemming van de uitgever.

Ontwerp omslag: wa T Ontwerpers, Utrecht

Lay-out: Trees Vulto D P P en Boekproductie, Schalkwijk

Uitgeverij Aksant, Cruquiusweg 31, 1019 A T Amsterdam, www.aksant.nl 


\section{Inhoudsopgave}

VOORWOORD 9

1 Sauerkraut en Liberty Cabbage | Inleiding 11

De Winkel van Sinkel 11

Groepsvorming, integratie en etniciteit 14

Trouwen, wonen, werken en sociaal verkeer 17

Opzet van het onderzoek 20

Een viervoudige vergelijking $\quad 21$

2 'IS ALMEDE VRUCHTELOOS ALLE NASPORING BEPROEFT' |

Vreemdelingenwetgeving 25

Een geweldige overlast van vreemde indringers en vagebonden? 25

'Smoussen en andere vreemde lopers van buiten inkomende' 26

Vreemdelingen, gelijkgestelden en gevestigden 27

Een 'wandelboekje' en een 'schoolgetuigenis' 29

De praktijk in Utrecht 31

Het domicilie van onderstand 34

Tot besluit 37

3 'ICH Pien Schweitzer!' | Beeldvorming 39

Onopvallende Duitsers 40

'Wenn mir etwas zustösse' 41

Laat je daar opknopen! 46

Arme Duitsers 48

'Bij de tegenwoordig overal heerschende revolutie-koorts' 51

'Bekwame handwerkers uit het buitenland van Roomsch Katholijken

belijdenis' 55

'Die papenboel zou gauw over de grenzen zijn' 56

Spionnen die iedere dag inlichtingen naar Berlijn zenden $\quad 57$

Prusofobie 68

Tot besluit 69

4 'EeNe SOORT POLIS VOOR HULP' | Registratie, omvang,

herkomst en vestiging 71

Domicilie van onderstand en patentwetgeving $\quad 72$

Vreemdelingenregisters 74

Geboorteplaats 75 
Cappeln en Cappelle 76

Utrecht in het midden? 79

Geografische herkomst 82

Binnen en buiten de wallen 90

Stad en voorsteden 93

Little Germany? 95

Tot besluit 100

5 'HeEFT STEEDS ALTIJD MET HARE HANDEL HET LAND RONDGEREISD' |

Migratiepatroon, leeftijdsopbouw en religie 103

Leeftijdsopbouw 105

Religieuze diversiteit 105

Netwerken 110

Lineair, stapsgewijs, seizoensmatig of circulair 112

Tot besluit 120

6 'Wat is een Duitscher voor een vrouw? | Huwelijksgedrag 121

Gemengde huwelijken 122

Duits-Duitse huwelijken 123

'Aufgebot' 127

Eerste huwelijken en huwelijksleeftijd 130

Scheiding en verlating 131

Buitenechtelijke geboorten 132

Tot besluit 133

7 'WaAraan herken Je een Duitser?' | Organisaties 135

Het Deutsches Theater 136

De Handels-Societeit 140

Bayerisch bier 142

Religieuze heterogeniteit 146

De lutherse kerk 146

Inwendige zending 150

Werken in de diaspora 152

Het gilde van de kerkenbouwers 156

De Shelfish-club 160

Muzikanten en muziekmeesters 162

De Liedertafel Aurora 164

Studentenverenigingen 170

Duitse kranten en turnverenigingen 173

Een Duitse school? 175

Deutsche Verein zu Utrecht $\quad 178$

Tot besluit 180 
8 'T LEKKERST ROGGEBROOD WAT JE EET, IS GEKNEED MET MOFFENZWEET' | Beroepsstructuur 183

Het algemene beeld $\quad 188$

Oververtegenwoordiging of niet? 190

Nichevorming 192

Typisch Duits? 194

Ludwig Stern 195

Prostituees 199

Kelners 201

Sigarenmakers 202

Fotografen 203

Ornamentenfabriek Rencker 205

Hoedenfabrikant Brenner 208

De Chemiker 209

De orgelbouwers 210

Bakkers 212

Kleermakers 215

Tot besluit $\quad 216$

9 'WaAr Duitsers haAst een Kolonie vormden' | Westerwalders 219

Een kolonie van in grof aardewerk handelende Duitsers 220

Het Westerwald en migratie vanuit Nassau 221

Steengoed 224

De handel 225

Veranderingen in het vervoer en in de vraag 227

Wetgeving 229

Het migratiepatroon 231

Vreemde ende uytheemsche personen, die dagelycx met hare kannen alhier ter merkt komen 232

Omlopers in Keulse potten 235

De klompenparochie 239

Johann Kalb viıi 243

Pottenbakkers 244

Spelend op een harmonica 245

Doopbriefjes 247

Amsterdam, Delft en andere plaatsen 248

Handelaren uit Sauerland 255

Tot besluit $\quad 257$ 
10 'Een eeuw Van ILlusie en Zinbegoocheling' | Winkeliers en hun personeel 259

Tödden: continuïteit en discontinuïteit 263

De familie Veerkamp; representanten van de oude Töddenhandel 265

Vernieuwende ondernemers 266

Grote werkgevers 268

De Winkel van Sinkel 269

Het kosthuis van Sinkel 272

Maseland: uit de kweekvijver van Sinkel 273

Van der Sandt \& co 274

Peek \& Cloppenburg 276

Hoyng, Schlüter en Bohlen 278

De kweekvijvers $\quad 282$

Inlands fabrikaat 283

Tot besluit $\quad 285$

11 'Eene Geldersche Keukemeid' | Vijlenkappers, stukadoors, dienstbodes, spoorbeambten en studenten 287

Vijlenkappers 288

Stukadoors 293

Dienstbodes 298

Beambten bij het spoor 302

Studenten en hoogleraren 304

Tot besluit 309

12 'Door HongaArsche zon verbruind' | Een multiculturele samenleving 311

Jutphaas, Zuilen, Maarssen, De Bilt en Zeist 312

Strohoedenmakers en andere Belgische immigranten 314

Lestrade en Yrondy, Franse paraplumakers uit de Auvergne 316

Italiaanse schoorsteenvegers en pleistergieters 320

Tiroler handelaren in gemsleren handschoenen 323

Kapenaars en andere vreemde studenten $\quad 325$

West- en Oost-Indië 325

Tot besluit 327

13 INTERACTIEVE GROEPSFORMATIE | Samenvatting en conclusie 329

Noten 337

LiteratUURLIJST 391

INDEX 409 


\section{Voorwoord}

Terwijl ik werkte aan dit boek, werd twee huizen verderop een pand verbouwd. Regelmatig parkeerde voor de deur een busje van stukadoorsbedrijf Lüschen. Een telefoontje naar het nummer op de zijkant van het busje, leerde mij dat deze stukadoor een rechtstreekse nakomeling was van de stukadoor Christiaan Lüschen, die met zijn broers en neven in het midden van de negentiende eeuw uit de Duitse plaats Littel in Oldenburg naar Utrecht kwam. Het was een ingrijpende verbouwing, die weken duurde en waarbij een groot aantal mensen betrokken was. Er werden in de vroege ochtenduren door de aannemer niet alleen Nederlandse werklieden aangevoerd, maar er kwam ook regelmatig een busje met werklui uit Duitsland. ${ }^{1}$ Om een uur of elf werd er luid naar de mensen in en rond het huis geroepen : 'koffie, kaffee'. Alles was anders, maar toch ook een beetje hetzelfde als anderhalve eeuw eerder.

Dit boek zou er niet zijn gekomen zonder de hulp van veel mensen. Ten eerste zijn dat de genealogen die ik in archieven tegenkwam, waarmee ikzelf contact zocht of die contact met mij opnamen. De hulp van al deze genealogen werd door mij zeer gewaardeerd. Een aantal mensen wil ik met name noemen. Jules Huf, Rene Beiler, G. Dorenbosch, Joke Sickmann, Wilfried Pott, Ben Rigter, C.J. Erdman, K. Padberg Evenboer, J. M. van Orden-Oldenhof, A.M van Loo-Ditmar, Theo Lüschen en A.H. Klokke stuurden of gaven mij belangrijke informatie in de vorm van kwartierstaten, genealogieën en familiedocumenten. Jules Huf hielp mij bovendien aan zeer mooi fotomateriaal. De medewerkers van het Utrechts Archief waren behulpzaam bij mijn onderzoek. Voor hun geduld wil ik met name Piet van Mameren en Mustafa Ahdoudi bedanken. Jos Kaldenbach hielp bij de transcriptie van enkele gotische documenten. Franz Baaden, historicus van de Duitse plaats Ransbach-Baumbach, gaf mij inzage in zijn zeer omvangrijke archief. Adri van der Meulen en Paul Smeele hielpen mij met hun uitgebreide en gedegen kennis omtrent keramiek. Steven Wachlin deed hetzelfde met zijn kennis van de negentiende-eeuwse fotografie. Wendy Holmes, Harald Koninckx en Karijn Delen voerden een deel van de data in. Kees Mandemakers en de vrijwilligers van de H SN verzamelden de data voor de zogenaamde H sN-controlegroep. Gerard de Punder, Annelies Krekel, Peter Zwaal, Gert-Jan Janssen, Hans Sterk, Hein Klemann, Ronald Rommes, Richard Loontjens en Peter Vuijst stonden materiaal, dat ze in het kader van hun eigen eerdere onderzoek hadden verzameld, aan mij af en bevorderden door deze collegialiteit mijn werk. Ronald Rommes las bovendien een eerdere versie van het manuscript en gaf mij talloze tips en suggesties. Corrie van Eijl deed suggesties ten aanzien van het wetgevende hoofdstuk. Jelle van Lottum las het hele manuscript en gaf allerlei 
commentaar. Met Rinus Penninx schreef ik, terwijl ik aan dit boek werkte, een essay over groepsvorming onder immigranten. Mijn gedachtewisseling met hem in dat kader, heeft me geholpen bij het schrijven van mijn hoofdstuk over eigen organisaties. Iets vergelijkbaars gold voor Floris Vermeulen, met wie ik voor de European Social Science History Conference een sessie organiseerde over dit onderwerp. Trees Vulto zorgde als vormgeefster dat dit een mooi boek werd. Het vertrouwen dat Marti Huetink als uitgever in dit project had stimuleerde mij in de laatste maanden. Mijn vader Frans Schrover, die bijna vijftig jaar bij het kadaster werkte, hielp mij bij het ingewikkelde kadastrale onderzoek. Aja Gil las de laatste versie van het manuscript en verbeterde een groot aantal fouten. Jan Lucassen en Maarten Prak waren bereid mijn aanvraag bij Nwo te ondersteunen en maakten zo dit onderzoek mede mogelijk. Hun fundamentele commentaar en dat van Gertjan de Groot maakten van dit boek een beter boek. Het onderzoek werd financieel mogelijk gemaakt door Nwo. 


\section{Sauerkraut en Liberty Cabbage}

\section{Inleiding}

In De Volkskrant van 10 september 2001 werd de chaotisch verlopende oprichtingsvergadering beschreven van de Arabische Democratische Partij. ${ }^{1}$ Tien mensen kwamen er naar de bijeenkomst in Amsterdam. Een van hen maakte bezwaar tegen de naam van de nieuwe organisatie; hij was geen Arabier maar een Berber. De Marokkaanse voorzitter, Mustafa Aboustib, reageerde verontwaardigd: 'Hoe kunt u dat bewijzen [...] Al eeuwen wonen Arabische vrouwen tussen de Berbers. Hoe kunt u mij vertellen dat u geen Arabisch bloed hebt?' Niemand vroeg hem waarom hij naar de oprichtingsvergadering van de Arabische Democratische Partij was gekomen. De Egyptenaar Ibrahim Farouk, initiatiefnemer van de bijeenkomst, greep in. 'Jullie hebben een Marokkaans probleem naar Nederland gebracht. Prima, maar dit conflict moeten jullie niet hier uitvechten.' Door de keuze van zijn woorden maakte Farouk duidelijk dat het in ieder geval niet zijn probleem was, maar dat van 'jullie'. De Marokkaan die zich als Berber identificeerde verliet scheldend de vergadering. Even later kreeg voorzitter Aboustib van een Tunesiër te horen dat hij in het Nederlands moest spreken en niet in het Arabisch. Aboustib werd woedend. 'Wij zijn toch een Arabische partij?' 'Ja, maar je bent in Nederland.' Taal, geloof en geografische herkomst werden binnen een uur naar voren geschoven als basis voor de nieuwe partij en binnen een uur was het aantal aanwezigen gehalveerd. vvD-kamerlid Cherribi noemde de oprichtingsvergadering een zielig initiatief, dat niet serieus genomen moest worden. Niemand, behalve wat radicalen, zat hier op te wachten. De gewone man wilde inburgeren, volgens Cherribi. Wie die gewone man was, werd niet helemaal duidelijk. Wel duidelijk was dat twee dagen na de vergadering - op 11 september - niet alle mensen in Nederland meer zeker wisten of iedereen wel wilde inburgeren.

Groepsvorming langs etnische lijnen is een actueel onderwerp van discussie en is daarom tot inzet van dit boek gemaakt. Onderwerp zijn de Duitse immigranten die tot de Tweede Wereldoorlog eeuwenlang in Nederland de grootste groep vreemdelingen vormden.

\section{De Winkel van Sinkel}

In 1839 opende de Duitse immigrant Anton Sinkel zijn winkel aan de Oudegracht in Utrecht. De Utrechtsche Courant wijdde er een artikel aan en dat was uitzonderlijk. Gewoonlijk besteedde de krant weinig aandacht aan dit soort plaatselijk nieuws in de ver- 
onderstelling dat de stadsbewoners er ook zonder berichtgeving wel van op de hoogte zouden zijn. Omdat in Amsterdamse periodieken veel ophef over de nieuwe winkel was gemaakt, meende de Utrechtse krant niet te kunnen achterblijven.

Wij erkennen dat het een Paleis-Winkel is, gelijk die dagbladen het noemen, en dat er welligt geenen wedergade van zoodanig grooten winkel te vinden is. ${ }^{2}$

De krant vervolgde met een gedetailleerde beschrijving van de winkel. Sinkels gebouw kreeg navolgers, zij het niet allemaal even luxueus. Met verlichte etalages veranderden deze winkels het aanzien van de negentiende-eeuwse stad. Het 'winkelen' als vrijetijdsbesteding deed zijn intrede. ${ }^{3}$ In de tweede helft van de negentiende eeuw openden aan dezelfde Oudegracht en in de omliggende straten ook andere Duitse immigranten hun grote zaken. Sommige namen klinken nu nog bekend: Peek \& Cloppenburg, Kreymborg, Hunkemöller, c\& A en V\&D. Daarnaast waren er talloze andere, vergelijkbare ondernemingen die in de negentiende eeuw door Duitse immigranten werden opgezet, maar die niet overleefden tot in de twintigste eeuw. Dat lot deelden ze met de winkel van Sinkel, maar als eerste winkel waar alles te koop was, heeft deze zaak een plaats in het collectieve geheugen behouden

Van de buiten Nederland geboren vreemdelingen was in de tweede helft van de negentiende eeuw 60 procent Duits. Zij bleven de grootste groep vreemdelingen tot de komst van de gastarbeiders in de twintigste eeuw. Zij hebben hun sporen nagelaten in de Nederlandse samenleving. Duitse woorden als turnen en kellner werden in die tijd overgenomen in de Nederlandse taal. De boterhamworst en het lichte bovengistende bier zoals we die nu kennen, werden in de negentiende eeuw door Duitse immigranten in Nederland geïntroduceerd. De gewoonte om tegen kersttijd een kerstboom in de huiskamer te plaatsen werd door burgergezinnen van Duitse winkeliers overgenomen. De winkeliers plaatsten de kerstboom in hun etalage als lokkertje voor het winkelende publiek. Uiteindelijk werd de boom een vast onderdeel van de Nederlandse huiskamer in kersttijd. ${ }^{4}$

Duitsers waren getalsmatig de belangrijkste groep immigranten in Nederland, maar juist over het lot van deze grootste groep is relatief weinig bekend. ${ }^{5}$ Dit geldt vooral voor migranten in de stedelijke omgeving waarheen het merendeel van hen zijn schreden richtte. ${ }^{6}$ Opmerkelijk is dat eenzelfde verwaarlozing geldt voor Duitse immigranten in andere landen waar ze evenals in Nederland een belangrijk deel van de immigrantenpopulatie uitmaakten. ${ }^{7}$

Deze geringe belangstelling vloeit in de eerste plaats voort uit de veronderstelling dat Duitse immigranten relatief gemakkelijk in de ontvangende samenleving zijn opgegaan. ${ }^{8}$ De historicus Rogier schreef in 1962 over Duitse immigranten in eerdere eeuwen:

Overal in ons land treffen ons het verbijsterende gemak, waarmee zij naar voren traden als representanten van het Nederlandse volk, en de argeloosheid, waarmee de Nederlandse goe-gemeente hen als zodanig aanvaard heeft. ${ }^{9}$ 
Rogiers beschrijving echoot eerdere omschrijvingen uit andere landen. In 1928 schreef de Duits-Amerikaanse onderzoeker Mencken: 'The children of the German-American are totally American. [...] The melting pot has devoured them, as no other group'. ${ }^{10}$

Vanuit een historisch perspectief wordt de zichtbaarheid van de Duitse immigranten beïnvloed door gebeurtenissen in latere tijdvakken. Een tweede verklaring voor de geringe belangstelling voor Duitse immigratie is daarom het feit dat hun nakomelingen in de tijd dat immigrantenstudies zich als discipline ontwikkelde - en dat was in Europa na de Tweede Wereldoorlog - niet de behoefte voelden om zich als Duitsers of als nakomelingen daarvan te profileren. De oorlog was daar debet aan. In de Verenigde Staten had de Eerste Wereldoorlog, die daar gepaard ging met sterke antiDuitse sentimenten, eenzelfde effect gehad. In Amerikaanse studies wordt de oorzaak voor de verwaarlozing van de Duitse immigratie aangeduid als 'the w w I effect'. "Zo de Duitse Amerikanen na 1914 nog Sauerkraut aten - in de Eerste Wereldoorlog omgedoopt tot Liberty Cabbage - deden ze dat achter gesloten gordijnen. ${ }^{12}$ Van een etnische profilering als Duitsers kon weinig voordeel worden verwacht. De terughoudendheid over een Duitse afkomst speelt ook Nederlandse genealogen parten. 'Uit mijn jeugd weet ik', schreef een van hen mij, 'dat in de dertiger jaren mijn grootvader met mijn vader Duits sprak, daar hield het mee op.' De gebeurtenissen in Duitsland voor en tijdens de Tweede Wereldoorlog maakten de Duitse afkomst onbespreekbaar. 'Over de ouders en grootouders van mijn vaders' zijde werd nooit meer gesproken. Duitsland was taboe'. ${ }^{13}$

De heterogeniteit van de Duitse immigrantenpopulatie verklaart, op de derde plaats, eveneens de geringe belangstelling. Studies naar Duitse gemeenschappen elders hebben laten zien dat deze gekenmerkt werden door een grote interne verscheidenheid. ${ }^{14}$ In zekere zin bestonden de Duitse immigranten niet als groep. Vooral de religieuze verdeeldheid is aangemerkt als een belangrijke verklaring voor het gebrek aan belangstelling onder historici. ${ }^{15}$ In migratie-onderzoek bestaat een opvallende voorkeur voor (religieus) homogene gemeenschappen. De geringe homogeniteit van de Duitse gemeenschappen maakt beschrijving en typering een moeilijke en daarmee weinig aantrekkelijke taak.

Als laatste biedt de aard van de migratie van de Duitse nieuwkomers een verklaring. De Duitse immigranten kwamen merendeels als economische migranten, druppelsgewijs over een lange periode en niet zoals bijvoorbeeld de Hugenoten als grote groep in een kort tijdvak. In de migratieliteratuur is de meeste interesse tot dusver uitgegaan naar vluchtelingen. ${ }^{16}$ Hun komst, in een korte periode en meestal in familieverband, wekte ook bij tijdgenoten belangstelling en leidde daardoor tot bemoeienis en archiefvorming. Voor de Duitse immigranten gold dat niet.

De geringe belangstelling kan wel worden verklaard, maar daarmee wordt ze nog niet gerechtvaardigd. Met dit boek over de geschiedenis van Duitse immigranten in Nederland streef ik meer na dan het opvullen van een lacune. Ik probeer ook een verdieping aan te brengen in het inzicht in het proces van groepsvorming. Uit historisch onderzoek is gebleken dat alle migranten periodes hebben gekend waarin ze als groep 
herkenbaar waren in de hen omringende samenleving. ${ }^{17} \mathrm{Na}$ twee of drie generaties was dat merendeels niet langer het geval. ${ }^{18}$ Immigranten vormden evenwel niet allemaal even lang een herkenbare groep. Sommige ethnic pockets bleven langer bestaan dan andere. ${ }^{19}$ Wat de continuïteit van de groepsvorming bepaalde is echter nog geenszins duidelijk. Voor zover groepsvorming onder immigranten vanuit een historisch perspectief is onderzocht, is de aandacht vooral uitgegaan naar vluchtelingen - die groepsgewijs en in een beperkt tijdvak kwamen - of naar joden en zigeuners, die geconfronteerd werden met een langdurige en systematische uitsluiting. Mate en duur van groepsvorming onder migranten die druppelsgewijs kwamen over een langere periode - zoals de Duitsers - is nog nauwelijks onderzocht.

\section{Groepsvorming, integratie en etniciteit}

Soessy wordt de hedendaagse dichter Abdelaziz Ajaarouj door zijn vrienden genoemd omdat hij uit Souss komt in het zuiden van Marokko. ${ }^{20}$ Hij is Moslim, Marokkaan, Nederlander en Utrechtenaar, maar hij is ook een Soessy. 'Duitse immigranten' is net zozeer een containerbegrip als 'Marokkaanse immigranten'.

De termen 'groep' en 'groepsvorming' zijn in het bovenstaande gebruikt in een wisselende en vage betekenis, zoals dat in het dagelijks taalgebruik gangbaar is. Om tot een duidelijke omschrijving van het onderwerp van dit boek te komen, is precisering, verfijning en problematisering van deze begrippen noodzakelijk. Centraal in dit onderzoek staat groepsvorming onder immigranten langs zogenaamde etnische scheidslijnen. De tegenhanger van groepsvorming is integratie: immigranten en hun nakomelingen zijn geïntegreerd als groepsvorming zich niet (meer) voordoet. Groepsvorming en integratie zijn onderdelen van het vestigingsproces van immigranten. Voor groepsvorming wordt in de hedendaagse discussie ook het begrip minderheidsvorming gebruikt. Ik wijk daar opzettelijk van af, omdat minderheidsvorming een concentratie op de laagste sporten van de maatschappelijke ladder impliceert. ${ }^{21}$

Vrij algemeen wordt geaccepteerd dat 'groepen' en 'etniciteit' sociale constructies zijn, maar dat het gebruik van deze constructies bij het vormgeven van sociale verhoudingen reële, bestudeerbare consequenties heeft. ${ }^{22}$ Bij de definiëring van groepen zijn drie partijen betrokken: mensen kunnen zelf vinden dat ze tot een bepaalde groep behoren, anderen, die hun tijdgenoten zijn, kunnen dat vinden, of wetenschappers kunnen in hun reconstructie achteraf tot de conclusie komen dat er van groepsvorming sprake was. Zelfdefinitie en definitie door anderen hoeven daarbij niet samen te vallen.

Etniciteit is lange tijd opgevat als een cultureel fenomeen. Etnische groepen hadden, volgens de zogenaamde primordialisten, hun eigen cultuur die hen zou onderscheiden van andere etnische groepen. Omdat etniciteit als een gegeven werd gezien, behoefde het weinig verklaring. De antropoloog Fredrik Barth introduceerde in 1969 een nieuw perspectief en legde de nadruk op de sociale organisatie van verschillen en overeenkomsten. ${ }^{23}$ Etniciteit vatte hij op als sociale identiteit, waarbij processen van 
(zelf)toeschrijving voorop stonden. De context bepaalde in hoge mate etnische identiteit. Etniciteit als constructie vereiste, in tegenstelling tot etniciteit als gegeven, wel een verklaring. Dit inzicht vond weerklank bij antropologen en sociologen, maar vrijwel niet bij historici. ${ }^{24}$

Ik zie groepsvorming langs etnische lijnen als de uitkomst van een dynamisch proces, waarbij verschillen voortdurend worden gevormd en hervormd. ${ }^{25}$ Etniciteit draait om verschillen die verschil maken. ${ }^{26}$ Om te weten wie van wie verschilt en op welke manier, moet je weten hoe tijdgenoten zichzelf en anderen definiëren. Wie zijn 'wij' en wie zijn 'zij'? ${ }^{27}$ Het antwoord op die vragen is afhankelijk van wie ze stelt en wie ze beantwoordt. Wie houdt de mythe van een collectieve band in stand en met welk doel? Machtsverhoudingen spelen daarbij een rol. Hoe groter de concurrentie om schaarse goederen, zoals economische posities, politieke macht of een huwelijkspartner, des te groter het belang van afbakening. ${ }^{28}$

Overeenstemming omtrent de sociale constructie van etniciteit betekent niet dat het begrip etniciteit door iedereen hetzelfde wordt ingevuld. ${ }^{29}$ Een typerend en tegelijkertijd vaag voorbeeld van invulling is: etniciteit is een vorm van sociale binding, die voortkomt uit een speciale band tussen mensen met een gedeelde oorsprong en een afkeer van mensen met een andere oorsprong. ${ }^{30}$ Slechts weinig auteurs geven een meer concrete invulling, maar ze zijn het er merendeels wel over eens dat etniciteit iets met groepsrelaties te maken heeft. ${ }^{31}$ Duidelijker gezegd: etniciteit is gerelateerd aan groepsformatie in verband met migratie en presenteert zich in de vorm van collectieve en doelbewuste acties. ${ }^{32}$ Niet alle groepsvorming is etnische groepsvorming. Daarvan is slechts sprake, wanneer betekenis wordt gehecht aan een (vermeende) gemeenschappelijke geschiedenis, afstamming of oorsprong en, daarvan afgeleid, aan fysiek voorkomen, taal of religie. ${ }^{33}$ Groepsvorming houdt ook verband met de aard en omvang van de migratie. Voor vluchtelingen en anderen, die langere tijd de hoop koesterden dat zij naar hun land zouden kunnen terugkeren, was de band met de eigen groep belangrijker dan die met de rest van de ontvangende samenleving. ${ }^{34}$ Het makte bovendien verschil of de migratie bestond uit families of uit individuen. Migratie van families lijkt het proces van groepsvorming te hebben versterkt. ${ }^{35}$

Groepsvorming langs etnische lijnen raakt aan de definitie van 'volk' of 'natie' in een verouderde betekenis. Die twee begrippen kennen, evenals het begrip groep, geen heldere invulling. De begrippen refereren aan het abstracte en het gevoelsmatige. Het is taalgebruik dat realiteiten schept door ze 'op te roepen'. ${ }^{36}$ Gemeenschappelijke geschiedenis, afstamming of oorsprong, fysiek voorkomen, taal of religie, zijn ieder voor zich geen voorwaarden voor groepsvorming, maar er mogen niet teveel elementen ontbreken. ${ }^{37}$ Gemeenschappelijke kenmerken hoeven daarbij niet reëel te zijn. Groepen kunnen hun samenhang ontlenen aan mythen omtrent gedeelde afstamming. ${ }^{38}$ Geloof in gemeenschappelijkheid - binnen de groep zelf of bij anderen - is belangrijker dan werkelijke gemeenschappelijkheid. Een vermeende of werkelijke gemeenschappelijkheid kan altijd wel ergens in worden gevonden. Niet elke gemeenschappelijkheid is echter even aannemelijk. De maakbaarheid van etniciteit is beperkt tot wat op een gegeven 
moment als aannemelijk wordt beschouwd. ${ }^{39}$ Etniciteit is daarenboven situationeel; mensen passen hun etniciteit aan, aan de situatie waarin ze verkeren. Bij de keuze van een huwelijkspartner kan etniciteit een andere betekenis hebben dan bij het zoeken naar werk. ${ }^{40}$

De etnische identiteit krijgt pas invulling en betekenis, wanneer groepen in contact komen met elkaar en zich als verschillend gaan definiëren. ${ }^{41}$ Als gevolg van het contact wordt de etnische identiteit gecreëerd en vormgegeven. In concrete termen betekent dit, dat Duitse immigranten in verschillende landen niet dezelfde 'etniciteit' hoeven te hebben. ${ }^{42}$ Etniciteit bestaat niet los van contact; slechts door contact tussen groepen wordt etniciteit ingevuld en vormgegeven. Op het praktische niveau betekent dit, dat immigranten door de tijd heen of per plaats niet noodzakelijkerwijs steeds dezelfde identiteit hadden.

In het bovenstaande is gesproken over Duitsers en Duitsland in navolging van de internationale historiografie waarin ook met deze verzamelbegrippen wordt gewerkt. ${ }^{43}$ In het grootste deel van de negentiende eeuw vormde de herkomststreek van de immigranten echter geen staatkundige eenheid, terwijl de immigranten zichzelf lang niet altijd als Duitsers zagen, maar veeleer als bijvoorbeeld Oldenburgers, Westfalers of Westerwalders. Eerder onderzoek in Londen, New York en Kopenhagen, heeft aangetoond dat Duitse immigranten niet één groep vormden. ${ }^{44}$ De Duitse gemeenschap was, zoals alle nationale gemeenschappen, niet alleen verdeeld naar sekse, klasse, religie en beroep, maar ook nog eens naar regionale oorsprong. Dat betekent dat er waarschijnlijk geen sprake was groepsvorming van Duitsers als collectiviteit, maar van groepsvorming binnen de Duitse immigrantenpopulatie.

Integratie wordt, net als etniciteit, niet altijd even helder gedefinieerd. ${ }^{45}$ In plaats van integratie worden ook andere termen gebruikt, zoals assimilatie, acculturatie en interculturatie, die echter niet precies hetzelfde betekenen. ${ }^{46}$ De termen zijn geen aanduidingen voor eenzelfde proces, maar omschrijven stadia binnen dat proces of verschillende processen en verschillende (gewenste) uitkomsten. De discussie is, vooral in het Engelse taalgebied, nogal politiek geladen en overgoten met een saus van politieke correctheid.

In de discussie over integratie staan twee tradities tegenover elkaar, die gerelateerd zijn aan de migratiegeschiedenis van de landen waarin ze overheersen. De binnen-Europese migratiegeschiedenis wijkt af van de migratie naar de Verenigde Staten als immigratieland bij uitstek. ${ }^{47}$ In Europa wordt ervan uitgegaan dat groepsvorming van migranten weliswaar als fenomeen bestaat, maar dat het slechts tijdelijk is en dat het uiteindelijke resultaat integratie is. De onderzoekstraditie die meer recent in Amerika aanhang heeft gevonden, stoelt op de aanname dat aan etniciteit gerelateerde groepsvorming door migratie wordt versterkt. Groepsvorming en etniciteit worden in deze optiek gezien als fenomenen met een duurzaam karakter. Het tegen elkaar afzetten van het Europese 'onproblematische assimilatieperspectief' en het Amerikaanse 'eeuwige etniciteitsperspectief, is een wat simplistische voorstelling van zaken, maar vat de discussie wel redelijk samen. ${ }^{48}$ 


\section{Trouwen, wonen, werken en sociaal verkeer}

In 1966 was de Marokkaan Camel El Makrini op bezoek bij familie in Beusichem, een plaats aan de Lek. Aan de andere kant van de rivier zag hij hoge fabrieksschoorstenen. ${ }^{49}$ Rokende schoorstenen betekenen werk, besloot El Makrini. Hij nam de pont en liep naar Wijk bij Duurstede, naar de steenfabriek onder de schoorsteen. Van beroep was hij geen steenbakker, maar de fabriek kampte met een personeelstekort en haalde El Makrini graag binnen als nieuwe arbeidskracht. In 2000 woonden er 157 Marokkanen in Wijk bij Duurstede. Ze kwamen vrijwel allemaal uit het geboortedorp van Camel El Makrini of uit de directe omgeving en waren gedeeltelijk aan elkaar verwant. Alle mannen van deze groep hebben in de steenfabriek gewerkt. Samen vormden ze een hechte gemeenschap.

Etniciteit laat zich niet in objectieve termen meten omdat het gaat om een subjectieve beleving. ${ }^{50}$ Studies over etniciteit stellen die subjectieve beleving centraal: mensen zijn Duits of Marokkaans omdat ze zichzelf zo zien of door anderen zo worden gezien. ${ }^{51}$ In een (historisch) onderzoek is deze subjectieve benadering moeilijk te operationaliseren. Gelukkig bestaat er onder onderzoekers wel consensus, wanneer het gaat om de elementen waarin een collectieve identiteit een uitdrukking vindt: endogamie, geconcentreerde bewoning, concentratie in beroepen en concentraties in verenigingen (waaronder kerkelijke activiteiten). ${ }^{52}$

Taal is gepresenteerd als uitvloeisel van een gedeelde afkomst. In het vasthouden aan de eigen taal vindt etniciteit haar uitdrukking. Het vasthouden aan de eigen taal leidt tot het oprichten van eigen kranten, scholen en theaters en godsdienstoefening in de eigen taal.

Dat religie een belangrijke rol speelt bij groepsvorming wordt door onderzoekers niet betwist. Toch is de rol van religie niet zonder problemen. Studies die een grote rol toeschrijven aan religie als samenbindende factor, hebben vaak gemeenschappen als onderwerp die religieus homogeen zijn, maar waarbij de leden van de gemeenschap bovendien hun geografische herkomst en hun sociale klasse delen. ${ }^{53}$ Op die manier is de samenbindende functie van religie moeilijk te toetsen.

In de literatuur over etniciteit is een verschuiving waar te nemen in het primaat van de factoren waarin etniciteit een uitdrukking vindt. Aanvankelijk werd in onderzoek de nadruk gelegd op de koppeling tussen etniciteit en werk. Later verschoof de nadruk naar sociaal verkeer. Welk verband belangrijk is, is niet voor alle immigranten gelijk. Voor de eerste generatie immigranten is etniciteit vooral verbonden aan werk of klasse; voor de latere generaties wordt het meer een element van de vrijetijdsbesteding of sociaal verkeer. ${ }^{54}$ Wat etniciteit bepaalt, kan van de ene op de andere generatie immigranten verschillen. Voor dit boek, waarin het gaat om intergenerationele etniciteit, betekent dit, dat we mogen verwachten dat de ene generatie etniciteit anders invult dan de volgende.

Groepsvorming langs etnische lijnen wordt in dit boek onderzocht door te kijken naar connubium (trouwen) en convivium (werken, wonen, sociaal verkeer of vrijetijds- 
besteding). ${ }^{55}$ Het gaat om de vraag of immigranten en hun nakomelingen op deze punten opvallend afwijken van anderen in hun nieuwe omgeving. Een opvallende afwijking wordt opgevat als indicatie voor een collectieve identiteit en daarmee van groepsvorming. Waar het in alle gevallen om gaat, is de mate van sociaal contact. Huwelijken met mensen van de eigen groep, wonen en werken binnen een beperkte groep en sociaal verkeer binnen die groep, duiden allemaal op beperkte sociale interactie. Een rangorde in de factoren is niet te geven. Daarom spreek ik over groepsvorming wanneer er op alle vier punten opvallende concentraties zijn.

Het ligt in de lijn der verwachting, dat in deze concentraties verandering optreedt naarmate men langer in het nieuwe land gevestigd is. Met andere woorden, de eerste generatie migranten zal in het algemeen bijvoorbeeld meer onderling huwen dan de tweede. We raken hier aan een van de kernvragen van de migratiegeschiedenis: de mate waarin na verloop van tijd, en over meerdere generaties, sprake is van integratie.

Aan huwelijksgedrag wordt gewoonlijk veel gewicht gehecht wanneer het gaat om groepsvorming. Exogamie, het trouwen buiten de 'eigen' groep, wordt beschouwd als een teken van contact en integratie tussen groepen; endogamie, het trouwen binnen de ‘eigen' kring, als een indicatie dat immigranten vooral contacten hebben met mensen met eenzelfde achtergrond. ${ }^{56}$ Gemengde huwelijken spelen een dubbelrol in het integratieproces: ze zijn zowel het resultaat van als een stimulans voor integratie. ${ }^{77} \mathrm{Ge}-$ mengde huwelijken krijgen een belangrijke rol toegeschreven, omdat partnerkeuze wordt gezien als een zogenaamde kernkeuze. De gedachte is dat, wanneer een immigrant bij het huwelijksgedrag van houding verandert, de integratie een belangrijke laatste fase is ingegaan..$^{58}$ De partnerkeuze kan zo een indicatie zijn van identiteitsidealen en in- en uitsluitingsprocessen. ${ }^{59}$ Gemengde huwelijken worden gezien als de voornaamste indicator voor de mate waarin immigranten geïntegreerd zijn in de ontvangende samenleving. ${ }^{60}$ Het verband tussen gemengd huwen en integratie wordt soms nog extremer gesteld: integratie en gemengd huwen zijn aan elkaar gelijk. ${ }^{61}$ Gemengde huwelijken zijn dan een noodzakelijke voorwaarde voor integratie. Integratie lijkt in deze visie niet te bestaan buiten het gemengd huwen, terwijl gemengd gehuwden per definitie als geïntegreerd worden beschouwd.

Bij de tweede maatstaf - werken - gaat het om de mate van concentratie van immigranten in beroepen. Concentratie in een beperkt aantal beroepen, gewoonlijk aangeduid als economische nichevorming, is een verschijnsel dat zich frequent voordoet onder immigranten. ${ }^{62}$ Iedereen die zich bezighoudt met migratiestudies komt dit verschijnsel tegen. ${ }^{63}$ De Amerikaanse socioloog Richard Waldinger ziet nichevorming daarom als een logisch uitvloeisel van migratie. ${ }^{64}$ Nieuwkomers hebben slechts een beperkt aantal contacten en vooral met mensen van de eigen groep, en daarom lopen de uitwisseling van informatie over arbeidsmogelijkheden en het werven van personeel via deze netwerken, met nichevorming als gevolg, zo luidt Waldingers these. Zodra de contacten zich verbreden, verwatert de niche. De mate van nichevorming is daarom een geschikte maatstaf voor integratie. De vraag hierbij blijft, waarom niet alle migranten niches vormden en waarom sommige niches langer bleven voortbestaan dan an- 
dere. Bij nichevorming is sprake van een proces dat kan worden aangeduid als interactieve groepsformatie. ${ }^{65}$ Concentratie in beroepen versterkt de sociale banden en daarmee het proces van groepsvorming, terwijl omgekeerd een hechte groep meer mogelijkheden heeft om zich niches toe te eigenen en het bestaan ervan te continueren. Nichevorming is een indicatie voor gebrekkige integratie; succesvolle nichevorming continueert de groepsvorming. In feite wordt aan nichevorming, zij het niet expliciet, eenzelfde dubbelrol toegeschreven als aan huwelijksgedrag. De concentratie van immigranten in bepaalde beroepen wordt niet alleen opgevat als een maatstaf voor groepsvorming, maar ook als instrument dat groepsvorming versterkt. Concentratie in een beroep maakt de lonendheid van het beroep tot een collectief belang en versterkt zo de onderlinge band.

Bij wonen, als derde maatstaf voor integratie, kan worden vastgesteld dat ruimtelijke en sociale segregatie aan elkaar gerelateerde processen zijn. Concentraties van immigranten in bepaalde wijken van een stad, zijn een indicatie voor groepsvorming en gebrekkige integratie. ${ }^{66}$ Bij wonen geldt, net als bij de twee vorige indicatoren, dat er sprake is van een wisselwerking. Een grote geografische afstand kan leiden tot gering contact en daarmee een grote sociale afstand, terwijl de grote sociale afstand aan het ontstaan van de geografische afstand ten grondslag ligt. Met andere woorden: geografisch isolement is tegelijk oorzaak en gevolg van sociaal isolement.

De vierde en laatste maatstaf is de mate waarin immigranten zich concentreren in eigen organisaties (inclusief religieuze). Of immigranten organisaties oprichten en welke organisaties dat zijn, wordt zowel bepaald door de kenmerken van de migrantengemeenschap - leeftijd, sekseratio, beroepsstructuur - als door de toegankelijkheid voor immigranten van reeds bestaande algemene organisaties. Concentratie in eigen organisaties kan worden gezien als een indicatie van geringe integratie. Tegelijkertijd geldt dat organisaties van migranten, om succesvol te kunnen zijn, moeten functioneren binnen de cultuur van de ontvangende samenleving, hetgeen overname van codes van de Nederlandse cultuur impliceert. Emancipatie in eigen kring versterkt bovendien het zelfvertrouwen en maakt ook zo integratie gemakkelijker.

Terwijl er consensus bestaat omtrent de maatstaven waaraan integratie kan worden afgemeten - trouwen, werken, wonen en sociaal verkeer - laat het bestaande onderzoek ons in de steek wanneer het gaat om het in absolute termen meten van groepsvorming. Wanneer alle immigranten in hetzelfde beroep werken, als ze allemaal in dezelfde buurt bijeen wonen, als ze allemaal trouwen met mensen uit dezelfde groep en als ze allemaal samenklonteren in beperkt aantal verenigingen, dan is groepsvorming overduidelijk. Zo simpel is de werkelijkheid echter niet. De vraag is wanneer er nog wel sprake is van groepsvorming en wanneer niet meer. Het antwoord is afhankelijk van de afbakening van de groep. Als een groep gedefinieerd wordt als iets dat van de context afhankelijk is en het resultaat van voortdurende constructie en onderhandeling - zoals in dit boek - dan staat het trekken van absolute grenzen daar haaks op. Er zijn dan ook, in de lijn van deze gedachte, vrijwel geen auteurs die zich afvragen in welk percentage integratie een uitdrukking vindt. Slechts een enkeling laat zich hierover uit, zoals de Ameri- 
kaanse onderzoekster Ruby Jo Reeves Kennedy. ${ }^{67} \mathrm{Zij}$ stelt dat er sprake is van integratie als dertig procent van de mensen buiten de eigen groep huwt. Waarom ze voor deze grens kiest is niet duidelijk. De implicatie van dat percentage is dat evenmin; de groep houdt immers niet op te bestaan en blijft herkenbaar als entiteit. Reeves Kennedy lijkt te bedoelen dat er nu sprake is van een geïntegreerde groep. Hierboven zijn groepsvorming en integratie gepresenteerd als elkaars tegenpolen. Wat is dan een geïntegreerde groep? Tussen volledige integratie aan de ene kant en volledige isolatie aan de andere kant zit een breed spectrum. Omtrent de beide uiteinden van het spectrum bestaat helderheid, maar iedere auteur trekt - merendeels impliciet - eigen grenzen binnen dat spectrum waar groepsvorming ophoudt en integratie begint. Een geïntegreerde groep lijkt zich ergens tussen die twee uiteinden te bevinden. Het trekken van absolute grenzen binnen dat spectrum is te willekeurig. Daarvoor is de afbakening van groepen immers te zeer contextafhankelijk. De oplossing voor het probleem ligt in het kijken naar de uiteinden. Daartussen is er een groot grijs gebied waar de ene groep in de andere overgaat. $^{68}$

\section{Opzet van het onderzoek}

Woonden de Duitse immigranten die in de tweede helft van de negentiende eeuw naar Utrecht kwamen bij elkaar, trouwden ze met elkaar, werkten ze samen en zaten ze samen in clubs en verenigingen? Het is pas echt goed mogelijk deze vragen te beantwoorden vanaf de algemene invoering van het bevolkingsregister. Nederland beschikt, sedert de introductie van het bevolkingsregister in 1850 over een unieke en waardevolle bron die een dynamisch beeld kan geven van de bevolking. ${ }^{69}$ Deze bron biedt niet slechts kale abstracte cijfers, maar ook veel contextuele informatie. Het is een bron die onderzoekers in slechts weinig andere landen in de wereld ter beschikking staat. De bron is bij uitstek geschikt voor het doen van onderzoek naar migratie en groepsvorming. Bevolkingsregisters konden in principe op twee manieren worden opgezet: op naam of op adres. Bij de adresgewijze ordening, zoals die in Utrecht werd gehanteerd, kunnen in een oogopslag geografische concentraties van immigranten worden opgemerkt. Zo kunnen relatief eenvoudig gemeenschappen van immigranten opgespoord worden. In de bevolkingsregisters kunnen we onmiddellijk zien of immigranten met andere immigranten in eenzelfde huis, straat of buurt woonden. Bovendien maken de bevolkingsregisters het mogelijk om in andere bronnen, zoals ledenlijsten van verenigingen, die wel namen, maar geen geboorteplaats of nationaliteit vermelden, op te zoeken welke leden Duits waren en welke niet.

De bevolkingsregisters vormen een omvangrijke en bewerkelijke bron. De Utrechtse bevolkingsregisters zijn voor een periode van dertig jaar (begin 1850 tot einde 1879) integraal doorgenomen op zoek naar mensen die buiten Nederland werden geboren. Mensen werden gevolgd tot 1912. In Utrecht bestond het register van 1850-1859 uit 26 lijvige boekdelen; dat van 1900-1912 kende 150 delen. De eerste tien jaar van het register 
(1850-1859) bevat 11.580 bladen. In totaal heb ik een kleine 50.000 bladzijden nagespeurd op in het buitenland geborenen. Eindjaar van het onderzoek is 1912 omdat toen in Utrecht van het zogenaamde boeksysteem, dat op adres was geordend, werd overgegaan op het kaartsysteem, dat op naam was geordend. Hiermee laten concentraties zich veel minder makkelijk reconstrueren.

Het Utrechtse bevolkingsregister werd - zo leert een vergelijking met de bevolkingsregisters in andere plaatsten - vrij 'netjes' bijgehouden. Terwijl elders de doorhalingen en verwijzingen zo chaotisch zijn dat werken met het register moeilijk wordt, is in Utrecht goed met het register te werken. De stad Utrecht heeft bovendien als voordeel dat ze wel behoorde tot de grote steden van Nederland, maar minder groot was dan Amsterdam of Rotterdam. Dit maakte het mogelijk om het hele bevolkingsregister voor een periode van dertig jaar door te werken. Deze integrale onderzoeksaanpak was belangrijk omdat, zoals we zullen zien, de Duitse immigranten niet gelijkelijk over de verschillende stadswijken - en daarbinnen over de verschillende buurten - waren verdeeld. Er waren meerdere concentraties binnen de stad. Een dergelijke spreiding maakt een steekproefgewijze aanpak minder geschikt. Voor het in kaart brengen van een populatie die gedeeltelijk in kleine concentraties over de stad verspreid woonde, zou de steekproef immers erg groot moeten zijn. Zo niet, dan ontstaat een sterk vertekend beeld. De aanpak die hier is gevolgd is dan zowel beter als eenvoudiger.

\section{Een viervoudige vergelijking}

Het verloop van het vestigingsproces van immigranten - tussen groepsvorming en integratie - werd bepaald door de kansen en mogelijkheden die zij vonden in hun nieuwe omgeving. De Amerikaanse migratie-onderzoekers Ewa Morawska en Richard Waldinger gebruiken de term kansenstructuur (opportunity structure) om het geheel van mogelijkheden aan te duiden dat een samenleving aan immigranten biedt. ${ }^{70}$ De kansenstructuur omvat naast de economische mogelijkheden, ook de politieke en sociale mogelijkheden die openstaan voor immigranten, de kans op steun van een gemeenschap van lotgenoten die hen voorgingen, religieuze of politieke vrijheid en bekendheid met omstandigheden in de ontvangende samenleving. Landelijke wetgeving en lokaal beleid ten aanzien van vreemdelingen, beeldvorming en de mogelijkheden in de stad Utrecht vormden alle onderdeel van die kansenstructuur.

De wetgeving ten aanzien van vreemdelingen (beschreven in hoofdstuk 2) bepaalde welke beperkingen aan immigranten werden opgelegd. De uitvoeringspraktijk kon echter in de negentiende eeuw per plaats aanzienlijk verschillen.

Het beeld dat in Nederland bestond omtrent de Duitse nieuwkomers en het beeld dat zij hadden van Nederland (beschreven in hoofdstuk 3 ) bepaalden onder meer of economische sectoren voor immigranten werden afgesloten of juist gereserveerd. Werden Duitse nieuwkomers bij uitstek geschikt geacht voor het doen van een bepaald type 
werk? Beeldvorming speelde ook een rol bij huwelijksgedrag en bij ruimtelijke segregatie.

De Amerikaanse historica Nancy Green heeft gewaarschuwd voor de gevaren die schuilen in het bestuderen van één groep immigranten in één stad. Bij het bestuderen van Duitsers in Utrecht moeten we die waarschuwing ter harte nemen. Een dergelijke benadering maakt het namelijk onmogelijk om hun woongedrag, huwelijksgedrag, hun verdeling over beroepen en hun deelname aan het sociaal verkeer te verklaren vanuit kenmerken van de groep of vanuit kenmerken van de ontvangende samenleving. Om hierover toch uitspraken te doen werden de Utrechtse Duitsers met een aantal andere groepen vergeleken. Ten eerste is dat een controlegroep van niet-immigranten, die met (een selectie uit) de Duitse immigranten gemeen hadden dat zij behoorden tot hetzelfde geboortecohort: 1810-1835. Deze controlegroep is opgebouwd uit twee delen: de zogenaamde HSN-controlegroep en de winterbedeelden. De eerste controlegroep waarvoor een representatieve steekproef werd getrokken uit de geboorteregisters binnen het kader van het project Historische Steekpoef Nederland - bestaat uit mensen die werden geboren in Utrecht tussen 1812 en 1835 en die ook in deze stad trouwden. ${ }^{71}$ De tweede groep bestond uit mensen die geboren waren tussen 1810 en 1835 en die in de extreem koude winters van 1853-54 en 1854-55 een extra vorm van bedeling kregen. Zij werden bijna allemaal in Utrecht geboren. ${ }^{72}$ De twee controlegroepen werden geacht representatief te zijn voor in Utrecht woonachtige geboren Nederlanders; de eerste voor de hele bevolking, de tweede meer voor de armere bevolking. Bij de HSN-groep gaat het om mensen die in Utrecht zijn geboren en getrouwd. Bij de winterbedeelden gaat het om mensen die vrijwel allemaal in Utrecht werden geboren en er als volwassene werden bedeeld. In wat volgt wordt de eerste groep aangeduid als de autochtone Utrechtse bevolking en de tweede als de armere autochtone Utrechtse bevolking.

Op de tweede plaats worden de Utrechtse Duitsers vergeleken met Duitse immigranten in andere steden. Dit noemt Green een divergente vergelijking. 'The study of single national groups across space is [...] particularly interesting in order to evaluate the relative importance of cultural baggage or social-economic factors with regard to emigration and adaptation' ${ }^{73}$ De divergente benadering maakt het mogelijk om het belang van de culturele bagage af te zetten tegen het belang van bijvoorbeeld de mogelijkheden van de stad. Duitse immigranten in Utrecht worden in dit boek vergeleken met Duitse immigranten in andere landen. ${ }^{74}$ Die vergelijking wordt vooral gemaakt met Duitse immigranten in een stedelijke omgeving. De beschrijvingen die Stanley Nadel, Panikos Panayi en Gesa Snell maakten van de Duitse immigrantengemeenschappen van respectievelijk New York, Londen en Kopenhagen in de tweede helft van de negentiende eeuw zijn het meest vergelijkbaar. ${ }^{75}$ Op basis van het werk van Ronald Rommes, die de Duitse immigranten in Utrecht in een eerdere periode beschreef, wordt een vergelijking gemaakt in de tijd.

De vergelijking met de controlegroep en de toepassing van het divergente model vindt plaats in de hoofdstukken waarin de algemene kenmerken van de Duitse migrantenpopulatie worden beschreven (hoofdstukken 5 tot 8). 
De derde vergelijking gaat in op de verschillen binnen de Duitse migrantenpopulatie. In het voorafgaande is steeds gesuggereerd dat de Duitse immigranten één groep vormden. In feite bestond deze populatie uit verschillende deelgroepen. De grootste groep werd gevormd door de Westerwalder steengoed- of pottenhandelaren (ongeveer 35 procent), gevolgd door de winkeliers uit Münsterland en hun personeel (ongeveer 20 procent). Aan deze grootste groepen worden afzonderlijk hoofdstukken besteed (hoofdstukken 9 en 10). De beide groepen hadden niet alleen met elkaar gemeen dat ze omvangrijk waren. Ze bestonden ook beide uit zowel mannen als vrouwen. De Amerikaanse onderzoekers Light en Karageorgis hebben erop gewezen dat die combinatie van factoren groepsvorming versterkt. ${ }^{76}$ Om dat te toetsen worden deze beide groepen vergeleken met vijf andere groepen die alleen bestonden uit mannen of vrouwen: vijlenkappers, stukadoors, dienstbodes, spoorbeambten en studenten (hoofdstuk 11).

De vierde en laatste vergelijking (hoofdstuk 12) betreft Duitse immigranten en andere immigranten in Utrecht in hetzelfde tijdvak, wat Green het convergente model noemt. 'By taking a place, the city, as the constant, the comparison implies from the outset that difference will be found at the level of the immigrant groups themselves. Cultural origins thus explain the varying modes of adaptation to the city. ${ }^{77}$ De Duitse migranten worden vergeleken met Belgen, Fransen, Britten, Italianen en kleinere andere groepen. 



\section{2 'Is almede vruchteloos alle nasporing beproeft' Vreemdelingenwetgeving}

In 1850 overwoog de Amsterdamse politie de Duitser Conrad Herbig over de grens te zetten. ${ }^{1}$ Herbig woonde van 1840 tot 1847 in Utrecht. ${ }^{2}$ Hij was in 1839 uit Frankfurt am Main gekomen en had in Tiel, Alkmaar, Dordrecht en Den Bosch gewoond, voordat hij zich vestigde in de Domstad. In 1847 vertrok hij uit Utrecht in stilte naar Den Haag, met achterlating van veel schulden. Hij was vijftig jaar oud toen hij in Amsterdam opdook en gaf tegenover de politie te kennen 'onderwijzer in de Hoogduitsche taal te zijn en van Herleshausen in Keur Hessen geboortig te wezen.' Hij kwam naar Amsterdam om 'met een boekhandelaar over de uitgave van een werk te spreken.' Hij verkocht een bundeltje getiteld Ernst- und Scherzhafter Gedichte. De Amsterdamse politie wilde Herbig wegens gebrekkige middelen van bestaan uitleiden, maar vroeg, gezien zijn langjarig verblijf in Nederland, advies aan de Minister van Justitie. Bij de politie van Den Haag en Utrecht werd over Herbig informatie ingewonnen. De Haagse politie verklaarde dat Herbig een 'opligter en bedrieger' was, zonder middelen van bestaan, 'noch door werkzaamheid kan verkrijgen, zich doorgaans aan het misbruik van sterken drank overgaf, bij onderscheiden personen kost en inwoning genoten had en zonder hen te betalen' vertrokken was.

Gebrek aan middelen van bestaan was een grond voor uitwijzing van vreemdelingen, sinds enkele maanden vóór Herbigs aanhouding de Vreemdelingenwet in werking was getreden. Het voornaamste doel van deze wet was het weren van armlastige vreemdelingen. De wet regelde op welke gronden vreemdelingen over de grens konden worden gezet. ${ }^{3}$

\section{Een geweldige overlast van vreemde indringers en vagebonden?}

Het voorstel voor de eerste Nederlandse Vreemdelingenwet passeerde de Tweede Kamer niet zonder discussie. Vier dagen lang - van donderdag 18 juli tot en met maandag 23 juli 1849 - werd in de Kamer over niets anders gedebatteerd. Op zaterdag 21 juli gingen de debatten de hele dag en avond door. Wie de verslagen leest, krijgt de indruk dat Nederland in het midden van de negentiende eeuw werd overspoeld door vreemde bedelaars en onruststokers. Niets was minder waar. In vergelijking met eerdere tijdvakken was de immigratie sterk afgenomen. Desondanks werd een afzonderlijke wetgeving op dit punt noodzakelijk geacht. 
Een voor het hele land geldende Vreemdelingenwet betekende nog niet een uniforme uitvoeringspraktijk. In de tweede helft van de negentiende eeuw hadden de lokale overheden relatief veel vrijheid bij de toepassing van het landelijk beleid. De plaatselijke uitvoering van het vreemdelingenbeleid werd mede bepaald door de aard en de omvang van de migratie in een plaats. De migratie naar Utrecht was, in vergelijking met die naar andere grote Nederlandse steden, niet bijzonder omvangrijk. Naar Utrecht kwamen bovendien andere migranten dan naar Amsterdam of Rotterdam. Er waren geen vreemde havenarbeiders, doortrekkende migranten op weg naar Amerika, of mannen die aanmonsterden op zeeschepen. Het aantal immigrerende mannen en vrouwen hield elkaar in de Domstad bovendien ongeveer in evenwicht. In Amsterdam en Rotterdam overtrof het aantal mannen het aantal vrouwen, vooral omstreeks $1850 .{ }^{4}$ De samenstelling van de migrantenpopulatie had tot gevolg dat het beleid in Utrecht weinig gestreng werd toegepast.

\section{'Smoussen en andere vreemde lopers van buiten inkomende'}

Het negentiende-eeuwse vreemdelingenbeleid was in zekere zin een voortzetting van beleid in eerdere tijdvakken. Voor alle tijdvakken gold dat politieke of sociale onrust aanleiding was om beleid te herzien of aan te scherpen. ${ }^{5}$ Net als eerder en later, vormde het weren van (potentieel) armlastigen de kern van het beleid. Het belangrijkste verschil tussen eerdere periodes en de negentiende eeuw was, dat het onderscheid op basis van geloof verdween.

Utrecht weigerde tot 1788 formeel de vestiging van joden, die soms gelijkgesteld werden aan andere vreemde kooplieden. ${ }^{6}$ In 1738 werd verordonneerd dat herbergiers geen onderdak mochten verlenen aan vreemde kooplieden 'voornamelijk Smoussen [joden] en andere vreemde lopers, van buiten inkomende." In de negentiende eeuw vervielen de beperkingen op de vestiging van joden. Tot een grote toename van het aantal joden in de stad leidde dat niet. Het weren van binnen- en buitenlandse joden in de achttiende eeuw, had tot gevolg dat de joodse gemeenschap in Utrecht aan het begin van de negentiende eeuw bijzonder klein was en dat bleef ook zo in de tweede helft van de negentiende eeuw.

Voor katholieke vreemdelingen was het eveneens gedurende enige tijd moeilijk om in Utrecht rechten te verkrijgen. De stad kende sedert 1655 voor katholieken beperkingen op de verwerving van burgerrecht, gildenlidmaatschap en recht van inwoning. Katholieken die reeds rechten hadden, behielden die. In latere jaren werd de regeling voor katholieke nieuwkomers van binnen de landsgrenzen versoepeld, maar voor 'buitenlandse' katholieken werd ze gehandhaafd. Katholieke nieuwkomers mochten zich wel in Utrecht vestigen, maar konden slechts met enige moeite burgerrecht verkrijgen en daardoor geen lid worden van een gilde en geen zelfstandige productiehuishouding opzetten. ${ }^{8}$ Voor buitenlandse katholieken gold dat alleen 'nuttige en nodige Roomsgezinde' werden toegelaten. ${ }^{9}$ In de praktijk werd deze maatregel aan het einde van de 
achttiende eeuw redelijk ruimhartig toegepast. Een katholieke Duitse brouwersknecht kreeg het burgerschap en aan katholieke Franse ketellappers en scharenslijpers werd het recht van inwoning verleend. Dienstbodes en -boden hoefden evenmin recht van inwoning te verwerven. ${ }^{10}$ Ondanks de ruimhartige toepassing, betekende het wegvallen van beperkingen op het burgerschap en gildenlidmaatschap dat de economische mogelijkheden voor katholieke immigranten werden vergroot.

Na het einde van de Republiek verschoof de politieke macht van het stedelijke naar het nationale niveau. ${ }^{11}$ Het belangrijkste gevolg was dat 'vreemdelingen' in de negentiende eeuw niet langer meer mensen waren van buiten de stadsgrenzen, maar van buiten de landsgrenzen. De bemoeienis van de landelijke overheid nam toe, maar tegelijkertijd was de landelijke overheid niet bereid of in staat om alle macht naar zich toe te trekken. ${ }^{12}$ Lokale overheden behielden hierdoor een vergaande autonomie en waren bovendien niet altijd van het landelijk beleid op de hoogte. Een landelijk beleid betekende bijgevolg niet dat er een landelijk uniforme uitvoeringspraktijk was.

\section{Vreemdelingen, gelijkgestelden en gevestigden}

Om te weten wat de gevolgen waren van het vreemdelingenbeleid, moet eerst duidelijk zijn wie vreemdeling was. Het Nederlanderschap werd wettig geregeld in het Burgerlijk Wetboek van 1838. Uitgangspunt was het zogenaamde territorialiteits- of geboortelandprincipe (jus soli). Nederlander was iedereen die op Nederlandse grond, in Nederland of in de koloniën, was geboren uit ouders die daar waren gevestigd. In Nederland geboren kinderen van ouders die daar niet waren gevestigd, konden Nederlander worden als ze zelf hun woonplaats in Nederland vestigden. Bovendien kregen kinderen die buiten Nederland waren geboren, tijdens een buitenlandse reis van ouders die Nederlands waren of die in Nederland of in de koloniën waren gevestigd, de Nederlandse nationaliteit. De Nederlandse nationaliteit ging verloren door naturalisatie in het buitenland, vreemde krijgs- of staatsdienst en vestiging in het buitenland met de bedoeling niet terug te keren. Gehuwde vrouwen hadden de nationaliteit van hun man. Een Nederlandse vrouw die met een niet-Nederlandse man trouwde, verruilde haar Nederlandse nationaliteit voor de nationaliteit van haar echtgenoot. Na scheiding of na overlijden van haar man, kon de vrouw haar oorspronkelijke nationaliteit op verzoek en binnen een jaar terugkrijgen.

In artikel 8 van het Burgerlijk Wetboek van 1838, werd bepaald dat vreemdelingen op verzoek met Nederlanders gelijkgesteld konden worden, wanneer zij zes jaar in dezelfde gemeente hadden gewoond en aan het gemeentebestuur lieten weten van plan te zijn in Nederland te blijven wonen. ${ }^{13}$ Deze gelijkstelling betekende niet dat deze vreemdelingen hierdoor de Nederlandse nationaliteit kregen.

Naast gelijkgestelden waren er gevestigden. Gevestigden of ingezetenen waren mensen die drie jaar in Nederland gewoond hadden, of aan het bestuur van hun woon- 
plaats te kennen hadden gegeven zich te willen vestigen en vervolgens achttien maanden in die plaats hadden gewoond. ${ }^{14}$

De regeling in het Burgerlijk Wetboek had betrekking op het burgerlijk recht. In het midden van de negentiende eeuw gingen er stemmen op om een aparte regeling te treffen voor het politiek Nederlanderschap. Het politiek recht had betrekking op het (census)kiesrecht en de uitoefening van openbare functies. De Nationaliteitswet van 1850 voorzag in de regeling van het politiek Nederlanderschap. ${ }^{15}$ De regeling in het Burgerlijk Wetboek bleef van kracht en hierdoor waren er nu dus twee wetten die bepaalden wie Nederlander was: het Burgerlijk Wetboek van 1838 regelde de burgerlijke rechten en de Nationaliteitswet van 1850 de staatkundige. De Nationaliteitswet van 1850, die bepaalde wie er in politiek opzicht Nederlander was, werd van kracht naast de Vreemdelingenwet van 1849 , die bepaalde op welke gronden vreemdelingen konden worden uitgewezen.

De Nationaliteitswet van 1850 wijzigde de positie van de bevolking van de koloniën. Politiek Nederlanderschap werd niet meer verkregen door geboorte uit in de koloniën gevestigde ouders. Hierdoor waren, naast de inheemse bevolking, ook de meeste kinderen van in de koloniën wonende immigranten, uit andere landen dan Nederland, van het politiek Nederlanderschap uitgesloten. Kinderen die in Nederlands-Indië geboren werden uit Duitse ouders, waren in politieke zin geen Nederlanders; kinderen die in Nederland geboren werden uit Duitse ouders waren dat wel.

In 1893 trad een nieuwe wet op het Nederlanderschap in werking en vervielen de oudere regelingen. De Vreemdelingenwet bleef van kracht. In de Nationaliteitswet werd het geboortelandprincipe verlaten. Nederlanderschap kon niet meer zowel door geboorte uit Nederlandse ouders, als door geboorte uit in Nederland gevestigde ouders worden verkregen. Voortaan konden alleen kinderen van Nederlandse vaders en natuurlijke kinderen van Nederlandse moeders bij geboorte de Nederlandse nationaliteit krijgen (jus sanguinis). Een uitzondering werd gemaakt voor wat we nu de derde generatie noemen. De kleinkinderen van immigranten konden de Nederlandse nationaliteit krijgen, wanneer ze anders stateloos zouden worden. Nederlanders verloren hun nationaliteit na een verblijf van tien jaar in het buitenland, tenzij zij een verklaring indienden dat zij hun nationaliteit wilden behouden. Overigens was deze regel niet nieuw. Eerder was er ook reeds in het beleid van uitgegaan, dat een langjarig verblijf buiten de landsgrenzen betekende dat een Nederlander het land verlaten had met het oogmerk niet terug te keren, waarmee hij zijn hoedanigheid van Nederlander had verloren. ${ }^{16}$

Vreemdelingen konden zich tot Nederlander laten naturaliseren. De belangstelling daarvoor was echter gering. ${ }^{17}$ Voor vreemdelingen die in het Nederlandse of Nederlands-Indische leger hadden gediend was naturalisatie kostenloos. Zij hadden, zoals dat heette, betaald met hun persoon. ${ }^{18}$ Vreemdelingen konden voorts van nationaliteit veranderen door langdurig verblijf buiten hun geboorteland, waardoor ze hun nationaliteit verloren en stateloos werden. Tot 1913 gold voor Pruisische onderdanen, dat zij na tien jaar ononderbroken verblijf in het buitenland het Pruisische staatsburgerschap verloren. Tot 1870 bestond een soortgelijke regeling voor andere Duitse gebieden, zoals 
Hamburg (na vijftien jaar), Lübeck, Mecklenburg-Schwerin, Mecklenburg-Strelitz, Oldenburg, Reuss, Saksen, Saksen-Weimar en Waldeck. In het koninkrijk Württemberg verloor de emigrant al onmiddellijk na emigratie zijn staatsburgerschap. ${ }^{19}$ Verlies van de oorspronkelijke nationaliteit betekende niet het automatisch het verwerven van de Nederlandse nationaliteit.

\section{Een 'wandelboekje' en een 'schoolgetuigenis'}

Reeds vóór de invoering van de Vreemdelingenwet van 1849 konden vreemdelingen over de grens worden gezet. Artikel 272 van de Code Pénal (1810) luidde: [personen die bij vonnis door de rechtbank tot] 'landloopers verklaard worden, zullen ingeval zij vreemdelingen zijn, op last van de Hooge Regering buiten het rijksgebied gebragt mogen worden. ${ }^{20}$ De registratie van vreemdelingen, die uit de Vreemdelingenwet voortvloeide, was in 1849 evenmin nieuw. In 1815 werd al bepaald dat een vreemdeling die in de gemeente wilde verblijven, zich binnen twaalf uur na aankomst moest melden bij de directeur of de commissaris van politie, en in kleinere plaatsen bij het gemeentebestuur. Aan hem of haar werd in ruil voor het paspoort een veiligheidskaart verstrekt, indien de vreemdeling langer dan 24 uur in de gemeente dacht te blijven. De veiligheidskaart moest elke veertien dagen worden vernieuwd. Bij vertrek werd het paspoort teruggegeven. Wanneer de vreemdeling niet over een pas beschikte, moest de persoon bij wie hij of zij logeerde, dit binnen twaalf uur melden bij de politie of het gemeentebestuur. Behalve een pas konden ook andere identiteitspapieren worden overlegd. De Italiaanse beeldenkoopman Camillo Bapretti reisde in 1847 door Nederland op een pas die hem in 1845 was verschaft door de Duitse consul in Den Haag. ${ }^{21}$ Bij de boerenarbeider Johann Mengendoht, die in hetzelfde jaar met koorts in het Utrechtse stadsziekenhuis werd opgenomen, werd als identiteitsbewijs een geboorte-extract uit zijn geboorteplaats Lemgo in het vorstendom Lippe gevonden. ${ }^{22}$ Chistina Wagner, een kraamster in Eau de Cologne uit Hunsdorf in Nassau, die in het Utrechtse ziekenhuis beviel van een buitenechtelijk kind, had behalve een extract uit het geboorteregister, als identiteitsbewijs een 'schoolgetuigenis' bij zich dat was afgegeven door de plaatselijke onderwijzer, en een 'attest van goed gedrag'. ${ }^{23}$ De steendrukker Carl Heinz uit Gotha had een 'wandelboekje' waaruit zijn identiteit bleek. ${ }^{24}$ Met het 'wandelboekje' werd het zogenaamde Wanderbuch bedoeld, waarmee Duitse ambachtslieden gewoonlijk rondreisden en waarin hun opeenvolgende werkgevers aantekeningen maakten omtrent hun gedrag en werkervaring.

De Minister van Buitenlandse Zaken wilde graag dat er slechts vreemdelingen werden toegelaten die ten minste voorzien waren van een Heimatschein. Dit was een bewijsstuk waarin een Duitse gemeente verklaarde dat iemand in haar gebied woonde en bij terugkeer dus niet zou worden geweigerd. Pruisen weigerde regelmatig eigen onderdanen opnieuw toe te laten na een als tijdelijk bedoelde afwezigheid, en was tegelij- 
kertijd, zo klaagde de Nederlandse Minister van Justitie, weinig royaal in het afgeven van een Heimatschein. ${ }^{25}$

Door de revolutionaire spanningen buiten de landsgrenzen, werden in 1848 de regels ten aanzien van Duitse seizoensarbeiders aangescherpt. In het revolutiejaar 1848 werd aan diplomatieke vertegenwoordigers opgedragen, om bij de regeringen van Lippe-Detmold, Hessen, Hannover en Oldenburg de nodige stappen te ondernemen, om te zorgen dat aan vreemde seizoensarbeiders door hun regeringen passen of bewijzen werden gegeven waarop hun terugkeer zou zijn gewaarborgd.

Weldra nadert het tijdstip, waarop talrijke scharen vreemde arbeiders die gewoon zijn herwaarts te komen om in het grasmaayen en veenen werk te zoeken, hetwelk zij gereedelijk vinden. Die lieden komen echter gewoonlijk het Rijk binnen zonder Heimatscheinen of reispassen. Is dit in het algemeen eene afwijking van den regel, aan welken tegenover sommige regeringen vooral de hand moet worden gehouden, wegens de bekende angstvalligheid derzelven in de weder toelating van buiten 's lands gereisd of verwijld hebbende onderdanen, in den tegenwoordigen tijd eischt de voorzichtigheid dubbele zorg en toezicht te dezen opzigte. $^{26}$

De Vreemdelingenwet van 1849 verplichtte vreemdelingen zich bij aankomst en vertrek bij de politie te melden. Besliste de politie dat de vreemdeling kon worden toegelaten, dan kreeg hij of zij een reis- en verblijfpas. Van het toekennen en weigeren van deze passen, de driemaandelijkse verlenging, de wettelijke vrijstellingen en van de uitzetting van vreemdelingen, werden registers bijgehouden. ${ }^{27}$

Vreemdelingen waren in principe welkom in Nederland, mits ze voldoende middelen van bestaan hadden of die konden verwerven. Vreemdelingen moesten zich kunnen legitimeren, bijvoorbeeld door middel van een paspoort van het eigen land. Het paspoort was echter, evenals voorheen, geen vereiste. Het bezit van andere geleidebrieven kon toelating wettigen, wanneer daaruit bleek wie de houder was en van waar en met welk doel hij of zij was gekomen. Vreemdelingen konden bovendien worden toegelaten op 'bloote aanmelding van hunne personen, met opgave wie zij zijn, en van waar en met welk doel zij herwaarts komen.' In dit geval werd een bewijs van bekendheid gevorderd, getekend door twee of meer bij de politie bekende personen. Vreemdelingen aan wie geen reis- of verblijfpas kon worden verstrekt, moesten het land verlaten.

De Vreemdelingenwet was niet van toepassing op vreemdelingen die met Nederlanders gelijkgesteld waren ingevolge artikel 8 van het Burgerlijk Wetboek, of op mannelijke vreemdelingen die met een Nederlandse vrouw getrouwd waren en kinderen bij haar hadden. ${ }^{28}$ In de Vreemdelingenwet van 1849 werd onderscheid gemaakt tussen toegelaten en niet toegelaten vreemdelingen. Toegelaten vreemdelingen kregen een reis- en verblijfpas die drie maanden geldig was. ${ }^{29} \mathrm{Zij}$ konden slechts door tussenkomst van het Kantongerecht over de grens worden gezet. Indien uitgezette vreemdelingen 
binnen vijf jaar opnieuw in Nederland werden aangetroffen, konden zij gestraft worden met een gevangenisstraf van acht dagen tot drie maanden. De verwijdering uit het rijk werd op de pas of andere identiteitspapieren aangetekend, zodat de overheid in het land van herkomst daarvan op de hoogte werd gebracht.

De ambtenaren die de bevolkingsregisters bijhielden, vroegen bij inschrijving van vreemdelingen naar de reis- en verblijfpas en makkte daaromtrent aantekeningen in het register.

Aanvankelijk werd de Vreemdelingenwet streng toegepast, maar reeds na enkele jaren verwaterde de uitvoering van de wet. Vreemdelingen vroegen niet langer een reisen verblijfpas aan of lieten de pas niet verlengen.

In 1851 en 1852 werden circulaires uitgegeven, waarin werd bepaald dat er geen reisen verblijfpassen meer mochten worden afgegeven aan rondreizende buitenlandse muzikanten en kermisreizigers. Een jaar later werden hier zogenaamde 'Hongaarse oliekopers', een soort rondreizende kwakzalvers, aan toegevoegd. ${ }^{30} \mathrm{Zij}$ kregen geen passen, golden niet als toegelaten vreemdelingen en konden zonder tussenkomst van het Kantongerecht over de grens worden gezet. Na 1 mei 1862 hoefden buitenlandse paspoorten niet langer in bewaring te worden gegeven of getoond. ${ }^{31}$ Vóór 1862 waren er reeds met enkele landen afzonderlijk overeenkomsten getroffen, zodat wederzijdse onderdanen hun paspoort niet hoefden te tonen. In 1861 werd bijvoorbeeld tussen Nederland en Pruisen afgesproken dat onderdanen van Pruisen die naar Nederland reisden, geen geviseerd paspoort hoefden te hebben, noch een paspoort dat speciaal voor de reis naar Nederland was afgegeven. Voor Nederlandse onderdanen in Pruisen gold hetzelfde. ${ }^{32}$ Kort daarop werd eenzelfde verklaring uitgewisseld met Hannover. ${ }^{33}$

Het minder streng toepassen van de Vreemdelingenwet, dat eerst vooral lijkt te zijn voortgekomen uit laksheid, werd omstreeks 1870 officieel beleid. Aan vreemdelingen werd niet langer een reis- en verblijfpas uitgereikt, ook niet als ze daarom vroegen. Gevolg en doel van deze weigering waren dat vreemdelingen op elk moment konden worden uitgezet. Vreemdelingen zonder reis- en verblijfpassen waren 'zonder de minste bescherming geheel en al in de hand der politie, en onder deze categorie tracht men, in strijd met den geest der wet, zooveel mogelijk alle vreemdelingen te brengen. ${ }^{34}$

De versoepeling van de toepassing van de Vreemdelingenwet was gunstig voor handel en nijverheid. De wet werd echter niet afgeschaft, zodat hij op elk moment weer met grotere gestrengheid kon worden toegepast. Toen Pruisen in 1875 Jezuieten uitwees, werd ervoor gepleit de Vreemdelingenwet in de oorspronkelijke gestrengheid te doen herleven. ${ }^{35}$

\section{De praktijk in Utrecht}

Het beleid dat de stad Utrecht tegenover vreemdelingen voerde, is moeilijk te reconstrueren. Het bestuur van de stad was laks en nalatig in het aan de nationale overheid rapporteren van de uitvoering van het vreemdelingenbeleid. Terwijl sommige andere 
steden of provincies elk kwartaal een uitgebreid verslag aan het Ministerie van Justitie stuurden - soms inclusief de namen van de uitgewezen personen - volstond Utrecht elk kwartaal met een korte opsomming, die sterk de indruk wekt te zijn overgeschreven uit het verslag van het daaraan voorafgaande kwartaal. ${ }^{36}$ In het laatste kwartaal van 1871 werd bijvoorbeeld gemeld dat in het arrondissement één paspoort of Wanderbuch was geviseerd, twee reis- en verblijfpassen waren afgegeven, zeven passen waren verlengd en vijf mensen uit het rijk waren verwijderd. Het verslag van het kwartaal daarna, was vrijwel gelijkluidend.

Op basis van de kwartaalverslagen die door de procureurs-generaal aan het Ministerie van Justitie werden gestuurd, kan voor de jaren 1851 tot 1855 een overzicht voor de provincie Utrecht worden gegeven (zie tabel 2.1). Zoals uit de tabel blijkt, was het aantal vreemdelingen dat naar deze provincie kwam, niet bijzonder groot. Er waren wel forse schommelingen. Het aantal in de provincie aangekomen vreemdelingen was in 1854 bijna vier keer zo groot als drie jaar eerder.

Tabel 2.1 Overzicht van vreemdelingen in de Provincie Utrecht 1851-1855.

\begin{tabular}{lcccc}
\hline & 1851 & 1852 & 1854 & 1855 \\
\hline aangekomen vreemdelingen & 354 & 797 & 1240 & 988 \\
paspoorten van personen die naar elders doortrekken & 328 & 543 & 528 & 418 \\
afgegeven reis- en verblijfpassen & 96 & 206 & 230 & 182 \\
uitgeleide vreemdelingen & 4 & 13 & 4 & 0 \\
\hline
\end{tabular}

Bron ARA 2.09.01 5190, Toelating en uitzetting van vreemdelingen (Vreemdelingenwet) 1849-1876. ${ }^{37}$

De gegevens in het verslag aan het Ministerie van Justitie verschillen van die in het gemeenteverslag. In het Utrechtse gemeenteverslag van 1855 werd melding gemaakt van de uitzetting van acht vreemdelingen, terwijl in het verslag van de procureur geen uitleidingen werden genoemd. Dit bevestigt het weinig betrouwbare karakter van de rapportage. Wel is duidelijk dat het aantal uitzettingen gering was. Terwijl Utrecht in 1855 acht mensen uitwees, meldde Rotterdam voor datzelfde jaar 363 uitzettingen. ${ }^{38}$ In Harderwijk, waar het koloniaal werfdepot was gevestigd, dat nogal wat vreemdelingen trok, werden jaarlijks tussen de drie- en vijfhonderd mensen uitgeleid. ${ }^{39}$

Naleving van de Vreemdelingenwet leverde in Utrecht, wanneer we afgaan op de verslagen, in het algemeen niet veel problemen op. In 1850 schreef politiecommissaris W. van Goudoever dat er geen moeilijkheden of bijzonderheden waren in verband met naleving van de wet.

[... uit de elders afgegevene reis- en verblijfpassen, welke mij van tijd tot tijd door reizigers ter prolongatie worden aangeboden blijkt, dat de bepalingen der voorschreven wet in alle gedeelten van dit Rijk behoorlijk schijnen te worden in acht genomen. ${ }^{40}$ 
In 1854 werd uit de provincie Utrecht opnieuw gemeld dat de bestuurders tevreden waren over de werking van de wet.

De vreemdelingen, die in deze provincie kwamen om vooral in de veenderijen werk te zoeken, waren meestal van behoorlijke passen voorzien, hetgeen vroeger niet het geval was. Het getal der doortrekkende behoeftigen vreemdelingen schijnt, sedert de invoering der wet, belangrijk te zijn verminderd. Te Utrecht is opgemerkt, dat de wet gunstig werkt ten opzigte der algemeene veiligheid, daar het getal misdrijven door vreemdelingen gepleegd aanzienlijk minder is dan vroeger $[\ldots] .^{41}$

Na de introductie van de Vreemdelingenwet, werden in Utrecht minder vreemdelingen verpleegd in ziekenhuizen en gevangenissen. In de periode 1845-1849 waren dat er 151 ; in de periode 1850-1854, na de inwerkingtreding van de wet, slechts $48 .^{42}$

In incidentele gevallen deden zich wel problemen voor. In 1849 werd de vreemde bedelaar Hessink uitgewezen. De Minister van Justitie gaf de gouverneur opdracht hem na verhoor

bij open water, onder goed geleide naar Rotterdam [onderstreept in origineel] te doen brengen, hem aldaar ter beschikking te stellen van den Directeur van Policie en [...] voor zijne verwijdering uit Nederland de noodige zorg te dragen. $^{43}$

In 1856 schreef Van Goudoever een brief aan Burgemeester en Wethouders van Utrecht, betreffende de werking van de Vreemdelingenwet, waarin hij benadrukte dat streng toezicht werd gehouden

op de te dezen stede aankomende of verblijfhoudende vreemdelingen als blijk waarvan ook dienen kan dat gedurende het afgelopen jaar niet minder dan acht en twintig [onderstreept in het origineel] vreemdelingen hetzij ter zake dat zij als broodeloos konden worden beschouwd, het zij doordien zij niet van behoorlijke legitimatiepapieren waren voorzien van hier uit het Rijk zijn verwijderd.

Het toezicht was wel moeilijker geworden.

Dat door de aansluiting van den Nederlandsche Rijnspoorweg met den Pruissische Spoorweg, het toezigt op de vreemdelingen in de binnen Provincien van dit Rijk wel moeijelijker is geworden doch door mij voor deze stad zooveel in mijn vermogen is en het Personeel der Policie zulks toelaat, die maatregelen genomen zijn welke de werking der wet kunnen bevorderen. ${ }^{44}$ 
In 1857 was het oordeel over de werking van de Vreemdelingenwet in de provincie Utrecht nog immer gunstig.

In de veenderijen komen voortdurend vele vreemdelingen werk zoeken. Dit zijn over het algemeen personen, die sedert jaren bekend zijn, zich goed gedragen, en bijna allen van behoorlijke papieren zijn voorzien. Het getal doortrekkende behoeftige vreemdelingen schijnt steeds, sedert de invoering der wet, belangrijk te zijn verminderd. In de berigten der besturen van 4 gemeenten [in de provincie Utrecht] komt voor, dat uit deze 11 personen over de grenzen zijn uitgeleid. ${ }^{45}$

\section{Het domicilie van onderstand}

Niet de Vreemdelingenwet, maar de Wet op het Domicilie van Onderstand gaf de meeste aanleiding tot correspondentie over vreemdelingen. De Wet op het Domicilie van Onderstand werd ingevoerd in 1818 en bepaalde dat indien een armlastige bijstand kreeg, de kosten daarvan voor rekening van de domiciliegemeente kwamen. ${ }^{46}$ De domiciliegemeente was de plaats waar de arme was geboren of de laatste vier jaar had gewoond. Voor vreemdelingen gold dat dit de laatste plaats was waar ze zes jaar hadden gewoond, terwijl bovendien als eis werd gesteld dat ze in die periode geen onderstand mochten hebben aangevraagd. De plaats waarin iemand tot armoede verviel had het recht een rekening naar de domiciliegemeente te sturen, die deze rekening in beginsel moest betalen. Bij de uitvoering van deze wet deden zich twee problemen voor. Ten eerste was het, omdat er tot 1849 geen bevolkingsregister was, moeilijk om te bepalen in welke gemeente iemand had gewoond en hoe lang. Ten tweede weigerden gemeenten voorbij de landsgrenzen de aan hen opgestuurde rekeningen te voldoen.

Bepalingen omtrent het domicilie van onderstand gaven aanleiding tot eindeloze verwarring en correspondentie. In februari 1849 werd de 'vreemde landloper' Heinrich Hessink in het Utrechtse 'stedelijk policiehuis' verpleegd en werd hem kleding verschaft. ${ }^{47}$ De totale kosten bedroegen 74,35 gulden. Hessink had opgegeven van Lette, een dorp op 'drie uren afstands van Coesfeld' te zijn gekomen. De plaatselijke overheid van Lette verklaarde echter

dat hij aldaar volstrekt onbekend is, en dat ook nimmer aan iemand van dien naam eene vergunning is afgegeven om naar Holland [onderstreept in origineel] te reizen. In andere gelijknamige plaatsen, waar men vermoed heeft dat deze vreemdeling welligt zou kunnen geboren zijn, is almede vruchteloos alle nasporing beproeft. Het schijnt alzoo dat deze Heinrich Hessink verkeerde opgaven heeft gedaan en waarschijnlijk zal hij daarvoor redenen hebben. ${ }^{48}$ 
Het Ministerie van Justitie achtte 'uit dien hoofde een nader ernstig verhoor noodzakelijk. ${ }^{39}$

Bij Hessink was het moeilijk om een domicilie van onderstand aan te wijzen omdat hijzelf daartoe verkeerde of ontoereikende informatie verschafte. Bij Hendrik Kalkhoff was het verhalen van de kosten ook ingewikkeld, maar om een andere reden. Kalkhoff was een arbeider, geboren in Oldenburg in 1801 en ongehuwd. In 1848 werd hij in het ziekenhuis van Utrecht opgenomen met syfilis. Hij bevond zich sedert 1829 in Nederland en was

bij afwisseling aan onderscheidene landwerken als in Vriesland aan kanalen in Overijssel aan de straatweg in noordholland aan de indijking, aan het Haarlemmermeer, zuidplas, Rijnspoorweg aan de forten bij Utrecht van alles het langst te Schiedam alwaar hij een jaar op een branderij heeft gewerkt. ${ }^{50}$

Kalkhoff was te lang weg uit Oldenburg om die plaats verantwoordelijk te houden voor de kosten van zijn verpleging. In geen van de Nederlandse plaatsen had hij zich zes jaar opgehouden, dus kon daar ook niet worden aangeklopt voor vergoeding. Utrecht wilde evenmin voor het onderhoud van deze vreemdeling betalen.

In de correspondentie van het Provinciaal Bestuur van Utrecht zijn stapels zogeheten signalementen te vinden die verband houden met het domicilie van onderstand. Ze zijn simpelweg gerubriceerd onder de letter $\mathrm{V}$ van vreemdeling. Op deze signalementen wordt behalve het uiterlijk van de vreemdeling ook de laatste zesjarige verblijfplaats vermeld. De signalementen bieden een mooi beeld van zowel de moeilijkheden bij het vaststellen van het onderstandsdomicilie, als van het reispatroon van de mensen die het betrof. De Minister van Binnenlandse Zaken verzocht Gedeputeerde Staten van de provincie Utrecht regelmatig om aanvullende informatie op de 'staten die zijn ingezonden'. ${ }^{51}$ In april 1847 vroeg de minister bijvoorbeeld informatie over F.L. Burgers.

Uit het geen in de $2 \mathrm{e}$ kolom dier staten omtrent de ouders van dezen persoon is aangeteekend is de vraag gerezen of hij of schoon in Hannover geboren, ook als Nederlander zou moeten worden aangemerkt, en of hij in dat geval, na zijne meerderjarig wording, door eene vierjarige achtereenvolgende inwoning in eene gemeente hier te lande, ook domicilie van onderstand zou kunnen verworven hebben.

B en W van Utrecht konden de vragen niet beantwoorden. Zij schreven een maand later aan Gedeputeerde Staten der Provincie:

hebben wij de eer te berigten dat Frederik Leendert Burgers, bij het verlaten van het stads ziekenhuis alhier, naar elders is vertrokken, zonder dat is kunnen blijken, werwaarts hij zich heeft begeven, zoo dat men buiten magte is, nadere renseignementen omtrent zijn verblijf hier te lande na zijne meerderjarig worden te 
bekomen, wanneer intusschen de opgaven, in den renseignementstaat gedaan, juist zijn, kan de genoemde F.L. Burgers / geboren mei 1812 / na het tijdstip van zijn meerderjarig worden / 1 mei 1833 / nergens elders een vaste woonplaats van jaren gehad hebben. ${ }^{52}$

De Minister van Justitie raadde in 1849 gemeentebesturen aan geen pogingen te ondernemen om kosten vergoed te krijgen. ${ }^{53}$ De pogingen uit het verleden hadden nimmer resultaat gehad, terwijl er wel kosten waren gemaakt.

In 1854 werd de regelgeving betreffende het domicilie van onderstand gewijzigd. Nadrukkelijk werd vastgesteld dat de kerk de eerst verantwoordelijke was voor onderstand aan haar geloofsgenoten. Gemeenten droegen slechts de kosten wanneer dat strikt onvermijdelijk was. Belangrijk was voorts dat voortaan uitsluitend de geboorteplaats als onderstandsdomicilie gold. ${ }^{54}$ In de praktijk bleef de regelgeving voor verwarring zorgen. In het Jaarverslag over 1861 van het Provinciaal Bestuur van Utrecht werd geschreven:

Het R.C. armbestuur te Utrecht weigerde een behoeftige, die bijna zijn geheele leven aldaar gewoond had, te bedeelen, omdat hij elders geboren was, en hoewel men de juistheid erkende van de daartegen door het onderstands-domicilie aangevoerde beschouwingen, bleef het parochiaal armbestuur toch weigeren om behoeftigen, die volgens de wet elders domicilie hebben, te ondersteunen. ${ }^{55}$

$\mathrm{Na} 1870$ werd de gemeente waar iemand woonde, verantwoordelijk voor de onderstand. $^{56}$

De Wet op het Domicilie van Onderstand was gekoppeld aan de Vreemdelingenwet. Op 11 april 1856 stuurde de Minister van Binnenlandse Zaken een missive aan de Commissarissen des Konings in de provinciën:

Wanneer een vreemdeling zich om onderstand aanmeldt, moet de eerste vraag zijn, of er ook termen zijn om hem over de grenzen te verwijderen. Ten aanzien van behoeftige vreemdelingen kan die verwijdering in de meeste gevallen geschieden.

Slechts in vier gevallen kon dat niet. Ten eerste moest onderstand worden verleend aan vreemdelingen die ingevolge artikel 19 van de Vreemdelingenwet niet onder de Vreemdelingenwet vielen (gelijkgestelden naar artikel 8 van het Burgerlijk Wetboek en vreemdelingen die met een Nederlandse vrouw waren gehuwd en bij haar kinderen hadden). Verwijdering was evenmin gewenst in die gevallen waarin de vreemdelingen vóór 7 april 1850 een 'zoodanig aantal jaren in dienst van den lande of van zijne overzeesche bezittingen hebben doorgebragt, dat zij, uit redenen van menschelijkheid, van Staatswege onderstand mogen genieten.' Vreemdelingen in het bezit van een niet verlopen reis- en verblijfpas konden niet worden verwijderd, zieke vreemdelingen even- 
min. Vreemdelingen die voordat de Vreemdelingenwet in werking trad waren binnengekomen en geen reis- en verblijfpas hadden, konden wel worden verwijderd. Wanneer een vreemdeling niet onder een van deze uitzonderingen viel en geen steun kon krijgen van een kerkelijke of particuliere instelling, kon de politie verwijdering gelasten. Op het moment dat de pas verliep, ontstonden er nieuwe mogelijkheden.

Wanneer dus een vreemdeling [...] onderstand vraagt en volstrekt onvermijdelijk behoeft, dan moet worden onderzocht, tot hoe lang die pas loopt, en gezorgd, dat de behoeftige vreemdeling op het tijdstip der expiratie van den pas, of zoo spoedig mogelijk daarna, worde verwijderd. ${ }^{57}$

Bestuurders hadden er dus belang bij om de passen te laten verlopen.

\section{Tot besluit}

De grondslag van het vreemdelingenbeleid was de wens vreemde (potentieel) armlastigen te weren. Vanzelfsprekend waren niet alle vreemdelingen arm. Vreemdelingen die in hun onderhoud konden voorzien, waren vrijwel altijd welkom. De pogingen om vreemde armlastigen te weren, hadden echter ook gevolgen voor andere vreemdelingen. De introductie van de Vreemdelingenwet in 1849, betekende dat alle vreemdelingen een reis- en verblijfpas moesten aanvragen en elke drie maanden laten verlengen. Om dat te kunnen doen moesten ze legitimatiepapieren overleggen. De invoering van de Vreemdelingenwet betekende dus controle op de handel en wandel van alle vreemdelingen. Huwelijk met een Nederlander of gelijkstelling na een langjarig verblijf, betekende dat een vreemdeling niet onder de Vreemdelingenwet viel. Tijdelijke migranten, recente nieuwkomers en seizoensmatig op en neer reizende vreemdelingen, ondervonden de meeste beperkingen van de wet.

Het criterium dat vreemdelingen konden worden uitgezet, wanneer ze onvoldoende middelen van bestaan hadden of niet in staat waren die te verwerven, was moeilijk toe te passen. Bij vreemdelingen die overduidelijk over vermogen beschikten, was er weinig aanleiding tot discussie. Bij armere vreemdelingen was het de vraag in hoeverre zij in hun onderhoud zouden kunnen voorzien. Toegelaten vreemdelingen konden slechts worden uitgezet na tussenkomst van het Kantongerecht. Na verloop van tijd gingen tal van gemeenten er daarom toe over om geen reis- en verblijfpassen meer af te geven. Vreemdelingen die wel een reis- en verblijfpas hadden, moesten zelf zorgen voor een verlenging na drie maanden. Omdat het niet verlengen van de pas weinig directe consequenties had, lieten veel vreemdelingen dit na. Het gevolg was dat vreemdelingen soms jarenlang in Nederland woonden zonder officieel te zijn toegelaten. Zij konden in principe over de grens worden gezet, maar zolang ze in hun onderhoud konden voorzien was die dreiging weinig reëel. Een probleem ontstond pas op het moment dat een vreemdeling onderstand aanvroeg. Dan werd immers duidelijk 
dat de middelen van bestaan onvoldoende waren en kon, ingevolgde de Vreemdelingenwet, verwijdering worden gelast. De gevolgen van de Vreemdelingenwet en de manier waarop die werd toegepast, moeten vooral worden gezien in dit kader. Uitzetting kwam niet veel voor, maar dreiging met uitzetting bestond in de praktijk wel. Uitzetting dreigde vooral voor de tijdelijke immigranten en voor degenen die tot armoede vervielen. Immigranten die seizoensmatig op en neer reisden tussen hun herkomststreek en Nederland, liepen bovendien de kans dat ze niet opnieuw werden toegelaten wanneer ze na een tijdelijk verblijf in hun geboortestreek weer naar Nederland kwamen. 


\section{3 'Ich pien Schweitser!'}

\section{Beeldvorming}

Belgenmoppen, over de domheid van de zuiderburen, waren populair in Nederland in de jaren zeventig en tachtig van de twintigste eeuw. Omgekeerd maakten Belgen zich vrolijk over de Nederlandse krenterigheid. Britten maken al decennialang grappen over de gierigheid van hun Schotse buren. Grappenmakerij over de bewoners van het buurland kent een lange traditie. Bovendien meende Huizinga reeds:

Het algemeene oordeel van één natie over een andere is altijd ongunstig, althans indien het volken betreft, die iets met elkaar uit te staan hebben. Hoe nader de betrekkingen, hoe scherper de reactie.

In de negentiende eeuw waren er Poepenmoppen over domme Duitsers. ${ }^{2}$ Poepen was de benaming voor Duitsers die als seizoensarbeiders in de Nederlandse landbouw werkten.

Twee Poepen zagen de maan in het water schijnen.

"Een kaasje," zei de een.

"Dat moeten wij ja bewaren."

De een hield de ander aan de beenen vast en liet hem zakken. Al dieper en dieper, totdat hij verdronk. ${ }^{3}$

Het verhaal komt in de negentiende eeuw in talloze variaties voor, onder meer in het werk van de schrijver Justus van Maurik, die Duitse immigranten in het Amsterdam van 1861 beschreef. Bij Van Maurik is de kaas een schaal en valt de Duitser slechts in het water en verdrinkt niet. ${ }^{4}$

In hoeverre deze grappenmakerij het werkelijk beeld weerspiegelde dat Nederlanders van Duitsers hadden, is moeilijk te zeggen. In juni 1892 verscheen in het Utrechtsch Provinciaal en Stedelijk Dagblad een bericht over een ongeluk van een Duitse koopman.

Gisterenavond had een Duitsch koopman het ongeluk, dat zijn wagen van de brug aan den Krommen Rijn in het water geraakte, omdat hij bij het afgaan dien niet kon tegen houden. Zijne geheele negotie, houten nappen, potlepels, zeeften, galanteriewaren, enz, scheen verloren. Een gedeelte dreef, maar veel was dadelijk gezonken. Dadelijk deden velen, met den armen koopman begaan, hun best om hem te helpen. Eenigen waren spoedig met schuiten bij de hand en 
anderen begaven zelfs zich te water, om voor den koopman zooveel zij konden te redden, maar toch is de schade voor den man betrekkelijk zeer groot. ${ }^{5}$

Er waren, althans volgens dit krantenbericht, geen omstanders die zich op de brug vrolijk maakten over de domme Duitser die zijn koopwaar zag wegzakken in het water van de Kromme Rijn. Er waren geen baldadige jongens die met zijn pollepels en nappen aan de haal gingen. Het bericht maakt slechts melding van mensen die met bootjes toesnelden en in het water sprongen om voor de 'arme koopman' te redden wat er te redden viel. Uit romans, autobiografische aantekeningen, krantenberichten en debatten in de Tweede Kamer laat zich reconstrueren hoe Nederlanders de Duitse immigranten zagen en hoe de Duitse immigranten aankeken tegen de (vermeende) verschillen tussen hen en de Nederlanders. Uit dat materiaal - hoe fragmentarisch ook - komt een samenhangend beeld naar voren met een relatief grote continuïteit. Duitse immigranten werden vooral afgeschilderd als armoedig. Ondanks die continuïteit was het beeld gevoelig voor politieke veranderingen.

\section{Onopvallende Duitsers}

In het Utrechtsch Provinciaal en Stedelijk Dagblad van 15 juni 1892 verscheen een bericht over de arrestatie van enkele Duitsers.

De politie alhier heeft heden morgen in een bierhuis een paar Duitschers gearresteerd, die de aandacht trokken door het roekeloos omgaan met veel geld. De inspecteur Woldringh en de rechercheur Werkmeester, namen hen mede naar het bureau, waar bij fouilleering bleek, dat zij nog in het bezit waren van 900 mark in Duitsch geld en eenig Hollandsch bankpapier. Zij bekenden de Dresdener bank te Berlijn voor 1500 mark te hebben bestolen. ${ }^{6}$

Het krantenbericht is uitzonderlijk, omdat Duitse immigranten weinig figureren in het stadsnieuws. Duitsers waren de grootste groep vreemdelingen in Utrecht en in Nederland, maar een opvallende groep waren ze niet. Duitse immigranten lijken zelfs pogingen te hebben gedaan zo onopvallend mogelijk te zijn. Terwijl Franse gouvernantes en Franse kappers hun diensten in de lokale krant aanprezen in het Frans - de taal van de elite - kozen de Duitse immigranten voor het Nederlands. 'De heer T. PHL. Ermann, Duitscher van geboorte' liet in 1851 in de Utrechtsche Provinciale en Stadscourant weten dat hij 'met 1e October aanstaande zijne cursus in de Duitsche taal voor eerstbeginnenden en meer gevorderden [zou] hervatten'.7 Ermanns keuze was niet onlogisch, hij richtte zich immers tot mensen die het Duits nog moesten leren. Andere Duitse immigranten bedienden zich echter ook van de taal van het nieuwe land. Een koetsier uit Pruisen bood zijn diensten aan in het Nederlands. ${ }^{8}$ N. Güsbacher, een 'Dames Schoenmaker uit Mainz', prees in het Nederlands 'zijne wel gesorteerde kraam van 
Dames en kinderschoenen en laarzen op deze kermis het geëerde publiek aan. Geplaatst op het st. Janskerkhof met een S-bild boven de Kraam. ${ }^{9}$ De Duitse klokkenmaker Bunte adverteerde in december 1851 niet alleen in het Nederlands, maar benadrukte bovendien het feit dat hij Utrechts fabrikaat maakte.

De ondergeteekende heeft een buitengewoon zeer kunstig zamengesteld uurwerk vervaardigd [...] Dit Uurwerk is geen buitenlandsch werk, met een inlandschen naam bestempeld, om onkundigen daarmede te doen gelooven eigenmaaksel te zullen zien, zoo als wel meer het geval is geweest, maar dit Uurwerk is door den ondergeteekende zelf ontworpen en eigenhandig gemaakt, zoo dat hetzelfde met regt een Utrechtsch Fabricaat kan genoemd worden. ${ }^{10}$

Duitse klokkenmakers vormden in Nederland een herkenbare groep, maar Bunte gaf er de voorkeur aan het 'Utrechtsch Fabricaat' te benadrukken boven de Duitse traditie die in dit vak bestond.

Duitse immigranten traden het liefst niet als Duitser op de voorgrond. Een profilering als Duitser leverde, door de associatie met domheid en armoede, slechts weinig winst op. Er was echter ook een ander probleem. Voor de Duitse eenwording van 1870 zou identificatie als Duitser alleen kunnen stoelen op culturele identiteit en niet op politieke eenheid. Die culturele eenheid bestond wel; componisten, schrijvers, denkers en dichters waren de dragers van een collectieve Duitse cultuur. Niet alle Duitse immigranten identificeerden zich echter daarmee of werden ermee geïdentificeerd. Conrad Busken Huet laat zijn half-Italiaanse hoofdfiguur, dokter Ruardi, over de Duitsers zeggen:

De Duitsers praten van kultuurvolken, en zij houden zichzelf één daarvan. Ik mag het lijden, ofschoon het mij nooit is mogen gelukken, in de Duitse beschaving iets noemenswaardig te ontdekken wat niet van de Fransen of de Engelsen geborgd was. Indien de Duitsers werkelijk een kultuurvolk zijn, zijn zij het van nabootsing; hetgeen, let wel, in elk geval beter is dan, zoals wij, zelfs in de nabootsing niet uit te munten en traînards te zijn tot in de assimilatie toe. ${ }^{11}$

De negatieve mening van dokter Ruardi werd door de Nederlandse burgerij, die bekend was met het werk van Schiller en Heine, niet algemeen gedeeld. ${ }^{12}$

\section{'Wenn mir etwas zustösse'}

In 1853 kreeg de Duitse zilversmid Hermann Bauer, in het Zuidduitse Schwäbisch Gmünd, bezoek van 'ein Herr van Kempen aus Utrecht', die hem vroeg of hij in zijn fabriek wilde komen werken. Hermann Bauer beschreef zijn kennismaking met Utrecht, waarmee we over een uniek document beschikken. ${ }^{13}$ 
Van Kempen wist van Bauers bestaan via een van zijn werknemers, die vroeger met de Duitse zilversmid had gewerkt. Bauer vroeg bedenktijd; zijn moeder en andere familieleden maakten bezwaar. 'Wenn mir etwas zustösse, wenn ich krank würde, wäre ich hilflos usw.'. Bauer ging desondanks. Een reis naar 'Holland' werd in Bauers herkomststreek als een 'Ereignis angesehen [...] mehr noch ein Wagnis'. Het was een verre reis, maar de kosten werden tenminste door Van Kempen gedragen. 'Eisenbahnverbindung von uns aus mit diesem Lande gab es noch keine'. Bauer reisde per Rijnstoomboot, een lange reis en een tijdrovende onderneming. 'Somit ist Holland noch als ein sehr fernliegendes Land angesehen worden [...]' Na aankomst van zijn schip in Arnhem, nam Bauer de trein naar Utrecht. Hij reisde in de goedkoopste klasse, maar

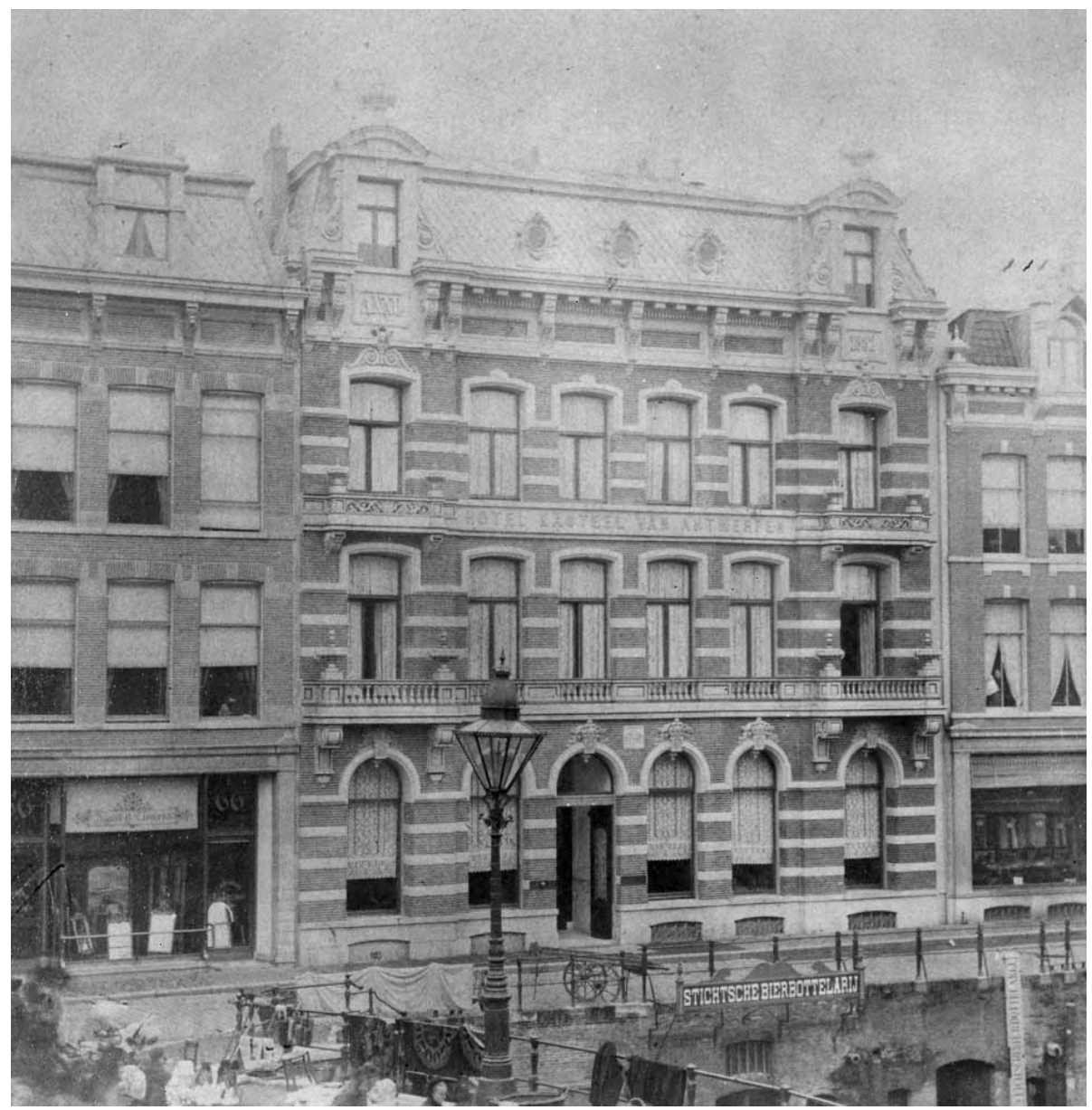

Hotel Het Kasteel van Antwerpen in 1885. In dit hotel vond Hermann Bauer onderdak toen hij voor het eerst in Utrecht arriveerde. Het ontging hem dat de eigenaars van het hotel en vier van de hotelbedienden Duits waren. Op de voorgrond de pottenmarkt waar de Westerwalders hun handel dreven. 
dat viel hem tegen. De wagen was open en de wind had vrij spel. Bauer meende reeds de scherpe zeelucht te voelen.

'Spät Abends kam ich in Utrecht an. Da ich keine Gelegenheit hatte, mich vorher wegen eines Gasthauses zu informieren, hatte ich Mühe jemand zu finden, der deutsch verstand, um mich nach einem der ersten Hotels zu erkundigen.' Een 'Bahndiener' bracht hem naar het hotel 'Het Oude Kasteel van Antwerpen'. Onderweg naar het hotel viel het hem vooral op dat de huizen zonder onderbreking als een lint aan elkaar waren gebouwd. Het hotel maakte een goede indruk. 'Auf meine Anfrage wegen Unterkunft hat man mir deutsch geantwortet.' Dat het hotelpersoneel Duits sprak, was een hele opluchting voor Bauer. Het ontging Bauer klaarblijkelijk dat de uitbaters van zijn hotel, Frederik Geuer en zijn vrouw Emilie Jaeger zelf Duitsers waren, evenals vier van de hotelbedienden. ${ }^{14}$

In de hotelkamer keek Bauer zijn ogen uit. Op de vloer lag tapijt en het hemelbed was in wit kant gehuld. In de eetzaal kreeg hij als 'Abendtee' een broodmaaltijd voorgezet, waarvan het gewicht, volgens Bauer, de tafel bijna deed doorbuigen Zijn tafelgenoot en de enige andere gast in het hotel, was een Duitse fabrikant op handelsreis. Ditmaal herkende Bauer wel een landgenoot in zijn gesprekspartner. 'Derselbe bereiste geschäftlich schon eine geraume zeit Holland und hat mich mit seiner Darlegungen auf manches Wissenswerte aufmerksam gemacht.'

De volgende ochtend bekeek Bauer op weg naar zijn werk de stad. Behalve de hoge Domtoren trok de Oudegracht zijn belangstelling, door hem omschreven als een zeer brede straat met een kanaal in het midden. Bauer merkte op hoe praktisch het was dat het kanaal zo'n lage waterspiegel had, met een laaggelegen weg erlangs, waardoor goederen direct van het water in de kelders konden worden gebracht.

Bauer meldde zich bij zijn nieuwe werkgever en werd vriendelijk ontvangen. De bedoeling van de fabrikant was dat Bauer 'seine noch nicht sehr bedeutende Silberwarenfabrik und Schmuckwarenfabrikation' zou 'vergrössern, wozu ich ihm für die erforderlichen technischen Einrichtungen behilflich sein solle.' Bauer was wat teleurgesteld door de inrichting van de fabriek. De stoommachine was er vooral om indruk te maken; het werk werd merendeels met de hand gedaan. Zijn werkruimte was provisorisch ingericht. De verhoudingen in het bedrijf, waar 25 mensen werkten, noemde Bauer in lovende zin patriarchaal. Koffie en thee waren er in overvloed en werden geleverd door de baas. De werknemers namen hun 'trockene Frühstück' van huis mee. Iedereen had drinkgerei dat nog het meest leek op een wasteil, welke tot de rand toe volgegoten werd met koffie. De koffieketel was zo groot, dat men er een kind in kon baden. Het meest verbaasd was Bauer echter over het feit dat de 'Kabinettmeister' voor het ontbijt met een lessenaar verscheen, daarop een bijbel legde en een hoofdstuk voorlas. Pas daarna werd er ontbeten. 'Ueberhaupt ist in Holland der Brauch, wenn jemand nur ein Butterbrot isst, legt er vor dem Verspeisen die Hände zusammen.'

$\mathrm{Na}$ enige dagen wilden zijn collega's hem helpen een 'Wohnung mit Verplegung' te vinden. Dat lukte niet meteen. In de tussentijd verhuisde Bauer naar een iets minder duur gasthuis dat 'tot de Postpaarden' heette. Daar bleef hij enkele weken. De taal werd 
nu wel een probleem. 'Hatte im ersten Hotel jedermann deutsch gesprochen, ging es im zweiten stockholländisch her, was bei der gegenseitigen Verständigung zu den drolligsten Auseinandersetzungen führte.' Bauer had met het Nederlands veel moeite. Lezen lukte wel, maar verstaan was lastiger.

Die holländische Sprache, hauptsächlich in der Schrift, ist eben ein in sich abgeschlossenes Plattdeutsch und nicht schwer zu erlernen, allein im Sprechen mit seinen vielen Kehllauten ist sie für einen Neuling total unverständlich. Die Auseinandersetzungen waren oft zum Totlachen.

De logementhoudster imiteerde kakelend en fladderend een leggende kip, om duidelijk te maken dat ze vroeg hoeveel eieren hij bij zijn ontbijt wilde. Na enkele weken verhuisde Bauer naar, zoals hij het noemde, een studentenhuis op de Neude. De woning bestond uit twee kamers met opnieuw, tot zijn verbazing, tapijt op de vloer en goed gemeubileerd. Zijn huisbaas heette Bockhofen en was kapper.

Bauer was tevreden en schreef aan zijn moeder hoe goed het hem ging. Hij schreef ook veelvuldig aan 'Freund' Gustav Bauer in Berlijn. ${ }^{15}$ Op verzoek van Gustav informeerde Hermann Bauer of er misschien ook voor hem mogelijkheden waren bij Van Kempen en kort daarop kwam 'Freund' Gustav naar Utrecht en nam zijn intrek in de kamers van Hermann Bauer. Gustav kwam met enige dagen vertraging in Utrecht aan. Hij was namelijk te voet door de Harz gereisd; hij was platzak en had onderweg geld moeten lenen. Hij reisde met de zekerheid dat Hermann Bauer onderdak en werk voor hem had geregeld.

Gustav en Hermann Bauer volgden in de wintermaanden in Utrecht samen een cursus tekenen en modelleren. Beide Duitsers waren bij hun medeleerlingen niet zo geliefd 'als Ausländer' en vanwege hun 'hervorragenden Leistungen. '[... es kam sogar gewisser Hass zum Ausdruck.' Gustav en Hermann Bauer wilden enige tijd in Utrecht blijven en dan over Brussel naar Parijs reizen. De beide Bauers raakten echter steeds meer opgenomen in de Utrechtse samenleving, waardoor hun plan veranderde. De sociale contacten die ze opbouwden, vooral via hun huisbaas, waren daar debet aan.

Het begin van deze contacten lag, volgens Bauer, in het in Utrecht ontbreken van bier- en wijnschenkerijen zoals hij die in Zuid-Duitsland kende. 'Das Leben spielte sich in den Familienkreisen ab. Wenn bei einem Fremden ein gewisses Misstrauen überwunden u. derselbe als ein "Versoenliker [fatsoenlijk] Mensch" anerkannt war, und einmal in einer Familie eingeführt gewesen ist, dann gab es den Verkehr mit Freunden u. Verwandten'. De Nederlanders waren buitenshuis stug en onbenaderbaar, maar binnenshuis spontaan en uitgelaten. Een ongedwongen omgang was er ook tussen jongens en meisjes. 'Besonders diese Art der Annäherung hat mir bald sehr conveniert, als ich einigermassen die Sprache beherrschte.' 'Freund Gustav' toonde voor een van de dames bijzondere belangstelling. Vrienden en kennissen van haar bevorderden vervolgens die relatie. 'Der kaufmännische Geist, den das ganze Leben in Holland durchdringt, macht sich sogar auch in Liebesangelegenheiten geltend.' Gustav Bauer kon- 
digde tegenover Hermann zijn huwelijk aan. 'Die Sonne der Liebe hatte den Mond der Freundschaft total verdunkelt'. Hermann Bauer vond het leven in Utrecht niet meer zo leuk. Van Kempen betaalde minder dan Hermann Bauer zich waard achtte en de kosten van levensonderhoud waren zo hoog dat hij niets aan zijn moeder kon sturen. Hij besloot alleen de reis naar Brussel en Parijs te maken. Hij schreef aan een 'Graveurgeschäft' in Brussel, waarvan hij toevallig het adres had, maar kreeg geen antwoord. Later bleek dat het Belgische bedrijf bij Van Kempen had geïnformeerd naar zijn vaardigheden en dat zijn baas een negatief beeld van hem had geschetst. Hermann Bauer reisde desondanks in 1854 via Brussel en Parijs naar Duitsland, vestigde zich uiteindelijk als sieradenfabrikant in Pforzheim en vanaf 1867 in Schwäbisch Gmünd. ${ }^{16}$

Nederland was in Bauers ogen ver weg. Er was een cultuurverschil en het aanzien van de stad was anders dan wat hij kende. De Nederlandse taal was moeilijk te verstaan. In zijn eerste hotel was hij onder de indruk van de rijkdom: het kant rond het bed en een copieuze maaltijd. Zijn werkgever was gul met koffie en thee. De outillage van de fabriek vond Bauer minder dan hij gewend was, zijn eigen kennis en vaardigheden schatte hij hoger in dan die van zijn Nederlandse vakgenoten. Dat laatste leidde tot wrijving. De Nederlanders die hij tegenkwam waren behulpzaam, maar op het persoonlijke vlak gereserveerd. Een sociaal leven buitenshuis, in de kroeg, ontbrak. De Nederlanders waren zakelijk, ook waar het de liefde betrof en het sociale leven was, volgens Bauer, doortrokken van een koopmansgeest. Tegelijkertijd waren de Nederlanders religieus: zelfs voor het eten van een boterham in de fabriek werd er gebeden.

Bauers ervaringen waren niet noodzakelijkerwijs dezelfde als die van andere Duitse immigranten. Schwaben was een typisch gebied, met een dialect dat vrijwel onverstaanbaar was voor mensen die Hoogduits spraken. Een groot deel van de Duitse immigranten in Utrecht kwam uit streken die dichter bij Nederland lagen en waar Platduits gesproken werd, dat meer op het Nederlands leek. Bauer zette bovendien zijn herinneringen aan Utrecht pas in 1913 op papier. Zijn relaas kan zijn beïnvloed door de veranderingen die ondertussen hadden plaatsgevonden. Versterking van de Duitse identiteit door de Duitse eenwording kan ertoe hebben geleid dat hij verschillen meer aanzette. Niet iedereen voelde de verschillen zo sterk als Bauer. In de roman Das Mädchen von Utrecht, brengt de Duitse hoofdpersoon Mathijs tegenover zijn nieuwbakken Utrechtse vriendin het verschil tussen Duitsland en Nederland onder woorden:

\footnotetext{
"Nun," sagt Mathijs, "dies Land ringsum ist weiblich, und das, aus dem ich stamme, männlich. Strenger, härter und doch dasselbe Land. Drüben ist der Rhein noch einig, hier zerteilt. Und die Möwen fliegen zuweilen bis nach Köln!"'17
}

Er was, volgens Mathijs, verschil tussen Duitsland en Nederland; Nederland was vrouwelijk, Duitsland mannelijk. Het verschil was echter naar zijn idee niet zo heel grootveel minder groot dan Bauer meende - en de meeuwen vlogen van Utrecht naar Keulen. Voor hen was er geen grens. 
In Bauers indrukken van zijn nieuwe woonplaats, zien we de ideeën weerspiegeld die in Nederland omtrent de Duitse nieuwkomers bestonden. Nederlanders vonden Duitsers dom en Duitse immigranten ergerden zich aan de Nederlandse hooghartigheid en de minachting van hun vaardigheden. Bauer miste de kroeg en de Nederlanders maakten zich vrolijk, zoals we nog zullen zien, over het kroegbezoek van de Duitse immigranten.

\section{Laat je daar opknopen!}

In een Gronings liedje uit 1823 werd de spot gedreven met drie Duitse immigranten, die een glaasje zaten te drinken,

En pochten op ihr Vaters Haus

En op 't viel besser Leben

Bij heur te lande, en dat ihr Wein

Kwam van viel zeuter Reben

De Duitsers pochten over hun vaderland, waar het leven beter was en de wijn werd gemaakt van zoetere druiven. De Nederlandse toehoorder raakte geïrriteerd:

Körtom, hier deugde 't alles niks;

Ik kon 't nijt langer heuren,

En 'k zee: “jij loeders! Is 't zo fiks

Bij jou, hou kon 't dan beuren

Dat jij zoo geern hier wonen wilt,

En komt bij ganse hopen?

Wie ropt jou hier - loopt na jou land,

En laat je daar opknoopen."18

Als het zo goed was bij jullie, wat doen jullie dan hier, vroeg de boze toehoorder. Het Groningse liedje stond niet op zichzelf. Van Maurik liet een knecht zeggen:

Och, weet je meneer, 't waren eigenlijk nog niet heelemaal menschen, ik heb ze altijd voor een soort halfgare kaffers gehouden. Grooter uilen bestonden er niet, dom als 't achterend van een varken en ze roken, met uw's permissie ook niet machtig veel beter. ${ }^{19}$

Van Mauriks opmerking dat Duitse immigranten stonken, komen we ook tegen in andere, oudere bronnen. In een achttiende-eeuwse klucht ging het over Trien, 'een Westfaalsche Boterbloem, die naar de koestront riekt'. In de klucht werd voorgesteld om het 'Moffenlijk gebroed een bijzondere Wijk' te geven in de stad 'met de naam Moffen- 
wijk' ${ }^{20}$ In de negentiende-eeuwse roman Onder de pannen gaat het ook om stinkende Duitsers. Drie reizigers maken hun entree in een volkslogement en worden begroet door de vaste bewoners, met de bijnamen Vrouwendief en Krakepoot.

\begin{abstract}
"Sind wir hier terecht?" vroeg de oudste, zich voorstellend: "Wilhelm!" "Moffen!” snoof de Vrouwendief, in zijn neus knijpend om z'n afkeer duidelijk te maken [...] "Ich pien Schweitser!" corrigeerde de verdachte ... "Ja, dat kennen we," gromde Krakepoot. "Zwitserland heeft nog nooit zoveel inwoners gehad als tegenwoordig!"21
\end{abstract}

Het verwijt van stinken of onreinheid is een klassiek onderdeel van de demarcatie tussen de wij- en de zij-groep. ${ }^{22}$ Opvallend is de reactie van de reiziger die zich verweerde door zijn Duitse identiteit te ontkennen.

Volgens de volkskundige Theo Meder, die onderzoek deed naar de Poepenmoppen, ligt de functie van grappenmakerij over Duitse vreemdelingen voor de hand. De verhalen creëerden bij verteller en publiek een gevoel van saamhorigheid, dat een als 'vreemd', 'anders' en 'minder' ervaren groep buitensloot. Verteller en publiek konden zich, bij zoveel domheid, aangenaam wentelen in hun eigen intelligentie en superioriteit. ${ }^{23}$ De vraag is of de grappen inderdaad deze functie vervulden, en om het onderscheid tussen welke twee groepen het dan ging. De beeldvorming ten aanzien van de Poepen hoeft bijvoorbeeld niet te hebben gegolden voor Duitse ambachtslieden en handelaren in steden. Het woord 'Poepen' was immers oorspronkelijk een aanduiding voor seizoensarbeiders op het platteland. Niet alle Duitse immigranten waren Poepen en dus werden ze evenmin noodzakelijkerwijs allemaal begrepen onder dezelfde beeldvorming.

Tussen Duitse immigranten uit verschillende regio's werd in de negentiende eeuw wel degelijk onderscheid gemaakt. Met het bijvoeglijk naamwoord 'Westfaalsch' werd in de negentiende eeuw eerder plomp en bedrieglijk bedoeld, dan dom. ${ }^{24}$ 'Sauger' was een iets neutralere term, waarmee zowel de koopman als zijn Duitse pijp werden aangeduid. 'Sauger' refereerde aan het lurken aan de lange pijp, maar tegelijkertijd had het woord de connotatie van zuiger en uitzuiger. ${ }^{25}$ Mensen uit Pruisen waren dan eerder streng en somber. Alex van Nancy schreef over rondtrekkende handelaren:

Een Pruis met loerende oogen, en sombere plooi op 't voorhoofd, de tronie van een menschenhater, volgt met een heele rits muizenvallen en van ijzerdraad in elkaar geknutselde driepootjes op zijn rug. ${ }^{26}$

De handel van de 'Pruis' was niet erg lonend en de andere logementengasten maakten hem daarom uit voor stommeling. 
Dat ie 'n "stommeling" was, liet de nijdige Pruis zich zoo maar niet aanleunen. Hij vloog schuimbekkend overeind, greep een stoel, en zwaaide dezen boven 't hoofd van zijn lotgenoot, die den slag nog tijdig wist te ontwijken. ${ }^{27}$

De 'Pruis' was, volgens Nancy, streng, somber en agressief.

De aanduiding Moffen, die voor Duitsers werd gebruikt, had in de negentiende eeuw een andere betekenis dan ze in en na de Tweede Wereldoorlog zou krijgen, maar een scheldnaam was het wel. Mof was afgeleid van het Duitse 'muff'; een aanduiding voor een knorrepot, mopperaar of iemand die onbeleefd, ongemanierd en niet erg spraakzaam was. In de zeventiende eeuw werd het woord vooral gebruikt als een negatief geladen aanduiding voor Duitse soldaten. In de negentiende eeuw was het scheldwoord minder scherp. ${ }^{28}$ Het werd gebruikt in een zeer brede en neutrale betekenis; Hollanders duidden er ook de bewoners van de Oost-Nederlandse provincies mee aan. In 1913 meende een redacteur van het Woordenboek der Nederlandse Taal zelfs, dat de term geheel vrij was van minachting. ${ }^{29}$ Pas in de Tweede Wereldoorlog herkreeg het woord de eerdere negatieve klank.

Er werd enig onderscheid gemaakt tussen Duitse immigranten met een uiteenlopende achtergrond, maar erg verfijnd was dat onderscheid niet. Volgens Van Maurik was Poepen in de tweede helft van de negentiende eeuw verworden tot een scheldnaam voor

allerlei slag van Duitschers, die, vooral in dien tijd, ons land plachte te doorkruisen met koopwaar van verschillende aard enz. Dus niet slechts voor Hannekemaaiers, maar o.a. ook voor marskramers, pottenventers, ketellappers, straatmuzikanten, oliekoopen (kwakzalvers) enz. Slechts weinigen van hen spraken een verstaanbaar woord Hollandsch; de spraakmakende, sarcastische gemeente maakte het woord "poepen" voor hen allen communis generis. ${ }^{30}$

\section{Arme Duitsers}

De negentiende-eeuwse beeldvorming sloot aan bij die in zeventiende- en achttiendeeeuwse kluchten, waarin Duitse immigranten werden voorgesteld als domme, lompe drinkebroers, of omhooggevallen mannen en vrouwen die hun afkomst vergaten of probeerden te verdoezelen. ${ }^{31}$ In de Vroegmoderne Tijd werd een groot aantal Moffenkluchten geschreven, die veelvuldig werden opgevoerd, ook nog in de negentiende eeuw. ${ }^{32}$ Ofschoon de kluchten een wijde verbreiding kenden, waren ze vooral een Hollands en stedelijk fenomeen.

Één element uit de eerdere beeldvorming kende een lang leven. In de zeventiende eeuw schreef Samuel Coster, dat Duitse immigranten op een 'stroo-wis' over de Rijn waren komen aandrijven. ${ }^{33}$ Armoedzaaiers waren het, gekomen in de hoop een graantje mee te pikken van de Hollandse of Nederlandse welvaart. De strowis werd een cliché 
dat tot in de jaren vijftig van de twintigste eeuw werd herhaald. ${ }^{34}$ De kale moffen, blaaspoepen, pottenverkopers, branderknechts en klokkenmakers, zo herhaalden tal van schrijvers, waren eeuwenlang een gemakkelijk voorwerp van spot en hoon, waarbij keer op keer de strowis werd genoemd. ${ }^{35}$

De Pruisische legers, die in de jaren 1786-1787 door de stad Utrecht trokken en ook elders in Nederland hun opwachting maakten, verbeterden het imago van de Duitsers, dat in de voorafgaande periode was opgebouwd, niet. 'De Pruisen gevoelden zich in het rijke Holland spoedig op hun gemak, en waren, gelijk men hun destijds reeds nagaf, niet beschroomd om, als het lukken kon, zich eens anders goed toe te eigenen. ${ }^{36}$ Arm, dat waren de nieuwkomers, en uit op de Nederlandse welvaart. Straatjongens zongen:

Op een stroowisch aangedreven

uit een schraal en arm kwartier

Zeg, wat doen die Pruisen hier?

'k Weet niet wat dat moffengoed

in ons goede Holland doet. ${ }^{37}$

De twintigste-eeuwse beeldvorming voegde aan de negentiende-eeuwse een nieuw element toe. De historicus Rogier schreef in 1962, met de Tweede Wereldoorlog nog vers in zijn geheugen, over de midden negentiende-eeuwse medicus-journalist J.W. Cramer (1817-1884):

Jan Willem Cramer vertegenwoordigde heel duidelijk het overrompelend en soms wat aanmatigend Duits immigrantendom, dat zich in heel Nederland door stugge, degelijke vlijt van de achtergrond der naamlozen in een of twee generaties naar voren heeft weten te dringen om daar een vrijwel onbestreden eerste plaats in te nemen. ${ }^{38}$

Rogier ging uitvoerig in op de geschiedenis van de familie Cramer omdat hij daarin een voorbeeld vond van 'Duitse bloedsmenging', die een belangrijke bijdrage had geleverd aan 'de opbouw van het katholieke volksdeel'. ${ }^{39}$ Dat katholieke volksdeel bestond, volgens Rogier, voor een groot deel uit Duitse immigranten of nakomelingen daarvan. Antipapistische en anti-Duitse sentimenten vielen bij hem samen. Volgens Rogier geneerden de Duitse immigranten en hun nakomelingen 'zich meestal voor hun afkomst en ontveinsden die, waar ze konden. De neiging bleek erfelijk. ${ }^{40}$

De negatieve beeldvorming ten aanzien van de Duitse nieuwkomers, droeg in Rogiers optiek bij aan een snelle assimilatie in de Nederlandse samenleving. Een Duitse afkomst was immers niet iets om je op voor te laten staan.

De kinderen der Duitse immigranten trachtten daarentegen angstvallig hun afkomst te doen vergeten. Het is echter begrijpelijk, want de vroeg-zeventiendeeeuwse Amsterdamse spot met de Brabantse botmuilen [...] is zachtmoedig en 
kortstondig geweest, vergeleken bij de hardnekkigheid, waarmee de Noordnederlanders van Thomas Asselijn af tot Justus van Maurik toe de tallozen verguisden, die op een houtvlot of op een strowis de Rijn waren komen afzakken. Een Fransman mocht wuft en gekunsteld zijn, een Engelsman hooghartig en kurkdroog, een Mof was arm en kaal en niets moet in het oog van een volk, dat de eerbied voor de oude kous was ingeboren, groter smaad geweest zijn. ${ }^{41}$

Rogier veronderstelde dat negatieve beeldvorming bijdroeg aan snelle integratie. Dat is opmerkelijk. De beeldvorming omtrent joden en zigeuners was in de negentiende eeuw en eerder evenmin positief, maar hun integratie lijkt er niet door te zijn bevorderd, integendeel. Rogiers mening lijkt hiermee in tegenspraak. De Amerikaanse onderzoekster Karmela Liebkind heeft er echter op gewezen dat negatieve beeldvorming twee tegengestelde gevolgen kan hebben. Immigranten die behoren tot een groep die onderwerp is van negatieve beeldvorming, kunnen de eigen groep (proberen te) verlaten en zich sterk met de ontvangende samenleving identificeren. Of ze kunnen hun gevoel voor eigenwaarde proberen te redden, door zich juist van de meerderheid af te keren en verschillen en groepsbanden te versterken. ${ }^{42}$

Rogiers relaas werd gekleurd door de Tweede Wereldoorlog en doet nu clichématig aan. De weinig positieve toon vinden we echter eveneens in negentiende-eeuwse bronnen. Het feit dat er ook rijke en geslaagde Duitse immigranten waren, deed aan de beeldvorming niets af. Duitse immigranten konden moeilijk aan de beeldvorming ontsnappen. De Duitse historicus Tack schreef in 1902, dat Duitse trekarbeiders door Nederlanders werden beschouwd als bijgelovig, minderbegaafd en traag van begrip. 'Diese soziale Missachtung erhielt sich, trotz aller wirtschaftlichen Wertschätzung, bis in das 19. Jahrhundert. ${ }^{43}$ De economische vooruitgang van Duitsland kon aan de minachting geen einde maken. De nadruk op de armoede van de Duitse nieuwkomers overheerste in de hele negentiende eeuw. In 1843 schreef de burgemeester van Assen over de Duitse arbeiders: 'Door zich hier op te houden, en dikwijls te vestigen, vermeerderen zij de armoed in dit Rijk, als voor de eigene ingezetene de middelen van bestaan innemend, daardoor berooven. ${ }^{44}$ De Duitse trekarbeiders waren arm en bovendien waren ze goedkope concurrenten van de Nederlandse bevolking.

Van Maurik zette daar, ondanks al zijn spotternij met de Duitsers, toch ook een ander beeld naast:

't Is toch wel eigenaardig, dat de Duitschers zich hier overal zoo inwerkten. De beste slagers, de knapste stukadoors, de suikerbakkers, kwamen uit Duitschland, de bakkers ook veelal, maar de roggebroodbakkers waren allemaal moffen. ${ }^{45}$

De historica Leonie van Nierop, die in dezelfde periode schreef als Van Maurik, gaf een min of meer vergelijkbare typering. ${ }^{46}$ Bij haar waren de Duitsers niet dom of lui. Concurrenten waren het evenmin. 
De niet in de stad geboren arbeider is [in 1850] veelal uit Duitschland gekomen. De bakkers, slagers, stukadoors zijn vooral Duitschers. Duitschland is in dezen tijd nog een arm land, de arbeidskracht zijner bewoners vindt in het land zelve geen voldoende veld, en het schijnt dat de Nederlandsche werkman van die dagen voor bovengenoemde beroepen of weinig geschiktheid of weinig neiging heeft. ${ }^{47}$

Volgens Van Nierop deden de Duitse immigranten het werk dat Nederlanders niet wilden of konden doen.

\section{'Bij de tegenwoordig overal heerschende revolutie-koorts'}

De felle debatten, die in 1849 in de Tweede Kamer werden gevoerd bij de introductie van de Vreemdelingenwet, reflecteerden, bevestigden en versterkten de beeldvorming die er omtrent Duitse immigranten bestond. Het debat werd niet in kleine kring gevoerd; verslagen van de kamerdebatten werden, integraal of samengevat, gepubliceerd in alle grote Nederlandse kranten.

De revolutie van 1848, die Europa beroerde, was samen met de vrees voor de komst van Duitse armlastigen aanleiding voor de introductie van de Vreemdelingenwet. Die vrees werd versterkt door de heersende voedselcrisis en duurte. Het kamerlid Godefroi, afgevaardigde voor Amsterdam, meende:

Ik wil geene gastvrijheid, waardoor Nederland een toevlugtsoord zou worden voor de woelzieken en onruststokers, die andere landen uitwerpen, - een algemeen armengesticht voor de behoeftigen, de bedelaars, de landloopers van alle oorden der wereld. ${ }^{48}$

Op deze beeldvorming kwam, bij de bespreking van het wetsvoorstel, ook kritiek. De regering had met het opstellen van de wet, zo luidde het verwijt van de Commissie van Rapporteurs, uitsluitend het weren van behoeftige vreemdelingen op het oog. 'Men bestempelde daarom haar voorstel met den naam van eene bedelaars- en vagebondenwet. ${ }^{39}$ Dat was echter niet de wet die was gevorderd.

Bedelarij en landlooperij zijn, volgens de nog bestaande strafwetgeving, delicten [...]. Ieder persoon, die aan landlooperij schuldig wordt verklaard, kon onder de bestaande Grondwet, indien hij een vreemdeling is [...] over de grenzen worden gebragt. ${ }^{50}$

Een nieuwe wet op deze gronden was dus volgens de Commissie overbodig. Het kamerlid Costerus was het daar niet mee eens. De situatie had zich gewijzigd en er waren 'thans duizenden onzer landgenooten zonder werk en brood'. ${ }^{51}$ Nieuwe armen kon Ne- 
derland nu zeker niet gebruiken. Vreemde armlastigen moesten worden geweerd, maar dat was, volgens een groot deel van de kamerleden, niet eenvoudig onder de vigerende wetgeving. De gemeentebesturen maakten niet alleen, zo vonden meerdere kamerleden, bij het weren van vreemde landlopers grote kosten, maar deze kosten waren bovendien ook vaak tevergeefs.

Is men het dan vergeten hoe naburige regeringen de behoeftigen, van hier verdreven, weigeren te ontvangen, hoe dikwerf, na uren of dagen reizens, de teruggedreven vreemdeling op nieuw ons grondgebied betreedt om daar voortdurend tot last onzer armenkassen te strekken? ${ }^{52}$

De vreemdelingen werden over de grens gebracht, maar keerden spoedig daarop weer in Nederland terug. In de kamerdebatten ging het niet alleen over armlastige vreemdelingen, maar ook over criminele.

Men sla eens de registers van ons strafregt op, om te zien hoeveel crimineel veroordeelden daarop voorkomen. Men raadplege eens de ondervinding in de grens-provinciën, welk een geweldigen overlast men daar heeft van die vreemde indringers en vagebonden; een last die des daags en des nachts gevoeld wordt, maar vooral des nachts regt drukkend kan genoemd worden..$^{53}$

Probleem met immigranten uit Pruisen was dat zij naar Nederland kwamen met een zogenaamde Auswanderungs-Pass. Wanneer een migrant de regering om een dergelijke pas vroeg, kon hij of zij bij eventuele terugkeer geen aanspraak meer maken op onderstand. Door het aanvragen van de pas werd de migrant 'aus dem Untertanen-Verband entlassen' en was dus niet langer een inwoner van Pruisen. 'Wanneer de Pruissische ingezetene eenmaal hier met zoodanigen pas is opgenomen, dan is voor hem onze nabuur Pruissen omringd als met een Chineesche muur, en er is geen mogelijkheid den eens toegelatene terug te zenden. ${ }^{54}$

Men vrage eens hoe of onze armbesturen gedrukt worden door het onderhoud van vreemdelingen, van Duitschers die zich zes jaren in het land hebben weten staande te houden. Men vrage eens aan de gemeentebesturen tot welk eene correspondentie, tot welke onkosten en uitgaven het vervoer van vreemdelingen, die over de grenzen moeten gebragt worden, aanleiding geeft, omdat men ze niet dadelijk aan de grenzen kon weren. ${ }^{55}$

Duitse immigranten waren potentieel armlastig en als ze er eenmaal waren, gingen ze niet meer weg, zo meende een groot deel van de kamerleden. De toestand van dat moment was echter uitzonderlijk, zeiden sommigen. Politieke onrust buiten de landsgrenzen, toename van het aantal vreemde bedelaars en landlopers en pauperisme in ei- 
gen land vielen samen. ${ }^{56}$ Daarom was een nieuwe wet noodzakelijk. Het kamerlid Hengst merkte op:

Dat ten slotte de arm- en gemeentebesturen verpligt zijn eene menigte vreemdelingen te onderhouden [...] Ziedaar de uitwerking van de thans bestaande gastvrijheid! ${ }^{57}$

Hij vroeg aandacht voor de keerzijde van de Nederlandse gastvrijheid

voor den armen Nederlandschen burger: - hij ziet den vreemdeling het brood eten, waarop hij als Nederlander aanspraak had; door het uitputten der armenfondsen, wordt hij in eenen poel van ongelukken gestort en moedeloos staart hij op de toekomst. ${ }^{58}$

Naast vrees voor horden armlastige vreemdelingen, gaven sommige kamerleden blijk van waardering voor het werk dat Duitse immigranten in Nederland deden. Waardering en angst voor verdringing wisselden elkaar af. De Commissie van Rapporteurs stelde dat de wet moest worden gezien als een preventieve maatregel

tegen het binnendringen van behoeftige vreemdelingen, die hier te lande door handenarbeid hun levensonderhoud trachten te verdienen, maar niet zelden aan inboorlingen uit de arbeidende klassen op eene voor dezen belemmerende wijze in den weg staan. Men heeft echter begrepen, dat wij door zulke preventieve maatregelen onregt aan ons zelven zouden plegen; dat men langs dien weg menschen zou weren, die hunnen arbeid tot lageren prijs aanbieden, dan dien men voor dezelfde verrigtingen aan inboorlingen moet betalen; en dat het uit meer dan één oogpunt nuttig en noodzakelijk is, vreemde arbeid aan onze nijverheid te verbinden, gelijk die dan ook te allen tijde, tot groot voordeel van den lande, daaraan is verbonden geweest. ${ }^{59}$

De vreemdelingen waren goedkope arbeidskrachten, die mogelijk de Nederlandse arbeiders concurrentie aandeden, maar die men toch niet graag wilde missen omdat ze de economie tot voordeel strekten. De nieuwe wet moest niet tot gevolg hebben dat deze goedkope arbeidskrachten uit Nederland wegbleven. Het kamerlid Godefroi verwoordde dat standpunt nadrukkelijker dat de Commissieleden.

Er zijn vreemdelingen, die jaarlijks hierheen trekken tot uitoefening van zekere beroepen of werkzaamheden, die, in het belang van handel, nijverheid en landbouw, alleen door die vreemdelingen verrigt kunnen worden omdat deze hiertoe sedert jaren gebezigd zijn en onze eigen landgenooten de bekwaamheid daartoe missen. Ik heb het oog op de vreemde grasmaaijers, turfgravers enz. Ik geloof, dat het in het belang van handel, nijverheid en landbouw noodig is, dat 
het de personen, welke ik hier bedoel ontslagen worden van moeijelijkheden in de toelating. ${ }^{60}$

De kwaliteiten van deze immigranten werden positief gewaardeerd. Het was geenszins de bedoeling van de regering om deze groep vreemdelingen de toegang tot Nederland te ontzeggen. Volgens sommige kamerleden zou de wet ook niet zo uitwerken.

[...] ook de door sommigen geuite vrees voor willekeur ten aanzien der zoogenaamde hannekemaaijers kan ik niet delen. In dit opzigt bestaat geenerlei gevaar. Die lieden komen jaarlijks niet te sluik maar met geheele troepen binnen, doorgaans met viool of klarinet voorop; zij zijn als het ware habitués in ons land, maar ook slechts tijdelijke gasten, veelal bij dezelfde landgebruikers werkzaam. De meesten hunner zijn van vader op zoon bij de ingezetenen der grensgemeenten bekend $[\ldots]^{6}{ }^{6}$

Tijdens de besprekingen bestond er een consensus over het feit dat de vreemde land- en fabrieksarbeiders, die jaarlijks naar Nederland kwamen, niets in de weg moest worden gelegd. Vreemde armoedzaaiers moesten wel worden geweerd.

De onveiligheid van personen en goederen ten platten lande [... laat in sommige der provinciën nog voordurend maar al te veel te wenschen over. Naar evenredigheid is het aantal Duitsche landloopers, die aldaar wegens misdrijven tegen de openbare veiligheid gestraft worden, zeer groot. De armbesturen in de plaatsen aan de grenzen bezwijken onder den last van vreemdelingen, die zij moeten bedeelen. Het kwaad is te erger, omdat regeringen van naburige rijken maar al te gemakkelijk zijn in het afgeven van passen aan behoeftigen, en het verhuizen van dezen naar Nederland opzettelijk aanmoedigen $[\ldots]{ }^{62}$

Behalve voor de toestroom van vreemde bedelaars en landlopers werd ook gevreesd voor de komst van vreemdelingen met andere motieven.

[...] wie hebben wij nu te wachten? Socialisten, die bij verdeeling van goederen slechts kunnen winnen; woelgeesten, die voordeel zoeken in omverwerping van den Staat. ${ }^{63}$

De 'mannen in blauwe kielen' - waarmee de bedelaars uit Pruisen werden bedoeld werden evenzeer gevreesd als 'Proudhon' - de Franse revolutionairen. De dreiging werd aangewakkerd door verbetering van de reismogelijkheden, meende het kamerlid Van Heiden Reinestein

[...] dat het bij de tegenwoordig overal heerschende revolutie-koorts en bij de versnelde middelen van vervoer, ten gevolge waarvan een massa kwaadwilligen 
of onruststokers zich zoo spoedig op een gegeven punt kunnen vereenigen om de vlam des oproers aan te blazen en hunne misdadige plannen te verwezenlijken, thans dubbel gewigtig is zulke maatregelen ter beteugeling in het werk te stellen $[\ldots] .{ }^{64}$

De dreiging die Van Heiden Reinestein en andere kamerleden voelden, kwam mede voort uit een demonstratie die op 24 maart 1848 plaatsvond op de Dam in Amsterdam. De leiders van een slechts uit enkele tientallen leden bestaande vereniging van Duitse communisten hadden een oproep doen uitgaan naar ambachts- en werklieden. Zo'n tweeduizend mensen gaven aan de oproep gehoor, maar onder hen was een groot aantal op rellen beluste, opgeschoten jongens. Zij namen geen deel aan de demonstratie, maar trokken plunderend en ruiteningooiend door de stad. ${ }^{65}$ Het effect van de oproep van de Duitse communisten was niet zoals zij hadden beoogd. Het gevolg was wel vrees voor revolutie en de rol die vreemdelingen daarbij zouden kunnen spelen.

\section{'Bekwame handwerkers uit het buitenland van Roomsch Katholijken belijdenis'}

Op 4 maart 1853 werd met de pauselijke breve Ex qua die de Nederlandse kerkprovincie opgericht. Utrecht werd aangewezen als zetel van de aartsbisschop. Dit wekte ongenoegen onder de protestanten en leidde tot een golf van protest die wordt aangeduid als de Aprilbeweging. Deze beweging had vooral in de stad Utrecht veel aanhang. ${ }^{66}$ Op het hoogtepunt van de Aprilbeweging werd niet alleen lucht gegeven aan antikatholieke sentimenten, maar ook aan anti-Duitse. Anti-Belgische gevoelens traden minder op de voorgrond. De Belgische immigranten waren weliswaar ook katholiek - net als een deel van de Duitsers - maar ze waren minder talrijk. Wel liet de protestantse vereniging Unitas zich in positieve zin uit over de eerdere afscheiding van België, omdat daardoor de getalsmatige verhouding tussen katholieken en protestanten in het voordeel van de protestanten verschoof. ${ }^{67}$

Koning Willem II kreeg op 15 april 1853 in de Domstad een petitie met 200.000 handtekeningen overhandigd, met het verzoek zich te keren tegen het besluit van Rome om van Utrecht een aartsbisdom te maken. De welwillende reactie van de vorst tegenover de aanbieders leidde tot de val van het Ministerie-Thorbecke, maar maakte de aanwijzing van de Domstad als bisschopsstad niet ongedaan.

Ten tijde van de Aprilbeweging heerste er in Utrecht een ware antikatholieke psychose. In de Waakzaamheid, Protestantsche Courant, werd geschreven: 'Alle R.K. winkels zijn eensklaps verlaten. Een groot aantal R.K. arbeiders zijn plotseling afgedankt.' In de stad circuleerde een pamflet, waarin werd opgeroepen katholieke winkels te boycotten. 'De Roomschen moeten 't voelen, dat wij de baas zijn, als 't er op aan komt. ${ }^{, 68}$ In pamfletten werd de protestantse bevolking afgeraden om bij katholieke winkeliers te kopen. Het gerucht ging dat protestantse verenigingen zwarte lijsten had- 
den met daarop namen van katholieke winkeliers. ${ }^{69}$ Het idee van de zwarte lijsten werd versterkt door het bestaan van protestantse genootschappen, die zorgvuldig geheim hielden wie hun leden waren. De katholieke bevolking klaagde over de protestantse kopersboycot, wat weer een reactie van protestantse zijde uitlokte.

De Genootschappen, zegt gij, zoeken het bederf der Roomschen en willen hen tot den bedelstaf, tot hongersnood brengen, hen geheel bederven, door hun alle voorregt en allen invloed te ontnemen.

De onmogelijkheid daarvan het ik getracht u [...] te doen gevoelen. Hunne middelen zijn daartoe veel te gering, de voorspoed van de Roomsche winkeliers is veel te zigtbaar. Waarlijk uwe Sinkels en Bahlmans moeten verbaast staan $[\ldots]^{70}$

De anonieme schrijver noemde niet toevallig de namen van twee grote Duitse winkeliers.

\section{'Die papenboel zou gauw over de grenzen zijn'}

De antikatholieke sentimenten en de dreiging met een kopersboycot zullen de katholieke winkeliers niet koud hebben gelaten. Op woensdagavond 14 september bezocht de koning de Domstad en bekeek de illuminatie van winkels aan de Oudegracht, die ter ere van hem waren aangebracht. De winkel van de Duitse katholiek Sinkel muntte door 'fraaiheid' boven alle andere panden uit. 'Sinkel demonstreerde dus kennelijk een Oranjeliefde boven geloofsverdeeldheid', concludeerde de historicus Rogier in een rede in $1959 .^{71}$ Sinkel wilde ongetwijfeld niet alleen de koning, maar ook zijn potentiële publiek van zijn aanhankelijkheid aan het Oranjehuis overtuigen.

Pamfletten en brochures speelden in de Aprilbeweging een belangrijke rol. In een Toespraak eener Protestantsche Christin aan hare landgenooten werden vrouwen opgeroepen hun 'roomsche dienstboden' af te schaffen en alleen te kopen in 'niet-roomsche winkels of van niet-roomsche winkeliers'. ${ }^{72}$ In een ander pamflet werd een gesprek tussen enkele dames weergegeven:

De Vrouw des huizes valt in: "Zoo weet ik, dat vele Roomsche winkels bitter klagen in de laatste dagen, en vele dames van mijne kennis hebben aan onze vermaning gehoor gegeven en zijn van leveranciers veranderd. [...] Mevrouw Sephar heeft zelfs eene Roomsche meid weggezonden, ofschoon ze haar al twaalf jaar gehad had en 't Mevrouw wel wat aan haar hart ging; maar ze begreep terecht, dat dwaze gevoeligheid hier niet te pas kwam.”

Haar opmerking kreeg de goedkeuring van haar gesprekspartners. 
“Braaf, Mevrouw, en juist gezien. Deden allen zoo, die papenboel zou gauw over de grenzen zijn. Zij zijn hier immers niet op hun plaats in het't vrije protestantse Nederland. De grond moet hun, dunkt mij, onder de voeten branden." ${ }^{173}$

De opmerking dat de papenboel de grens over moest worden gejaagd, is opmerkelijk en typerend. Het anti-papisme richtte zich niet alleen tegen katholieken in het algemeen, maar ook tegen katholieke nieuwkomers. ${ }^{74}$ Daarbij speelde een rol dat het katholieke geloof, gezien het gezag van Rome, als een onvaderlandse religie werd aangemerkt.

De protestantse vereniging Unitas, die vooral in Utrecht actief was, riep op tot steun aan protestantse winkeliers, vooral in manufacturen en bood steun aan de opleiding van protestantse ambachtslieden.

[... daar vele ambachten hoe langer zoo meer in handen der Roomsch Katholijken bij uitsluiting overgaan, vooral dewijl bekwame handwerkers uit het buitenland van Roomsch Katholijken belijdenis zich in Nederland neerzetten. ${ }^{75}$

In het eerste nummer van het antipapistische blad De Fakkel, dat in 1848 verscheen, werd geschreven dat Nederland 1,2 miljoen katholieken telde: 'De twaalfmaal honderdduizend zijn voor de grootste helft vreemdelingen. ${ }^{76}$ Het katholieke volksdeel zou, aldus het blad, de vijfentwintig voorgaande jaren verdubbeld zijn, voornamelijk door immigratie uit Duitse bergstreken. Rogier wees een eeuw later eveneens op deze vermeende verbinding tussen immigratie en katholicisme. Vooral het katholieke volksdeel was door immigratie beïnvloed:

op deze grond berusten ten minste tal van liefelijkheden, waarmee het negentiende-eeuwse antipapisme de katholieke medeburgers bestempelde als "een niet-volk", ontstaan uit hongerlijdende Westfaalse indringers. ${ }^{77}$

\section{Spionnen die iedere dag inlichtingen naar Berlijn zenden}

De beeldvorming was niet statisch, maar verschoof onder invloed van politieke en sociale ontwikkelingen in Duitsland en Nederland. De oorlogen van 1866 en 1870 speelden daarbij een belangrijke rol. Bij de revolutie van 1848 vinden we reeds een voorafschaduwing van het nieuwe beeld dat in de tweede eeuwhelft zou gaan overheersen. Het wordt mooi verwoord in de dichtbundel Voor mijn vaderland die S.J. van den Bergh in 1851 publiceerde. ${ }^{78}$ Van den Bergh schreef in zijn gedicht Aan de Duitschers bewonderend over 'Teutoos zonen, die zoo lang, gekromd laagt onder vorstendwang'. Hij prees de Duitsers die het juk van zich hadden geworpen. Aan een nieuwe eenheid wilde men gaan bouwen, maar de revolutie ontspoorde en Van den Berghs bewondering sloeg om in angst. Hij klaagde dat de revolutionairen 
een zwakker volk hebt weggesleept

en schand voor glorie gingt behalen

Toen had ik met u uitgedweept!

Hij zag een nieuwe dreiging nu in Duitsland een nieuwe taal werd gesproken.

Een taal, die van uw driestheid tuigt:

"Zeg Holland, dat het voor ons buigt

En Limburg onze kleur doe dragen.

't Is Duitsch - dat erf: 't moet onzer zijn!'

Toen was 't als hoorde ik u reeds vragen:

“Geef op, geef op den Duitschen Rhijn!”.

Van den Bergh vreesde dat Limburg bij Duitsland zou worden ingelijfd en dat de Duitsers daar niet zouden stoppen. ${ }^{79}$ De zogenaamde Limburgse Kwestie van 1848 lag aan zijn vrees ten grondslag. Nederlands Limburg was, met uitzondering van Maastricht en Venlo, in 1839 als hertogdom toegetreden tot de Duitse Bond. Tegelijkertijd bleef het een Nederlandse provincie. ${ }^{80}$ In 1848 ontstond er een kortstondige crisis, toen in Limburg gepleit werd voor losmaking uit het Nederlands staatsverband en aansluiting bij een nieuw te vormen Duitse eenheidsstaat. De Duitse Nationale Vergadering stemde hiermee in, op het Limburgse platteland werd feest gevierd en Duitse vlaggen wapperden op de torens. Na korte tijd werd het Nederlands gezag in Limburg echter hersteld en zakte de Limburgse aansluitingsbeweging in. ${ }^{81}$

Buiten Limburg waren er in deze jaren ook Nederlanders, die aansluiting bij Duitsland als een reële optie zagen. De Amsterdamse hoogleraar P.J. Veth, redacteur van De Gids, vond Nederland als afzonderlijke staat nauwelijks levensvatbaar; aansluiting bij Duitsland was de enige oplossing, al zou het nog wel even duren voordat die wens in vervulling kon gaan. Het Germaans gemeenschapsgevoel was immers nog onvoldoende ontwikkeld. ${ }^{82}$ Veth was echter een van de weinige voorstanders van deze mogelijkheid. Merendeels overheerste de angst voor annexatie. Bij de verwoording van die angst werd teruggegrepen op oudere sentimenten. In september 1787 waren achttienduizend Pruisische soldaten de Nederlandse oostgrens overgestoken. Toen zij Utrecht naderden, vluchtten duizenden mensen richting Amsterdam. Van de troepen werd niet veel goeds verwacht en van de Pruisen hadden de Nederlanders, althans volgens een tijdgenoot, een 'instinctmatigen afkeer' ${ }^{33}$ Die afkeer gold niet steeds exclusief de Duitsers. De Fransen werden een tijdlang eveneens met een zeker wantrouwen bekeken. In 1839 werd er een ingezonden brief geplaatst in de Utrechtsche Courant, waarin de anonieme auteur zich keerde tegen een Franse handelaar die aan studenten pornografische boeken verkocht. Hij wilde

de Zulks ter kennis van het publiek brengende, vraag ik of de jonglieden wel weten, dat de angel, welke onder het gras ligt, zeer gevaarlijk is? en of vreemde 
natien dien angel ook hier zouden kunnen leggen, om de Noord Nederlanders te ontzenuwen, opdat zij geheel onverschillig voor hun vaderland worden, vreemde bedorven zeden inzuigen en eindelijk geheel verfranschen, waardoor het den vreemdelingen gemakkelijk zal worden, het ontzenuwde en ontaarde geslacht te overwinnen of zonder slag of stoot te overheerschen en verder in banden te kluisteren, waarvan alleen den ouden van dagen nog herinnering hebben. ${ }^{84}$

De briefschrijver maakte niet alleen bezwaar tegen de lustopwekkende inhoud van de boeken, maar waarschuwde vooral voor verfransing en uiteindelijk annexatie van Nederland door Frankrijk. Zo'n vijftig jaar later was echter niet langer Frankrijk, maar Duitsland de vijand.

De vrees voor annexatie had gevolgen voor de houding van de Nederlandse overheid tegenover de nieuwkomers. In 1854 werd, bij de indiening van het wetsontwerp Regeling en beperking der uitoefening van het regt van Vereeniging en Vergadering, voorgesteld om vreemdelingen en migranten-ingezetenen het recht tot lidmaatschap van staatkundige verenigingen te ontzeggen. Via die verenigingen zouden ze immers ver-

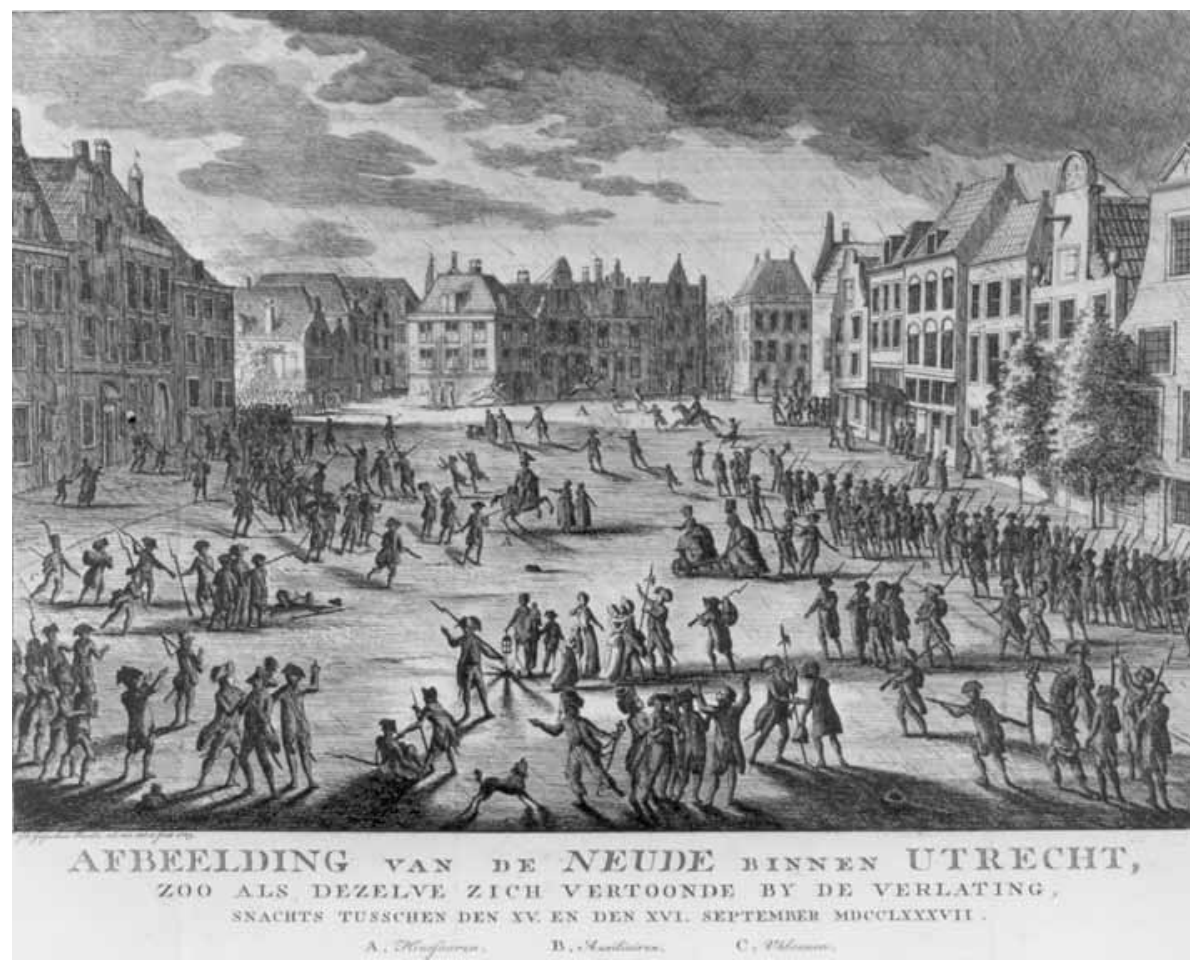

De Neude in de nacht van 15 op 16 september 1787. De Utrechtse bevolking vlucht weg voor de Pruisische troepen.

Atlas van Stolk 4784. 
zwakking van de Nederlandse staat kunnen bevorderen. Na bezwaren uit de Kamer werd het voorstel gewijzigd. Alleen vreemdelingen werd het recht van lidmaatschap ontzegd. ${ }^{85}$ Ingezetenen - mensen die reeds drie jaar in een Nederlandse gemeente woonden en te kennen hadden gegeven in die gemeente te willen blijven - mochten wel lid worden van staatkundige verenigingen.

In 1855 werden vreemdelingen uitgesloten van het geven van openbaar onderwijs. Alleen Nederlanders of genaturaliseerden 'leverden genoegzame waarborgen op, dat zij de jeugd in eenen Nederlandschen geest zouden opleiden. ${ }^{, 86}$ Tegenover de dreiging van annexatie werden aanspraken op een 'Nederlandse geest' belangrijker.

De angst voor annexatie kwam in versterkte vorm terug na de plotselinge en onverwachte Duitse militaire successen in 1866 en $1870 .{ }^{87}$ De verrassende Duitse overwinning op Frankrijk in 1870, waarbij dit land binnen een maand verslagen werd, leidde tot zowel angst als bewondering. ${ }^{88}$ Sommige Nederlanders waren van mening dat in Nederland Pruisisch onderwijs en Pruisische krijgstucht ingang moesten vinden. Tegelijkertijd moest de Nederlandse 'nationale geest' worden opgewekt. ${ }^{89}$ Nederland had zich gedurende de oorlog bedreigd gevoeld en had zijn leger gemobiliseerd. Toen de directe dreiging was afgewend, schreef de oud-militair G. Umbgrove in 1871 de brochure Neerlands Roeping, waarin hij uitgebreid op het nieuwe Duitse annexatiegevaar inging. Dit gevaar kende drie oorzaken: de Duitse bevolking telde veertig miljoen zielen, de Rijn werd beschouwd als een Duitse rivier, maar de monding van die rivier lag in Nederland, en als laatste werd het Nederlandse volk door de Duitsers als een Duitse stam gezien met nagenoeg dezelfde gewoonten en taal. Umbgrove wilde het gevaar keren en daarom het onderwijs in vreemde talen beperken of afschaffen..$^{\circ}$ Er was echter, volgens Umbgrove, nog een vierde en belangrijkere factor die, naar zijn idee, door veel mensen over het hoofd werd gezien.

Denemarken is aangevallen door Pruisen, om eene Duitschsprekende bevolking te beschermen, en verloor daardoor haar twee provinciën: Sleeswijk en Holstein. In Frankrijk, en meer bepaald in Parijs, waren duizenden Duitschers, die, toen het beleg werd voorzien, bij politieke maatregel, zeer wijselijk uit het land werden gezet; over welken maatregel de heeren Duitschers niet weinig gebelgd waren, omdat hun spionnenstelsel daardoor niet alleen veel heeft geleden, maar tevens nu voor hen een magtig middel ontbreekt tot het stoken van onrust, burgerkrijg, mogelijk wel tot de zamenstelling van een klein agerend legerkorps binnen de wallen van Parijs. ${ }^{91}$

Gemeenschappen van Duitsers in het buitenland vormden, volgens Umbgrove, een bedreiging voor de veiligheid en soevereiniteit van de landen waarin zij woonden. Deze dreiging bestond volgens hem ook in Nederland. Op de handelskantoren in de grote Nederlandse steden waren reeds 
meer Duitschers dan Hollanders te vinden [...], wat in verloop van tijd een zeer groot gevaar voor ons zelfstandig bestaan als volk kan opleveren. ${ }^{92}$

[...] In vredestijd bevindt zich een groot aantal Duitschers in ons land, en meer bepaald in de groote koopsteden. Worden wij in een oorlog gewikkeld, dan zal het gevolg zijn dat die lieden het land verlaten en waarschijnlijk de wapenen tegen ons zullen opvatten [...]. Van de zijde der Regering zal mogelijk om staatkundige redenen, daartegen niets te doen zijn, en geene maatregelen kunnen worden genomen, om die logeergasten te doen verminderen. Het volk, en vooral de meergegoeden, de handelsstand, alleen kunnen uitkomst in deze geven, door de zedelijke verpligting op zich te nemen, geene vreemden in dienst te nemen of te bevoorregten. Daardoor zal de armoede verminderen, het volk meer ontwikkeld en beschaafd worden, en ieder regtgeaard Nederlander het genoegen smaken, zijne taal overal in de lande te horen spreken, en niet gedwongen worden tot het uitstooten van vreemden poespas, om geholpen te worden. ${ }^{93}$

Burgers zouden niet bij Duitse winkeliers moeten kopen, winkeliers zouden geen Duitse bedienden moeten aanstellen en handelshuizen geen Duitse klerken.

Van de verwijdering van Duitse immigranten uit Parijs ging een precedentwerking uit, meende de Duitsgezinde, Utrechtse hoogleraar wijsbegeerte C.W. Opzoomer, in een rede in 1871. Op 17 juli 1870 werd in de Frankfurter Zeitung geschreven dat alle Duitse werklui uit Straatsburg waren verjaagd. Een dag later melde een Belgische krant dat alle Pruisische onderdanen uit Parijs waren verbannen. Zulke verbanningen en verdrijvingen waren in de recente geschiedenis niet voorgekomen. Franse kranten moedigden het beleid aan. Opzoomer haalde de Franse krant Le Pays aan: 'Er zijn honderdduizend Duitschers in Parijs. Het zijn even veel spionnen, die iedere dag inlichtingen naar Berlijn zenden.' De Duitse immigranten in Frankrijk werden afgeschilderd als wat later een vijfde colonne zou worden genoemd. De Franse regering moest in actie komen. 'Verzuimt zij haar plicht, dan zullen wij de bevolking van Parijs bidden, de onmiddellijke uitzetting van de Duitschers te eisen. ${ }^{94}$

Van uitzetting van Duitsers was in Nederland geen sprake, Umbgrove's waarschuwingen ten spijt. ${ }^{95}$ De Franse houding ten opzichte van de Duitse immigranten in hun land, had niet direct gevolgen voor de Duitsers in Nederland. Opzoomer haalde een niet bij naam genoemd Keuls dagblad aan, waaruit bleek dat alles in Nederland nog wel meeviel. Een Duitser die in Nederland woonde had in de Keulse krant, aldus Opzoomer, geschreven:

Wij erkennen dankbaar de sympathie van het verstandige deel der Nederlandsche natie. In Zwitserland, in Engeland, in Rumenië zijn de Duitschers beleedigd en aangerand, hier in Holland hebben wij in vrede en vriendschap geleefd en onze Hollandsche medeburgers hebben deel genomen aan ons vredefeest. 


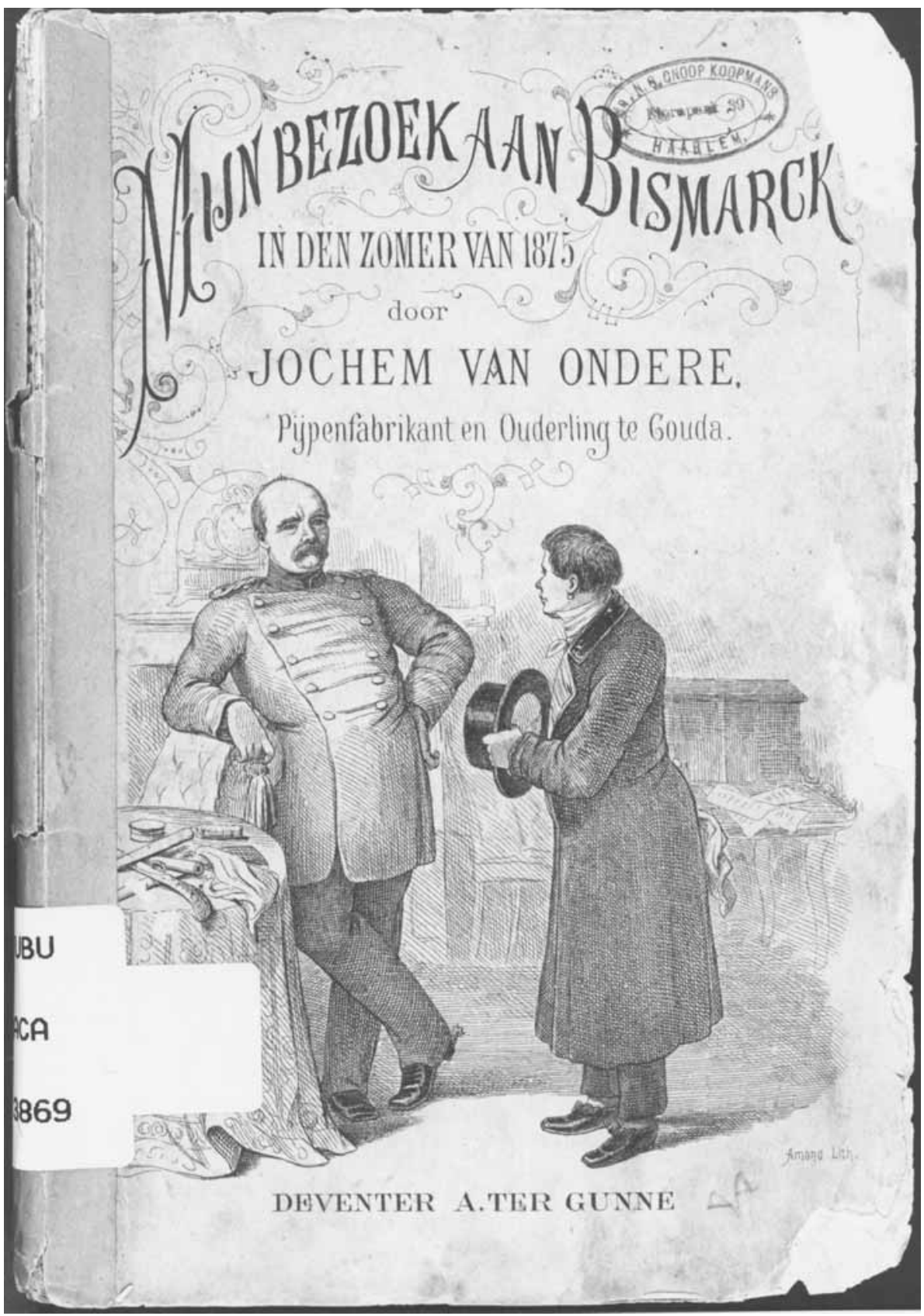

Voorkant van het boek Mijn bezoek aan Bismarck van Jochem van Ondere, pijpenfabrikant en ouderling te Gouda. Van Ondere vroeg in het boek aan Bismarck hoe hij de annexatie van Nederland door Duitsland zou kunnen bevorderen. Bibliotheek Universiteit Utrecht. 
Wij zijn hier gelukkig en tevreden en we koesteren den wensch, dat het altijd zoo moge blijven. ${ }^{96}$

De Prusofobie die in dit tijdvak onder meer Engeland trof, ${ }^{97}$ kende geen Nederlandse tegenhanger. Fransgezinde Nederlanders zongen nu, volgens Opzoomer, wel een toontje lager, 'terwijl ze nog kort geleden niet fel genoeg konden schimpen op die lompe en plompe en ruwe Duitschers, die het fijnere Fransche element niet uit onze beschaving mochten wegnemen. ${ }^{98}$

Uit de lessen, die we volgens Opzoomer van Duitsland moesten leren, blijkt de nieuwe beeldvorming: 'Het is niet de vrijheid, die wij van Duitschland moeten leeren, het is de degelijkheid, de orde, het plichtbesef, de krachtige organisatie en administratie. $^{.99}$

De annexatiedreiging was omstreeks 1870 een belangrijk onderwerp in de Nederlandse pers. ${ }^{100}$ Jochem van Ondere, 'Pijpenfabrikant en ouderling te Gouda', publiceerde in 1876 een boekje over mogelijke annexatie van Nederland door Duitsland met als titel Mijn bezoek aan Bismarck in den zomer van $1875 .{ }^{101}$ Uit Van Ondere's schets komen heel mooi de vermeende verschillen tussen Nederlanders en Duitsers naar voren.

Wat Duitschland wel van ons zou willen annexeeren?

- Wel, dat lijdt geen twijfel, schreeuwen de Prusophoben: de Hermann-reus wil de geheele Nederlandsche Maagd.

- Huwen? vraagt gij. Dat was misschien nog zoo'n slechte partij niet!

- Zoo'n slechte partij niet? Een huwelijk met Blauwbaard! Wilt ge de blonde meid zien bungelen in 't kamertje naar de juffers Elzas, Lotharingen, Holstein ... Maar ik zeg u, Hermann is erger dan Blauwbaard: 't is de Reus, die steeds snuffelt, of hij ook menschenvleesch ruikt. [...]

- Wat ge zegt! Nederland [...] zou door den Germaanschen reus verzwolgen worden? Dat nimmer! Nederland is geen Hannover, geen Hessen, geen Nassau. ${ }^{102}$

Duitsland werd gelijkgesteld met Pruisen en de Duitse eenwording werd gezien als gevolg van de Pruisische annexatiedrift.

Van Ondere's ikpersoon ging naar Bismarck om hem te vragen hoe het stond met de annexatieplannen. Wat moesten de Nederlanders doen om geannexeerd te worden, vroeg hij.

'zou Germania hare verdoolde schapen weer in haren stal willen opnemen?'

'Neen; zooals gijlieden thans zijt, niet! Wordt eerst weder Germanen!'

'Ik wil, heer! Wat moeten we doen?'

'Bier drinken.'

't is kolossaal, zooveel als dat tegenwoordig bij ons gedronken wordt.'

'Turnen.' 
'Er wordt reeds ijverig in geëxamineerd.'

'Wapenhandel.'

'Alle ondermeesters zijn leden van vereenigingen voor de wapenhandel.'

'Uithuizig worden en uwen tijd doorbrengen in Kneipen.'

'We doen het, heer; bierhuizen en bierhallen, waar ge komt; en weldra nemen we vrouw en kinderen mede er heen.'

'Uniformen dragen.'

De auteur beloofde ook op dit punt verbetering

'Uwe schrijftaal laten varen.'

Volgens de auteur ging dat ook de goede kant op.

[...] 't krielt alles niet alleen van spel- en taalfouten, maar't vloeit ook over van barbarismen, en wel grootendeels van germanismen.

Verder stelde Bismarck aan Van Ondere voor de 'Zwarten' het land uit te jagen. Hiermee werden de Jezuïeten en andere katholieke geestelijken bedoeld. De Nederlanders moesten ook leren de 'Fransozen' te haten. Als laatste ordonneerde Bismarck:

Met vrouw en kind scheep gaan, een nieuw Nederland stichten op uw heerlijken Indischen Archipel en het oude Nederland aan mijne Duitschers overlaten. ${ }^{103}$

De kans hierop achtte Van Ondere gering en de dreiging van de annexatie was daarmee in zijn ogen geweken. Zoals uit de opsomming van Van Ondere blijkt, zag hij een mogelijke annexatie van Nederland gedeeltelijk als een uitvloeisel van de Nederlandse overname van Duitse gewoonten. Van Ondere keurde dit af en toonde naast angst voor annexatie ook een zekere afkeer van Duitsers. Wanneer Van Ondere's ikpersoon thuiskomt van zijn Duitse reis, maken zijn dochters grapjes. Ze vragen of moeder wel een spuugbak met zand in de hoek van kamer heeft gezet.

[...] maar weet ge dan niet, dat die Moffen altijd spuwen; dat zij, als er geen spuwbak staat, zich met een hoek van de kamer behelpen; en dat zij, als de spuwbak niet groot genoeg is, zoo vrij zijn om het ernaast te doen. ${ }^{104}$

Van Ondere's ikpersoon maakt zijn koffer open om geschenken voor zijn vrouw en dochters uit te pakken.

'Man', roept mijne vrouw, met zekere schrik, 'haal dat ding toch niet in de kamer. Zet het in den gang op de steenen, of liever nog op de binnenplaats. Er 
kon eens wat inzitten. De Duitsche huizen krioelen immers van gij weet wel wat voor lieve diertjes. ${ }^{\text {,105 }}$

Van Ondere dreef de spot met de annexatieangst. Anderen namen de dreiging serieuzer, zoals de Utrechtse professor G.W. Vreede, die zijn mening doorlopend kenbaar maakte in de Utrechtse krant. In 1871 schreef hij aan het hoofdbestuur van de Algemeene Nederlandsche Vredebond:

Het gevaar dat Nederland dreigt [...] ligt [...] buiten onze grenzen, te Berlijn, en in de permanente krijgskas van het Duitsche Rijk, dáár in Pruisen, in Duitschland, dáár, waar [...] de "kazerne-philosophie" aan de orde is, en de drie Staatsmagten Artillerie, Kavalerie en Infanterie heerschen [...]. ${ }^{106}$

Vreede verklaarde zich bereid stappen te nemen ter bestrijding van de 'kazerne-philosophie' te Berlijn en van de Duitsche annexatie-koorts [...]. Hij haalde zijn eigen brief vier jaar later aan in het Utrechtsche Dagblad van 8 mei 1875. De dreiging was niet afgewend, zo stelde hij. In tegendeel. 'De Mauser-geweren zijn reeds even voortreffelijk bevonden als de Krupp-kanonnen'. De kleinere buurstaten van Duitsland, zoals Nederland, liepen het gevaar 'met of zonder oorlogsverklaring' onverhoeds door 'geweld van buiten besprongen te worden' ${ }^{107}$ In Duitsland vonden we, volgens Vreede, de van

kinds af [...] door de tucht van de schoolmeester, door het norsch bevel van politieagenten en door den stok van den korporaal onafgebroken ingescherpte vrees voor allen, die hooger geplaatst zijn en gezag oefenen. ${ }^{108}$

Vreede's klacht werd door andere auteurs herhaald. Naar de mening van sommige lezers, schoten kranten daarin echter te ver door en creëerden een overdreven annexatieangst. In 1875 verscheen er in het Utrechtsch Provinciaal en Stedelijk Dagblad een artikel over een feestmaal, dat door een internationaal gezelschap van wetenschappers in Duitsland was gehouden. In dat artikel leek het, of enkele Duitse wetenschappers zich expliciet voor annexatie van Nederland hadden uigesproken. Een gelijkluidend bericht was ook in andere Nederlandse kranten verschenen en daarop was fel gereageerd. Een anonieme auteur stuurde naar de Utrechtse krant een correctie op wat er eerder over het feestmaal was geschreven.

Aan het feestmaal namen geleerden deel uit de meeste landen van Europa. In een toast op de aanwezige vreemdelingen werden Zwitsers en Nederlanders niet bij name genoemd. Bij de hierop gemaakte aanmerking klonk het: zij zijn ons geen vreemden.

En op de erkenning, dat zij wetenschappelijk met Duitschland tot één verbonden zijn, werd schertsend het woord vorläufig gehoord. Nu stond een der aanwezigen op, om deze ongepaste scherts te wraken. Hij schilderde in korte trek- 
ken, hoe Nederland voor zijne onafhankelijkheid had gestreden, die onafhankelijkheid lief had en als een onvervreemdbaar recht beschouwde, en noodigde allen, om met hem te drinken op den bloei van Nederland, als zelfstandig en onafhankelijk land $[\ldots] .^{109}$

De aanwezige wetenschappers hadden de spreker toegejuicht en instemmend het glas geheven. De commentator betreurde het dat het voorval in meerdere Nederlandse kranten onjuist was beschreven. De vrees voor annexatie werd hierdoor onnodig aangewakkerd.

Zou niet de wijze, waarop sommigen onder ons, hunne vrees voor inlijving aan den dag leggen en door het verzinnen en vervalschen van feiten aan die vrees voedsel geven, ons aan spotternij blootstellen. ${ }^{110}$

De redactie van de krant was het daar niet helemaal mee eens; de annexatiedreiging was volgens de redactie wel degelijk reëel.

Terwijl wij deze verbetering gaarne opnemen, en, bij dankzegging voor 't gezonden schrijven, ons verheugen dat de zaak zooveel gewenschter afloop had, dan eerst werd medegedeeld, moeten wij alleen opmerken, dat - tegenover de aanmatigingen, die niet alleen in de Duitsche pers, maar ook in school- en andere boeken door Duitschers ten opzichte van Nederland telkens worden gevonden, $[\ldots]$ - waarschuwing en herhaalde waarschuwing niet overbodig schijnt.

De annexatieangst was vermengd met waarschuwingen voor Duitse culturele invloeden en 'taalvermoffing'..$^{111}$ In de negentiende eeuw zou het gebruik van Duitse woorden in de Nederlandse taal sterk zijn toegenomen.

Hoe de taal van de handel, van de techniek, van de geneeskunde, heden ten dage doorspekt is met Duitsche vormen, behoeft aan geen Hollander met eenig taalgevoel te worden betoogd. ${ }^{112}$

Deze waarschuwingen riepen een tegenreactie op. Op 17 november 1872 schreef Rochussen, de Nederlands gezant in Berlijn, aan minister Gericke van Herwijnen en klaagde over de vijandige houding van de Nederlandse pers tegenover Duitsers. ${ }^{113} \mathrm{Mi}-$ nister van Justitie De Vries vond deze kritiek onterecht en reageerde hierop.

Worden de Duitsche kooplieden hier niet met open armen ontvangen en vinden zij hier geene uitnemende gelegenheid om binnen weinig jaren rijk te worden? Laat men in de verschillende vakken van handel en industrie in onze groote steden eens nagaan, hoevele Duitsche namen daar gevonden worden, 
alle van menschen, die arm en zonder iets uit hun Duitsche vaderland aangekomen, op onze gastvrijen bodem een veilige werkplaats en rijke beloning van hun arbeid hebben gevonden. ${ }^{114}$

Voor deze gastvrijheid bestond wel erg weinig waardering, meende de Vries.

De nieuwe dreiging van annexatie kon de oude beeldvorming, waarbij de Duitsers vooral als vreemde bedelaars en landlopers werden voorgesteld, niet helemaal verdringen. Na enkele jaren ebde de annexatieangst weg en op 4 februari 1884 konden Utrechters in hun plaatselijke krant een bericht lezen dat teruggreep op de oudere vrees voor armlastige vreemdelingen.

Van verschillende kanten gaan er luidde klachten op over de toenemenden landlooperij. In Wurtemberg is die landplaag zoo uitgebreid, dat er zeer veel moet worden gedaan, om de openbare veiligheid te kunnen handhaven. [...] Herhaaldelijk worden de boerderijen overvallen door groepen rondzwervende bedelaars, die kortaf een eisch stellen, en wanneer daaraan niet terstond wordt voldaan, zich met geweld meester maken van het geen hun aanstaat. Sommige boeren hebben op die wijze dagelijks met een twintig of dertigtal bedelende mannen en vrouwen te doen. [...] In sommige gedeelten des rijks bestaat het kwaad in een anderen vorm. Aldaar ziet men minder eigenlijke bedelaars, maar zooveel te meer reizende rondventers, die evenwel, onder den schijn eener kleine negotie, het even lastig maken met brutale eischen of met bedriegelijk beroep op de goedhartigheid der ingezetenen. ${ }^{115}$

Kranten hadden in het algemeen weinig belangstelling voor sociale verhoudingen in andere landen, tenzij deze verhoudingen het eigen land of de eigen stad direct raakten. Het krantenbericht moet dan ook worden gezien als een impliciete waarschuwing. De Duitse rondventers waren voor het Utrechtse publiek geen vreemden.

Aan het einde van de negentiende eeuw leidde een meer emotionele invulling van het begrip nationaliteit ertoe dat er anders werd aangekeken tegen Duitse immigranten. Deze veranderde optiek kwam naar voren bij de invoering van de Nationaliteitswet van $1892 .{ }^{116}$ Een belangrijke reden om een nieuwe Nationaliteitswet in te voeren was de twijfel of het 'enkele feit der geboorte in Nederland' voldoende waarborg bood dat de geborene 'zich door eenigen band bijzonder aan ons land gehecht zal gevoelen en dààrom alleen onze nationaliteit waard en waardig zou zijn.' ${ }^{117}$ Aan nationaliteit werd steeds meer betekenis gehecht en die betekenis kreeg in toenemende mate een emotionele lading. Bij de Algemene Beschouwingen over de nieuwe wet, werd in 1892 een kritische kanttekening gemaakt. Gevreesd werd dat door de wet

hier te lande geheele kolonien van vreemdelingen, meest van Duitsers, zouden ontstaan, die wel is waar genaturaliseerd konden worden, maar dien indien zij van deze immers min of meer kostbare en omslachtige bevoegdheid geen 
gebruik maakten, òf bleven behooren tot een ander Staatsverband, òf geene nationaliteit zouden bezitten, en dit niettegenstaande zij zelven, hunne ouders en wellicht hunne voorouders gedurende lange jaren in Nederland gewoond hadden, en zij in ieder opzicht, behalve in wettelijke zin, Nederlanders waren geworden. $^{118}$

Volgens deze critici waren de kinderen en kleinkinderen van Duitse immigranten wel degelijk Nederlanders. Deze mening werd echter niet algemeen gedeeld; na 1892 was geboorte op Nederlandse bodem geen grond meer voor het verkrijgen een Nederlandse nationaliteit.

\section{Prusofobie}

In Engeland komen we dezelfde stereotyperingen tegen van Duitse immigranten, als in Nederland. ${ }^{119}$ Waardering voor Duitse schrijvers en componisten bestond naast een afkeer van Duitse armen in Londen. Leopold Katscher schreef in 1887:

Many Englishmen who esteem the Germans do not love them because they compete in the labour market with the natives of this country. German bakers, tailors, waiters, hairdressers, watchmakers, clerks, music teachers, schoolmasters, \&c, are naturally the horror of all the English who work in these various industries, for the Germans are satisfied with lower salaries, and are therefore preferred, not only by their own countrymen, but frequently also by English employers. $^{120}$

In het midden van de negentiende eeuw werden Duitse immigranten in Londen, net als in Nederland, afgeschilderd als armoedzaaiers, die bovendien vies en lomp waren. Deense publicaties waren gelijkluidend. Het reine Deense volk werd afgezet tegen de Duitse nieuwkomers, die het land overspoelden. Ze vergaten, aldus de Deense krant, dat ze het Deense brood aten en in Deense huizen woonden, en hielden vast aan hun Deutschtum, hun Duitse houding en denkwijze en hun Duitse taal. ${ }^{121}$ Net als in Nederland, was er in Denemarken in het midden van de negentiende eeuw geen sprake van de komst van grote aantallen Duitse nieuwkomers. De term 'overspoelen' werd met opzet gebruikt om de suggestie te wekken dat dit wel het geval was. In Denemarken gingen de anti-Duitse gevoelens verder dan in Nederland. Na de tweede Deens-Duitse oorlog, die eindigde in een nederlaag voor Denemarken, werd in kranten opgeroepen alle banden met de Duitse buren te verbreken. Duitse immigranten moesten zich volledig aan Denemarken aanpassen. Seizoensarbeiders uit Lippe, die in de zomermaanden op de steenbakkerijen kwamen werken, werden met geweld verdreven. ${ }^{122}$

In Engeland ging de vijandigheid minder ver dan in Denemarken. De overwinning van Duitsland op Frankrijk leidde daar, net als in Nederland, tot een mengeling van be- 
wondering en vrees. In Engeland ontstond daaruit in 1871 een nieuw literair genre, de invasion novel, waarin de Duitse invasie werd beschreven. ${ }^{123}$

Denemarken beschouwde zich als slachtoffer van de Duitse annexatiedrift. In Engeland was die dreiging minder dichtbij of minder reëel, en mengde angst zich met bewondering. Nederland zat met een milde variant van annexatieangst, tussen die beide landen in.

\section{Tot besluit}

Duitse immigranten, en vooral de recente nieuwkomers onder hen, waren door hun spraak en kleding herkenbaar als Duitsers. De invloed van Poepenmoppen en Moffenkluchten op de dagelijkse omgang tussen Duitsers en Nederlanders zal desondanks gering zijn geweest. Daarvoor lagen beeld en werkelijkheid teveel uit elkaar. De grappenmakerij had slechts beperkt een wij-zij-functie. ${ }^{124}$ In die visie wordt aan de grappenmakerij een te grote rol toebedeeld. De beeldvorming beïnvloedde wel het overheidsbeleid. Alle immigranten werden gezien als (potentieel) armlastigen, met uitzondering van diegenen die geschaard konden worden onder de 'woelzieken'. In een poging armlastigen en woelzieke geesten te weren, werden aan alle Duitse immigranten beperkingen opgelegd. Het overheidsbeleid vloeide niet alleen voort uit de beeldvorming, maar versterkte het beeld ook via de kamerdebatten en de neerslag daarvan in kranten.

De weinig vleiende beeldvorming had nog een ander gevolg. De ontkenning van de Duitse identiteit, zoals de fictieve Duitse Wilhelm dat doet met zijn uitroep "Ich pien Schweitser!", of de snelle assimilatie waaraan Rogier refereerde, kunnen worden geduid als een reactie op uitsluiting en negatieve beeldvorming.

Het toedichten van bepaalde kenmerken, gebeurde door mensen die behoorden tot de ontvangende samenleving en door migranten zelf. ${ }^{125}$ Duitse immigranten zelf maakten wellicht onderscheid binnen een, in Nederlandse ogen, amorfe en vage groep. Nederlanders deden dat soms ook en makten dan onderscheid tussen Moffen, Poepen, Westfalers of Pruisen, om ze vervolgens met hetzelfde gemak ook weer op een hoop te vegen.

Waar in kamerdebatten, kranten of romans waardering werd uitgesproken voor de kwaliteiten van de Duitse nieuwkomers, werd benadrukt dat ze goedkope arbeidskrachten waren. In deze eenzijdige beeldvorming lijkt de Duitse immigrantenpopulatie vooral te bestaan uit (seizoens)arbeiders op het platteland. Handelaren, kooplui, kantoorklerken, winkeliers en andere stedelijke immigranten zijn minder opvallend aanwezig in de beeldvorming; vrouwen ontbreken vrijwel helemaal. Als gerefereerd wordt aan handelaren, klerken en bedienden, wordt het beeld opgeroepen van een vijfde colonne, die in geval van oorlog de Duitse annexatielegers zal steunen.

De angst- of sympathiegevoelens voor Duitsers waren waarschijnlijk niet op alle Duitse immigranten gelijkelijk van toepassing. Duitsland werd in de beeldvorming op 
bepaalde momenten gelijkgesteld met het protestantse Pruisen, vooral na 1866 of 1870. We kunnen aannemen dat die beeldvorming op immigranten uit het katholieke Nassau, in 1866 zelf 'slachtoffer' van de Pruisische annexatiedrift, minder van toepassing was, ofschoon een hard bewijs daarvoor ontbreekt.

Immigranten zijn in het proces van beeldvorming geen passieve subjecten. Aan de beeldvorming ligt een wisselwerking ten grondslag, tussen het beeld dat immigranten van hun nieuwe omgeving hebben en het beeld dat de ontvangende samenleving heeft van de nieuwkomers. De waardering van bepaalde capaciteiten en vaardigheden die aan een groep immigranten werden toegedicht, was niet steeds gelijk; positieve waardering kon omslaan in negatieve en omgekeerd. Politieke ontwikkelingen in het land van herkomst en in het land van bestemming, hadden invloed op de bejegening van immigranten en op hun eigen houding. ${ }^{126}$

Beeldvorming is zelden lovend. Van Maurik vermaakte zijn lezerspubliek met negatieve typeringen, niet met een opsomming van deugden. Bovendien zit in de beeldvorming ten aanzien van immigranten - niet alleen de Duitse immigranten in de negentiende eeuw, maar ook nieuwkomers in eerdere en latere tijdvakken - iets universeels; hun armoede is ons probleem en daarmee het centrale element in de beeldvorming. Naast de herhaalde nadruk op armoede, valt daarom vooral de veranderlijkheid van de beeldvorming op. Beeldvorming was geenszins statisch. In de loop van de negentiende eeuw veranderde het beeld van de Duitse immigranten onder invloed van ontwikkelingen in Nederland en Duitsland. Een onderwaardering van kwaliteiten, zoals Bauer die voelde, de vrees dat vreemdelingen zouden teren op de zak van de overheid, zoals in de kamerdebatten van 1849 werd benadrukt, afkeer van een toevloed van vooral katholieke nieuwkomers die het katholieke volksdeel zouden versterken, zoals die in 1853 naar voren kwam, of de angst dat Duitse immigranten de annexatie van Nederland actief zouden helpen bevorderen, zoals die werd verwoord na 1866 en 1870, volgden elkaar op in de beeldvorming. Door de oorlogen van 1866 en 1870, waarin Pruisen als winnaar te voorschijn kwam, werden lomp, ruw en ongemanierd als stereotypen vervangen door gezagsgetrouw, opgevoed in de 'kazerne-philosophie' met een nadruk op plichtsbesef en orde. De strowis waarop de Duitse immigranten kwamen aandrijven, bleef eeuwenlang terugkeren in de beeldvorming, maar beeldvorming was desondanks bijzonder gevoelig voor ontwikkelingen binnen en buiten de landsgrenzen. 


\section{4 'Eene soort polis voor hulp' Registratie, omvang, herkomst en vestiging}

In 1892 werd in de Tweede Kamer een uitgebreide discussie gevoerd over het kieswetsontwerp van Tak van Poortvliet, de Minister van Binnenlandse Zaken. In die discussie werd een poging gedaan om het bevolkingsregister te verheffen tot grondslag voor het kiesrecht. Het is een interessante discussie, omdat ze zicht biedt op wie wel en wie niet voorkwam in de bevolkingsregisters - de hoofdbron van dit onderzoek. ${ }^{1}$ De voorstanders van de verheffing van het bevolkingsregister tot grondslag voor het kiesrecht, voerden aan dat zo in ieder geval de zwervende bevolking het kiesrecht ontzegd werd.

Zwervende bevolking, die geenerlei welstand bezit, als landloopers, venters, reizende marskramers enz. voorzoover zij enkel op de verblijfsregisters voorkomen, blijven dus van kiesrecht verstoken. ${ }^{2}$

Het bevolkingsregister bood, zo dachten zij, de zekerheid dat de potentiële kiezer ten minste drie maanden in een plaats woonde. Mensen die er minder lang woonden werden immers, meenden de voorstanders, ingeschreven in het verblijfsregister. Tegenstanders van het voorstel stelden, dat een verblijfsregister in veel plaatsen niet werd bijgehouden; de tijdelijke bevolking werd gewoon in de bevolkingsregisters opgenomen. In de bevolkingsregisters kwamen bovendien wel degelijk zwervers voor. Juist de economisch zwakken, waaronder de zwervers, zouden hechten aan inschrijving in het bevolkingsregister.

Bij bedeeling, gemeentelijke onderstand en opname in ziekenhuizen wordt in grote steden bewijs van inschrijving in bevolkingsregisters gevorderd.[...] Deze categorie beschouwt die inschrijving als eene soort polis voor verzekering en hulp. ${ }^{3}$

Een artikel in de Nieuwe Rotterdamsche Courant van 23 april 1893 voedde de discussie. Hierin werd gesteld dat bedelaars en landlopers er wel voor zorgden dat ze 'op het bevolkingsregister gebracht werden'. ${ }^{4}$ Voor hen was het immers belangrijk dat zij een domicilie van onderstand hadden. ${ }^{5}$ Nijvere ambtenaren traceerden in de bevolkingsregisters voor kamerleden en journalisten enkele notoire landlopers. Meerdere kamerleden sloten zich hierop bij de visie van het krantenartikel aan. 
Juist tot deze categorie behoorende personen, die een reizend beroep uitoefenen, vestigen zich, voorzien van een behoorlijk verhuisbiljet, bij voorkeur in groote steden met eigen ziekenhuizen en vele liefdadige instellingen waar zij in kosthuizen hunnen intrek nemen of eene kamer in een onaanzienlijke buurt betrekken; van daar uit beginnen zij hunne operatiën en keeren naar hun punt van uitgang terug, om daar de vruchten van hun arbeiden te genieten en zich op nieuwe strooptochten voor te bereiden. ${ }^{6}$

Het armlastige deel van de vreemdelingen was in de bevolkingsregisters niet ondervertegenwoordigd. Sterker nog, ook wie zich overwegend op het platteland ophield, deed er goed aan zich in de stad te laten inschrijven.

\section{Domicilie van onderstand en patentwetgeving}

De inschrijving van mensen in het bevolkingsregister werd bepaald door de registratiegrondslag. Tussen 1850 en 1861 was dat het wettelijk domicilie. Dit betekende dat er slechts mensen werden ingeschreven die officieel hun domicilie of woonplaats in die gemeente hadden. Dat hoefde niet te betekenen dat zij ook werkelijk daar woonden. Sommige mensen woonden allang niet meer in de stad, maar hielden er toch hun domicilie aan. Omgekeerd konden er jarenlang mensen in een plaats wonen die hun wettig domicilie elders aanhielden en die derhalve niet in het bevolkingsregister werden ingeschreven. Het wettig domicilie als grondslag voor registratie leidde ertoe, dat het bevolkingsregister een juridisch beeld gaf van de bevolking, dat niet met de werkelijkheid overeen kwam. Het verschil tussen beide cijfers was niet onbetekenend. In 1859 telde Utrecht bijvoorbeeld een wettige bevolking van 51.579 en een werkelijke van 54.080 .

In 1861 werd de registratiegrondslag gewijzigd en werd niet langer de wettige bevolking geregistreerd, maar de werkelijke. Deze wijziging had met enige vertraging gevolgen voor de bevolkingsregisters. Omdat er in 1861 geen volkstelling werd gehouden, moesten mensen die reeds in de stad woonden, maar daar niet hun domicilie hadden, min of meer 'ontdekt' worden door de ambtenaren die de registers bijhielden. Dat gebeurde bij de halfjaarlijkse rondgang die, ter controle van de bevolkingsregistergegevens, door de wijk werd gemaakt, bij de aangifte van geboorte, huwelijk of overlijden, of bij verhuizing naar een andere gemeente. Nog enige tijd na de wijziging van 1861 bleven de bevolkingsregisters vooral een afspiegeling van de wettelijke bevolking. Immigranten konden in principe tot de volkstelling van 1869 in de stad wonen zonder in een bevolkingsadministratie te worden opgenomen.

In 1861 werden in Utrecht twaalf Duitse immigranten 'suppletoir' in het bevolkingsregister ingeschreven, als uitvloeisel van de wijziging van de registratiegrondslag. Na 1861 werden druppelsgewijs, tot de volkstelling in 1869, suppletoir 141 Duitse immi- 
granten in het bevolkingsregister ingeschreven. De vermelding 'suppletoir' betekent dat zij er reeds enige tijd waren, maar nog niet geregistreerd stonden.

$\mathrm{Na} 1861$ werd door ambtenaren geprobeerd om groepen die een grote mobiliteit kenden, buiten de bevolkingsregisters te houden. Dienstbodes, gestichtbewoners, tijdelijke immigranten, militairen, schippers en later woonwagenbewoners 'vervuilden' in zekere zin de bevolkingsadministratie. Hun veelvuldige in- en uitschrijvingen, waarbij de vervallen inschrijvingen werden doorgehaald, gaven de bevolkingsregisters een rommelig en onoverzichtelijk aanzien. Hierom kwamen er na 1861 mogelijkheden voor afzonderlijke registratie van deze groepen. Verplicht was dat niet en in Utrecht werd er geen gebruik van gemaakt. Op het eerste blad van het vuistdikke maar verder lege Utrechtse schippersregister staat: 'zie voor de schippers de wijken A tot en met M'; dit waren alle Utrechtse wijken. De varende en later ook de rijdende bevolking werd in de Domstad niet in de afzonderlijke registers ingeschreven, maar gewoon op de adressen waar ze hun schip (soms) hadden afgemeerd. Woonwagenbewoners werden in de bevolkingsregisters ingeschreven op het adres van het kamp.

In principe werden zowel voor als na 1861 alleen mensen ingeschreven in het bevolkingsregister, van wie het verblijf kon worden aangemerkt als niet van 'kennelijk tijdelijke' aard. ${ }^{8}$ Migranten die wel kennelijk tijdelijk in een plaats verbleven, konden in principe na 1861 worden ingeschreven in een zogenaamd verblijfsregister. In het kamerdebat van 1892 werd hieraan gerefereerd. Opname in het verblijfsregister was niet gekoppeld aan de werkelijke verblijfsduur. Zowel in het bevolkingsregister als in het verblijfsregister werden mensen ingeschreven die slechts kort in de stad verbleven; de eersten hadden kennelijk het voornemen om langer te blijven, de laatsten niet. De grens tussen inschrijving in het bevolkingsregister of in het verblijfsregister bestond niet uit een vast aantal dagen. Het 'kennelijk' voornemen om tijdelijk te blijven kon door de vreemdelingen zelf worden verwoord, of de gemeenteambtenaar kon om een of andere reden besluiten dat de vreemdeling dat kennelijk van plan was. De vreemdeling kon bijvoorbeeld tot een beroepsgroep behoren waarvan de leden gewoonlijk slechts tijdelijk in een stad verbleven, zoals de stukadoors.

Inschrijving in het verblijfsregister betekende niet dat het verblijf daadwerkelijk tijdelijk was; het was alleen 'kennelijk tijdelijk' bedoeld wat betekende dat of de ambtenaar of de vreemdeling zelf dacht dat het verblijf slechts tijdelijk zou zijn. In de praktijk kon een vreemdeling die in het verblijfsregister was ingeschreven jarenlang in een stad wonen. Na enige tijd - soms na een langjarig verblijf - kon de vreemdeling door de gemeenteambtenaar worden overgeschreven van het verblijfsregister naar het bevolkingsregister, omdat het verblijf niet zo tijdelijk was als het in eerste instantie leek. De periode die verliep voor de overschrijving van het ene naar het andere register stond niet vast. Sommige gemeenteambtenaren hanteerden drie jaar als termijn, andere zes. Er waren echter ook gemeenteambtenaren die bij een verblijf van minder dan drie jaar overgingen tot overschrijving van het ene register in het andere.

Bijhouden van een verblijfsregister was niet verplicht en de meeste gemeenten deden dat niet of slechts tijdelijk. ${ }^{9}$ Utrecht kende geen verblijfsregister. Dat is een voor- 
deel, omdat dit betekende dat vreemdelingen sneller in het bevolkingsregister werden ingeschreven. Waarschijnlijk zijn slechts de echt tijdelijk aanwezigen - zoals toeristen buiten de bevolkingsadministratie gebleven.

Vreemdelingen hadden belang bij inschrijving in het bevolkingsregister omdat zij die in het verblijfsregister waren ingeschreven en niet in het bevolkingsregister, niet werden beschouwd als ingezetenen. ${ }^{10}$ Dat had niet alleen gevolgen voor het domicilie van onderstand, maar ook voor de patentbelasting. De patentbelasting werd in 1805 ingevoerd als 'regt van patent op allen handel, neringen, beroepen en bedrijven en eenige andere objecten van vermaak of weelde'. ${ }^{11}$ De belasting heeft - zij het steeds minder beroepen omvattend - bestaan tot 1893 . In de patentwetgeving werd onderscheid gemaakt tussen vreemde en inlandse kramers en kooplieden. ${ }^{12}$ Vreemde kramers en kooplieden betaalden twee keer zoveel belasting als inlandse. Vreemde scharenslijpers en ketelboeters werden eveneens afzonderlijk belast. Deze maatregel werd tot de opheffing van de patentbelasting gehandhaafd.

Met vreemde kramers werden geen mensen bedoeld die in het buitenland waren geboren, maar slechts mensen die niet waren ingeschreven in het bevolkingsregister. Als voorbeeld kunnen Hendrik Muller en Georg Seelberg worden genoemd. Hendrik Muller, geboren in Westfeld in Pruisen, werd in de patentbelasting aangeslagen als inlands kramer, ventende in de provincie Utrecht en 'voorstaande op de markt te Utrecht' met hout- en ijzerwaren en kousen. Muller woonde met enkele andere handelaren die eveneens uit Westfeld kwamen, in het centrum van de stad. Zijn collega Seelberg handelde in dezelfde producten. Hij werd in het bevolkingsregister niet op het adres van Muller ingeschreven, maar gaf dit adres wel op voor de patentbelasting. Hij vond dus bij zijn collega's onderdak. Hij werd aangeslagen als 'vreemd kramer' en betaalde dubbele belasting. ${ }^{13}$ Inschrijving hoefde niet te geschieden in de plaats waarin men als handelaar actief was, maar slechts in de plaats waar men een patent aanvroeg.

De regelgeving omtrent het domicilie van onderstand en de patentwetgeving maakten het aantrekkelijk voor vreemdelingen om zich in het bevolkingsregister te laten inschrijven. We kunnen veilig aannemen dat slechts weinig vreemdelingen, die voor meer dan drie maanden in de Domstad woonden, buiten deze registratie zijn gebleven.

\section{Vreemdelingenregisters}

Vreemdelingen werden ook geregistreerd in vreemdelingenregisters waarvan de correcte naam was Register van uitgegeven reis- en verblijfpassen. ${ }^{14}$ In dit register, dat werd aangelegd als uitvloeisel van de Vreemdelingenwet van 1849, werd aangetekend wie om zo'n pas verzocht. In Utrecht ontbreekt dit register. Het zou onderdeel moeten zijn van het politiearchief, maar dat archief is in Utrecht in de Tweede Wereldoorlog goeddeels verloren gegaan. Een gemis is dat niet echt. Vreemdelingen die werden ingeschreven in het register van reis- en verblijfpassen en die kennelijk voornemens waren om in een 
bepaalde plaats te blijven, werden ook ingeschreven in het bevolkingsregister. Met zeer grote regelmaat werd in de kolom 'aanmerkingen' van het bevolkingsregister vermeld: 'Ingeschreven op vertoon van reis- en verblijfpas getekend en afgegeven door de politie alhier' of getekend door 'den heer van Goudoever', de Utrechtse commissaris van politie. De registers van reis- en verblijfpassen bevatten bovendien niet alle vreemdelingen die in een stad aanwezig waren, maar slechts de vreemdelingen die verplicht werden een reis- en verblijfpas aan te vragen. In de tweede helft van de negentiende eeuw verwaterde voorts de uitgifte van reis- en verblijfpassen. Dit betekende dat deze passen ook niet meer werden uitgegeven aan mensen die daarvoor in principe volgens de Vreemdelingenwet wel in aanmerking kwamen. Twintig jaar na de invoering van het register van reis- en verblijfpassen was de registratie zozeer verwaterd, dat de registers nog slechts een zeer onvolledig beeld van de immigrantenpopulatie bieden. ${ }^{15}$

\section{Geboorteplaats}

Bevolkingsregisters vermelden geen nationaliteit. ${ }^{16}$ Een voorstel dat in 1892 werd gedaan, om in het bevolkingsregister de nationaliteit te vermelden, haalde het niet. ${ }^{17} \mathrm{Na}-$ tionaliteit bleef ontbreken tot 1920, ofschoon het gedurende de tweede helft van de negentiende eeuw in publieke debatten steeds belangrijker was geworden. Probleem was echter dat de nationaliteit van alle inwoners van Nederland geenszins duidelijk was.

Uitgangspunt van dit onderzoek naar Duitsers was daarom de geboorteplaats. Van alle personen die in de bevolkingsregisters van 1850 tot 1879 voorkwamen, en die geboren waren in Duitsland, zijn alle kenmerken overgenomen in een database. ${ }^{18}$ Gegevens van familie- en huisgenoten, ook wanneer die niet in Duitsland waren geboren, werden eveneens opgenomen. In het bevolkingsregister staan voor elk huis of zelfstandig huisdeel voor elke bewoner een twintigtal gegevens genoteerd. ${ }^{19}$

Het bevolkingsregister kent als grondslag de tienjaarlijkse volkstellingen. In de tien jaren tussen de volkstellingen werden in de registers alle mutaties bijgehouden, zoals veranderingen in de samenstelling van het huishouden. Dit betekent dat er voor elke Duitse immigrant een veelheid aan gegevens is. Voor Duitse immigranten en hun huisgenoten is vervolgens in andere bronnen naar aanvullende gegevens gezocht. De Amerikaanse historicus Kamphoefner noemt deze werkwijze de 'genealogische methode'. ${ }^{20}$ De bronnen zijn dezelfde als die waarvan genealogen gebruik maken, maar de vragen die worden gesteld zijn anders. Het resultaat is een groot aantal 'aangeklede' stambomen - stambomen met veel extra informatie - die het mogelijk maken om de levens van immigranten dichtbij te brengen, en tevens door hun aantal de mogelijkheid geven om meer algemene uitspraken te doen.

Het resultaat van het zoekwerk in het bevolkingsregister, was een databestand met gegevens over 2188 in Duitsland geboren personen, die tussen 1850 en 1879 in Utrecht woonden. Deze 2188 immigranten zijn in de bevolkingsregisters - voor zover mogelijk - gevolgd over een periode van dertig jaar. Aanvullend materiaal is verzameld in de be- 
volkingsregisters tot 1912 en in de oudere volkstellingsregisters van 1839 en 1829. De namen uit het bestand zijn bovendien opgezocht in tal van andere bronnen, die wel namen en andere gegevens als adres of geloof vermelden, maar geen geboorteplaats. Vooral hierin ligt de waarde van de database; het bestand maakt het mogelijk om te identificeren wie Duits is en wie niet, en vervolgens in welke mate Duitse immigranten wonen, trouwen, werken en sociaal verkeren met andere Duitsers en niet-Duitsers.

\section{Cappeln en Cappelle}

Het onderzoek in de bevolkingsregisters bracht in Utrecht een opvallende onderregistratie aan het licht. Vergelijking van de bevolkingsregisters met andere bronnen, zoals huwelijksregisters, leerde dat in de bevolkingsregisters regelmatig Duitse geboorteplaatsen als Nederlandse werden genoteerd. In het bevolkingsregister werd het Duitse Olfen geregistreerd als Alphen, Hagen als Princenhage en 's Gravenhage, Au-

Pagina uit het Utrechtse bevolkingsregister van 1860-1879 met een voorbeeld van plaatsnaamverwarring. Dit is een gedeelte van de inschrijvingen van het kosthuis van de Winkel van Sinkel. Als nummer 9 wordt vermeld Joseph Dresler. Bij zijn geboorteplaats is Meppen Drenthe in gevuld. Hij vertrok echter in 1860 naar Meppen in Hannover. Een inschrijving in een ander bevolkingsregisterdeel vermeldt Meppen Hannover als geboorteplaats.

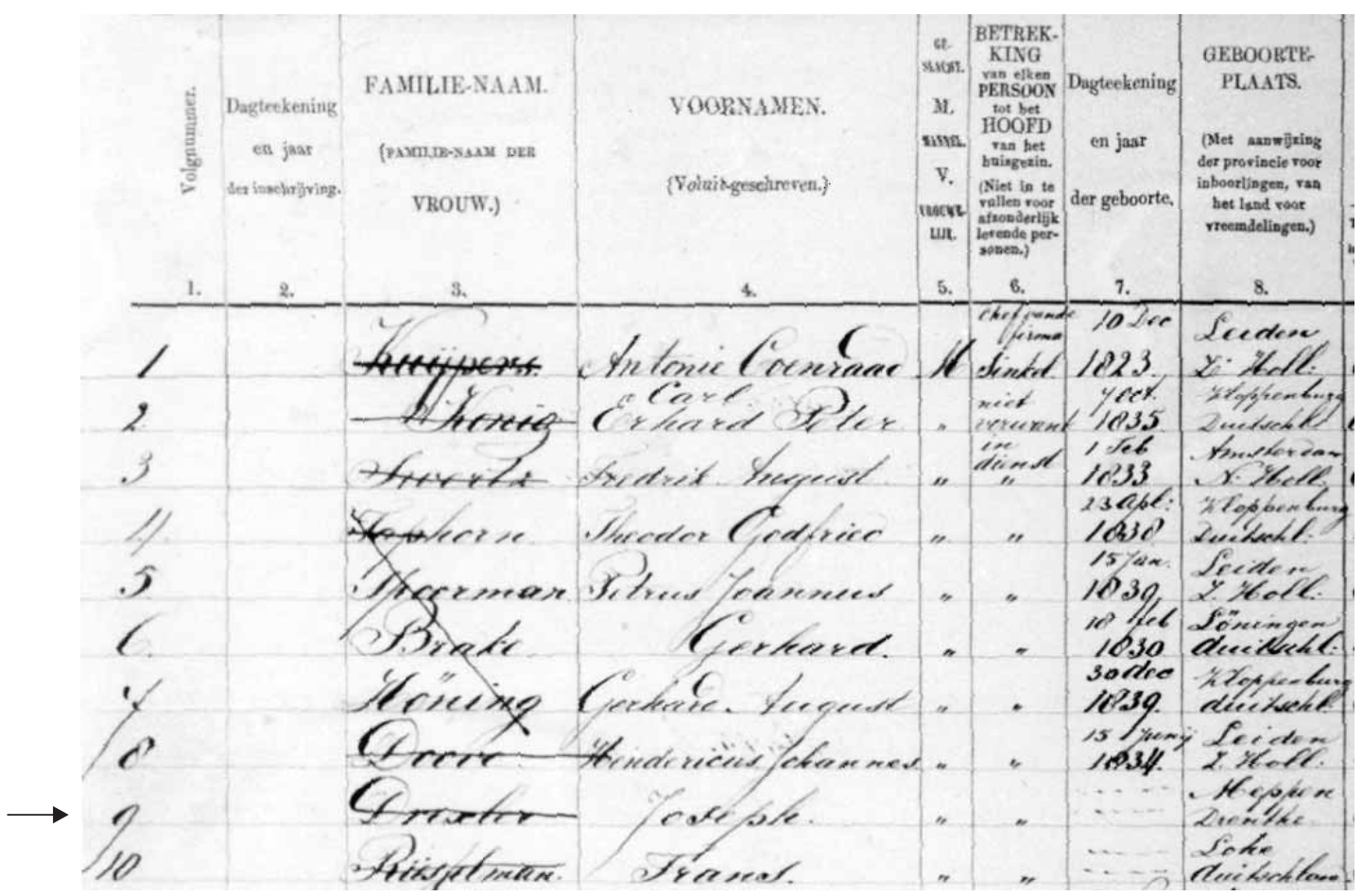


rich als Utrecht, het Duitse Cappeln als Cappelle aan den IJssel, Bunde in Oost-Friesland als Bunde in Limburg, Veurden bij Hagen werd verward met Vorden in Gelderland, Rees in Pruisen met De Rees bij Brummen in Gelderland en het Duitse Udem met het Brabantse Uden, om enkele voorbeelden te noemen (zie afbeelding van het bevolkingsregister).

Deze opmerkelijke plaatsnaamverwarringen zijn een gevolg van de wijze waarop volkstellings- en bevolkingsregistergegevens werden verzameld en verwerkt. Bij de volkstellingen werden gegevens door de betrokkenen of door de vrijwilligers die bij de volkstelling werden ingezet, zoals schoolmeesters of politieagenten, ingevuld op formulieren. Deze gegevens werden vervolgens overgeschreven in registers door één of enkele ambtenaren. Hierbij werden aan de plaatsnamen provincie- of landsnamen toegevoegd. Tenzij op het formulier nadrukkelijk anders was vermeld, werd door de overschrijvende ambtenaar systematisch uitgegaan van de veronderstelling dat bij twijfel een Nederlandse plaats werd bedoeld. Gevolg was, dat nogal wat mensen die buiten de Nederlandse landsgrenzen waren geboren, in de bevolkingsregisters toch niet als vreemdelingen werden genoteerd.

Volgens de volkstelling van 1849 waren er in de Domstad 535 Duitsers. In het bevolkingsregister over de periode 1850-1859 konden 918 Duitsers worden getraceerd. Van 714 van hen kon met zekerheid worden vastgesteld dat zij er reeds waren op het mo-

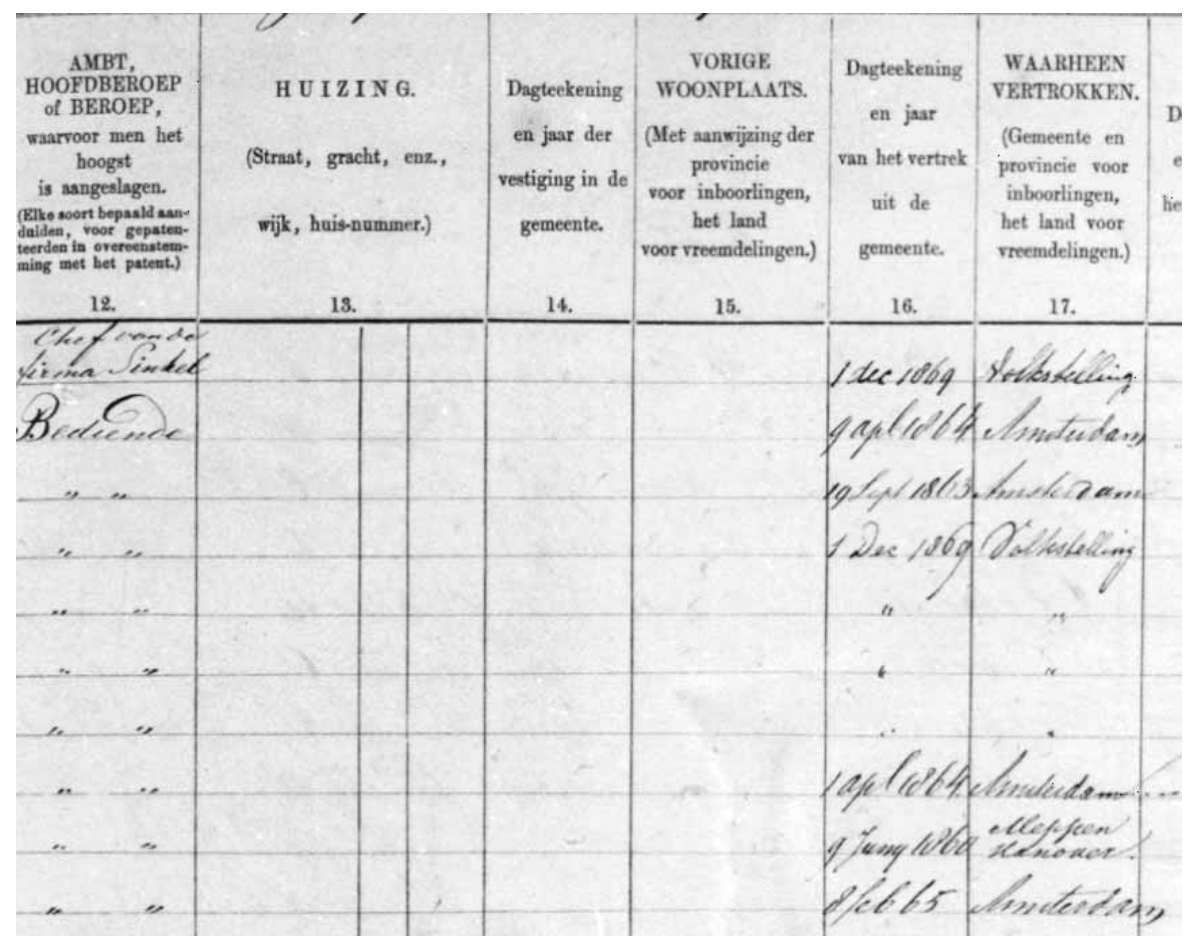


ment dat het bevolkingsregister werd aangelegd (1-1-1850). Zij stonden wel in het bevolkingsregister van 1850-1859 ingeschreven, maar niet met een Duitse geboorteplaats en dus ook niet als Duitsers. Dat ze wel in Duitsland geboren waren, bleek uit inschrijvingen in het bevolkingsregister van 1860-1879, of uit huwelijks- en overlijdensregisters. Bij een huwelijk moest een geboortebewijs worden overlegd; voor inschrijving in het bevolkingsregister was dat niet het geval.

Iemand die een of enkele keren in de registers van 1850-1859 werd ingeschreven als geboren in Nederland, maar in de latere, betrouwbaardere bevolkingsregisters of in de huwelijks- en overlijdensregisters als geboren in Duitsland, heb ik aangemerkt als Duits. De registers van de burgerlijke stand gaven de doorslag. In enkele gevallen bleef twijfel bestaan. Joana Fruschel werd tussen 1850 en 1912 zeven maal in de bevolkingsregisters vermeld. Vier maal werd hierbij een Duitse geboorteplaats opgegeven, maar niet steeds dezelfde: afwisselend werden Baden en Hamburg genoemd. Drie keer werd Wijk bij Duurstede als geboorteplaats vermeld. Het overlijdensregister geeft als geboorteplaats ook Wijk bij Duurstede. In de geboorteregisters van Wijk bij Duurstede werd ze niet gevonden. Vanwege deze onduidelijkheid is Fruschel buiten de tellingen gehouden.

Wanneer de gegevens uit de bevolkingsregisters gecorrigeerd worden voor plaatsnaamverwarring blijkt het aantal Duitsers maar liefst 33 procent hoger te liggen; geen 535 maar 714. Wanneer deze onderregistratie een algemeen Nederlands verschijnsel zou zijn, moeten uitspraken over het aantal vreemdelingen in Nederland, die stoelen op de

Figuur 4.1 Aantal Duitse immigranten volgens de volkstellingen en schatting omtrent aantal, wanneer onderregistratie ook opgaat voor andere jaren en plaatsen.

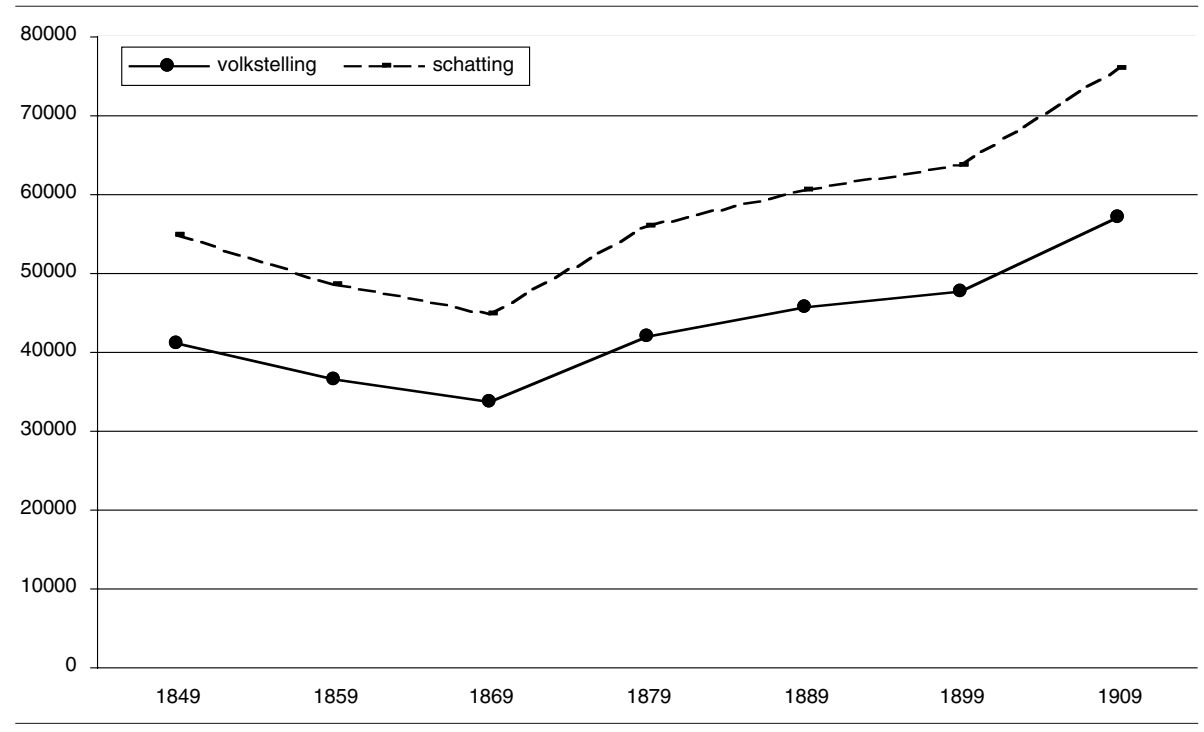

Bron Bewerking van volkstellingsgegevens en schatting op basis van resultaten voor Utrecht. 
negentiende-eeuwse volkstellingen, sterk naar boven worden bijgesteld. Onderzoek in andere plaatsen heeft inmiddels aangetoond dat deze plaatsnaamverwarring niet beperkt bleef tot Utrecht. ${ }^{21}$ Onduidelijk is vooralsnog of de onderregistratie overal even groot was. Volgens de volkstelling van 1849, telde Nederland 41.000 mensen die in Duitsland waren geboren. Als de plaatsnaamverwarring elders tot een vergelijkbare onderregistratie heeft geleid, zou Nederland in 1849 niet 41.00o maar 55.00o Duitsers hebben geteld. Extrapolatie op basis van de Utrechtse gegevens is echter riskant, omdat de onderregistratie van Duitsers als gevolg van plaatsnaamverwarring niet voor alle wijken binnen Utrecht gelijk was. Aangenomen kan worden dat hetzelfde gold voor de verschillende steden (zie figuur 4.1).

\section{Utrecht in het midden?}

Elke Nederlandse stad heeft haar eigen migratiegeschiedenis. Utrecht is echter een goede middenmoter, wanneer het gaat om het percentage vreemdelingen in de stad, het aantal Duitsers onder hen, of de sekseratio binnen de Duitse migrantenpopulatie.

Duitse immigranten vormden tussen 1849 en 1879 ongeveer zestig procent van het totale aantal vreemdelingen in Nederland. In de provincie Utrecht lag het percentage Duitse immigranten op het totale aantal vreemdelingen iets hoger (65 tot 68 procent). In absolute aantallen woonden er in 1849 volgens de volkstellingsgegevens ongeveer

Figuur 4.2 Percentage Duitsers per provincie 1849-1889.

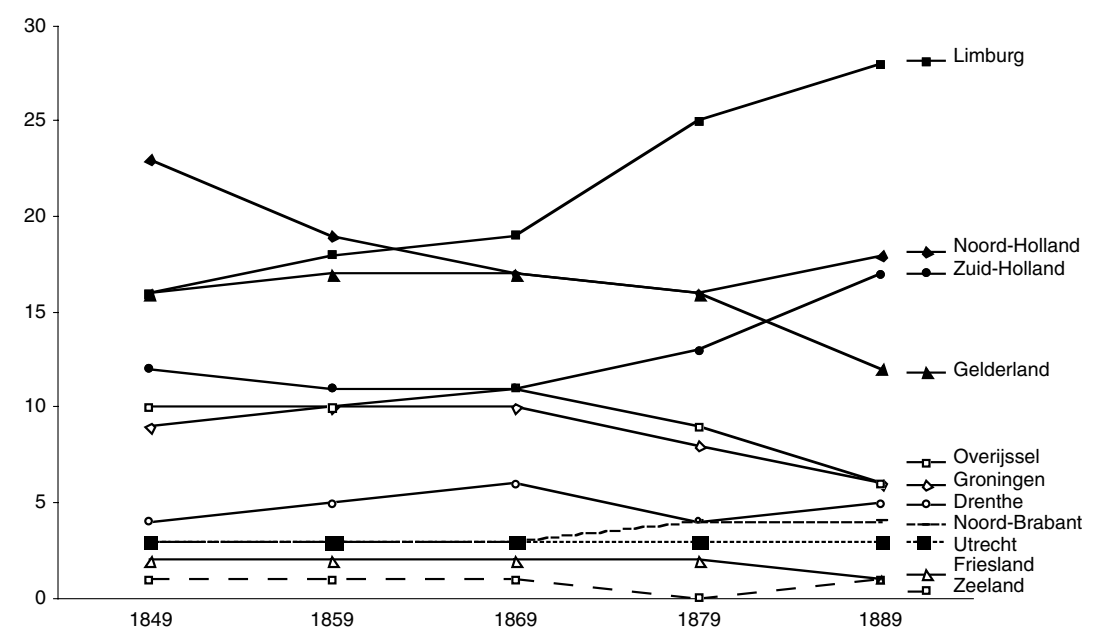

Bron Bewerking van volkstellingsgegevens. 
41.0oo Duitsers in Nederland en in 1879 42.00o. Er deed zich in dertig jaar dus een geringe absolute groei voor. Die groei was vooral een gevolg van toename van het aantal Duitse immigranten in de provincie Limburg (van 6.600 naar 11.00o). In de meeste andere provincies liep het aantal Duitse immigranten terug, behalve in Zuid-Holland, waar het aantal toenam van 5.000 naar 5.400. De provincie Utrecht past in het algemene Nederlandse beeld; in die provincie woonden in 18491327 Duitsers en dertig jaar later 1175 (zie figuur 4.2).

Duitse immigranten richtten binnen Nederland hun schreden hoofdzakelijk naar Noord-Holland (23 procent van de Duitse immigranten in 1849 en 16 procent in 1879), Zuid-Holland (respectievelijk 12 en 13 procent), Limburg (16 en 25 procent) en Gelderland (steeds 16 procent). De provincie Utrecht trok drie procent van het totaal aantal Duitse immigranten. Daarmee was deze provincie, ondanks de goede verkeersverbinding met Duitsland, en ondanks het feit dat de afstand tot de Duitse grens korter was dan die vanuit Noord- of Zuid-Holland, minder belangrijk als aantrekkingsgebied dan de kustprovincies.

Mensen geboren in Duitsland vormden tussen 1849 en 1879 1,3 tot 1 procent van de Nederlandse bevolking. Dit percentage was voor de provincie Limburg het hoogst $(3,2$ tot 4,5 procent) en voor Zeeland het laagst (o,2 tot 0,1 procent). De provincie Utrecht lag, met 0,9 procent in 1849 en 0,6 procent in 1879 , onder het midden.

Immigratie van Duitsers was vooral een stedelijk fenomeen. Dit gold bij uitstek voor de provincie Noord-Holland; in 1849 woonde 76 procent van de Duitsers in de stad Amsterdam. In de provincie Zuid-Holland woonde in 184935 procent van de Duitsers in Rotterdam. In de provincie Utrecht woonde in 184940 procent van de Duitse immigranten in de provinciehoofdstad; in 1879 was dat 54 procent. Dit relatief hoge cijfer wordt verklaard door het weinig stedelijke karakter van de provincie. In Zuid-Holland kreeg Rotterdam concurrentie van Den Haag, Leiden, Delft, Dordrecht en Schiedam. In de provincie Utrecht was, behalve de Domstad, alleen Amersfoort belangrijk (zie figuur 4.3).

De sekseratio binnen de migrantenpopulatie - het aantal mannen in verhouding tot het aantal vrouwen - was per provincie zeer verschillend. In de provincie Friesland - koploper op dit punt - was in 1849 de verhouding tussen het aantal mannen en het aantal vrouwen drie op een. In Noord- en Zuid-Holland was in 1849 de verhouding ongeveer twee op een $(2,3$ en 2,0). In 1879 lag dat cijfer lager $(1,7$ en 1,4). Dit betekent dat de migratie van vrouwen naar deze provincies verhoudingsgewijs sterker toenam dan die van mannen. In de provincie Utrecht was de sekseratio 1,5 in 1849 en 1,0 in 1879. In dat laatste jaar bestond de Duitse populatie in Utrecht dus voor de helft uit mannen en de helft uit vrouwen (zie figuur 4.4).

Er waren bij de sekseratio niet alleen verschillen tussen provincies, maar ook tussen steden. Uitschieters waren Nijmegen en Maastricht, waar het aantal Duitse vrouwen in 1849 groter was dan het aantal mannen (respectievelijk 0,7 en o,8). Een uitschieter aan de andere kant van het spectrum was Schiedam, waar veel Duitse mannen in de jeneverstokerijen werkten. Hier lag de sekseratio juist uitzonderlijk hoog en was de verhou- 
Figuur 4.3 Percentage migranten dat in de genoemde grote stad woont als aandeel van totaal per provincie in de jaren 1849 en 1879.

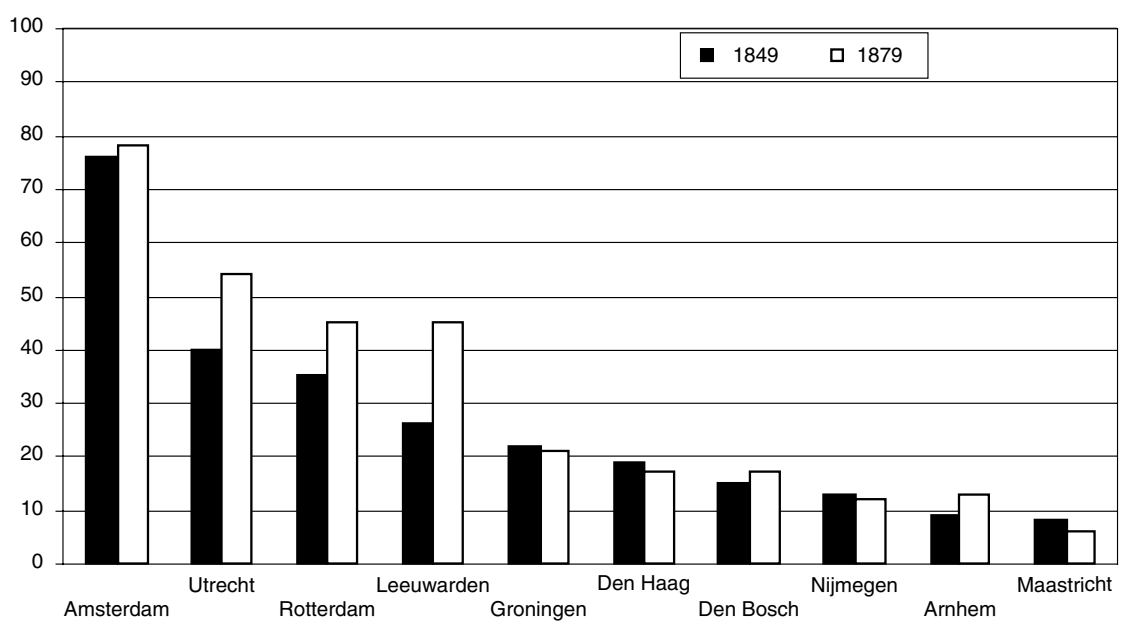

Bron Bewerking van volkstellingsgegevens 1849 en 1879.

Figuur 4.4 Percentage Duitse mannen per provincie 1849 en 1879.

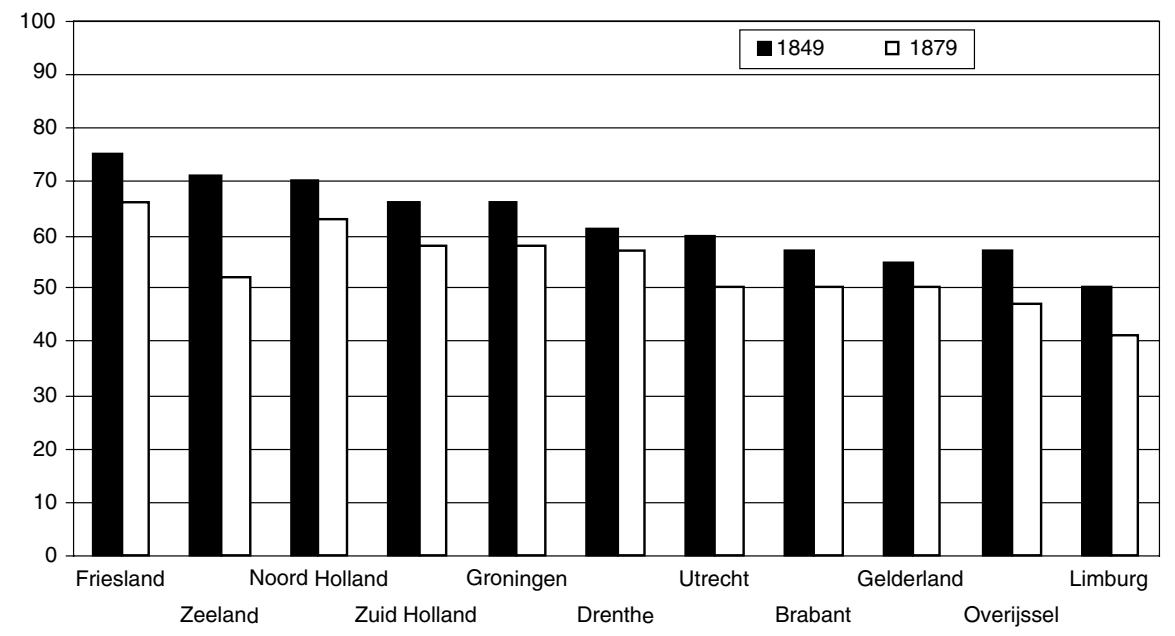

Bron Bewerking van volkstellingsgegevens. 
ding zes op een $(6,3)$. In Amsterdam en Rotterdam was de sekseratio in 1849 ongeveer twee, in de Domstad 1,3 (zie figuur 4.5).

Wanneer het gehele Utrechtse beeld wordt overzien en afgezet tegen het landelijke, dan kan de Duitse migratie naar Utrecht worden getypeerd als niet bijzonder omvangrijk, stabiel in aantal en met een min of meer gelijke verhouding tussen het aantal vrouwen en mannen. De migratie naar de provincie en de Domstad was op geen van de genoemde punten een uitschieter en nam ongeveer een positie in het midden in.

\section{Geografische herkomst}

In de zestiende eeuw nam, met de welvaart, ook de migratie naar Nederland toe. Het merendeel van de nieuwkomers kwam ook toen reeds uit Duitse streken. Na 1780 stagneerde de economie en liep het aantal nieuwkomers terug. In de Domstad was de Duitse immigratie, net als elders in Nederland, reeds lang voor 1800 belangrijk. ${ }^{22}$ Van de totale Utrechtse bevolking was in 1750 drie procent - ongeveer duizend personen afkomstig uit Duitse streken. ${ }^{23}$ Een eeuw eerder, omstreeks 1650, lag het percentage Duitse immigranten met 11 tot 16 veel hoger. ${ }^{24}$

Vóór 1580 was driekwart van de Duitse immigranten afkomstig uit het stroomgebied van de Rijn en zijn zijrivieren als de Ruhr en de Lippe. ${ }^{25}$ Keulen, Neuss en Wesel waren belangrijke herkomstplaatsen. Na 1580 nam het aantal Duitse migranten absoluut en verhoudingsgewijs toe en breidde het afstotingsgebied zich uit. Aken en Essen

Figuur 4.5 Percentage mannen onder de Duitse immigranten per stad in 1849.

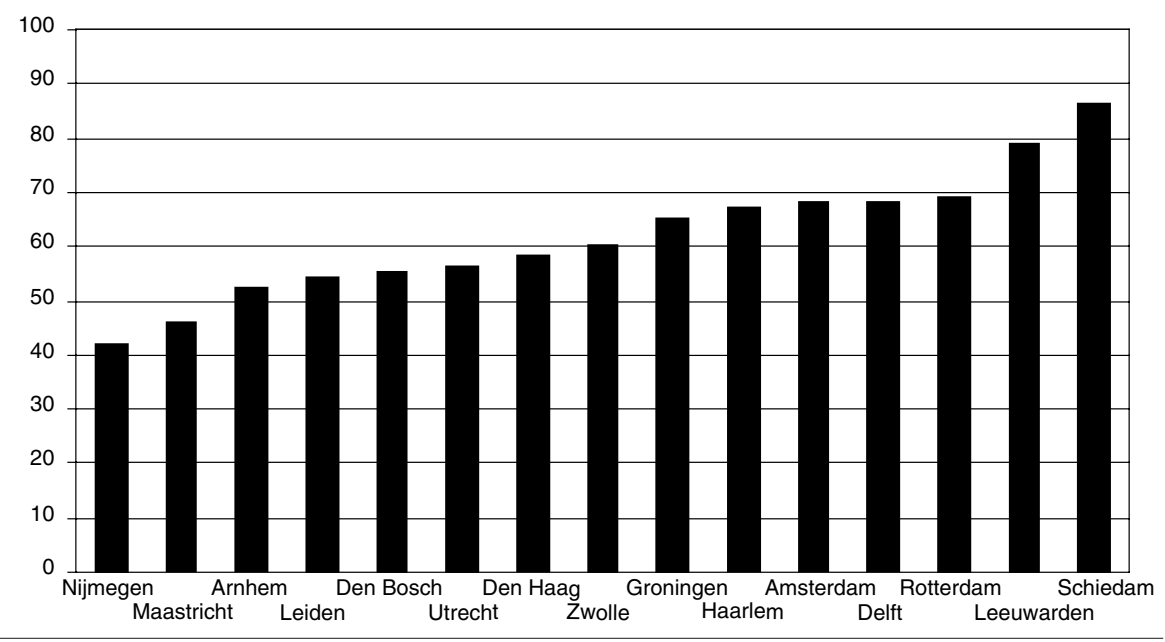

Bron Bewerking van volkstellingsgegevens 1849. 
werden nu belangrijk. Nieuw was de migratie uit het Noordduitse kustgebied. Na 1630 kwamen er bovendien protestantse vluchtelingen uit de (Neder-)Palts. In de achttiende eeuw werden Hessen en Nassau belangrijker en nam de migratie uit Saksen en Thüringen toe. De Rijnprovincies en de kuststreken namen in betekenis af. Het belangrijkste was dat er in de achttiende eeuw, in tegenstelling tot eerdere periodes, niet langer sprake was van één of enkele duidelijk herkenbare herkomststreken. ${ }^{26}$ In de negentiende eeuw veranderde dat.

Het verschil tussen de negentiende eeuw en eerdere tijdvakken kan een gevolg zijn van een verschil in bronnen. Uit eerdere tijdvakken weten we weinig over de herkomstplaatsen van katholieke nieuwkomers. Bij huwelijksregisters, de meest gebruikte bron voor de vroegere periode, moet onderscheid worden gemaakt tussen de huwelijken die werden aangetekend bij de nederduitsgereformeerde kerk en de huwelijken van katholieken en doopsgezinden, die werden gesloten voor schout en schepenen. ${ }^{27}$ In de eerste registers werd in de zeventiende eeuw meestal een herkomstplaats vermeld; in de achttiende eeuw was dat niet het geval. Bij de huwelijken voor schout en schepenen ontbraken steeds de herkomstplaatsen. ${ }^{28}$ Over de herkomst van katholieke en doopsgezinde immigranten hebben we dus geen informatie. De lidmatenregisters van de nederduitsgereformeerde, waalse, doopsgezinde en lutherse kerken geven ook zicht op herkomstof geboorteplaats van immigranten. ${ }^{29}$ Voor katholieken ontbreekt echter in dit geval eveneens een vergelijkbare registratie. Als laatste geven de inschrijvingen in de burgerboeken, van mensen die het burgerrecht verwierven, een beeld van de herkomstplaatsen van nieuwkomers in de stad, zij het slechts van degenen die in staat en bereid waren burgerrecht te verwerven. Opnieuw vinden we een ondervertegenwoordiging van katholieke vreemdelingen, omdat het verwerven van burgerrecht door vreemde katholieke immigranten in Utrecht lange tijd werd bemoeilijkt. De ondervertegenwoordiging van katholieken is belangrijk, omdat het in de negentiende eeuw vooral enkele overwegend katholieke streken in Duitsland waren, waar een groot deel van de nieuwkomers vandaan kwam.

In de negentiende eeuw was migratie van Duitsers naar Nederland onderdeel van een grootschalige uittocht. Het merendeel van de Duitse emigranten ging overzee, met Amerika als voornaamste bestemming. Voor de omvang van deze overzeese migratie zijn Duitse cijfers beschikbaar. Hetzelfde geldt niet voor de negentiende-eeuwse migratie naar Nederland en andere buurlanden. In het algemeen is echter wel duidelijk, dat de streken of plaatsen vanwaar Duitsers naar overzeese bestemmingen migreerden niet dezelfde waren als de plaatsen die veel - seizoensmatige - migratie naar Nederland kenden..$^{30}$ De overzeese en binnen-Europese migratiebewegingen vonden weliswaar gelijktijdig plaats, maar waren niet gelijk van aard en waren evenmin onderdeel van eenzelfde migratiesysteem.

Omdat Duitsland in een groot deel van de negentiende eeuw geen politieke eenheid was, moet worden aangegeven welke afbakening in dit boek is gehanteerd. Ik ben uitgegaan van de grenzen van het Duitse Rijk zoals die golden juist vóór de annexatie van Elzas-Lotharingen in 1871. Mensen uit Elzas-Lotharingen vallen dus buiten het onder- 
Kaart 4.1 Herkomstplaatsen van Duitse migranten in periode 1849-1879, met als referentie de plaatsen Hamburg, Berlijn, Leipzig, München, Stuttgart, Saarbrücken en Bonn.

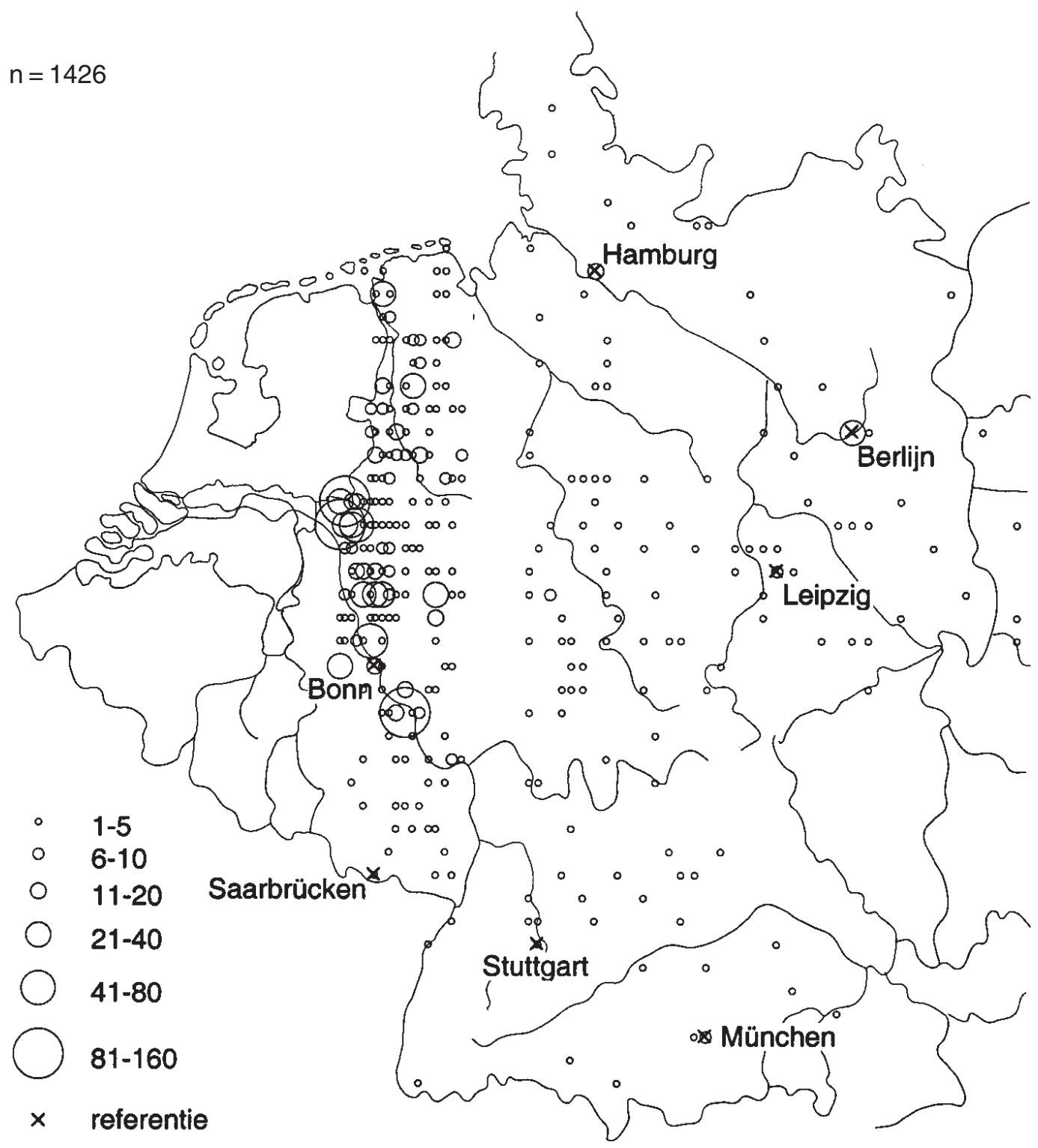

Toelichting $n=1426$. Het kaartje heeft alleen betrekking op volwassen immigranten en niet hun in Duitsland geboren kinderen (155).

Bron Bestand Duitsers in Utrecht. 
zoek en immigranten uit het in 1866 geannexeerde Sleeswijk-Holstein vallen erbinnen. Anders gezegd, als Duitsers zijn beschouwd mensen die geboren werden binnen het gebied van de Duitse Bond, zonder Oostenrijk, Luxemburg en Limburg en inclusief die delen die wel tot het Koninkrijk Pruisen behoorden, maar niet tot de Duitse Bond. De grenzen zouden ook anders kunnen worden getrokken. Duitssprekende migranten uit Bohemen beschouwden zichzelf in de negentiende eeuw ook als Duitsers. ${ }^{31}$ Bij de hier gehanteerde afbakening waren ze dat niet. De negentiende-eeuwse zelfdefinitie hoefde niet helemaal met de hier gebruikte afbakening te overlappen. Een andere, ruimere definitie van de grenzen, zou echter voor de uitkomsten weinig verschil hebben opgeleverd. Er kwamen slechts weinig mensen uit Sleeswijk-Holstein of uit Elzas-Lotharingen naar Utrecht. In dertig jaar kwam er slechts één persoon uit Straatsburg. De immigratie uit het meest oostelijke deel van het Duitse Rijk was nihil en er waren slechts drie mensen die geboren waren in Bohemen.

Kaart 4.1 geeft een beeld van de geografische herkomst van de Duitse immigranten in Utrecht. De kaart heeft betrekking op 65 procent van de Duitse immigranten. Van de overige migranten was de geboorteplaats niet op een kaart aan te wijzen. De belangrijkste reden hiervoor was dat de plaatsnaam meerdere keren voorkwam. Neuenkirchen komt minstens twaalf keer voor in Duitsland; Ransbach, de naam van het dorp waar de in dit boek getalsmatig belangrijke Westerwalders vandaan kwamen, minstens zes keer. Daarnaast werd de naam van een bestuurlijk centrum of de hoofdplaats van een kerkparochie soms gebruikt als aanduiding voor een groter omliggend gebied. Omgekeerd gaven Duitse immigranten in enkele gevallen de naam van een gehucht, buurtschap of parochie op als hun geboorteplaats. ${ }^{32}$ Van een gedeelte van de immigranten was slechts bekend dat zij in 'Pruissen' of in 'Duitschland' waren geboren. Hannover en Oldenburg duiden zowel een stad als een landstreek aan.

Combinaties van gegevens uit de verschillende inschrijvingen in de bevolkingsregisters en gegevens uit registers van de burgerlijke stand, boden in bepaalde gevallen uitkomst. Waar de bevolkingsregisters in het ene geval volstonden met 'Hannover', bleek elders uit een huwelijks- of overlijdensakte dat het om een plaats in de landsstreek ging en niet om de stad. In een aantal gevallen - 32 voor Hannover en 18 voor Oldenburg - bleef onduidelijkheid bestaan. Deze gevallen zijn daarom buiten de kaarten gehouden en dat betekent dat de migratie uit deze plaatsen of streken feitelijk iets groter was dan uit de kaarten blijkt.

In de Utrechtse bevolkingsregisters werd bij een plaatsnaam ook vaak een streek vermeld, bijvoorbeeld 'Ankum, Hannover'. Niet in alle gevallen was die toevoeging correct. De meest voorkomende vergissing was, dat plaatsen die feitelijk in Hannover lagen werden gesitueerd in Oldenburg. ${ }^{33}$ Het probleem kwam gedeeltelijk voort uit het verschil tussen een geografische en een bestuurlijke betekenis.

Op kaart 4.1 zijn bepaalde concentraties herkenbaar. Uit het Westerwald in Nassau, uit Oldenburg, Sauerland, Kleefsland en uit de omgeving van Remscheid kwamen opvallend veel immigranten. Uit deze streken tezamen kwam 70 procent van de Duitse 
immigranten. Deze migratie hield verband met regiogebonden specialisatie in bepaalde beroepen. ${ }^{34}$ Er waren ook regio's en plaatsen waar relatief veel immigranten vandaan kwamen, zonder dat sprake was van combinatie met een beroepsspecialisatie. Als voorbeeld kan het belangrijke Duitse textielcentrum Elberfeld worden genoemd. Uit Elberfeld kwamen geen textielarbeiders of -arbeidsters naar Utrecht. Zowel de

Kaart 4.2 Herkomstplaatsen van Duitse vrouwen in periode 1849-1879.

$\mathrm{n}=611$

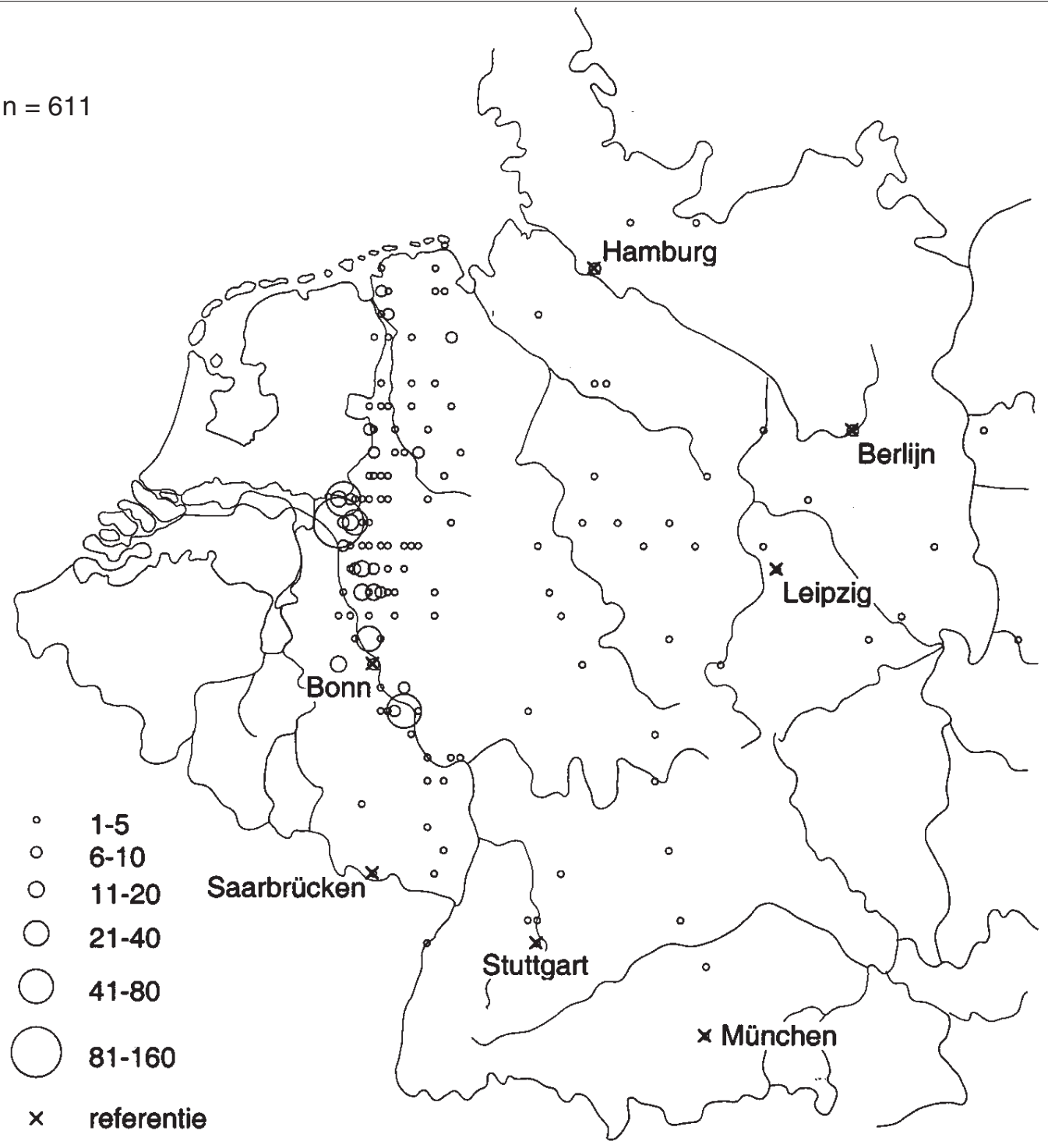

Bron Bestand Duitsers in Utrecht. 
bloei van de industrie in Elberfeld, als het ontbreken van een textielindustrie van enige betekenis in Utrecht kunnen dat verklaren. De Elberfelder immigranten in Utrecht - 28 in totaal - werkten in uiteenlopende beroepen, woonden verspreid over de stad en hadden geen gemeenschappelijk geloof.

Kaart 4.3 Herkomstplaatsen van Duitse mannen in periode 1849-1879.

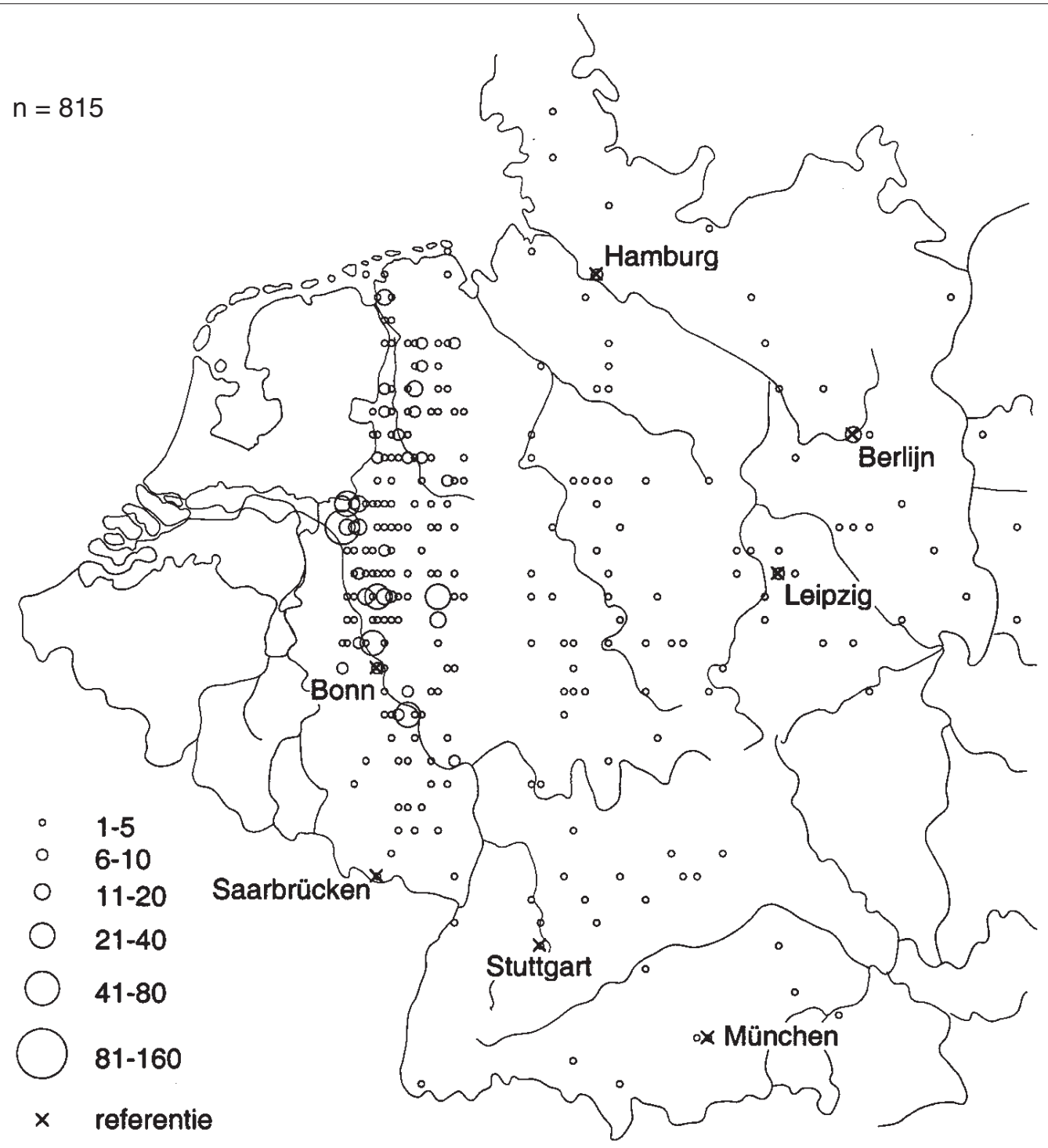

Bron Bestand Duitsers in Utrecht. 
Veruit het grootste deel van de Duitse immigranten kwam uit kleinere plaatsen. In dertig jaar kwamen er slechts 22 mensen uit Berlijn, 18 uit Bremen, 17 uit Hamburg en vijf uit Duisburg. Uit een kleine grensplaats als Emmerich kwamen daarentegen 84 immigranten en uit Kleef 92.

Kaart 4.4 Herkomstplaatsen van Duitse migranten in periode 1849-1859.

$\mathrm{n}=696$

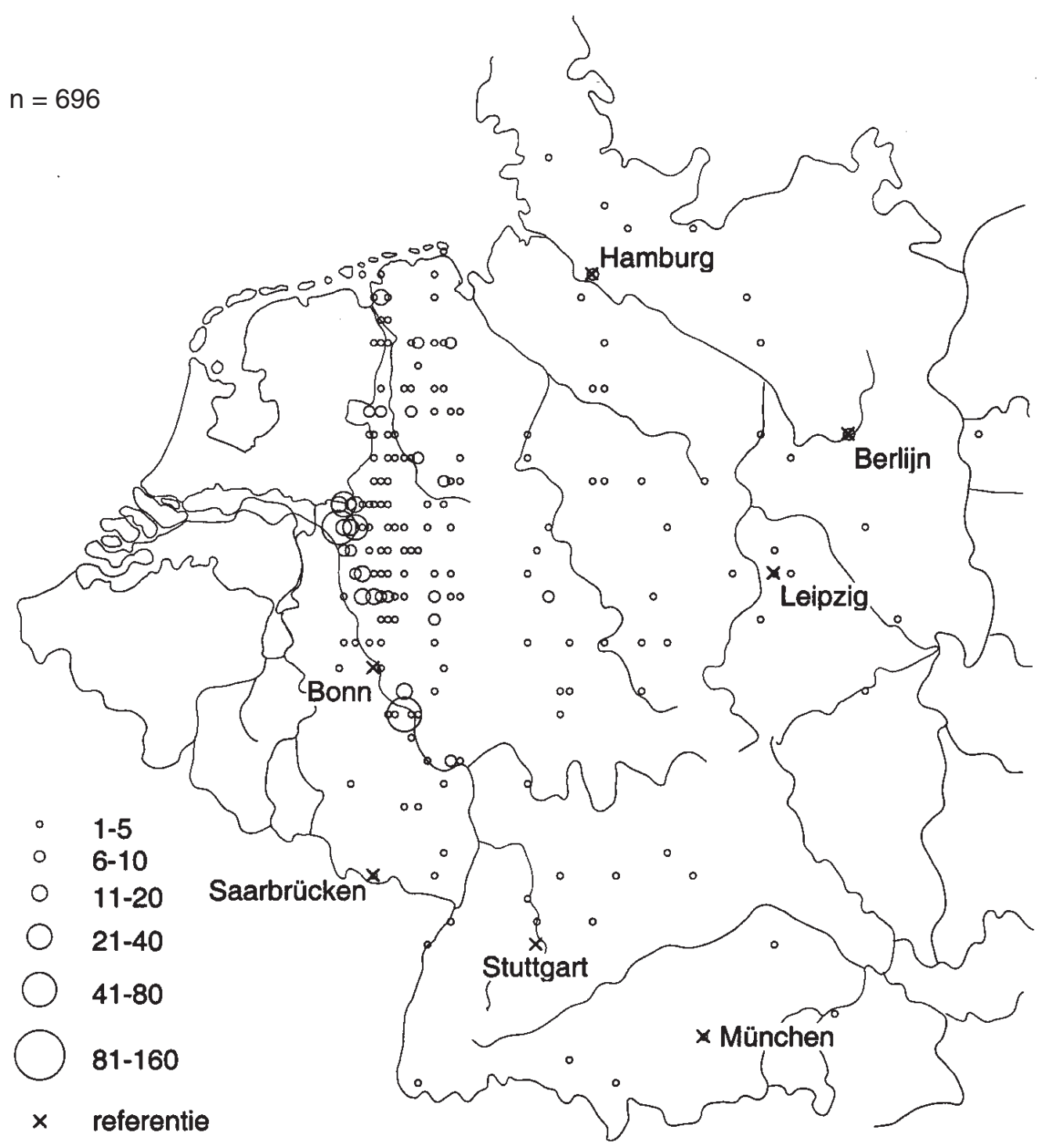

Bron Bestand Duitsers in Utrecht. 
De herkomstgebieden van Duitse immigranten kunnen worden onderverdeeld naar sekse (zie kaarten 4.2 en 4.3). Vrouwen kenden een grotere concentratie aan de Nederlands-Duitse grens in Kleefsland. Hier kwam een groot deel van de Duitse dienstbodes vandaan. Duitse mannen kenden een grotere diversiteit en een grotere spreiding dan

Kaart 4.5 Herkomstplaatsen van Duitse migranten in periode 1860-1879.

$n=730$

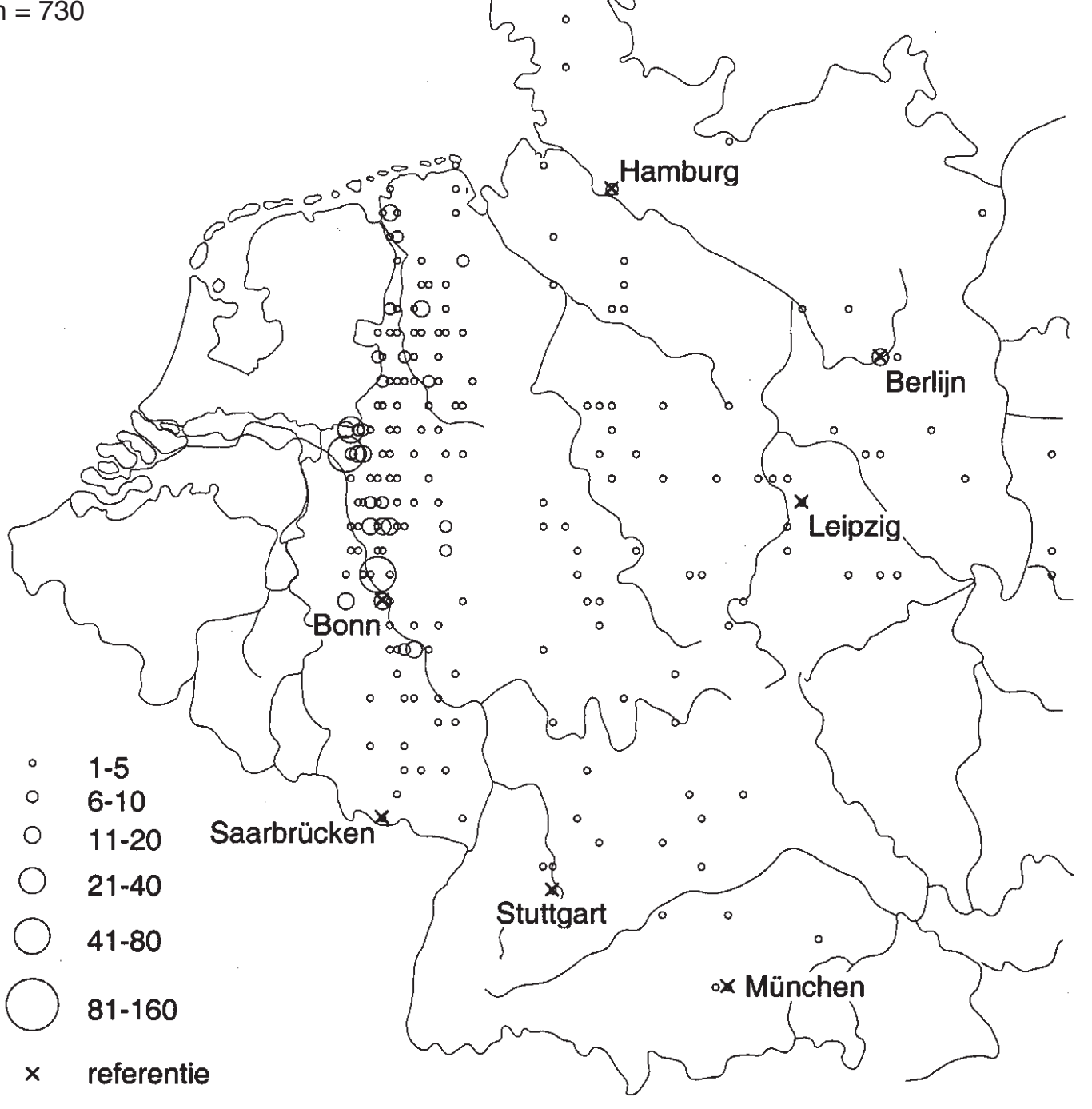

Bron Bestand Duitsers in Utrecht. 
vrouwen, waar het gaat om de herkomst. Sauerland en de regio rond Remscheid zijn herkomstgebieden waar meer mannen vandaan kwamen. Hetzelfde geldt voor de langgerekte strook langs de rivier de Ems. Dit gebied, dat grofweg zou kunnen worden aangeduid als Oldenburgs Münsterland, was het herkomstgebied van de Duitse kledingwinkeliers en hun personeel.

De herkomstgebieden kunnen ook worden onderverdeeld naar tijdvak (zie kaarten 4.4 en 4.5 ). Wanneer we de kaart voor 1849-1859 vergelijken met die voor de periode 1860-1879, vallen twee dingen op. Ten eerste neemt de migratie uit het Münsterland toe in de latere periode. Ten tweede verschilde de herkomststreek in de eerste periode niet noemenswaardig van die in de latere. Gebieden die in de eerste periode belangrijk waren bleven dat ook in de tweede periode.

De streek waar de Duitse migranten in Utrecht vandaan kwamen, vormde geen eenheid in taalkundige zin (zie kaart 4.6). Volgens de historicus Rogier, kwamen de Duitse immigranten 'uit stukken gemankeerd Nederland, waar onze taal tot diep in de negentiende eeuw de boventoon heeft gevoerd: Oost-Friesland, Arenberg-Meppen, Bentheim, Lingen, het land van Kleef.' ${ }^{35}$ Voor de Domstad klopt deze observatie maar ten dele. De diversiteit in talen was veel groter dan dit citaat suggereert.

Op het platteland en in de lagere klassen werd meer Platduits gesproken dan in de steden en in de hogere sociale klassen, waar Hoogduits de norm was. De dialecten die aan de grens werden gesproken, waren voor Nederlanders wel min of meer verstaanbaar. Het Rasber Platt, het dialect van de Westerwalders zoals dat in Ransbach in Nassau gesproken werd, zal voor Nederlanders volstrekt onverstaanbaar zijn geweest, zoals het dat nu is. In Nederland bedienden deze immigranten zich van Hoogduits of Nederlands.

\section{Binnen en buiten de wallen}

Duitse immigranten vestigden zich niet gelijkelijk in alle Utrechtse wijken. De Utrechtse wijken verschilden van karakter. Groei en ontwikkeling van de stad bepaalden mede waar migranten terecht kwamen.

Utrecht telde in 1849 ongeveer 50.000 inwoners; dat aantal was in 1900 verdubbeld. De stadsbevolking groeide meer dan die van het omliggende platteland of van Nederland als geheel. ${ }^{36}$ Andere steden groeiden sneller. Dit gold vooral voor Amsterdam en Rotterdam, maar ook Tilburg, Den Haag, Arnhem, Haarlem en Nijmegen kenden een grotere groei. ${ }^{37}$ De groei van de Utrechtse bevolking werd onderbroken door sterfte als gevolg van epidemieën, waarvan de cholera-epidemie van 1866, met 1725 doden, de belangrijkste was. ${ }^{38}$ Het aantal choleradoden in de Domstad was, in vergelijking met andere steden, relatief groot. In 1866 stierven in de hele provincie Utrecht 2.695 mensen aan de cholera. Utrecht kwam daarmee op de tweede plaats, na Zuid-Holland waar 7.688 mensen stierven, en voor Noord-Holland met 2.594 doden. ${ }^{39}$ Ondanks het relatief grote aantal choleradoden, werd de gezondheidstoestand van de Utrechtse bevol- 
king over het algemeen niet als ongunstig aangemerkt, in vergelijking met andere grote Nederlandse steden. ${ }^{40}$

Groei van de stad betekende het ontstaan van nieuwe buitenwijken. In de eerste helft van de negentiende eeuw concentreerde de Utrechtse bevolking zich nog binnen de stadswallen. In 1890 woonde al meer dan de helft van de stadsbevolking erbuiten. In het overvolle oude centrum was halverwege de negentiende eeuw weinig ruimte voor nieuwbouw. De cholera-epidemie van 1866 was bovendien aanleiding voor het stadsbestuur om in het oude centrum enkele slechte buurten te slopen. De wallen en poorten rond de stad verdwenen. Binnen de singels bleef het aantal huizen met zesduizend min of meer gelijk. In de buitenwijken groeide het aantal daarentegen van tweeduizend in 1850 naar meer dan negenduizend veertig jaar later. Woningbouw en de aanleg van de daarbij behorende infrastructuur betekenden werkgelegenheid in de bouwnijver-

Kaart 4.6 Taalgrenzen in Duitsland voor 1900.

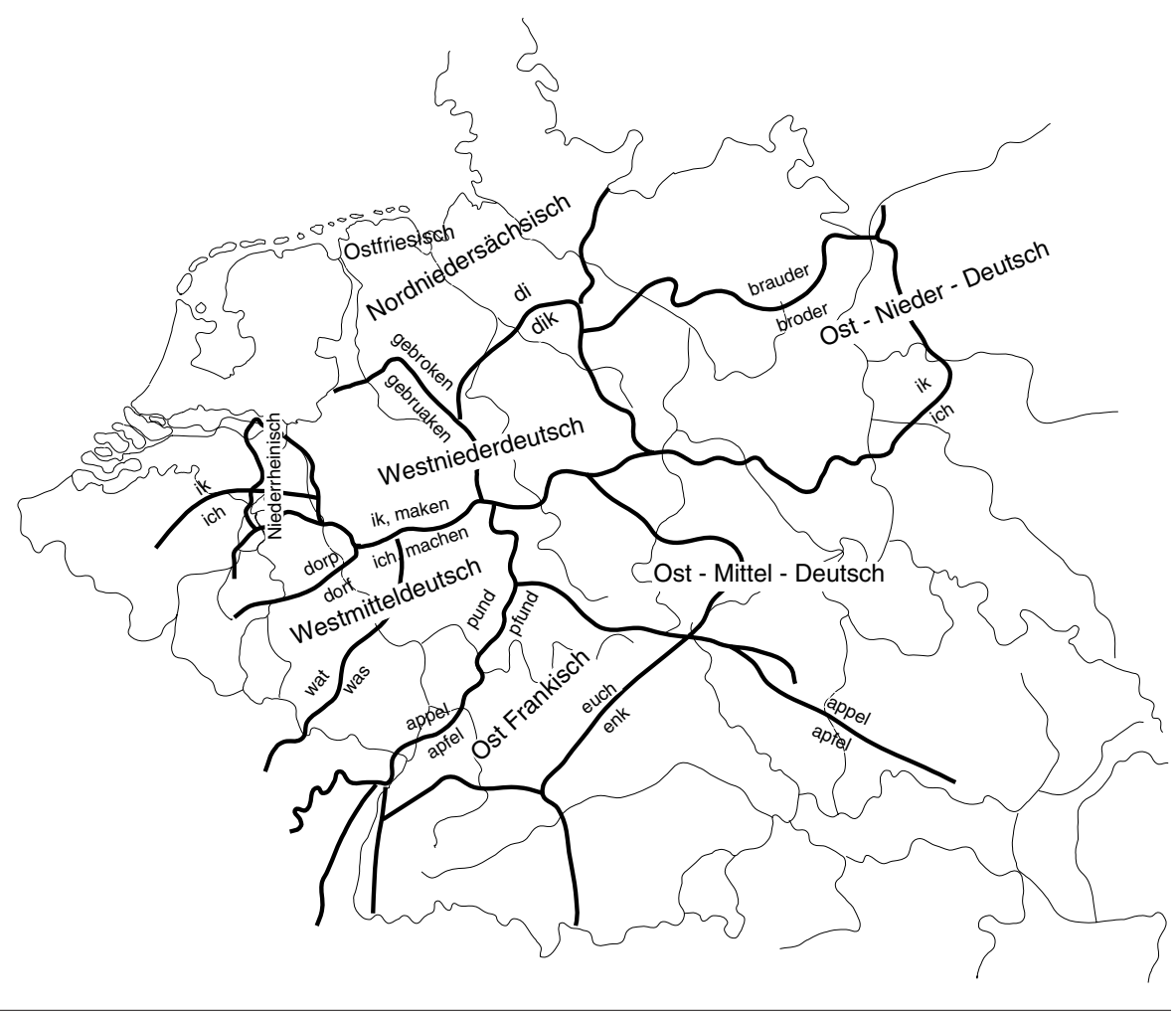

Bron Bewerking van gegevens uit Werner König, DTV-Atlas zur deutschen Sprache: Tafeln und Texte (München 1996) 230. 
Kaart 4.7 De wijken van Utrecht.

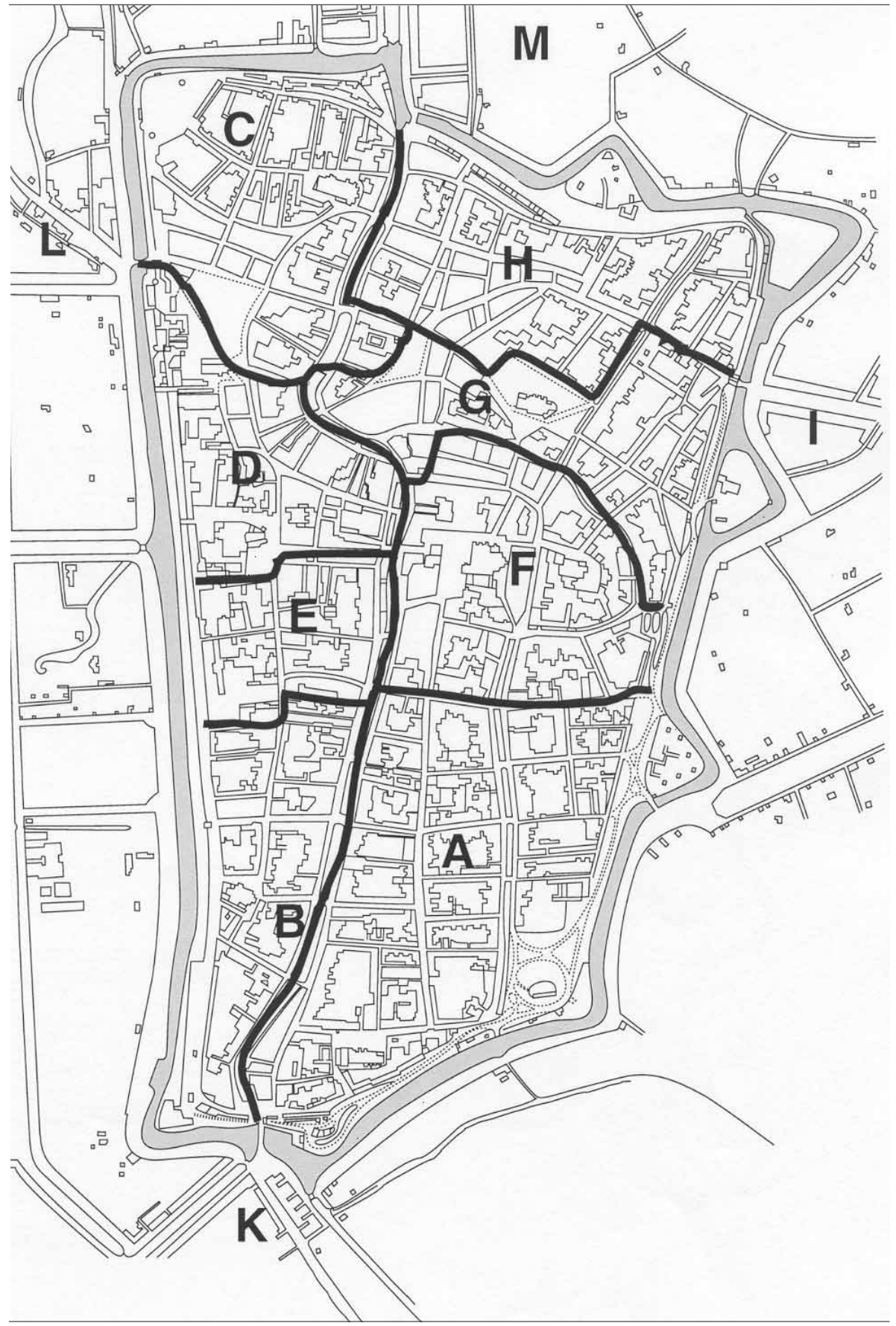


heid. In deze sector vonden in 1849 zo'n 1400 mensen werk; acht procent van de beroepsbevolking. ${ }^{41}$

De uitbreiding van het aantal huizen kon niet voorkomen dat er periodes waren van ernstige woningnood. In kleine woningen woonden soms vijf tot zeven gezinnen. In het Verslag van de Vereeniging tot Verbetering van de Volksgezondheid werd geschreven: 'Tengevolge van het gebrek aan woningen worden nieuw gebouwde huizen reeds betrokken voor ze geheel voltooid zijn. Vandaar dat de muren nog uitwasemen en de vloeren vocht opgeven. ${ }^{42}$

Binnen de voormalige wallen bleef de omvang van de bevolking min of meer stabiel, daarbuiten groeide zij van elfduizend in 1850, naar vijftigduizend veertig jaar later. De nieuwbouw buiten de oude stad betekende geen leegloop van het oude centrum. De groei en ontwikkeling van Utrecht leidden ertoe, dat nieuwkomers vooral een woonplaats konden vinden in de wijken buiten het centrum. Dit dwong op voorhand een zekere geografische concentratie af. Het effect daarvan was niet voor alle buitenwijken gelijk.

\section{Stad en voorsteden}

Sinds de napoleontische tijd was de stad Utrecht verdeeld in twaalf wijken (zie kaart 4.7). De kleurrijke wijknamen uit de zeventiende en achttiende eeuw, waren onder het Franse bestuur - zoals in alle Nederlandse steden - verruild voor letters. In de Domstad waren dat de letters A tot en met M. De J werd niet gebruikt in verband met mogelijke verwarring met de I. De stadswijken verschilden van elkaar in sociaal en in economisch opzicht.

De wijken A tot en met $\mathrm{H}$ lagen binnen de singels, ofwel de stadsbuitengrachten die de stad omsloten. De vier wijken buiten de singels, I, K, L en M, ook aangeduid als Abstede, Tolsteeg, Catharijne en Lauwerecht, vormden in het verleden de zogenaamde buitengerechten of voorsteden. In eerdere periodes hadden deze buitengerechten enige bestuurlijke autonomie gekend. ${ }^{43}$ Gevolg was, dat er min of meer zelfstandige gemeenschappen net buiten de stadswallen waren ontstaan. In 1823 werden de voorsteden in bestuurlijke zin bij de stad gevoegd. De binnenstad bleef echter geografisch en bestuurlijk gescheiden van de buitenwijken. Over de singels waren slechts vijf bruggen. Er voer een beperkt aantal overhaalschuitjes, waarvoor betaald moest worden. Tot 1866 moesten bovendien invoerrechten worden betaald voor goederen die de stad in werden gebracht. ${ }^{44}$ Er bestond ook een sociale scheiding tussen stad en voorsteden; ofschoon beslist niet iedereen binnen de singels rijk was, gold wel tot het einde van de negentiende eeuw dat de rijken vooral binnen de singels woonden en niet erbuiten.

Binnen elke wijk lagen rijkere en armere straten naast elkaar. Toch kan in het algemeen, op basis van de waarde van de huizen, gesteld worden dat F en G de rijkere wijken waren en $\mathrm{C}$, $\mathrm{K}$ en $\mathrm{M}$ de armere. ${ }^{45}$ Dit beeld wordt door andere gegevens bevestigd. Toen er in 1832 en 1849 geld werd opgehaald in verband met de heersende cholera-epi- 
demieën, kwamen de grootste bijdragen uit de wijken $\mathrm{F}, \mathrm{G}$ en $\mathrm{H} .{ }^{46}$ Bij de winterbedeling, die in het midden van de negentiende eeuw werd gegeven, was in de wijken $\mathrm{C}, \mathrm{K}$ en $\mathrm{M}$ het percentage bedeelden het grootst en in wijk $\mathrm{F}$ het kleinst. ${ }^{47}$

Binnen de wijken - zowel de betere als de mindere - konden straten worden aangewezen waar de woonomstandigheden bijzonder slecht waren. De nieuwbouwwijk I was in het algemeen een vrij redelijke wijk. De Gasthuissteeg in deze wijk, waar tijdens de cholera-epidemie van 1866 de sterfte schrikbarend hoog was, vormde op dit gunstige beeld een uitzondering. Iets vergelijkbaars gold voor enkele straten in wijk B bij Bierbrouwerij De Boog aan de Oudegracht. Bij deze brouwerij lagen enkele straten die bekend stonden als de Zeven Steegjes. De huizen in dit buurtje werden in 1843 gebouwd door het Katholiek Armbestuur, dat ook de brouwerij exploiteerde. De Zeven Steegjes vormden een van de notoire achterbuurten. In wijk E was er, in de buurt van de Springweg en de Stroosteeg, een aantal totaal verpauperde straten rondom de zogeheten Holle Bildt. Wijk C kende eveneens enkele zeer slechte straten. In wijk K was er rond de Gansstraat een stelsel van sloppen en stegen, dat zeer ongunstig bekend stond. Tolsteeg of wijk K was de voorstad met de oudste en dichtste bebouwing. Het was tevens de minst aanzienlijke van de vier voorsteden..$^{48}$ De wijk was uitgestrekt en viel ruimtelijk gezien uiteen in drie delen. Bij de stadspoort was een dichtbebouwde buurt, die veelbetekenend werd aangeduid als het Schrale Eind. Verder van de stad af en ten westen van de Vaartse Rijn, was de wijk slechts dun bebouwd. Daar woonden hoveniers met hun knechten en meiden. De katholieke hoveniers in Tolsteeg vormden samen met die in het aangrenzende Abstede (wijk I), een aparte groep. Het was een hechte, gesloten gemeenschap, met een hoge mate van onderlinge verwantschap. ${ }^{49}$ Aan de Vaartse Rijn woonden arbeiders van de steen-, pannen- en tegelbakkerijen. Zij werden gescheiden van het dichtbebouwde buurtje bij de stadspoort, door de in 1845 aangelegde spoorweg naar Arnhem.

Het karakter van wijk $\mathrm{C}$ verdient extra aandacht, omdat deze wijk werd gezien als de minst toegankelijke wijk voor buitenstaanders. Wijk $\mathrm{C}$ was een dichtbebouwde buurt met veel straathandelaars en sjouwers. ${ }^{50}$ In het midden van de negentiende eeuw lagen veertien van de zeventien volkslogementen in deze wijk. Deze logementen herbergden tijdelijke bewoners, maar er waren ook mensen die jarenlang in een logement woonden. Binnen de wijk moet onderscheid gemaakt worden tussen de bebouwing aan de buitenranden van de wijk, waar de betere huizen stonden, en de sloppen en stegen in het centrale deel. In dit deel verplaatsten de bewoners zich wel binnen de wijk, maar zelden naar andere delen van de stad. De geograaf en letterkundige De Vooys, die onderzoek deed naar wijk $\mathrm{C}$, wees op deze opvallende migratie binnen de wijk en op het uiterst geringe aantal mensen van buiten dat hier een woonplaats vond. ${ }^{51}$ Volgens de criminoloog Jens, die onderzoek deed naar verschillende Utrechtse wijken, trouwden de wijk-C'ers veelvuldig onderling. ${ }^{52}$ In combinatie met een leven dat zich vooral op straat afspeelde, was het gevolg een grote samenhang binnen de wijk. Buitenstaanders werden buitengesloten, inclusief de gasten van de vele logementen. ${ }^{53}$ Stadschroniqueur Broers schreef in 1908 over deze wijk: 
In de bevolking van de voormalige wijk $\mathrm{C}$ leeft nog het meest het origineel Utrechtsch volkstype voort.[...] De menschen zijn [...] nog al "hokvast" en het komt niet zelden voor dat men er families aantreft, wier overgrootouders tot in den zesden of zevenden graad altijd in hetzelfde huis gewoond hebben, met altijd dezelfde nering of hetzelfde handwerk en wier huisgezinnen dan ook altijd even talrijk en gezegend waren als die van hunne hedendaagsche nakomelingen. Aan familie-relaties doet men er sterk, al schijnt het nu wel wat overdreven, wanneer men beweert, dat "geheel wijk C eigenlijk familie van elkaar is." ${ }^{4}$

\section{Little Germany?}

De Amerikaanse historicus Fogleman heeft voor de Verenigde Staten aangetoond dat Duitse immigranten zich, meer dan andere migrantengroepen, concentreerden in bepaalde wijken of plaatsen. ${ }^{55}$ Gedeeltelijk was deze concentratie het gevolg van de groepsgewijze migratie van mensen, die in de Verenigde Staten de religieuze vrijheid zochten die hen in Duitsland werd ontzegd. In het nieuwe beloofde land stichtten zij kleine, homogeen Duitse gemeenschappen. In de grotere steden was deze vorm van immigratie minder belangrijk. De grotere steden hadden desondanks ook allemaal hun Little Germany. De Little Germanies waren echter niet alleen etnisch, maar veelal ook sociaal homogeen. Zoals de Amerikaanse historicus McCaffery heeft aangetoond, kan

Figuur 4.6 Concentraties in geselecteerde wijken van verschillende steden in 1849.

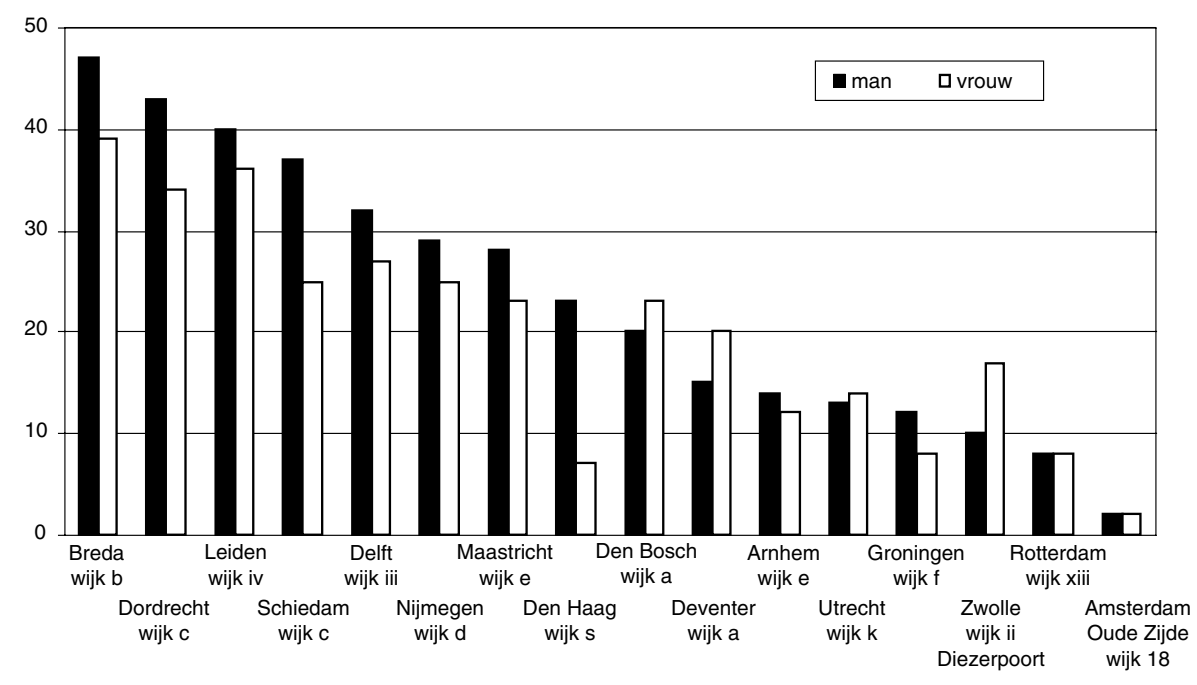

Bron Bewerking van volkstellingsgegevens. Geselecteerd werden de wijken met de grootste concentratie. 
de concentratie van Duitse immigranten in Amerikaanse steden net zo goed gerelateerd worden aan klasse als aan etniciteit. De Duitse buurten waren in de eerste plaats arbeidersbuurten. ${ }^{56}$

In Amsterdam zag de schrijver Van Maurik aan het eind van de negentiende eeuw ook een Duitse wijk.

De Oudebrugsteeg scheen in die dagen bijna een Duitsche kolonie, want de kroeghouder, zoowel als de kleermaker, de slager en de kruidenier, die er woonden, waren van Germaanschen stam. ${ }^{57}$

Wat hiervan ook waar moge zijn, in de Domstad was er geen Little Germany, evenmin als in andere Nederlandse steden. ${ }^{58}$ Zoals uit figuur 4.6 blijkt, gold in het algemeen dat hoe groter de stad was, hoe kleiner de concentratie in bepaalde wijken was.

De verspreide bewoning weerspiegelt de sociale heterogeniteit van de Duitse immigrantenpopulatie in Utrecht. Dit laat onverlet dat er wel enkele concentraties kunnen

Tabel 4.1 Bevolking van Utrecht per wijk, aantal mensen geboren in Duitsland per wijk, percentuele verdeling en percentage Duitsers per wijk als onderdeel van de totale wijkbevolking 1849 (exclusief gestichtbevolking en militairen).

\begin{tabular}{lcccc}
\hline & $\begin{array}{c}\text { Duitsers } \\
\text { totaal aantal } \\
\text { bewoners } \\
\text { perwijk }\end{array}$ & $\begin{array}{c}\text { absoluut aantal } \\
\text { Duitsers }\end{array}$ & $\begin{array}{c}\text { procentueel } \\
\text { aandeel per wijk }\end{array}$ & $\begin{array}{c}\text { procentuele } \\
\text { verdeling over } \\
\text { de wijken }\end{array}$ \\
\hline wijk a & 6307 & 35 & 0,6 & 7,0 \\
wijk b & 6032 & 53 & 0,9 & 10,6 \\
wijk c & 6831 & 55 & 0,8 & 11,0 \\
wijk d & 3282 & 19 & 0,6 & 3,8 \\
wijk e & 3386 & 39 & 1,2 & 7,8 \\
wijk f & 2625 & 48 & 1,8 & 9,6 \\
wijk g & 3432 & 56 & 1,6 & 11,2 \\
wijk h & 4552 & 54 & 1,2 & 10,8 \\
wijk i & 2549 & 29 & 1,1 & 5,8 \\
wijk k & 2322 & 72 & 3,1 & 14,4 \\
wijk I & 2130 & 13 & 0,6 & 3,8 \\
wijk m & 4882 & 27 & 0,6 & 5,4 \\
totaal & 48330 & 500 & 1,0 & \\
\hline
\end{tabular}

Bron Bewerking van gegevens uit de volkstelling van 1849. 
Figuur 4.7 Percentage Duitsers per wijk 1849.

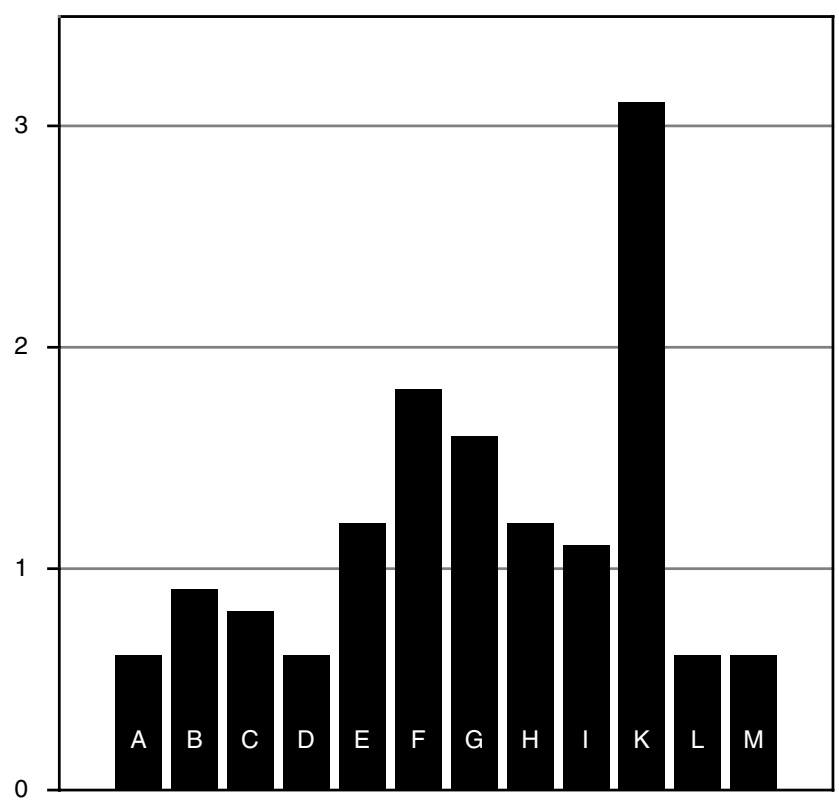

Bron Bestand Duitsers in Utrecht.

Figuur 4.8 Verloop per wijk. Aantal Duitsers in de wijken A tot en met $M$ in de periodes 1850-1859 en 1860-1879.

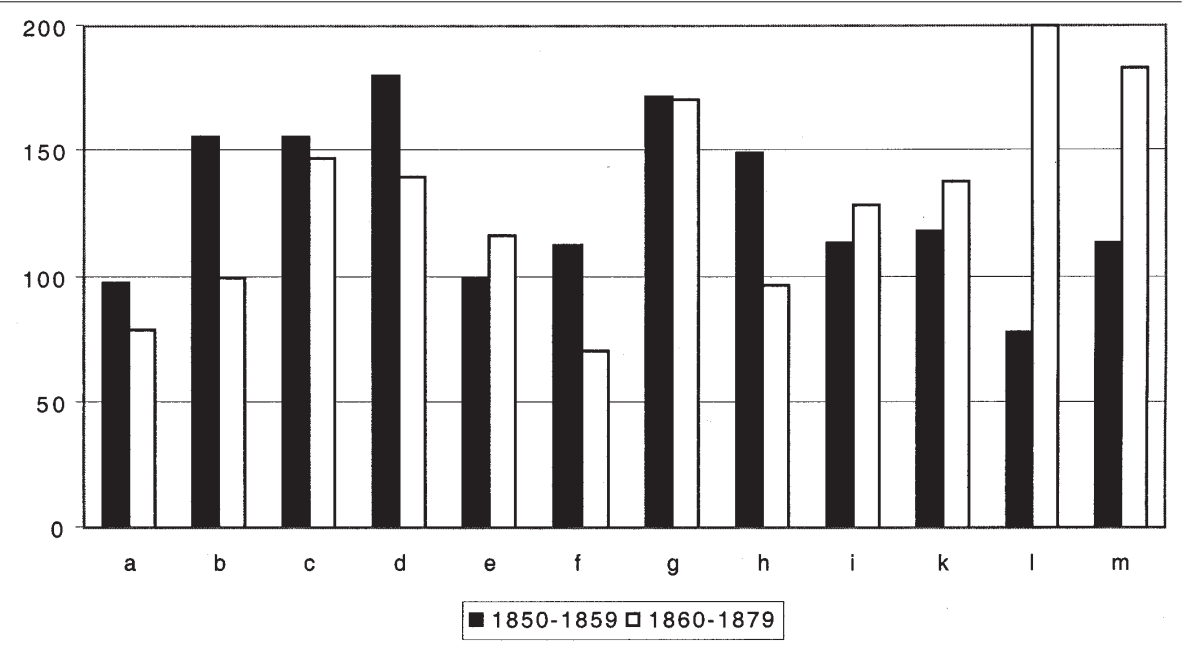

Bron Bestand Duitsers in Utrecht. 
worden aangewezen. De Duitsers concentreerden zich echter niet als groep in de armere of rijkere delen van de stad. Er waren geen concentraties van Duitse immigranten in notoire achterbuurten als de Gasthuissteeg in wijk I, de Zeven Steegjes in Wijk B, de Holle Bildt in wijk E en in verschillende delen van wijk C, ofschoon er in al deze buurten wel verspreid Duitse immigranten woonden. Slechts het stelsel van sloppen en stegen rondom de Gansstraat in wijk K werd vrijwel geheel bevolkt door Duitse immigranten.

Van 500 van de 535 Duitsers die volgens de volkstelling van 1849 in Utrecht woonden, is bekend in welke wijk ze huisden. De overige 35 Duitsers woonden in gestichten en instellingen, die afzonderlijk werden geteld, maar waarbij niet werd aangegeven wie waar precies woonde. Er werd dus niet aangegeven hoeveel van deze Duitsers er bijvoorbeeld in een kazerne woonden en hoeveel in een gesticht.

Duitse immigranten waren niet gelijkelijk over de stadswijken verdeeld (zie tabel 4.1 en figuur 4.7). In 1849 woonden er in de wijken A en L minder Duitsers dan het gemiddelde voor de hele stad. Vooral voor wijk L is dit opmerkelijk omdat dit een snelgroeiende nieuwe wijk was, die in karakter niet noemenswaardig verschilde van de aangrenzende wijk K. Spoorwegpersoneel vormde in wijk L de hoofdmoot van de Duitse immigranten. In de eveneens sterk groeiende, maar iets betere nieuwe wijk I is het aantal Duitsers ook niet noemenswaard. Behalve dienstbodes vinden we hier redelijk veel Duitse (oud)militairen. In D en G bestond de Duitse wijkbevolking uit winkeliers en hun personeel; in de chique wijk F woonden vooral Duitse dienstbodes. In wijk E vinden we winkeliers en hun personeel in de goede straten, zoals de Lijnmarkt en de Choorstraat. De Oudegracht loopt bovendien ook nog gedeeltelijk door deze wijk en daar vinden we eveneens Duitse winkeliers. In het slechte deel van wijk E, de Holle Bildt, treffen we, zoals gezegd, verspreid enkele Duitsers aan. In de armoedige wijk C, die werd aangemerkt als een voor buitenstaanders gesloten wijk, vinden we iets minder dan het gemiddelde aantal Duitsers. De Duitse migranten in deze wijk concentreerden zich niet aan de randen, die in het algemeen als meer toegankelijk werden gezien, maar we vinden hen ook in het hart van de wijk. Het zijn merendeels - in zo'n 80 procent van de gevallen - Duitse mannen met een Nederlandse vrouw, die werkten in een voor de wijk typerend beroep, zoals handelaar. Dat iemand een vreemdeling was, betekende klaarblijkelijk niet automatisch dat hij of zij ook een buitenstaander was. In de arme wijk K - een grote en uitdijende buitenwijk - vormden Duitse migranten meer dan drie procent van de bevolking. Binnen deze wijk woonden de Duitsers, die vrijwel allemaal uit het Westerwald in Nassau kwamen, geconcentreerd in slechts enkele straten, waar ze een absolute meerderheid vormden. ${ }^{59}$

In de periode van 1860 tot 1879 nam de concentratie van Duitsers toe in de wijken $\mathrm{D}$, F en $G$ in wijk K. In de nieuwe wijken L en M nam het aantal Duitsers eveneens toe, zij het minder. Binnen de wijken was het verloop onder de Duitse immigranten niet gelijk (zie figuur 4.8). In figuur 4.8 wordt het verloop per wijk weergegeven voor de periodes 1850-1859 en 1860-1879. Het gaat om het aantal Duitsers dat op enig moment in deze periodes in een van deze wijken woonde. De wijken D en G kenden een relatief groot ver- 
Tabel 4.2 Aantal mensen geboren in Duitsland per wijk, volgens de volkstelling en volgens de analyse van het bevolkingsregister.

\begin{tabular}{lccc}
\hline & $\begin{array}{c}\text { bevolkingsregister } \\
1850-1859\end{array}$ & $\begin{array}{c}\text { waarvan aanwezig } \\
\text { in 1850 }\end{array}$ & volkstelling 1849 \\
\hline wijk a & 61 & 39 & 35 \\
wijk b & 89 & 64 & 53 \\
wijk c & 94 & 66 & 55 \\
wijk d & 107 & 82 & 19 \\
wijk e & 69 & 52 & 39 \\
wijk f & 66 & 46 & 48 \\
wijk g & 109 & 71 & 56 \\
wijk h & 75 & 59 & 54 \\
wijk i & 49 & 36 & 29 \\
wijk k & 86 & 74 & 72 \\
wijk I & 25 & 13 & 13 \\
wijk m & 88 & 62 & 27 \\
'intstellingen' & & & 35 \\
totaal & 918 & 714 & 535 \\
\hline
\end{tabular}

Bron Volkstelling 1849 en bevolkingsregister van 1850-1859

Figuur 4.9 Verschil in absolute aantallen Duitsers per wijk 1849-1850.

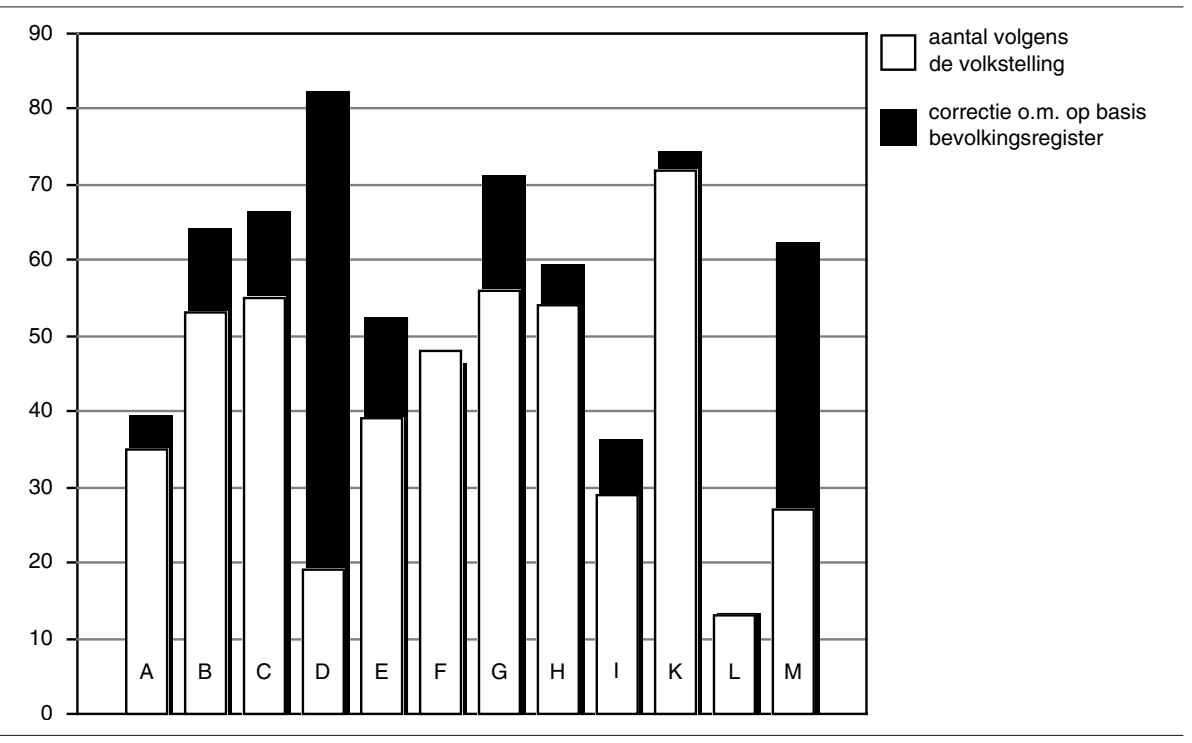

Bron Bewerking van volkstellingsgegevens en bestand Duitsers in Utrecht. 
loop in beide periodes. Voor de wijken L en M is vooral het verloop in de periode $1860-$ 1879 opvallend. Nieuwkomers vonden in deze wijken een tijdelijk onderdak en woonden er slechts kort.

De reeds genoemde onderregistratie als gevolg van plaatsnaamverwarring was niet voor alle wijken in de stad gelijk (zie tabel 4.2 en figuur 4.9). In tabel 4.2 wordt de verdeling per wijk in het volkstellingregister vergeleken met die in het bevolkingsregister. In de wijken D, E, G en M was de onderregistratie groter dan in andere wijken. Dit zou een gevolg kunnen zijn van de mate van (on)zorgvuldigheid van de verschillende wijkmeesters, die de registers bijhielden. ${ }^{60}$ Het zou ook verklaard kunnen worden uit het verschillende karakter van de wijken. In wijk $\mathrm{K}$, met een zeer geconcentreerd wonende en herkenbare Duitse populatie, was de plaatsnaamverwarring aanzienlijk minder. Hier waren de Duitsers herkenbaarder 'Duits' dan in andere delen van de stad.

\section{Tot besluit}

Dit hoofdstuk handelde over de registratie van Duitse immigranten, over de omvang van de Duitse migrantenpopulatie in Nederland en in Utrecht, over de geografische herkomst en over de vestiging in de stad.

Het bevolkingsregister is vanzelfsprekend niet alleen een registratie van vreemdelingen, maar het is tegelijkertijd wel de meest volledige registratie van vreemdelingen in Nederland die er is. Het bevolkingsregister kende een onderregistratie wanneer het ging om vreemdelingen. Niet alle Duitse immigranten stonden in het bevolkingsregister als Duitsers genoteerd. Door een combinatie van gegevens uit verschillende bevolkingsregisters en door vergelijking met gegevens uit de burgerlijke stand, is die onderregistratie gecorrigeerd. Voor Utrecht betekende dat, dat het werkelijke aantal Duitse immigranten maar liefst 33 procent hoger lag dan de uitkomsten van de volkstellingen doen geloven. Indien uit aanvullend onderzoek voor heel Nederland blijkt dat dit ook elders geldt - en voorlopig onderzoek in Amsterdam en Gouda duidt daar reeds op dan zou het aantal Duitsers in Nederland in 1849 niet 41.000 maar 55.000 zijn geweest. Het percentage Duitsers in 1849 verschuift in dat geval van 1,3 naar 1,8 .

Utrecht was een gemiddelde stad wanneer het gaat om het percentage vreemdelingen, het aantal Duitsers onder hen en de sekseratio binnen de Duitse migrantenpopulatie. De Duitse migratie naar Utrecht was niet bijzonder omvangrijk en was stabiel in aantal. Omdat Utrecht geen opvallende uitzonderingen kende ten opzichte van het landelijke beeld, kunnen we aannemen dat althans een gedeelte van de uitspraken voor deze stad ook zal gelden voor andere Nederlandse steden.

Duitse immigranten kwamen uit tal van plaatsen, maar daarbinnen zijn enkele duidelijke concentraties aan te wijzen: het Westerwald, Oldenburg, Sauerland, Kleefsland en de omgeving van Remscheid. Uit deze regio's tezamen kwam 70 procent van de Duitse immigranten. Deze migratie hield verband met de regiogebonden specialisatie in bepaalde beroepen, die in een volgend hoofdstuk besproken zal worden. Bij vesti- 
ging geldt iets vergelijkbaars; in alle delen van de stad vinden we Duitse immigranten en het is dus geenszins zo dat alle Duitse migranten in een wijk woonden. Er waren wel enkele concentraties aan te wijzen. De opvallendste zijn de concentraties rond de Oudegracht en in wijk K. Ook in dit geval is er een verband met concentraties in beroepen. Geografische herkomst en vestiging in de stad Utrecht, duiden erop dat er geen sprake was van groepsvorming van de Duitse migrantenpopulatie als geheel, maar vooral van groepsvorming binnen de Duitse migrantenpopulatie. 



\section{5 'Heeft steeds altijd met hare handel het land rondgereisd' Migratiepatroon, leeftijdsopbouw en religie}

De katholieke Christina Leijting werd in 1821 geboren in Kleef. In 1857 kwam ze naar Utrecht vanuit Den Haag, waar haar man Wilhelm Braun was overleden. Met haar drie kleine kinderen vestigde zij zich in de nogal armoedige Utrechtse Boterstraat. Ze trok in bij haar zeven jaar oudere zus Maria Leijting, haar Duitse zwager Theodorus Reintjes en hun zes kinderen. ${ }^{1}$ Reintjes was rijtuigschilder, Maria Leijting tafelhoudster. Samen vormden ze een huishouden van drie volwassenen en negen kinderen. In 1864 hertrouwde Christina Leijting, op 43-jarige leeftijd, met de 37-jarige Utrechtse weduwnaar Hendrik Wilson. ${ }^{2}$ Wilson had een restaurant in de nabijheid van het station en aandelen in de Utrechtse Stoom Briquetten Frabriek. ${ }^{3}$ Drie jaar later trok Christina's 23jarige nicht bij de familie Wilson in. ${ }^{4}$ Nicht Adelheid bleef in eerste instantie slechts kort in Utrecht; binnen twee jaar ging zij terug naar Kleef. In 1869 kwam ze echter opnieuw naar de Domstad en trouwde met de weduwnaar Herman Wormer. ${ }^{5}$ Hij was 54, zij 25. Wormer was onderwijzer. Zijn eerste vrouw was in 1850 overleden. Voorafgaande aan zijn tweede huwelijk woonde hij met drie kinderen uit zijn eerste huwelijk, zijn broer, zijn verweduwde zwager, twee neefjes, een nichtje en zijn moeder op de Mariaplaats, vlakbij Adelheids tantes Maria en Christina. De tantes waren min of meer even oud als hij. Vlak voor zijn tweede huwelijk overleden in zeer korte tijd twee van zijn halfvolwassen kinderen, zijn moeder en een neefje en nichtje. De overige huisgenoten vertrokken.

Adelheid Leijting en Herman Wormer trouwden in 1869 in Kleef, waar de bruid weliswaar niet meer woonde, maar wel haar domicilie had aangehouden. ${ }^{6}$ Eerste getuige bij het huwelijk was de Belgische katholieke strohoedenmaker Eustachius Frenaij, die in Utrecht woonde en in het stadscentrum zijn bedrijf uitoefende. Tweede getuige was de joodse koopman Hartog Moses Drukker, woonachtig in Kleef. Waarschijnlijk was hij verwant aan de Utrechtse joodse koopman Hermanus Mozes Drukker, die uit de buurt van Kleef kwam en was via hem het contact tussen Wormer en Drukker tot stand gekomen. Derde en vierde getuige waren Adelheids oom Hendrik Wilson en een stadhuisgetuige uit Kleef. De getuigen bieden enig zicht op het netwerk van het nieuwe bruidspaar. $^{7}$

Adelheid Leijting en Herman Wormer kregen vier kinderen. Kort na de geboorte van het derde kind, in 1874, trok Adelheids drie jaar jongere zus Johanna bij de familie in. ${ }^{8}$

Vrouwen waren bij de migraties van de familie Leijting belangrijk. Maria Leijting nam haar zus Christina in huis; Christina verleende, zodra ze zelfstandig woonde, gast- 
vrijheid aan haar nicht Adelheid, en Adelheid haalde op haar beurt haar zus Johanna in huis. Door tantes en zussen werden de nieuwkomers geïntroduceerd in de Utrechtse samenleving. In Utrecht waren in totaal 38 katholieke vrouwen uit Kleef in de periode 1849-1879. Meer dan een kwart (11) had vrouwelijke verwanten in de stad, merendeels zussen.

Figuur 5.1 Aantal Duitsers in Utrecht tussen 1849 en 1859 naar geboortejaar.

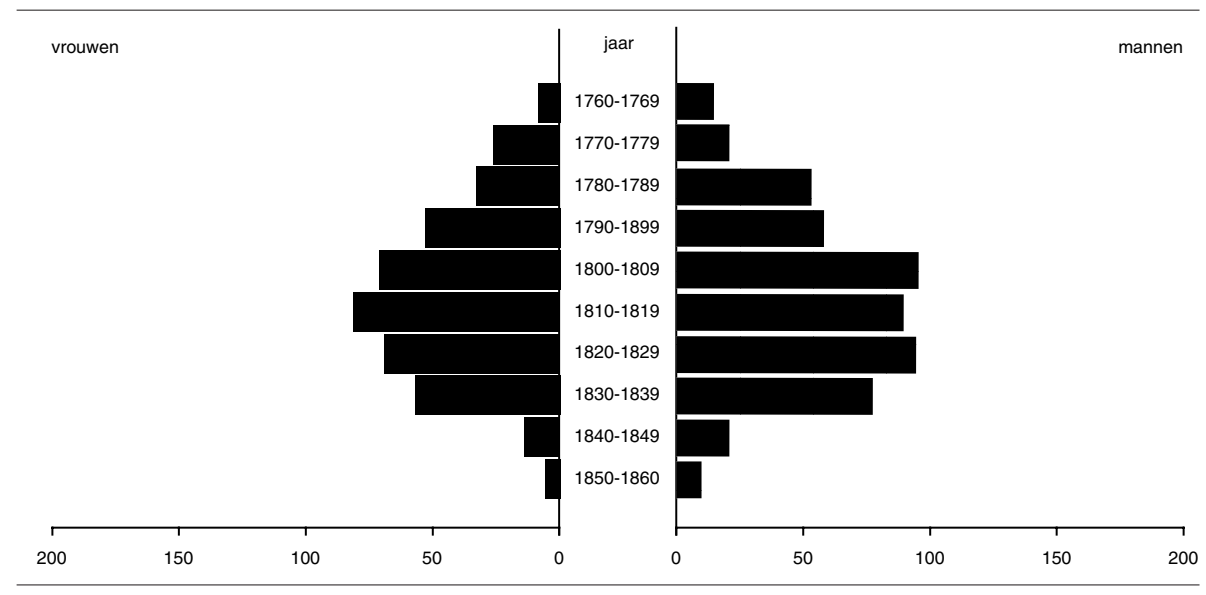

Figuur 5.2 Aantal nieuwe Duitse immigranten in Utrecht tussen 1860 en 1879 naar geboortejaar.

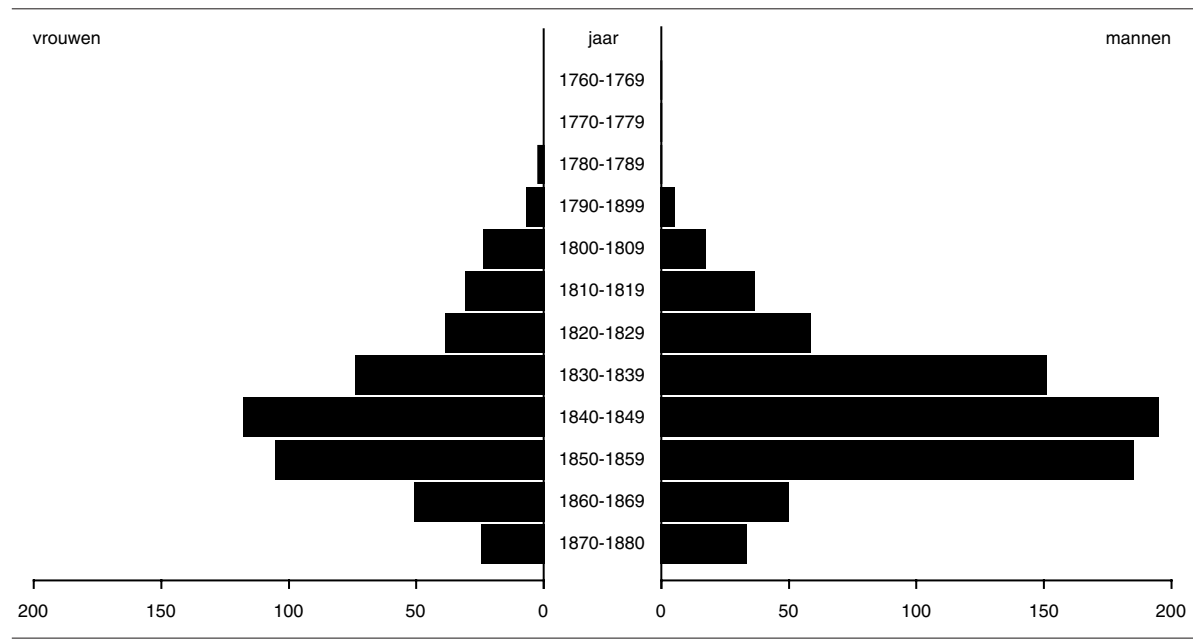

Bron Bestand Duitsers in Utrecht. 


\section{Leeftijdsopbouw}

In figuur 5.1 en 5.2 wordt de opbouw van de Duitse immigrantenpopulatie naar geslacht en leeftijd in beeld gebracht.

De eerste piramide heeft betrekking op de periode van 1850 tot 1859 . Het gaat om de 957 Duitse immigranten, die in Utrecht waren of naar die stad kwamen voor 1859; 535 mannen en 422 vrouwen. De leeftijdscategorie tussen 20 en 50 is in de piramide het sterkst vertegenwoordigd, zowel bij de mannen als bij de vrouwen. Er kwamen weinig in Duitsland geboren kinderen naar Utrecht. De migratie bestond overwegend uit alleenlopende personen en niet uit gezinnen.

De tweede piramide heeft betrekking op de periode van 1860 tot 1879 . Het gaat om 1231 Duitse immigranten die in die jaren naar de Domstad kwamen: 747 mannen en 484 vrouwen. Hier is eveneens een concentratie bij de leeftijdsgroep 20 tot 50-jarigen. Kinderen en bejaarden waren ook de tweede periode de grote afwezigen. Opvallend is de toename van het aantal mannen. Omdat de sekseratio in de volkstellingsjaren min of meer gelijk bleef, betekent dit dat het verloop onder de mannelijke Duitse nieuwkomers in de periode 1860-1879 groter was dan onder de vrouwen. Bij deze Duitse mannen gaat het vooral om katholieke winkelbedienden.

Mannen en vrouwen waren grofweg gelijkelijk over de stadswijken verdeeld. Er bestonden op dit punt geen opvallende concentraties (zie figuren 5.3 en 5.4).

\section{Religieuze diversiteit}

De stad Utrecht als geheel kende een naar geloof gemengde bevolking, waarvan in 1849 grofweg eenderde deel katholiek was en tweederde deel protestant. De protestanten waren overwegend hervormd; lutheranen vormden drie procent van de totale bevolking. Oud-katholieken waren met twee procent een minderheid onder de katholieken. Joden maakten iets meer dan een procent uit van de totale bevolking.

In de oude stad, binnen de singels, woonden twee keer zoveel hervormden als katholieken, hetgeen overeenkwam met het gemiddelde beeld. In de buitenwijken I en L hielden deze groepen elkaar, qua aantal, min of meer in evenwicht in de jaren 1860 en 1870. In 1880 woonden in deze wijken echter opvallend meer hervormden. Wijk M was aanvankelijk eveneens een gemengde wijk, maar in 1880 waren juist hier de katholieken sterker vertegenwoordigd.

Oud-katholieken concentreerden zich in de wijken buiten de singels en vooral in I en M. De lutheranen woonden merendeels binnen de singels. Van de wijken buiten de singels had M de grootste aantrekkingskracht op lutheranen. Er woonden joden in wijk B, rond de synagoge aan de Springweg. ${ }^{9}$ Het merendeel van de joden woonde in de wijken $\mathrm{D}$ en $\mathrm{E}$, en in mindere mate in $\mathrm{C}$ en $\mathrm{F}$. Van een concentratie van joden was geen sprake. $^{10}$ 
Wijk K was gedurende de hele periode uitgesproken katholiek. Het katholieke karakter van deze wijk dateerde reeds van voor de negentiende eeuw. Toen de katholieke religie werd verboden, bleef er buiten de Tolsteegpoort een katholieke gemeenschap bestaan, die in een schuilkerk bijeen kwam. Buiten de Weerdpoort en de Wittevrouwenpoort waren ook katholieke schuilkerken. Het katholieke karakter van Tolsteeg bleek in 1797, toen de wijkvergaderingen voorstellen mochten doen aan het stadsbe-

Figuur 5.3 Aantal Duitse mannen en vrouwen per wijk in de periode 1850-1859.

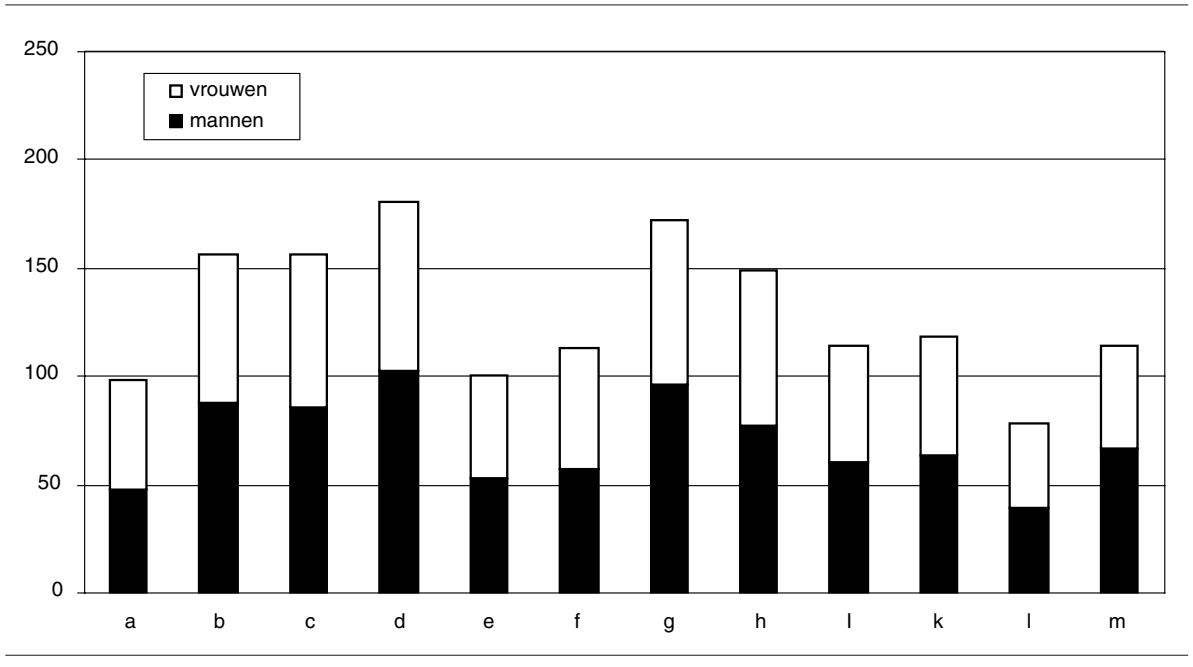

Figuur 5.4 Aantal Duitse mannen en vrouwen per wijk in de periode 1860-1879.

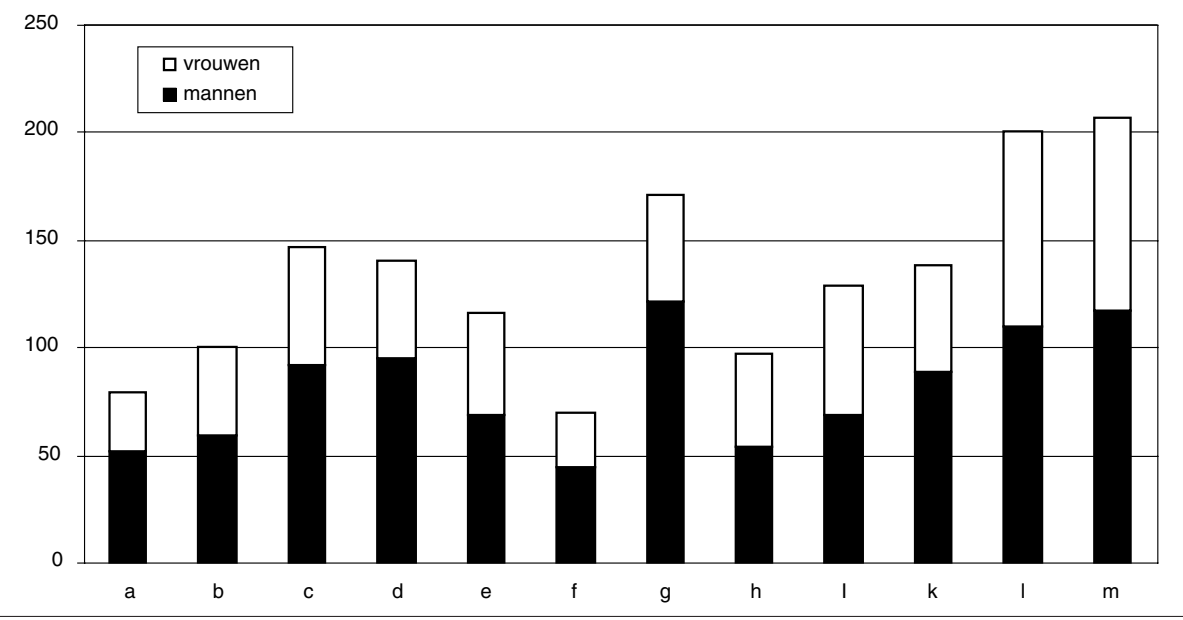

Bron Bestand Duitsers in Utrecht. 
stuur. Wijk K kwam als enige met de suggestie voor gelijkberechtiging van leden van de verschillende kerkgenootschappen, bij het onderwijs aan 'behoeftige kinderen en bij de armenzorg. ${ }^{11}$ Hiermee had de wijkvergadering uitdrukkelijk het oog op katholieke armen.

De getalsmatige verhouding tussen katholieken en protestanten binnen de Domstad, verschoof in de loop van de negentiende eeuw. Het percentage hervormden nam af van 61 in 1809, naar iets meer dan 56 in 1849. Daarna daalde het verder naar ongeveer 51 procent in 1899. Het percentage katholieken steeg van 32,3 in 1809 naar 35,5 in 1849. Daarna bleef het percentage tot 1899 gelijk. De katholieke minderheid van Utrecht was belangrijker dan die van Amsterdam (22 procent) of Den Haag (30 procent). ${ }^{12}$

De positie van de katholieken binnen de Utrechtse samenleving, verschilde van die van de protestanten. Katholieken werkten veel in handel en winkelbedrijf, ze waren geconcentreerd in de lagere sociale klassen en makten slechts een kwart van de kiesgerechtigden uit. ${ }^{13}$ In 1853 werd meer dan een kwart van de katholieken bedeeld, tegen twaalf procent van de hervormden. De katholieke armen concentreerden zich in bepaalde wijken van de stad. Van de zes Utrechtse parochies was de Martinusparochie de armoedigste. Deze zogenaamde 'klompenparochie' viel gedeeltelijk samen met wijk K.

Katholieken werden, volgens hun eigen zeggen, in Utrecht door de protestantse elite systematisch uitgesloten van openbare ambten. In 1854 zaten in de gemeenteraad wel, zo werd geklaagd in een krantenadvertentie in de Utrechtsche Courant, 'een Israeliet, een Oud-Roomsche, een Luthersche, een Remonstrant', maar geen enkele katholiek. ${ }^{14}$ Katholieken werden geweerd uit 'alle, eenig gezigt, aanzien of voordeel gevende betrekkingen $[. .$.$] eene omstandigheid, welke de herinnering der vroegere onderdruk-$ king levendig houdt. ${ }^{, 15}$

Binnen de Duitse immigrantenpopulatie was, in de periode 1850-1859, iets minder dan 53 procent van de Duitse immigranten protestants en bijna 45 procent katholiek. Nog geen drie procent was joods. ${ }^{16}$ Vooral katholieken en in iets mindere mate joden, waren onder de Duitse immigranten sterker vertegenwoordigd dan in de Utrechtse bevolking in het algemeen (zie figuur 5.5).

De protestantse Duitse immigranten kunnen worden onderscheiden in lutheranen en calvinisten. ${ }^{17}$ Het onderscheid is enigszins problematisch, omdat sommige immigranten de ene keer in de bevolkingsregisters als luthers en de andere keer als calvinistisch werden genoteerd. Klaarblijkelijk werd, of door de immigranten zelf, of door de ambtenaren die de registers bijhielden, niet veel waarde gehecht aan het onderscheid tussen beide geloven. Van de protestantse Duitsers was 45 procent luthers in de periode 1850-1859 en 53 in de periode 1860-1879. Het lutherse aandeel werd in de tweede periode groter, of luthers en calvinistisch werden toen in de registratie zorgvuldiger onderscheiden. Het aandeel van de lutheranen onder de Duitse immigranten, was aanzienlijk hoger dan hun aandeel in de Utrechtse bevolking in het algemeen, ofschoon het geenszins zo was dat alle Duitse protestanten luthers waren. 
Zowel in de eerste als de tweede periode, was 73 procent van de lutheranen man. Een scheve sekseratio bestond ook reeds onder lutheranen in eerdere tijdvakken. ${ }^{18}$ Deze getalsmatige verdeling tussen mannen en vrouwen bij de lutheranen, houdt verband met de immigratie van enkele groepen die vrijwel geheel uit mannen bestonden, zoals stukadoors en vijlenkappers.

De Duitse nieuwkomers die tussen 1860 en 1879 kwamen, waren voor 45 procent protestants en voor 52 procent katholiek; twee procent was joods. De toename van het aantal katholieken in de tweede periode werd vooral veroorzaakt door een groter aan-

Tabel 5.1 Verdeling naar religie: immigranten aanwezig in de periode 1850-1859 en nieuwkomers in de periode 1860-1879; absolute aantallen met tussen haakjes percentages.

\begin{tabular}{lrrrrrr|rrrrrr}
\hline & \multicolumn{7}{c|}{$1850-1859$} & \multicolumn{7}{c}{$1860-1879$} \\
\hline & $\mathrm{m}$ & \multicolumn{1}{c|}{$\mathrm{v}$} & $\mathrm{t}$ & $\mathrm{m}$ & \multicolumn{1}{c}{$\mathrm{v}$} & \multicolumn{1}{c}{$\mathrm{t}$} \\
\hline luthers & 159 & $(30)$ & 60 & $(15)$ & 219 & $(24)$ & 202 & $(28)$ & 92 & $(19)$ & 294 & $(24)$ \\
calvinistisch & 133 & $(26)$ & 131 & $(33)$ & 264 & $(29)$ & 149 & $(20)$ & 105 & $(22)$ & 254 & $(21)$ \\
katholiek & 214 & $(41)$ & 201 & $(50)$ & 415 & $(45)$ & 363 & $(50)$ & 266 & $(56)$ & 629 & $(52)$ \\
joods & 14 & $(3)$ & 11 & $(3)$ & 25 & $(3)$ & 16 & $(2)$ & 11 & $(2)$ & 27 & $(2)$ \\
totaal & 520 & & 403 & & 923 & & 730 & & 474 & 1204 & \\
\hline
\end{tabular}

Bron Bestand Duitsers in Utrecht 1849-1879.

Niet verwerkt in deze tabel zijn 61 Duitse immigranten die christelijk afgescheiden (1), doopsgezind (2), waals (6), hersteld luthers (3), hernhutter (1), oud-katholiek (2), remonstrants (1), of episcopaals (4) waren, waarbij geen geloof werd vermeld (20), of die van geloof veranderden (21).

Figuur 5.5 Duitse mannen en vrouwen. Verdeling naar geloof in de periodes 1850-1859 en $1860-1879$.

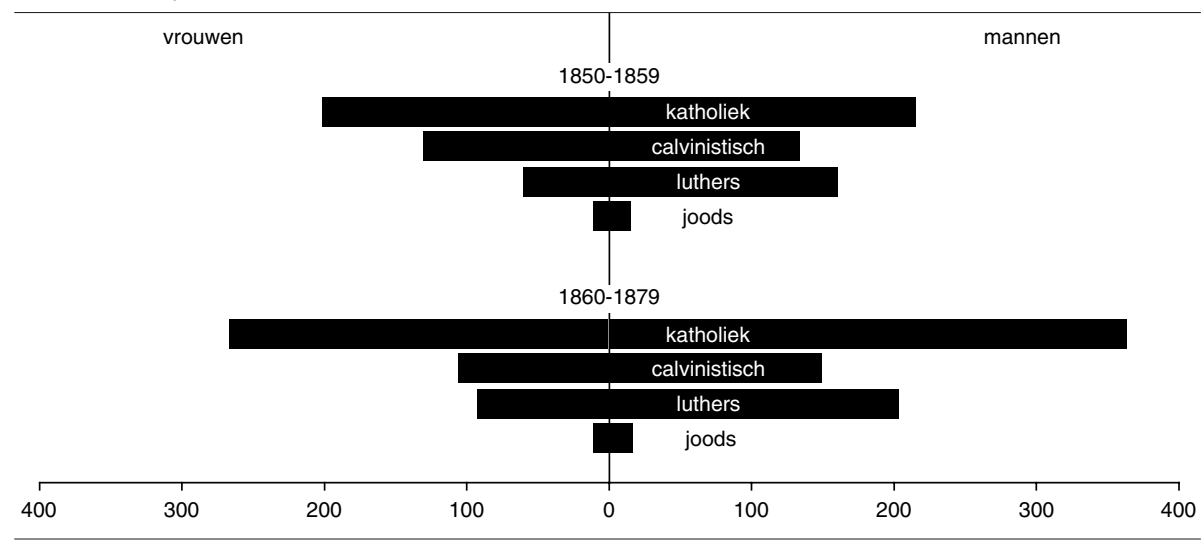

Bron Bestand Duitsers in Utrecht. 
Figuur 5.6 Verdeling naar geloof per wijk in de periode 1850-1859.

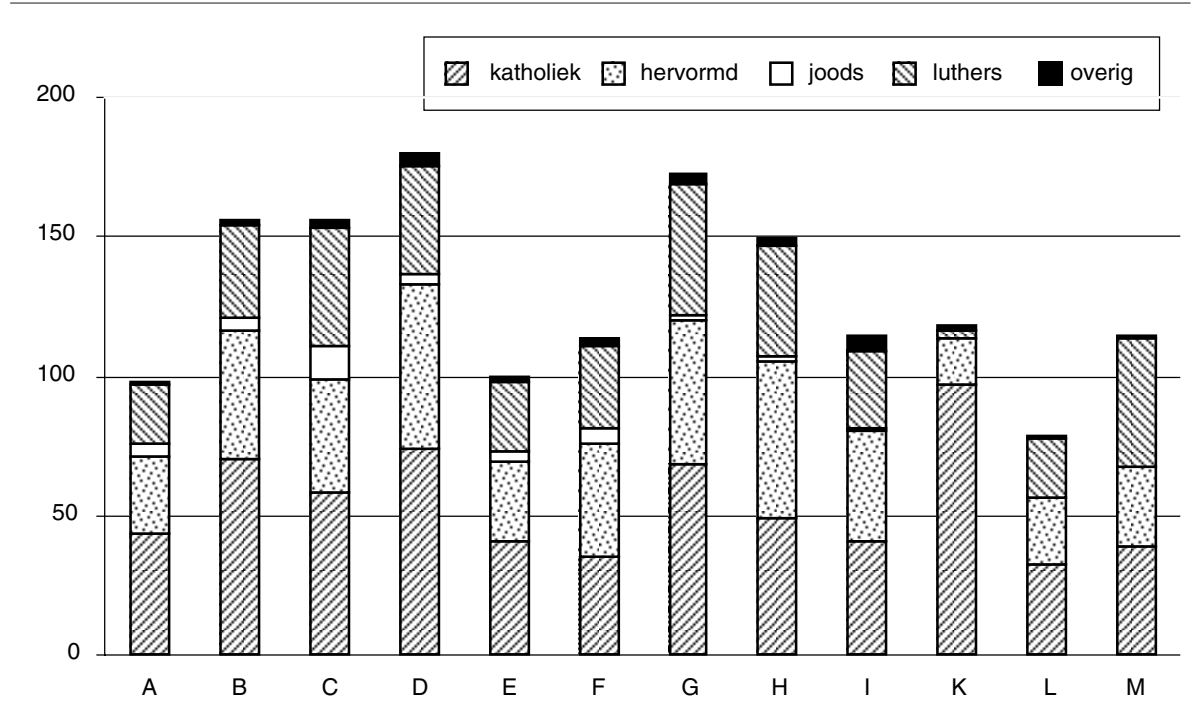

Figuur 5.7 Verdeling naar geloof per wijk in de periode 1860-1879.

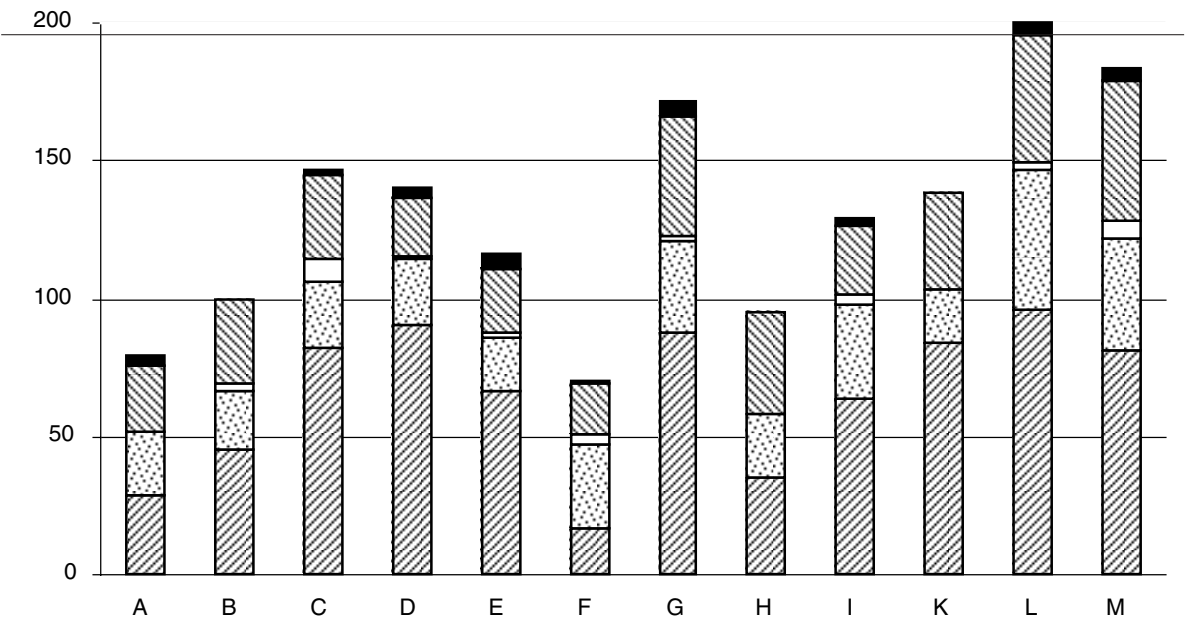

Bron Bestand Duitsers in Utrecht. 
tal katholieke mannen. Terwijl in de eerste periode het aantal katholieke mannen en vrouwen vrijwel gelijk was, gold dat niet voor de tweede periode. De groep bestond, zoals gezegd, voor een groot deel uit jonge mannen die als winkelbedienden werkten.

Duitse lutheranen vestigden zich in de buitenwijk $\mathrm{M}$ en in de aangrenzende wijken binnen de singels, maar weinig in de buurt van de reeds gevestigde lutheranen in het stadscentrum. Tussen beide groepen lijkt geen sterke band te hebben bestaan. Onder de Duitse calvinisten is geen concentratie herkenbaar. Katholieke nieuwkomers vinden we verspreid over de hele stad, met een zwaartepunt rondom de centraal gelegen Oudegracht en in de buitenwijk K. Joodse nieuwkomers concentreerden zich meer dan gevestigde joden in de wijken B en C. Een gemeenschappelijk geloof was overduidelijk geen basis voor groepsvorming onder de Duitse immigranten (zie figuur 5.6 en 5.7).

Binnen de Duitse immigrantenpopulatie bestond er, zoals te verwachten, een verband tussen geloof en regionale herkomst. Dit verband ligt voor de hand, gezien het zogenaamde Duitse adagium 'Cuius regio, eius religio' of 'wessen Gebiet, dessen Religion', wat inhield dat de landsheer het geloof van zijn onderdanen bepaalde. Gevolg hiervan was, dat immigranten die uit een beperkt geografisch gebied kwamen, vrijwel automatisch eveneens hun religie met elkaar gemeen hadden. Helemaal ging deze regel niet op; er waren religieus gemengde gebieden en ook steden kenden een religieus gemengde bevolking. Wanneer een indeling wordt gemaakt in grotere politieke eenheden, overheerst de religieuze diversiteit. Westfalen telde in 1852 bijvoorbeeld 1.422 .000 inwoners waarvan 798.100 katholieken, 610.000 lutheranen en 13.800 joden. ${ }^{19}$ Met andere woorden, zeker in het westen gold, hoe kleiner de gebieden, des te groter de religieuze homogeniteit. Nassau kende een religieus gemengde bevolking; de dorpen in het Westerwald in Nassau, waar de immigranten in Utrecht vandaan kwamen, waren echter vrijwel geheel katholiek.

\section{Netwerken}

Omdat in de bevolkingsregisters de (familie)band tussen de hoofdbewoner en andere huisgenoten wordt aangegeven, is het mogelijk netwerken in kaart te brengen. In het bevolkingsregister kunnen we zien of twee volwassen mannen met dezelfde achternaam, die in hetzelfde huis woonden, broers of neven van elkaar waren. Van de 2188 Duitse immigranten die tussen 1849 en 1879 in Utrecht woonden, leefden er 221 met een volwassen familielid in een huis (10 procent). Het samenwonen van volwassen kinderen met hun ouders is hier buiten beschouwing gelaten. Het gaat hier om samenlevingsvormen als die van de familie Leijting waarmee dit hoofdstuk begon.

De migranten uit het Westerwald woonden wel geconcentreerd in enkele dicht bijeen liggende straten, maar het samenwonen van verwanten of niet-verwanten in hetzelfde huis, was bij deze groep van beperkte betekenis, omdat de huizen waarin zij woonden merendeels zeer klein waren. 
Wanneer mensen niet onder hetzelfde dak woonden, maar wel dezelfde achternaam hadden, is de familieband moeilijk te achterhalen. Soms geven huwelijksakten uitsluitsel, omdat daarin de namen van de ouders worden genoemd. Als huwelijksakten ontbreken wordt het lastiger, vooral wanneer het gaat om gebruikelijke namen als Koch, Stein en Müller. Bij minder gangbare namen konden wel aannames worden gemaakt. In Utrecht woonden bijvoorbeeld Maria en Helena Hausmann. Zij werden geboren in Kleef in respectievelijk 1837 en 1838, en werkten als dienstbodes in twee verschillende huishoudens. De naam Hausmann kwam in Utrecht slechts tweemaal voor; alleen Maria en Helena droegen deze naam. Hun geboorteplaats en -data maken het aannemelijk dat ze familie van elkaar waren en waarschijnlijk zussen. Buiten de sterk verzwagerde gemeenschap van de Westerwalders, waren nog in 22 vergelijkbare gevallen de aanwijzingen duidelijk genoeg om aan te nemen, dat Duitse immigranten familieleden in de stad hadden met wie ze niet onder een dak woonden.

Van de tien procent van de immigranten die wel met familieleden onder een dak woonden, ging het in 197 van de 221 gevallen, om mannen of vrouwen die met een broer of zus samenwoonden ( 89 procent). In de overige gevallen ging het om minder nabije verwanten; ooms, neven, tantes en nichten. De 197 gevallen kunnen nog verder worden opgesplitst: in 153 gevallen ging het om twee of meer broers die gezamenlijk een huishouden vormden (78) of om samenwonende broers en zussen (75). Huishoudens waarin we twee of meer zussen vinden waren minder gebruikelijk (44).

Mannen woonden veelal samen met broers die in hetzelfde beroep werkten, bijvoorbeeld twee of drie mannen die werkten als handelaar of winkelier. Er waren ook enkele ambachtslieden die gezamenlijk een huishouden vormden of samen inwoonden bij hun werkgever. Voor vrouwen was deze vorm van samenwonen ongebruikelijk.

Veel van de Duitse vrouwen werkten als dienstbodes; in totaal ongeveer honderd. Duitse dienstbodes woonden, net als andere dienstbodes, in bij hun werkgever. Enkele rijke families in Utrecht hadden meer dan een dienstbode; het merendeel van de gezinnen had er echter slechts een. De kans dat een Duitse dienstbode met een zus of nicht in het huishouden van haar werkgeefster woonde, was derhalve gering. Desondanks kwam het toch drie keer voor. Wilhelmina en Johanna Tenhalff waren twee zussen die gedurende zes jaar samen bij de familie van een Amsterdamse majoor werkten. Theodora en haar zus Hendrina Halthausen vonden als dienstbodes werk bij een Duitse logementouder. De zussen Petronella, Sibilla en Dorothea Muskens werkten bij een welgestelde Rotterdamse weduwe, zij het niet alle drie tegelijk. Aanvankelijk woonden Petronella en Dorothea onder hetzelfde dak. Toen Petronella vertrok, werd zij opgevolgd door haar jongere zus Sibilla.

Deze dienstbodes waren echter uitzonderlijk. In zeventig gevallen trok een jonge, ongetrouwde vrouw in bij een oudere, reeds getrouwde zus of broer, zoals bij de vrouwen uit de familie Leijting. Bij deze jonge vrouwen werd in het bevolkingsregister geen beroep vermeld. De vrouwen bleven in het huishouden van hun broer of zus, totdat ze trouwden en een eigen huishouden begonnen. Bij de mannen vinden we deze vorm van samenwonen vrijwel niet. 
Tegenover de ongeveer tien procent van de Duitse immigranten die onderdak vonden bij een familielid, stond negentig procent waarvoor dat niet gold. Mogelijk hadden zij wel andere banden dan familiebanden met mensen binnen de stad. Die banden zijn niet altijd eenvoudig vast te stellen. De Duitse schoenmaker Frans Ebenwien, geboren in Hannover in 1813 en luthers, kwam in 1859 naar Utrecht uit Schoonrewoerd. Hij nam zijn intrek bij de weduwe Van den Heuvel, een schuitentrekster in wijk M. Hier bleef hij drie maanden, waarna hij naar Beest vertrok. Krap drie jaar later kwam hij opnieuw naar Utrecht en vond onderdak bij een Nederlandse familie in de Gasthuissteeg in wijk I. Na meer dan een jaar nam hij zijn intrek bij zijn Duitse collega-schoenmaker en streekgenoot Johan Groen (geboren in Lingen in Hannover in 1816 en katholiek). Op dit adres overleed hij vijf maanden later op 56-jarige leeftijd. Van de twee jaar dat Ebenwien in Utrecht was, woonde hij dus vijf maanden bij zijn beroeps- en streekgenoot. Dit patroon zien we ook bij andere Duitse immigranten. Ze woonden een deel van hun tijd bij een werkgever, collega of streekgenoot, en de rest van de tijd niet.

Bij de niet-familiale netwerken speelde vooral het beroep een rol. Het Duitse winkelpersoneel, een omvangrijke groep onder de Duitse immigranten, werd gedeeltelijk gehuisvest in grote internaten behorende bij de winkels. Deze internaten herbergden gedurende enkele tientallen jaren honderden Duitse immigranten. Vijlenkappers en stukadoors woonden voor een deel bij hun werkgever. Bij de andere beroepsgroepen zien we ook wel dat jongere ambachtslieden bij oudere beroepsgenoten inwoonden. Een groot aantal jonge mannelijke migranten, zo'n dertig procent van de alleengaande jonge mannen, woonde echter in kosthuizen, waar ze geen band met hun huisbaas lijken te hebben gehad. Duitse studenten woonden verspreid over de stad in studentenhuizen, ofschoon er wel één huis als een Duits studentenhuis kon worden aangemerkt.

\section{Lineair, stapsgewijs, seizoensmatig of circulair}

In 1875 verscheen in het Utrechtsch Provinciaal en Stedelijk Dagblad een advertentie van Mina Schütze. ${ }^{20}$

\section{Mina Schütze,}

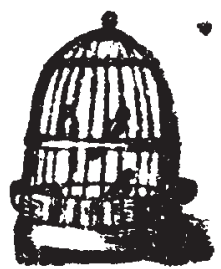

Weder gearriveerd met een geheel nieuwe pa!tij Bakalsche Kanarlvogels, zingende Belrol, Waterrol en IIolrol, zoo goed bij avon 1 als bij dag. Gelugeert bij C. SCHOONDERWOERT, Elisabe:hstraat, blijvende zes dagen. 
Mina Schütze behoorde tot een groep rondreizende handelaren die nergens lang bleef. Deze groep bestond niet alleen uit venters of kramers, maar ook uit mensen die zich richtten op een meer welgesteld publiek en die hun uitstallingen presenteerden in hotels. Scharzman, die in de krant van 18 december 1839 adverteerde, behoorde tot deze groep.

Magazijn van galanterien en fer de Berlin S. Scharzman, uitgepakt in het Logement den gouden Leeuw, berigt het geërde publiek, dat hij vele nieuwigheden ontvangen heeft [...] en zullen alle voorhandene goederen tot de laagste Fabrijkprijzen uitverkoopen; blijft uiterlijk tot Vrijdag 20 december uitgepakt. ${ }^{21}$

Aan de hand van krantenadvertenties kunnen deze rondreizende handelaren op hun weg door Nederland worden gevolgd.

Voor armere immigranten biedt de correspondentie omtrent het domicilie van onderstand een mogelijkheid voor reconstructie van het migratiepatroon. Wilhelmina Fuchs, die werd geboren in 1822 in Norden in Oostfriesland, kwam naar Nederland als koopvrouw in kindergoed. In 1847 werd over haar geschreven:

Zij bevindt zich sedert 6 jaren binnen hetzelve [Nederland], en heeft steeds altijd met hare handel het land rondgereisd, zonder ergens een vaste verblijfplaats te hebben gevonden. Alleen lijkt zij eenige weken te Arnhem geweest en aldaar den 4 november 1846 van eene dochter bevallen. ${ }^{22}$

Over Catharina Maria Wagner, geboren in 1822 in Hundsdorf in Nassau, werd in 1847 geschreven:

In maart 1842 is zij in dit Rijk gekomen en per stoomboot direct op Rotterdam gereisd en vervolgens op Leijden alwaar zij is gebleven tot in het laatst van 1844 . Daarna is zij als rondventster in potten en pannen in de provincien Zuid Holland en Utrecht van de eene plaats op de ander gegaan en heeft zich slechts eenige dagen opeen in dezelfde plaats opgehouden. ${ }^{23}$

Schütze en Scharzman reisden seizoensmatig met hun handel. Fuchs en Wagner trokken jaren achtereen rond, zonder ergens lang te blijven.

De geboorteplaatsen van kinderen bieden, naast krantenadvertenties en correspondentie omtrent het domicilie van onderstand, een indicatie van het migratiepatroon. Geboorteplaatsen van kinderen worden in migratieonderzoek veelvuldig gebruikt voor het reconstrueren van migratiepatronen. ${ }^{24}$ Aan de hand van geboorteplaatsen kunnen niet alle migratiebewegingen in kaart worden gebracht, maar ontstaat er wel een beeld van het minimale aantal migraties dat een gezin heeft doorgemaakt. De kinderen van de Duitse werkman Johannes Fischer en zijn vrouw Margaretha Klosch, werden achtereenvolgens geboren in de Duitse plaatsen Eschweiler en Ehrenbreitstein, in 
Deil in Gelderland, en in Utrecht. ${ }^{25}$ De familie kwam in 1867 uit Pruisen en ging daar in 1872 weer naar terug. De kinderen van de Duitse muzikant Georg Frétropp en de Luxemburgse Maria Huebsch, werden geboren in de Belgische plaatsen St. JeanMolenbeek en Brugge, in Givet in Frankrijk en in Utrecht. ${ }^{26}$ De familie kwam in 1865 naar Utrecht en vertrok twee jaar later naar Harderwijk. Beide families waren niet kenmerkend voor de Duitse migrantenpopulatie in Utrecht. Voor meer dan 80 procent van de gezinnen gold dat de kinderen of in de geboorteplaats van een van beide ouders of in Utrecht waren geboren. De families Fischer en Frétropp waren, afgaande op de geboorteplaatsen van de kinderen en in vergelijking met de andere Duitse immigranten, bijzonder mobiel.

Het migratiepatroon van broer en zus Böker, hier merendeels gereconstrueerd op basis van gegevens in het bevolkingsregister, was minder uitzonderlijk. Op 18 maart 1871 overleed in Utrecht om half tien in de avond de Duitse Maria Gertrud Böker. Ze werd 42 jaar, was volgens de overlijdensakte zonder beroep en werd geboren in Südlohn net over de Nederlands-Duitse grens bij Winterswijk. Haar twee jaar oudere echtgenoot Dirk Prijs, werkman en geboren in het Nederlandse Beusichem, ging haar zes uur eerder voor in de dood. ${ }^{27}$ De beide dochtertjes van het echtpaar, Maria Gesina en Angenita, twee en zes jaar oud, werden overgebracht naar het katholieke weeshuis, maar alleen het oudste kind werd daadwerkelijk op dat adres ingeschreven. ${ }^{28}$ De dood van de echtelieden was geen gevolg van een ongeluk of misdrijf. In de lokale krant, die gewoonlijk juist wel dit soort berichten opnam, werd in de dagen rondom hun dood geen melding gemaakt van zo'n voorval. Maria Böker en haar man werden het slachtoffer van de heersende pokkenepidemie. In de week van hun overlijden bezweken 43 mensen aan de pokken, terwijl er zich tien nieuwe ziektegevallen voordeden. Tussen januari en half maart 1871 werden bijna negenhonderd mensen in Utrecht aangetast door de pokken, waarvan er in maart reeds ongeveer 350 waren overleden. ${ }^{29}$

Maria Böker kwam oorspronkelijk naar Utrecht met haar vijf jaar oudere broer Johan en samen vestigden ze zich op het Vredenburg. Johan Böker werd net als zijn zus geboren in Südlohn. Beiden waren katholiek. Volgens de opeenvolgende inschrijvingen in het bevolkingsregister was Johan Böker koopman in boter en kaas, bediende, schrijver en muzikant. In 1851 trouwde hij met de Nederlandse Alberta Agtenberg en het jaar daarop werd hun zoon Gerardus geboren. ${ }^{30}$ Toen de vrouw kort daarna overleed werd haar zoontje ondergebracht bij Alberta's zus en broer, Christina en Franciscus Agtenberg. Vier jaar later, in 1856, beviel Christina van een dochter, Wilhelmina. Vervolgens is niet helemaal duidelijk wat er met Johan Böker gebeurde. Hij verliet de Domstad en wij zien hem pas in 1874 in de registers terug. Hij kwam toen uit Nederlands-Indië en trouwde met zijn schoonzus Christina, moeder van zijn dochter Wilhelmina en pleegmoeder van zijn zoon Gerardus. Bij dit huwelijk werd de inmiddels 18jarige Wilhelmina door hem erkend. Johan Böker vroeg en verwierf dispensatie voor het huwelijk met zijn schoonzus. Voor huwelijken met een naaste verwante, zoals een schoonzus, was dit een vereiste. De laatste twintig jaar van zijn leven sleet Böker in Utrecht tot hij in 1894 overleed. 
Het leven van Maria Böker was intussen niet over rozen gegaan. Vanuit de Domstad werd ze 'opgezonden', zoals dat heette, naar een bedelaarskolonie in Drenthe. In 1857 kwam ze opnieuw naar Utrecht en vond onderdak bij broer en zus Agtenberg, de aangetrouwde verwanten van haar broer Johan. Ze werkte als dienstbode. In 1863 beviel ze buitenechtelijk van een dochter, Maria Gesina. Ze ging naar Duitsland, maar was binnen een maand weer terug in Utrecht, nu als koopvrouw. Haar dochter overleed kort daarop. Maria Gesina werd gevolgd door twee andere buitenechtelijke kinderen: Dirk in 1864, die vrijwel meteen overleed, en opnieuw een Maria Gesina in 1865. In 1866 trouwde Maria Böker met de protestantse Dirk Prijs, een inlands kramer. ${ }^{31}$ De bruid zette haar handtekening op de huwelijksakte, de bruidegom verklaarde niet te kunnen schrijven. Bij het huwelijk werd dochter Maria Gesina geëcht. In 1869 werd Angenita geboren. Twee jaar later overleden, zoals we zagen, binnen enkele uren na elkaar de beide ouders.

Er zijn op basis van het databestand talloze migratieverhalen te schrijven zoals die van Maria en Johan Böker. Broer en zus hadden Südlohn definitief verlaten, Utrecht was de plaats waar ze beiden stierven. Hier woonden ook hun kinderen en aangetrouwde familieleden. Toch betekende dit nog niet dat zij zelf permanent in deze stad woonden. Hun verblijf vertoonde grote hiaten, ofschoon ze met enige regelmaat naar de Domstad terugkeerden. Het is moeilijk om het migratiepatroon van broer en zus Böker in een simpele omschrijving te vangen.

Migratiepatronen worden gewoonlijk onderscheiden in lineaire, stapsgewijze, seizoensmatige en circulaire migratie en kettingmigratie. Daarnaast is er carrièremigratie, waarbij mensen door internationale ondernemingen of organisaties worden overgeplaatst van het ene land naar het andere, en koloniale migratie, die verband houdt met processen van kolonialisatie en dekolonialisatie. ${ }^{32}$ Het onderscheid tussen de verschillende vormen ligt zowel in de mate waarin migranten een band houden met de samenleving waar ze vandaan komen als in de mate waarin de migratie permanent is. Bij de band met het herkomstgebied gaat het in feite om een spectrum, waarbij aan de ene zijde de door de Amerikaanse historicus Handlin beschreven uprooted staan. ${ }^{33}$ Dit zijn de mensen voor wie migratie een breuk betekende met al het bekende. Zij kenden niemand in hun nieuwe woonplaats en namen uit hun oude woonplaats vrijwel niets mee. Aan de andere kant van het spectrum staan de transplanted villages van de Amerikaanse historicus Kamphoefner. ${ }^{34}$ Hierbij nemen migranten hun familieleden, buren en vrienden mee naar de nieuwe woonplaats, evenals alle sociale verhoudingen van hun geboortedorp.

De genoemde migratiepatronen kunnen beperkt of breed worden opgevat. In een beperkte opvatting, zoals die hieronder geïllustreerd zal worden, valt slechts een klein deel van de migratie naar Utrecht - iets meer dan dertig procent - in te delen in een bepaalde categorie. In tabel 5.2 wordt dat samengevat.

Van vrijwel alle migratiepatronen, zoals die gewoonlijk worden onderscheiden, kunnen in Utrecht voorbeelden worden gevonden. Een min of meer lineaire migratiebeweging maakte bijvoorbeeld Barnardina Wilting. Ze werd in 1826 geboren in Anholt 
bij Emmerich en was katholiek. In 1853 kwam zij uit deze plaats naar Utrecht en was toen 27 jaar. Ze werkte bij een echtpaar op de Biltstraat in wijk I en bij hoogleraar Donders in wijk G. Na op nog enkele adressen te hebben gewoond, verhuisde ze, met de familie bij wie ze diende, naar Den Haag. Kort daarop, in 1872, kwam ze terug en werkte bij griffier Blankenstein in wijk I en vervolgens bij een gepensioneerd luitenant ter zee in wijk F. In een periode van vijftien jaar werkte zij bij vijf verschillende families. Dit was, in vergelijking met haar Nederlandse collega-dienstbodes, niet opvallend veel. In 1879 - ze was toen 53 jaar - werd ze huishoudster in het kosthuis van Peek \& Cloppenburg. Zij vervulde die functie veertien jaar. Tot slot woonde ze enige tijd samen met een Belgische oud-dienstbode in wijk I en overleed daar in 1908, 80 jaar oud. Wanneer we het korte verblijf in Den Haag buiten beschouwing laten, migreerde Wilting van haar geboorteplaats Anholt naar Utrecht, waar ze meer dan vijftig jaar later overleed. Deze lineaire vorm van migratie was echter uiterst zeldzaam. Slechts weinig migranten minder dan een procent - kwamen uit hun geboorteplaats naar Utrecht om daar de rest van hun jaren te slijten.

Stapsgewijze migratie was gebruikelijker. De joodse, Duitse koopman Joseph Wolff en zijn vrouw Esther Marx, migreerden van hun geboorteplaatsen Bornheim en Wesseling - plaatsen tussen Bonn en Keulen - naar Keulen en kwamen vervolgens in 1875 naar Utrecht. Bij een stapsgewijs migratiepatroon wordt uitgegaan van een zekere progressie; iemand verhuist eerst naar een plaats die groter is dan de geboorteplaats, om vervolgens verder te migreren naar een nog groter of verderweg gelegen oord. Bij Wolff en Marx herkennen we dit patroon min of meer. Bij de lutherse dienstbode Adelheid Richter gaat dat beeld niet helemaal op. Adelheid Richter werd in 1848 in Dresden geboren, ging naar Rotterdam en kwam in 1882 naar Utrecht. Zes maanden later vertrok zij naar Engeland. Bij stapsgewijze migratie konden Nederlandse steden voor Duitse migranten dienen als tussenstap voor migratie naar overzee. De katholieke winkelbediende Heinrich Osthues werd in 1869 geboren in het Duitse Beckum. In 1885 kwam hij

Tabel 5.2 Percentage van de migratie die gerekend kan worden tot een bepaalde typologie, opgevat in engere zin.

\begin{tabular}{lc}
\hline lineaire migratie & 1 \\
stapsgewijze migratie & 3 \\
circulaire migratie & 13 \\
seizoensmigratie & 7 \\
carrièremigratie & 6 \\
koloniale migratie & 1 \\
totaal & 31 \\
\hline
\end{tabular}

Bron Bestand Duitsers in Utrecht. 
uit die plaats naar de Domstad. Hij werkte vijf jaar als winkelbediende bij het Duitse manufacturenwarenhuis Van der Sandt \& co. In 1890 vertrok hij naar Buffalo in Amerika. Osthues verre bestemming was niet typerend voor zijn Duitse collega-winkelbedienden; het merendeel ging naar een van de andere grotere Nederlandse steden. Slechts bij drie procent van de immigranten kan het migratiepatroon als stapsgewijs in engere zin worden aangemerkt.

Van een zuiver circulair migratiepatroon, waarbij iemand een rondreis maakte om uiteindelijk naar de geboorteplaats terug te keren, kan geen voorbeeld worden gegeven uit het Utrechtse materiaal. De winkelbedienden reisden binnen Nederland wel veelvuldig heen en weer tussen steden, maar een circulair migratiepatroon was dit niet. Heinrich Esselman werkte bijvoorbeeld voor Sinkel in Utrecht en eveneens als winkelbediende in Rotterdam. ${ }^{35}$ De winkelbedienden lijken een rondreis langs de Duitse winkels in Nederland te hebben gemaakt. Ze gingen naar allerlei plaatsen in een ogenschijnlijk willekeurige volgorde en keerden merendeels niet terug naar hun geboortegrond.

Een rondreis, maar dan met een gemiddeld kortere verblijfsduur, maakten ook de prostituees. Zij werkten enkele maanden in een bordeel, om dan verder te reizen naar een andere grote stad in Nederland of daarbuiten. Na verloop van tijd keerden ze terug naar in Utrecht. Zowel bij de winkelbedienden als bij de prostituees was het rondreizen beroepsgebonden. Bij de winkelbedienden was het onderdeel van hun opleiding; het rondreizen van de prostituees hing samen met de veronderstelling dat vaste klanten van bordelen regelmatig nieuwe gezichten wilden zien. Ongeveer dertien procent van de Duitse immigranten kende een periode van rondreizen binnen Nederland en daarbuiten, alvorens uiteindelijk ergens een vaste verblijfplaats te vinden of, zoals veel prostituees, betrapt te worden door de dood, die aan hun rondreizen een einde maakte.

Seizoensmatige migratie vinden we veel bij trekhandelaren en trekarbeiders, die met vaste regelmaat naar een bepaalde bestemming reisden om na enkele maanden weer naar hun geboortegrond terug te keren. De Westerwalder potverkopers vertoonden dit patroon gedeeltelijk. Niet alle Westerwalders keerden echter na een seizoen terug naar hun geboortestreek; een gedeelte woonde permanent in de Domstad, of ging vanuit Utrecht naar een andere Nederlandse stad. Het seizoensmatig op en neer trekken zien we bij zeven procent van de Duitse immigranten.

Bij de Westerwalders was sprake van een overgang van seizoensmatige migratie naar kettingmigratie. Die kettingmigratie kan gedeeltelijk worden omschreven in termen van Kamphoefner's transplanted villages. ${ }^{36}$ Het dorp Ransbach in het Westerwald in Nassau telde in 18451462 inwoners. In Utrecht woonden in het midden van de negentiende eeuw ten minste 55 mensen die in dit dorp waren geboren. Het werkelijke aantal was waarschijnlijk hoger omdat er ook nogal wat Duitse immigranten waren - 21 in totaal - bij wie slechts 'Nassau' als geboorteplaats werd vermeld. Het concept transplanted villages dekt in dit geval niet helemaal de lading. De Westerwalders kwamen niet alleen uit Ransbach, maar uit een groter omliggend gebied. Op dit punt waren ze vergelijkbaar met het winkelpersoneel; er was niet zozeer één dorp aan te wijzen, als wel een grotere regio. Het waren niet de buren uit één dorp die buren werden in de stad van 
bestemming. Het afstotingsgebied was groter en diffuser dan de metafoor van de transplanted village suggereert.

Als voorbeelden van negentiende-eeuwse carrièremigratie, kunnen leraren en universiteitspersoneel worden genoemd. De verplaatsing van legeronderdelen kan eveneens onder deze noemer worden gebracht. Beroepsmilitairen - zowel de Nederlandse als de niet-Nederlandse - vormden een mobiele groep. Ze werden groepsgewijs van de ene garnizoensplaats naar de andere overgeplaatst, samen met hun vrouwen en kinderen.

Verlofgangers uit Nederlands-Indië, die in Duitsland waren geboren en die in Utrecht met hun familieleden en personeel een verlof van enkele maanden doorbrachten, vallen onder de noemer koloniale migratie. In Utrecht waren elf families waarvan de man Duits was en in het Nederlandse leger in Oost-Indië diende. Carl Vohl, bijvoorbeeld, werd in 1832 geboren in Bonn. ${ }^{37}$ Hij was officier in het Oost-Indische leger. In mei 1879 kwam hij met zijn vrouw Amalia Muller, geboren in Soerabaja in 1854, naar Utrecht. Twee maanden later reisde de familie verder naar Godesberg. De vader van Amalia Muller kende een vergelijkbaar migratiepatroon. Hij werd geboren in Saksen, trouwde een Amsterdamse vrouw en vertrok als militair naar Oost-Indië in dienst van het Nederlandse leger. De kinderen van het echtpaar werden geboren in Maarssen, Soerabaja en Batavia. Met enige regelmaat kwam het gezin met verlof naar Utrecht. Minder dan een procent van de Duitse immigranten kan worden aangemerkt als koloniale migranten.

De bestaande migratietypologieën dekken, zeker wanneer ze in beperkte zin worden toegepast, de Utrechtse werkelijkheid onvoldoende. Migratiepatronen bestonden naast elkaar en vloeiden in elkaar over. De migratiepatronen vormden geen strak van elkaar gescheiden systemen. Circulaire migratie en seizoensmigratie konden overgaan in kettingmigratie. De mogelijkheden die migranten hadden en veranderingen daarin, bepaalden uiteindelijk of cirkels kettingen werden. Een vroege dood maakte van een circulair of seizoensmatig bedoelde migratie een lineaire.

Christiaan Wagner werd op 18 december 1837 geboren in het Utrechtse stadsziekenhuis. ${ }^{38}$ Zijn lutherse vader was Johann Wagner uit het Duitse Wesel; zijn katholieke moeder was Maria Louise Flegelskamp uit Kaiserswerth. Het echtpaar trouwde volgens de huwelijkakte pas op 14 december 1860, 22 jaar na de geboorte van hun zoon, in Spellen in Pruisen. Noch in de geboorteakte, noch in de huwelijksakte werd een erkenning van zoon Christiaan opgenomen. Op 8 december 1855 vertrok de familie Wagner vanuit Utrecht naar Amsterdam. Vader Johann Wagner was kermisreiziger. Eerder werkte hij als dompteur, totdat een leeuw een vingerkootje van zijn rechter wijsvinger afbeet, zoals het signalement op zijn reispapieren vermeldt. Zoon Christiaan trouwde in 1863 met Maria Xhaflaire, geboren in een familie van kermisreizigers uit Roermond. In 1874 vertrok vader Johann Wagner met zijn draaimolen naar Amerika. Christiaan, zijn vrouw en hun jongste kind reisden met hem mee. Christiaans drie oudere kinderen bleven in Nederland achter. Christiaan Wagner keerde voortijdig met vrouw en kind 
terug naar Nederland, omdat zijn schoonmoeder stervende was. Johann Wagner bleef in Amerika. Hij zou met een latere boot volgen, maar kwam nooit meer terug.

Een iets bredere invulling van de migratietypologieën leidt tot een betere dekking. Bij de orgelbouwer Christian Witte zien we een migratiepatroon dat ruimweg kan worden aangeduid als een variant op stapsgewijze migratie. Witte begon zijn reis naar Utrecht op 27 april 1824. Hij reisde te voet en volgde een vooropgezet plan. Hij kende de namen van orgelbouwers in Duitsland en Nederland, die hij wilde bezoeken. Witte liep van Achim naar Hannover, toen naar Göttingen, vervolgens naar Kassel, Frankfurt am Main, Koblenz, Keulen en Münster. ${ }^{39}$ Van Münster ging hij naar Utrecht, waar hij na een reis van meer dan een maand, op 4 juni 1824 aankwam. Witte reisde geenszins via de kortste weg. Hannover ligt hemelsbreed nog geen 350 kilometer van de Domstad. Witte's reisweg was meer dan 750 kilometer lang. Witte vond in Utrecht, net als in alle eerdere plaatsen die hij aandeed, geen werk en daarom nam hij de trekschuit naar Gouda en reisde door naar Leiden, Delft, Den Haag en Haarlem. Vier dagen na zijn vertrek uit Utrecht, op 8 juni 1824, arriveerde hij in Amsterdam. Pas twee jaar later, in 1826, keerde hij in de Domstad terug om daar uiteindelijk vast werk te vinden en er, na enkele reizen naar Suriname en Berbice, te sterven..$^{40}$

De vijlenkapper Eduard Lange had een migratiepatroon dat min of meer vergelijkbaar was met dat van Witte. Hij werd geboren in 1839 in het Duitse Voerde en kwam reeds voor 1850 met zijn moeder naar Utrecht. ${ }^{41}$ In 1864 vertrok hij naar Engeland. Vervolgens ging hij in 1869 ging naar Den Haag, waar hij trouwde met de Haagse Johanna Pontier en waar zijn eerste kind werd geboren. In 1871 keerde hij terug naar de Domstad. Hij was nu niet langer vijlenkapper, maar werkte als beambte bij het spoor. Een jaar later werd in deze stad zijn tweede kind geboren. In 1875 overleed hij op 35-jarige leeftijd.

De migratie van Ferdinand Thiessing is ook een voorbeeld van een variant in ruimere zin van stapsgewijze migratie. Hij werd in 1843 geboren in het Duitse Münster. Hij trouwde met Maria Moormann, die in 1852 in Londen werd geboren als dochter van een bekende Duitse handelaar uit Münsterland, die onder meer in Nederland actief was. De kinderen van het echtpaar Thiessing-Moormann werden geboren in het Engelse Bowdon, in Loth in België, en in Amsterdam, Hilversum en Utrecht. ${ }^{42}$ In 1904 verkreeg de familie de Nederlandse nationaliteit en vertrok kort daarop naar Duitsland. Een vergelijkbaar migratiepatroon zien we bij de zoon van een andere grote Duitse handelaar, Engelbert van der Sandt. Hij werd in 1852 in Amsterdam geboren als zoon van de Duitser Gerardus van der Sandt (geboren in Elten in 1822) en Paula Moormann (geboren in Mettingen in 1819). Engelbert van der Sandt trouwde in New York met de Amerikaanse Neena Mary Wolfe (die in 1852 in New York werd geboren). ${ }^{43}$ In 1875 kwam het echtpaar uit New York naar Utrecht, waar hun eerste kind werd geboren. Nog hetzelfde jaar vertrok de familie naar Parijs. De winkeliers en hun kinderen legden grote afstanden af en woonden afwisselend in Utrecht en in wereldsteden als Parijs, Londen en New York.

Voorbeelden van een migratiepatroon zoals dat van Witte, Lange, Thiessing of Van der Sandt zijn er te over onder de Duitse immigranten in Utrecht. Het was een zoe- 
kende migratiebeweging, die meerdere jaren omspande en waarbij verschillende plaatsen werden aangedaan die ver uiteen lagen, en die pas na langere tijd op een definitieve bestemming eindigde. Er was bij dat zoeken niet zozeer sprake van migratie van een kleine naar een grotere plaats. Min of meer toevallige factoren lijken bovendien te hebben bepaald waar een reis eindigde. Had Witte in Göttingen, Kassel, Frankfurt am Main, Koblenz, Keulen of Münster werk gevonden, dan was hij mogelijk niet doorgereisd naar Gouda, Leiden, Delft, Den Haag, Haarlem en uiteindelijk Utrecht. Met wat minder geluk had hij in Berbice, in Suriname of op zee reeds zijn graf gevonden. Bijna zeventig procent van de migratie kan worden gebracht onder de noemer mengvorm van circulaire en stapsgewijze migratie in ruimere zin, met een zoekend karakter en een grote actieradius.

\section{Tot besluit}

In dit hoofdstuk zijn beschreven de leeftijdsopbouw van de Duitse migrantenpopulatie, de religieuze samenstelling van de groep en het migratiepatroon.

De Duitse migrantenpopulatie bestond in Utrecht grofweg voor de helft uit katholieken en voor de helft uit protestanten. In deze verhouding deden zich in de tweede helft van de negentiende eeuw geen grote veranderingen voor. De enige verandering op dit punt was de komst, in de periode 1860-1879, van jonge, katholieke Duitse mannen, die slechts kort bleven en als winkelbediende werkten.

Religie was geen basis voor groepsvorming onder de Duitse immigranten in Utrecht. We zien slechts concentraties van Duitse katholieke immigranten rond de Oudegracht en in wijk K. De overige immigranten verdeelden zich min of meer willekeurig over de stad, waarbij lutherse en joodse nieuwkomers niet terecht kwamen in de nabijheid van reeds gevestigde geloofsgenoten.

De mogelijkheden voor katholieke immigranten in Utrecht waren niet gelijk aan die van protestanten. Katholieke tijdgenoten klaagden over achterstelling en over het feit dat zij uit openbare functies zouden worden geweerd. Ondanks de afschaffing van formele barrières betekende dat, dat de kansen voor bestuurlijke invloed en ontplooiing minder waren.

Bij het migratiepatroon zien we het hele spectrum van Handlin's uprooted tot Kamphoefner's transplanted villages. Het belangrijkste is dat de migratie niet in één patroon te vatten is. De in de literatuur genoemde migratiepatronen dekken in beperkte zin slechts eenderde van de Utrechtse werkelijkheid. Bij verder migratieonderzoek zou van een al te rigide indeling in migratietypologieën afstand moeten worden genomen. Het zoekende migratiepatroon, zoals hier is omschreven, kan niet worden afgedaan als een variant van het lineaire migratiepatroon, waarbij vreemdelingen feitelijk van A naar B reisden, zij het met een omweg. Het zoekende migratiepatroon impliceert dat migranten reisden met een weinig vastomlijnd idee van hun uiteindelijk bestemming, waarbij toeval en mogelijkheden op hun weg bepaalden, waar de reis eindigde. 


\title{
6 'Wat is een Duitscher voor een vrouw? Huwelijksgedrag
}

In zijn boek Mijn bezoek aan Bismarck laat Jochem van Ondere, 'Pijpenfabrikant en ouderling te Gouda', 'zijn ik-persoon, die juist terugkeert van zijn reis naar Duitsland, tegen zijn vrouw en drie volwassen dochters zeggen dat een Duitse huwelijkspartner toch wel een aantrekkelijk vooruitzicht is.

\begin{abstract}
'Man, pa, mensch, monster!' Gilde het uit vier monden. 'Zijt gij krankzinnig geworden! Onze lieve dochters weggevoerd naar dat land, waar ze net als de boeren om twaalf uur eten, waar men onder de bedden slaapt in plaats van erop, waar geene tapijten op den vloer liggen, waar men vergaat van de koude voeten, omdat ze er geene stoven kennen ...'2
\end{abstract}

De dochters hadden dan toch veel liever een Fransman. Van Ondere's ik-persoon wierp tegen:

'Maar, liefste, de Duitscher is immers tegenwoordig ook zeer galant voor dames ..'

'Ach, wat Duitscher!' Viel mijne lieve dochter Mietje in, 'wat is een Duitscher voor een vrouw? [...] als ik moest kiezen, dan nog honderdmaal liever een luchtigen Franschman dan zoo'n zwaarmoedigen Duitscher.'3 [... ' waag het nimmer bij de Nederlandsche vrouwen met uwe Duitschers op de proppen te komen. We willen nu eenmaal die Germanen, of hoe noemt ge al dat Noordsche volk, niet'. ${ }^{4}$

Fransen wilden de dochters wel met open armen ontvangen.

'Doch die Moffen ... wij zullen hen het land uitschrobben en uitboenen! - En gij, kom ons niet weer aan met zulke malle praatjes van uwe huwelijken met Duitschers! Wat gij hier - misschien een beetje soezend, van dat nare Moffenbier, waar aan ge u waarschijnlijk op de grenzen nog rijkelijk heb te goed gedaan - gezegd hebt, blijft natuurlijk onder ons. Maar waag het niet in tegenwoordigheid van ééne vrouw een enkel woord ter verdediging van de Duitschers te zeggen. 


\section{Gemengde huwelijken}

Eenderde deel van de Duitse immigranten was reeds gehuwd bij hun komst naar Utrecht. Van de mannen was een op de drie à vier reeds gehuwd. Sommigen hadden hun vrouwen achtergelaten in de herkomststreek. Bij de vrouwen was het aantal ongehuwden groter. Van de vrouwen was in de periode van 1849 tot 1879 een op de acht à tien gehuwd toen ze naar Utrecht kwamen. Slechts in enkele gevallen was hun echtgenoot in de herkomststreek achtergebleven. Of immigranten reeds getrouwd waren op het moment van hun komst, was sterk beroepsgebonden. Dienstbodes waren nooit gehuwd, winkelpersoneel evenmin. Winkeleigenaren waren vaak wel gehuwd, stukadoors en vijlenkappers merendeels niet. De Westerwalder potverkopers waren gedeeltelijk wel en gedeeltelijk niet gehuwd.

Het is niet eenvoudig om vast te stellen hoeveel van de Duitse immigranten, die betrokken waren bij een Duits-Duits huwelijk, reeds in Duitsland waren getrouwd, maar in het grootste deel van de gevallen moeten we hiermee wel rekening houden. Bij 38 huwelijken werd het oudste kind in Duitsland geboren, zodat verondersteld kan worden dat het huwelijk voor de migratie had plaatsgevonden. Van 91 huwelijken van Duitse immigranten werd in Utrecht een huwelijksakte gevonden, zodat zeker is dat dat huwelijk in Utrecht werd gesloten. Van deze huwelijken hebben er vijf betrekking op een Duits-Duits huwelijk; de overige 86 huwelijken zijn gemengd. Van de huwelijken die niet in Utrecht werden gesloten en waarbij het oudste kind niet in Duitsland werd geboren, is onduidelijk of ze in Nederland, of in Duitsland zijn gesloten. Veel van deze huwelijken zullen toch wel in Duitsland voltrokken zijn. Immigranten die in Utrecht woonden, konden eenvoudig naar Duitsland terugkeren om daar te trouwen. ${ }^{6}$

Gemengde huwelijken worden hier gebruikt als maatstaf voor integratie en worden gezien als het resultaat van en een stimulans voor integratie. Historisch gezien is aan het begrip gemengd huwelijk niet steeds dezelfde betekenis toegekend. ${ }^{8}$ De term kan betrekking hebben op een huwelijk waarbij de partners verschillen wat betreft religie, fysiek voorkomen, etniciteit of nationaliteit. Huwelijken waarbij een verschil bestaat in leeftijd, lokale herkomst, opleiding en sociale klasse, vallen gewoonlijk buiten de definitie.

In het algemeen geldt dat, wanneer veel jonge alleenstaanden permanent migreren, de kans op gemengde huwelijken groter is, dan wanneer veel van de immigranten reeds getrouwd zijn en in familieverband migreren, of hun partner in de herkomststreek achterlaten. In plaatsen met een hoog percentage ongehuwde immigranten, zo luidt mijn veronderstelling, kan een sneller verloop van de integratie worden verwacht dan in plaatsen waarin dit percentage lager ligt. Wanneer een groot deel van de migranten reeds gehuwd is, is het verloop van de integratie langzamer. Pas de tweede generatie maakt dan immers kans op het sluiten van een gemengd huwelijk.

Endogamie, het trouwen binnen de eigen groep, werd beïnvloed door de mate waarin binnen een groep genoeg mannelijke en vrouwelijke huwelijkskandidaten beschikbaar waren. ${ }^{9}$ Bij wat gewoonlijk in demografisch onderzoek een scheve sekseratio 
wordt genoemd, is het aantal vrouwen binnen een populatie ongelijk aan het aantal mannen. Wanneer binnen een immigrantengroep het aantal vrouwen aanzienlijk kleiner is dan het aantal mannen, dan kunnen wel alle vrouwen, maar niet alle mannen binnen de eigen groep huwen. Dit verschijnsel wordt de marriage-squeeze genoemd. ${ }^{10}$ Cruciaal is dat, wanneer er inderdaad sprake is van een relatie tussen endogamie en groepsvorming, verloop en tempo van integratie voor mannen en vrouwen binnen eenzelfde immigrantenpopulatie ongelijk kunnen zijn. Bij de binnen de 'eigen' groep gehuwde vrouwen, zou de integratie anders en langzamer kunnen verlopen dan bij mannen uit dezelfde immigrantengroep die buiten de groep trouwen. Wanneer het tempo van de integratie voor mannen en vrouwen binnen eenzelfde groep niet gelijk is, kan de vraag gesteld worden hoe het integratieproces voor de groep als geheel moet worden geduid.

Naast de sekseratio binnen de groep immigranten is ook die binnen de bevolking als geheel van invloed op de mate van endogamie. Endogamie wordt voorts beïnvloed door de homogeniteit van een groep immigranten in sociaal opzicht. ${ }^{11}$ Een weinig homogene groep zal een grotere exogamie kennen.

\section{Duits-Duitse huwelijken}

Van de Duitse immigranten in Utrecht, die trouwden, waren er 622 met een nietDuitse partner getrouwd (64 procent) en 353 met een Duitse partner ( 36 procent) (zie figuur 6.1).

Het huwelijksgedrag was voor mannen en vrouwen niet geheel gelijk. Er trouwden minder Duitse mannen dan Duitse vrouwen. Duitse vrouwen trouwden iets vaker binnen de eigen groep dan Duitse mannen. Het verschil tussen mannen en vrouwen is niet

Tabel 6.1 Huwelijken van Duitsers in Utrecht 1849-1879.

\begin{tabular}{lrr}
\hline & $1850-1859$ & $1860-1879$ \\
\hline Duitse mannen met Duitse vrouw & $67(21 \%)$ & $108(45 \%)$ \\
Duitse mannen met een niet-Duitse vrouw & $250(79 \%)$ & $133(55 \%)$ \\
& 317 & 241 \\
Duitse vrouwen met een Duitse man & $67(30 \%)$ & $111(57 \%)$ \\
Duitse vrouwen met een niet-Duitse man & $155(70 \%)$ & $84(43 \%)$ \\
& 222 & 195 \\
\hline
\end{tabular}

Bron bestand Duitsers in Utrecht.

Toelichting Het aantal Duitse vrouwen dat in de periode 1860-1879 trouwde met een Duitse man is niet gelijk aan het aantal Duitse mannen dat in die zelfde periode trouwde met een Duitse vrouw, omdat drie vrouwen trouwden met een Duitse weduwnaar, die daarvoor ook reeds met een Duitse vrouw was gehuwd. 
bijzonder groot. Opvallend is wel dat het huwelijksgedrag overeenkomt met dat van Duitse vrouwen in de Verenigde Staten. ${ }^{12}$ Duitse vrouwen daar trouwden ook vaker dan mannen binnen de eigen groep. In de Verenigde Staten was de sekseratio veel schever dan in Utrecht (veel meer mannen dan vrouwen). Ondanks de minder scheve sekseratio in Utrecht, was de endogamie onder vrouwen groter dan die onder mannen.

Verder valt in tabel 6.1 het verschil tussen beide tijdvakken op. Van de immigranten die er reeds waren of kwamen tussen 1850 en 1859, was het grootste deel betrokken bij een gemengd huwelijk. Bij de immigranten die naar Utrecht kwamen in de periode 1860-1879 was het merendeel getrouwd binnen de eigen Duitse groep. Het aantal huwelijken binnen de tweede groep was kleiner dan dat binnen de eerste groep. Er bestaat een verband met andere verschillen tussen beide groepen: de leden van de tweede groep waren gemiddeld jonger en korter in Utrecht. Zij hadden dus nog weinig tijd en kans gehad om een huwelijkspartner buiten de eigen groep te vinden.

Tussen enkele grotere groepen met een gedeelde regionale herkomst bestonden verschillen wat betreft het huwelijksgedrag. Van de immigranten uit het Westerwald in Nassau trouwde een kwart, van de winkeliers en hun personeel 17 procent en van de dienstbodes slechts 6 procent. Van de winkeliers en hun personeel trouwde 68 procent met een niet-Duitse partner. Van de Duitse dienstbodes, die een lage huwelijksfrequentie hadden, trouwde niemand met een Duitse partner. De Amerikaanse historica

Figuur 6.1 Percentage Duits-Duitse huwelijken.

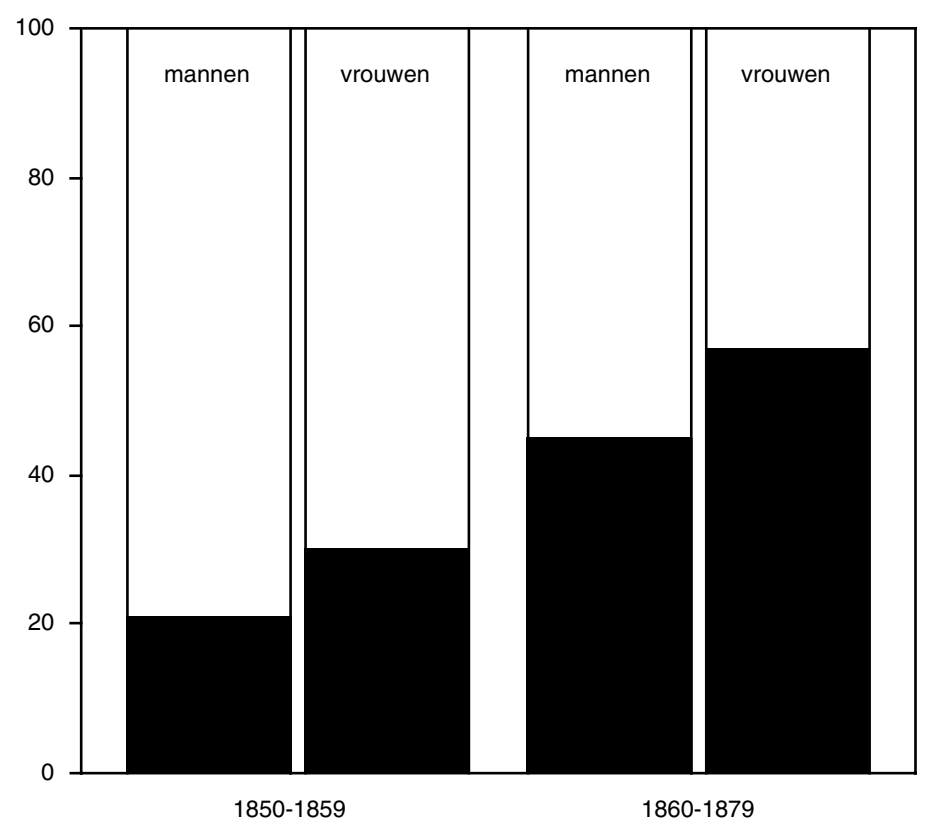

Bron Bestand Duitsers in Utrecht. 
Lauren Ann Kattner heeft vastgesteld dat sommige Duitse immigranten niet alleen trouwden met andere Duitsers, maar vooral ook met andere Duitse immigranten uit dezelfde herkomststreek. ${ }^{13}$ De 'Nassauers' in Texas kenden een grotere regionale endogamie dan andere Duitse immigranten. ${ }^{14}$ Hierin stemmen ze overeen met de Westerwalders uit Nassau in Utrecht. Van de 'Utrechtse' Westerwalders trouwde 85 procent met een andere Westerwalder. Bij deze groep was de endogamie het grootst van alle Duitsers.

Van de Duitse immigranten trouwde 2 procent met iemand die geboren was in Utrecht en 37 procent trouwde met een partner die elders in Nederland was geboren. Opvallend zijn de huwelijken - 21 procent - met mensen die noch in Nederland, noch in Duitsland waren geboren: Frankrijk, Nederlands-Indië, België, Italië, Luxemburg, Denemarken en Oostenrijk. Huwelijken tussen Belgen en Duitsers kwamen het meest voor. Omdat Belgen naar omvang de tweede groep immigranten in Utrecht vormden, is dit niet onverwacht. Migranten uit andere landen waren er slechts in zeer beperkte aantallen en de kans op een huwelijk was bijgevolg gering. Dat er desondanks tussen migranten uit verschillende landen werd getrouwd, is daarmee des te opvallender. Wanneer Duitse migranten buiten de eigen groep trouwden, trouwden ze met anderebinnenlandse of buitenlandse - migranten.

Wanneer migranten samenwoonden in bepaalde buurten of samenwerkten in beroepen, was de kans groot dat ze ook een huwelijkspartner binnen die kring vonden. De Duitse immigranten woonden, zoals gezegd, niet geconcentreerd in één buurt, met uitzondering van de Westerwalders en de Münsterlandse winkeliers en hun personeel. Deze twee groepen kenden dan ook de grootste endogamie. Deze endogamie werd echter niet alleen bevorderd door veelvuldige contacten. Onderlinge huwelijken konden ook worden gebruikt als strategie om het groepsgebonden monopolie te behouden. ${ }^{15}$ Dit verband tussen nichevorming en endogamie werd versterkt wanneer de niches mogelijkheden boden aan zowel mannen als vrouwen, zoals vooral bij de Westerwalders het geval was. ${ }^{16}$ Endogamie was bij de Westerwalders gedurende de gehele negentiende eeuw regel, tot hun niche aan het einde van die eeuw verviel.

Onder de Duitse migranten waren, zoals eerder bleek, ongeveer evenveel mannen als vrouwen. Van een marriage squeeze was in Utrecht geen sprake. Naast de sekseratio binnen de groep migranten, is ook die binnen de bevolking als geheel van invloed op de mate van endogamie. ${ }^{17}$ In Amsterdam waren er aan het begin van de negentiende eeuw in de bevolking als geheel aanzienlijk meer vrouwen dan mannen: 123 vrouwen voor elke 100 mannen. Volgens de historicus Herman Diederiks werd dit veroorzaakt door het grote aantal dienstbodes dat in de stad werkte, in totaal zo'n twaalf- tot dertienduizend. ${ }^{18}$ Deze scheve sekseratio binnen de bevolking als geheel verklaart, volgens Diederiks, de door hem vastgestelde geringere huwelijkskansen van Duitse immigrantes. Omdat er in de stad als geheel meer vrouwen waren dan mannen, gaven zowel Duitse als Nederlandse mannen de voorkeur aan een Nederlandse boven een Duitse vrouw. De scheve sekseratio stelde mannen in staat hun voorkeur te realiseren. In Utrecht was geen sprake van een scheve sekseratio in de bevolking als geheel. Aan het begin van de 
negentiende eeuw waren er in Utrecht, in de leeftijdsgroep van 15 tot 45 jaar, iets meer vrouwen dan mannen. ${ }^{19}$ In de tweede helft van de negentiende eeuw waren de aantallen echter vrijwel gelijk.

Huwelijksgedrag wordt beïnvloed door wetgeving. De vrouw volgde haar man waar het ging om de nationaliteit. Bij een huwelijk tussen een Nederlandse man en een Duitse vrouw, verloor de vrouw haar oorspronkelijke nationaliteit en verwierf ze de nationaliteit van haar man. Trouwde een Duitse man met een Nederlandse vrouw, dan werd zij Duitse. Bij overlijden van haar Nederlandse man of beëindiging van het huwelijk door scheiding, kon een vrouw haar oorspronkelijke nationaliteit terugkrijgen, mits ze daarom verzocht. Duitse vrouwen zouden in principe een huwelijk met een Nederlandse man kunnen nastreven, om zo de Nederlandse nationaliteit te verwerven. Een Nederlandse nationaliteit bood echter slechts geringe voordelen. Het belangrijkste was dat een vreemde vrouw, die met een Nederlandse man was getrouwd, niet onder de Vreemdelingenwet viel. Hetzelfde gold voor een vreemde man die met een Nederlandse vrouw was getrouwd en met haar kinderen had, die in Nederland waren geboren. Bij armenzorg en bij het betalen van patentbelasting bood een Nederlandse nationaliteit, zoals we zagen, ook enige voordelen.

Bij het huwelijk van bordeelhoudster Maria Mörs, speelde mogelijk nationaliteit een rol. Mörs trouwde in 1876 met Jean Rijsselberge. Hij werd geboren in Den Bosch en woonde in Parijs. Zijn ouders woonden in Utrecht. Jean Rijsselberge werd na zijn huwelijk in het Utrechtse bevolkingsregister ingeschreven. Volgens die inschrijving was hij geboren in 1859. Bij zijn huwelijk zou hij dan 17 jaar zijn geweest. Maria Mörs was 54. Volgens de huwelijksakte was Rijsselberge 21 jaar. Omdat hij in beide gevallen minderjarig was, moesten zijn ouders toestemming geven voor het huwelijk. In 1879, drie jaar na het huwelijk, vertrok hij naar Rotterdam. Op 15 juni 1880 werd het huwelijk door echtscheiding ontbonden. Mörs verwierf bij haar huwelijk de Nederlandse nationaliteit. Indien zij na haar echtscheiding niet binnen een jaar haar Duitse nationaliteit terugvroeg, behield zij de Nederlandse nationaliteit en viel zij niet onder de Vreemdelingenwet. Mörs maakte na haar scheiding enkele reizen naar Duitsland, waar zij nieuw personeel wierf voor haar bordeel. Een Nederlandse nationaliteit was voor haar op dat moment belangrijk, omdat ze waarschijnlijk, en gezien haar beroep niet onterecht, vreesde na een reis naar Duitsland niet opnieuw te worden toegelaten.

De houding ten aanzien van religieus gemengde huwelijken onder immigranten zal beïnvloed zijn geweest door ideeën daaromtrent in het land van herkomst. De zogenaamde Keulse Kwestie, die speelde van 1836 tot 1840, heeft daarop invloed gehad. In 1825 werd in Pruisen een Koninklijk Besluit uitgevaardigd dat kinderen die binnen een gemengd huwelijk werden geboren, opgevoed moesten worden in het geloof van hun vader. Dit besluit leidde tot problemen, toen in 1836 Clemens August Droste als nieuwe aartsbisschop van Keulen aantrad. Droste hield vast aan het canonieke recht, dat bepaalde dat een huwelijk slechts kerkelijk kon worden ingezegend, wanneer de echtelieden verklaarden hun kinderen katholiek op te voeden. Vanwege zijn verzet tegen het Koninklijk Besluit kreeg Droste van de Pruisische overheid opdracht zijn werk neer te 
leggen en zijn bisdom te verlaten. Toen hij weigerde, werd hij gearresteerd en opgesloten. Omdat er geen aanklacht was, verscheen hij niet voor een rechter en werd er geen uitspraak gedaan over de duur van zijn gevangenschap. ${ }^{20}$ De Keulse Kwestie kreeg in de Nederlandse bladen veel aandacht. ${ }^{21}$ De kwestie verscherpte in Pruisen de tegenstellingen tussen katholieken en protestanten. In $1840 \mathrm{kwam}$ aan de kwestie een einde met de troonsbestijging van Friedrich Wilhelm I. Het к в verviel en de Pruisische staat bemoeide zich niet langer met gemengde huwelijken. In 1874 werd in Pruisen het burgerlijk huwelijk verplicht gesteld. Tot die tijd was het alleen mogelijk geweest om voor de kerk te trouwen. De kerk kon daarbij voorwaarden stellen, bijvoorbeeld ten aanzien van de opvoeding van kinderen die werden geboren uit een gemengd huwelijk. Na 1874 verloren de kerken hun monopolie op huwelijksvoltrekking. ${ }^{22} \mathrm{Na} 1876$ ging de 'obligatorische Zivilehe' voor het hele Rijk gelden. ${ }^{23}$

De Nederlandse katholieke geestelijkheid stelde ook voorwaarden ten aanzien van de opvoeding van kinderen, die werden geboren uit een gemengd huwelijk. Vooral bij verzoeken om onderstand kon aan die voorwaarde worden vastgehouden. Wel was het in Nederland al sedert 1811 mogelijk om alleen een burgerlijk huwelijk te sluiten.

Behalve de kerkelijke overheid, was er ook de wereldlijke overheid, die beperkingen oplegde ten aanzien van het huwelijk. Met uitzondering van Pruisen en Saksen golden er voor alle Duitse staten beperkingen op huwelijkssluiting wanneer het ging om huwelijken tussen potentieel armlastigen. Ondanks de Duitse eenwording bleven de beperkingen plaatselijk gelden tot na $1900 .{ }^{24}$

\section{'Aufgebot'}

'Aufgebot' liet Izak Frenkel in 1892 boven een in de Duits gesteld advertentie in het Utrechtsch Provinciaal en Stedelijk Dagblad zetten, waarin hij aankondigde dat hij ging trouwen met Emma Seligberger. Izak Frenkel woonde met zijn ouders in Utrecht, zijn bruid en haar ouders woonden in Würzburg. De advertentie verscheen gelijktijdig in de Utrechtse krant en in een tegenhanger in Würzburg. ${ }^{25}$ De partnerkeuze van de joodse Frenkel paste bij die van zijn geloofsgenoten in Utrecht. Duitse joden in Utrecht trouwden vrijwel allemaal binnen de joodse groep, maar ze trouwden lang niet allemaal met een Duitse partner. Religieuze endogamie was in dit geval belangrijker dan regionale. Dit was niet voor alle geloofsgroepen het geval.

Van de 381 mensen die buiten de Duitse groep huwden, trouwden in totaal 70 mensen buiten het eigen geloof en $241 \mathrm{er}$ binnen (zie tabel 6.2 en figuur 6.2). Er was dus sprake van religieuze endogamie. Van de katholieke Duitsers trouwden 154 mensen buiten de Duitse immigrantenpopulatie. Daarvan trouwde 80 procent binnen de eigen geloofsgroep. De katholieke Westerwalders huwden veelvuldig met in Utrecht geboren Westerwalders van de zogenaamde tweede of derde generatie. Van de lutheranen trouwde 30 procent binnen de eigen geloofsgroep, voor de hervormden was dat 59 procent en voor de joden 90 procent. De Duitse lutheranen kenden de minste religieuze 
endogamie. Dit is ook vastgesteld voor Amsterdam in de negentiende eeuw en voor Utrecht in eerdere eeuwen. ${ }^{26}$ Katholieken en joden kende een grote religieuze endogamie. Bij katholieken houdt deze endogamie gedeeltelijk verband met het aantal katholieken in Utrecht. Omdat zij een grote groep vormden, was de kans op een huwelijk

Tabel 6.2 Religieuze endogamie bij Duitse immigranten die buiten de Duitse immigrantenpopulatie trouwden in absolute aantallen.

\begin{tabular}{|c|c|c|c|c|c|c|}
\hline & katholiek & calvinist & luthers & joods & totaal & $\%$ binnen eigen geloof \\
\hline katholiek & 123 & 22 & 8 & 1 & 154 & $80 \%$ \\
\hline calvinist & & 87 & 39 & 0 & 148 & $59 \%$ \\
\hline luthers & & & 21 & 1 & 68 & $31 \%$ \\
\hline joods & & & & 10 & 11 & $90 \%$ \\
\hline totaal & & & & & 381 & $63 \%$ \\
\hline
\end{tabular}

Bron Bestand Duitse immigranten 1849-1879.

Buiten de tabel zijn gehouden negen huwelijken met remonstranten, hersteld luthers, doopsgezind, waals en oud-katholiek en drie huwelijken waarbij het geloof van een van beide partners niet vermeld was.

Duitse calvinisten worden in de bronnen soms vermeld als reformiert. Ze zijn gelijkgesteld met Nederlands Hervormden en in de tabel aangeduid als calvinisten.

Figuur 6.2 Religieuze endogamie als percentage.

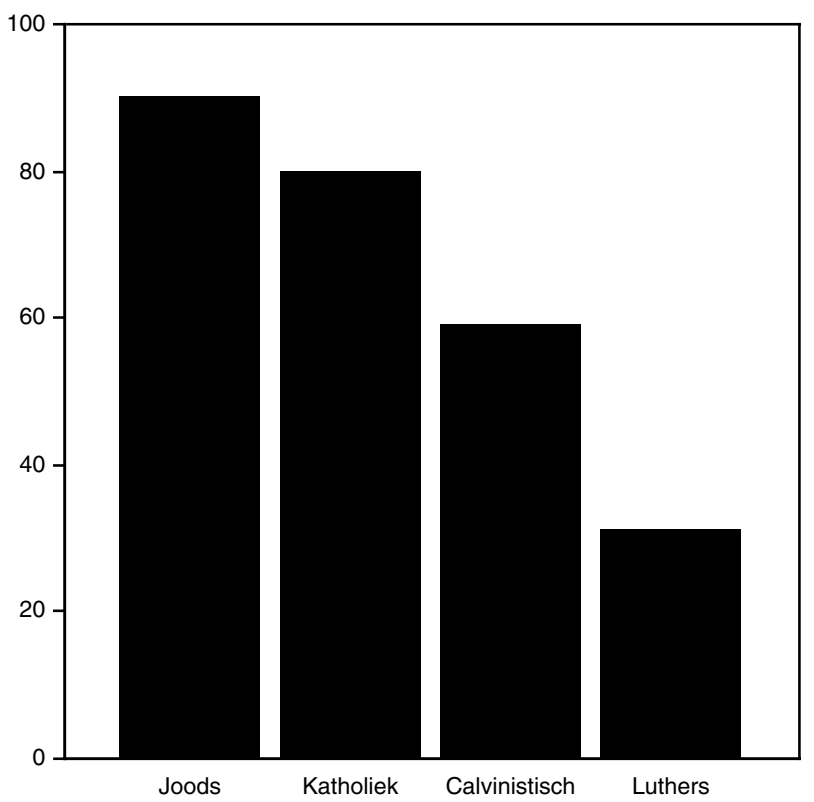

Bron Bestand Duitsers in Utrecht. 
binnen deze geloofsgroep groter. Bij de joodse immigranten speelde mee dat de kloof tussen hen en niet-joden groter was dan tussen de verschillende groepen christenen, en een huwelijk dus minder waarschijnlijk (zie figuur 6.3).

Lutherse Duitse immigranten, die buiten de eigen geloofsgroep trouwden, traden in het huwelijk met zowel calvinisten als met katholieken.

Als laatste kan bij de religieus gemengde huwelijken een opmerking worden gemaakt over het geloof van de kinderen. Kinderen werden gewoonlijk in het bevolkingsregister ingeschreven met het geloof van een van beide ouders. Dit was net zo vaak het geloof van de moeder als dat van de vader. Op dit punt springen alleen de gemengd gehuwde lutheranen eruit. Bij hen bestond in de negentiende eeuw een opvallende gewoonte; zij lieten hun kinderen afwisselend als bijvoorbeeld luthers en hervormd registreren, of ze kozen voor een patroon waarbij alle meisjes als luthers werden genoteerd en alle jongens als hervormd. We zien dit patroon bij de familie Halbisch. Jacob Halbisch, een luthers werkman uit Württemberg, was getrouwd met de hervormde Johanna Rennert uit Utrecht. Hun zonen Wilhelmus en Johannes werden ingeschreven

Figuur 6.3 Religieus gemengde huwelijken.

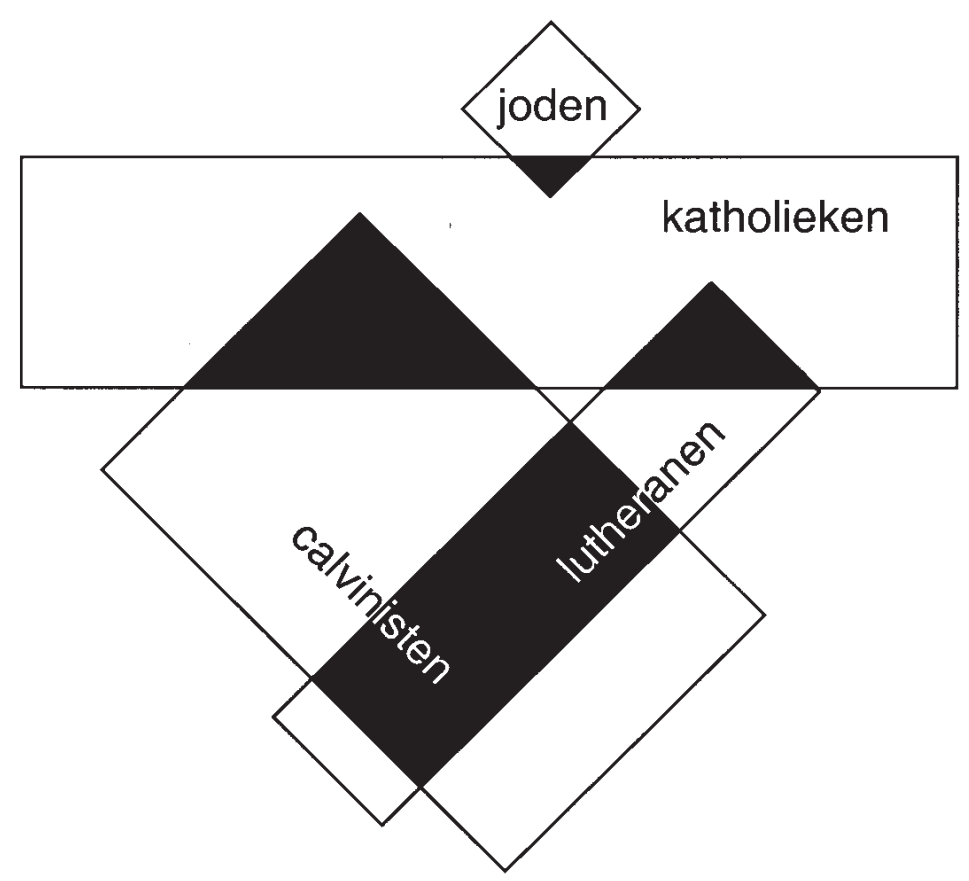

Bron Bestand Duitsers in Utrecht.

Toelichting Het oppervlak van de vlakken komt overeen met het aandeel binnen de Duitse immigrantenpopulatie. 
in het bevolkingsregister als luthers, hun dochter Johanna en Wilhelmina als hervormd. ${ }^{27}$

\section{Eerste huwelijken en huwelijksleeftijd}

Hermina Schütter werd in 1838 geboren in Neuenhaus in Hannover en was protestants. ${ }^{28}$ In 1870 kwam ze op 32-jarige leeftijd naar Utrecht uit Vuren, samen met mevrouw Julia van Hall-Viruly, voor wie ze in Utrecht zou werken. Ze bleef vijf jaar als dienstbode bij de deftige familie Van Hall op de Stationsstraat. Toen trouwde ze met de tien jaar oudere, protestantse, Nederlandse weduwnaar Jacobus Smits. ${ }^{29}$ Hij had uit zijn eerste huwelijk drie kinderen die tussen de 23 en 13 jaar oud waren. Zijn eerste vrouw was een half jaar eerder overleden. Smits was conducteur bij het spoor. Hermina Schütter en Jacobus Smits kregen nog twee kinderen, die zij samen met het in dezelfde tijd geboren buitenechtelijke zoontje van Jacobus Smits' oudste dochter opvoedden. Duitse dienstbodes trouwden over het algemeen weinig en als ze trouwden, was het vaak met een weduwnaar en was er sprake van een groot leeftijdsverschil tussen de echtelieden. Dit beeld ging echter niet op voor de Duitse migrantenpopulatie in het algemeen.

In het midden van de negentiende eeuw werd 75 tot 80 procent van de huwelijken in Nederland gesloten tussen een man en een vrouw die niet eerder getrouwd waren geweest. In de loop van de negentiende eeuw nam dit toe tot 90 procent. ${ }^{30}$ In Utrecht was het algemene beeld niet anders. In 13 procent van de gevallen was het huwelijk geen eerste, maar een tweede of derde huwelijk. ${ }^{31}$ De Duitse immigranten verschilden op dit punt niet van de Utrechtse of Nederlandse bevolking. Van de 425 huwelijken waren er 55 geen eerste huwelijk (dertien procent).

De gemiddelde huwelijksleeftijd van de Duitse immigranten lag wel boven die van de Utrechtse bevolking. ${ }^{32}$ Bij de Duitse immigranten ontbreken vooral de lagere leeftijden. Bij een gedeelte van de immigranten, van wie we de huwelijksleeftijd niet weten omdat de huwelijksdatum onbekend is, zal het gaan om mensen die reeds in Duitsland en op jonge leeftijd zijn getrouwd. Het ontbreken van dit gegeven duwt de gemiddelde huwelijksleeftijd omhoog. ${ }^{33}$ Terwijl de laagste leeftijden ontbreken, kwamen onder de Duitse immigranten huwelijken op relatief hoge leeftijd opvallend vaker voor. Zo waren er bijvoorbeeld de zussen Euphemia en Antonetta Buhrs, die een winkel dreven op de Twijnstraat in Utrecht. De zussen trouwden op dezelfde dag. Euphemia (48) trad in het huwelijk met de 59-jarige Nederlandse schilder-glazenmaker en reeds tweevoudig weduwnaar Johannes de Bruijn (59). Antonetta (51) trouwde met de Duitse koopman Bernard Segbers (43). De zussen waren met hun relatief hoge huwelijksleeftijd geen uitzondering. $^{34}$

De hogere huwelijksleeftijd van migranten, zou opgevat kunnen worden als een indicatie voor het ontbreken van sociale netwerken, die het vinden van een huwelijkspartner zouden moeten bevorderen. Er zijn echter ook twee alternatieve verklaringen. 
Ten eerste houdt een relatief hoge huwelijksleeftijd verband met de leeftijdsopbouw van de migrantenpopulatie. De wat oudere migranten waren onder hen, zoals we zagen, sterker vertegenwoordigd. De beroepsstructuur speelt eveneens een rol. Bij eerder onderzoek werd vastgesteld, dat in het midden van de negentiende eeuw in Utrecht de huwelijksleeftijd van kooplieden gemiddeld hoger lag dan die van andere sociale groepen. ${ }^{35}$ Het grote aandeel van handelaren en kooplieden onder de Duitse immigranten, kan de hogere huwelijksleeftijd mede verklaren.

\section{Scheiding en verlating}

Johann Rosenbaum werd geboren in Keulen in 1812 en kwam in 1870 uit Pruisen naar Utrecht. De eerste twee keer dat hij kwam - in juni 1870 en mei 1872 - werd hij in het bevolkingsregister ingeschreven als 'Israëliet', daarna als katholiek. Van beroep was hij muzikant en koopman. Rosenbaum woonde in kosthuizen op meerdere adressen in het armoedige deel van wijk C. Tussendoor woonde hij ook op andere adressen in de stad. Hij verhuisde vaak: zeven keer in twee jaar. In 1874 trouwde hij met de Utrechtse, protestantse koopvrouw Maria Haagen. ${ }^{36} \mathrm{Zij}$ was bij het huwelijk 31, hij 62. Maria Haagen was een natuurlijke dochter van de uitdraagster-koopvrouw Martiena Haagen. ${ }^{37}$ Johann Rosenbaum was vier jaar ouder dan zijn schoonmoeder. Maria Haagen had reeds twee kinderen, die bij het huwelijk werden geëcht. Er kwamen nog vier kinderen bij. Rosenbaum was 71 bij de geboorte van zijn laatste kind. In 1887 vertrok hij zonder zijn vrouw, schoonmoeder en kinderen naar Arnhem, waarna zijn vrouw in het bevolkingsregister wordt vermeld als verlaten vrouw.

Het huwelijk van Johann Rosenbaum en Maria Haagen lijkt voorbestemd voor een slecht einde. Het grote leeftijdsverschil tussen de echtelieden en Maria's onduidelijke relaties voor het huwelijk, dreigen de afloop te voorspellen. Het huwelijk was uitzonderlijk. In de literatuur omtrent gemengde huwelijken, is het echter niet ongebruikelijk dat er een verband wordt gelegd tussen gemengde huwelijken en scheidingen. ${ }^{38}$ De veronderstelling is, dat gemengde huwelijken een grotere kans lopen om in een scheiding te eindigen dan niet-gemengde huwelijken.

Om de vraag te kunnen beantwoorden of scheidingen bij de gemengd gehuwde Duitsers vaak voorkwamen, moeten we weten welk scheidingspercentage in de tweede helft van de negentiende eeuw gebruikelijk was. Officiële scheidingen kwamen in de negentiende eeuw weinig voor. ${ }^{39}$ Scheiding was vooral een stedelijk verschijnsel, maar tussen de grote steden waren belangrijke verschillen. Het scheidingspercentage lag in Amsterdam, Rotterdam en Den Haag veel hoger dan in Utrecht. Terwijl in deze drie steden gezamenlijk tussen 1848 en 18811312 scheidingen werden geregistreerd, lag dit cijfer in Utrecht op $29 .^{40}$

Wanneer een getrouwde vrouw door haar man was verlaten, werd dit in het bevolkingsregister aangetekend. Bij gehuwde mannen die hun vrouw hadden verlaten, werd 
geen vergelijkbare vermelding opgenomen. Verlatingen kwamen meer voor dan officiele scheidingen.

Bij de autochtone Utrechtse bevolking eindigde minder dan een procent van de huwelijken in een scheiding. ${ }^{41}$ Bij de huwelijken van gemengd gehuwde Duitse immigranten in Utrecht lag het percentage hoger. Vijf huwelijken eindigden in een scheiding (twee procent) en dertien in een verlating (vijf procent) ${ }^{42}$ Scheiding en verlating kwamen onder gemengd gehuwde Duitse immigranten meer voor dan onder de Utrechtse bevolking in het algemeen.

\section{Buitenechtelijke geboorten}

De scharenslijper Joseph Waldorf werd in 1824 geboren in Düsseldorf. In 1853 werd hij ontslagen uit de gevangenis in Hoorn. In Utrecht trok hij in bij de familie DucaatZevenboom; een gezin met vier kinderen. De vader was metselaar, de moeder koopvrouw. Eén van de dochters, Stina - geboren 1827 in Amersfoort - had reeds drie onechte kinderen, die werden geboren tussen 1849 en 1855. Stina Ducaat was koopvrouw en ventte met garen, band en galanterieën. Johan Waldorf en Stina Ducaat, beiden protestants, vormden samen een huishouden, maar trouwden niet. In 1860 woonden zij met de kinderen in het Poortje Nooit Gedacht in wijk C. Hier werd in 1862 een zoon geboren en 1866 een dochter. Deze twee kinderen overleden kort na hun geboorte. In 1862 trouwden Ducaat en Waldorf en werden de nog levende kinderen, waarvan de oudste inmiddels dertien jaar was, gewettigd.

Stina Ducaat kreeg vijf buitenechtelijke kinderen. Waldorf was waarschijnlijk de vader van de twee jongsten, maar van de drie ouderen zeker niet. Vijf buitenechtelijke kinderen was volgens negentiende-eeuwse normen uitzonderlijk veel. De Westerwalder koopvrouw Catharina Klauer kreeg vier buitenechtelijke kinderen - in 1855, 1857, 1860 en 1863 - voordat ze in 1863 trouwde met de Utrechtse werkman en weduwnaar Nicolaas Bergsteijn. ${ }^{43}$ Catharina Klauer was zelf een zogenaamde natuurlijke dochter van de koopvrouw Anna Eva Klauer.

Opmerkelijk was ook het leven van Anna Catharina Rulfs, die in 1810 werd geboren in Bremen. Zij woonde in 1849 bij haar oom en tante aan de Oudegracht. Haar oom, Johan Momberg, geboren in Wildingen in 1781, was een gepensioneerd legerkapitein. In november 1849 beviel Anna Catharina Rulfs in het huis van een politieagent aan de Biltstraat van haar dochter Anna Karolina. Ze erkende het kind niet. Dat deed ze pas bijna tien jaar later, in 1858, kort na de dood van haar tante. Weer enkele jaren later, bleek wie de vader van het kind was; haar oom Johan Momberg. In 1862 verwierf dochter Anna Karolina het recht om haar ooms naam Momberg aan de hare toe te voegen. ${ }^{44}$

Als laatste voorbeeld kan Marianne Welters worden genoemd. ${ }^{45}$ Ze werd in 1819 in Kleef geboren. In Utrecht woonde ze aanvankelijk in een slaapstee in wijk C. In 1840 beviel ze in Utrecht, op 21-jarige leeftijd, buitenechtelijk van haar dochter Johanna. In 1843 volgde Geertruida en in 1845 Carel. In 1847 trouwde ze met de muzikant Carel 
Muijs. Carel Muijs was geboren in Deventer en woonde steeds enkele huizen van haar vandaan. Bij de geboorte van Marianne Welters' eerste kind was hij 15 jaar. Hoewel de voorkinderen bij het huwelijk niet werden erkend, bleven ze wel hij het echtpaar wonen. Het gezin kreeg nog zes kinderen en vertrok in 1870 naar Hilversum.

De levens van deze Duitse immigranten waren opmerkelijk, maar de vraag is of ze ook uitzonderlijk waren voor de Duitse immigranten, of voor de Utrechtse bevolking in het algemeen. In de negentiende eeuw was het niet ongebruikelijk dat er een kind net voor of na een huwelijk werd geboren. ${ }^{46}$ Bij de autochtone Utrechtse bevolking was bij negen procent van de huwelijken sprake van erkenning van een kind of meer. ${ }^{47}$ Bij veruit het grootste deel van de huwelijken ging het slechts om één kind. Dat betekent niet dat er ook slechts één kind voor het huwelijk werd geboren. Er kunnen meer kinderen zijn geboren, die op het moment van het huwelijk reeds waren overleden of die bij het huwelijk niet werden erkend. Een vergelijking tussen de gegevens uit geboorte- en huwelijksakten leert, dat niet alle voorechtelijk geboren kinderen, die nog leefden, bij het huwelijk werden erkend. Zo kreeg de Utrechtse Maria Ras een kind een jaar voor haar huwelijk met Lambert de Bruin. Ofschoon dit kind bij het huwelijk nog leefde, werd het niet erkend. ${ }^{48}$

Terwijl één buitenechtelijk geboren kind niet ongewoon was in de negentiende eeuw, gold dat niet voor meerdere buitenechtelijke kinderen. Vrouwen met meerdere voorechtelijke kinderen behoorden tot de groep (clandestiene) prostituees, of maakten deel uit van zeer geïsoleerde, mogelijk incestueuze groepjes in notoire achterbuurtjes. ${ }^{49}$ Het handjevol mensen dat hierboven is beschreven, behoorde wel tot een dergelijke geisoleerde groep. Voor het merendeel van de Duitse immigranten gold dat echter niet.

\section{Tot besluit}

In het bovenstaande zijn tal van factoren genoemd die endogamie beïnvloeden. In schema 6.1 worden die factoren samengevat. Gemengde huwelijken zijn hier gebruikt als een van de voornaamste indicatoren voor de mate waarin immigranten geïntegreerd zijn in de ontvangende samenleving. Indien we dat als uitgangspunt nemen, blijkt de integratie van Duitse immigranten beperkt te zijn geweest. Wanneer Duitse immigranten buiten hun eigen groep trouwden, trouwden ze met andere - binnenlandse of buitenlandse - migranten en slechts zeer beperkt met mensen die geboren waren in Utrecht.

Binnen de Duitse immigrantenpopulatie als geheel, was geen sprake van een scheve sekseratio. Voor de verschillende deelgroepen binnen de Duitse migrantenpopulatie lag dat anders. De grootste exogamie kenden die migranten die behoorden tot groepen die alleen uit mannen of alleen uit vrouwen bestonden, zoals stukadoors, vijlenkappers en dienstbodes. Winkeliers en Westerwalders, waarbij de sekseratio binnen de groep min of meer gelijk was, kenden een grotere endogamie. Bij de Westerwalders vinden we bovendien het grootste aantal mensen dat reeds gehuwd was voor hun komst naar 
Nederland. Een eventueel gemengd huwelijk was in dat geval pas mogelijk bij de zogenaamde tweede generatie, maar ook bij deze tweede en zelfs bij de derde generatie Westerwalders kwam endogamie vrij veel voor. Nakomelingen van Westerwalders trouwden op grote schaal met kinderen en kleinkinderen van andere Westerwalders.

Exogamie was gerelateerd aan geloof. Lutheranen kenden een grote exogamie, joden en katholieken een geringe. Bij de stukadoors, die merendeels luthers waren, is er een overlap tussen beroepsgebonden en religieuze exogamie. Voor de eveneens lutherse vijlenkappers gold dat minder; zij trouwden niet met Duitse vrouwen, maar wel overwegend met lutherse. Huwelijken binnen de eigen groep hielden voorts verband met concentraties in bewoning. De verspreid wonende dienstbodes kenden de grootste exogamie, de geconcentreerd wonende Westerwalders de grootste endogamie.

Van de gemengde gehuwde Duitsers, eindigden er meer huwelijken in een scheiding dan bij de autochtone Utrechtse bevolking. Ofschoon aan de relatie tussen scheiding en gemengd huwelijk in de literatuur relatief veel aandacht wordt besteed, wordt daar geen uitspraak gedaan over het effect dat een scheiding kan hebben op het integratieproces. $^{50}$ Gaat dit proces ondanks de scheiding door, stopt het of keert het zich juist om? Een antwoord op deze vraag is moeilijk te geven. Het aantal scheidingen onder de Duitse immigranten was weliswaar groter dan onder de Utrechtse bevolking als geheel, maar het aantal was toch nog wel zo laag dat het effect op de totale populatie gering zal zijn geweest.

De Duitse immigranten waren, gemeten naar hun huwelijksgedrag, wel slecht geintegreerd, maar tussen de groepen bestonden grote verschillen. De Duitse migrantenpopulatie vormde immers een weinig homogene groep. Een grote heterogeniteit zou, volgens de theorie, moeten leiden tot een grote exogamie. ${ }^{51}$ Dat er desondanks binnen de Duitse migrantenpopulatie groepen waren met een geringe exogamie, bevestigt het beeld van groepsvorming binnen de migrantenpopulatie.

Schema 6.1 Factoren die endogamie beïnvloeden.

- omvang van de immigrantenpopulatie (hoe kleiner de populatie, hoe groter de exogamie)

- samenstelling immigrantenpopulatie naar huwelijkse staat (hoe meer ongehuwden, hoe groter de exogamie)

- concentratie van immigranten in wijken en beroepen (hoe groter de concentratie, hoe groter de endogamie)

- homogeniteit van de immigrantenpopulatie in sociaal-economische en religieuze zin (hoe groter de homogeniteit, hoe groter de endogamie)

- sekseratio binnen immigrantenpopulatie (hoe schever de sekseratio hoe groter exogamie)

- sekseratio binnen bevolking als geheel (hoe schever de sekseratio, hoe groter de exogamie)

- aard van het migratieproces

- beeldvorming 


\section{7 'Waaraan herken je een Duitser?'}

\section{Organisaties}

'Waaraan herken je een Duitser? Als er twee zijn richten ze een vereniging op, komt er een derde bij dan zijn er twee verenigingen.' Het is een grap die Duitse immigranten in het hedendaagse Argentinië onder elkaar vertellen. ${ }^{1}$ De grap echoot een beschrijving uit 1903 van Duitse immigranten in Londen: 'It has been said with truth that whenever

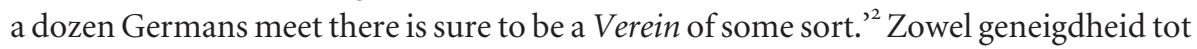
organisatie, als particularisme waren kenmerkend voor Duitse immigrantengemeenschappen. De Duitse nieuwkomers vormden beslist geen eenheid in politiek of sociaal opzicht, maar waren wel - of misschien juist daardoor - de best georganiseerde immigranten. Ze klonterden samen in talloze organisaties. ${ }^{3}$

Deutschtum is de term die in (Engelstalige) studies wordt gebruikt om zowel de sociale infrastructuur te beschrijven van Duitse immigrantengemeenschappen, als die gemeenschappen zelf. Het woord duidt niet alleen op Duitsheid of Duits-zijn, als meer op alles waarin dat Duits-zijn vorm wordt gegeven: taal, kranten, kerken, voedsel en drank, theater en muziek. ${ }^{4}$ Duitse immigranten richtten verenigingen op - en zelfs opmerkelijk veel - maar ze organiseerden zich niet als één Duitse gemeenschap. ${ }^{5}$ Ze organiseerden zich niet als één groep, maar wel afzonderlijk van de Nederlandse, Amerikaanse of Engelse samenleving. McCaffery sprak daarom in zijn boek uit 1996 over Islands of Deutschtum in de Amerikaanse samenleving. ${ }^{6}$ Wilhelm Sahner typeerde het Holland-Deutschtum van voor de Tweede Wereldoorlog tientallen jaren eerder in gelijkluidende termen en sprak van 'Insel- oder Streudeutschtum'?

Het is niet mogelijk om aan te geven hoeveel Duitse immigranten er precies in Utrecht georganiseerd waren en in welke verenigingen, evenmin als het mogelijk is om voor alle genootschappen en verenigingen die Utrecht telde na te gaan of er Duitse leden waren. ${ }^{8}$ Van lang niet alle verenigingen zijn immers de ledenlijsten bewaard gebleven en waar dat wel het geval was, zijn in de administraties niet alle data van in- en uittreden zorgvuldig genoteerd. Het aantal verenigingen was daarenboven zo talrijk, dat zelfs wanneer alle materiaal voorhanden was, het niet doenlijk zou zijn om een dergelijk onderzoek uit te voeren. In de Utrechtsche Provinciale en Stads Almanak worden jaarlijks tientallen gezelschappen genoemd. Het werkelijke aantal was veel groter. Zo vermeldt de Utrechtsche Studentenalmanak voor 1862 alleen al 46 verschillende studentenverenigingen. ${ }^{9}$ Naast de formele verenigingen, die hun weerslag vonden in de bronnen, waren er informele organisaties, die geen sporen in archieven hebben nagelaten. Om antwoord te geven op vragen omtrent de deelname van Duitse immigranten aan organisaties is het echter niet noodzakelijk om van elk gezelschap - hoe efemerisch en 
kleinschalig ook - het ledenbestand te kennen. Gegevens over de grotere en belangrijkere organisaties volstaan en die zijn er gelukkig wel.

Bij de verenigingen kan onderscheid worden gemaakt tussen organisaties die toegankelijk waren voor Duitse immigranten, organisaties die zich Duits noemden of zich als Duits profileerden en organisaties die vooral Duitse leden hadden. Het onderzoek naar de verenigingen was slechts mogelijk met behulp van het bestand van Duitse immigranten dat op basis van de bevolkingsregistergegevens werd samengesteld. De ledenadministraties van verenigingen vermelden immers wel namen en soms aanvullende gegevens zoals adressen, maar nooit nationaliteit of geboorteplaats. Alleen door de combinatie van deze ledenadministraties met het bestand van Duitsers kon worden vastgesteld of organisaties toegankelijk waren voor Duitse immigranten en hoeveel leden er Duits waren.

Als sociaal verkeer een indicator is van collectieve identiteit, dan moet de vraag worden gesteld wanneer een vereniging als Duits kan worden aangemerkt. Zoals zal blijken, veranderde het karakter van organisaties veelvuldig na verloop van tijd. Organisaties konden meer of minder 'Duits' worden onder invloed van ontwikkelingen in zowel de herkomststreek als in Utrecht of Nederland. De vraag naar de deelname van Duitse immigranten aan het sociale verkeer valt uiteen in drie deelvragen: waren algemene verenigingen toegankelijk voor Duitse immigranten? Hoe 'Duits' waren Duitse verenigingen en welke Duitse immigranten vinden we in welke verenigingen?

\section{Het Deutsches Theater}

Op 29 maart 1839 kondigde het 'Deutsches Theater in der Amstelstrasse' te Amsterdam in de krant De Avondbode in het Duits aan dat enkele dagen later de opera 'Othello oder der Mohr von Venedig' zou worden opgevoerd. ${ }^{10}$ Het was de 51ste voorstelling die het zeer actieve Deutsches Theater in Amsterdam dat theaterseizoen gaf. Twee keer per week was er de afgelopen maanden een uitvoering geweest, steeds van een andere opera of een ander muziekstuk. ${ }^{11}$ Bezoekende Duitse zangers en zangeressen werden voor de leidende rollen gevraagd. Ondanks deze grote activiteit ging het toch niet goed met het Deutsches Theater. Een halve week na de opvoering van Othello verscheen er een ingezonden mededeling in De Avondbode - in het Nederlands ditmaal - waarin werd gemeld dat het met de 'Hoogduitsche' schouwburg financieel slecht ging. Het zou jammer zijn als de schouwburg, 'de eenigste van dien aard in geheel Nederland', daardoor zou moeten sluiten, meende de directie. Behalve financiële problemen speelden gebrekkige belangstelling en interne tegenstelling het theater parten. Met het Theatre Français, zo werd geklaagd, ging het een stuk beter. ${ }^{12}$

Utrecht had in 1839 geen Duits theater en zou er later in de negentiende eeuw ook geen krijgen. Een Frans theater was er wel. Ongetwijfeld werd dat theater niet alleen gefrequenteerd door Franse immigranten, die een veel kleinere gemeenschap vormden 
dan de Duitsers, maar eveneens door leden van de Utrechtse elite, die de Franse taal en cultuur hoog aansloegen.

De problemen rond het Deutsches Theater, die in 1839 in Amsterdam speelden, illustreren twee van de factoren die aard en omvang van organisaties van migranten beinvloedden: organisaties moesten een draagvlak hebben om te kunnen blijven bestaan en dat draagvlak werd aangetast door interne verdeeldheid. ${ }^{13}$ De omvang van het draagvlak-zo leert de vergelijking met het Theatre Français - werd mede bepaald door de mogelijkheid om mensen buiten de eigen, in dit geval Duitstalige, groep voor initiatieven te interesseren. Daarnaast waren er andere factoren, die hieronder kort de revue passeren.

Bij een inventarisatie van factoren die de mogelijkheden en beperkingen van eigen organisaties bepaalden, moet een eng lokale opvatting worden vermeden. In de tweede helft van de negentiende eeuw ontstond er de nieuwe mogelijkheid om in de avonduren vanuit Utrecht het Duitse theater in Amsterdam te bezoeken. In januari 1878 liet de Rhijnspoorwegmaatschappij speciale zogenaamde nachttreinen rijden tussen Utrecht en Amsterdam. Daar voorstellingen vroeg begonnen - om 7 uur's avonds - was een reis van en naar Amsterdam in de avonduren goed mogelijk. De trein deed een uur over het traject. 't Is te verwachten', zo werd er geschreven in het Utrechtsch Provinciaal en Stedelijk Dagblad, 'dat velen [...] van deze gelegenheid gebruik maken, om te Amsterdam de aangekondigde voorstellingen bij te kunnen wonen. ${ }^{14} 272$ mensen gingen er die avond van Utrecht naar Amsterdam. Niet allemaal gingen ze echter naar het Duitse theater; er

\section{Grand Théätre van A. van Lier TE AMSTERDAM. - DINSDAG 15 JaNdÁRI 1878, ten 8 ure om ten $101 / 2$ ure te eindigen. \\ Door het DUITSCHE GWELLSCHAP, Eene eerste oproering van}

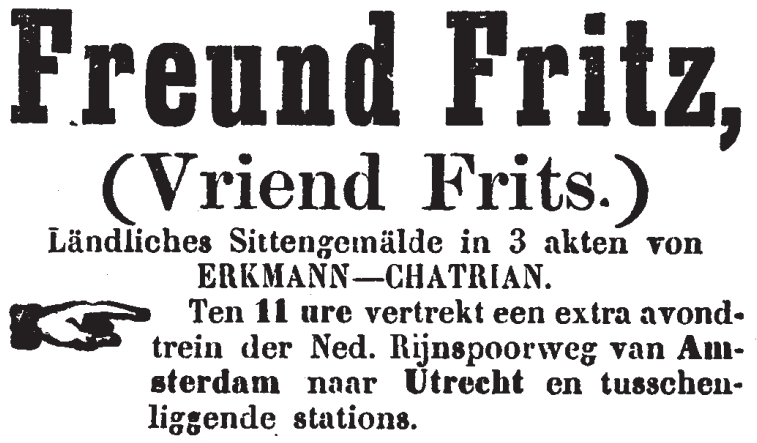


was ook een voorstelling van Circus Carré. Veertien dagen later reed er een speciale avondtrein, zodat mensen uit Utrecht in Amsterdam de voorstelling 'Freund Fritz' konden bezoeken. De voorstelling werd gegeven in het 'Grand Theatre' van A. van Lier, door het 'Duitsch gezelschap'. ${ }^{15}$ (zie advertentie op de vorige pagina)

Het publiek reisde niet alleen naar het vermaak, het vermaak kwam ook naar het publiek. In januari 1875 werd in het Utrechtsch Provinciaal en Stedelijk Dagblad geschreven:

Maandag wacht den kunstkenner een muziekaal genot van geheel anderen aard. Het Duitsche operapersoneel uit Rotterdam komt dan den Lohengrin van Wagner geven, een toondicht, 't welk hier te lande reeds lang bekend, te Utrecht nog niet werd gegeven, en toch als een der schoonste gewrochten, van den Duitschen komponist, een kennismaking zozeer verdient. ${ }^{16}$

Het krantenartikel vervolgde met een beschrijving van Wagners leven en werk. Het 'Duitsche operapersoneel uit Rotterdam' hoefde niet op vergelijkbare wijze bij de Utrechtse lezers te worden geïntroduceerd.

Wat orkest en uitvoering door 't personeel betreft kan men een genotrijken avond te gemoet zien. Lederer met zijn jeugdig en frisch geluid zingt de Lohengrin uitstekend; Rübsam, zegt men, is als Frederik, Fassbender als Hendrik de Vogelaar zeer goed. Mevr. Ubrich treedt als Elsa van Braband en mej. Koch als Ortrud op. De bezetting is dus naar wensch.

De schrijver van het krantenartikel ging er overduidelijk van uit dat de krantenlezers de zangers en zangeressen van het Duitse operapersoneel kenden; Utrechtse liefhebbers van de Duitse opera bezochten regelmatig voorstellingen in Rotterdam en het Rotterdamse gezelschap gaf vaker optredens in Utrecht.

De omvang van de immigrantengemeenschap bepaalde mede of er eigen organisaties waren. De Duitse immigranten waren wel het meest talrijk in Utrecht, maar hun aantal was kleiner dan dat in Amsterdam of Rotterdam. Buiten Nederland bestonden er in steden als Londen, New York of Chicago Duitse gemeenschappen die getalsmatig nog veel groter waren. ${ }^{17}$ Het percentage Duitsers in Londen in het midden van de negentiende eeuw wordt geschat op 0,4 tot 1,8 procent. Dat percentage was niet veel groter dan dat in Utrecht, maar het absolute aantal was dat uiteraard wel. ${ }^{18}$ In New York woonden tussen 1855 en 1880 meer Duitsers dan in Berlijn. ${ }^{19}$ In steden met een getalsmatig grotere migrantengemeenschap bestond een uitgebreidere en meer gedifferentieerde etnische infrastructuur. In Chicago vonden de Duitse immigranten in de tweede helft van de negentiende eeuw een aan alle wensen tegemoetkomend institutioneel netwerk met banken, winkels, kroegen, kerken, scholen, turn- en carnavalsverenigingen, geheime loges en socialistische clubs. ${ }^{20}$ Waar gemeenschappen kleiner waren, zoals in Utrecht, was de infrastructuur minder uitgebreid. ${ }^{21}$ 
In 1859 woonden er in Amsterdam 5.286 Duitsers op een totale bevolking van 241.348. Ofschoon het verschil tussen Utrecht en Amsterdam verhoudingsgewijs (2 versus 1,4 procent) niet zo heel groot was, bood het kleinere absolute aantal Duitse immigranten in Utrecht minder mogelijkheden voor activiteiten gericht op de eigen gemeenschap. Een groter aantal immigranten betekende overigens wel meer organisaties, maar niet noodzakelijkerwijs een grotere samenhang. Het verband tussen het aantal immigranten en de eenheid binnen de verenigingen kan beter als een klokvormige curve worden verbeeld dan als een rechte lijn. Voor een handjevol immigranten was het enerzijds weinig lonend om iets te organiseren - en zeker niet om een dergelijk initiatief te formaliseren - maar anderzijds leidde een zeer groot aantal immigranten tot verwatering en verdeeldheid en daarmee tot afname van de eenheid in organisatie. ${ }^{22}$

De noodzaak of wens tot het oprichten van eigen organisaties werd, behalve door de omvang van de gemeenschap, op de tweede plaats bepaald door het bestaan van vergelijkbare - concurrerende - organisaties in de ontvangende samenleving. ${ }^{23}$ Wanneer er, bijvoorbeeld, reeds een kegelclub bestond, was het voor immigranten niet noodzakelijk daar een eigen organisatie naast te zetten, mits de bestaande organisatie voor hen toegankelijk en aantrekkelijk was. Het Park Tivoli in Utrecht had een kegelbaan, die elke avond beschikbaar was voor leden. ${ }^{24}$ In Rotterdam was er een Duitse club met een kegelbaan, maar in Utrecht vervulde de algemene baan bij Tivoli deze behoefte.

In het negentiende-eeuwse Nederland waren er talrijke organisaties, veelal verkaveld naar religie en klasse, die zich bezighielden met bevordering van de geneeskunde, verbetering van de volksgezondheid en de landbouw, bescherming van dieren, bestrijding van drankmisbruik en prostitutie, ziekenverzorging en reclassering, onderwijs, huisvesting van armen, werkverschaffing en ontspanning voor minvermogenden, 'rechtbeoefenende gezelschappen', verenigingen tot vermindering van criminaliteit bij de jeugd, en kunst en wetenschap bevorderende maatschappijen. Sport in georganiseerd verband was belangrijk: boogschutterij en schietverenigingen, roeiverenigingen, turn-, scherm- en gymnastiekverenigingen en als laatste de voetbalclubs. Hiernaast waren er buurtverenigingen met een gezelligheidsdoel. ${ }^{25}$ In dit woud van organisaties moesten die van immigranten een plaats zien te vinden. Formeel waren er weinig barrières. De enige wettelijke beperking was dat vreemdelingen die geen ingezetenen waren, uitgesloten werden van het lidmaatschap van staatkundige genootschappen. Aan vreemdelingen die wel ingezetenen waren, werden geen beperkingen opgelegd. Voor lidmaatschap van culturele verenigingen gold geen enkele beperking.

In Utrecht bestond een fijnmazig netwerk van verenigingen en instellingen, ieder met hun eigen cliëntèle. In 1872 werd geschreven:

Wie Utrecht kent, weet dat nergens de Chinese afscheidingsmuren sterker tusschen de standen, neen tusschen de coterieën zijn opgetrokken dan juist hier. Vandaar die talrijke vereenigingen hier ter stede. ${ }^{26}$ 
De scheidslijnen tussen de verenigingen waren niet zo sterk als dit citaat wil doen geloven. Onder de bestuurders van de uiteenlopende verenigingen komen de namen voor van steeds dezelfde Utrechtse vooraanstaande burgers. ${ }^{27}$ Die verstrengeling maakte de verenigingen echter niet makkelijker toegankelijk voor buitenstaanders, in tegendeel.

De economische en sociale samenstelling van de immigrantenpopulatie had een weerslag op het soort organisaties dat ontstond. ${ }^{28}$ Het relatief grote aantal Duitse arbeiders in New York en Londen leidde tot het ontstaan van Duitse arbeidersorganisaties. In Amsterdam speelden in het midden van de negentiende eeuw Duitse kleermakersgezellen een rol in de organisatie van een protestbijeenkomst op de Dam. ${ }^{29}$ Duitse werklieden hadden in Amsterdam in het midden van de negentiende eeuw een rol in de beginnende arbeidersbeweging. Het ontbreken in Utrecht van een Duits proletariaat van enige omvang, verklaart de afwezigheid van een dergelijke organisatie in deze stad. Omdat Utrecht geen industriestad bij uitstek was, kwam de arbeidersbeweging hier laat en traag tot stand..$^{30}$ Slechts in één geval zijn er sporen van de bemoeienis van vreemde arbeiders met de arbeidersorganisatie. In 1866 richtten enkele geschoolde werklieden een coöperatie op. Onder het handjevol oprichters waren H.L. Köhler, civiel ingenieur en de kleermaker Henri Steppé, beiden uit Brussel en de Duitser Julius Sabler, een horlogemaker uit Essen. De coöperatie was geen lang leven beschoren. De cholera en de oorlog in Pruisen maakten van de tweede vergadering meteen de laatste, zo melden de notulen. ${ }^{31}$

Het maatschappelijk aanzien van immigranten speelde een rol bij de toegankelijkheid van verenigingen. Zo was Christiaan Schober, gepensioneerd luitenant kolonel, sedert 1817 regent van de verenigde gods- en gasthuizen. ${ }^{32}$ Deze positie dankte hij ongetwijfeld aan het maatschappelijk aanzien dat hij binnen de Utrechtse samenleving genoot. We komen Schober ook tegen als honorair lid van andere verenigingen, zoals de Utrechtsche Mannenzangvereeniging. Klasse bepaalde mede de toegankelijkheid van verenigingen.

Politieke ontwikkelingen in Duitsland hadden hun weerslag op de organisatie van Duitse immigranten in landen daarbuiten. Duitse immigranten in Chili voelden de gevolgen van de Duitse eenwording van na 1871 zeer sterk in de houding die tegenover hen in hun nieuwe vaderland werd aangenomen. Een Duitse immigrant schreef naar een oud-klasgenoot dat hij sedert 1871 met heel andere ogen werd bekeken. Men zag hem voor het eerst als Duitser, als onderdaan van een machtig land, en zo voelde hij zich ook. ${ }^{33}$ De Duitse eenwording leidde onder de Duitsers in Chili tot 'retrospectief Duits patriottisme'. ${ }^{34}$ Iets vergelijkbaars zal voor Duitsers in Nederland hebben gegolden.

\section{De Handels-Societeit}

Om te bezien in hoeverre Duitse immigranten toegang hadden tot meer algemene maatschappelijke organisaties, wordt hier gekeken naar één van de belangrijkste lo- 
kaal-politieke verenigingen in Utrecht: De Handels-Societeit. Deze organisatie was niet alleen belangrijk in de lokale verhoudingen, het was bovendien een vereniging die actief was in de handel; de sector waarin veel Duitse immigranten in Utrecht werkzaam waren.

Het initiatief tot oprichting van de Handels-Societeit werd in 1851 genomen door drie handelaren, waaronder de lutherse Duitser Peter Voswinkel Dorselen. ${ }^{35}$ Voswinkel Dorselen was een genaturaliseerde Westfaler, eigenaar van het Suikerhuis - de suikerfabriek - aan het Lucas Bolwerk en lid van de gemeenteraad. ${ }^{36}$ De drie initiatiefnemers nodigden zeven andere handelaren en fabrikanten uit om hun plan te steunen. Hieronder was ook de katholieke groothandelaar Trip, geboren in Weesp uit Duitse ouders. Deze tien mannen richtten in 1852 gezamenlijk de Handels-Societeit op. Aanleiding was de instelling van een Kamer van Koophandel. Doel van de vereniging was de keuze van geschikte leden te bevorderen en voor te bereiden. ${ }^{37}$ De vereniging was dus wat we in hedendaagse termen een lobby-organisatie zouden noemen; ze bracht een stemadvies uit en benaderde stemgerechtigden om hun keuze te beïnvloeden. De vereniging bewoog zich op een nieuw terrein. In het gedenkboek ter gelegenheid van het vijftigjarig bestaan van de Handels-Societeit werd geschreven:

Er bestond destijds te Utrecht niet het minste vereenigingspunt voor handelaren en fabrikanten, er bestond wel eene afdeeling of Departement "Utrecht" van de Mij. tot bevordering van Nijverheid, doch de handelaren hadden er geen deel aan en de weinige fabrikanten, die er toe behoorden, werden gewoonlijk overstemd, door personen, die met de nijverheid niets te maken hadden, door: geleerden, advocaten, ambtenaren en anderen; - vandaar, dat de oprichters bij de vaststelling van het reglement, met opzet, het er op aan gelegd hebben, om allen, die niet tot Handel of Nijverheid behoorden, buiten de kring der Handels-Societeit te houden. ${ }^{38}$

Het idee van de Handels-Societeit sloeg aan. Het ledental groeide van 20, naar 40 en 53. Bij het veertigjarig bestaan telde de vereniging 66 leden. Het lidmaatschap werd aangeboden; geïnteresseerden konden zich niet zelf aanmelden. De vereniging wist haar doelstelling te verwezenlijken.

De jonge vereeniging had al dadelijk succes. Bij de eerste verkiezingen voor de Kamer van Koophandel werden al hare candidaten gekozen (April 1852) en toen deze Kamer den 5en Juni d.a.v. optrad, bestond zij geheel uit leden der HandelsSocieteit. ${ }^{39}$

Welke Duitse immigranten hadden toegang tot deze relatief exclusieve club? Onderzoek van de ledenlijsten leert dat er in totaal tussen 1852 en 1892180 handelaren en fabrikanten lid waren van de Handels-Societeit, waaronder vijftien Duitsers. Duidelijk is dat de Handels-Societeit wel openstond voor Duitse ondernemers. 
Niet alle ondernemers waren even lang lid. Sommigen bedankten reeds na korte tijd - enkele Duitsers omdat ze teruggingen naar Duitsland - anderen waren tientallen jaren lid. Het cijfer van vijftien kan daarom niet simpelweg tot een percentage worden omgerekend. Wel kan worden gezegd dat ongeveer tien tot vijftien procent van de leden Duits was. Daarmee waren Duitsers in deze organisatie sterker vertegenwoordigd dan in de Utrechtse bevolking als geheel.

De vijftien Duitse leden waren, net als de andere leden, handelaars en fabrikanten. Ze behoorden daarbinnen niet tot één beroepsgroep, kwamen niet uit een bepaald deel van Duitsland en behoorden evenmin tot één geloof. Onder leden vinden we de lutheranen Christiaan Schanze uit Leipzig, een ingenieur-werktuigkundige bij het spoor, Carl Grothe, werktuigkundige uit het Westfaalse Hagen, ornamentenfabrikant Rencker en orgelbouwer Witte. De grote Duitse winkeliers uit het centrum van de stad waren in de Handels-Societeit eveneens goed vertegenwoordigd door de protestantse winkeliers Thueré, Bohlen en August en Heinrich Schlüter en hun katholieke tegenhangers Stuckenborg en Van der Sandt. Verder waren lid Johan Carp, een waals fabrikant uit Düsseldorf, en de pianohandelaar Rahr. Uit deze opsomming blijkt dat de vereniging openstond voor zowel katholieken als protestanten. Alle leden behoorden tot de economische top van de Utrechtse gemeenschap. Welstand of klasse was veel meer een selectiecriterium dan geloof. De katholieke Westerwalder handelaren, die het grootste percentage van de Duitse immigrantenpopulatie uitmaakten, vinden we niet onder de leden van de Handels-Societeit. Deze afwezigheid kan verklaard worden uit het feit dat zij tot een lagere sociale klasse behoorden dan de katholieke winkeliers aan de Oudegracht. Het kan echter ook duiden op een geringe integratie in de Utrechtse samenleving.

\section{Bayerisch bier}

Eten en drinken en de gewoonten die ermee samenhangen hebben samenbindende, groepsafbakenende en identiteitbepalende kenmerken. ${ }^{40}$ Als er drie Duitsers naar Amerika emigreren, opent de eerste een kroeg, zodat de andere twee een plek hebben om ruzie met elkaar te maken. Het is een negentiende-eeuwse grap die in Duitsland over de Amerikagangers werd gemaakt. ${ }^{41}$ Het koffiehuis was meer dan alleen een plek om koffie of bier te drinken. In de negentiende eeuw verschaften koffiehuizen georganiseerd vermaak in de vorm van concerten, optredens en lezingen. ${ }^{42}$ Bovendien waren ze een plaats van vergadering voor verenigingen en clubs. Koffiehuizen boden de mogelijkheid kranten te lezen, waaronder buitenlandse periodieken. Mede hierdoor konden koffiehuizen of kroegen een trefpunt zijn voor immigranten.

Een van de voorwaarden waaronder eten en drinken een rol kunnen spelen als etnische marker zijn de verschillen met de ontvangende samenleving. Het Bayerisch bier was in ieder geval anders dan het Nederlandse. Het bovengistende bier werd in de negentiende eeuw door Duitse brouwers in Nederland geïntroduceerd. Het Bayerisch 
bier verdrong in rap tempo het Nederlandse en het is het bier dat nu standaard in Nederland wordt gedronken.

In het midden van de negentiende eeuw openden kroegen hun deuren die zich toelegden op de verkoop van het Bayerisch bier. In de zomermaanden werd in het zogenaamde Spanjaardsgat een Bayerische Bierhalle ingericht. Het Spanjaardsgat was een restant van het kasteel dat ooit op het Utrechtse Vredenburg had gestaan. De dikke muren en het Duitse bier moesten verkoeling brengen in de warme zomermaanden.

De Bayerische Bierhalle was niet de enige 'Duitse' gelegenheid in Utrecht. Tussen 1849 en 1879 waren er in Utrecht 35 Duitsers die als ondernemers in de horeca werkten. Er waren twee Duitse bierhuishouders en -houdsters, vier koffiehuishouders en -houdsters, acht tappers en tapsters, vijf logementhouders en -houdsters, zes kasteleins en drie kroeghouders en -houdsters. In 1879 waren vijf van de dertig bierhuishouders in Utrecht Duits. ${ }^{43}$ Van de negentien logementen die de stad telde, waren er drie in Duitse handen. ${ }^{44}$ De benaming logement is wat misleidend. Onder deze aanduiding werd bij-

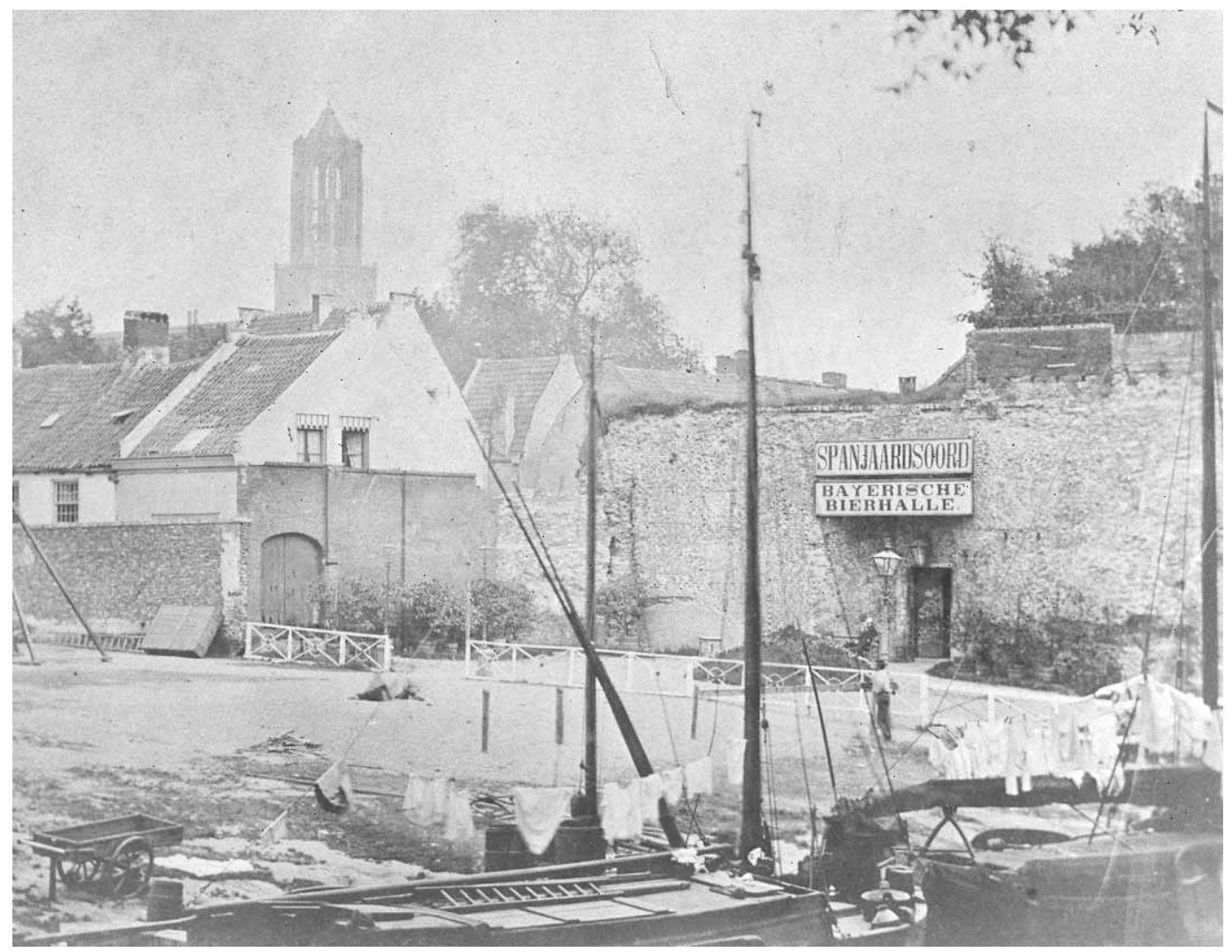

Bayerische Bierhalle op het Vredenburg 1880. De Bierhalle werd in de zomermaanden ingericht in een restant van het kasteel dat hier ooit had gestaan. Achter de dikke muren was het aangenaam koel. Er werd in deze gelegenheid Duits bier geschonken, maar of dat bier verdween in Duitse kelen is de vraag.

Het Utrechts Archief C. 5086. 
voorbeeld ook verstaan Het Oude Kasteel van Antwerpen op de Bakkerbrug van de Duitser F.H. Geuer. Dit is niet het soort gelegenheid waar we aan denken bij het woord logement. Iets vergelijkbaars geldt voor hotel Bellevue op het Vredenburg van de Duitser W. Holterman (zie illustratie), dat ook in de categorie logementen werd gerangschikt.

Er waren in Utrecht enkele uitspanningen die als Duits kunnen worden aangemerkt omdat ze in bezit waren van opeenvolgende Duitse eigenaars en met Duits personeel werkten. Het bierhuis van Heinrich Mönzert is daar een voorbeeld van. Mönzert, die krantenadvertenties zijn naam ook spelde als Munzert, kwam in 1870 naar Utrecht uit Zeist. ${ }^{45}$ Hij vestigde zich in de Lange Janstraat en nam een bierhuis over van de Duitser Johannes Rapp. ${ }^{46}$ Rapp begon een nieuw bierhuis op de Mariaplaats. Mönzert trouwde in 1871 met de Duitse Johanna Wurlitzer. ${ }^{47}$ In 1873 had Mönzert een bierhuis op de Neude, drie jaar later een bierhuis op de Oudegracht. Mönzert adverteerde met zijn 'echt Beijersch lager-bier', dat hij naar eigen zeggen betrok uit de brouwerijen ' $\mathrm{H}$. Henniger \& zoon, te Frankfurt a/M en Erlangen. ${ }^{38}$ Mönzert had een voorkeur voor Duits personeel. In zijn bierhuis op de Oudegracht werkten tussen 1876 en 1879 zes Duitse dienstbodes en kelners. In de periode 1880-1889

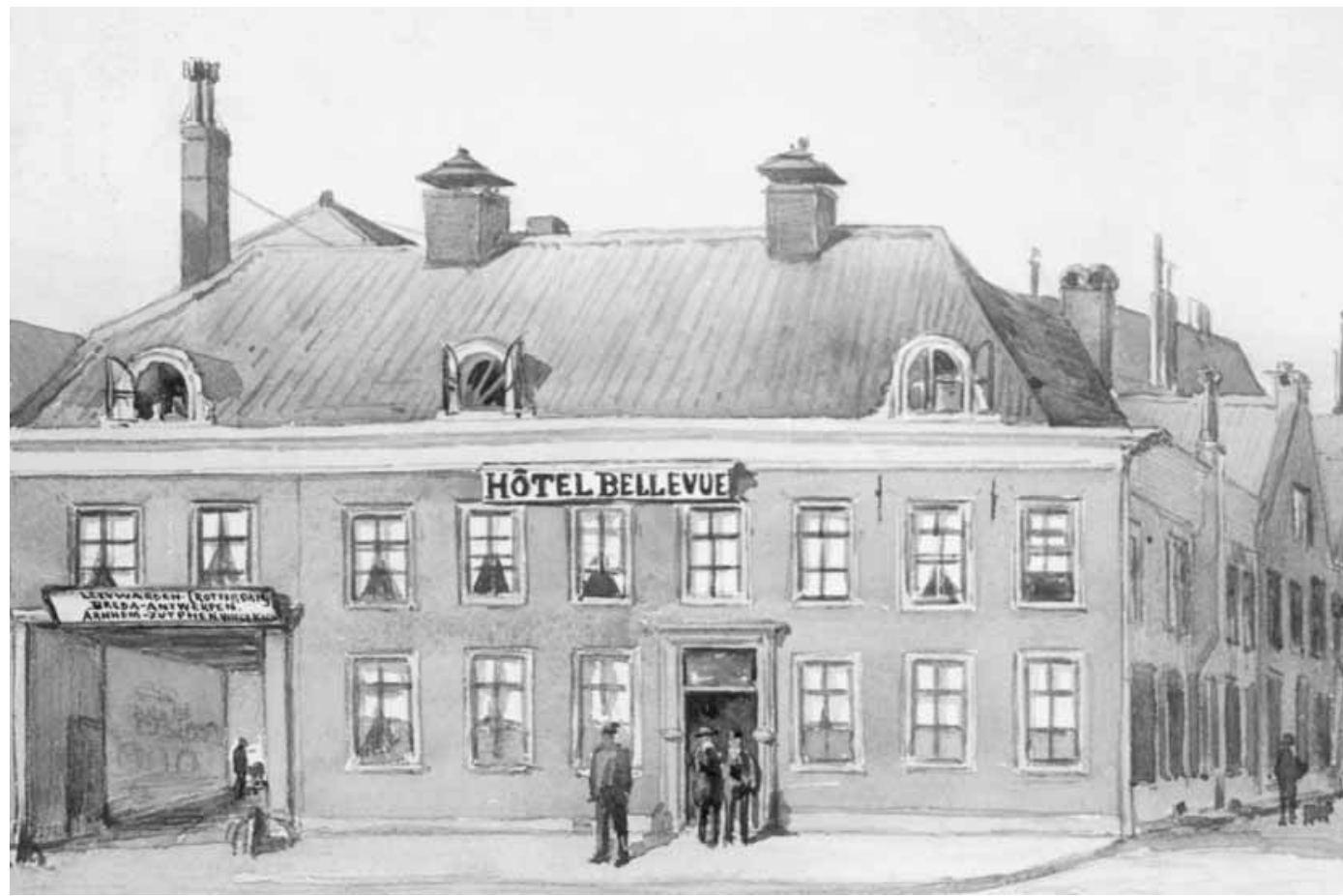

Hotel Bellevue op het Vredenburg in 1884, eigendom van het Duitse echtpaar Holterman-Veerkamp. Vanaf hier vertrokken diligences naar onder meer Zutphen en Antwerpen. Het Utrechts Archief C.20.933. 
had hij nog steeds een uitspanning op de Oudegracht, nu een koffiehuis genoemd. Hij had zes Duitse kelners, buffetjuffrouwen - een nieuwe beroepsgroep in deze periode een keukenmeid en meerdere bediendes. In 1883 werd dit koffiehuis overgenomen door een Oostenrijker. ${ }^{49}$

Behalve het echtpaar Mönzert hadden ook Johan Rieges en zijn vrouw Anna Maria Hummer een bierhuis op de Voorstraat. Beiden waren geboren in Nürnberg. Rieges overleed in 1864, waarna zijn vrouw het bierhuis voortzette. Nadat ook haar zoon was overleden, deed ze het bierhuis in 1888 over aan het Duitse echtpaar Franz Sturm en Maria Louise Kunde. ${ }^{50}$ Dit echtpaar had een Duitse buffetjuffrouw en kelnerin in dienst. ${ }^{51}$ Eerder hielden de Westerwalder Johan Koch en zijn Nederlandse vrouw Maria Harmsen een 'tafel' in een ander pand op de Voorstraat. In tegenstelling tot Mönzert en Rieges hadden zij geen Duits personeel.

De laatste gelegenheid die nog kan worden genoemd in dit rijtje is die van de tapper Johannes Schröder in de Donkerstraat, in een buurt vol bordelen. Schröder was katholiek en werd in 1793 geboren in Delmenhorst in Oldenburg. Deze uitspanning werd in de wandeling aangeduid als de tapperij van Jan de Poep (Jan de Duitser). ${ }^{52}$

Ofschoon er in Utrecht een redelijk aantal gelegenheden waren die als Duits kunnen worden aangemerkt - met Duitse eigenaars, Duitse bedienden en Duits bier - is het de vraag in hoeverre het Duitse bier ook verdween in Duitse kelen. Waren de Duitse gelegenheden vergelijkbaar met de hedendaagse Italiaanse pizzeria's, die vooral door Nederlanders worden beklant, of meer met de Turkse koffiehuizen, waar vooral Turken komen? Of waren de Duitse kroegen en koffiehuizen iets er tussenin; een plek waar Duitsers en Nederlanders elkaar ontmoetten? We weten dat de eigenaars, het personeel en het bier Duits waren, maar naar de klandizie kunnen we slechts gissen. Daarmee is het ook moeilijk hun rol te duiden in de Duitse sociale infrastructuur.

\section{Café MUN"igR'.}

De ondergeteekende bericht bij deze aán zijne geëerd begunstigers, dat de

Tuin achter zijn Café GEOPEND is. Tevens de ontrangst van Originaal PICSENCR ZOMER-TAGERTIER.

\section{W. MUNZERT.}

Advertentie uit de Stichtsche Spiegel van15-5-1879 van de Duitse bierhuishouder Mönzert, die zijn naam in advertenties ook spelde als Munzert. 


\section{Religieuze heterogeniteit}

Bij de religieuze organisaties speelde de religieuze heterogeniteit van de Duitse immigrantenpopulatie een rol. Net als bij andere organisaties, geldt ook voor kerken dat de noodzaak voor het opzetten van immigrantenkerken gerelateerd was aan de toegankelijkheid van de bestaande kerken. De katholieke kerk verschilde op dit punt van de lutherse. In de katholieke kerk was de liturgie in het Latijn en was de (Nederlandse) preek minder belangrijk dan in protestantse kerken. Verondersteld zou daarom kunnen worden dat katholieke Duitse immigranten minder behoefte hadden aan een Duitstalige parochie. Slechts de verplichte biecht voor Pasen was een probleem..$^{53}$ Opmerkelijk is dat de biecht in Amerikaanse studies wordt genoemd als een belangrijke motief voor het oprichten van een eigen Duitstalige parochie. ${ }^{54}$ In de familiekroniek van het winkeliersgeslacht Schlatmann, waarvan de leden ook in Utrecht actief waar, staat een opmerking over de biecht. De leden van de familie die in Duitsland waren geboren, verschilden uiterlijk niet van Nederlandse katholieke standsgenoten. 'Het accent was afgesleten en ook onderling werd bijna geen Duits meer gesproken. Alleen hun zonden biechtten ze nog in het Duits, maar dat ging verder geen sterveling aan'. ${ }^{55}$ Of onder de stervelingen ook de pastoor werd begrepen is niet duidelijk. De Duitse immigranten uit het Westerwald, die seizoensmatig op en neer reisden tussen hun geboortegrond en Nederland, ondervingen het probleem door voor hun vertrek in Duitsland te biechten. Duitse immigranten die langer in Nederland waren, moesten een andere mogelijkheid zoeken. Uit de registers van de Martinusparochie blijkt dat ze daar te biecht gingen. Tot initiatieven voor het oprichten van een Duitstalige parochie kwam het in Utrecht niet. Nederlandse priesters beheersten het Duits waarschijnlijk voldoende om een biecht af te nemen. De katholieke Duitse gemeenschap was bovendien te verdeeld in sociaal opzicht voor de oprichting van een eigen parochie. De grote Duitse katholieke winkeliers, die in het centrum van de stad naar de kerk gingen, zochten geen aansluiting bij de 'klompenparochie' waartoe de Westerwalders behoorden.

\section{De lutherse kerk}

De lutherse kerk is als casus interessant omdat deze kerk in Nederland vóór 1800 zowel een minderheids- als een immigrantenkerk was. Deze kerk was in dat tijdvak een organisatie van overwegend Duitse immigranten. In andere landen, en bij uitstek in de Verenigde Staten, wordt de lutherse kerk gezien als 'one of the strongest bulwarks of [...] Deutschtum'. ${ }^{56}$ Via eigen scholen en de dienst in het Duits wist juist de lutherse kerk de Duitse cultuur en de samenhang binnen (een gedeelte) van de Duitse immigrantengemeenschap te behouden.

In het midden van de zeventiende eeuw was het merendeel van de lutheranen in Utrecht van Duitse oorsprong. ${ }^{57}$ Geografische oorsprong, taal en religieuze zelforganisatie vielen hierdoor grotendeels samen. De lutherse gemeenschap was echter minder 
een eenheid dan op het eerste gezicht lijkt. Voor 1800 werd jaren achtereen en steeds opnieuw strijd gevoerd over de vraag of er een Duits of Nederlands sprekende predikant moest worden aangesteld. De strijd ging niet alleen over wie het best verstaanbaar was voor de kerkbezoekers. De inzet was vooral aanpassing aan Nederland dan wel orientatie op het herkomstgebied. ${ }^{58}$ Daarnaast speelde ook de mate van orthodoxie een rol. In Holland ontwikkelde zich binnen de lutherse kerk een stroming die zich minder vijandig opstelde tegenover andere godsdiensten dan gebruikelijk was in Duitsland. Dit was logisch, gezien de positie van de lutheranen als kleine religieuze minderheid binnen de Republiek. In veel Duitse gebieden had de lutherse kerk het karakter van een staatskerk en kon daarom strenger in de leer zijn dan haar Nederlandse tegenhanger. ${ }^{59}$ De orthodoxe Duitse theologische opvattingen werden in Republiek verkondigd door predikanten die hun opleiding aan Duitse universiteiten hadden genoten. Amsterdamse aanhangers van de zogenaamde Hollandse richting probeerden dit te veranderen door een eigen opleiding op te zetten. ${ }^{60}$

Binnen de Utrechtse lutherse kerk, waar vanaf 1608 in het Duits werd gepreekt en na 1638 bovendien ook in het Nederlands, ontwikkelde zich een heftig conflict. Na 1770 probeerde een gedeelte van de gelovigen, merendeels in Nederland geboren lutheranen, de Duitse preek af te schaffen. Zij stelden dat als vreemdelingen Nederlands geld accepteerden, zij zich ook aan de Nederlandse taal moesten gewennen. Zij dreigden niet meer aan de collecte bij te dragen. De kerkenraad schaarde zich achter hun wens voor een Nederlandstalige predikant. Een gedeelte van het kerkvolk, waarschijnlijk de meerderheid, wenste vast te houden aan een Duitstalige predikant. Deze merendeels in Duitse streken geboren lidmaten voerden aan dat vreemdelingen anders niet meer in staat waren de preek te volgen. Zij vroegen het Utrechtse stadsbestuur om in te grijpen en de beroeping van een Hoogduitse predikant mogelijk te maken. Het stadsbestuur kwam aan deze wens tegemoet.

Het conflict binnen de lutherse kerk werd aangewakkerd door de politieke strijd tussen Patriotten en Orangisten die gelijktijdig op een ander toneel werd gestreden. De Orangisten kwamen aanvankelijk als overwinnaars uit de bus. De Patriotten weten hun nederlaag aan het 'buitenlands geweld' - de inval van de Pruisische troepen. Dit leidde tot anti-Duitse gevoelens in de Utrechtse samenleving. Toen in 1795 de Patriotten weer aan de macht kwamen, werd de Duitse predikant mede om deze reden ontslagen. Volgens Rommes brak

[m] et deze gebeurtenis [...] de lutherse gemeente van Utrecht op symbolische wijze met haar historische wortels als Duitse immigrantengemeenschap en werd definitief een Nederlandse gemeente. ${ }^{61}$

Aan deze breuk droeg bij dat het aantal Duitsers in deze periode sterk was teruggelopen. Het merendeel van de gemeenteleden was inmiddels in Nederland geboren. De politieke omslag van 1795 speelde eveneens een rol. De invoering van de scheiding tussen kerk en staat ontnam het Utrechtse stadsbestuur de mogelijkheid om de Duitstalige 
predikant nog langer te steunen tegen de wens van de kerkenraad in. Na het wegvallen van deze steun werd de positie van de predikant onhoudbaar.

Conflicten waren er niet alleen binnen de lutherse kerk in Utrecht, maar ook in andere Nederlandse plaatsen. In tal van plaatsen deed zich een 'Verholländerungs'-proces voor. ${ }^{62}$ De breuk in Utrecht en vergelijkbare conflicten elders hadden tot gevolg dat in 1792 de hersteld-lutherse kerk zich van de lutherse kerk afsplitste. In deze nieuwe kerk verenigden zich de orthodoxe en Duits-georiënteerde lutheranen. De scheuring werd gezien als een conflict tussen de Hollandse en de Duitse richting. Bij het conflict speelden ook een generatieprobleem en een klassenverschil een rol. De leden van de hersteld-lutherse kerk waren recentere nieuwkomers dan de lidmaten van de lutherse kerk. Aanvankelijk werden de hersteld-luthersen bovendien uitgemaakt voor 'suikerbakkers' en 'metselaarsmoffen', wat duidt op een aanhang binnen die beroepsgroepen. ${ }^{63}$ De hersteld-lutherse kerk was echter in Utrecht niet erg belangrijk. Het ontbreken van 'suikerbakkers' en 'metselaarsmoffen' en teruglopende immigratie van Duitsers kunnen dat verklaren.

In 1803 werd Jacob Nieuwenhuis benoemd tot predikant van de lutherse gemeente in Utrecht. Nu werd niet alleen symbolisch gebroken met de Duitse oorsprong, maar ook met het conflict dat de hele achttiende eeuw de lutherse kerk had geplaagd. Nieuwenhuis schreef in zijn memoires dat 'er nog een partij in de gemeente was geweest, die weer een Duitse predikant had gewild, maar dat het hoofd van deze partij, de horlogemaker Fricke, wonende buiten de Tolsteeg, bij de legpaats van het Vaartse schuitje, op een avond bij hem kwam om hem namens de zijnen mede te delen dat men met hem tevreden was. Hij overhandigde hem een pak met alle requesten en brieven, die in deze zaak waren gewisseld. Samen besloten ze toen die te verbranden. ${ }^{64}$ Met deze daad werd het conflict ten grave gedragen. Gepreekt werd er alleen nog maar in het Nederlands. Geen van de predikanten die Nieuwenhuis opvolgde in de negentiende eeuw was Duits. Aanbod van Duitse predikanten is er ongetwijfeld wel geweest; er was immers een overschot aan lutherse predikanten in Duitsland en predikanten werden gewijd op de uitdrukkelijke voorwaarde dat ze niet in Duitsland emplooi zouden zoeken. ${ }^{65}$

Het conflict binnen de lutherse kerk in Nederland vertoonde opvallende overeenkomsten met conflicten in andere landen. In Utrecht speelde het conflict vooral in de achttiende eeuw. Elders waren er ook problemen in de negentiende eeuw. De taalkwestie speelde in alle gevallen. 'So lange noch fünf Gemeindeglieder beim Gottesdienst die deutsche Sprache wünschen, soll kein Englisch in unsere Kirche gepredigt werden', werd er in het midden van de negentiende eeuw geschreven naar aanleiding van het conflict binnen de lutherse kerk in Cincinnati in de Verenigde Staten. ${ }^{66}$ Opmerkelijk is dat waar in Nederland het conflict werd gezien als een tegenstelling tussen reeds gevestigde lutheranen - kinderen of kleinkinderen van eerdere immigranten - en recente nieuwkomers, het in de Verenigde Staten bovendien werd beschouwd als een conflict tussen Platduitssprekende immigranten, die vooral uit de omgeving van Oldenburg kwamen, en hun Hoogduitsprekende geloofsgenoten uit het zuiden van Duitsland. Omstreeks 1830 bestond de lutherse gemeenschap in Cincinnati uit Württembergers 
en Zwitsers. Na 1830 kwamen er nieuwe immigranten uit het noorden van Duitsland. De Platduitssprekende immigranten waren over het algemeen meer orthodox; de Hoogduitssprekende immigranten waren meer liberaal. De Platduitssprekende immigranten werden uiteindelijk gedwongen de gevestigde kerk te verlaten en begonnen hun eigen kerk. De gemeenteleden die lid wilden worden van de kerkenraad van deze kerk moesten Platduits spreken.

Verschillen in regionale herkomst en verschillen in dialect werden bij het Utrechtse conflict niet genoemd. Verschil in orthodoxie speelde in beide kwesties een rol. Het grote verschil tussen beide conflicten was, dat de Utrechtse kwestie beïnvloed werd door politieke tegenstellingen tussen Orangisten en Patriotten en de anti-Duitse sentimenten die daarmee gepaard gingen. Vooral hierdoor werd de lutherse kerk omstreeks 1800 minder een Duitse kerk. Elders ontbreekt een vergelijkbare ontwikkeling.

Het weinig 'Duitse' karakter van de lutherse kerk in Utrecht in de tweede helft van de negentiende eeuw blijkt uit de samenstelling van het kerkbestuur. Onder de bestuurders van de Evangelisch-Lutherse kerk in Utrecht waren maar enkele Duitsers. In 1861 was de Duitse orgelmaker Christiaan Witte thesaurier van de Evangelisch Lutherse gemeente. August Herman Schlüter - geboren in Embden in 1823 en winkelier op de Oudegracht zat in de commissie voor de lutherse armenschool. ${ }^{67}$ Van de achttien functies binnen de lutherse kerk werden er slechts twee vervuld door een Duitse immigrant. Opvallend is het ontbreken in het bestuur van enkele vooraanstaande Duits-lutherse immigranten, zoals de stukadoor Abeling of de ornamentenfabrikant Rencker. Ze waren ook geen lidmaat. Pas in 1900 komen we hun zonen tegen als ouderlingen van de EvangelischLuthersche gemeente. ${ }^{68}$ Abeling, die zoals verderop blijkt, wel actief was op religieus gebied, vond de lutherse kerk wellicht te weinig orthodox.

Van de kerkbestuurders was dus slechts een klein deel Duits. Gold dit ook voor de lidmaten? Waren alle lutheranen in Utrecht Duits? En, omgekeerd, waren alle Duitse lutheranen lid van de lutherse kerk? Om deze vragen te kunnen beantwoorden heb ik de ledenlijsten van de lutherse gemeente in Utrecht van het jaar 1850 vergeleken met de lutheranen in het onderzoeksbestand. Hieruit bleek dat geenszins alle lutheranen in Utrecht Duits waren. De lutherse bevolking van Utrecht bestond volgens de volkstelling van 1849 uit 650 mannen en 685 vrouwen (in totaal 1335 mensen). Het aantal lidmaten van de kerk was iets kleiner. Op de ledenlijst van de lutheranen staan 940 namen. In 1850 waren er in Utrecht 219 Duitse lutheranen. Dit betekent dat slechts 16 procent van alle lutheranen in Utrecht Duits was. In het midden van de negentiende eeuw waren vier van de vijf lutheranen niet in Duitsland geboren. Niet alle Duitse lutheranen waren bovendien, zo leert een vergelijking van de lidmatenlijst van 1850 met het bestand van Duitse immigranten, lid van de lutherse gemeente. Dit gold slechts voor iets minder dan de helft van de Duitse lutheranen (93). Van de lutherse lidmaten was slechts 19 procent Duits. De overige lidmaten waren mogelijk wel nakomelingen van Duitse immigranten, maar ze waren niet zelf in Duitse streken geboren. De lutherse kerk was daarmee nog steeds wel de meest 'Duitse' kerk in Utrecht, maar een immigrantenkerk was het in het midden van de negentiende eeuw zeker niet meer. 
Welke Duitse lutheranen werden er wel lid van de lutherse gemeente en welke niet? Analyse van de lijst leert dat ten eerste vooral de oudere Duitse lutheranen zich bij de lutherse gemeente hebben aangesloten. Die keuze werd mogelijk beïnvloed door hoop op een plaats in het luthers oudemannen- en vrouwenhuis. Die hoop was misschien een motief, maar in de praktijk werd het lutherse oudemannen- en vrouwenhuis in de tweede helft van de negentiende eeuw niet bevolkt door Duitse lutheranen. In de periode 1860 tot 1873 waren slechts drie van de 27 bewoners Duits. ${ }^{69}$

Een alternatieve verklaring kan zijn dat mensen pas na een verblijf van enkele jaren in een plaats zich als lidmaat van de lutherse kerk lieten inschrijven. Jonge en tijdelijke immigranten zouden dan in de registers ontbreken. Deze veronderstelling klopt niet voor alle Duitse lutheranen. Zo vinden we in de lidmatenregisters wel de 25-jarige Oldenburgse stukadoor Frederik Eilers en zijn even oude maat en streekgenoot Jan Knoop. Beiden waren slechts kort in Utrecht en behoorden typisch tot de meer vlottende populatie, maar zij lieten zich wel als lidmaat inschrijven. Het lidmaatschap van Eilers en Knoop leidt tot de veronderstelling dat beroep een bepalende factor was. Qua beroep vertonen de lidmaten een even grote diversiteit als de Duitse lutherse immigranten tezamen. Opmerkelijk is slechts dat alle vijlenkappers lid waren van de lutherse gemeente; een gegeven dat mogelijk hun onderlinge verbondenheid illustreert. De stukadoors waren slechts gedeeltelijk lid.

De laatste en meest plausibele verklaring voor de relatief hoge leeftijd van de Duitse lidmaten is dat zij behoorden tot een eerdere generatie migranten, voor wie lidmaatschap van de lutherse kerk (nog) wel voor de hand lag - passend bij een oudere traditie - terwijl dat niet gold voor de generatie die enkele decennia later kwam. Het veranderde karakter van de kerk is daarvan zowel de oorzaak als het gevolg.

Zoals eerder opgemerkt bestond er in Nederland nog een lutherse kerk: de hersteld lutherse kerk. Bij de oprichting van deze kerk speelde de oriëntatie op Duitsland een rol. Dit was echter ook niet de plek waar Duitse lutheranen onderdak vonden. De hersteld lutherse kerk in Utrecht was onbelangrijk. Bij de volkstelling van 1849 telde deze kerk in de Domstad in totaal zeven mannen en vijf vrouwen als lidmaat. ${ }^{70}$ Onder de Duitsers die in de periode 1849 tot 1879 in Utrecht waren, treffen we slechts één hersteld lutherse immigrant aan. De hersteld lutherse kerk bood, althans in Utrecht, geen alternatief voor het minder Duits worden van de gevestigde lutherse kerk.

\section{Inwendige zending}

De 'vernederlandsing' van de lutherse kerk is gerelateerd aan het succes van een organisatie die in het Nederlands de Inwendige Zending of Innerlijke Zending werd genoemd en in het Duits officieel de Zentralausschuss für Innere Mission heette. De Innere Mission was geen eigen organisatie van migranten in hun nieuwe land, maar een organisatie die zich vanuit het moederland (onder meer) richtte op landgenoten in den vreemde. De Innere Mission kan wel worden aangemerkt als een zogenaamde concurrerende instel- 
ling. Het bestaan van deze organisatie, maakte immers eigen initiatieven van immigranten minder noodzakelijk.

De Innere Mission was een protestantse organisatie die zendingswerk verrichtte binnen Duitsland. Zij zond echter ook predikanten naar Nederland om hier onder de tijdelijk aanwezige Duitse immigranten te preken. De zendingsorganisatie maakte daarbij geen onderscheid tussen de verschillende protestantse richtingen. De predikanten van de Innere Mission reisden door heel Nederland, preekten op tientallen plaatsen en stimuleerden het opzetten van samenwerkingsverbanden tussen Duitse immigranten. ${ }^{71}$ De predikanten hadden geen eigen kerken. Zij preekten in Nederlandse protestantse kerken die niet noodzakelijkerwijs luthers waren. De predikanten bezochten vooral arbeiders op de steenbakkerijen en in de turfwinnerij, maar ze richtten zich ook tot de stukadoors in de steden. De predikanten deelden boekjes uit met de min of meer symbolische titel Wegweiser zur Heimat. Bij de Innere Mission werd het behoud voor het geloof nadrukkelijk verbonden met het behoud voor het vaderland.

De Innere Mission was actief onder de Utrechtse stukadoors. In juli 1876 bezocht de predikant van deze organisatie, Heinrich Otto Rathmann, Utrecht. Zijn contactpersoon was de Duitse stukadoor Herman Heinrich Abeling. ${ }^{72}$ De rondreizende predikanten vonden, zo blijkt uit hun aantekeningen, gewoonlijk hun contactpersonen door in een plaats waar ze reeds met succes hadden gewerkt te vragen wie ze in een volgende plaats konden benaderen. Zo was Rathmann ook in contact gekomen met Abeling. Rathmann vond in Abeling, naar zijn zeggen, een degelijk zakenman en een nederig christen. Abeling verzocht Rathmann een dienst in het Duits te verzorgen. Er waren veertig Duitse stukadoors die voor het zomerseizoen in Utrecht waren en die naar verwachting belangstelling zouden hebben, maar Abeling nam aan dat ook andere Duitsers met plezier aan de dienst zouden deelnemen. ${ }^{73}$ Abeling liet op zijn kosten een advertentie plaatsen in het Utrechtsch Provinciaal en Stedelijk Dagblad om mensen op de godsdienstoefening attent te maken. Opvallend is dat de oefening weliswaar in het Duits was, maar de advertentie in het Nederlands.

Godsdienstoefening in het Hoogduitsch. De Heer Rathmann, predikant te Berlijn, is voornemens om morgen, zondag der namiddags te half een ure in de Marnixzaal op het Munsterkerkhof eene godsdienstoefening in de Hoogduitsche taal te houden, ten behoeve van de in Utrecht wonende Duitschers. ${ }^{74}$

De Marnixzaal lag in een gebouw van de lutherse gemeente aan het Domplein, dat toen nog Munsterkerkhof heette. ${ }^{75}$ In de rubriek Stadsnieuws van dezelfde krant werd de oefening eveneens aangekondigd.

Rathmann vond zijn godsdienstoefening een succes. Behalve de veertig seizoensmatig in Utrecht verblijvende stukadoors waren er evenveel in Utrecht wonende Duitsers aanwezig. Bij het zingen van de Duitse liederen merkte hij dat velen diep innerlijk bewogen waren. Er waren, aldus Rathmann, veel mensen aanwezig die sedert tientallen jaren geen Duitse preek gehoord hadden. Dat gold ook voor Abeling, die uit de buurt 
van Osnabrück kwam. ${ }^{76}$ Abeling was Rathmann zeer dankbaar. Hij had de dagen voor de dienst veel gedaan en kosten gemaakt om de aan de bijeenkomst bekendheid te geven. Abeling was bezorgd om het zielenheil van zijn landgenoten. Veel van zijn landgenoten hadden, volgens Abeling, gehoopt in Nederland snel rijk te worden, maar hun ziel was verarmd. Vier jaar later, in 1880, werd Utrecht opnieuw bezocht door een predikant van de Innere Mission. Ditmaal was het Werner Droß. ${ }^{77}$ Hij maakte opnieuw gebruik van de bemiddeling van Abeling.

De Innere Mission was geen organisatie van immigranten, maar richtte zich wel op hen. De activiteiten van de Innere Mission vulde het gat dat ontstaan was door de vernederlandsing van de lutherse kerk.

\section{Werken in de diaspora}

Een organisatie die op bepaalde punten vergelijkbaar was met de Innere Mission was de Gustaaf Adolf Vereeniging ( GAv). Raakpunt was dat beide protestants-Duitse organisaties een band hadden met het opkomende Duitse nationalisme. Bij de Gustaaf Adolf Vereeniging werd behoud voor het geloof, evenals bij de Innere Mission, gelijk gesteld met behoud voor de Duitse natie. Het waren aanvankelijk vooral protestantse verenigingen die zich vanuit Duitsland richtten op hun geloofsgenoten in den vreemde. Pas omstreeks 1900 kwamen daar katholieke organisaties naast. Evenals de Innere Mission was de Gustaaf Adolf Vereeniging geen organisatie van immigranten, maar wel een organisatie gericht op hen.

De ontstaansgeschiedenis van de Nederlandse Gustaaf Adolf Vereeniging is tegelijkertijd ingewikkeld en illustratief voor de dilemma's waartoe een 'overplanting' van Duitse organisaties leidde. In 1832 werd in het Duitse Leipzig de Gustav Adolf Stiftung (GAs) opgericht. De vereniging werd genoemd naar de Zweedse koning Gustaaf Adolf, die op 16 november 1632 in de slag bij Lützen in Duitsland viel in de strijd voor het behoud van het lutheranisme - zo werd in de negentiende eeuw benadrukt. Na zijn dood groeide hij uit tot een lutherse 'heilige'. De GAs werd opgericht bij de herdenking van de tweehonderdste verjaardag van zijn sterfdatum. In 1853 stuurde de GAs, niet toevalligerwijs kort na het hoogtepunt van de Aprilbeweging, twee afgevaardigden naar Nederland. Zij kwamen terecht in Leiden bij L.J.F. Janssen, een Nederlander die vlot Duits sprak en schreef. ${ }^{78}$ Janssen zocht op 23 september 1853 steun van Dr. Chantepie de la Saussaye, predikant bij de Waalse gemeente in Leiden en bij hem vond de oproep van de twee zendelingen weerklank. Opmerkelijk is dat de twee zendelingen niet aanklopten bij de lutherse kerk. Op 3 november 1853 - een half jaar na aanvang van de Aprilbeweging - werd een Nederlandse zustervereniging opgericht. De oprichters van de vereniging waren geen Duitsers, maar Nederlanders. Notulen en verslagen werden van meet af aan in het Nederlands geschreven. ${ }^{79}$

Opvallend is ook dat de GAv geen onderafdeling werd van de reeds bestaande GAs, maar een zelfstandige organisatie met de naam Gustaaf Adolf Vereeniging. De reden 
hiervoor was dat de Nederlandse vereniging in oprichting niet akkoord ging met artikel 2 van de statuten van de Duitse Gas. Daarin werd de nadruk gelegd op het lutherse karakter van de vereniging. Het was een evangelische vereniging waarin ook 'Unionisten' en 'Reformierten' welkom waren, maar remonstranten en doopsgezinden nadrukkelijk niet. Voor Nederland, zo vonden de Nederlandse bestuurders en oprichters, kon dat niet opgaan. In Nederland was de lutherse kerk een minderheidskerk. De Nederlandse GAV wilde toegankelijk zijn voor alle protestanten, nadrukkelijk inclusief de remonstranten en doopsgezinden. Op dit punt kwam het tot een breuk met de GAs en daarom werd de nieuwe vereniging een zelfstandige Nederlandse organisatie 'doch in broederlijk verband met de Duitsche vereeniging. ${ }^{80}$ De Duitse Gas betreurde dit besluit. $^{81}$

Doel van de Duitse Gas was steun aan protestanten die woonden in overwegend katholieke streken. Voor deze protestanten werd geld ingezameld zodat zij hun kerk konden bouwen of repareren, een predikant konden betalen en een school stichten. De collectes werden ondersteund door dramatische verhalen in het verenigingsblad over protestanten in katholieke streken die werden uitgescholden, van wie de kinderen op school werden gepest en van wie de graven in de nacht werden opengemaakt. Tekeningen van vervallen kerkjes ondersteunden het betoog. De Gas gaf hulp aan protestanten in katholieke delen van Duitsland zoals Nassau en Westfalen, in OostenrijkHongarije en in Polen. In de loop van de eeuw werd het werkterrein uitgebreid met verderaf gelegen oorden. Zo ging er geld naar protestantse gemeenschappen in ZuidAmerika. Noodlijdende gemeentes konden een verzoek om steun direct aan een plaatselijke afdeling van de GAs richten of aan het hoofdbestuur in Leipzig. De lokale afdelingen ondersteunden doelen naar hun keuze en droegen de rest van de opbrengst van collectes af aan Leipzig.

De Nederlandse GAv sloot zich aan bij deze werkwijze van de GAs. Vrijwel onmiddellijk na de oprichting kwamen er verzoeken binnen om subsidies uit plaatsen in Duitsland, Hongarije en Letland. De collectes van de GAv werden aangekondigd in hervormde kerken. Vergaderd werd onder meer in de gebouwen van de doopsgezinden. Een jaar na de oprichting van de vereniging waren er al afdelingen in twaalf Nederlandse steden waaronder Utrecht. In totaal telde de vereniging in dat jaar 1650 leden. ${ }^{82}$ De afdelingen haalden geld op, maakten een keuze uit de doelen en droegen via het hoofdbestuur in Leiden de rest af aan Leipzig. Het geld werd door Leipzig geaccepteerd en die acceptatie werd gevolgd door een uitnodiging voor de Algemene Vergadering van de GAs. De Nederlandse GAv interpreteerde de acceptatie van het geld en de uitnodiging als een erkenning van haar zelfstandige status als zustervereniging van de GAs. Toch lag de verhouding tussen GAv en GAs niet zo simpel.

Er waren in Nederland al leden van de G A s voor de oprichting van de G A v. Sommigen van hen bleven lid van de Duitse organisatie. Het naast elkaar bestaan van de GAS en GAV leidde in 1867 tot een breuk binnen de GAv. De Rotterdamse afdeling van de GAV noemde zich de Neue GAV en wilde zich nauwer met de Duitse organisatie verbinden. De agitatie werd vooral gevoerd door de Duitse leden. Kennelijk was in Rotterdam 
de Duitse invloed in de GAV groter dan in andere steden. De reeds bestaande GAV was niet erg gelukkig met de Neue GAV. De GAv schreef naar Leipzig dat zij liever gezien had dat deze leden zich, zoals andere Duitsers in Nederland, rechtstreeks bij de Duitse GAs hadden aangesloten, in plaats van een splitsing in de Nederlandse GAv te forceren. ${ }^{83}$ De Neue GAV deed een verzoek aan het hoofdbestuur in Leipzig om als organisatie te worden erkend. ${ }^{84}$ Leipzig koos er echter voor om de Nederlandse G Av te blijven steunen en de Neue GAV verliep.

Ofschoon de Nederlandse GAv zich door Leipzig als zelfstandige organisatie erkend voelde, en bij het conflict in 1867 ook door de GAs werd gesteund, bleef de relatie met de Duitse zustervereniging ingewikkeld. Dat werd erger naarmate het nationalisme in Duitsland sterker werd. In 1882 bezochten Nederlandse afgevaardigden de Algemene Vergadering van de GAs, die extra feestelijk was vanwege het vijftigjarige bestaan. Daar merkten de Nederlandse afgevaardigden dat het opkomende Duitse nationalisme in de GAs haar sporen naliet. Een van de GAv-bestuurders, die de GAs-bijeenkomst in Duitsland bezocht, schreef hierover:

Niets is ook meer natuurlijk dan dat de Duitscher in deze Vereeniging tevens zoekt en waardeert een steun voor den nationalen geest. [...] het is toch onloochenbaar dat de Duitsche volksgeest alleen door het Protestantisme tot zijn recht en tot volle ontvouwing van zijn rijken inhoud kan komen. Met elke kerk en elke school door de G.A.v. gesticht is een nieuwe steun gegeven niet alleen aan de Protestantsche belijdenis, maar ook aan het echt nationaal belang. Zoo stemt de steeds toenemende bloei van de G.A.v. volkomen overeen met de wederopwekking van den Duitschen volksgeest [...] Voor den arbeid der Vereeniging binnen de grenzen van het Duitsche Rijke en onder de over de gansche wereld verspreide Duitschers, is het derhalve evenzeer onvermijdelijk als natuurlijk dat het godsdienstig en het nationaal belang gelijkelijk tot doel worden gesteld. Maar zoodra die arbeid de grenzen van de Duitsche nationaliteit overschrijdt, dan gelde de regel: in Christus is noch Duitscher noch vreemdeling. ${ }^{85}$

De Nederlandse afgevaardigden vonden dat de vreemde nationaliteit meer geëerbiedigd zou moeten worden. De nationalistische ondertoon stoorde de Nederlanders:

zoo vraagt men zich ook van dit groote Duitsche werk met zijn vertakkingen over de geheel wereld, af: wat zal daaruit worden? Een steun voor gezonde vrije volksontwikkeling ook in andere landen of een poging tot overheersing van vreemden landaard door Duitsch belang en Duitsche zin? ${ }^{86}$

De Nederlandse afgevaardigden toonden zich zeer gekwetst toen de Duitse predikant dr. Kögel zijn jaren als predikant in Den Haag als een arbeid in de diaspora omschreef. Dat was zeker niet zoals de Nederlandse vertegenwoordigers hun werk zagen. ${ }^{87}$ De Ne- 
derlandse GAV ergerde zich bovendien jaren lang aan het feit dat in de verslagen van de GAS 27 Nederlandse gemeenten voorkwamen, die steun uit Duitsland leken te ontvangen. In feite ging het om gemeenten - vooral in Brabant en Limburg - die door de Nederlandse GAV werden ondersteund. Het stoorde de GAV dat het in de verslagen leek alsof Nederlandse gemeenten uit Duitsland steun kregen. ${ }^{88}$

De GAv telde in Utrecht in de tweede helft van de negentiende eeuw drie- tot vierhonderd leden. ${ }^{89}$ Er zijn geen ledenlijsten bewaard gebleven, zodat niet kan worden vastgesteld hoeveel van hen Duits waren. Onwaarschijnlijk is dat deze leden allemaal Duitse lutheranen of protestanten waren. Was dat wel zo, dan zouden vrijwel alle Duitse protestantse volwassen mannen zich bij deze vereniging hebben aangesloten. Vast staat in ieder geval dat de leiders van de beweging in Utrecht, evenals de oprichters van de GAv, geen Duitsers waren. Een ontwikkeling zoals in Rotterdam, waar een deel van de leden de GAv probeerde te 'verduitsen', vond in Utrecht geen navolging. Toch was de GAv ook weer niet een geheel Nederlandse organisatie. Vurig pleitbezorger van de vereniging was Carl Euler, een Duitse turnmeester die op 28 februari 1854 in de Remonstrantse Kerk in Utrecht een rede over deze organisatie hield. Nederland zou naar zijn idee de brug moeten zijn waarover de Gustaaf Adolf Vereeniging een toegang tot Engeland en Amerika zou moeten banen..$^{90}$

Tegenstanders van de GAv waarschuwden voor het Duitse karakter van de organisatie. Deze tegenstanders waren, tot verwondering van de GAv-leden, niet de katholieke Nederlanders, maar de hervormden. In de hervormde periodieken Kerkelijke Courant en Kerkelijk Weekblad werd lidmaatschap van de nieuwe organisatie ontraden. In het Kerkelijk Weekblad werd geschreven:

Wij aarzelen niet ernstig en dringend aan eenen iederen Nederlander de deelneming in de Nederlandsche Gustaaf-Adolfvereeniging te ontraden, wanneer de bepaling wet wordt, dat een vierde der inkomsten naar Duitschland aan het centraal-bestuur zal worden gezonden [...] Duitschers, die in Nederland voor de Gustaaf-Adolfvereeniging in gemoede ijveren, geldt onze aanbeveling natuurlijk niet. ${ }^{91}$

Conrad Busken Huet, die boos op deze opmerkingen in het Kerkelijk Weekblad reageerde, schreef ironiserend dat het klaarblijkelijk in het vrije Nederland noodzakelijk was om Duitsers de verzekering te geven zij de vrijheid hadden om zich te organiseren zoals het hen goeddunkte.

Hij houde het ons ten goede zoo wij hem als een bekrompen man, een particularist, aanmerken, als iemand in wien men het alleen om den wille zijner vreemdelingschap verdraagt, dat hij zich niet verheffen weet tot het Nederlandschkerkelijk-universalisme $\left[\ldots . .^{92}\right.$ 
Volgens Busken Huet vond het Kerkelijk Weekblad dat de Duitsers voor hun Duitse geloofsgenoten konden zorgen en de Nederlanders voor de Nederlandse. Daarmee werd van de GAv toch weer meer een Duitse vereniging gemaakt dan de ze zelf graag wilde zijn.

\section{Het gilde van de kerkenbouwers}

Een opmerkelijke organisatie waarin katholieke Duitsers een belangrijke rol speelden, was het Bernulphusgilde. De kerkenbouwers van dit gilde waren katholieke Duitse immigranten die een hechte groep vormden rond de Nederlandse kapelaan Van Heukelum. ${ }^{93}$ De vorming van het gilde viel samen met de grote bouwactiviteit die volgde op het herstel van de bisschoppelijke hiërarchie in 1853. Tussen 1853 en 1893 werden in Nederland 412 katholieke kerken ingezegend, merendeels gebouwd in neogotische stijl. ${ }^{94}$ Bij de bouw van deze kerken, verspreid over heel Nederland, was een groep Duitse kerkenbouwers betrokken die Utrecht als basis had.

De Duitse kerkenbouwers hadden een zeer sterke positie. In de tweede helft van de negentiende eeuw waren er twee stromingen onder de kerkenbouwers. Ten eerste waren daar Cuypers en Alberdingk Thijm, die zich oriënteerden op vroege, dertiendeeeuwse gotiek en die geïnspireerd werden door Franse kerkenbouwers als Viollet-leDuc. Daarnaast waren er de kerkenbouwers van het Bernulphusgilde, die zich richtten op de Nederrijnse vijftiende- en zestiende-eeuwse variant van de gotiek. De stromingen hadden invloed in hun eigen bisdom; Cuypers in Haarlem en het Bernulphusgilde in Utrecht. Het bisdom Haarlem besloeg de provincies Noord- en Zuid-Holland. Het aartsbisdom Utrecht omvatte grofweg alle overige provincies boven de grote rivieren. De 'Bernulfianen', en daarbinnen de Duitse immigranten, waren oppermachtig in het bisdom Utrecht en Cuypers' stroming kreeg daar geen voet aan de grond. ${ }^{95}$ De kerkhistoricus Brom schreef over Cuypers' positie in Utrecht: 'De Limburgse Amster-

\section{* In het Aartsbisdom van Utrecht bestaat een St. BERNULFUS. GILD. Door dat Gild wordt al het beeldhouwwerk aan één beeld- houwer, en al het bouwwerk aan één bouwmeester opgedragen, en elk ander met goweld buiten gesloten.}

Advertentie uit het Utrechtsch Provinciaal en Stedelijk Dagblad van 10-1-1878, gericht tegen de monopoliepositie van het Bernulphusgilde. 
dammer bleef een vreemdeling, erger vreemdeling dan de Duitsers, die zich in de stad van Willibrord wisten in te burgeren'. ${ }^{96}$

De macht van het Bernulphusgilde werd door sommigen met afgunst bekeken. In het Utrechtsch Provinciaal en Stedelijk Dagblad werd in 1875, zes jaar na de oprichting van het gilde, een anonieme advertentie geplaatst (zie illustratie op vorige pagina).

Het Bernulphusgilde werd in 1869 opgericht door Gerard van Heukelum, kapelaan van de Utrechtse St. Catharijnekerk. Doel was de liefde voor en beoefening van de kerkelijke kunst te bevorderen. Het Bernulphusgilde was een actieve vereniging. Tussen 1869 en 1872 - in een periode van drie jaar - kwam de vereniging 32 keer bijeen. Aanvankelijk konden alleen geestelijken lid worden. In 1872 telde de vereniging meer dan tweehonderd zogenaamde volwaardige leden, afkomstig uit Nederlandse bisdommen. Kunstenaars en kunstkenners konden geen volwaardig lid worden, maar wel de vereniging ondersteunen. ${ }^{97}$

Van Heukelum was de drijvende kracht achter het gilde. Hij trok uit het Duitse Rijnland verscheidene kunstenaars aan. Hierdoor ontstond in Utrecht een soort afspiegeling van de in 1823 in Keulen opnieuw opgerichte zogenaamde Dombauhütte. De Dombauhütte was een centrum voor scholing van kerkenbouwers in de neogotische stijl, dat in het begin van de negentiende eeuw opnieuw werd opgericht om de Keulse dom te kunnen restaureren en voltooien. 'De hegemonie van Duitsland liet zich', volgens de kerkhistoricus Brom, 'biezonder gelden voor Utrecht, een stad aan dezelfde Rijn, waarlangs de kerkelike beschaving vanouds ons land binnenstroomde. Werd het Zuiden nog altijd gevuld met Belgisch werk, het Noorden gaf zich aan Duitse krachten over, die geleidelik de geest hielpen vormen. ${ }^{98}$ De leden van het Bernulphusgilde meenden dat de Rijn hen samenvlocht met hun broeders in die andere stad aan dezelfde rivier. ${ }^{99}$ Jaarlijks maakten de gildenleden een reis naar een historisch monument. Het waren reizen vol 'Duitse gezelligheid', waarbij de 'met Rijnwijn gedoopte kunstenaars' de boventoon voerden. 'Duits was nu eenmaal de "dressuurmethode", die 'de eenvormigheid van dit genootschap' bepaalde. ${ }^{100}$

Door het aantrekken van de kerkenbouwers uit het Rijnland werd Utrecht, volgens de kerkhistoricus Rogier, 'een soort Duitse nederzetting in de Nederlandse kerkelijke kunst. ${ }^{, 101}$ De herleving van de kerkelijke kunst vond vooral plaats in de Domstad. ${ }^{102} \mathrm{Be}-$ langrijk binnen het Bernulphusgilde was het zogenaamde Utrechts kwartet, dat werd gevormd door de architect Alfred Tepe, de beeldhouwer Friedrich Mengelberg, de glasschilder Heinrich Geuer en de Nederlandse edelsmid Gerard Blom. ${ }^{103}$

Alfred Tepe werd in 1840 in Amsterdam geboren uit Duitse ouders. Hij studeerde van 1861 tot 1864 aan de Bau-Akademie in Berlijn en werkte in Keulen. Van 1867 tot 1872 woonde hij in Amsterdam. In 1872 kwam hij - op verzoek van Van Heukelum - naar Utrecht en bouwde voor zichzelf een huis aan de Maliebaan. Hij was getrouwd met de in Münster geboren Maria Savels. Hij deelde zijn huis met de Duitse beeldhouwer Friedrich Mengelberg en diens vrouw Helena Schattenberg uit het Duitse Altona. De familie Mengelberg had negen kinderen; de familie Tepe een zoon. Tepe bouwde meer 
dan zeventig kerken, waaronder de Utrechtse St. Willibrord en de Onze Lieve Vrouwenkerk. Hij ontwierp ook het katholieke weeshuis aan de Maliesingel in Utrecht. Bovendien bouwde hij kerken in Duitsland, waar hij zich in 1906 vestigde. In 1920 overleed hij in Düsseldorf. ${ }^{104}$

Mengelberg was in 1837 in Keulen geboren als zoon van protestantse ouders, maar had zich tot het katholicisme bekeerd. ${ }^{105}$ Hij overleed in Utrecht in 1909 . Hij was opgeleid aan de Keulse Dombauhütte en werkte vanaf 1869 in Utrecht. Hij vervaardigde houten en stenen altaren en kerkbeelden. In Utrecht ontstond onder zijn leiding wat Rogier 'een grootbedrijf van kerkelijke kunst' noemde, dat 'een zondvloed van neogotische kerkmeubelen en beelden over alle gewesten uitgoot'. ${ }^{106}$ Mengelberg had zijn bedrijf aan de Maliebaan. In 1893 werkten hier 27 mannen. Twee jaar later was dat aantal opgelopen tot 36 mannen en vier jongens en in 1900 telde het bedrijf 43 mannen en negen jongens. Voor Mengelberg werkten ook zijn broers en later zijn zonen. 'Mengelberg was', aldus Brom, 'een overstelpend productief talent en strooide werken wijd om zich heen: vleugelaltaren met panelen en gesneden groepen, geschilderde of geboetseerde kruiswegen, reeksen heiligenbeelden, allemaal even vlot geleverd door de welbespraakte kunstenaar'. ${ }^{107}$ Mengelbergs onderneming was succesvol. In het gemeenteverslag van 1890 werd geschreven: 'Wat Mengelberg als beeldhouwer presenteerde, heeft hem zoo hier te lande als elders een gevestigde naam verzekerd. ${ }^{108}$ Mengelberg werkte niet alleen voor Nederlandse kerken. In 1892 meldde het gemeenteverslag dat Mengelberg belangrijke orders voor de Dom van Keulen uitvoerde, maar ook veel beeldhouwwerk had voor het universiteitsgebouw in Utrecht. ${ }^{109}$ De trend zette zich voort. In 1893 bloeide de zaak van Mengelberg, 'vooral op het gebied van kerkwerk' en had veel bestellingen uit het buitenland. ${ }^{110}$ In 1895 is te lezen in het gemeenteverslag: 'Beeldhouwkunst werkt zeer veel voor het buitenland; bezwaar is, dat de benoodigde grondstoffen uit het buitenland moeten worden aangevoerd; hierop zijn zooveel inkomende rechten, dat men er sterk over denkt deze voor de gemeente zoo belangrijke industrie naar het buitenland te verplaatsen. ${ }^{\text {,11 }}$ Zover kwam het niet. 'De welbekende beeldhouwer Mengelberg mocht zich in meer dan voldoende opdrachten verheugen; de waardering van zijn kunst bij onze naburen was oorzaak dat hij in Keulen een tweede atelier deed inrichten. ${ }^{\text {'112 }}$

Van Heukelum legde de gildenleden een bepaalde dwang op, waarbij ze moesten werken volgens zijn interpretatie van de gotiek. Dat weerhield Mengelberg er niet van om daarnaast in Romaanse stijl te werken wanneer zijn Duitse opdrachtgevers daarom vroegen. Van Heukelum kon de drukke Mengelberg, die volgens Brom 'met zijn hand evenmin als met zijn mond ooit zuiver Nederlands leerde' slechts tot op beperkte hoogte beïnvloeden. ${ }^{113}$

Mengelberg rekruteerde voor zijn bedrijf beeldhouwers uit Duitsland. In 1878 kwamen bijvoorbeeld Georg Sigler en Wilhelm Boudriat uit Keulen naar Utrecht. ${ }^{114}$ In totaal kwamen er tussen 1849 en 1879 veertien Duitse beeldhouwers, merendeels aan het einde van de jaren zeventig. Later volgden er meer. De beeldhouwers waren vrijwel allemaal katholiek en kwamen overwegend uit de buurt van Keulen. Het waren allemaal 
mannen en met uitzondering van Mengelberg zelf, arriveerden ze zonder familie. Mengelberg stelde in zijn werkplaats niet alleen beeldhouwers te werk, maar ook timmerlui, schilders en vergulders. Brom heeft het over 'Duitse borstels' die de 'Utrechtse kathedralen volspatten'. ${ }^{115}$ De werklieden van Mengelberg woonden niet geconcentreerd. Ze woonden in de wijken I en K, in de buurt van Mengelbergs werkplaats, en ook in logementen binnen de singels. Hierdoor is niet precies vast te stellen hoeveel van

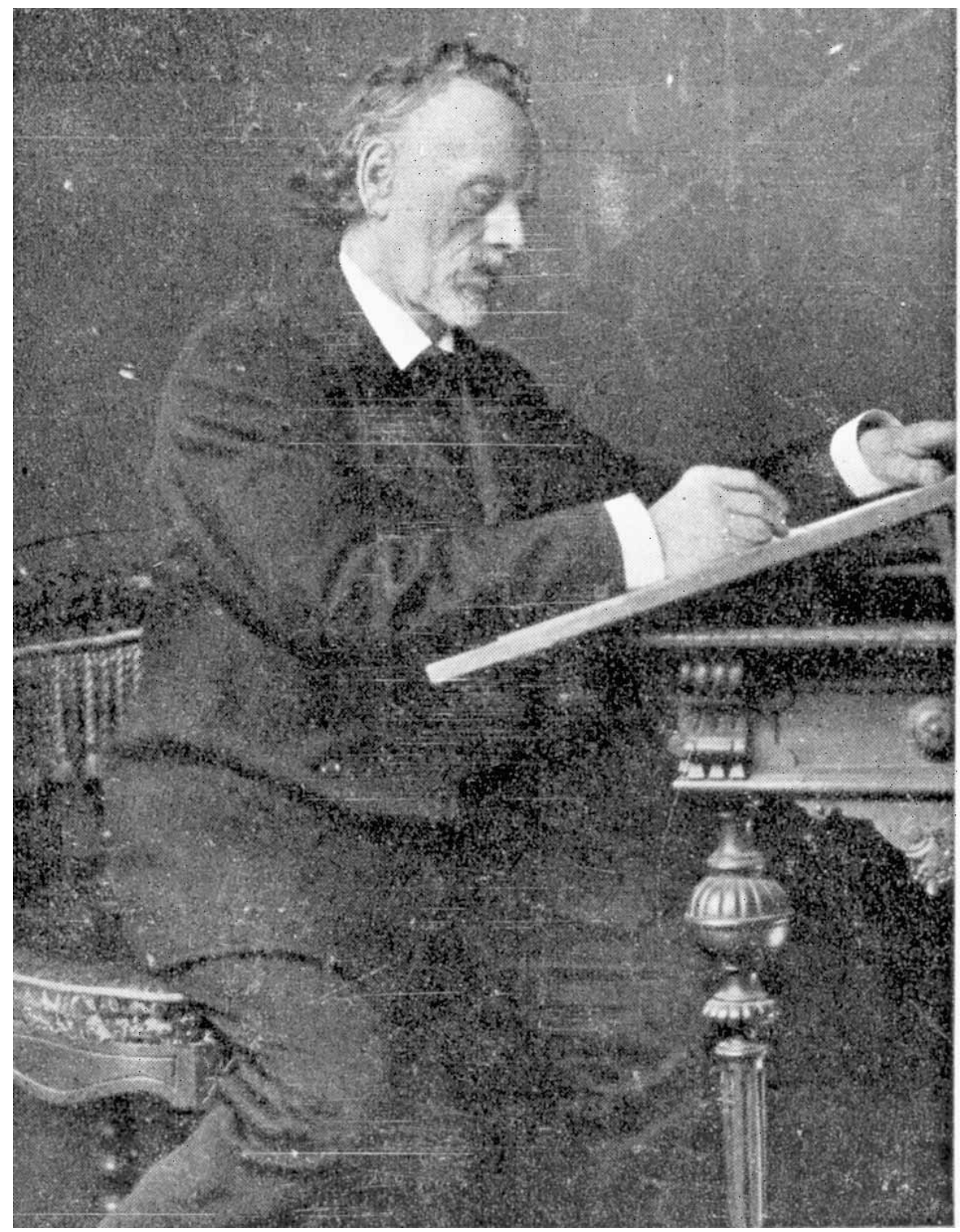

Friedrich Wilhelm Mengelberg.

Het Utrechts Archief C.50.348. 
de Duitse timmerlui, beeldhouwers en schilders die Utrecht woonden en werkten, precies tot de groep rond Mengelberg moeten worden gerekend. De veertien beeldhouwers vormen een minimum aantal.

De glasschilder Heinrich Geuer werd in 1841 geboren in Keulen. In 1871 werd hij door Van Heukelum uit Keulen aangetrokken en nam hij zijn intrek in een huis in de Zonsteeg in de Utrechtse wijk I, samen met twee andere Keulse glasschilders. In 1875 trouwde Geuer met de Duitse Josephina Stein, die zich kort daarvoor uit Duitsland bij hem had gevoegd. Beiden waren katholiek. Bij de familie voegden zich nog een vierde Duitse glasschilder en een Duitse dienstbode. Geuer makkte geschilderd en gebrand glas voor binnen- en buitenlandse kerkgebouwen. ${ }^{116}$ Er werkten zeven Duitse glasschilders in Utrecht, allen katholieke mannen afkomstig uit Keulen. Net als de beeldhouwers van Mengelberg kwamen zij zonder familie. Ze kwamen pas na 1871. De grootste roem van Geuer moest toen nog beginnen. Later werden zij, evenals de beeldhouwers van Mengelberg, gevolgd door andere Duitse glasschilders uit Keulen. Zowel bij de glasschilders als bij de beeldhouwers overheersten Duitsers het vak.

De betekenis van Duitse immigranten onder de kerkenbouwers nam tegen de eeuwwisseling af. Brom schreef: 'Binnen vijf en dertig jaar beleefde, bij wijze van voorbeeld, de oude kerk in Zevenaar drie volgende trappen van Utrechtse beweging: in 1870 vergroot volgens het ontwerp van een Duitser, dan door een halve Duitser met toren uitgebreid en eindelik aan de restauratie van een echt Nederlandse Gildebroeder toevertrouwd. De krachten hoefden niet langer geleend, niet eens meer verplant te worden, sinds ze hier zelf groeiden aan de vruchtbare boom van Sint Bernulf.' ${ }^{117}$

Bescherming door Van Heukelum betekende werk voor de gildenleden. Van Heukelum voelde zich verantwoordelijk voor de mensen die hij had aangetrokken. 'Na deze krachten op eigen verantwoording naar Utrecht gehaald te hebben, moest hij ze trouw beschermen. ${ }^{\text {118 }}$

Het Bernulphusgilde was een Duitse vereniging omdat Duitse kunstenaars er de boventoon voerden. De leden van het gilde waren niet allemaal Duits. De betekenis van het gilde voor de Duitse gemeenschap in Utrecht strekte zich uit tot voorbij de gildenleden. De Duitse kunstenaars haalden Duitse werklieden - beeldhouwers, glasschilders, timmerlui, schilders en vergulders - naar Utrecht, die net als hun werkgevers katholieken uit de omgeving van Keulen waren. De Shelfish-club, die door de Bernulfiaan Heinrich Geuer werd opgericht, was min of meer een cultureel nevenverschijnsel van het Bernulphusgilde.

\section{De Shelfish-club}

Het Bernulphusgilde was tegelijkertijd een organisatie die aan de kerkenbouwers bescherming bood op het economische vlak - door afbakening en monopolisering van een sector - en het was een organisatie op cultureel gebied, met een uitgesproken Duitse identiteit. Die identiteit was onderdeel van de afbakeningsstrategie. 
De Shelfish-club was een onderafdeling van de in 1883 opgerichte Utrechtsche Kunstkring. In de Shelfish-club verenigden zich enkele leden die 'moeder natuur zeer ruim bedeeld had met de gave die in Nederland betrekkelijk schaars wordt aangetroffen': spotzucht of uitbundigheid. ${ }^{119}$ 'Een der leden van den Kunstkring was de glasschilder H.J.J. Geuër in de Heerenstraat, een Duitscher.' De historicus Van Dokkum beschreef de oprichting van deze club als volgt:

[Geuer] klaagde op één van de Kunstkring-avonden in een "hoogfideele" stemming, zijn nood, dat hij hier in Utrecht de vroolijke avonden missen moest, die men in zijn geboortestad Keulen "schelvisch-avonden" noemde, omdat ze met een schelvisch-maal besloten werden. Er gebeurde daar, wat de Duitschers "Unsinnmachen" noemen. Er werden moppen getapt, jolige liedjes gezongen, voordrachten geïmproviseerd, potpourri's in elkander geflansd, om kort te

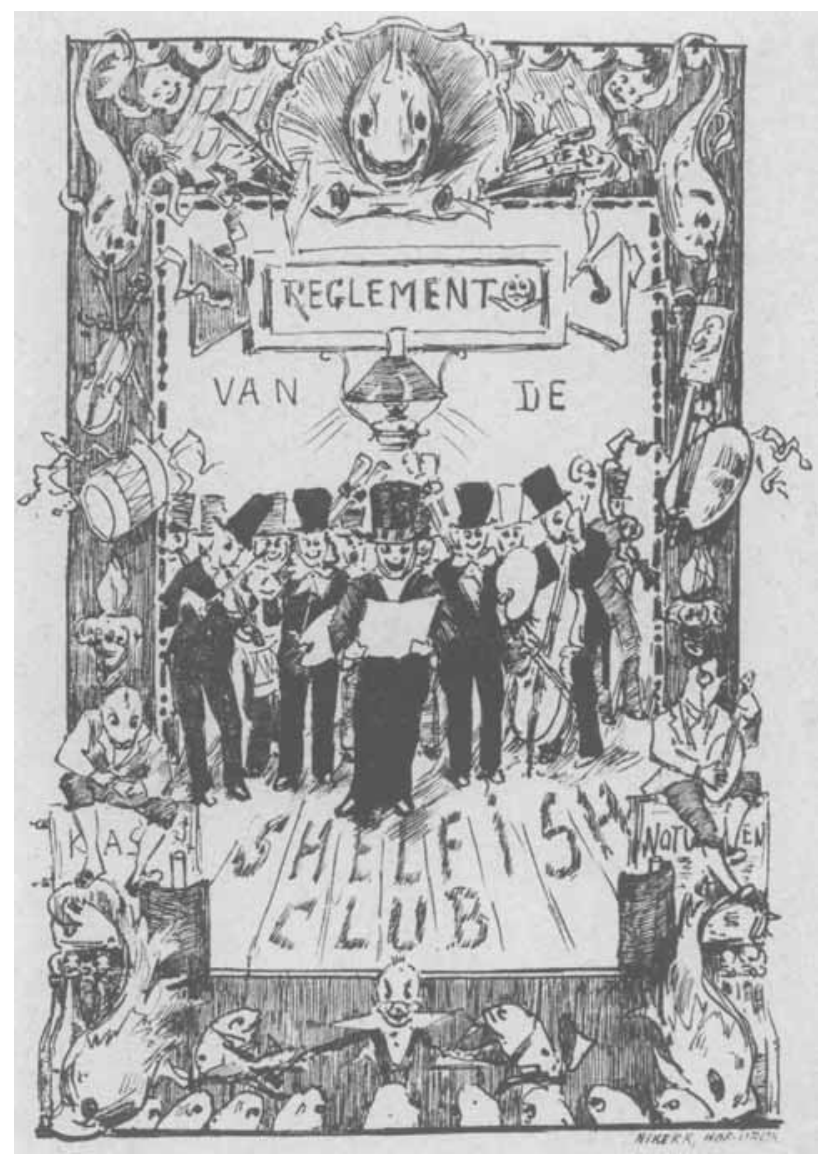

Reglement van de Shelfish club, opgericht door de Duitser Heinrich Geuer, die in Utrecht het Duitse Unsinnmachen miste. Het Utrechts Archief, Archief Shelfish club XLII F 1. 
gaan: het waren avonden, om de geheele wereld te vergeten. De Duitscher vertelde dit alles met tranen van 'Sehnsucht' in de stem ... en toen, opeens, gebeurde het wonder: het vroolijke kringetje kwam spontaan tot de ontdekking, dat men coûte que coûte hier ook zulke schelvisch-avonden hebben moest, al was het dan ook alleen met de jool en zonder de schelvisch. ${ }^{120}$

De eerste bijeenkomst was een succes en spoedig werd besloten de 'geslaagde Duitsche uitvinding' in vaster vorm te gieten. 'Zijn naam, het woord "schelvisch" met een sterk Duitsch accent uitgesproken bracht hij mee ter wereld.' Het met een Duits accent uitgesproken 'schelvisch' werd geschreven als het Engelse 'Shelfish' (maar met slechts een 1), als grap en ter mystificatie van de oorsprong van de club. 'Het was slechts half haar schuld, dat men haar voor een Engelsche aanzag ... is 't niet vreeslijk, zij, uit een Duitsche gedachte geboren! ${ }^{121}$

De Shelfish-club was een 'Duitse' vereniging omdat een gemis aan een bepaalde sfeer aan de oprichting ten grondslag lag. De club was echter geen Duitse vereniging waar het ging om de leden of de stukken die werden opgevoerd. Ledenlijsten zijn niet bewaard, maar er zijn geen aanwijzingen dat alle leden Duits waren. In ieder geval waren de mensen die in programmaboekjes werden vermeld niet Duits. De muziekstukken die werden opgevoerd waren dat overigens weer wel, maar dat gold voor veel stukken in de negentiende eeuw.

\section{Muzikanten en muziekmeesters}

De Rotterdamse havenarbeider Hein Mol noemde ze in zijn memoires 'de Oempa's', Duitse straatmuzikanten die van de ene plaats naar de andere trokken. ${ }^{122} \mathrm{Zij}$ hielden van een glas bier, vertelden graag in gebroken Hollands een mop en handelden daarnaast zo'n beetje in Duitse pijpen. 'Het was een schamel stukje brood, dat deze hard werkende menschen verdienden, die in clubjes van zes tot acht man "den boer" op gingen.' De Oempa's speelden op bruiloften en partijen. De groepen bestonden alleen uit mannen, hun betaling soms alleen uit bier. ${ }^{123}$ Rondreizende groepen Duitse muzikanten waren ook in andere Europese landen een gebruikelijke verschijning. Het ging gedeeltelijk om seizoensmatig werkende straatmuzikanten. ${ }^{124}$

Voor de sociale infrastructuur van de Duitse immigrantengemeenschap waren de Oempa's minder belangrijk dan de permanent in de stad wonende Duitse muziekmeesters. Daarvan waren er in totaal zes. De muziekmeesters behoorden tot de betere stand en hadden gedeeltelijk een band met het leger. Als voorbeeld kan Jacob Umland worden genoemd. Umland werd geboren in Freyburg, een plaats in Thüringen tussen Erfurt en Leipzig. Uit deze omgeving trokken meerdere muzikanten naar Nederland. ${ }^{125}$ Een deel van hen diende als muzikant in het Nederlandse leger. $\mathrm{Na}$ het verlaten van het leger vonden zij als muzikanten in de burgersamenleving emplooi. Bezuinigingen in 1843 leidden tot opheffing van vrijwel alle militaire muziekkapellen en daarmee tot een 
toename van het aantal Duitse muzikanten dat buiten het leger een bestaan zocht. In Denemarken vinden we Duitse immigranten die eenzelfde functie in leger en samenleving vervulden. ${ }^{126}$

In de Utrechtse muziekwereld waren Duitse immigranten belangrijk. Enkelen hadden zelfs een spilfunctie in het sociale leven. Dit gold voor de katholieke Johann Kufferath. Hij werd in 1797 geboren in Mühlheim aan de rivier de Ruhr en was ge-

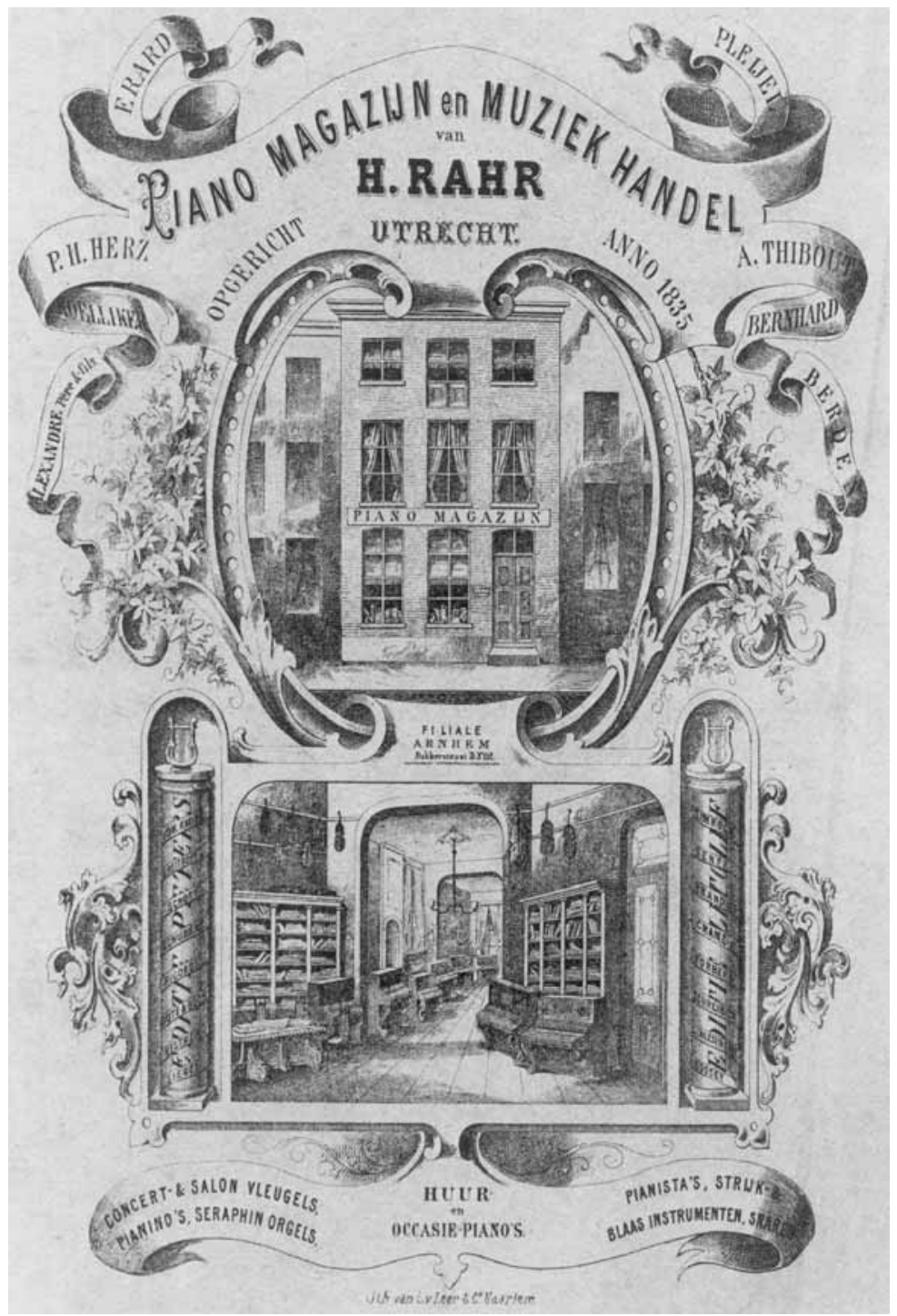

De winkel van Henry Jacques Rahr omstreeks 1880. Rahr speelde een centrale rol in het Utrechtse muziekleven.

Het Utrechts Archief C.50.466. Tc.22.7. 
trouwd met de Duitse Elisabeth Reintjes. ${ }^{127}$ Het echtpaar woonde veertig jaar op het Oud Munsterkerkhof (Domplein) in het centrum van de stad. Kufferath werd in 1829 door de gemeente aangesteld als 'Stadsmuziekdirecteur' van Utrecht. De Domstad had in de negentiende eeuw een bloeiend muziekleven met talloze gezelschappen en verenigingen, die actief werden ondersteund door het gemeentebestuur. ${ }^{128}$ De muziekdirecteur was verantwoordelijk voor de bezetting en de repertoirekeuze van het stadsorkest en voor het muziekonderwijs. Voor zijn benoeming in Utrecht speelde Kufferath in het Pruisische leger en was hij muziekdirecteur te Bielefeld. Hij werd door de Duitser J.H. Lübeck, stadsmuziekdirecteur in Den Haag, aanbevolen in Utrecht. ${ }^{129}$ In de bijna veertig jaar dat Kufferath in Utrecht in de muziekwereld actief was, drukte hij zijn stempel op de keuze van het repertoire en de bezetting. ${ }^{130}$ Talloze Duitse solisten werden naar Utrecht gehaald. Nederlandse muzikanten reisden door het toedoen van Kufferath veelvuldig naar Duitse steden om daar hun muzikale opleiding te voltooien. ${ }^{131}$

Een belangrijke rol in het muzikale leven van Utrecht speelde ook de protestantse Henry Jacques Rahr. Hij werd in 1809 geboren te Xanten in Pruisen, als zoon van een bierbrouwster uit Wesel, en kwam naar Utrecht als student in de godgeleerdheid. Toen hij 26 was en nog in zijn studententijd, verwekte hij een kind bij de 22-jarige Maria van Boom, dochter van een muziekmeester wonende aan de Kromme Nieuwegracht. Het kind werd op 22 juni 1835 geboren en een maand later geëcht bij het huwelijk tussen Rahr en Van Boom. Rahr werd muziekhandelaar en woonde, vergezeld van een met de jaren toenemend aantal kinderen aan de Oudegracht. ${ }^{132}$

Rahr verkocht naast bladmuziek, ook piano's waarvan hij er in zijn winkel een groot aantal had uitgestald. Tevens verkocht hij tweedehands piano's en repareerde en stemde hij piano's aan huis. ${ }^{133}$ Rahr benadrukte in zijn advertenties zijn band met Duitsland. Hij vermeldde dat hij in Nederland en de koloniën de enige vertegenwoordiger was van de fabriek Haake in Hannover. ${ }^{134}$ Rahr maakte deel uit van tal van gezelschappen en organiseerde met grote regelmaat concerten in het gebouw voor Kunsten en Wetenschappen aan de Mariaplaats. ${ }^{135}$

\section{De Liedertafel Aurora}

Waar de ene onderzoeker de kerk - en dan bij uitstek de lutherse kerk - aanwijst als cruciaal voor het behoud van het Deutschtum, wijst een ander op taal of eetgewoonten. De Amerikaanse historicus Bohlman is van mening dat een centrale rol in het behoud van een Duitse identiteit is weggelegd voor het zingen. ${ }^{136}$ Duitse immigranten in de Verenigde Staten zongen langer samen in het Duits, dan dat ze met elkaar Duits spraken. Het samen zingen was ook essentieel voor het vormen van een Duits-Amerikaanse identiteit. Het was iets dat Duitse immigranten verbond, ongeacht hun regionale herkomst of hun religieuze gezindheid. Zangverenigingen waren toegankelijk voor Duitse mannen met een zeer diverse achtergrond. Het samen zingen was daarbij niet zozeer 
belangrijk voor het behoud van een oorspronkelijke regionaal bepaalde identiteit, als meer voor het creëren van een nieuwe identiteit als Duitse immigrant in Amerika.

De mannenzangverenigingen zijn niet alleen vanuit deze optiek interessant. In het bovenstaande is meerdere malen gerefereerd aan de vraag wanneer een vereniging kan worden aangemerkt als een organisatie van Duitse immigranten. Het antwoord op deze vraag bleek steeds niet simpel. De casus van de mannenzangverenigingen of Liedertafeln illustreert heel mooi de hybriditeit van verenigingen. Moesten de Nederlandse Liedertafeln de gevoelsmatige eenheid van de Nederlanders versterken, zoals de Liedertafeln in Duitsland naar grotere Duitse eenheid streefden? En hoe kon dat als een groot deel van de leden Duits was? Of moeten we de Liedertafeln meer zien als immigrantenorganisaties van Duitsers waarin ook Nederlanders een plaats konden vinden? De historici Panayi en Nadel beschouwen de Liedertafeln in respectievelijk Londen en New York vooral als immigrantenorganisaties, maar de positie van de verenigingen daar was anders dan die in landen die grensden aan het wordende Duitsland, zoals België, Nederland en Denemarken. De mannenzangverenigingen in Nederland en elders waren geen exclusief Duitse organisaties. Tegelijkertijd waren ze een exponent bij uitstek van het verenigingsleven van Duitse immigranten. 'But no description of German life, be it Verein or home life, can be complete without reference to the Lied. Every Verein [...] has its Lieder-Tafel [...]', schreef Armfelt in 1903 over de Duitse immigranten in Engeland. ${ }^{137}$ Hetzelfde werd gezegd over Duitsers in Kopenhagen of New York. ${ }^{138}$ De Liedertafel was wat Duitsers in de verstrooiing met elkaar gemeen hadden.

In Duitsland waren de Liedertafeln boegbeeld van het streven naar nationale eenheid. De eerste Liedertafel werd in 1809 in Berlijn opgericht. ${ }^{139}$ Er ging een sterke samenbindende werking uit van het gezamenlijk zingen. Bovendien vormden de zangverenigingen in Duitsland in de jaren 1840 een alternatief voor de verboden of met argwaan bekeken politieke organisaties. Het idee van de Liedertafeln vond snelle verbreiding naar andere landen. Het karakter van de Liedertafeln buiten Duitsland veranderde in de loop der tijd. De Liedertafeln die in Vlaanderen werden opgericht, zijn van deze verschuiving een mooi voorbeeld. De Vlaamse Liedertafeln, die in 1844 als een VlaamsDuits zangersverbond het licht zagen, combineerden een streven naar Vlaamse eenheid en emancipatie met een keuze voor Duitsland en tegen Frankrijk. Tot het Vlaams-Duitse zangersverbond traden meerdere, reeds bestaande zangverenigingen toe, die onder hun leden Duitse immigranten telden, maar het verbond werd niet opgezet als een Duitse immigrantenorganisatie. De Vlaamse Liedertafeln wilden gelijktijdig de Vlaamse cultuur en de band met Duitsland versterken. Volgens de Nederlandse historicus Von der Dunk zagen de Duitse zangverenigingen hun Vlaamse tegenhangers vooral als verbreiders van de grootduitse gedachte, net zoals de zangverenigingen in Sleeswijk-Holstein de Duitse aansluitingsbeweging daar hadden versterkt. De Kölnische Zeitung noemde het doel van het Vlaams-Duitse zangersverbond 'die Niederreißung der Grenzen zwischen Nieder- und Oberdeutschland, um ein gemeinsames Bollwerk der Brüdervölker zu schmieden gegen den Feind von außen. ${ }^{140}$ Met Niederdeutschland werden Nederland en Vlaanderen bedoeld, de vijand was Frankrijk. Bij de 
oprichting van de Vlaams-Duitse zangersbond was de kiem voor tweespalt reeds aanwezig. Vlamingen vonden dat hun Duitse collega's teveel gericht waren op het Duitse nationalisme; de Duitsers verweten de Vlamingen een te geringe betrokkenheid bij het Duitse nationalisme. De identiteit van het verbond werd nog moeilijker te duiden toen de Belgische overheid - met een blik op de eenwording van Duitsland - in de zangverenigingen een middel ter versterking van de Belgische - en niet de Vlaamse - eenheid zag en besloot de verenigingen te subsidiëren. Enigszins tegengesteld aan de oorspronkelijke bedoelingen van het Vlaams-Duits zangersverbond, traden vervolgens ook twee Waalse zangverenigingen toe tot deze organisatie. Het Vlaams-Duitse zangersverbond maakte zo een interessante evolutie door. Druk van de Duitse zusterorganisatie om meer waarde te hechten aan de grootduitse gedachte, leidde tot tweespalt binnen de Vlaamse vereniging, met als uiteindelijke uitkomst dat de vereniging minder op Duits-

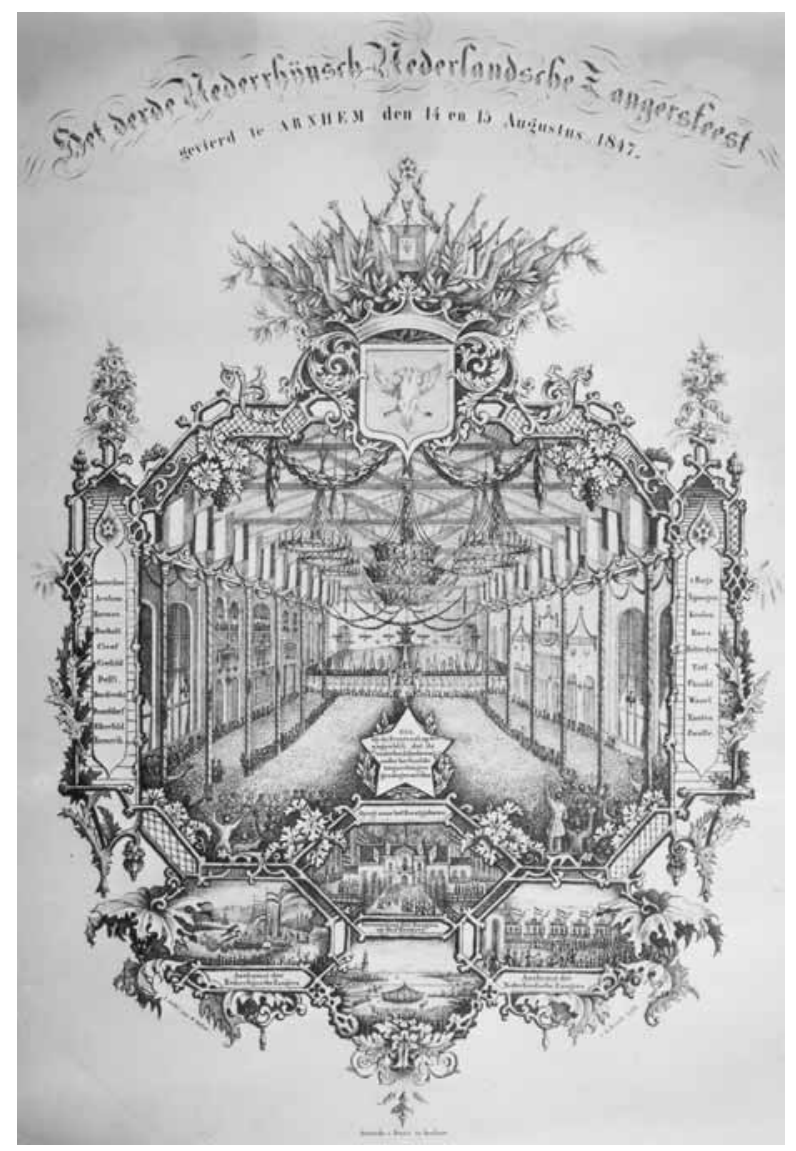

Aankondiging van het derde Nederrhijnsch-Nederlandsche Zangersfeest op 14 en 15 augustus 1847 in Arnhem. Tussen 1845 en 1852 hielden de Nederlandse en Duitse mannenzangverenigingen gezamenlijke zangfeesten. Na 1852 kwamen er afzonderlijke feesten voor beide landen. 
land georiënteerd raakte en uiteindelijk zelfs meer een Belgisch dan een Vlaams karakter kreeg.

In het Deense Kopenhagen nam het lot van de Liedertafel een andere wending. De Deense Liedertafeln hadden zich een groot voorstander getoond van nauwere banden met het zich verenigende Duitsland. Nadat Sleeswijk en Holstein Duits waren geworden, werden de anti-Duitse sympathieën in Denemarken sterker. Dit had gevolgen voor de Liedertafeln. Anti-Duitse sympathieën makten de zangverenigingen meer Duits. In de statuten van de Deense Liedertafel werd in 1867 expliciet gesteld dat alleen Duitse immigranten en hun zonen lid konden worden. Deze eis verdween weliswaar drie jaar later, maar de officiële taal van de vergaderingen, zo werd in de statuten vastgesteld, bleef Duits. Als reactie op de anti-Duitse houding trokken de Duitse immigranten zich in hun eigen organisaties terug. ${ }^{141}$

Waren de Nederlandse Liedertafeln vergelijkbaar met de Britse en de Amerikaanse of eerder met de Belgische of de Deense? De Liedertafeln ontstonden in Nederland aan het begin van de negentiende eeuw. ${ }^{142}$ Tussen 1827 en 1915 werden in Nederland een kleine vijfhonderd van deze mannenzangverenigingen opgericht, met als eerste een Liedertafel in Dordrecht in 1827. De Nederlandse Liedertafeln stonden veelal onder Duitse leiding, gebruikten Duitse les- en studiemethoden en zongen zonder uitzondering Duits repertoire. Tussen 1845 en 1852 werden door Nederlandse en Duitse mannenzangverenigingen de jaarlijkse Nederrijns-Nederlandse Zangerfeesten gehouden, afwisselend in Kleef en Arnhem. Na 1852 nam de Duitse belangstelling voor deze gezamenlijke feesten af. In Nederland deed zich daarna een explosieve groei voor van het aantal Liedertafeln. In 1853 vormden 25 Nederlandse Liedertafeln hun eigen Nationaal Nederlands Zangersverbond, dat in Arnhem zijn eerste Nationaal Nederlands Zangersfeest hield.

In Duitsland werden de zanggezelschappen, zoals gezegd, gezien als een steun voor het zich ontwikkelende nationalisme. Eenzelfde rol konden de Nederlandse gezelschappen voor Nederland niet vervullen zolang ze in het Duits zongen. De overkoepelende organisaties van de zanggezelschappen probeerden daarom het Nederlandse element te versterken door op nationale en regionale concoursen Nederlands repertoire verplicht te stellen. Er werden componisten uitgenodigd om Nederlandse liederen te schrijven en Nederlandse methoden te ontwikkelen. Hiermee werd een vernederlandsing van de zangverenigingen ingezet.

In Utrecht was er de Liedertafel Aurora, opgericht in 1845 door de Nederlander F.C. Kist. In het eerste jaar had deze vereniging zestig leden. Aurora verschilde van de reeds bestaande Utrechtse zanggenootschappen omdat er in Duitse Liedertafel-stijl gezongen werd, zittend aan tafels. ${ }^{143}$ De ledenlijsten van Aurora zijn bewaard gebleven. Alleen mannen waren lid van de zangvereniging. Aurora kende werkende leden en buitengewone leden. Beide soorten leden zongen - de ledenlijsten vermeldden hun zangstem maar de werkende leden lijken vooral te zijn aangezocht vanwege hun goede stem. De werkende leden betaalden minder contributie dan de buitengewone leden. De buiten- 
gewone leden mochten zonder extra betaling gasten meenemen naar de uitvoeringen, zo blijkt uit de ledenadministratie.

Op de ledenlijsten van de Liedertafel Aurora komen honderden namen voor. Tussen 1847 en 1864 werden 179 werkende leden ingeschreven en meer dan driehonderd buitengewone leden. Hoeveel leden de vereniging precies op enig moment telde, is niet duidelijk, omdat data van in- en uitschrijving onvolledig vermeld zijn. Bovendien werden sommige leden meerdere keren ingeschreven; ze bedankten of werden wegens het niet betalen van contributie geroyeerd, om later opnieuw lid te worden. Omdat de inen uitschrijfdata niet volledig bekend zijn, is het niet mogelijk het percentage Duitse leden precies te berekenen. Een schatting, op basis van het percentage Duitsers onder de inschrijvingen, kan wel worden gegeven; ongeveer één op de vijf leden was Duits. Duidelijk is dat de Liedertafel geenszins een exclusief Duitse vereniging was, zoals de Deense dat op een gegeven moment wel was. Het was meer een algemene vereniging die voor Duitse immigranten en anderen openstond.

Had de Liedertafel de verenigende functie die Bohlman vond voor Amerika? Aurora stond inderdaad, zoals dat ook gold voor de Amerikaanse verenigingen, open voor mensen uit verschillende geloofsgroepen. Onder de leden vinden we de Nederlandsjoodse advocaat Salomon van Lier en zijn Duitse geloofsgenoot Ludwig Mond uit Kassel. Monds lidmaatschap van de Liedertafel is opvallend omdat hij slechts kort in Utrecht woonde. Onder de Liedertafel-leden vinden we de grote katholieke Duitse winkeliers zoals Bohlen, Van der Sandt, Thueré en Stuckenborg en de protestantse Duitse werktuigkundige Carl Grothe. De protestantse pianohandelaar Rahr was, gezien zijn beroep enigszins voor de hand liggend, eveneens lid van de Liedertafel. De glazenier Geuer, de eerdergenoemde oprichter van de Shelfish-club, was ook lid, evenals de Duitse stadsmuziekdirecteur Kufferath. ${ }^{144}$ Opvallend is verder dat we onder de Nederlandse leden ook H.J. Vernède aantreffen, de voorzitter van de Utrechtse afdeling van de Gustaaf Adolf Vereeniging. Voorts vinden we onder de Liedertafel-leden niet alleen Duitse immigranten. De grote katholieke Belgische strohoedenfabrikant Eustache Frenay zong er de bas.

De tot nu toe genoemde leden behoorden min of meer tot de Utrechtse elite. Er waren ook leden die daar iets onder zaten zoals de lutherse spoorwegbeambte Julius Haagen uit Düsseldorf, zijn protestantse collega Friedrich Wustenberg uit Neuenkirchen, de protestantse onderwijzer Julius Hisgen uit Emmerich en Johannes Lohrmann, een protestantse mandenmaker uit Fulda in Hessen-Kassel. Bij katholieke Duitsers vinden we onder meer de winkelbediende August Kleine uit Münster, de portretschilder en fotograaf Frederich Kaijser uit Hamm in Westfalen, de tapper Johannes Schröder uit Delmenhort in Oldenburg, de koopman-logementhouder Mathias Veerkamp uit Hopsten en de koopman Johann Veltmann uit Nordhorn. Zoals uit deze opsomming blijkt, stond Aurora open voor mensen uit meerdere lagen van de bevolking met uiteenlopende regionale en religieuze achtergronden.

Onder de buitengewone leden bevonden zich de lutheranen Theodor Finger, instrumentmaker uit Görne, Christoffel Meijer, verhuurder van paarden en rijtuigen uit 
Dibbersen in Brunswijk en de spoorwegbeambte Ludwig Peacock uit Hamburg, en de protestanten Johannes Bierhaus uit Wirth in Pruisen, belastingontvanger, Johan Büdde, koopman uit Bentheim en katoenfabrikant Ludwig Amelung uit Wesel. Opvallend is dat er onder de buitengewone leden, in tegenstelling tot bij de werkende leden, geen katholieke Duitsers voorkomen.

De Westerwalders, de grootste groep Duitse immigranten in Utrecht, ontbreken volledig in het ledenbestand van de Liedertafel. Mogelijk behoorden de Westerwalders tot een andere zangvereniging; Aurora was immers niet de enige vereniging in Utrecht. Om deze veronderstelling te toetsen heb ik gekeken naar het ledenbestand van de concurrerende grote vereniging: de Koninklijke Utrechtsche Mannenzangvereeniging (UMZV). ${ }^{145}$ De UMzV werd opgericht in 1849, dus vier jaar na de Liedertafel Aurora. Men kon slechts lid worden op voordracht en door ballotage. Leden van Aurora werden expliciet uitgesloten van lidmaatschap. De umzv was ongeveer even groot als Aurora. Op de ledenlijsten staan 770 namen, maar het aantal dubbele inschrijvingen is groter dan bij Aurora. Opvallend is dat beide ledenbestanden elkaar overlappen. Mensen konden weliswaar geen lid zijn van beide verenigingen tegelijk, maar stapten klaarblijkelijk wel gemakkelijk over van de ene naar de andere zangvereniging en terug. Zo zien we bij U MZV opnieuw de Belgische strohoedenfabrikant Frenay de bas zingen, ditmaal in gezelschap van zijn collega en streekgenoot Corbesier. De U mzv kende ook andere, niet-Duitse immigranten als lid, zoals de Poolse kleermaker Glazewski. In de ledenbestanden van Aurora en de U Mzv komen we dezelfde Duitse immigranten tegen: Lohrmann, Kufferath, Geuer, Rahr, Hisgen, Wustenberg, Kaijser en Schröder waren achtereenvolgens of afwisselend lid van beide zangverenigingen. De grote katholieke Duitse winkeliers op de Oudegracht, die we bij Aurora tegenkwamen, maakten klaarblijkelijk niet de overstap naar de UMZV, maar in het ledenbestand zitten wel hun Duitse collega's zoals Maseland, Grasveld en Povel. Bij de U Mzv vinden we ook mensen die min of meer beroepshalve met muziek te maken hadden, zoals orgelfabrikant Witte, muziekmeesters Patzer en Umland en kapelmeester Rudersdorf. Opvallend is het lidmaatschap van W. Koenig, burgemeester van Kleef. Zijn lidmaatschap was waarschijnlijk symbolisch; bij de wekelijkse oefeningen zal hij verstek hebben laten gaan. Westerwalders vinden we ook in dit gezelschap niet.

Naast de UMzv en Aurora was er nog de mannenzangvereniging Fidelio, opgezet en geleid door muzikant en muziekleraar Reinholt Schirmer. ${ }^{146}$ Schirmer was luthers en werd geboren in Schwartzburg. Hij kwam in 1873 naar Utrecht. Wie er lid waren van zijn gezelschap is niet bekend. De organisatie lijkt geen lang leven beschoren te zijn geweest en heeft weinig sporen nagelaten.

Waarom is het ontbreken van de grootste minderheid in deze zanggezelschappen opvallend? Wellicht zongen de Westerwalders 's avonds hun liedjes in hun eigen wijk, gezeten aan de waterkant, zoals Van Rijnsoever in zijn geschiedenis van de St. Martinusparochie schreef. ${ }^{147}$ Mogelijk zongen ze in het koor van de St. Martinuskerk. ${ }^{148}$ Dorpschroniqueur Fohr, die een geschiedenis van het Westerwalder dorp Ransbach schreef, noemt de zangvereniging Stets Froh die daar in de jaren 1840 werd opgericht. ${ }^{149}$ 
Wellicht namen de Westerwalders die organisatie in geformaliseerde of informele vorm mee naar Utrecht. Hun afwezigheid in de Utrechtse zangverenigingen is belangrijk, omdat het een indicatie is voor het feit dat ze, indien ze zich organiseerden, dit deden buiten de verenigingen waarin de andere Duitse immigranten een plaats vonden.

\section{Studentenverenigingen}

Toen Carl graaf von Wedel in de eerste helft van de negentiende eeuw naar Utrecht kwam om rechten te studeren, besloot hij zich verre te houden van het Utrechtse studentenleven. ${ }^{150}$ Hij had reeds twee jaar in Göttingen gestudeerd en daar het Duitse studentenleven leren kennen met zijn gewelddadige gebruiken, zoals duelleren. Zijn Utrechtse medestudenten merkten hem echter op bij de colleges en nodigden hem uit voor hun vereniging. Hij liet zich uitvoerig voorlichten door de pedel van de vereniging. De ontgroening, waarbij hem een narrenkap zou worden opgezet, achtte hij beneden zijn waardigheid en het corps onthief hem van deze verplichting, omdat hij reeds in Göttingen had gestudeerd. Hij kreeg een aangepaste ceremonie, die zoals gebruikelijk gehouden werd in het Latijn. Daarna volgde een souper ter ere van het nieuwe lid. De taal aan tafel was Nederlands. Von Wedel bediende zich bij zijn tafelgesprek van het Frans. De pedel van de vereniging las in het Nederlands de regels van de vereniging voor. 'Ich verstand kein Wort davon'. Von Wedel werd door zijn medestudenten aangezet zich te bedrinken, maar weigerde. Een van zijn medestudenten, Van Ess genaamd, vatte dat op als een belediging en er ontstond een twistgesprek. 'Bis dahin war die Unterredung in französischer Sprache geführt, Jetzt sprang van Ess vom Stühle auf, warf mir einen wüthenden Blick zu und redete in Heftigkeit allerhand holländische Worte heraus [...].' Von Wedel nam aan dat dit beledigingen waren, werd boos en gooide zijn medestudent een wijnfles naar het hoofd, die achter Van Ess' hoofd tegen de muur uiteenspatte. Als straf gebood de pedel van de vereniging hem een bokaal wijn leeg te drinken waarin minstens een hele fles was leeggegoten. 'Mann muss die Sitten des Landes, in dem man lebt, respektieren', stelde de pedel en de straf op het gooien met flessen was het leegdrinken van de bokaal, zo was Von Wedel tijdens de tafelrede verteld. 'Ich verstehe kein Hollandisch' wierp hij tegen. Dan had hij het maar moeten vragen, meende de pedel en hij beval de andere studenten Von Wedel vol te gieten met wijn. Von Wedel werd boos, greep een tafelmes en wilde zich zo tegen zijn medestudenten verweren. De pedel loodste hem de zaal uit. "“Ich bedaure”, sagte er draussen, "dass van Ess durch seine Zudringlichkeit und Sie durch Ihre Unkenntniss unserer Sprache diesen ärgerlichen Auftritt herbeigeführt haben.' Von Wedel werd voor de keus gesteld. Hij kon het gezelschap verlaten, maar zou dan door alle studenten worden uitgesloten uit hun gemeenschap, of hij kon zijn straf aanvaarden, waarbij de pedel hem na enkele slokken zou ontheffen van de verplichting de bokaal geheel leeg te drinken. Von Wedel koos het laatste, keerde terug naar de zaal, dronk enkele slokken en bood ook Van Ess aan met hem te drinken. Van Ess stelde voor hem de volgende 
morgen genoegdoening te schenken. De volgende ochtend stond Van Ess plots naast het bed van Von Wedel, die schrok en dacht dat Van Ess, zoals in Göttingen gebruikelijk, genoegdoening in de vorm van een duel kwam eisen. Van Ess zei dat hij daar inderdaad op uit was. De getuigen waren reeds in het strijdperk. Von Wedel zou een wapen mogen kiezen dat op de grond gereed lag. Van Ess bracht de zeer opgewonden Von Wedel echter naar de zaal waar de vorige avond het souper was geweest. Op de grond lag slechts een dronken student. Van Ess nodigde hem uit voor een ontbijt, niet voor een duel.

Het Utrechtse studentencorps wilde Von Wedel graag als lid in de vereniging opnemen, ongetwijfeld ook omdat hij een graaf was. Von Wedel was afhoudend, gezien zijn ervaringen met het studentenleven in Göttingen. Die ervaring, samen met de taalproblemen, speelden door in zijn uiteindelijke kennismaking met de Utrechtse vereniging. Hij verwachtte elk moment voor een bloedig duel te worden uitgedaagd. Zijn Utrechtse medestudenten dreven een beetje de spot met de opvliegende Von Wedel, maar waren hem toch overwegend goed gezind. De anekdote laat zien hoe moeilijk de toegankelijkheid van verenigingen is te duiden. Von Wedel was afhoudend, zijn medestudenten drongen aan, maar taal vormde een barrière.

Het lidmaatschap van Duitse studenten van Utrechtse studentenverenigingen kan als voorbeeld dienen wanneer het gaat om de toegankelijkheid van bestaande of concurrerende organisaties. In 1861 waren van de zeven Duitse studenten die de universiteit in dat jaar telde, er vier geen lid van het Utrechtse studentencorps en drie wel. Betekent dit nu dat het corps voor Duitse studenten moeilijk toegankelijk was? We kunnen hier alleen een uitspraak over doen, wanneer we het cijfer afzetten tegen het totale percentage van studenten dat lid was van het corps. Het overzicht van lidmaatschap van het studentencorps leert dat ongeveer eenderde van de studenten geen lid was van deze organisatie. ${ }^{151}$ Onder de Duitse studenten waren de corpsleden verhoudingsgewijs dus iets minder talrijk, maar gezien het geringe aantal Duitse studenten is het verschil nauwelijks opmerkelijk te noemen.

In principe zou het lidmaatschap van het corps kunnen worden beïnvloed door de studierichting van de studenten: niet alle studierichtingen waren even goed vertegenwoordigd in het corps en de Duitsers studeerden vrijwel allemaal theologie. De studierichting, zo blijkt bij onderzoek, was echter niet bepalend. Frederik Fabricius, Harold Holm, Ludwig Metzlar en Ernst Hoffmann waren in 1861 geen lid van studentencorps. Zij studeerden allen theologie. Carl Gronemeijer en Willem Lamping studeerden ook theologie en waren wel lid van het corps. Gronemeijer was zelfs thesaurus van deze vereniging en voorzitter van het leesgezelschap ' 1798 '. Carel Lamping, een broer van Willem, studeerde medicijnen en was eveneens lid van het corps.

Duitse studenten konden natuurlijk ook hun eigen organisaties opzetten. Vreemde studenten hadden in eerdere tijdvakken een traditie waarbij ze zich verenigden in nationes of collegia nationalia. Omdat het bestaan van deze collegiën aanleiding was tot georganiseerde nachtbrakerij, werd in 1643 door het gemeentebestuur een proclamatie uitgevaardigd tegen 'nationale ofte provinciale collegiën.' Desondanks bleven de colle- 
giën vrolijk voortbestaan. ${ }^{152}$ In het midden van de negentiende eeuw vinden we in Utrecht gezelschappen als Hagania, Daventrium, Transissalania, Frisia, Ultrajectina en Roterodamum, maar een Duitse organisatie ontbreekt in het overzicht van de Studentenalmanak. ${ }^{153}$ In 1914 werd echter opgemerkt dat er in de tweede helft van de negentiende eeuw wel degelijk twee Duitse studentenverenigingen in de Domstad waren: het Verein deutscher und ungarische studenten en het Convent der deutschen und ungarischen studenten. De archieven van deze verenigingen gingen echter bij een verhuizing verloren. ${ }^{154}$

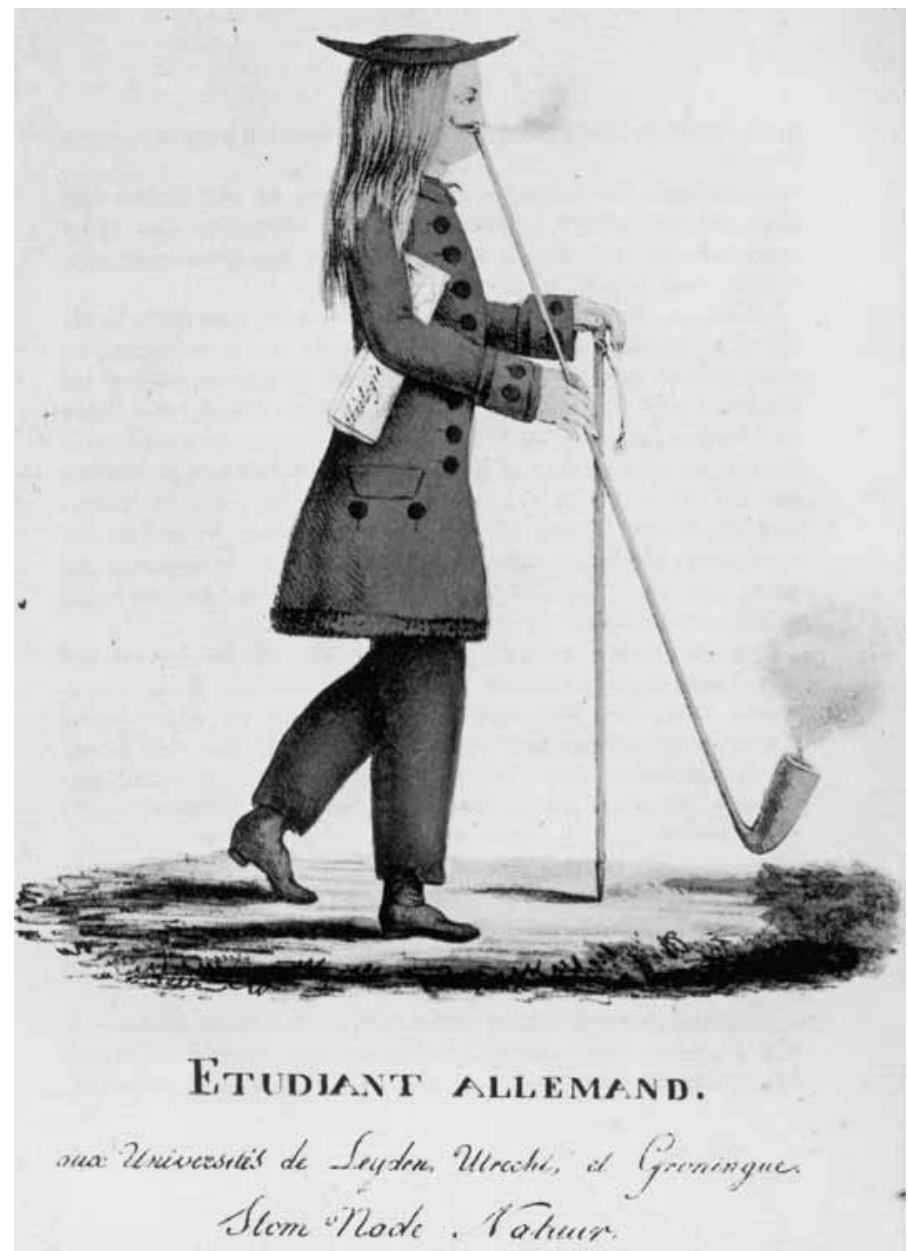

Tekening van een Duitse student, afgebeeld met een extreem lange Duitse pijp. Overgenomen uit: 'Een ontgroeningspartij te Utrecht 1809', Bijlage XXII van W.C.A. van Vredenburgh, Schets van eene geschiedenis van het Utrechtsche studentenleven (Utrecht 1914) 239-255. 


\section{Duitse kranten en turnverenigingen}

Kranten en turnverenigingen hadden een rol die vergelijkbaar was met die van de Liedertafeln. In andere landen waren de turnverenigingen typerend voor het Deutschtum. ${ }^{155}$ Deze verenigingen vonden hun oorsprong in een nationalistische en fysieke culturele beweging die door Ludwig Jahn werd opgericht in het napoleontische Duitsland. Deze beweging richtte zich op een sterk en verenigd Duitsland en werd uiteindelijk een trefpunt voor revolutionairen. De Duitse overheid beschouwde de turnverenigingen als subversieve organisaties. Tussen 1820 en 1842 werd het turnen verboden. Deze jaren werden aangeduid als de Turnsperre. De turnverenigingen verplaatsten hun activiteiten van de openlucht, waar ze aanvankelijk hadden plaatsgevonden, naar zaaltjes, en de meeste verenigingen gingen ondergronds. Na het mislukken van de revolutie van 1848 vertrokken veel 'Turners', zoals deze revolutionairen werden genoemd, naar de Verenigde Staten en stichtten daar met eerdere Duitse immigranten de German-American Turner Movement. De Turners bereidden zich voor op een nieuwe revolutionaire omwenteling in Europa. Tegelijkertijd verbreedden ze hun activiteiten met een zangvereniging, toneelclub, school, schietvereniging of schaakclub. ${ }^{156}$ De turnhallen die de Duitse immigranten in Amerika bouwden, waren het centrum van de Duitse immigrantengemeenschap en dienden voor veel meer doelen dan slechts de huisvesting van de turnclub. Behalve theatervoorstellingen en uitvoeringen van de mannenzangvereniging, werden er kerst- en carnavalsfeesten en politieke debatten gehouden. ${ }^{157}$

In Utrecht hadden de turnverenigingen geenszins een vergelijkbare functie. De belangrijkste reden daarvoor was dat de revolutionairen die Duitsland verlieten niet naar Utrecht gingen, maar eerder naar Londen en New York. Bovendien waren er in Utrecht ook algemene verenigingen die zich met turnen bezighielden. Er waren er zelfs veel. In 1861 werd geschreven: 'de Scherm- en Gymnastiek-gezelschappen te Utrecht verkeren in bloeijenden toestand'. Er waren vijf verenigingen met in totaal 338 leden. ${ }^{158}$

Er was één belangrijke Duitse 'turnimmigrant' die wel naar Utrecht kwam. ${ }^{159}$ Carl Euler (1809-1882) studeerde theologie en filosofie in Berlijn en turnde bij Ernst Eiselen, de oudste leerling van de grondlegger van het turnen, Jahn. ${ }^{160}$ In 1838 vertrok Euler naar Danzig, waar hij als turnleraar werkte. In 1843 ging hij naar Keulen, waar hij opnieuw turnonderwijs gaf en met anderen de Kölnische Turnverein oprichtte. Vervolgens gaf hij les in Bonn, Mannheim, Freiburg en Karlsruhe. In 1848 nam hij deel aan de Septemberrevolutie in Frankfurt en de Oktoberdagen in Wenen. Op advies van enkele Nederlandse officieren ging hij naar Amsterdam, waar hij als een gevluchte barricadeheld werd gezien. De Amsterdamse politie stond niet erg welwillend tegenover barricadehelden. De medicus Schröder van der Kolk haalde hem hierom vervolgens naar Utrecht. In Schets van eene geschiedenis van het Utrechtsche studentenleven werd geschreven: 
Dat men er in 1848 de gymnastiek bij ging beoefenen was het gevolg mirabile dictu! van ... politieke strubbelingen in het buitenland! In 1848 vluchtte een Duitsche "Turnlehrer", Carl Euler naar Utrecht. ${ }^{161}$

De reeds bestaande schermvereniging Olympia stelde Euler aan als turnleraar. Euler bleef slechts kort in de Domstad. In 1851 kreeg hij een baan als gymnastiekleraar in Leeuwarden en vervolgens in Haarlem. Olympia bleef ondanks Eulers vertrek als turnen schermvereniging voortbestaan. De studenten werden op de hoorcolleges opgeroepen zich bij deze vereniging aan te sluiten. In 1861 telde de vereniging 153 leden.

In 1850 werd bovendien de turn- en schermvereniging Kallistheneia opgericht. In de notulen van de eerste vergadering werd als reden voor de oprichting gegeven dat de groep, die reeds informeel bestond rond Carl Euler, in zijn geest wilde voortgaan nu deze meester naar Leeuwarden vertrok. Opvallend is het woord dat in de notulen werd gebruikt voor de mensen die de turnoefeningen moesten voordoen: voortoerners. Uit de spelling blijkt de Duitse wijze waarop het woord werd uitgesproken. Toch was ook Kallistheneia niet echt een Duitse vereniging. Van de 150 leden die de vereniging volgens de ledenlijsten in haar tweejarig bestaan kende, was er slechts één Duits.

Euler keerde nog wel eens terug naar Utrecht. In 1854 bezocht hij de stad als pleitbezorger van de Gustaaf Adolf Vereeniging. Twee jaar later publiceerde hij in het Nederlands het boek De Gymnastiek en hare invoering in Nederland. Euler woonde acht jaar in Haarlem en daarna kort in Den Haag. In 1860 ging hij naar Brussel, waar hij een gymschool opende die tot 1865 bestond. Hij overleed in 1882 in Brussel.

In 1870 werd opnieuw een initiatief genomen voor een 'Duitse' turnvereniging. In 1870 begon de Duitse kok Frederik Schulze met de 'Utr. Gmn. Ver. Milo'. ${ }^{162}$ Deze organisatie was slechts een kort leven beschoren.

De turnverenigingen waren in Utrecht minder een 'Duits' verschijnsel dan in andere landen. Het turnen was ook minder een politieke bezigheid dan in Amerika. Opmerkelijk is dat geen van de Utrechtse turnverenigingen een Duits klinkende naam had en dat geen van de verenigingen, in tegenstelling tot hun Amerikaanse en Engelse tegenhangers, het Duitse woord Verein gebruikte in hun naam.

De turnclubs vertonen op bepaalde punten overeenkomsten met de Duitse kranten. De kranten waren in Utrecht - en in de rest van Nederland - evenals de turnverenigingen van minder betekenis dan in bijvoorbeeld Amerika. Zodra een Duitse gemeenschap enige omvang bereikte, werd er in Amerika een Duitstalige krant uitgegeven. In Nederland lag dat anders. In Amerika werden de Duitstalige kranten, net als de turnverenigingen, opgericht door migranten die Duitsland ontvluchtten na de Revolutie van $1848 .{ }^{163}$ In Nederland ontbrak deze drijvende kracht. Voor een krant was de basis van de Duitse gemeenschap ook te klein in Utrecht. Die basis werd nog eens versmald door de religieuze heterogeniteit van de migrantenpopulatie. Een Duitse krant kon katholieke of protestantse lezers trekken, maar geen lezers uit beide geloofsgroepen.

Een belangrijke andere reden voor het ontbreken van een Duitse krant was, dat er in Nederland ook in Duitsland gedrukte kranten - zoals de Kölnische Zeitung - los kon- 
den worden gekocht. Door het postrecht werden buitenlandse kranten in Nederland wel extra zwaar belast en bijgevolg waren ze duur. Buitenlandse kranten konden echter worden gelezen in sociëteiten en koffiehuizen. Bovendien konden Duitse bladen worden gelezen bij de in de negentiende eeuw zeer populaire leesgezelschappen. Het grote Utrechtse leesgezelschap Van Allerlei Slag had bijvoorbeeld een abonnement op 26 bladen, waaronder zeven Duitse. ${ }^{164}$

$\mathrm{Na}$ de opheffing van het zegelrecht in de tweede helft van de negentiende eeuw, werden buitenlandse kranten veel goedkoper. Tegelijkertijd werden er ook Duitse kranten in Nederland gedrukt: Wöchentlicher Marktbericht, Handels- und SchiffahrtsZeitung, Allgemeine Kaffeezeitung, Holländische Nachrichten Zeitung für Handel, Industrie, Kunst und Wissenschaft en Niederländische Handels- und Schiffahrts-Zeitung. ${ }^{165}$ Als laatste kwam daar in 1893 nog de Deutsche Wochenzeitung in den Niederlanden bij. De betekenis van deze kranten voor Utrecht moet niet worden overschat. Als voorbeeld kan het Wöchentlicher Marktbericht worden genomen. Dit blad verscheen omstreeks 1870 en richtte zich vooral op de Duitse handelaren in Amsterdam en Rotterdam. De krant, die bestond uit twee of drie dichtbedrukte pagina's, vermeldde voor tal van producten de prijzen waarvoor goederen waren verhandeld. Het ging om groothandelsprijzen van goederen met overzeese bestemming of van overzeese herkomst. Verder vermeldde het blad de data waarop schepen in zeehavens werden verwacht. De gegevens in de krant waren voor de Duitse handelaren in Utrecht, die niet in deze overzeese handel actief waren, nauwelijks interessant.

\section{Een Duitse school?}

De Duitse school werd in de Verenigde Staten gezien als het middel bij uitstek om de Duitse taal en daarmee de Duitse herkenbaarheid als groep te behouden. ${ }^{167}$ Kerk en school waren nauw met elkaar verbonden. Behoud voor de taal was verbonden aan behoud voor het geloof. In Kopenhagen was het eveneens de lutherse kerk die een school oprichtte en in stand hield. ${ }^{168}$

In het negentiende-eeuwse Utrecht was de keuze voor een school, net als elders in Nederland, verbonden met het lidmaatschap van een bepaalde kerk. Katholieke Duitse immigranten stuurden hun kinderen niet naar een Duits-lutherse school, zo die er zou zijn. Voor de armen gold dit in versterkte mate, omdat voorwaarde voor bedeling door de kerk was dat kinderen de 'eigen' school bezochten. Als laatste werkte ook de sociale heterogeniteit van de Duitse gemeenschap door in de schoolkeuze. In de negentiende eeuw was er een scherp onderscheid tussen scholen van de betere stand en scholen van de mindere bevolking. De kinderen van de katholieke Duitse potverkopers gingen niet op school met de kinderen van de grote katholieke Duitse winkeliers.

Daar de lutherse kerk in Utrecht in het midden van de negentiende eeuw geen Duitstalige kerk meer was, had de kerk minder belang bij het behoud van de Duitse taal. De lutherse kerk had immers uitdrukkelijk gebroken met de Duitse oorsprong. Streven 
naar het behoud van de Duitse taal door een Duitstalige school georganiseerd door de lutherse kerk, lag dus niet voor de hand.

Een Duitstalige school kon alleen een functie vervullen in het behoud van de Duitse taal, als de immigranten die taal spraken. Taalverschillen binnen de Duitse immigrantenpopulatie maakten het oprichten van een Duitse school weinig lonend. Diversiteit naar religie en herkomst leidde ertoe dat het draagvlak voor een Duitse school in Utrecht klein was. Zelfs in Rotterdam, waar de lutherse gemeenschap vele malen groter was, lukte het aan het einde van de negentiende eeuw niet om een Duitse lutherse school van de grond te krijgen. ${ }^{168}$

In 1850 waren er in Utrecht 45 scholen, waarvan er twee openbaar waren. De bijzondere scholen waren merendeels in particuliere handen. ${ }^{169}$ In het verslag van de schoolopziener over 1836 werd voor Utrecht melding gemaakt van het bestaan van een Engelse, een Franse en een Hoogduitse school. Het waren allemaal bijzondere scholen, hetgeen betekende dat ze door particulieren werden gedreven, die zelf hun lokaal regelden en de onderwijzers betaalden. ${ }^{170}$ In deze drie gevallen ging het om kleine schooltjes met ieder zo'n dertig leerlingen, waarvan eenderde intern. In latere verslagen komen deze scholen niet meer voor.

In het midden van de negentiende eeuw was het schoolbezoek in de stad Utrecht in het algemeen gunstig. Er waren weinig kinderen die nooit op school kwamen, maar er waren wel kinderen die regelmatig de school verzuimden. Dat verzuim was wijkgebonden. Het kwam het meest voor in de wijken buiten de singels, waar de kinderen grotere afstanden moesten afleggen naar hun school. Wijk K stak bij deze buitenwijken in ongunstige zin af. In 1861 werd geschreven dat kinderen daar zeer onregelmatig de school bezochten:

waarvan de oorzaak aan verregaande onverschilligheid en nalatigheid der ouders mag worden toegeschreven. Die ouders belijden de Roomsch Katholijke godsdienst, behooren tot de geringste volksklasse en trachten door kleine negotie of anderzins de kost te verdienen, zijn elken dag van huis en laten de kinderen aan hun lot over, die bij de straat loopen om een of ander op te halen en keeren op ongezette tijden naar de woning terug om aldaar de zeer ongregelde te huiskomst van vader of moeder af te wachten. ${ }^{171}$

In deze omschrijving herkennen we de gemeenschap van de Westerwalders. De andere wijkbewoners waren weliswaar ook merendeels katholiek, maar het waren steenbakkers of landbouwers en geen mensen die met een kleine negotie rondliepen. Uit het rapport kunnen we derhalve opmaken dat een deel van de kinderen van de Westerwalders niet regelmatig naar school ging.

In 1861 werd in totaal slechts één geval gemeld waarbij kinderen de school in het geheel niet bezochten. Het betrof de kinderen van het Duitse echtpaar Frederich Wustenberg en Catharina Röhm. Deze familie was in 1861 uit Amsterdam naar Utrecht gekomen. Hun twee oudste kinderen waren in Keulen geboren, het derde kind in Amster- 
dam in 1861. Wustenberg was geëmployeerd aan het spoor. Het gezin woonde met een dienstmeisje op de Gruttersdijk-Bemuurde Weerd in wijk M. In 1861 gingen de twee oudste kinderen, Agnes (11) en Frederich (9) niet naar school. ${ }^{172}$ Als reden gaf Wustenberg op dat hij vreemdeling was en niet bekend met de regels. Zoon Frederich werd later naar kostschool in Oudenbosch gestuurd. In 1873 verhuisde de familie naar het Duitse Goch.

De noodzaak voor het oprichten van een eigen school werd beïnvloed door de toegankelijkheid van het Nederlandse onderwijs. Indien daarin Duitse leerkrachten werkten, zal dat die toegankelijkheid hebben vergemakkelijkt. Er waren tussen 1849 en 1879 zeven Duitse mannen en drie Duitse vrouwen bij het onderwijs betrokken. In 1849 werkten in Utrecht in totaal 135 mannen en jongens en 60 vrouwen in het onderwijs. Het Duitse onderwijzend personeel maakte daarvan slechts een klein deel uit. Het was dus in ieder geval niet dit handjevol Duitse onderwijzers binnen het reguliere onderwijs dat een Duitse school overbodig maakte. Een gedeelte van deze onderwijzers richtte zich bovendien op een gespecialiseerd publiek. De katholieke onderwijzer Philip Ermann gaf bijvoorbeeld als privaatdocent onder meer les in Duitse handelscorrespondentie. ${ }^{173}$ Alleen Diderik Grothe had een belangrijke invloed op een gedeelte van het onderwijs. Hij was directeur en docent aan de technische school aan de Ganzenmarkt. Hij gaf stel-, reken- en meetkunde, natuurkunde, werktuigkunde, scheikundige technologie, tropische aardrijkskunde, land- en volkenkunde en bouwkundig- en werktuigtekenen. ${ }^{174}$ Grothe werd in 1806 in Herscheid geboren en was luthers. Hij was lid van enkele meer culturele organisaties en ook van alle organisaties die raakten aan techniek. Grothe was een zeer actief lid en de voornaamste spreker van het Natuurkundig Gezelschap. Voor dit gezelschap hield hij met de regelmaat van de klok verhandelingen over bijvoorbeeld de bewerking van ijzer. ${ }^{175}$ Grothe was ook lid van het bestuur van de ruim vierhonderd leden tellende Vereeniging ter bevordering van nuttige kennis, en commissaris van het Utrechts Schaakgezelschap. ${ }^{176}$ Wie zijn school op de Ganzenmarkt bezocht is niet bekend, maar het zullen zeker niet alleen Duitse leerlingen zijn geweest.

Kinderen van Duitse immigranten gingen, getuige de inschrijvingen in het bevolkingsregister, ook buiten de stad op kostschool. Ze gingen naar Duitsland, België of naar plaatsen elders in Nederland. ${ }^{177}$ In Utrecht zelf was er ook een bescheiden internationale kostschool voor jonge dames, die werd gedreven in het huis van de Brit James Venning aan de statige Kromme Nieuwegracht. Venning was lector aan de universiteit. Zijn Nederlandse vrouw Henriette Venning dreef de kostschool. Een van de onderwijzeressen was de Duitse Auguste Graf. ${ }^{178}$ Daarnaast waren er onderwijzeressen uit Frankrijk, Engeland en Zwitserland, en Nederlandse kostschoolleerlingen. Voor Duitse kinderen was deze school niet bestemd.

Een alternatief voor een Duitse school kon door meer welgestelden in principe worden gevonden in een Duitse gouvernante. In Engeland was de Duitse gouvernante een gebruikelijke verschijning. Als voornaamste drijfveer voor hun komst naar dat land werd genoemd de wens om hun kennis van de Engelse taal te verbeteren. Hierdoor zouden ze, bij terugkeer naar Duitsland, een betere positie op de arbeidsmarkt heb- 
ben. ${ }^{179}$ Er was een Association of German Governesses in England, opgericht in 1876. Deze organisatie bemiddelde gedurende haar dertigjarig bestaan bij 6.000 posities; gemiddeld 200 per jaar. ${ }^{180}$ Duitse gouvernantes waren ook in Denemarken niet ongebruikelijk. $^{181}$

In Nederland waren gouvernantes juist overwegend niet Duits. ${ }^{182}$ Er bestond in Nederland een sterke voorkeur voor gouvernantes die het Frans goed beheersten; dat was immers de taal waarmee de elite zich onderscheidde van de rest van de bevolking. Dit betekende een voorkeur voor gouvernantes uit Franstalige gebieden: Frankrijk, België en Zwitserland. In de tweede helft van de negentiende eeuw kwam er een nieuwe mode en raakte ook de Engelse gouvernante in zwang. ${ }^{183}$ Duitse gouvernantes waren in Nederland nooit populair.

In de volkstelling van 1849 ontbreekt 'gouvernante' als afzonderlijke beroepsgroep. Gouvernantes zijn ondergebracht in de groep 'onderwijzers, onderwijzeressen, ondermeesters, kwekelingen, gouverneurs, gouvernantes'. In 1849 bestond deze groep uit negen jongens (waarschijnlijk de kwekelingen), 126 mannen en 60 vrouwen. Deze zestig vrouwen waren niet allemaal gouvernantes; er waren immers ook onderwijzeressen. Een inventarisatie van de gouvernantes in het bevolkingsregister leerde, dat er in 1850 ongeveer dertig vrouwen als gouvernante werkzaam waren. Deftige families op de Drift en het Janskerkhof stelden buitenlandse gouvernantes aan voor hun kinderen. De gouvernantes in Utrecht kwamen, zoals die elders in Nederland, uit Frankrijk, België en vooral Zwitserland. Er waren ook meerdere Engelse gouvernantes. Enkelen van hen kwamen mee met het Britse spoorwegpersoneel. Het merendeel werkte echter bij Nederlandse families. De meeste gouvernantes deden dat werk slechts enkele jaren. In de rijkere families zien we dan ook een opeenvolging van gouvernantes uit allerlei landen. De griffier van het militair gerechtshof Oldenbarneveld employeerde bijvoorbeeld in een periode van tien jaar voor zijn vijf (en later zes) kinderen achtereenvolgens de gouvernantes Retine Bonhôte uit Peteux in Zwitserland, Adelaide Aeberhardt uit Parijs, Esther Perrin uit Aux Ponss in Zwitserland en Mary-Ann Thompson uit Londen. ${ }^{184}$

Gouvernantes op zoek naar een baan adverteerden veelvuldig in de Utrechtse kranten, merendeels in het Frans: 'Une Dame, ayant quelques heures du jour à sa disposition désiderait trouver une ou deux jeunes demoiselles pour les apprendre les langues modernes, et tout ce qui appartient à une éducation soignée. ${ }^{, 185}$ Advertenties in het Duits zijn er niet. Kennis van die taal was niet iets om zich op voor te laten staan. In de periode van 1849 tot 1879 werkten er negen Duitse gouvernantes in Utrecht. Slechts een van hen werkte voor een familie waarvan de vrouw Duitse was. Duitse families, zelfs niet de rijkeren, stelden niet op grote schaal Duitse gouvernantes aan.

\section{Deutsche Verein zu Utrecht}

In het bovenstaande zijn tal van organisaties de revue gepasseerd. We moeten echter wachten tot het einde van de negentiende eeuw voordat de eerste 'echte' Duitse vereni- 
ging er kwam. De in 1897 opgerichte Deutsche Verein zu Utrecht had als doel: 'Deutsches Wesen, Geselligkeit und Vaterlandsliebe zu pflegen, Zusammenkünfte jeden Sonnabend abends 9 Uhr im Hotel de l'Europe zu Utrecht. ${ }^{186}$ Het waren vooral recente nieuwkomers die deze vereniging oprichtten. Het Adresboek van 1899-190o vermeldt als voorzitter Ludwig Wickop. Hij was ingenieur aan het Technisch Bureau voor de Chemische Industrie aan de Maliebaan. In het bevolkingsregister wordt hij 'chemiker', fabrikant en ingenieur genoemd. Hij was luthers en werd geboren in Crefeld in 1858 . Wickop was getrouwd met Marie Hermine Lehning, die in 1862 in Elberfeld was geboren en eveneens luthers was. Hun twee kinderen waren ook in Duitsland geboren. Op het moment dat de Verein werd opgericht was hij slechts een jaar in Utrecht. Tweede voorzitter was Dr. L. Wirth, geboren in 1847 in Rheinpalz en protestants, privaatdocent aan de Rijksuniversiteit en leraar aan het gymnasium. Hij woonde al wat langer in Nederland - zijn oudste kind werd in 1873 in Breda geboren - en was getrouwd met een Nederlandse vrouw. Gezien het bestuur van deze vereniging, lijkt bij deze organisatie Duitse identiteit gekoppeld te zijn geweest aan een protestantse identiteit. In het algemeen speelden in deze vereniging in latere jaren Duitse leraren een belangrijke rol. Het kegelspel was de belangrijkste vorm van vermaak. ${ }^{187}$ Tijdens de Eerste Wereldoorlog spendeerde de vereniging haar vermogen aan de hulp aan vluchtelingen uit Duitsland. Daarna kwam er een Hilfskasse tot stand, gericht op zorg voor wezen en sanatoriumverpleging.

De oprichting van de Utrechtse Verein past bij ontwikkelingen in andere delen van Nederland. In 1950 publiceerde de Duitse onderzoeker Wilhelm Sahner een overzicht van de Duitse organisaties die er voor de Tweede Wereldoorlog in Nederland bestonden. ${ }^{188}$ Sahner gaf ook zijn visie op de aard en omvang van Duitse organisaties in Nederland. Belangrijk in zijn ogen, voor de vorming en het voortbestaan van organisaties was, dat er een culturele en een taalverwantschap bestond tussen Duitsland en Nederland en dat er tussen beide landen op allerlei gebieden nauwe betrekkingen bestonden. Voor de tweede generatie gold dat zij slechts zelden foutloos Duits kon schrijven en dat het Nederlands haar omgangstaal was. 'Die nächste Generation war im allgemeinen

Schema 7.1 Factoren die het oprichten van eigen organisaties beïnvloeden.

- omvang van de immigrantenpopulatie

- opbouw van de immigrantenpopulatie naar leeftijd en geslacht, geografische herkomst en religie

- formele en feitelijke toegang tot bestaande organisaties

- bestaan van 'concurrerende' organisaties

- ideeën omtrent het tijdelijke of blijvende karakter van het verblijf en (symbolische) verbondenheid van immigranten met hun land van herkomst

- beeldvorming in ontvangende samenleving ten aanzien van het cultureel anders zijn van immigranten

- culturele bagage die immigranten meebrengen 
schon “verholländert”, vielfach vollständig eingebürgert'. Volgens Sahner waren de Nederlanders tegenover de Duitsers in het algemeen vriendelijk en konden de Duitse immigranten zich vrijelijk bewegen. De noodzaak voor het oprichten van eigen verenigingen was daarom lange tijd gering. Bovendien konden de Duitse immigranten gemakkelijk contact met hun geboorteland onderhouden. De behoefte aan eigen organisaties werd sterker gevoeld na de Eerste Wereldoorlog. Toen schoten de verenigingen als paddestoelen uit de grond. Verdeeldheid was daarbij kenmerkender dan eenheid. Amsterdam en Rotterdam telden ieder meer dan vijftien Duitse verenigingen, de religieuze niet meegeteld. Bij belangrijke gebeurtenissen, zoals het Hindenburg-Feier in Rotterdam in 1927, traden deze verenigingen echter als een 'geschlossene deutsche Kolonie' naar buiten. In de jaren twintig werd er ook geijverd voor een overkoepelende organisatie. In 1922 werd ter gelegenheid van het 25-jarig bestaan van de Utrechtse Verein het Verband deutscher Vereine in den Niederlanden opgericht. Er traden 14 verenigingen toe met 1800 leden. In 1930 waren er 26 verenigingen lid.

De verdeeldheid onder de Duitse immigranten bleef bestaan tot in de jaren dertig van de twintigste eeuw, toen onder invloed van de opkomst van het nationaal-socialisme in Duitsland, vanuit Duitsland pogingen werden gedaan om de verdeelde Duitsers in Nederland samen te brengen in één Duitse kolonie. ${ }^{189}$

\section{Tot besluit}

Organisaties zijn hier aangemerkt als indicatie voor groepsvorming onder Duitse immigranten. Twee kanttekeningen moeten bij deze maatstaf worden gemaakt. Op de eerste plaats weten we alleen iets over het sociale verkeer tussen migranten, voor zover dit leidde tot geformaliseerde verbanden. Hoeveel Duitsers elkaar troffen in de Duitse kroegen, waar ze Duits bier konden drinken en Duitse kranten lezen, weten we niet. Op de tweede plaats komen in de archieven van organisaties slechts de namen van mannen voor. Vrouwen speelden in het midden van de negentiende eeuw een geringe rol in het merendeel van de geformaliseerde sociale verbanden. ${ }^{190}$ Dat gold ook voor Duitse vrouwen. Vanuit een theoretisch standpunt bezien is dat niet onbelangrijk. Indien mannen wel en vrouwen niet meededen in organisaties of verenigingen, wat had dat dan voor gevolgen voor het proces van groepsvorming? Hoe moet bij een ongelijke deelname van mannen en vrouwen de indicator sociaal verkeer worden gehanteerd? Kan van groepsvorming worden gesproken als de mannen wel en de vrouwen niet deelnamen aan eigen organisaties? Het zijn vragen die in het kader van dit onderzoek moeilijk te beantwoorden zijn, maar die daarom nog niet irrelevant zijn.

In dit hoofdstuk zijn tal van factoren genoemd die het opzetten van organisaties onder immigranten beïnvloeden. In schema 7.1 worden die samengevat.

De sociale infrastructuur van de Duitse immigranten in Utrecht paste gedeeltelijk in het beeld zoals dat in andere beschrijvingen van Duitse immigrantengemeenschappen is geschetst. Studies van gemeenschappen elders kwamen tot de conclusie dat 
Duitse immigranten wel verenigingen oprichtten, maar zich niet als één Duitse gemeenschap organiseerden. ${ }^{191}$ In Utrecht richtten Duitse immigranten hun eigen organisaties op, maar ze vonden ook een plaats in algemene organisaties. In andere studies worden de algemene organisaties en hun toegankelijkheid veelal buiten beschouwing gelaten. In het Utrechtse geval bleek dat waar algemene organisaties voor Duitse immigranten toegankelijk waren, de wens of noodzaak voor het opzetten van eigen organisaties minder groot was.

Duitse immigranten vonden een plaats binnen Nederlandse organisaties. Die organisaties waren echter niet in gelijke mate voor alle Duitse immigranten toegankelijk. De toegang tot de verenigingen werd meer bepaald door klasse of stand dan door geografische oorsprong of religie.

De Duitse elite had wel toegang tot verenigingen, maar ontbrak bij allerlei lokale initiatieven waarvoor geldschieters werden gezocht. Uit het archief van de Arrondissementsrechtbank blijkt dat Duitse immigranten niet deelnamen aan het opzetten van lokale banken, de oprichting van de lokale krant en het theater, of de financiering van de suikerfabriek of de gasfabriek. In deze ondernemingen namen Utrechtse, regionale en nationale geldschieters deel, maar geen Duitse. Wanneer er in het vennootschapsregister een overeenkomst voorkomt waarbij een Duitse migrant is betrokken, dan is de partner veelal ook een Duitser.

De omvang en de heterogeniteit van de Duitse gemeenschap in Utrecht speelden een rol bij het ontstaan van Duitse verenigingen. Klasse, regionale herkomst en religie vormden de scheidslijnen tussen Duitse organisaties. Duitse immigranten konden in Utrecht Duitse liederen zingen bij de mannenzangvereniging, ze konden Duitse muziek beluisteren, Duits bier drinken en daarbij op zijn Duits 'Unsinnmachen'. Predikanten van de Innere Mission hielden op onregelmatige tijden een preek in het Duits. Het Duitse nationalisme, dat in de tweede helft van de negentiende eeuw tot ontwikkeling kwam, had gevolgen voor de 'Duitse' verenigingen. Dit gold bij uitstek voor de Liedertafeln. Doordat in Duitsland de Liedertafeln als een belangrijke steun voor het nationalisme werden gezien, veranderde de positie van de Nederlandse tegenhanger. De Nederlandse Liedertafeln, die aanvankelijk sterk op het Duitse model geënt waren, kregen een meer Nederlands karakter, wat tot uitdrukking kwam in een 'vernederlandsing' van het repertoire en de lesmethode. Iets vergelijkbaars deed zich voor bij de Gustaaf Adolf Vereeniging. In Duitsland werd deze vereniging sterk geassocieerd met het nationalisme. Dit bracht de Nederlandse tegenhanger in een dilemma en leidde tot spanningen en scheuringen binnen de Nederlandse organisatie. De lutherse kerk had, onder invloed van politieke ontwikkelingen omstreeks 1800 , reeds veel eerder de stap naar vernederlandsing gezet. De betekende dat er op dat gebied ruimte kwam voor een meer 'Duitse' organisatie. De Innere Mission vulde het gat dat ontstond door de vernederlandsing van de lutherse kerk.

Een Duitse school of een Duitse krant, in andere landen aangemerkt als exponenten en dragers van de Duitse gemeenschap, waren er niet in Utrecht. Duitse scholen elders werden merendeels opgezet door de lutherse kerk, die behoud van de taal gelijkstelde 
met behoud voor het geloof en behoud voor het land. Daar de lutherse kerk in Utrecht nadrukkelijk niet-Duits was, was een initiatief vanuit die hoek onwaarschijnlijk. Voor een Duitse krant was de Duitse gemeenschap te verdeeld, ontbrak een intellectuele elite die zo'n krant kon opzetten, en waren Duitse kranten te makkelijk te koop op straat of te lezen in kroegen en bij verenigingen.

De meeste verenigingen waren Duits in een relatief open zin. Ze waren opgezet door Duitsers of vanuit een Duitse inspiratiebron, maar ze waren toegankelijk voor niet-Duitsers en vonden reeds spoedig na hun oprichting weerklank onder de autochtone bevolking. Dit geldt vooral voor het zingen en het turnen.

De meeste verenigingen waren actief op sociaal-cultureel gebied en niet op politiek of economisch gebied. De eerste echte Duitse vereniging, die zich expliciet richtte op het behoud van Duitse waarden en normen dateerde pas van omstreeks 1900.

Westerwalders, de grootste groep Duitsers in Utrecht, ontbraken in alle verenigingen. Als ze zich organiseerden, deden ze dat afzonderlijk van andere Duitse immigranten. Het ontbreken van de Westerwalders in de verschillende organisaties kan in verband worden gebracht met klasse; de Westerwalders vormden het armere deel van de Duitse immigrantenpopulatie. Rijkere vreemdelingen vonden wel een plaats in organisaties of waren mede-initiatiefnemers ervan. Armere immigranten hadden die mogelijkheid niet. Gezien in dit licht is de gebrekkige integratie vooral een klassenfenomeen. 


\section{8 "t Lekkerst roggebrood wat je eet, is gekneed met moffenzweet'}

\section{Beroepsstructuur}

De winter van 1853-1854 viel vroeg in. In december 1853 vroor het reeds 29 dagen lang en de temperatuur zakte tot min veertien graden. De winter van 1854-1855 was een late en een lange winter. Het vroor de hele maand februari met als minimumtemperatuur min zeventien graden. In maart kwam het kwik 23 dagen niet boven het vriespunt. ${ }^{1}$ De uitzonderlijke kou van de jaren 1853 tot 1855 viel samen met hoge graanprijzen als gevolg van de oorlog op de Krim. In 1855 werd er in de Utrechtsche Provinciale en Stadscourant geschreven:

Een barre winter - een winter, die het lijden der armen op verschrikkelijke wijze verzwaart. Men kan zich van dat lijden van zoo vele duizenden nauwelijks een denkbeeld maken. Die er getuigen van geweest zijn in hunne kelderverblijven en hen op hunne zolderkamertjes bezocht hebben - men vrage het dezen aan welk hartverscheurend lijden duizenden en duizenden hulpbehoevende natuurgenooten op dit oogenblik, in dit jaargetijde, blootgesteld zijn, en het hart krimpt in een bij 't vernemen van het antwoord. Neen, van zulk lijden valt het moeijelijk zich een denkbeeld te maken. Alles is verteerd; de dure tijd heeft spoediger dan ooit alle hulpmiddelen uitgeput. En nu? Geen sprankje vuur aan den haard, en de togt, die door elke reet heengiert, en de ligchamen bijna verstijft van koude, en niets, niets ter verwarming: een bos stroo tot ligplaats en ter nauwernood een stuk deken tot dekking; kleeding, de versleten lappen en lompen, waarmee in het zachte jaargetijde de naaktheid dier ongelukkigen bedekt wordt, het eenige, waar zij zich in wikkelen kunnen, te hunner bescherming tegen de felle koude; voedsel, een bak warme spijze eene uitzondering; het roggebrood zelfs te duur; en gewordt hun nu en dan een verwarmend voedsel, ge moet zien, met welke gulzigheid dat verslonden wordt en met welke stomme vertwijfeling men daarna zich aanziet, daar de schotel of de kan leeg is en de kinderen toch nog zoo'n honger hebben. Zo is de toestand van duizenden en duizenden stadgenooten. ${ }^{2}$

Deze tekst was bedoeld als opwekking tot steun aan de misdeelden. Een aantrekkelijk beeld van Utrecht werd er niet mee geschetst. Door de extreme kou kwam het sociale en economische leven volledig tot stilstand. In allerlei bedrijfstakken was maandenlang 
geen werk voorhanden. Scheepvaart en vervoer over land waren onmogelijk. Een reis naar de Domstad was niet mogelijk en niet aantrekkelijk.

In het midden van de negentiende eeuw werd er in heel Nederland geklaagd over werkloosheid. In 1849 merkte het Kamerlid Costerus op dat er 'thans duizenden onzer landgenooten zonder werk en brood' waren. ${ }^{3}$ Zijn collega Van Engelen wees op 'het groote verschijnsel van dezen tijd, het pauperisme namelijk.' ${ }^{4}$ Enkele jaren later ging het in Utrecht iets beter. In 1863 leidde de toegenomen werkgelegenheid tot loonsverhogingen van arbeiders. In het Utrechtse gemeenteverslag van dat jaar werd geschreven dat de lonen waren verhoogd 'niettegenstaande veel arbeiders van elders zich hier zijn komen vestigen.'

Het negentiende-eeuwse Utrecht is herhaaldelijk beschreven als saai, kleinburgerlijk en rustig. Dit beeld is onlangs fors bijgesteld. ${ }^{6}$ Utrecht was in de tweede helft van de negentiende eeuw een redelijk welvarende handelsstad, verkeersknooppunt, bestuurscentrum en universiteitsstad. ${ }^{7}$ De industrie was in de Domstad ook niet onbelangrijk, maar de bedrijven waren merendeels kleinschalig. Utrecht was het belangrijkste stedelijke centrum voor een zeer grote omliggende regio en vanuit de stad waren tal van

Tabel 8.1 Structuur van de Utrechtse beroepsbevolking in 1849 en 1889 in percentages.

\begin{tabular}{lrrrr}
\hline & & 1849 & & \multicolumn{2}{r}{1889} \\
\hline industrie & $\mathrm{m}$ & $\mathrm{v}$ & $\mathrm{m}$ & $\mathrm{v}$ \\
landbouw en visserij & 53,6 & 40,1 & 46,8 & 18,3 \\
warenhandel & 5,8 & 2,6 & 3,8 & 2,5 \\
verkeerswezen & 11,6 & 7,5 & 10,0 & 12,3 \\
huishoudelijke dienst & 8,5 & 2,3 & 12,4 & 1,9 \\
'witte boorden'* & 3,8 & 44,2 & 1,6 & 57,3 \\
vrije beroepen & 3,7 & 0 & 10,3 & 1,1 \\
losse werklieden & 1,2 & 0 & 3,5 & 1,5 \\
onderwijs & 8,6 & 0 & 6,1 & 0 \\
overige* & 1,5 & 1,0 & 0,9 & 1,9 \\
\hline $\mathrm{n}=$ & 1,4 & 0,7 & 1,3 & 2,0 \\
\hline
\end{tabular}

Bron Uitkomsten der beroepstelling in het koninkrijk der Nederlanden op den een en dertigsten december 1889 deel VIII provincie Utrecht (Den Haag 1894) en uitkomsten der derde tienjarige volkstelling in het koninkrijk der Nederlanden op den negentienden november 1849 (Den Haag 1842) Utrecht.

De uitkomsten van de volkstelling van 1849 zijn door mij aangepast aan de indeling in beroepsgroepen in de telling van 1889 .

* Overige $=$ Handelondersteunende beroepen en verpleging en verzorging; 'witte boorden' $=$ in dienst van staat, provincie, gemeente, waterschap en kerkgenootschap. 
plaatsen over water en over land goed bereikbaar. In tabel 8.1 wordt de structuur van de Utrechtse beroepsbevolking weergegeven.

Handel en verkeer waren belangrijk voor de Domstad. De route van het Duitse achterland naar Amsterdam liep van oudsher via Utrecht. De Vaartse Rijn vormde onderdeel van de zogenaamde Keulse vaart, tussen Amsterdam en de Rijn. Het belang van deze handel in vroegere tijden blijkt uit het feit dat de Rijnkooplieden er hun eigen gilde hadden. ${ }^{8}$

Utrecht was verkeersknooppunt in regionale en internationale zin. In 1852 voeren er op de Domstad 49 beurtschuiten, 33 veerschuiten en 68 marktschuiten. Dagelijks kon men vanuit Utrecht zes keer de boot nemen naar Amsterdam. ${ }^{9}$ In 1843 werd de spoorverbinding Amsterdam-Utrecht gerealiseerd, die twee jaar later werd doorgetrokken naar Arnhem. Vervolgens kwamen spoorverbindingen tot stand met Rotterdam (1855), Zwolle (1863), Den Bosch (1870) en Hilversum (1878). Sedert 1856 was er een directe verbinding naar Pruisen. De spoorwegen werden een belangrijke werkgever in Utrecht.

In het midden van de negentiende eeuw telde Utrecht een groot aantal markten: 29 in totaal. ${ }^{10} \mathrm{Zij}$ waren gedeeltelijk van nationale of zelfs internationale betekenis. Dit gold bijvoorbeeld voor de paardenmarkt, die vijfmaal per jaar werd gehouden en die Franse, Duitse en Belgische kooplieden trok. De rundermarkt, waar vee werd verkocht naar België, Pruisen en Engeland, had eveneens een internationale uitstraling. De graanmarkt en de kaasmarkt hadden eerder een regionale of nationale functie. De dagelijkse en wekelijkse markten trokken kopers en verkopers uit de directe omgeving. Aardappelen werden, behalve uit Nederlandse provincies, ook uit Duitsland aangevoerd. Fruit werd opgekocht voor export naar Engeland en Duitsland. Een van de wekelijkse markten was de pottenmarkt, die op zaterdag op de Oudegracht rond de Bakkerbrug werd gehouden en waar vooral Duitse producten werden verkocht door Duitse handelaren.

Het stedelijke karakter van Utrecht liet onverlet dat er in 1849463 mannen en 118 vrouwen werden geteld in de categorie 'bloemisten, boomkwekers, tuiniers en warmoezeniers'. Met enkele aanverwante beroepen vormden zij de sector landbouw, waarin zes procent van de beroepsbevolking werkzaam was. Landbouwers woonden vooral in de buitenwijken van de stad, waar oude boerderijen stonden die reeds dateerden van vóór 1800 . Tussen de nieuwbouw van de buitenwijken, op de binnenterreinen, werden in de tweede eeuwhelft echter ook nieuwe bloem- en boomkwekerijen aangelegd. Dit verklaart dat deze sector van betekenis bleef, ondanks de uitbreiding van de stedelijke bebouwing.

Utrecht kende in het midden van de negentiende eeuw een relatief grote bovenlaag van bestuurders en renteniers. De aanwezigheid van de universiteit en de provinciale gerechtelijke en bestuurscolleges betekende dat er veel vraag was naar dienstpersoneel. De sector 'huishoudelijke diensten' was een van de belangrijkste economische sectoren. De vraag uit de midden- en hogere klasse, plus die van het in de Domstad gelegerde garnizoen, verklaart het grote aantal schoenmakers (512) en kleermakers (628). Opval- 
lend is het aantal knopenmakers; 145. De productie van houten en benen knopen, later gevolgd door metalen knopen, was in de zeventiende en achttiende eeuw een belangrijke bedrijfstak geweest. In de tweede helft van de negentiende eeuw raakte deze sector echter ernstig in verval.

In de tweede helft van de negentiende eeuw vroeg de bouw van zevenduizend woningen buiten de oude stadsmuren veel arbeidskrachten. In deze nieuwe wijken moesten straten worden aangelegd, terwijl tegelijkertijd de oude muren en poorten van de stad werden gesloopt. Metselaars (365), huisschilders en glazenmakers (369) en timmerlieden (653) waren in deze sector het meest talrijk. In het Jaarverslag van het Provinciaal Bestuur over 1861 werd opgemerkt dat 'metselaars, timmerlieden, verwers, smeden, meubelmakers, kamerbehangers' een overvloed aan werk hadden. ${ }^{11}$ De ruime arbeidsmarkt leidde tot immigratie. 'Voor pleisterwerk boden zich vele metselaars van elders aan, die, gewoon aan ruw werk, tot lagere prijzen wilden werken. ${ }^{12}$ Voor de lokale metselaars bleef desondanks voldoende werk over.

Metselaars hadden veel werk; bij eenigzins belangrijke bouwwerken werd, wel is waar, dikwerf door van elders komende metselaars, onder zoogenaamde ploegbazen, het onder dak brengen van gebouwen aangenomen, maar de meeste trekken gewoonlijk tegen den winter weder weg, en laten dan het afwerken van de gebouwen aan onze werklieden over. ${ }^{13}$

De metselaars die van buiten kwamen, waren wel concurrenten, maar er werd niet over geklaagd, althans niet in de gemeenteverslagen. In het schildersvak was sprake van zowel emigratie als immigratie.

De Huisschilders vonden wel genoeg te doen, maar stonden achter bij de werklieden, van buiten 's lands ontboden, om in verschillende tinten te schilderen. Enkele jeugdige huisschilders hebben zich daarom naar België begeven, ten einde zich verder in hun vak te bekwamen. ${ }^{14}$

Te klagen over werk hadden de huisschilders in de daarop volgende jaren niet. In het Jaarverslag van het Provinciaal Bestuur over 1862 werd geschreven:

Huisschilders hadden overvloed aan werk. Evenwel was bij velen het werk minder deugdzaam dan vroeger. Meer en meer begint men zich ook toe te leggen op betere nabootsing van fijnere hout- en marmersoorten. Aan bekwame decorateurs is nog steeds gebrek, zoodat deze meestal uit het buitenland moeten ontboden worden. ${ }^{15}$

In de steenhouwerijen was ook behoefte aan arbeidskrachten. ${ }^{16}$ 
Steenhouwers waren zeer bedrijvig, omdat er meer steenhouwerswerk dan vroeger aan de gebouwen wordt gebruikt, zoodat in dit vak ook bepaald vooruitgang te bespeuren is. Fraaije schoorsteenmantels worden thans veel vervaardigd, terwijl de middelmatige, zoogenaamde courante schoorsteenmantels, meestal minder in prijs, bij groote hoeveelheden uit België worden ingevoerd; op de kwaliteit en bewerking van deze laatste valt veel af te dingen. ${ }^{17}$

Opvallend is dat bij alle bedrijvigheid in de bouw Duitse werklieden niet worden genoemd.

Naast veel kleine bedrijven, kende Utrecht een veertigtal grote ondernemingen: sigarenfabrieken, bierbrouwerijen, textielfabrieken, houtzagerijen en de chemische en metaalnijverheid. De sigarenindustrie was de sterkst groeiende Utrechtse industrie. Daarnaast was de metaalindustrie belangrijk. In vroeger eeuwen genoten Utrechtse geweren in grote delen van Europa een goede reputatie. ${ }^{18}$ Terwijl de geweerindustrie in de achttiende eeuw verliep, ${ }^{19}$ bleef de metaalsector in het algemeen belangrijk, ook nog in de negentiende eeuw. In 1849 werkte er vier procent van de beroepsbevolking; in 1889 was dat opgelopen tot zeven procent. In de metaalsector bestond een aantal grote bedrijven, maar er waren vooral veel kleine bedrijven binnen deze sector actief, verdeeld over uiteenlopende beroepen. Zo was er in 1849 bijvoorbeeld de categorie 'koper- en blikslagers, draadvlechters en ketellappers' waarin 163 mensen werk vonden. Naast een grof smid en zeven hoefsmeden, waren er 383 mensen die als kachel- of andere smid werkten.

De industriële bedrijven lagen in de tweede helft van de negentiende eeuw voornamelijk aan de oevers van de waterwegen buiten het oude stadscentrum. De industrie concentreerde zich eerder buiten de Weerdpoort en buiten de Tolsteegpoort (in de wijken $\mathrm{M}$ en K), dan buiten de Catharijnepoort en de Wittevrouwenpoort (in de wijken L en I). De Weerdpoort lag aan de Amsterdamse kant van de stad, de Catharijnepoort aan de Leidse kant, de Wittevrouwenpoort aan de kant van Amersfoort en de Tolsteegpoort aan de kant van Den Bosch. De rivier de Vecht in het noorden en de Kromme Rijn en de Vaartse Rijn in het zuiden, boden mogelijkheden voor de aan- en afvoer over water. Bij de Weerdpoort maakte verval in het water bovendien de oprichting van door waterkracht aangedreven mechanische productiebedrijven mogelijk. ${ }^{20}$ In de achttiende eeuw had de zijde-industrie hiervan gebruik gemaakt. ${ }^{21}$ In de tweede helft van de negentiende eeuw was wijk $M$ de meest geïndustrialiseerde wijk van Utrecht. Hier lagen grote bedrijven, op het gebied van bijvoorbeeld chemie en metaalbewerking, aan het Lauwerecht en de Bemuurde Weerd. In deze wijk lag voorts een beenzwart- en loodwitfabriek, die het water van de wijk ernstig vervuilde. Wijk M trok veel mensen van buiten Utrecht, voornamelijk van het omliggende platteland.

Buiten de Tolsteegpoort waren er behalve de steen-, pannen- en tegelbakkerijen houtzaagmolens, scheepstimmerwerven, cement- of trasmolens en handelszaken. Wijk K was een wijk met een min of meer eigen karakter. 


\section{Het algemene beeld}

In tabel 8.2 en figuur 8.1 wordt de verdeling van Duitse immigranten afgezet tegen die van de Utrechtse beroepsbevolking in het algemeen.

Bij de vergelijking van de beroepsverdeling van de Duitse immigranten met die van de Utrechtse bevolking in het algemeen, op basis van de beroepstelling, vallen drie dingen op. Duitse immigranten waren, ten eerste, minder sterk vertegenwoordigd in de industrie dan de Utrechtse bevolking. Dit geldt bij uitstek voor vrouwen. Binnen de Utrechtse bevolking vinden we in de industrie vooral vrouwen die werkten in de kledingsector (als naaister en breister of wasster en bleekster). In 1849 werkten in Utrecht in de grote verzamelcategorie 'naaisters, breisters, mangelhoudsters, plooisters, strijksters, waschvrouwen, werksters en nettenbreijers' 2235 vrouwen. Bij de Duitse vrouwen kwamen deze beroepsaanduidingen vrijwel niet voor.

Tabel 8.2 De beroepsverdeling van de Duitse immigranten vergeleken met die van de Utrechtse bevolking in het algemeen 1849-1879 (1889) (in percentages).

\begin{tabular}{|c|c|c|c|c|c|c|}
\hline & \multicolumn{4}{|c|}{ Bevolking Utrecht algemeen } & \multirow{2}{*}{\multicolumn{2}{|c|}{$\begin{array}{c}\text { Duitsers } \\
1849-1879\end{array}$}} \\
\hline & \multicolumn{2}{|c|}{1849} & \multicolumn{2}{|c|}{1889} & & \\
\hline & $\mathrm{m}$ & v & $\mathrm{m}$ & v & $\mathrm{m}$ & $\mathrm{v}$ \\
\hline industrie & 53,6 & 40,1 & 46,8 & 18,3 & 37,0 & 0 \\
\hline landbouw en visserij & 5,8 & 2,6 & 3,8 & 2,5 & 0 & 0 \\
\hline warenhandel & 11,6 & 7,5 & 10,0 & 12,3 & 44,0 & 52,2 \\
\hline verkeerswezen & 8,5 & 2,3 & 12,4 & 1,9 & 12,0 & 5,9 \\
\hline huishoudelijke dienst & 3,8 & 44,2 & 1,6 & 57,3 & 1,0 & 29,5 \\
\hline ‘witte boorden’ & 3,7 & 0 & 10,3 & 1,1 & 2,0 & 0 \\
\hline vrije beroepen & 1,2 & 0 & 3,5 & 1,5 & o & 5,0 \\
\hline losse werklieden & 8,6 & 0 & 6,1 & 0 & 2,3 & 0 \\
\hline onderwijs & 1,5 & 1,0 & 0,9 & 1,9 & 0,6 & 5,0 \\
\hline overige* & 1,4 & 0,7 & 1,3 & 2,0 & 0 & 0 \\
\hline $\mathrm{n}=$ & 11.700 & 5.851 & 23.113 & 7.485 & 922 & 339 \\
\hline
\end{tabular}

Bron Uitkomsten der beroepstelling in het koninkrijk der Nederlanden op den een en dertigsten december 1889 deel VIII provincie Utrecht (Den Haag 1894) en uitkomsten der derde tienjarige volkstelling in het koninkrijk der Nederlanden op den negentienden November 1849 (Den Haag 1852) Utrecht.

De uitkomsten van de volkstelling van 1849 zijn door mij aangepast aan de indeling in beroepsgroepen in de telling van 1889. Voor 1879 is er geen beroepstelling.

*Overige = handel ondersteunende beroepen en verpleging en verzorging.

*Witte boorden = in dienst van staat, provincie, gemeente waterschap en kerkgenootschap. 
Duitse immigranten ontbreken op de tweede plaats in de landbouwsector en zijn sterk vertegenwoordigd in de warenhandel. Dit laatste geldt bij uitstek voor vrouwen. In de sector verkeerswezen, waartoe ook spoorbeambten, kroeghouders, kelners en prostituees behoren, zijn Duitse immigranten sterker vertegenwoordigd dan de Utrechtse bevolking in het algemeen. Opvallend is als laatste het feit dat losse werklieden numeriek vrij onbelangrijk zijn onder de Duitse immigranten.

Verschillen in beroepsstructuur zoals die bestonden tussen de Duitse immigranten en de Utrechtse bevolking, zouden verband kunnen houden met de leeftijdsopbouw binnen beide groepen. De leeftijdsopbouw van de populatie Duitse immigranten was

Figuur 8.1 Arbeidsmarkt verdeling Duitse immigranten en Utrechtse bevolking in het algemeen.

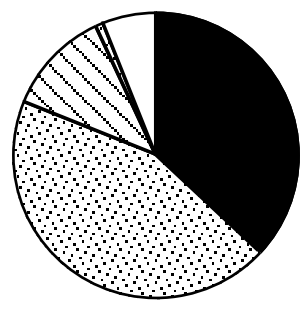

Duitse mannen

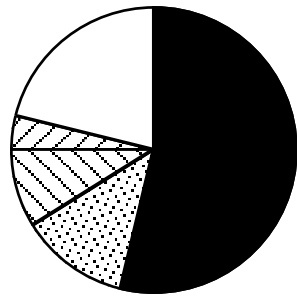

Alle mannen 1849

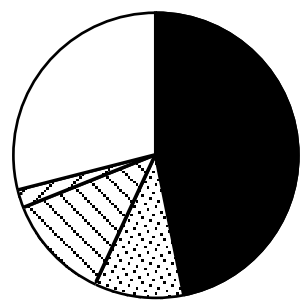

Alle mannen 1889

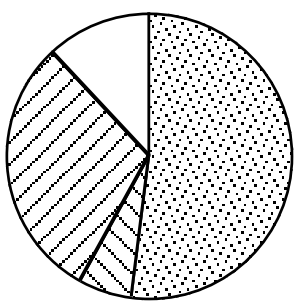

Duitse vrouwen

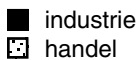

handel

$\square$ dienstboden

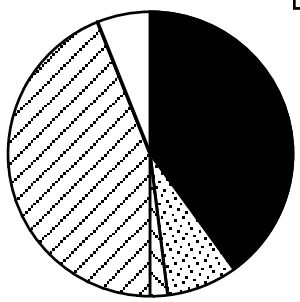

Alle vrouwen 1849

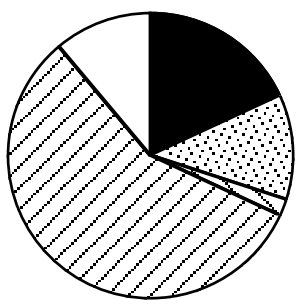

Alle vrouwen 1889

Bron idem tabel 8.2. 
immers niet gelijk aan die binnen de Utrechtse bevolking als geheel. Voor een juist beeld moeten Duitse immigranten worden vergeleken met hun leeftijdsgenoten. Het resultaat van die vergelijking wordt weergegeven in tabel 8.3.

Het eerdere beeld blijft bij deze vergelijking goeddeels overeind. De landbouwsector is, niet geheel verbazend, onder de migranten minder sterk vertegenwoordigd dan onder de autochtone Utrechtse bevolking. De industrie was minder belangrijk voor de Duitse immigranten; het verkeerswezen was belangrijker. Het opvallendste verschil is te vinden bij de Utrechtse vrouwen uit de lagere sociale klasse (winterbedeelden). Voor hen was, net als voor de Duitse migrantes, handel belangrijker dan huishoudelijke dienst. Nadere analyse leert echter dat de Utrechtse vrouwen niet in dezelfde beroepen werkten als de Duitse: bij de Duitse immigranten gaat het vooral om winkelmeisjes en koopvrouwen, bij de winterbedeelden zijn het merendeels winkeliersters.

\section{Oververtegenwoordiging of niet?}

In de hedendaagse Nederlandse samenleving zijn pizzabakkers Italiaans. Pizzeria's vormen een niche waarin merendeels Italianen werken. Voor niet-Italianen is het moeilijk

Tabel 8.3 De beroepsverdeling van de Duitse immigranten vergeleken met die van de autochtone Utrechtse bevolking (uitgesplitst in HSN-controlegroep en de controlegroep der winterbedeelden).

\begin{tabular}{|c|c|c|c|c|c|c|}
\hline & \multicolumn{2}{|c|}{ HSN geboren } & \multicolumn{2}{|c|}{$\begin{array}{c}\text { 'winterbedeelden' } \\
\text { selectie geboren }\end{array}$} & \multicolumn{2}{|c|}{$\begin{array}{c}\text { Duitsers } \\
\text { selectie geboren }\end{array}$} \\
\hline & \multicolumn{2}{|c|}{$1812-1835$} & \multicolumn{2}{|c|}{$1810-1830$} & \multicolumn{2}{|c|}{$1810-1835$} \\
\hline & $\mathrm{m}$ & v & $\mathrm{m}$ & $v$ & $\mathrm{~m}$ & $v$ \\
\hline industrie & 54 & 32 & 58 & 13 & 41 & 4 \\
\hline landbouw en visserij & 8 & 9 & 14 & 13 & 0 & 0 \\
\hline warenhandel & 14 & 6 & 12 & 40 & 28 & 51 \\
\hline verkeerswezen & 4 & 0 & 2 & 6 & 19 & 11 \\
\hline huiselijke dienst & 0 & 53 & 0 & 26 & 2 & 28 \\
\hline losse werklieden & 14 & 0 & 14 & 0 & 4 & 0 \\
\hline overige* & 4 & o & 0 & 0 & 6 & 6 \\
\hline $\mathrm{n}=$ & 260 & 117 & 168 & 51 & 316 & 94 \\
\hline
\end{tabular}

Bronnen HSN-controlegoep van mensen geboren tussen 1812-1835 en gehuwd in Utrecht. Controlegroep 'winterbedeelden' geboren tussen 1810 en 1830 en bedeeld in winters van 1853-1854 en 1854-1855.

*Overige handelondersteunende beroepen, verpleging en verzorging, in dienst van staat, provincie, gemeente waterschap en kerkgenootschap, vrije beroepen en onderwijs. 
om in deze bedrijfstak door te dringen. Turkse pizzeria-eigenaren doen zich voor als Italianen omdat zij, waarschijnlijk terecht, menen dat dit goed is voor hun onderneming, en zij bedienen zich in het restaurant van een handvol Italiaanse frases. ${ }^{22}$

Concentratie van immigranten in een beperkt aantal beroepen, gewoonlijk aangeduid als economische nichevorming, is en was een gangbaar verschijnsel onder immigranten. In het negentiende-eeuwse Nederland zien we dit bij handelaren in gipsen beelden uit het Italiaanse hertogdom Lucca, die in gemslederen handschoenen uit het Zillertal in Tirol en die in zeisen uit Sauerland. ${ }^{23}$ Nichevorming beperkte zich niet tot de handel, maar deed zich ook voor bij Franse paraplumakers, Belgische strohoedenmakers uit de Jekervallei, steenbakkers uit Lippe, gouvernantes uit het Franssprekende deel van Zwitserland, Italiaanse schoorsteenvegers en Italiaanse terrazzowerkers uit Friuli. ${ }^{24}$ Nichevorming was geen Nederlands verschijnsel, evenmin was het uitsluitend een negentiende-eeuws fenomeen. ${ }^{25} \mathrm{We}$ vinden het ook onder de Duitse immigranten. Het dagblad De Tijd schreef in 1954 over de Duitse immigranten in de negentiende eeuw:

Het meest bekend zijn de grasmaaiers, de hannekemaaiers [...] turfstekers, zuurkoolsnijders, maar ook stukadoors, slagers en bakkers [...] vooral als suiker- en roggebroodbakkers [...] de kooplui met manden vol houtwerk op de rug, muizenvallen en vogelkooien voor de borst en houten pollepels en raspen aan een touwtje langszij, de pottentrienen met haar voorraad Keuls aardewerk, de klokkenmakers uit het Schwarzwald [....$^{26}$

Bakker, suikerbakker, klerk en kleermaker worden in buitenlandse studies frequent genoemd als beroepen waarin veel Duitse immigranten werkzaam waren. ${ }^{27}$ Daarnaast worden ook andere beroepen afwisselend aangemerkt als 'typisch' Duits. In Amsterdam was er in 1853 een concentratie van zestig procent van de Duitse immigranten in zes beroepen. Er waren daar vooral veel bakkersknechts (meestal bij een Duitse patroon), dienstbodes, arbeiders (vooral op brouwerij De Gekroonde Valk en op de suikerraffinaderijen), handels- en winkelbedienden en kleermakers. ${ }^{28}$ Er is een overeenkomst tussen Amsterdam en Engeland. In Engeland waren belangrijke beroepsgroepen: bakkers, dienstbodes, zeelieden, suikerbakkers (ofschoon de omvang van deze groep snel afnam in tweede helft van de negentiende eeuw), kleermakers en kelners. ${ }^{29}$

In Utrecht waren er de twee grote concentraties; de Westerwalder potverkopers en de Münsterlandse winkeliers en hun personeel. Beroepen die elders als typisch Duits golden, ontbraken echter opvallend genoeg in Utrecht onder de Duitse immigranten. In wat volgt wordt geprobeerd die afwezigheid te verklaren. 


\section{Nichevorming}

Omtrent nichevorming bestaat een uitgebreide sociaal-wetenschappelijke literatuur, waarbij elke auteur met een nieuwe theorie lijkt te komen. ${ }^{30}$ De theorieën betreffende nichevorming refereren aan kenmerken van de immigranten of aan kenmerken van de markt. In het eerste geval gaat het bijvoorbeeld om voorkeuren van immigranten voor het werken met mensen van wie zij menen dat zij hen beter verstaan of begrijpen, die zij vertrouwen en die bereid zijn rekening te houden met speciale wensen, zoals werken tijdens de Ramadan of op de Sabbat..$^{31}$ Aan de kenmerken van de immigranten - hun culturele bagage, hun capaciteit om zich aan te passen of een taal te leren, de kennis en vaardigheden die ze meebrengen uit hun geboorteland - wordt gewoonlijk een groot verklarend gewicht toegekend. Concentratie in bepaalde beroepen wordt dan verklaard uit een grotere 'geschiktheid' voor bepaald werk. Chinese stokers op zeeschepen zouden, zo dachten hun Nederlandse werkgevers in de jaren 1930, blootgesteld kunnen worden aan veel hogere temperaturen, dan hun Europese collega's en waren daarom bij uitstek voor dit beroep geschikt. ${ }^{32}$ In 1927 meende de leiding van een Rotterdamse rederij kortweg: 'Aziaten zijn hittebestendiger' ${ }^{33}$ Deze 'kwaliteit' zou dan het grote aantal Chinezen onder de stokers moeten verklaren.

Kenmerken hoeven niet reëel te zijn. Migranten krijgen soms karaktereigenschappen toegedicht, waardoor bepaalde economische sectoren voor hen gesloten blijven of juist gereserveerd worden en er een associatie ontstaat tussen een specifieke groep en een economische sector. ${ }^{34}$

Bij het verband tussen nichevorming en kenmerken van de markt gaat het bijvoorbeeld om immigranten die een gat in de markt ontdekken. ${ }^{35}$ Ze komen met een onbekend product, zoals Chinese pindakoekjes of Italiaans ijs. Soms wordt hierbij een koppeling gemaakt tussen pre-migratoire kennis enerzijds en de associatie van een specialisatie met een groep anderzijds. Het ontstaan van een niche kan ook gerelateerd zijn aan voorzieningen voor de eigen gemeenschap, bijvoorbeeld van voedsel. Vraag naar speciaal voedsel kan verband houden met smaakvoorkeuren en kan versterkt worden door de wens te leven volgens spijsvoorschriften. ${ }^{36}$ Voorzieningen voor de eigen gemeenschap zijn vervolgens een springplank voor ondernemerschap in de samenleving als geheel. De mogelijkheden voor ondernemerschap binnen de eigen gemeenschap, ook wel enclave-economie genoemd, zijn mede afhankelijk van de omvang en de geografische concentratie van de groep, en van de mate waarin hun vraag afwijkt van het aanbod in de ontvangende samenleving.

Niches ontstaan, omdat immigranten via handelscontacten in hun herkomststreek toegang hebben tot producten die voor anderen minder gemakkelijk of tegen minder gunstige voorwaarden te krijgen zijn. De handelaren hebben dan de mogelijkheid om als alleenvertegenwoordiger van de handelswaar op te treden, of ze kunnen door familiebanden of andere contacten gunstigere voorwaarden bedingen. ${ }^{37} \mathrm{Zij}$ halen relatieve voordelen uit de toegang tot en de kennis van een specifieke markt. Gunstige handels- 
voorwaarden kunnen gecombineerd worden met het rekruteren van medewerkers in de herkomststreek, die bereid zijn tegen lagere dan de gangbare lonen te werken. ${ }^{38}$

Het nichevormingsproces wordt beïnvloed door de mogelijkheden die de niche biedt voor het meewerken van familieleden, zoals dat bijvoorbeeld het geval is bij het hedendaagse Chinese restaurantwezen. Wanneer zowel mannen als vrouwen in de niche werkzaam zijn, ontstaat er een hecht verband tussen de groep en de economische sector. ${ }^{39}$ Goedkope arbeiders bieden vooral voordelen in sectoren met een grote arbeidsintensiviteit, weinig (mogelijkheden voor) technologische innovatie en geringe groei van productiviteit. ${ }^{40}$

Of er een niche wordt gevormd, hangt af van de mogelijkheden om een inheritable economic base te verplaatsen van het ene land naar het andere. Deze erfelijke economische basis kan bestaan uit verhoudingen tussen arbeidskrachten, klassenverhoudingen of gildenlidmaatschap. ${ }^{41}$

Een groot verloop onder de in de niche werkende arbeidskrachten kan nichevorming bevorderen. ${ }^{42}$ Het verloop creëert een transfer of sector-specific human capital. Door een groot verloop van arbeidskrachten binnen de sector worden ideeën verspreid in een zich steeds uitdijende groep over hoe de sector georganiseerd en geleid moet worden. Door deze sectorspecifieke mobiliteit van human capital wordt de niche versterkt en gecontinueerd.

Indien de niche voldoende en lonende werkgelegenheid biedt voor het verruimen van de economische basis van de groep, kan de specialisatie blijven voortbestaan. ${ }^{43}$ De groep kan ook als geheel doorschuiven naar een nieuwe niche, waardoor onder aan de sociale ladder ruimte ontstaat voor een andere groep nieuwkomers.

Nichevorming hoeft niet tot positieve resultaten te leiden voor alle mensen die in de niche actief zijn. Succesvolle afsluiting van een sector kan ten koste gaan van de afhankelijke werknemers binnen de sector. Van de nichevorming kan op den duur zelfs een verstikkende werking uitgaan. Rekrutering van personeel uit de eigen kring, dat zich vervolgens verzelfstandigt, kan leiden tot een zo groot aantal ondernemers dat de winstgevendheid van de sector wordt aangetast. De lange termijnontwikkeling van de niche wordt daarom bepaald door het principe van concurrerende exclusie. ${ }^{44}$ Een niche kan slechts een beperkt aantal ondernemers ondersteunen en blijft bestaan zolang het lukt dit aantal beperkt te houden. Exclusie- en inclusiemechanismen zijn hierbij belangrijk en dus de hechtheid van de groep die deze mechanismen in handen heeft.

Samenvattend zijn het enerzijds de kenmerken van immigranten - hun culturele bagage of hun (vermeende) kwaliteiten - die tot nichevorming kunnen leiden en anderzijds de kenmerken van de markt, zoals nieuwe mogelijkheden of een snelle expansie, die nichevorming zouden moeten verklaren. 


\section{Typisch Duits?}

In tabel 8.4 worden elf beroepen opgesomd waarin Duitse immigranten in Utrecht werkten en waarin in andere tijden en op andere plaatsen Duitse immigranten sterk vertegenwoordigd waren. In deze elf beroepen werkte 16 procent van de Duitse immigranten. Het gaat hier niet om beroepen waarin Duitse immigranten bij uitstek sterk vertegenwoordigd waren. Die worden in volgende hoofdstukken besproken. Hier staat het vergelijkende perspectief centraal. De meeste theorieën betreffende nichevorming proberen een opvallende concentratie te verklaren. Hieronder wordt in feite het omgekeerde nagestreefd. Niet een getalsmatig sterke vertegenwoordiging, maar een opvallende afwezigheid is onderwerp van onderzoek. Deze benadering maakt het mogelijk

Tabel 8.4 Overzicht van de beroepen waarin een deel van de Duitse immigranten in Utrecht werkte.

\begin{tabular}{|c|c|c|c|}
\hline & \multirow{2}{*}{$\begin{array}{c}\begin{array}{c}\text { Duitsers werkzaam in } \\
\text { hele periode }\end{array} \\
1849-1879\end{array}$} & \multicolumn{2}{|c|}{$\begin{array}{l}\text { totaal aantal mensen } \\
\text { in beroepentelling }\end{array}$} \\
\hline & & 1889 & 1849 \\
\hline \multicolumn{4}{|l|}{ I Typisch Duits? } \\
\hline smeden & 26 & 391 & 905 \\
\hline schoenmakers & 15 & 512 & 617 \\
\hline horlogemakers & 9 & 33 & 67 \\
\hline zadelmakers & 2 & 149 & 76 \\
\hline militairen (geen manschappen) & 65 & 379 & 423 \\
\hline kleermakers & 33 & 628 & 890 \\
\hline bakkers en bakkersknechts & 10 & 284 & 486 \\
\hline prostituees & 17 & 26 & 9 \\
\hline \multicolumn{4}{|l|}{ II Nieuwe mogelijkheden? } \\
\hline kelners & 12 & n.v. & 101 \\
\hline fotografen & 7 & n.v. & 20 \\
\hline sigarenmakers & 4 & n.v. & 836 \\
\hline totaal & 200 & & \\
\hline totaal aantal Duitsers waarvan beroep bekend is & 1261 & & \\
\hline percentage in deze tabel vermeld & $16 \%$ & & \\
\hline
\end{tabular}

Bron gegevensbestand Duitse immigranten in Utrecht 1849-1879 en beroepentellingen 1849 en 1889. n.v. is niet afzonderlijk als beroep vermeld in volks- en beroepentellingen. 
om te toetsen in hoeverre culturele bagage of kenmerken van de markt een verklaring kunnen bieden.

In tabel 8.4 wordt een vergelijking gemaakt met het totaal aantal personen dat in Utrecht werkte volgens de beroepentellingen van 1849 en 1889 . Omdat in 1879 geen beroepentellingen werd gehouden, wordt in de tekst bovendien verwezen naar gegevens uit het Adresboek van 1879-1880. Adresboeken - vergelijkbaar met onze Gouden Gids hebben als nadeel dat ze niet alle mensen vermelden die in een bepaalde sector werkzaam waren. Zelfstandigen en werkgevers komen er wel in voor, maar loonafhankelijken niet. Adresboeken kunnen dus niet gebruikt worden voor het bepalen van het aandeel van immigranten in een sector, maar ze kunnen wel worden gebruikt voor het vaststellen van het aandeel van Duitse immigranten dat als ondernemer of zelfstandige werkte in een sector.

\section{Ludwig Stern}

In het midden van de negentiende eeuw vreesde Multatuli's Droogstoppel dat zijn voornaamste klant Ludwig Stern, 'eerste huis in koffie te Hamburg', overgenomen zou worden door zijn concurrent. ${ }^{45}$ Hij schreef daarom aan Stern dat de toename van zijn Noordduitse zaken een uitbreiding van zijn personeel noodzakelijk maakte. Hij zocht iemand voor correspondentie in het Duits. 'Dat weliswaar veel Duitse jongelingen, in Amsterdam aanwezig, hiertoe de vereiste bekwaamheden bezaten, maar dat een huis dat zich respecteert [...] niet omzichtig genoeg wezen kon met het engageren van sujetten.' Hij had gehoord dat de zoon van Ludwig Stern 'ter volmaking zijner commerciële kennis, enige tijd in een Hollands huis wenste geëmployeerd' te zijn. Hij zou dan ook graag zien dat de jonge Stern belast werd met 'de Duitse correspondentie van ons huis.' De jonge Stern zou bij de Droogstoppels kost en inwoning hebben, zodat de oude Stern zich verplicht zou voelen zijn zaken met Droogstoppel te continueren.

In Engeland was in 1871 1,3 procent van de klerken Duits. Duitse klerken waren ook in New York een gangbaar verschijnsel. ${ }^{46}$ In Utrecht vinden we geen enkele Duitse klerk. ${ }^{47}$ Een verklaring hiervoor ligt in het verschil in de aard van de handel. In Amsterdam, waar de meeste Duitse klerken te vinden waren, ging het om grootschalige internationale handelsondernemingen. In Utrecht waren de ondernemingen kleiner en minder op overzeese handel gericht.

In New York was de Plattdeutsch sprekende kruidenier uit Hannover een stereotiep figuur, terwijl dat eveneens gold voor de schoenmaker uit Hessen. ${ }^{48}$ Duitse kruideniers ontbreken volledig in Utrecht. Duitse schoenmakers waren er wel - vijftien in totaal maar slechts een van hen kwam uit Hessen. Op het totaal aantal schoenmakers in Utrecht (512 in 1849) waren zij onbelangrijk.

In het tijdvak tussen 1780 en 1795 waren Duitse immigranten in Utrecht oververtegenwoordigd in de bierbrouwerijen. ${ }^{49}$ Nog in 1801 hadden de Utrechtse bierbrouwerijen vooral Duitsers in dienst. ${ }^{50}$ In New York vormden omstreeks 1850 Duitse bier- 
brouwers eveneens een belangrijke groep..$^{51}$ In Amsterdam werkten er op de brouwerijen, zoals gezegd, ook veel Duitsers. Tot 1890 gold dat geschoold Duits personeel de nodige vakkennis moest leveren. Heineken had in 1871 veertig arbeiders, waarvan de helft Duits was. In 1899, toen de arbeiders bij Heineken looneisen stelden, waren de woordvoerders de Duitse kuipers. Meer dan twintig jaar nadat de eerste Duitsers werden aangesteld, was de Duitse invloed nog steeds sterk. In de brouwerijen werd gebruik gemaakt van Duitse vaktermen: 'het ligt wel voor de hand dat waar het toe- en opzicht houdend personeel voor een groot deel uit Duitschers bestaat, de Duitsche taal veel wordt gebruikt'. ${ }^{2}$

In Utrecht lag de situatie omstreeks 1850 heel anders. In 1879 waren er in de Domstad, volgens het Adresboek, drie bierbrouwers, maar zij waren geen van drieën Duits. In de hele periode van 1849 tot 1879 vinden we in Utrecht slechts twee Duitsers die bij de bierbrouwerij betrokken waren. ${ }^{53}$ De verklaring voor het verschil ligt in de stand van de bedrijfstak. Terwijl de sector in Amsterdam en elders expandeerde, was het tegenovergestelde het geval in Utrecht. Daar hadden de brouwerijen sterk aan betekenis ingeboet en deze tendens zette zich voort in de tweede helft van de negentiende eeuw. De kwijnende bedrijfstak trok geen arbeiders van elders.

Bij de suikerbakkers zien we een vergelijkbare ontwikkeling. In de achttiende eeuw werkten in Utrecht Duitsers in deze sector. In Amsterdam gold dat ook nog in de negentiende eeuw. Volgens de volkstelling van 1849 waren er in Utrecht in totaal zeven suiker- en pasteibakkers. Duitsers waren er echter in deze sector nog maar weinig. In het bevolkingsregister vinden we in de Suikerstraat de suikerbakker Christiaan Heuker. ${ }^{54}$ Hij overleed in 1854. In 1877 kwam Leo van Metzsch uit Dresden naar Utrecht, als opzichter van de suikerfabriek. ${ }^{55}$ De invloed van Duitsers in deze sector was niet geheel verdwenen, maar van een overwicht, zoals dat eerder en elders bestond, kan geenszins worden gesproken. Opnieuw geldt, net als bij de brouwerijen, dat de Utrechtse bedrijfstak veel minder belangrijk was dan de Amsterdamse.

In de achttiende eeuw waren in Utrecht Duitse zadelmakers niet onbelangrijk. ${ }^{56}$ In het midden van de negentiende eeuw had de zadelmakerij nog wel enige betekenis volgens de volkstelling van 1849 werkten 149 mannen en jongens als rijtuig-, wagen-, koffer- en zadelmakers, maar Duitsers speelden in deze sector geen rol meer. Theodoor Schultz kan beschouwd wordt als de laatste representant van een voorbij tijdvak. ${ }^{57} \mathrm{La}-$ ter vinden we in Utrecht nog slechts Jacob Gantevoort..$^{58}$ De afname van het aantal zadelmakers kan niet verklaard worden uit een teloorgang van deze sector, zoals dat gold voor de bierbrouwers en suikerbakkers.

In het verleden hadden Duitsers in de Utrechtse metaalsector een relatief belangrijke rol gespeeld. Na een sterke groei in deze sector in de zestiende eeuw en de komst van gespecialiseerde metaalbewerkers uit het Ruhrgebied en de regio Aken-Luik, vervielen onderdelen van deze bedrijfstak in de zeventiende eeuw en andere in de achttiende eeuw. In het belastingjaar 1793 werden de meeste metaalbewerkers in Utrecht als onvermogend aangemerkt. Gespecialiseerde metaalbewerkers uit Duitsland waren toen reeds verdwenen. Er kwamen in de achttiende eeuw nog wel knechts uit Duitsland 
in de Utrechtse metaalsector werken, zo blijkt uit het lidmatenregister van de lutherse gemeente, maar zij brachten het niet (meer) tot meester. ${ }^{59}$ Tinnegieters, geweermakers en zwaardvegers kenden een vergelijkbare geschiedenis. In 1849 werden er in totaal nog zeven mannen geteld die als beroep geschutgieter of geweermaker hadden. In de periode 1849 tot 1879 waren er in Utrecht vijf Duitse geweermakers. Van een zekere overheersing van het vak was in dit geval dus nog wel sprake. Erg belangrijk was de sector echter niet meer.

Naast de geweermakers waren er in de periode van 1849 tot 187926 Duitse smeden die verspreid over de stad woonden, met een lichte concentratie in wijk $\mathrm{M}$, waar het centrum van de Utrechtse metaalnijverheid was. De Duitse smeden vormden een klein deel van de in totaal bijna vierhonderd smeden die in 1849 in Utrecht werden geteld. De afwezigheid van Duitse immigranten is te meer opvallend, omdat de metaalsector in de tweede helft van de negentiende eeuw een expanderende sector was. In de metaalsector waren slechts twee opvallende groepen Duitsers werkzaam; de vijlenkappers, die in een volgend hoofdstuk besproken worden, en de werknemers van de ornamentenfabrikant Christiaan Rencker. Aan dat bedrijf wordt hieronder aandacht besteed. Binnen de metaalsector concentreerden Duitse immigranten zich in deze twee kleine deelsectoren.

Duitse militairen waren een belangrijke groep in Utrecht in de Vroegmoderne Tijd. ${ }^{60}$ Voor Denemarken gold in dat tijdvak hetzelfde en daar was de officiële commandotaal van het leger Duits. Na 1806 verdwenen de Duitse militairen echter uit de Deense krijgsmacht, als gevolg van kritiek op een zo grote vreemde invloed op het leger. ${ }^{61}$ In Nederland zijn er weinig aanwijzingen voor vergelijkbare kritiek. ${ }^{62}$ De rol van Duitse soldaten was in het midden van de negentiende eeuw desondanks aanzienlijk minder dan in eerdere periodes. In de periode 1849 tot 1879 vinden we in de stad Utrecht in de bevolkingsregistratie 65 Duitse militairen. Dit aantal zal in werkelijkheid iets hoger hebben gelegen, maar het zal de 85 niet hebben overstegen. ${ }^{63}$ In 1849 werden er in Utrecht in totaal 379 militairen geteld. De Duitse militairen waren voor een groot deel (in 32 gevallen) reeds gepensioneerd. Ze waren merendeels protestants; er waren slechts zeventien katholieken. Ze kwamen uit alle delen van Duitsland, zowel uit grote steden als Hamburg en Berlijn, als uit tal van kleinere plaatsen in Beieren, Oldenburg, Hessen, Nassau, Saksen, Hannover en het aan Nederland grenzende deel van Pruisen. De aanwezigheid van de Nassauers hing samen met het feit dat, in de eerste decennia van de negentiende eeuw, het regiment Nassau Oranien anderhalf jaar en de Nassausche Lichte Infanterie vijf jaar lang deel hadden uitgemaakt van het Nederlandse leger. ${ }^{64}$ De Nassause legeronderdelen, die zo'n vierduizend man telden, waren door Willem I niet alleen aangetrokken om het Nederlandse leger te versterken, maar ook in de hoop banden te kunnen aanhalen met het door Nederland verloren Nassau. Reeds voor 1820 keerden de meeste Nassause militairen terug naar Duitsland. Een klein deel werd opgenomen in het Nederlandse leger.

De Duitse klokkenmaker was in eerdere tijdvakken en elders een bekende verschijning. ${ }^{65}$ Bij de klokkenmakers bestond van oudsher een band met het Zwarte Woud als regionaal productiecentrum. In de tweede helft van de negentiende eeuw, was deze 
productie echter door opkomst van fabrieken sterk afgenomen. ${ }^{66}$ Klokkenmakers - in de bronnen ook aangeduid als uurwerkmakers of horlogemakers - vinden we wel in het negentiende-eeuwse Utrecht, maar het aantal Duitsers onder hen is gering. In de volkstelling van 1849 komen in totaal 33 uurwerkmakers voor. In 1879 waren er volgens het Adresboek in Utrecht 27 horlogemakers, waaronder twee Duitsers. In totaal vinden we over de gehele periode van 1849 tot 1879 in Utrecht negen Duitse horlogemakers. ${ }^{67}$ De horlogemakers woonden verspreid over de hele stad, en het waren merendeels alleenstaande mannen, die op zichzelf of in een kosthuis woonden. Ze woonden niet in bij collega's. ${ }^{68}$ De horlogemakers kwamen uit alle delen van Duitsland - niet speciaal uit het Zwarte Woud - en waren zowel katholiek als luthers.

In Engeland waren Duitse kappers en barbiers in het midden van de negentiende eeuw niet onbelangrijk. ${ }^{69}$ In het achttiende-eeuwse Kopenhagen speelden zij eveneens een belangrijke rol. Ze werden vanwege hun vermeende kwaliteiten speciaal in Hamburg geworven. In latere tijdvakken ontbreken ze in de Deense hoofdstad. ${ }^{70}$ In Utrecht vinden we in de hele periode van 1849 tot 1879 slechts één Duitse kapper en één kappersbediende. Duitse barbiers waren er helemaal niet. In 1849 werkten er volgens de volkstelling in totaal zo'n honderd mensen in deze sector. In 1879 waren er volgens het Adresboek 51 kappers, maar geen van hen was Duits. In Utrecht was het kappersvak geen Duits specialisme.

In 1849 werden er in de Domstad bijna duizend mensen geteld die als arbeider werkten. Deze aanduiding ontbreekt onder de Duitse immigranten. Duitse immigranten ontbraken eveneens in de expanderende bouwsector, met uitzondering van de later te bespreken stukadoors. In Amsterdam werkten juist wel veel Duitsers in de bouw. ${ }^{71}$ In Denemarken waren Duitse metselaars eveneens een gangbaar verschijnsel. ${ }^{72}$ De aanduiding metselaar of metselaarsknecht komt niet voor bij Duitse immigranten in het Utrechtse bevolkingsregister. In het Utrechtse adresboek van 1868-1869 worden 37 metselaars vermeld, allemaal zelfstandigen. Van hen kwam er geen een uit Duitsland. ${ }^{73}$ Tien jaar later waren er 35 metselaars, waaronder één Italiaan en opnieuw geen Duitsers. In eerdere tijdvakken waren Duitse metselaars in Utrecht evenmin belangrijk.

Duitse immigranten werkten in Utrecht niet als hoveniers en hoveniersmeid of hoveniersknecht. Hoveniers waren, zoals gezegd, een belangrijke beroepsgroep in Utrecht. ${ }^{74}$ De hoveniers, die aan de stadsranden hun bedrijven hadden waar ze groente en fruit kweekten voor de stedelijke markt, vormden een gesloten groep, verbonden door veel onderlinge huwelijken. Ze waren katholiek en voor een klein deel oud-katholiek. Verondersteld zou kunnen worden, dat deze stabiele, gesloten gemeenschap moeilijk toegankelijk was voor nieuwkomers. Bovendien was het beroep boer in hoge mate 'erfelijk'; kinderen volgden in het voetspoor van hun ouders. Opmerkelijk is, in dat licht, het verschil met de eveneens katholieke hoveniers aan de zogenaamde Boerenwetering bij Amsterdam. ${ }^{75}$ Hier waren Duitse immigranten zo belangrijk, dat de Boerenwetering een tijdlang de naam 'Moffenwetering' kreeg. De Duitsers kwamen uit Löhne en Dinklage (Ambt Vechta) of uit Essen (Ambt Cloppenburg) in Oldenburg. Deze immigranten kwamen aan het begin van de negentiende eeuw als seizoensarbei- 
ders naar de Boerenwetering, bleven daar na het seizoen hangen en werden er uiteindelijk zelf boer. In 1896 kon bij tweederde van de warmoezeniersgezinnen aan de Boerenwetering een Duitse oorsprong worden aangewezen. In Utrecht vinden we wel immigranten uit deze Duitse plaatsen, maar niet onder de hoveniers of hun personeel. Immigranten uit deze plaatsen behoorden in Utrecht zonder uitzondering tot de groep winkeliers en winkelpersoneel.

\section{Prostituees}

In de prostitutie werkten elders in de negentiende eeuw veel Duitse vrouwen. In Rotterdam werd in de negentiende eeuw geklaagd over het grote aantal Duitse vrouwen in de prostitutie. Overal 'kan men 's nachts en 's avonds, ja zelfs overdag van die blondharige Duitsche Loreley's zien staan. Zij gedragen zich als in veroverd land en versperren driest en onbeschaamd des avonds den eenzamen voorbijganger den weg. ${ }^{76}$ In Amersfoort waren er in 1881 problemen rond het restaurant 'Zum Deutschen Kaiser' dat jonge Duitse meisjes aantrok als kelnerinnen, om ze vervolgens in de prostitutie te laten werken. ${ }^{77}$ In andere plaatsen werd eveneens melding gemaakt van Duitse prostituees, maar niet overal in afkeurende zin. In Maastricht was de politie van mening dat dit werk beter door Duitse vrouwen kon worden gedaan, dan dat 'meisjes uit de streek' zich in het verderf zouden storten. In Rotterdam werden buitenlandse vrouwen ook als onmisbaar gezien voor dit beroep. ${ }^{78}$ De historici Bossenbroek en Kompagnie constateerden voor het laatste kwart van de negentiende eeuw een opvallende toename van het aantal Duitse prostituees in Nederland. De vrouwen waren afkomstig uit een 'bevoorradingscircuit', dat werd gevormd door de stedenvierhoek Düsseldorf-CrefeldKeulen-Elberfeld, en vonden, volgens de beide auteurs, vooral werk in Rotterdam, Amsterdam en Arnhem en in mindere mate in Deventer en Utrecht. Nijmegen vervulde de rol van toegangspoort tot Nederland. In deze stad was bijna de helft van de geregistreerde prostituees van Duitse origine. ${ }^{79}$

In Utrecht waren Duitse prostituees niet oververtegenwoordigd. Zicht op de samenstelling van de groep prostituees in de Domstad, krijgen we door het prostitutieregister. $^{80}$ Tussen 1858 en 1888 waren er 29 officieel geregistreerde bordelen in Utrecht, waarvan er 26 geleid werden door een vrouw. ${ }^{81}$ In deze periode werden 735 prostituees geregistreerd. Daarnaast was er een onbekend aantal niet geregistreerde prostituees. Prostituees mochten alleen geregistreerd worden als ze meerderjarig waren (ouder dan 21). De jongere prostituees vielen buiten de registratie.

In 1890 verbood Utrecht als eerste Nederlandse stad de prostitutie. Over dit verbod werd jarenlang gediscussieerd in de gemeenteraad. Min of meer voorafgaand aan dit debat, werden in een vrij korte periode opeens twaalf Duitse prostituees uitgewezen. In de jaren daarvoor was het aantal uitzettingen gering. De Duitse vrouwen die werden uitgewezen, verbleven merendeels slechts kort in Utrecht. In ongeveer de helft van de 
gevallen hadden ze syfilis, waardoor ze niet meer officieel konden werken. Geen van de uitgewezen vrouwen werd ingeschreven op het adres van een officieel bordeel.

In Utrecht werd wel veelvuldig geklaagd over prostituees, maar niet over Duitse. ${ }^{82}$ Van de in totaal 735 prostituees was 14 procent buiten Nederland geboren; 7,8 procent was Duits. Dit percentage heeft betrekking op negentien prostituees waarvan met zekerheid gezegd kan worden dat ze in Duitsland werden geboren. In 38 aanvullende gevallen was een Duitse geboorte waarschijnlijk; er werd geen geboorteplaats vermeld in het prostitutie- of bevolkingsregister, maar er waren andere redenen om aan te nemen dat het om Duitse vrouwen ging. Als voorbeeld kan Maria Agnes Theresia Peffer worden genoemd. Zij kwam op 2 november 1883 uit Elberfeld en keerde op 22 april 1884 daarheen terug. Ofschoon er bij haar geen geboorteplaats werd vermeld, suggereren naam, plaats van herkomst en bestemming dat zij Duitse was. Dit betekent dat een kwart van de prostituees Duits was. Het percentage Duitse vrouwen onder de prostituees was groter dan hun aandeel in de Utrechtse bevolking. Behalve Duitse vrouwen werkten er in de prostitutie één Engelse vrouw, acht vrouwen waarvan het zeker was dat ze Frans waren en zeven waarvan dat waarschijnlijk was, negen vrouwen die met zekerheid uit België kwamen en 19 vrouwen die waarschijnlijk Belgische waren. Buitenlandse vrouwen waren dus in de prostitutie nadrukkelijk aanwezig.

De komst van Duitse vrouwen was in Utrecht vooral gerelateerd aan de activiteiten van de reeds eerder genoemde Duitse bordeelhoudster Maria Mörs. Zij werd in 1821 geboren in Müngersdorf bij Keulen en kwam in 1871 naar Utrecht, na eerst kort in Amersfoort en Amsterdam te hebben gewoond. Ze was toen reeds weduwe van Johannes Ree. In het bevolkingsregister werd ze ingeschreven als tapster. Uit het Amersfoortse bevolkingsregister bleek echter dat ze daar reeds een bordeel had gehad. In Utrecht nam ze het bordeel in de Stroosteeg over van de Utrechtse Anthonia Levever, die deze gelegenheid sinds 1858 had. Zoals in alle bordelen, werkten voor Levever een groot aantal jonge vrouwen, die allen slechts korte tijd bleven. Ieder jaar vernieuwde de bordeelbevolking zich. Bij Levever was slechts één van de vrouwen Duits. Mörs bracht uit Amersfoort zeventien vrouwen mee onder wie één Duitse. Later kwamen er nog twee Duitse vrouwen bij. Het merendeel van de prostituees was Nederlands. Daarnaast waren er enkele Franse en Belgische vrouwen. In 1881 ging Mörs naar Duitsland, om enkele maanden later terug te keren naar Utrecht. Kennelijk had ze een succesvolle rekruteringstocht gemaakt, want in deze periode nam het aantal Duitse vrouwen in haar bordeel toe. In het bordeel werkten tussen 1880 en 1882 negen Duitse publieke vrouwen. Zij waren allen, net als Mörs, katholiek. Na de wervingsactie werkten in het bordeel merendeels Duitse vrouwen. De Duitse prostituees in Utrecht kwamen overwegend uit de door Bossenbroek en Kompagnie aangeduide stedenvierhoek.

In 1882 werd het bordeel overgenomen door een nieuwe bordeelhouder en zijn vrouw, beiden geboren in het Duitse Barmen. Voor hen werkten ook weer Duitse prostituees. Mörs verhuisde met de dochter van een van haar werkneemsters, omschreven als aangenomen kind, naar de Zonsteeg in wijk I. Daar woonde ze enkele maanden, waarna ze met het kind naar Duitsland vertrok. 
In het geval van de prostituees is niet geheel duidelijk of Duitse vrouwen in andere steden en op andere plaatsen inderdaad een belangrijk aandeel in deze beroepsgroep hadden, of althans belangrijker dan in Utrecht. Mogelijk werd er aanstoot genomen aan hun aanwezigheid en werd er vooral veel over hen geklaagd.

\title{
Kelners
}

De schrijver P.J. Andriessen dreef in 1871 de spot met de Duitse kelner en stak de draak met de slepende s-klank in zijn uitspraak van het Nederlands.

\begin{abstract}
"Was soll ich Ihnen sagen, meinherr," zeide de kellner, die een duitscher was en zo goed mogelijk nederlandsch poogde te spreken. "Es ist ein grap von den herren reiziger. Was die al nicht uithalen, dass kan man zich nicht voorsjtellen.”83
\end{abstract}

Het Nederlandse woord 'kelner', aanvankelijk gespeld als 'kellner', werd in het midden van de negentiende eeuw overgenomen uit het Duits als aanduiding voor hotel- en koffiehuisbediende. ${ }^{84}$ Hierin vinden we reeds een verwijzing naar het aandeel van Duitsers in deze beroepsgroep. Het hotel- en koffiehuispersoneel viel feitelijk uiteen in twee groepen. In 1907 werd hierover opgemerkt:

De koffiehuiskellner is gewoonlijk Hollander van geboorte en hij verlaat niet dan om bijzondere redenen het land; een groot aantal der in de Amsterdamse hotels werkende kellners daarentegen zijn vreemdelingen (meerendeels Duitschers) en, voor zoover zij Hollander zijn, verlaten zij weldra hunne betrekking en geboorteland, om plaatsing in den vreemde te zoeken; dit zwervend leven vindt voor een goed deel zijn oorzaak in de noodzakelijkheid voor den hotelkellner, om talen te kennen en wel zoo, dat alleen verblijf in het land zelf hem de noodige oefening kan verschaffen; voor den koffiehuiskellner bestaat deze noodzakelijkheid volstrekt niet. ${ }^{85}$

De kelners in de grote hotels waren internationaal georganiseerd in de Deutscher Kellner Bund Union Ganymèd. De Union Ganymèd was een internationale organisatie die in 1878 was opgezet. ${ }^{86}$ De bond had lokale onderafdelingen. ${ }^{87}$ De Union Ganymèd bemiddelde alleen al voor Den Haag en Scheveningen 1000 tot 2000 mensen per jaar. ${ }^{88}$ Zij hielp ook werkloos geworden Duitse kelners om naar Duitsland terug te keren.

Utrecht was echter geen Amsterdam, Den Haag of Scheveningen. In de eerste helft van de negentiende eeuw leidde de toename van handel en verkeer wel tot de oprichting van tal van hotels en logementen in Utrecht, ${ }^{89}$ maar er waren veel minder hotels dan in de andere drie plaatsen. De scheiding tussen koffiehuiskelner en hotelkelner was in Utrecht bijgevolg minder rigide. De Duitse kelners werkten zowel in de hotels als in de koffiehuizen. In Utrecht vinden we Duitse kelners onder meer bij Carl Hühmann in zijn 'Hotel la 
Station' op het Stationsplein..$^{90}$ Bij de volkstelling van 1879 werden hier de Duitse kelners Robert Biehme, Carl Krumbing en Carl Hoffman ingeschreven. Zij hadden zich kort daarvoor vanuit respectievelijk Parijs, Brussel en Den Haag in Utrecht gevestigd. In totaal waren er in Utrecht twaalf Duitse kelners in de periode 1849 tot 1879 . Het merendeel kwam aan het einde van deze periode. De kelners hadden weinig met elkaar gemeen wat betreft geloof en herkomststreek. Wel werkten ze merendeels voor Duitse werkgevers. De afwezigheid van een groot aantal Duitse kelners in Utrecht laat zich verklaren uit het feit dat de hotels kleiner waren en het toeristisch verkeer minder was.

\section{Sigarenmakers}

Werk was er juist wel in overvloed in de sigarenindustrie, de snelst groeiende Utrechtse industrie. In de volkstelling van 1849 komen nog geen sigarenmakers voor. Er waren wel tabakskervers: 201 jongens en mannen. Sigaren bestonden al, maar het merendeel van de tabak werd nog verwerkt tot snuif- en pruimtabak. Tussen 1850 en 1870 maakte de Utrechtse sigarenindustrie een zeer snelle ontwikkeling door. In 1869 telde deze nieuwe bedrijfstak in Utrecht 35 fabrieken, die werk gaven aan 1700 mensen. ${ }^{91}$ In de volkstelling van 1889 werden 841 sigarenmakers geteld. Omstreeks 1860 werd er geklaagd over een tekort aan personeel. ${ }^{92}$ Utrecht's grootste sigarenfabrikant, Ribbius Peletier, wees in 1859 orders af, omdat hij niet genoeg personeel had. ${ }^{93}$ Sigarenmakers maakten van de ruime werkgelegenheid gebruik door regelmatig van werkgever te veranderen. Ze werden aangemerkt als zwervend personeel, dat door heel het land werk zocht. Lonen in deze sector waren relatief hoog. ${ }^{94}$ Ribbius Peletier begon, naar zijn zeggen, vanwege een tekort aan mannelijke sigarenmakers met een vrouwenfabriek naast zijn reeds bestaande mannenfabriek. De vrouwenfabriek gaf in 1859 werk aan zeventig vrouwen. In 1865 waren er al 60 vrouwen en 79 meisjes. ${ }^{95}$

Als er in Utrecht ergens een gat in de markt was, dan zou dat hier moeten zijn: een nieuwe en sterk expanderende industrie, waarin verhoudingen nog niet vastlagen en de vraag naar personeel groot was. Opmerkelijk is daarom dat immigranten vrijwel ontbraken in deze nieuwe bedrijfstak. De afwezigheid van immigranten is ook opvallend, omdat het sigaren maken in Nederland werd geïntroduceerd door een Duitser. ${ }^{96}$ In New York waren er wel veel sigarenmakers onder de Duitse immigranten. ${ }^{97}$

In de hele periode van 1849 tot 1879 vinden we in Utrecht slechts vier Duitse sigarenmakers, die bovendien slechts tijdelijk in Utrecht verbleven. Zo was er bijvoorbeeld Jacob Niekiel. ${ }^{98}$ Hij woonde met zijn gezin in een periode van krap drie jaar in Utrecht, Gouda en in de sigarenstad Kampen. Bij hem in woonde de tien jaar jongere Pieter Niekiel, die tabakskerver was. ${ }^{99}$

Wie werkten er dan wel in de expanderende sigarenindustrie? Het is ondoenlijk om voor alle sigarenmakers op te zoeken waar ze vandaan kwamen. Opvallend is echter dat de socioloog De Vooys opmerkte dat sigaren maken een typisch 'inheems' beroep was, waarmee hij bedoelde, dat mensen die buiten de stad geboren waren er vrijwel geen 
emplooi in vonden. ${ }^{100}$ Op basis hiervan zouden we kunnen veronderstellen dat Utrechtse arbeiders deze zeer lonende sector gesloten hielden voor buitenstaanders. Gezien de tekorten aan arbeidskrachten in de bedrijfstak, is het echter weinig aannemelijk dat ze echt deze macht hadden. Wel duidelijk is, dat het gat in de markt een onvoldoende verklaring biedt voor het ontstaan van niches.

\section{Fotografen}

De fotografiesector is niet zozeer interessant omdat die elders werd aangemerkt als typisch Duits, als wel omdat we hier niet alleen te maken hebben met een nieuwe en expanderende markt, maar ook met een verschuiving van een niche van de ene groep migranten naar de andere. De Amerikaanse socioloog Waldinger ziet een dergelijke verschuiving als een historisch gangbaar verschijnsel onder immigranten. Volgens zijn 'stoelendans', of de successiethese, kon de 'stoel', die werd vrijgemaakt door de ene groep immigranten, worden ingenomen door een volgende groep. ${ }^{101}$ In Utrecht was de fotografie de enige sector waarbij we deze stoelendans zien, zij het in afgezwakte vorm.

Fotografie was een nieuw vak in de negentiende eeuw en aanvankelijk een uitgesproken Franse niche. Na Daguerre's uitvinding in 1839, werd fotografie ongekend populair in Parijs. ${ }^{102}$ De mode woei snel over, omdat mensen voor een foto minutenlang stil moesten zitten. Lijnen waren hard, de blik verkrampt en de ogen onnatuurlijk gesperd. Het resultaat was weinig flatteus. Toen de nieuwigheid er voor de Parijzenaars af was, zwierven Parijse fotografen uit over Europa. Het Nederlandse publiek was reeds van de Franse vinding op de hoogte, maar de fotografie werd nog niet actief beoefend. De markt lag dus open voor deze ondernemers.

De Franse fotografen resideerden in logementen, hotels of winkels en brachten via kranten hun meestal welgestelde publiek op de hoogte van hun komst. Ze bleven enkele weken. Daarna was de markt verzadigd en trokken ze verder. ${ }^{103}$ De kleine potentiële afzetmarkt maakte het voortdurend op en neer reizen van de fotografen noodzakelijk. ${ }^{104}$ Niet alle fotografen waren in dit tijdvak overigens even 'Frans' als ze zich voordeden. ${ }^{105}$ De associatie van fotografie met Franse immigranten, reserveerde deze sector in feite voor deze groep nieuwkomers, en fotografen die daar niet toe behoorden afficheerden zich als Frans, ook als ze dat niet waren.

Het Nederlandse publiek raakte, net als het Franse, spoedig op de nieuwe vinding uitgekeken en de markt zakte in. Omstreeks 1850 verbeterde de fototechniek, al bleef de prijs van een foto hoog: vier tot vierentwintig gulden. ${ }^{106}$ Van een foto kon bovendien slechts één afdruk worden gemaakt. Dit veranderde omstreeks 1860, waarna het zogenaamde visitekaartportret ongekend populair werd. ${ }^{107}$ Visitekaartportretten werden niet per stuk betaald, maar kostten zeven gulden per dozijn. Het uitwisselen van portretten en het in albums verzamelen van 'kiekjes' - genoemd naar de Leidse studentenfotograaf David Kiek - werd een rage. ${ }^{108}$ Omdat de markt verruimde, werd het voor fotografen mogelijk zich blijvend ergens te vestigen. De inkomsten waren echter nog 
steeds niet groot en dus combineerden fotografen hun beroep met dat van lithograaf, portretschilder of winkelier.

Opvallend is, dat niet de oorspronkelijke, Franse rondreizende fotografen de stap naar een gevestigd bestaan maakten, maar de Duitse. Groningen lijkt daarbij gefungeerd te hebben als de toegangspoort tot Nederland voor deze zogenaamde tweede lichting. Vanuit Groningen gingen de fotografen naar andere Nederlandse steden. ${ }^{109}$

Duitse fotografen overheersten het vak in Nederland niet. Numeriek waren de Nederlandse in de tweede helft van de negentiende eeuw belangrijker; ongeveer een op de twintig fotografen was Duits. ${ }^{110}$ Belangrijker dan een numeriek overwicht, was de Duitse invloed op de fotografie. Van de fotografen van naam was een groot deel wel Duits. ${ }^{111}$

In het midden van de negentiende eeuw hadden in Utrecht, net als elders, de Franse fotografen plaatsgemaakt voor Duitse. ${ }^{112}$ In Utrecht vormden zij een aanzienlijk aandeel van het totaal aantal fotografen. In 1849 komt deze nieuwe beroepscategorie nog niet voor in de beroepentelling. In 1889 waren het er in totaal al twintig. Het Adresboek van 1879 vermeldde veertien fotografen; vier van hen waren Duits. Hiermee was sprake van een zekere oververtegenwoordiging van Duitsers in deze sector. Het belang van de Duitsers werd versterkt door de omvang van hun ondernemingen. Alle grote zaken waren Duits.

In de periode van 1849 tot 1879 woonden er zeven Duitse fotografen in Utrecht. Ze waren zowel katholiek als protestants. De voor Groningen geconstateerde oververtegenwoordiging van joden onder de Duitse fotografen, ging voor Utrecht niet op. De Duitse fotografen hadden geen gemeenschappelijke regionale herkomst en woonden niet geconcentreerd. Ze kwamen onder meer uit streken als Saksen en Westfalen en uit plaatsen als Berlijn, Bonn, Oberhausen en Elberfeld. Zij werkten merendeels alleen of met één assistent en trokken dus niet op grote schaal personeel aan.

F.W. Deutmann, de eerste Duitse fotograaf in Utrecht, kwam in $1846 .{ }^{113} \mathrm{Hij}$ kwam eerst in maart en opnieuw tijdens de academische lustrumfeesten in juni, en keerde in maart en juni van het jaar daarop terug. Deutmann was tevens de eerste blijvende beroepsfotograaf in Nederland. Hij had eerst een galanteriezaak in Haarlem en opende daar een fotografische inrichting. ${ }^{114}$ In Utrecht werd hij gevolgd door de Duitser P. Bimermann, die op het Domplein een atelier onder de naam 'Weener photographie' inrichtte. In augustus 1854 kwam de Duitser Frederik Kayser, ook wel genoemd Frederick Kaijser. Kayser was katholiek en werd geboren in Hamm in Westfalen. Hij stond aanvankelijk genoteerd als portretschilder. ${ }^{115} \mathrm{Hij}$ installeerde zich in het logement van de weduwe De Groot op het Vredenburg. Een week later verhuisde hij naar de Lijnmarkt, waar hij zijn intrek nam bij schoenmaker La Marchand. In oktober nam hij de zaak van Bimermann over, die hij in het jaar daarop naar de Breedstraat verplaatste. ${ }^{116}$ Kayser werkte niet alleen in zijn atelier, maar vulde zijn inkomen aan door te reizen in de provincie. In 1865 werd de zaak opgeheven en vertrok Kayser met zijn gezin naar Zwolle.

Gustav Lüssow, de vierde Duitse fotograaf in Utrecht, werd in 1837 in Berlijn geboren. In 1863 werd hij in het Utrechtse bevolkingsregister ingeschreven als 'photograaf 
komende uit Berlijn. ${ }^{117}$ Hij was luthers en zijn vader was ambtenaar bij het Ministerie van Justitie in Berlijn. Hij verhuisde veelvuldig binnen de stad. ${ }^{118}$ In 1889 vertrok hij naar Berlijn.

Een andere belangrijke Duitse fotograaf in Utrecht was Wilhelm Küppers, die in 1838 in Bonn werd geboren. Hij was katholiek en kwam in 1869 naar Utrecht. ${ }^{119}$ In 1879 ging Küppers een vennootschap aan met de Duitser Wilhelm Mannebach, 'tot oprichting en uitoefening van de photographie en in verband daarmede de kunsthandel'. ${ }^{120}$ Het atelier van Küppers en Mannebach was gevestigd op het Vredenburg. In 1874 kwam Mannebach uit Amsterdam naar Utrecht. Hij stond in het bevolkingsregister niet alleen ingeschreven als fotograaf, maar later ook als kelner. ${ }^{121}$ In 1880 ging hij naar Xanten.

De fotograaf Richard Becher arriveerde in 1863 vanuit zijn geboorteplaats Oberhausen. ${ }^{122}$ Hij was toen reeds getrouwd met Louise Buddenberg uit Gravenhorst in Münster. Richard Becher overleed kort daarop op 25-jarige leeftijd. Zij weduwe adverteerde dat ze de zaak voortzette met een assistent. Ongetwijfeld was dit Jacob Blind (geboren in Mannheim in 1833), die naar Utrecht kwam in 1865 en later trouwde met de weduwe Buddenberg.

Behalve deze zelfstandig werkende fotografen, waren er in Utrecht, net als in enkele andere grote Nederlandse steden, filialen van grote Duitse foto-ondernemeningen. De belangrijkste waren Wegner \& Mottu en Büttinghausen. ${ }^{123}$ Hun Utrechtse filiaal bestond van 1868 tot 1883 en werd gedreven door Nederlandse fotografen. ${ }^{124}$ Het Utrechtse filiaal van de firma Büttinghausen werd geopend in $1879 .{ }^{125}$ Deze vestiging werd in 1880 gedreven door de Duitse fotograaf Gerard Brill en reeds na twee jaar opgeheven. ${ }^{126}$

In de fotografie konden Duitse immigranten meer mogelijkheden vinden dan in de sterk expanderende sigarenindustrie. De fotografen waren zelfstandigen in een weliswaar nieuwe, maar niet bijzonder lonende bedrijfstak. De markt was klein en gauw verzadigd. Daarmee werden in bepaalde opzichten grenzen gesteld aan de aanwezigheid van Duitse fotografen in de stad. Vernieuwing was er wel, maar expansie niet.

\section{Ornamentenfabriek Rencker}

Van vernieuwend ondernemerschap was ook sprake bij ornamentenfabriek Rencker. Christiaan Rencker, geboren in Groitzsch in Saksen in 1814, kan worden aangemerkt als een succesvol en innovatief ondernemer. Hij kwam in de jaren veertig van de negentiende eeuw naar Utrecht. ${ }^{127}$ Rencker was luthers, zijn vrouw Nederlands Hervormd. Hun twee kinderen werden luthers gedoopt. Bij Rencker werd bij zijn huwelijk genoteerd dat hij kunstdraaier en koopman in metalen ornamenten was. In het bevolkingsregister van 1860 werd hij vermeld als fabrikant van metalen ornamenten. Er lijkt op dat moment enige twijfel omtrent zijn beroep te hebben bestaan. Iemand - waarschijnlijk de wijkmeester - heeft met potlood in de marge van het bevolkingsregister geschreven dat Rencker elders vermeld staat als werkman. Rencker kwam in het gemeentever- 
slag van 1852 echter reeds voor als fabrikant van militaire ornamenten en metalen knopen. In de fabriek werkten op dat moment 23 mannen en 4 jongens. Veertien jaar later waren dat 25 mannen en 12 jongens. In 1871 werd in de fabriek een stoommachine geplaatst.

In de jaren tachtig van de vorige eeuw profiteerde Rencker van de groeiende vraag naar zijn producten, die mede bevorderd werd door de uitbreiding van zijn productenpakket. De militaire ornamenten en metalen knopen werden vervangen door een assortiment waarmee hij inspeelde op een nieuwe vraag. In het Adresboek van 1880-1881 staat bij de firma Rencker en zonen: 'koper en metaalgieterij, fabrikant van fournituren voor spoorwegrijtuigen, zadel- en wagenmakers, koper- en blikslagerij, smederij, metaaldrukkerij, stoom- en andere kranen, metalen ornamenten, koper- en zilverpleteering, stempelgravering in alle metalen, verlichting van spoorwegen, gas- en waterleiding, Beijersche luchtdrukbierpompen in alle soorten'. In 1883 leverde de fabriek veertig grote en twintig kleinere brandspuiten aan het Departement van Oorlog en Koloniën. Het bedrijf maakte ook de gaslantaarns voor de gemeente Utrecht en veel 'ver-

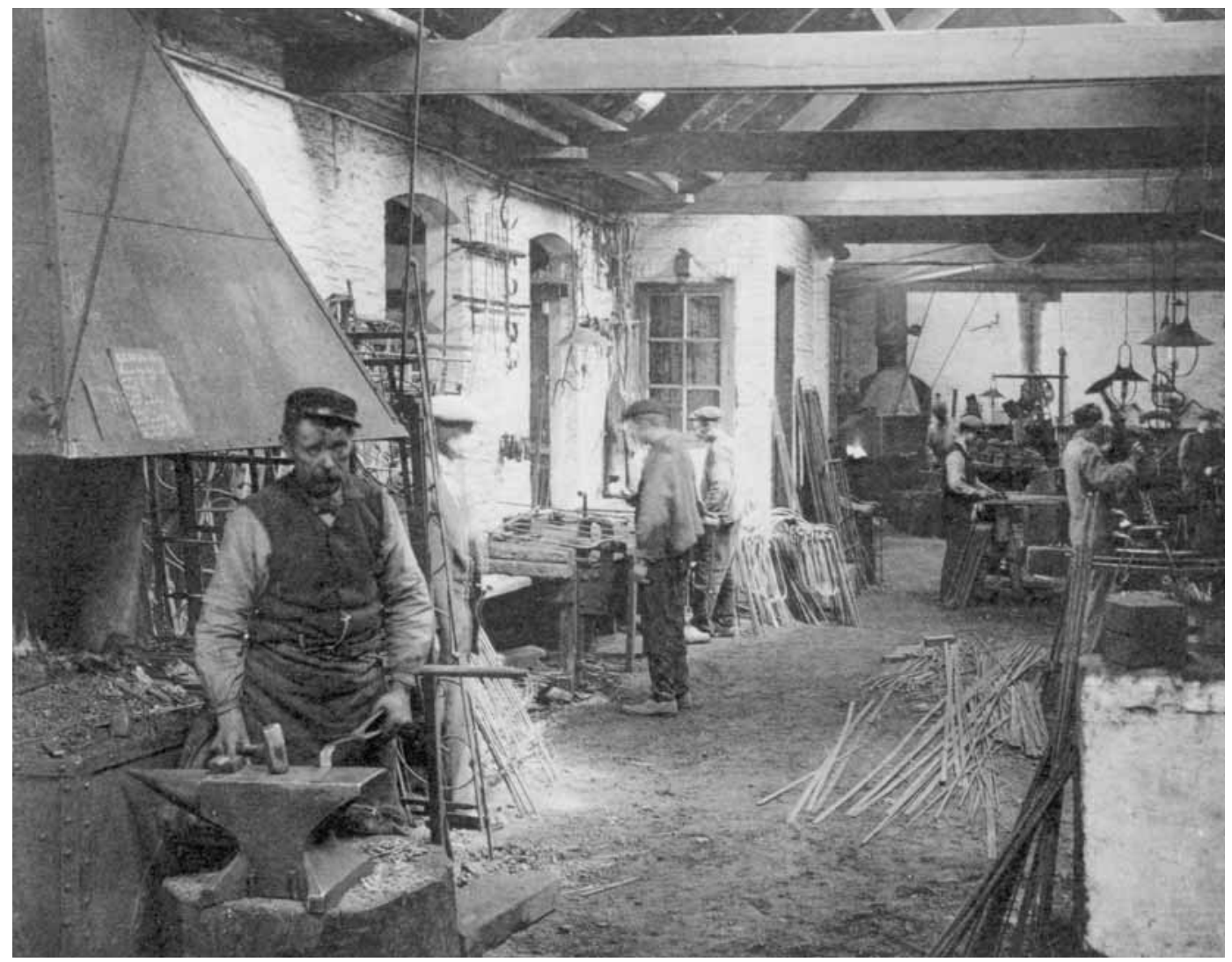


lichtingstoestellen' voor de tram- en spoorwegen. In 1895 werkten er 61 mannen en 8 jongens, terwijl de stoommachine er nu een was van $11 \mathrm{pk}$. Twee jaar later werd die vervangen door een machine van $30 \mathrm{pk}$.

In 1897 melde het gemeenteverslag dat de fabriek in geen jaren zoveel werk had gehad als thans. Het bedrijf legde stoom-, gas-, bel- en waterleidingen aan en leverde alle materialen voor gebruik van deze leidingen. In 1901-1902 werd Rencker vermeld als een 'Nederlandsche fabriek van koper- en metaalwerken, brandspuiten en verlichtingsmiddelen. Aanleg van stoom-, gas-, water-, spreekbuis- en electrische leidingen. Reparaties van stoommachines, het maken en aanbrengen van complete drijfwerken.' Het bedrijf had een telefoonaansluiting: nummer 70. Rencker junior was lid van de Kamer van Koophandel en Fabrieken. De succesvolle onderneming van Rencker werd voortgezet door zijn zoons. Een van Rencker's Duitse werklieden, Heinrich Siegel richtte in wijk $\mathrm{M}$ in 1882 een eigen werktuigenfabriek op.

Rencker speelde in op de nieuwe mogelijkheden van de markt. Hij werd een belangrijk leverancier van het stelsel van gas-, water- en elektriciteitsleidingen. Hij voorzag de Utrechtse straten, de treinen en de trams van de nieuwe verlichting. De geschiedenis van de firma Rencker is min of meer vergelijkbaar met die van zijn Amsterdamse tegenhanger Wilhelm Hibbeln, ${ }^{128}$ en de fabriek van de Duitser Benedictus Mohrmann in Leeuwarden. In deze fabrieken werd eveneens ingespeeld op de - door de introductie van gasverlichting - nieuwe behoefte aan 'straatmeubilair'. ${ }^{129}$ Hibbeln, Mohrmann en Rencker profiteerden van de komst van gasverlichting in de tweede helft van de negentiende eeuw. Hibbeln werd in 1847 in Kleinberg in Westfalen geboren. In 1869 begon hij in Amsterdam een groothandel in gasverlichtingsartikelen. Aanvankelijk importeerde hij zijn goederen uit Duitsland. Later zette hij in Amsterdam een grote metaalwarenfabriek op. Daarnaast bleef hij goederen uit Duitsland importeren uit de fabrieken die hij daar inmiddels had opgezet en verworven. Hibbeln's metaalwarenfabriek was groter dan die van Rencker en had meer dan 350 werknemers. Hibbeln rekruteerde voor zijn fabriek hoogopgeleide ambachtslieden uit Duitsland.

Rencker trok Duits personeel aan. Deze werknemers kwamen niet in één keer, maar verspreid over een langere periode. Hoe groot het aandeel van Duitsers onder zijn personeel was, is niet geheel duidelijk. Omstreeks de jaren zestig was ongeveer de helft van het dertigtallig personeel Duits. Op dat moment werd het personeel door Rencker centraal in de nabijheid van zijn fabriek gehuisvest, later was dat niet meer het geval. Wel woonden er in de nabijheid van de fabriek meerdere Duitse metaalbewerkers, fabrieksarbeiders en smeden. Zo woonde er naast de fabriek in een kosthuis een groot aantal alleenstaande mannen, die allen in het bevolkingsregister als metaalbewerker werden genoteerd. ${ }^{130}$ Twaalf van hen waren Duits. Het is aannemelijk dat zij voor Rencker werkten, maar helemaal zeker is het niet.

De Duitse personeelsleden van Rencker waren niet afkomstig uit één gebied in Duitsland, maar uit verschillende streken. Terwijl hijzelf uit Saksen kwam, kwamen zijn arbeiders onder meer uit Hannover, Westfalen en Pommeren (nabij Stettin). Rencker was luthers, de werklieden waren vrijwel allemaal katholiek. 
Rencker was een succesvol ondernemer, maar zijn bedrijf was geen niche, noch groeide zijn succes uit tot een niche. Succesvol ondernemerschap en nichevorming zijn niet automatisch met elkaar verbonden.

\section{Hoedenfabrikant Brenner}

De hoedenfabriek Brenner vertoonde overeenkomsten met de ornamentenfabriek Rencker, maar dan met veel minder continuïteit en succes. Mouritz Brenner, geboren in Keulen in 1844, kwam in 1878 met zijn Duitse vrouw en zijn twee in Duitsland geboren kinderen uit zijn geboorteplaats naar Utrecht. ${ }^{131}$ Samen met Nathan Cohn, wonende in Keulen, begon hij een viltenhoedenfabriek in Tolsteeg (wijk K), gedreven door stoom. De fabriek was gevestigd in de Gansstraat. Brenner zelf woonde met zijn gezin niet bij zijn fabriek, maar aan de statige Maliesingel en later aan de Oosterstraat, beide in wijk I. Deze straten in wijk I lagen niet ver van de Gansstraat. Volgens een in het Duits gestelde akte hadden Brenner en Cohn een handelsfirma in Keulen. ${ }^{132}$ Voor de oprichting van hun Duitsche Nederlandsche Stoom Viltenhoedenfabriek gingen beide ondernemers een firma aan voor de tijd van tien jaar met geldschieter J. de Groot. Alleen Brenner en Cohn waren hoofdelijk aansprakelijk.

Brenner bracht uit Duitsland niet minder dan 38 hoedenmakers mee. Enigszins opmerkelijk is, dat van hun komst of van de opening van de fabriek in de lokale krant geen enkele melding wordt gemaakt. Zeventien hoedenmakers waren geboren in Keulen, de rest elders in Duitsland en in Zwitserland, Hongarije, Noorwegen en Italië. ${ }^{133}$ Brenner en zijn compagnon Cohn waren beiden joods. De hoedenmakers die zij meebrachten waren hervormd, luthers, katholiek en een enkeling was joods. Er waren drie vrouwelijke hoedenmakers. Enkele mannen waren gehuwd en kwamen met hun Duitse vrouwen en in Duitsland geboren kinderen. De ongehuwde mannen vonden bij deze gehuwde collega's in de nabijheid van de fabriek onderdak. Alle hoedenmakers en hun families - zo'n vijftig mensen in totaal - woonden in wijk K.

Rondom de fabriek van Brenner ontstond een kleine gemeenschap van Duitsers, los van de grotere groep Westerwalders die eveneens in wijk K woonde. De groepsvorming was in dit geval een bijzonder kort leven beschoren. Dit had vooral te maken met het lot van de hoedenfabriek. In Utrecht was geen andere viltenhoedenfabriek en er waren verder ook nauwelijks hoedenmakers, althans niet van vilten hoeden. Desondanks ging het met de fabriek niet goed. In 1880 werd in het gemeenteverslag gemeld dat de stoomhoedenfabriek, die slechts drie jaar had bestaan, was opgeheven. ${ }^{134}$ In 1912 schreef Everwijn over deze poging tot fabrieksmatige productie van vilten hoeden:

Het machinaal bewerken van vilthoeden had hier te lande echter geen succes. Een paar pogingen, omstreeks 1880 te Utrecht en daarna te Rotterdam gedaan, mochten niet slagen; het afzetgebied binnen eigen grenzen scheen daartoe te klein en geoefende arbeidskrachten waren schaarsch. ${ }^{135}$ 
Daar Brenner zijn eigen arbeidskrachten uit Duitsland meebracht, lijkt de geringe afzet belangrijker te zijn geweest dan het tekort aan arbeidskrachten.

Brenners bedrijf werd gesloten. Bij notariële acte werd hij geboden zich verre te houden van het hoedenvak. ${ }^{136}$ Hij mocht noch aan fabrieken, noch aan winkels hoeden verkopen. De boete voor elke overtreding was vijfduizend gulden, te voldoen binnen vier weken aan de heer De Groot. ${ }^{137}$ Brenner vertrok in 1883 met zijn familie naar Amsterdam. De kleine gemeenschap van hoedenmakers bleef achter en viel spoedig uiteen. De meesten gingen terug naar Duitsland.

Brenner was een vernieuwend ondernemer, maar het gat in de markt dat hij meende te hebben gevonden, bleek meer een bodemloze put waarin het kapitaal van beide Keulse ondernemers en hun Utrechtse geldschieter verdween. Brenners bedrijf had in potentie het begin kunnen zijn van een niche, maar het bestaan van de onderneming was te kort. Continuïteit en succes blijken aanvullende voorwaarden te zijn, naast het gat in de markt.

\section{De Chemiker}

De chemische industrie was in de tweede helft van de negentiende eeuw een sterk expanderende bedrijfstak. Er deed zich een groeiende vraag voor naar het nieuwe industrieproduct zwavelzuur. Zwavelzuur was een van de belangrijkste grondstoffen van de negentiende-eeuwse chemische industrie. Het werd gebruikt bij de productie van kunstmest, kaarsen, rode kleurstof en soda en verder door katoendrukkerijen, ververijen en spinnerijen. De vraag naar zwavelzuur kende in de tweede helft van de negentiende eeuw een explosieve groei.

Tot 1833 waren er geen zwavelzuurfabrieken in Nederland. ${ }^{138}$ De eerste fabriek, opgericht in 1833, sloot reeds spoedig haar deuren. In 1835 werd in Utrecht de zwavelzuurfabriek Visser en Smits opgericht. Een jaar later werd daar de 27-jarige Duisburger Friedrich Wilhelm Roos in dienst genomen. Roos had reeds als meesterknecht voor andere Nederlandse zwavelzuurfabrieken gewerkt. ${ }^{139}$ De Nederlandse chemische industrie was in de negentiende eeuw voor haar bestaan in hoge mate afhankelijk van de kennis van Duitse meesterknechts, aan wie de leiding van het bedrijf werd toevertrouwd. Roos, die getrouwd was met een Friese vrouw en in Utrecht drie kinderen kreeg, bleef tot 1857 in de Domstad. In het bevolkingsregister wordt hij opzichter van de fabriek genoemd. In 1857 vertrok hij naar Uithoorn, waar in dat jaar de vierde Nederlandse zwavelzuurfabriek in werking trad.

De Nederlandse zwavelzuurindustrie kwam kort daarop in een crisis te verkeren, omdat door het uitbreken van de Amerikaanse burgeroorlog de vraag naar zwavelzuur terugliep. De zwavelzuurfabrieken namen hierop hun toevlucht tot het maken van soda. De productie hiervan kwam echter niet van de grond, door gebrek aan kennis. Om deze reden werd in 1862 Ludwig Mond naar Nederland gehaald. Mond werd in 1835 in Kassel geboren als zoon van een joodse zijdehandelaar. ${ }^{140}$ Hij studeerde in 1855 
aan de universiteit van Marburg en een jaar later in Heidelberg. Hij verliet de opleiding zonder een graad te hebben behaald en ging in 1860 werken als leerling in een azijnzuurfabriek in Mainz. Hij bezocht in Nederland de inmiddels samenwerkende zwavelzuurfabrieken, trad in 1863 in dienst van de firma Smits en begon in Utrecht met de bouw van een grote sodafabriek onder de naam Smits \& De Wolff. ${ }^{141}$

In 1865 huurde Mond een kamer bij een schippersweduwe aan de Weerdsingel nabij de fabriek. In het bevolkingsregister wordt hij onder meer vermeld als Chemiker. ${ }^{142}$ Hij trouwde met de Duits-joodse Frederika Loewenthal en vertrok in 1866 naar Keulen. ${ }^{143}$ Inmiddels had hij een patent verworven voor het produceren van soda. In de jaren zestig van de negentiende eeuw ging hij naar Engeland, omdat hij daar meer mogelijkheden zag voor zijn procédé en omdat, naar zijn idee de religieuze tolerantie tegenover joden er groter was. In 1881 opende hij in Engeland een alkalifabriek. ${ }^{144}$

De meesterknecht Roos en de Chemiker Mond zijn typerend voor de professionalisering die de nieuwe chemische industrie in de negentiende eeuw doormaakte. Nederlandse bedrijven haalden eerst geschoolde meesterknechts en later wetenschappers uit Duitsland. De noodzaak voor het aantrekken van personeel uit Duitsland verminderde, toen meer Nederlanders zich toelegden op de studie van de chemie. Gedeeltelijk gingen zij voor hun opleiding naar Duitsland. ${ }^{145}$

Duitsers speelden een belangrijke rol in de Nederlandse chemische industrie, maar hun aantal was beperkt. Roos en Mond werkten allebei voor alle zwavelzuurfabrieken in Nederland. In alle zwavelzuurfabrieken in Nederland was een Duitse immigrant prominent aanwezig, maar feitelijk ging het steeds om dezelfde twee mensen: Roos en Mond. Een Duitse overheersing van deze bedrijfstak kan dit moeilijk worden genoemd.

\section{De orgelbouwers}

Wel een belangrijke rol voor Duitse immigranten, maar eveneens geen overheersing van de bedrijfstak, vinden we bij de orgelbouwers. In Utrecht was gevestigd de orgelmakersfirma Bätz \& co. Bedrijfsleider van deze van oorsprong Duitse onderneming was in het midden van de negentiende eeuw de Duitser Christian Gottlieb Friedrich Witte. ${ }^{146}$ De firma werd gesticht door Johann Bätz, geboren in 1709 in Frankenroda in Saksen. Hij kwam in 1733 naar Utrecht en ging werken als knecht van een orgelbouwer. Kort daarop vestigde hij zich zelfstandig. Hij vernederlandste zijn naam en ondertekende zijn rekeningen met de naam Beets. Toen hij in 1770 overleed, zette zijn weduwe met haar zwager en zoons het bedrijf voort onder de oorspronkelijke naam Bätz. ${ }^{147}$ De firma Bätz nam pas een hoge vlucht onder de leiding van Witte, die door huwelijksbanden verbonden was aan de familie Bätz.

Witte werd op 12 januari 1802 in Rothenburg bij Hannover geboren. ${ }^{148}$ Hij ging in de leer bij orgelbouwer Baethmann in Hannover en in 1824 verliet hij zijn leermeester om elders ervaring op te doen. In Duitsland was vestiging als zelfstandig orgelbouwer 
moeilijk, vanwege het zogenaamde privilege- of monopoliestelsel dat daar voor orgelbouwers gold. Dit stelsel hield in dat een orgelbouwer in een bepaalde streek het monopolie kreeg op de bouw en het onderhoud van orgels. Nieuwe orgelmakers konden een monopolie overnemen, bijvoorbeeld na het overlijden van een collega, maar ze konden zich niet vrij vestigen. Veel jonge orgelmakers gingen daarom naar Nederland. ${ }^{149}$ Dat wil niet zeggen dat alle orgelbouwers in Nederland Duits waren. Behalve de firma Bätz, waren in het midden van de negentiende eeuw in Nederland onder meer de Duitsers C.F.A. Naber (uit Westfalen) en H.G. Holtgräve en E. Leichel (uit Duisburg) belangrijk. ${ }^{150}$ Daarnaast waren er Nederlandse ondernemers. Van de orgelbouwers die in west- en midden-Nederland actief waren, was de firma Bätz, onder Witte's leiding veruit de grootste.

De firma Bätz was gevestigd in Utrecht, maar bouwde instrumenten in tal van andere Nederlandse plaatsen, merendeels in het midden van het land..$^{151}$ De orgelbouwers werkten in de eerste helft van de negentiende eeuw niet alleen voor de lutherse gemeente, waartoe ze behoorden, maar ook voor andere protestantse kerkgenootschappen. In de bloeitijd van de firma kwamen de meeste opdrachten van hervormde kerken. ${ }^{152}$ De vele nieuwe katholieke kerken die in dit tijdvak verrezen, betrokken hun orgels van andere, katholieke orgelbouwers. ${ }^{153}$ De firma Bätz legde zich toe op de vervaardiging van grote orgels en wist in die markt een monopoliepositie te verwerven. ${ }^{154}$

De firma Bätz had beslist niet alleen Duits personeel in dienst. Orgelmakers werden niet als afzonderlijke beroepsgroep vermeld in de beroepentelling van 1849. In de verzamelcategorie 'Muzijkinstrument, orgel, forte pianomakers, stemmers en verkopers' vielen 32 mensen. Bij de telling van 1889 werden de orgelbouwers wel afzonderlijk vermeld; 19. Er waren slechts enkele Duitsers onder en zij overheersten deze sector niet.

De mogelijkheden om werk te vinden in deze sector waren wisselend. De vraag naar personeel werd beïnvloed door schommelingen in de vraag naar orgels. De orgelbouw maakte een bloei door in de tweede helft van de achttiende eeuw, een inzinking in de Bataafs-Franse tijd en een gestage vooruitgang in het begin van de negentiende eeuw. In 1815 klaagde Bätz dat hij geen personeel kon krijgen, een probleem dat ook enkele jaren daarna bleef bestaan. ${ }^{155}$ Omstreeks 1825 was er echter sprake van slapte in deze sector, waarna de werkgelegenheid in het midden van de eeuw weer toenam. Orgels wonnen aan populariteit en personeel werd schaarser. De vraag naar personeel bleef de hele tweede helft van de negentiende eeuw bestaan. In 1850 vroeg orgelbouwer Naber in een Amsterdamse krant om ervaren gezellen. In 1881 deed zijn Osse collega eenzelfde verzoek, maar nu in het Duits in Die Orgel- und pianobau-Zeitung. ${ }^{156}$ Het verloop onder de orgelbouwers was vrij groot. $\mathrm{Zij}$ reisden veelvuldig door Europa om hun opleiding te voltooien.

In 1852 werkten bij de firma Bätz \& co twaalf mannen en vier jongens. ${ }^{157}$ De omvang van het personeel bleef in de tweede helft van de negentiende eeuw vrij constant met veertien tot zestien personeelsleden. Het merendeel daarvan was Nederlands. Een belangrijke figuur binnen de firma was Carl Ludwig Horstman, die werd geboren in 1818 in het Duitse Minden en die bij de firma Bätz werkte als orgelmakersknecht en later or- 
gelmaker. Hij was, net als zijn werkgever, luthers. Hij kwam in 1851 uit Alkmaar en overleed in 1883 in Utrecht. ${ }^{158}$

Het voorbeeld van de orgelmakers is interessant, omdat er verschillende factoren samenkomen: er bestond een zekere traditie in de migratie van Duitse orgelbouwers, de orgelbouw was in de tweede helft van de negentiende eeuw een expanderende sector, het bedrijf van Bätz, dat onder leiding van Witte ook in de negentiende eeuw als een Duitse onderneming kan worden aangemerkt, had een monopoliepositie in een bepaald deel van de markt (de grote kerkorgels). Deze situatie verschilde van een klassiek voorbeeld van nichevorming omdat het hele monopolie slechts steunde op een handvol arbeidskrachten.

\section{Bakkers}

Hierboven ging het steeds om sectoren die in sommige tijden en op sommige plaatsen als Duits werden aangemerkt, maar die dat in het negentiende-eeuwse Utrecht niet waren. Opmerkelijk is dat in de Domstad echter ook twee beroepsgroepen ontbraken, die overal door Duitse migranten werden gedomineerd; bakkers en kleermakers.

In Amsterdam werd het bakkersbedrijf in eerdere tijdvakken door Duitse immigranten overheerst. ${ }^{159}$ In de negentiende eeuw bleven Duitse bakkers in deze stad belangrijk. ${ }^{160}$ Volgens Justus van Maurik was in 1901 het merendeel van de bakkers in Amsterdam Duits en in ieder geval alle roggebroodbakkers. 'Daarvan heb je nog 't rijmpje: 't Lekkerst roggebrood wat je eet, is gekneed met moffenzweet. ${ }^{161}$ In andere landen was de situatie vergelijkbaar met de Amsterdamse. In 1887 telde Londen vierduizend meesterbakkers, waarvan tenminste tweeduizend Duitsers. ${ }^{162}$ In Kopenhagen vormden Duitse bakkers eveneens een belangrijke groep: in 1846 waren van de 468 bakkers in die stad er 165 Duits. ${ }^{163}$ In het Russische St. Petersburg was in 1869 een kwart van de bakkers Duits en de 'Duitse bakker' was er een literair stereotype. ${ }^{164}$ Manhattan telde in 18801200 Duitse bakkers. Zij maakten de helft van de bakkers uit, terwijl Duitse immigranten slechts 15 procent van de bevolking vormden. ${ }^{165}$

De situatie in Utrecht week opmerkelijk af van dit algemene beeld. Er was een handjevol Duitse bakkersknechts, ${ }^{166}$ maar hun aantal viel in het niet bij het totale aantal van 284 bakkers en hun knechts, dat de stad in 1849 telde. De enige uitzondering op deze in Utrecht zeer 'Nederlandse' bedrijfstak is een 'Zwitserse' banketbakkerij, die veertig jaar lang nabij het Janskerkhof werd gedreven. De opeenvolgende Zwitserse eigenaars van deze zaak trokken voor hun bedrijf naast Zwitsers ook Duits personeel aan.

De afwezigheid van Duitse bakkers kan verklaard worden uit het ontbreken van een traditie in Utrecht op dit punt. ${ }^{167}$ Terwijl in Amsterdam de migratie van bakkers ver terug ging, komen we in Utrecht in eerdere tijdvakken ook slechts een enkele Duitse bakker tegen. ${ }^{168}$ In de eerste helft van de negentiende eeuw lijkt in die situatie enige verandering te komen. Jelle van Lottum vond in 1829 in Utrecht de Duitse bakker Johannes Arends, een lutheraan uit Emmerich, met drie Duitse knechts. Tien jaar later was zijn 
in Utrecht geboren zoon Dirk baas van de bakkerzaak en waren alle knechts Nederlands. ${ }^{169}$ Duitse bakkers waren er dus kortstondig wel in Utrecht, maar verdwenen tussen 1829 en 1839 . Hun aantal nam af en er kwamen geen nieuwe Duitse bakkers bij. ${ }^{170}$ Slechts kort na de opheffing van de gilden in 1805 vestigde zich een handvol Duitse bakkers in Utrecht. Omstreeks 1839 was hun rol al weer zo goed als uitgespeeld. Van Lottum vermoedt dat de Duitse bakkers in Utrecht hun geluk hebben beproefd en, bij uitblijven van een gunstig resultaat, naar elders zijn gegaan. ${ }^{171}$

In de tweede helft van de negentiende eeuw waren er enkele bakkers, maar zij hadden geen Duits personeel. De Duitse bakkerspatroon Hendrikus Gerritzen had tussen 1850 en 1859 elf knechts in dienst, die allen bij hem inwoonden. ${ }^{172}$ De elf knechts woonden er niet gelijktijdig, maar volgden elkaar op. Ze kwamen uit alle delen van Nederland, maar niet uit Duitsland. Een Duitse dienstbode had Gerritzen wel. De enige andere Duitser in zijn bedrijf was zijn jongere broer. In de periode 1860-1879 werkten opnieuw tientallen knechts voor Gerritzen. Zijn broer was inmiddels een zelfstandig bakkersbedrijf begonnen, waar ook een groot aantal knechts werk vond. Bij geen van beide broers waren de knechts Duits. De knechts waren wel overwegend katholiek, net als hun patroons.

Het handjevol Duitse bakkersknechts dat er in Utrecht was, woonde verspreid over de stad. Bakkersknechts woonden gewoonlijk bij hun werkgever in. Dit gold ook voor de Duitse knechts. We zien in het bevolkingsregister inschrijvingen van soms wel twintig tot dertig knechts, die gelijktijdig of achtereenvolgens op het adres van een bakker werden ingeschreven. Het verloop onder hen was groot. Voor een bakker werkten meestal slechts twee of drie knechts op hetzelfde moment. In die eindeloze rijen knechts vinden we een enkele min of meer verdwaalde Duitser.

De overheersing van het bakkersvak door Duitsers, wordt in de literatuur verklaard door het leerlingenstelsel en het inwonen van de knechts. Leerjongens en gezellen woonden bij hun patroon en hadden een persoonlijke band met hem. ${ }^{173}$ De Amerikaanse historica Dorothee Schneider, die het Duitse bakkersbedrijf in het negentiendeeeuwse New York heeft beschreven, kent aan het samenwonen van de bakkers en hun knechts eveneens een belangrijke rol toe. Volgens Schneider was het echter niet alleen de band tussen baas en knechts die een rol speelde, maar ook de mogelijkheid de arbeidsverhoudingen die reeds bestonden in Duitsland te continueren. Lange dagen, slechte arbeidsomstandigheden en onvoldoende huisvesting en voeding werden alleen door de knechts geaccepteerd binnen het kader van deze gecontinueerde patriarchale verhoudingen. We herkennen in deze verklaring de theorie van de inheritable economic base. ${ }^{174}$ Overheersing van de sector door Duitse werkgevers, hielp bij het in stand houden van deze verhoudingen. Een leerlingenstelsel en slechte arbeidsomstandigheden bestonden echter ook in het Utrechtse bakkerijbedrijf, maar Duitse knechts ontbraken er.

De afwezigheid van Duitse bakkersknechts kan niet worden verklaard uit een gebrek aan vraag naar Duits brood. In Utrecht werd wel Duits brood verkocht, maar 
door een in Utrecht geboren bakker. In 1878 adverteerde bakker C. de Bouter in het Utrechtsch Provinciaal en Stedelijk Dagblad met zijn Duitse brood (zie illustratie op deze pagina). ${ }^{175}$

De Bouter richtte zich tot Duitse immigranten. De aanhef van zijn advertentie H.H. - de heren - duidt erop dat hij als potentiële klanten meer welgestelden voor ogen had; waarschijnlijk in ieder geval de heren studenten. De Bouter zal zijn Duitse mikken echter ook aan anderen hebben afgezet. Hij had zijn winkel in de Ganssteeg in wijk K, waar immers het hart van de Duitse gemeenschap van Westerwalders was.

In de negentiende eeuw haalden mensen dagelijks vers brood bij een winkel op loopafstand. Het verspreid wonen van de Duitse immigranten beperkte de mogelijkheden voor Duitse bakkers. Tegelijkertijd had een bakkerswinkel om te kunnen bestaan echter voldoende aan de klandizie van zo'n 35 gezinnen. ${ }^{176}$ Bij de Oudegracht en in wijk $\mathrm{K}$ woonden in ieder geval genoeg Duitse immigranten bijeen om een onderneming lonend te maken, maar een Duitse bakker vinden we er niet.

Een verklaring voor het ontbreken van de Duitse bakkers, ligt waarschijnlijk in een combinatie van de geslotenheid van de groep bakkers en het erfelijke karakter van het beroep. Zonen van bakkers volgden veelal in de voetsporen van hun vaders. De bakkers vormden een vrij hechte gemeenschap. De getuigen bij inschrijving in het geboorteregister van het kind van een bakker, waren vrijwel altijd beroepsgenoten. De erfelijkheid van het beroep en de geslotenheid van de beroepsgroep, maakten het moeilijk voor buitenstaanders om in deze sector een eigen bedrijf te beginnen. Het waren ook deze kenmerken van het vak, die elders een Duitse overheersing van het vak in stand hielden wanneer het Duitse immigranten wel lukte om een succesvolle entree te maken.

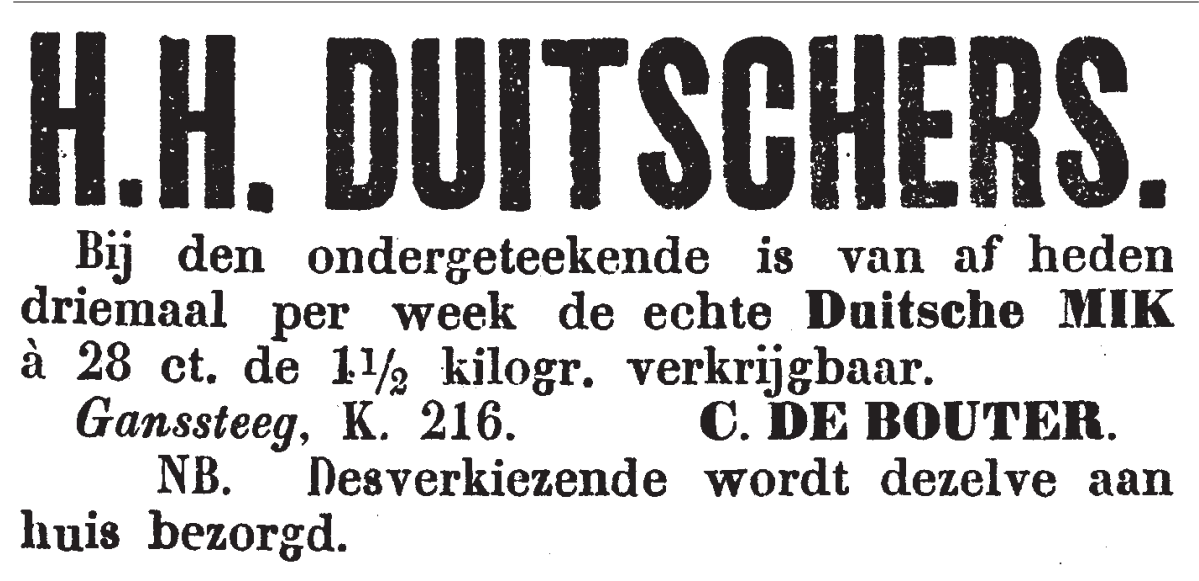

Advertentie van bakker C. de Bouter in het Utrechtsch Provinciaal en Stedelijk Dagblad 25-5-1878. De Bouter had zijn bakkerij in de Ganssteeg, in het hart van de Duitse gemeenschap van de Westerwalders. 


\section{Kleermakers}

Het kleermakersvak was, net als het bakkersvak, in andere landen een typerend beroep voor Duitse immigranten. ${ }^{177}$ De textielindustrie is wel aangemerkt als een bedrijfstak die zich bij uitstek leende voor nichevorming onder immigranten. De weg die joodse immigranten in de negentiende eeuw in New York in de textielindustrie gingen, blijkt een eeuw later opnieuw te kunnen worden gevolgd door Pakistanen in Manchester of Turken in Amsterdam. Werbner heeft de textielsector hierom aangeduid als de 'classic immigrant niche ${ }^{178}$ De sector is laagdrempelig en moeilijk af te sluiten en het werk is arbeidsintensief.

In het Deense Kopenhagen was in het midden van de negentiende eeuw ongeveer 25 procent van de Duitse ambachtslieden in de kledingproductie actief. ${ }^{179}$ Van de 1.615 kleermakers die Kopenhagen in 1845 telde, waren er 184 Duits (11 procent). ${ }^{180}$ In Amsterdam vormden Duitse kleermakers veruit de belangrijkste beroepsgroep onder de immigranten. ${ }^{181}$ Het overwicht van de Duitse kleermakers in Amsterdam kan in verband worden gebracht met een oudere migratietraditie. ${ }^{182}$ In de periode van 1730 tot 1811 kwamen de leden van het kleermakersgilde voor 37 procent uit Duitsland. ${ }^{183}$ In Amsterdam werkten in de negentiende eeuw op de maatateliers veel Duitsers. De kledingsector in Nederland als geheel expandeerde sterk. Er was tekort aan personeel en daarom werden werkkrachten van elders aangetrokken. ${ }^{184}$

In Utrecht waren er eerder wel Duitse kleermakers geweest, maar deze waren in de achttiende eeuw reeds verdwenen. ${ }^{185}$ In de periode van 1849 tot 1879 waren er in Utrecht 33 Duitse kleermakers. Dit aantal valt in het niet bij de 628 kleermakers die bij de volkstelling van 1849 werden geteld. De Duitse kleermakers in Utrecht vertoonden geen enkele samenhang. Ze kwamen uit allerlei plaatsen in Duitsland, zowel uit het westelijke deel, als uit plaatsen in het oosten, en waren luthers, calvinistisch of katholiek. Binnen Utrecht woonden ze niet geconcentreerd, ofschoon het aantal kleermakers in de wijken $\mathrm{E}$ en $\mathrm{G}$ groter was dan in de andere wijken.

Behalve de Duitse kleermakers in de stad waren er enkele Belgische kleermakers, een Zwitserse en drie Poolse: Dolinski uit Lemberg in Gallicië, ${ }^{186}$ Glazewski uit Krakau ${ }^{187}$ en Patraminski uit Rudana. ${ }^{188}$ De Polen waren allemaal katholiek en lijken mobieler te zijn geweest dan hun Duitse collega's. De vrouw en zoon van Glazewski waren in Parijs geboren, terwijl Patraminski in 1852 met zijn familie ook naar die stad vertrok.

Het ontbreken van Duitse kleermakers kan niet worden verklaard uit de lokale situatie van de bedrijfstak. De toestand in het Utrechtse kleermakersvak was immers in de tweede helft van de negentiende eeuw niet ongunstig. ${ }^{189}$ De Duitse kledingmagazijnen in Utrecht vroegen in krantenadvertenties veelvuldig om ervaren kleermakers. Zo bood de grote Duitse winkelier Van der Sandt 'extra hoog loon en vast werk' voor 'bekwame kleedermakers ${ }^{190}$ Tot een omvangrijke immigratie van Duitse werkkrachten leidde dit tekort niet (zie illustratie op de volgende pagina). 
De verklaringen die voor het ontbreken van de bakkers werden gegeven, gaan niet op voor de kleermakers. Over de reden voor het ontbreken van Duitse immigranten in het kleermakersvak in Utrecht kunnen we slechts speculeren. Belangrijk hier is, dat hun ontbreken duidelijk maakt, dat nieuwe of verruimende mogelijkheden niet automatisch tot nichevorming, of zelfs maar tot een sterke vertegenwoordiging in het vak leiden.

\section{Tot besluit}

Migranten hadden keuzes wanneer het ging om hun bestemming. Wie in de negentiende eeuw de Duitse armoede ontvluchtte om elders als boer een nieuw bestaan te vinden, ging naar Amerika, waar land beschikbaar was. Wie het Duitse politieke klimaat niet zinde, ging naar New York of Londen om daar aansluiting te zoeken bij een gemeenschap van gelijkgestemden. ${ }^{191}$ Londen was omstreeks 1850 volgens tijdgenoten het 'middenpunt der zamenzweringen der staatkundig uitgewekenen' ${ }^{192}$

Verschillen in kansenstructuur hadden tot gevolg dat immigranten met eenzelfde achtergrond in de ene stad iets heel anders deden dan in een andere stad. De kansenstructuur (opportunity structure) ${ }^{193}$ is het geheel aan mogelijkheden dat een samenleving aan immigranten biedt; de economische mogelijkheden van een plaats, de politieke en sociale mogelijkheden die openstaan voor immigranten, de kans op steun van een gemeenschap van lotgenoten en religieuze of politieke vrijheid. Zelfs bekendheid van immigranten met omstandigheden in de ontvangende samenleving wordt eronder begrepen, evenals de ligging van de stad ten opzichte van andere steden. ${ }^{194}$ De kansenstructuur is niet iets vaststaands. Nieuwkomers die tijdens een economische recessie kwamen, hadden andere mogelijkheden dan immigranten die arriveerden tijdens een

\section{G. H. VAN DER SANDT \& Co. vragen tegen Gxtra hoog Loon en vast Werk, EENIGE BEKWAME kleedermakers Zich aan te melden in persoon.}

Advertentie van de Duitse winkelier G.H. van der Sandt in het Utrechtsch Provinciaal en Stedelijk Dagblad 19-5-1878. De afwezigheid van Duitse kleermakers in Utrecht kan niet worden verklaard uit een gebrek aan vraag naar kleermakers. Van der Sandt en andere Duitse winkeliers vroegen in de krant met grote regelmaat om personeel. 
hausse. In dit hoofdstuk ging het vooral om de economische mogelijkheden voor immigranten.

Utrecht was de vierde stad van Nederland. Het was een groeiende stad, met vooral een regionale betekenis. In economisch opzicht bood de Domstad mogelijkheden aan mensen die zich wilden toeleggen op handel en nijverheid. De handelsfunctie van de stad was zowel lokaal als regionaal en bovenregionaal. De gunstige ligging tussen het Duitse achterland en de grote steden in het westen droeg daaraan bij. De overzeese, internationale handel was in Utrecht - in tegenstelling tot in Amsterdam en Rotterdam van minder betekenis. In de tweede helft van de negentiende eeuw ontstonden in Utrecht nieuwe mogelijkheden, vooral in handel en verkeerswezen, in de bouwsector en in de sigarenindustrie.

Concentratie in beroepen of economische nichevorming is hier aangemerkt als een belangrijke indicator voor groepsvorming. In het bovenstaande zijn tal van factoren genoemd die nichevorming kunnen beïnvloeden. In schema 8.1 worden die factoren samengevat.

Duitse immigranten werkten minder dan de autochtone Utrechtse bevolking in de industrie en waren vooral sterk vertegenwoordigd in de warenhandel. Losse arbeiders waren onder de Duitse immigranten relatief schaars. Onder Duitse immigranten vinden we twee opvallende concentraties in beroepen: de Westerwalder potverkopers en de Münsterlandse winkeliers en hun personeel, die in volgende hoofdstukken worden besproken.

Opmerkelijk is dat Duitse immigranten in Utrecht niet werkten in de sectoren waarin hun landgenoten elders wel belangrijk waren. Wanneer alle zogenaamd typische Duitse beroepen bij elkaar genomen worden, valt hieronder nog geen 16 procent van de totale Duitse populatie. Bij bierbrouwers en suikerbakkers was dat omdat het met deze bedrijfstakken in Utrecht niet goed ging. Bij de kelners is gewezen op het verschil tussen de Utrechtse hotels en die in andere grote steden. Utrechtse hotels waren kleiner en er was minder toeristisch verkeer. Duitse vrouwen werkten in Utrecht wel in de prostitutie, maar hun aandeel daarin lijkt kleiner te zijn geweest dan dat van Duitse

Schema 8.1 Overzicht van factoren die nichevorming beïnvloeden

\begin{tabular}{lcl}
\hline vraag naar: & mogelijkheden tot: & gestimuleerd door: \\
\hline - bepaalde vaardigheid & - voorziening voor eigen groep & - overheidsbeleid \\
- specialistisch product & - werk binnen de niche voor & - geen werk buiten de niche \\
- goedkope arbeidskracht & vrouwen en mannen & - uitblijven technologische \\
- seizoensmatige arbeid & - verplaatsen sociale & verandering \\
& verhoudingen & - associatie van een groep met \\
& - afsluiten van de niche & een vaardigheid of product \\
& - genereren sectorspecifiek & - aard van het migratieproces \\
& human capital & \\
\hline
\end{tabular}


prostituees elders. Mogelijk is er in dit geval sprake van een vertekend beeld en werd er elders vooral veel geklaagd over Duitse prostituees.

Oververtegenwoordiging van immigranten in een bepaalde sector is wel verklaard door te wijzen op nieuwe mogelijkheden die er in een bedrijfstak ontstonden. In Utrecht was sprake van een zeer sterke expansie in de nieuwe sigarenindustrie, maar Duitse immigranten vinden we daar niet. Vernieuwend ondernemerschap, zoals dat van Rencker en Brenner, leidde niet tot concentraties. In sectoren waarin de inbreng van enkele Duitse immigranten onontbeerlijk was, zoals bij de orgelbouwers en in de chemische industrie, leidde dat nog niet tot nichevorming. Het opmerkelijkst is het ontbreken van Duitse mannen in de 'typisch' Duitse beroepen bakker en kleermaker.

In dit hoofdstuk is niet zozeer geprobeerd te verklaren waarom nichevorming zich voordeed - dat gebeurt in volgende hoofdstukken - maar veeleer waarom het zich niet voordeed in sectoren waarin dat elders juist wel het geval was. Het achterliggende idee is de divergente benadering zoals die in het inleidende hoofdstuk is gepresenteerd. We kunnen alleen iets zinnigs over Duitse migranten zeggen wanneer we een vergelijking maken met andere plaatsen. Het verklaren van afwezigheid is echter veel moeilijker dan het verklaren van aanwezigheid.

Verklaringen die gerelateerd zijn aan de culturele bagage van immigranten, blijken in de hier gepresenteerde gevallen slechts een beperkte betekenis te hebben. Deze constatering is belangrijk, omdat juist aan kwaliteiten van immigranten - het 'Moffenzweet' uit de volksmond - veelvuldig gerefereerd wordt bij het verklaren van concentraties. Traditie, nieuwe mogelijkheden, het gat in de markt, of sterke expansie bieden evenmin voldoende verklaring. Dit betekent niet, zoals we zullen zien, dat deze factoren geen invloed kunnen hebben, maar wel dat bijvoorbeeld simpelweg een gat in de markt niet voldoende is voor het ontstaan van niches. Het belangrijkste is, dat de vergelijking met andere plaatsen leert dat concentraties zich veelvuldig voordoen, maar dat de aard van deze concentraties sterk per plaats kan verschillen. Lokale omstandigheden bepalen in hoge mate welke concentraties er ontstaan. 


\section{9 'Waar Duitsers haast een kolonie vormden' Westerwalders}

Justus van Maurik schreef, refererend aan de situatie rond 1860, met enige bewondering over de potverkoopsters uit het Duitse Westerwald:

Jongens, meneer! daar had je vrouwen onder als molenpaarden, met van dat dikke, gele haar en bruine gezichten vol sproeten. ${ }^{1}$

Van Maurik noemde de vrouwen pottentrienen, wat lijkt op de Duitse benaming Töpferweiber, die van oudsher in het Westerwald in zwang was. ${ }^{2}$ De aanduiding komen we, in variaties ook in andere bronnen tegen. Van Lennep laat zijn romanfiguur Susanna in zijn boek Ferdinand Huyck tegen de hoofdpersoon Ferdinand zeggen:

Wij hadden u zoo spoedig niet verwacht, Ferdinand! [...] ik dacht, dat gy in Westfalen verliefd waart geworden en met deze of gene moeffrikaanse pottedeern zoudt terugkomen $[\ldots]$. $^{3}$

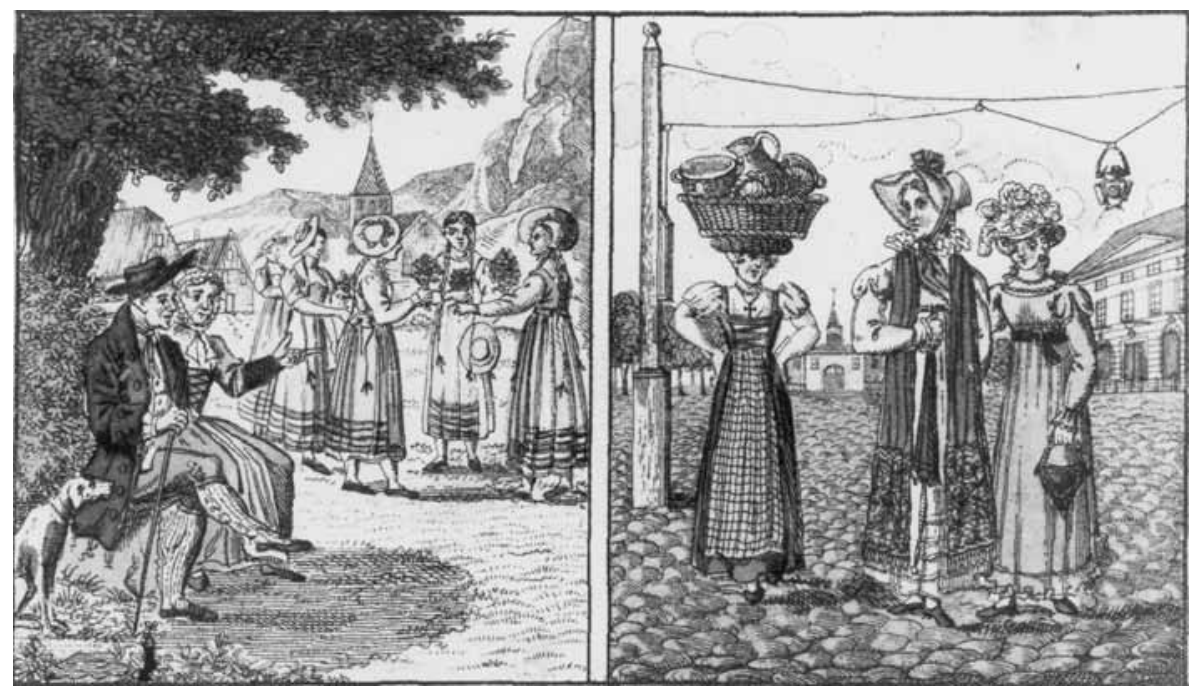

Westerwalder potverkoopster neemt afscheid van haar familie en vriendinnen in het Westerwald (links) en verkoopt potten in Amsterdam.

GA Amsterdam D 38415. 
Vleiend bedoeld was de benaming lang niet altijd. Couperus' Emilie zegt in De boeken der kleine zielen: 'En wat ziet die mama Van Raven er uit. Net een pottetrien.' ${ }^{4}$

De Westerwalder pottenkoopman of-vrouw was in de negentiende eeuw een gangbare verschijning. Potverkopers komen regelmatig voor in negentiende-eeuwse verhalen en gezegden. ${ }^{5}$ Dat het steengoed uit het Westerwald in Nederland algemeen gebruikt werd, blijkt wel uit het feit dat bij elke opgraving de scherven ervan voor het oprapen liggen. ${ }^{6}$

Immigranten uit het Westerwald in Nassau, hier door mij aangeduid als Westerwalders, waren het meest talrijk in Utrecht: 245 van de Duitse immigranten die tussen 1849 en 1879 in Utrecht woonden, behoorden tot deze groep (133 mannen en 112 vrouwen). Daarnaast waren er nog 43 in het Westerwald geboren kinderen, 452 kinderen die in Utrecht of elders buiten het Westerwald werden geboren en de nakomelingen van in ieder geval zo'n 200 eerdere migranten uit het Westerwald, die in het begin van de negentiende eeuw waren gekomen.

De Westerwalders kwamen uit een beperkte herkomststreek, werkten allemaal in hetzelfde beroep, woonden geconcentreerd en waren allemaal katholiek. Zowel de zogenaamde eerste generatie Westerwalders, als hun in Nederland geboren kinderen en kleinkinderen, trouwden veelvuldig onderling. De Westerwalders namen, in tegenstelling tot andere Duitse immigranten, nauwelijks deel aan het sociale verkeer. Als groep bleven zij vrijwel gedurende de gehele negentiende eeuw herkenbaar. Pas aan het einde van die eeuw viel deze groep uiteen.

Bij de Westerwalders was onmiskenbaar sprake van nichevorming. Hier zullen we zien dat deze nichevorming nauw samenhing met groepsvorming. De Westerwalder handelaren profiteerden van de band die zij hadden met de producenten in hun herkomststreek. Het steengoed, waar de Westerwalders in handelden en waarnaar steeds meer vraag ontstond, werd alleen daar gemaakt. Bovendien speelde een rol dat de handel van de Westerwalders mogelijkheden bood aan zowel mannen als vrouwen. Hierdoor bestond de migratie van Westerwalders, in tegenstelling tot die bij andere immigranten, gedeeltelijk uit hele gezinnen.

\section{Een kolonie van in grof aardewerk handelende Duitsers}

In een beschrijving van de belangrijke Utrechtse Handelsfirma Trip, werd opgemerkt dat het feit dat grondlegger Hendrik Trip werd geboren in Grieth in Kleefsland, in de familiekroniek weliswaar werd verzwegen, maar dat het in zijn woonomgeving toch wel bekend zou zijn geweest.

In de twintiger jaren [van de negentiende eeuw] kon dat geen geheim zijn buiten de Tolsteeg, aan de Helling, waar Hendrik Trip zich gevestigd had en waar in grof aardewerk handelende Duitsers haast een kolonie vormden. 
Op de straat die de Helling heette en in enkele omliggende straten, zoals de Westerkade en de Gansstraat, vinden we in de negentiende eeuw de Duitse handelaren in steengoed. Voor de beschrijving van deze groep immigranten beschikken we, behalve over Utrechtse bronnen, ook over het onderzoek dat de Duitser Johann Plenge deed in 1896 en $1897 .{ }^{8}$ Plenge sprak met ambtenaren, pastoors, artsen, leraren en burgemeesters over de Westerwalders, maar bovenal ook met de ambulante handelaren zelf.

Ofschoon de groep Westerwalders in Utrecht getalsmatig belangrijk was, is ze in de bronnen relatief onopvallend. De Westerwalder handelaren adverteerden, in tegenstelling tot de winkeliers uit Münsterland of de Franse parapluverkopers, niet veelvuldig in de lokale kranten. De Westerwalders werden door tijdgenoten niet met deze term aangeduid. Wanneer er aan hen gerefereerd werd, werden ze 'Duitse potverkopers' genoemd. Omdat de Westerwalder handelaren zich in de tweede helft van de negentiende eeuw in toenemende mate gingen toeleggen op handel in het algemeen, komen ze bovendien slechts sporadisch in de Adresboeken voor als handelaren in steengoed of aardewerk. Zelfs in de volkstellingen zijn ze niet opvallend aanwezig. In de volkstelling van 1849 werden voor Utrecht negentien 'kooplieden in aardewerk' gemeld; elf mannen en acht vrouwen. De Westerwalders gaan schuil in meer algemene categorieën: kooplieden (268 mannen en 139 vrouwen), kleinhandelaren (220 mannen en 182 vrouwen) en kramers, venters en leurders ( 57 mannen en 10 vrouwen).

De groep Westerwalders in Utrecht was veel groter dan uit de gelegenheidsstructuur van Utrecht kan worden verklaard. Er was in Utrecht geen werk voor honderden potverkopers, zelfs niet als we aannemen dat de Utrechtse handelaren ook op het omringende platteland actief waren en hun assortiment breder was dan de oorspronkelijke potten. Het waren op een gegeven moment niet zozeer de economische mogelijkheden die de trek naar Utrecht bepaalden, als wel het feit dat daar een Westerwalder gemeenschap bestond. De migratie werd gestimuleerd door een toenemende vraag naar steengoed. De mogelijkheden voor de handel in steengoed werden voorts aan het begin van de negentiende eeuw verruimd door het opheffen van de gilden en de verbetering van de vervoersmogelijkheden. De handel resulteerde in een migratiepatroon, dat enerzijds gekenmerkt werd door het naast elkaar bestaan van seizoensmigratie en permanente migratie, en anderzijds door het feit dat er eerder families dan individuen migreerden. Dit migratiepatroon werd beïnvloed door de wetgeving in de herkomststreek, die vooral gericht was op beperking van de seizoensmatige migratie van hele families.

\section{Het Westerwald en migratie vanuit Nassau}

Het Westerwald ligt ten noorden van Koblenz, op de rechter Rijnoever, in wat tot 1866 het Hertogdom Nassau was (zie kaart 9.1). Nassau had van oudsher banden met Nederland. In de loop van de negentiende eeuw onderging Nassau een aantal territoriale wijzigingen, waarbij het minder langgerekt en iets breder werd. Het Westerwald bleef ech- 
Kaart 9.1 Ligging van het Westerwald, de herkomst streek van de Duitse potverkopers, met de twee belangrijkste dorpen Ransbach en Baumbach.

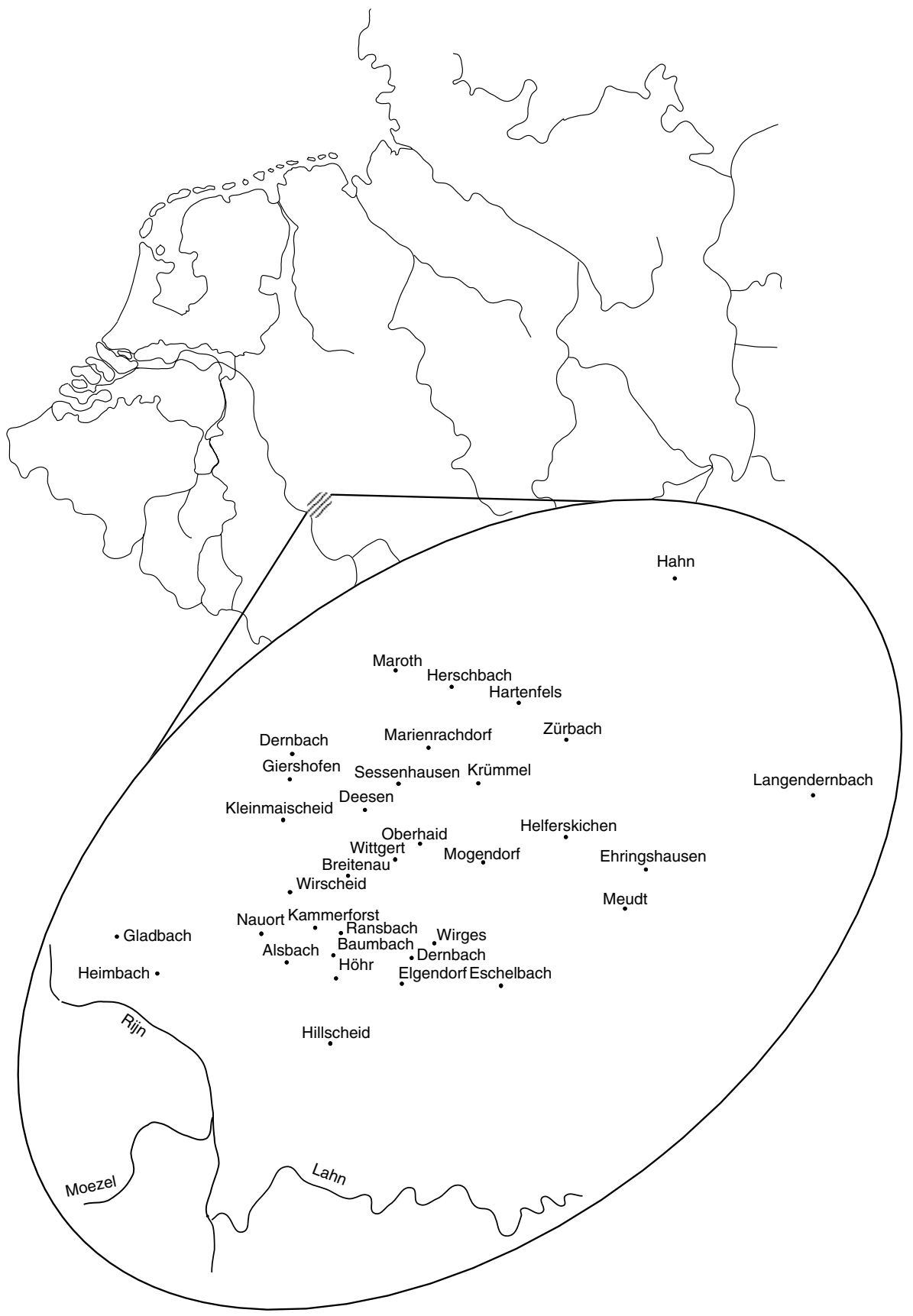


ter steeds min of meer in het midden van Nassau liggen. Voor 1789 lag Nassau ongeveer honderd kilometer van de Franse grens. Na Napoleons overwinning in 1805, schoof de Franse grens op naar het oosten waarna Nassau direct aan het napoleontische Frankrijk grensde, daarvan slechts gescheiden door de Rijn, en lid werd van de onder Napoleons protectie staande Rijnbond (1806-1813). De terugtrekkende Napoleontische en oprukkende geallieerde legers, trokken in 1813 en 1814 door Nassau om vervolgens de Rijn over te steken. Na 1815 schoof de Franse grens terug naar het westen. In die periode meende de Nederlandse koning Willem I kort en zonder succes aanspraken op Nassau te kunnen doen herleven. Nassau kwam in de Duitse Bond en in 1835 bij het Duits Tolverbond, dat onder Pruisische leiding stond. In 1866 werd het ingelijfd bij Pruisen. De Utrechtse Westerwalder potverkopers kwamen vooral uit het deel dat het 'hoge Westerwald' werd genoemd en dan met name uit de dorpen Ransbach en Baumbach.

Nassau kende in de negentiende eeuw en eerder, naast de seizoensmatige, ook een omvangrijke permanente emigratie. Permanente emigratie werd, in tegenstelling tot de tijdelijke migratie, door de lokale overheid aangemoedigd of bevorderd. In het midden van de achttiende eeuw vertrok een karavaan van vierhonderd personen naar Polen. Daar werden ze echter niet toegelaten waarop ze naar hun geboortegrond terugkeerden. Nassau kondigde vervolgens op 21 april 1750 een verordening af, waarin het emigranten werd verboden terug te keren. ${ }^{9}$

Omvangrijker dan de binnen-Europese emigratie, was die naar overzeese bestemmingen. Aan het begin van de negentiende eeuw ontstond het gerucht dat 40.000 mensen uit Nassau naar Brazilië wilden afreizen. Agenten reisden rond om mensen voor deze en vergelijkbare ondernemingen te werven. De regering waarschuwde tegen deze ronselpraktijken, omdat mensen in de wildernis aan hun lot werden overgelaten. ${ }^{10}$ Het ronselen werd afgekeurd, maar permanente emigratie werd aangemoedigd.

In de negentiende eeuw ging veruit het grootste deel van de migranten uit Nassau naar de Verenigde Staten. Deze overzeese migratie was niet zonder problemen. In 1847 strandden ongeveer achtduizend mensen in de haven van Bremen, waar ze op scheepsgelegenheid moesten wachten. Iets vergelijkbaars deed zich voor in Rotterdam, toen bij aankomst van de migranten de vervoersprijs plots gestegen bleek te zijn van 45 naar 90 en 100 Nassause guldens. ${ }^{11}$ Om de emigratie enigszins in goede banen te leiden, werd in 1842 in Nassau de Texas-Verein of Adelsverein opgericht. De bedoeling was dat de Nassauers allemaal hun schreden naar Texas zouden richten, waar ze een Duitstalige staat zouden vormen. Nassause waarden als vroomheid, gezagsgetrouwheid, vlijt en zindelijkheid zouden zo behouden kunnen blijven. De vereniging had enig succes. Omstreeks 1860 kwam 22 procent van de bevolking van west-centraal Texas uit Nassau, tegen minder dan één procent in andere delen van Noord-Amerika. ${ }^{12}$

De overzeese migratie overtrof in aantal bij verre de migratie naar Nederland. Een precieze indicatie van de verhouding tussen deze beide migratiestromen is niet te geven omdat de overzeese migratie veel beter is geregistreerd dan die naar de buurlanden. Terwijl er tienduizenden overzee gingen, gingen er jaarlijks tweeduizend Nassauers naar Nederland. Tussen beide migratiestromen bestonden duidelijke verschillen. De 
Nassauers die overzee gingen, kwamen uit alle lagen van de bevolking. Niet alleen de armeren migreerden, maar ook meer welgestelden. Dagloners en ambachtslieden waren daarbij oververtegenwoordigd. Bij de migratie naar Nederland waren de handelaren het belangrijkst. De overzeese migranten uit Nassau waren zowel protestants als katholiek, hetgeen de qua geloof gemengde samenstelling van de streek weerspiegelde. De migranten naar Nederland waren vrijwel zonder uitzondering katholiek. ${ }^{13}$ Dit is niet geheel verbazingwekkend daar ze ook overwegend uit katholieke dorpen kwamen.

\section{Steengoed}

De basis van de Westerwalder handel en migratie was het zogenaamde steengoed - in Nederland gewoonlijk Keulse potten genoemd -, dat zich onderscheidde van ander ke-

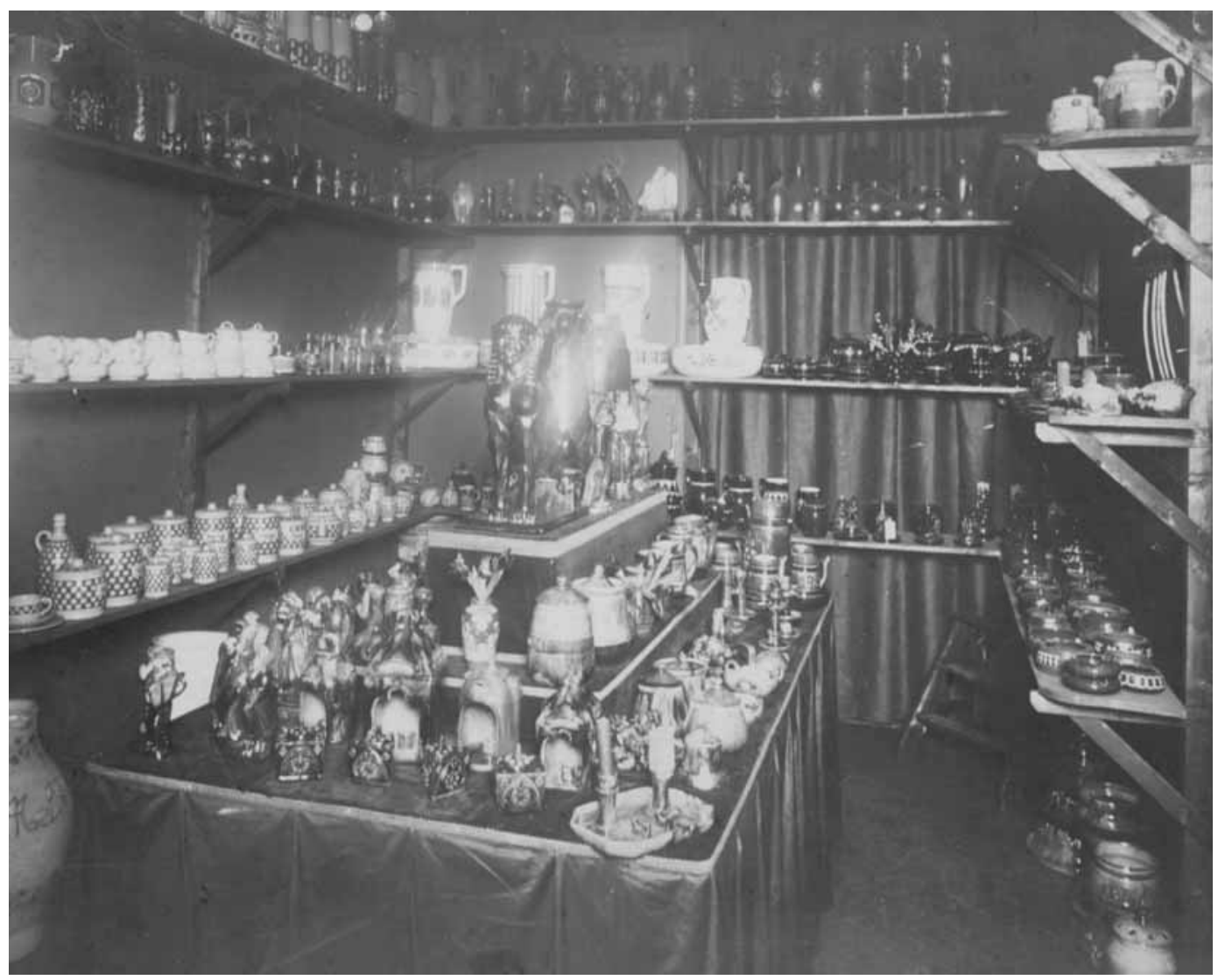

Assortiment van de Westerwalder handelaren in de winkel van August Fuchs aan de Prinsengracht in Amsterdam.

Foto privebezit Mencke-Fuchs. 
ramiek door de grijze kleur met blauwe decoratie. Steengoed is technisch gezien wel een keramisch product, maar geen aardewerk. Dit laat onverlet, dat de Westerwalder handelaars in Nederlandse bronnen veelvuldig werden aangeduid als kooplui in aardewerk. In het Westerwald werd het steengoed Kannenbäckerware genoemd. Dit specialistische product vond zijn oorsprong in de samenstelling van de klei in deze streek, die bij zeer hoge temperaturen kon worden gebakken, waarbij de kleideeltjes samensmolten tot een gesinterd lucht- en waterdicht geheel. Ofschoon er ook andere producten werden gemaakt, ging het bij het Westerwalder hardgebakken grès toch merendeels om kannen, kruiken en potten.

Het Westerwald was niet de enige streek in Duitsland waar op grote schaal keramiek werd geproduceerd. Het Westfaalse Ochtrup, niet ver van Enschede ten oosten van Gronau in het Münsterland, was bijvoorbeeld ook een bekend centrum van productie en handel. ${ }^{14}$ Het aardewerk uit Ochtrup werd door Ochtrupper handelaren naar Nederland verhandeld, maar in Utrecht komen we deze handelaren in het midden van de negentiende eeuw niet tegen. ${ }^{15}$

Dat de Westerwalders ondanks de aanwezigheid van andere producenten en handelaren in keukengerei een niche konden vinden, kwam doordat de keramiekmarkt sterk gesegmenteerd was. ${ }^{16}$ Aan de ene kant van die markt was er het zogenaamde Limburgs, Fries en Gouds tafelgoed en keukengerei van aardewerk, aan de andere kant waren er de vuurvaste aardewerk kookpotten. Het Westerwalder steengoed zat daar precies tussenin. Het werd niet gebruikt als tafelgoed en was evenmin geschikt om mee te koken. ${ }^{17}$ De stevigheid van het materiaal en de ondoorlaatbaarheid voor vloeistoffen, maakten de Westerwalder kannen en kruiken daarentegen bij uitstek geschikt om er bier, wijn, olie of andere vloeistoffen in te bergen. Het steengoed was ook bestand tegen de inwerking van zuur en zout en daardoor zeer geschikt voor het inleggen van groenten, vlees of vis. De potten werden eveneens gebruikt voor boter. De kruiken werden op grote schaal gebruikt voor mineraalwater, omdat ze in staat waren het natuurlijke koolzuur vast te houden.

\section{De handel}

Het Westerwald was reeds in de Romeinse tijd een productiecentrum van kannen en kruiken. Om optimaal van de ovens gebruik te maken, werd er meer gebakken dan lokaal kon worden afgezet. Het overschot werd in de zestiende eeuw door de pottenbakkers en hun vrouwen in de wijde omgeving uitgevent. Na verloop van tijd vond een groot deel van de bevolking van deze streek door venten in de nabije of verdere omgeving een bestaan. ${ }^{18}$

Ofschoon in de zestiende eeuw de producenten ook wel zelf met hun waren ventten, ontwikkelde zich reeds toen een professionele handel. Uit Duitse verordeningen uit 1591 en 1603 blijkt dat de handel in handen van beroepshandelaren was gekomen. In het midden van de zeventiende eeuw vormden deze handelaren een machtsblok tegen 
de producenten. Als reactie namen sommige producenten opnieuw de handel ter hand. Dat gebeurde ook in de achttiende eeuw nog een aantal keren. De handelaren waren echter beter bekend met de afzetmarkt en de handelende producenten konden zich niet staande houden.

De Westerwalder handelaren waren aanvankelijk door familiebanden gebonden aan de pottenbakkers. ${ }^{19}$ Ze konden daardoor gemakkelijk krediet krijgen en hoefden hun bestellingen pas te betalen bij terugkomst. Indien ze door ziekte of ongeluk minder hadden kunnen verdienen dan verwacht, kregen ze hun volgende levering echter slechts tegen een onderpand. Mogelijk werden als onderpand huizen en grond gebruikt. Dat de Westerwalder trekhandelaren huizen en grond hadden in hun geboortestreek, blijkt uit de dwangmatige veiling van de bezittingen in het midden van de negentiende eeuw. $^{20}$

De handelaren verkochten in de negentiende eeuw niet alleen steengoed dat in het Westerwald zelf was gemaakt, maar ook waren van fabrieken er net buiten. De fabrieken maakten aan de hand van voorbeelden uit de zeventiende eeuw en met behulp van de reliëfmatrijzen die ook in de eerdere eeuwen waren gebruikt, Westerwalder steengoed. Ofschoon de fabrieken buiten het Westerwald gevestigd waren, betrokken ze de grondstoffen en de kleurstoffen wel uit die streek. Het negentiende-eeuwse Westerwal-

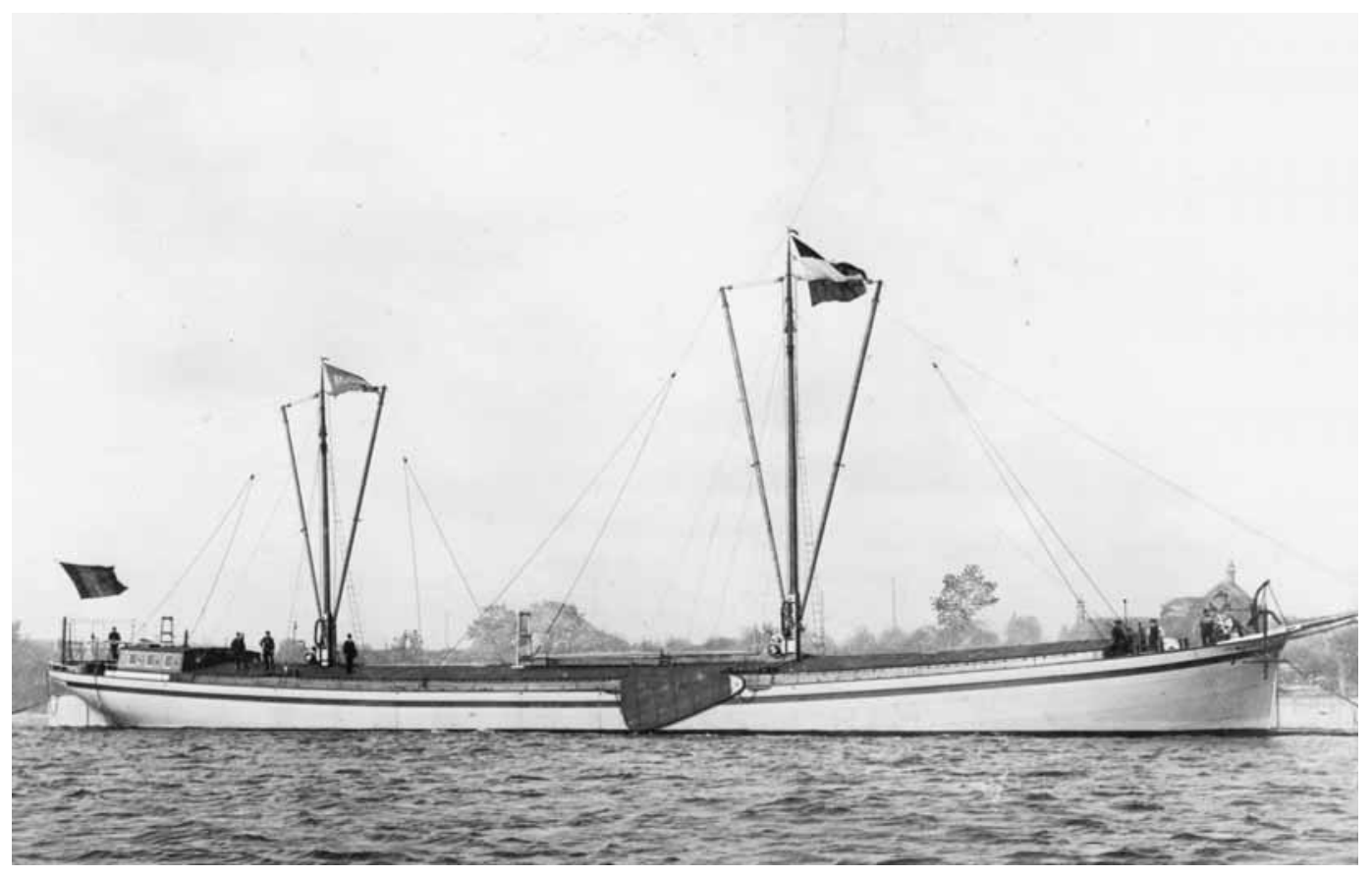

Rijnaak Rijn en Amstel, eigendom van de Westerwalder firma Aug. Fuchs in Amsterdam. De foto werd gemaakt door C.F. Mögle in Rotterdam. Met bolhoed naast de mast staat August Fuchs jr. Het schip werd in 1859 gekocht voor 7000 gulden en kon 140.000 kruiken vervoeren.

Foto privebezit Mencke-Fuchs. 
der steengoed was, door vormgeving, materiaalgebruik en productiewijze, en door de slijtvastheid van het eindproduct, zelfs voor experts moeilijk te onderscheiden van de zeventiende-eeuwse voortbrengselen. De kannen en kruiken werden echter niet gemaakt als vervalsingen, maar waren een geslaagde poging van de fabrikanten om in te spelen op de negentiende-eeuwse belangstelling voor de zeventiende eeuw. ${ }^{21}$ De grote fabrikanten zochten de handelaren op als ze in de winter in het Westerwald waren, en de handelaren deden hun bestellingen voor de zomer. Tijdens het handelsseizoen werden vanuit Nederland waren bijbesteld bij de fabrikanten.

Hoewel in principe in de negentiende eeuw ook andere handelaren steengoed konden verkopen, hadden de Westerwalders het voordeel van hun band met het oorspronkelijke productiecentrum. De producenten-kredietgevers maakten de drempel voor toetreding tot de steengoedhandel laag voor mensen die tot de groep behoorden, maar relatief hoog voor buitenstaanders.

\section{Veranderingen in het vervoer en in de vraag}

Niet alle Westerwalder handelaren gingen naar ver weg gelegen plaatsen. Bij de handel in 'Kannenbäckerware' moet onderscheid worden gemaakt tussen de zogenaamde Reffträger, die de goederen op de rug droegen, en de Kärner, die hun waar vervoerden met een kar. De Kärner brachten hun waren naar een gunstige plaats en verkochten het van daar uit. De Reffträger bleven dichter bij het Westerwald dan de Kärner.

De Westerwalder goederen werden per kar naar de Rijnhaven Vallendar bij Koblenz gebracht en daar ingescheept. Enkelen van de grote handelaren hadden een eigen schip voor hun vervoer (zie afbeelding op vorige pagina). ${ }^{22}$ Binnen Nederland werden de waren op kleinere zogenaamde potschepen vervoerd (zie afbeelding op volgende pagina). Het vervoer per stoomschip vergemakkelijkte het transport verder. ${ }^{23}$ Vanaf het midden van de negentiende eeuw konden Westerwalder handelaren hun goederen ook per spoor versturen. De verbeterde transportmogelijkheden schiepen de mogelijkheid om nieuwe markten te bereiken en maakten het mogelijk om te reageren op een toename van de vraag. In de negentiende eeuw werd een provisiekast vol steengoed-potten met in zout of zuur ingelegde groente en vlees, een symbool van welstand voor de kleine burgerij.

Het belangrijkste afzetgebied voor de lange-afstandshandelaren was in de zestiende eeuw reeds Nederland. In de zeventiende eeuw kwamen daar Noord-Duitsland, Frankrijk, België en overzeese gebieden bij. Nederland bleef echter tot in de negentiende eeuw het belangrijkst. Nederland was voor de Duitse handelaren een aantrekkelijk afzetgebied, omdat de levensstandaard er relatief hoog was.

Aan het einde van de negentiende eeuw bezochten de handelaren hun vaste klanten eens in de vier weken. Omdat mensen regelmatig potten en kruiken nodig hadden en de handelaren variatie konden aanbrengen in hun assortiment, konden vrij veel handelaren binnen een relatief klein gebied actief zijn. Ofschoon aan het einde van de negentiende eeuw de venters in toenemende mate concurrentie ondervonden van de 
winkels, werd hun handelsgebied toch niet beperkt tot het winkelarme platteland. Veel kopers vonden het ook toen nog makkelijk om het zware steengoed en de aanverwante producten aan huis te kopen. Volgens Plenge gold dit vooral in de arbeiderswijken bij de steden, waar vrouwen door kleine kinderen of werk aan huis gebonden waren. ${ }^{24}$

De Westerwalder handelaren beperkten in de loop van de negentiende eeuw hun activiteiten niet tot de handel in steengoed. Zij verkochten toen ook keramische producten uit andere streken, houten waren uit Sauerland, glas, mineraalwater, wasdoek, galanterieën, geweven goederen, Eau de Cologne en in mindere mate zeep, olie, blikwaren, schilderijen en kleedjes. ${ }^{25}$

Aan het einde van de negentiende eeuw wisten enkele Westerwalders zich op te werken tot groothandelaren in steengoed en aanverwante artikelen. ${ }^{26}$ Deze groothandelaren traden ook op als intermediair tussen Westerwalder steengoedfabrikanten en Nederlandse producenten van voedingsmiddelen. Nederlandse producenten bestelden via deze groothandelaren kruiken en potten gemerkt met hun bedrijfsnaam. Zo bestelde Wijnand Fockink, een Amsterdamse gedistilleerdproducent, stenen kruiken in het Westerwald, voorzien van zijn bedrijfsnaam. ${ }^{27}$ Gemerkte steengoed potten werden ook gebruikt voor boter, margarine, ansjovis, mosterd, zuur, ingemaakt fruit, rode kool, zuurkool, olie en zout. De potten en kruiken werden uitgegeven tegen statiegeld. ${ }^{28}$ Voor zover bekend werden ze vooral gebruikt door Amsterdamse en Rotterdamse bedrijven. Van Utrechtse bedrijven zijn (nog) geen gemerkte potten gevonden.

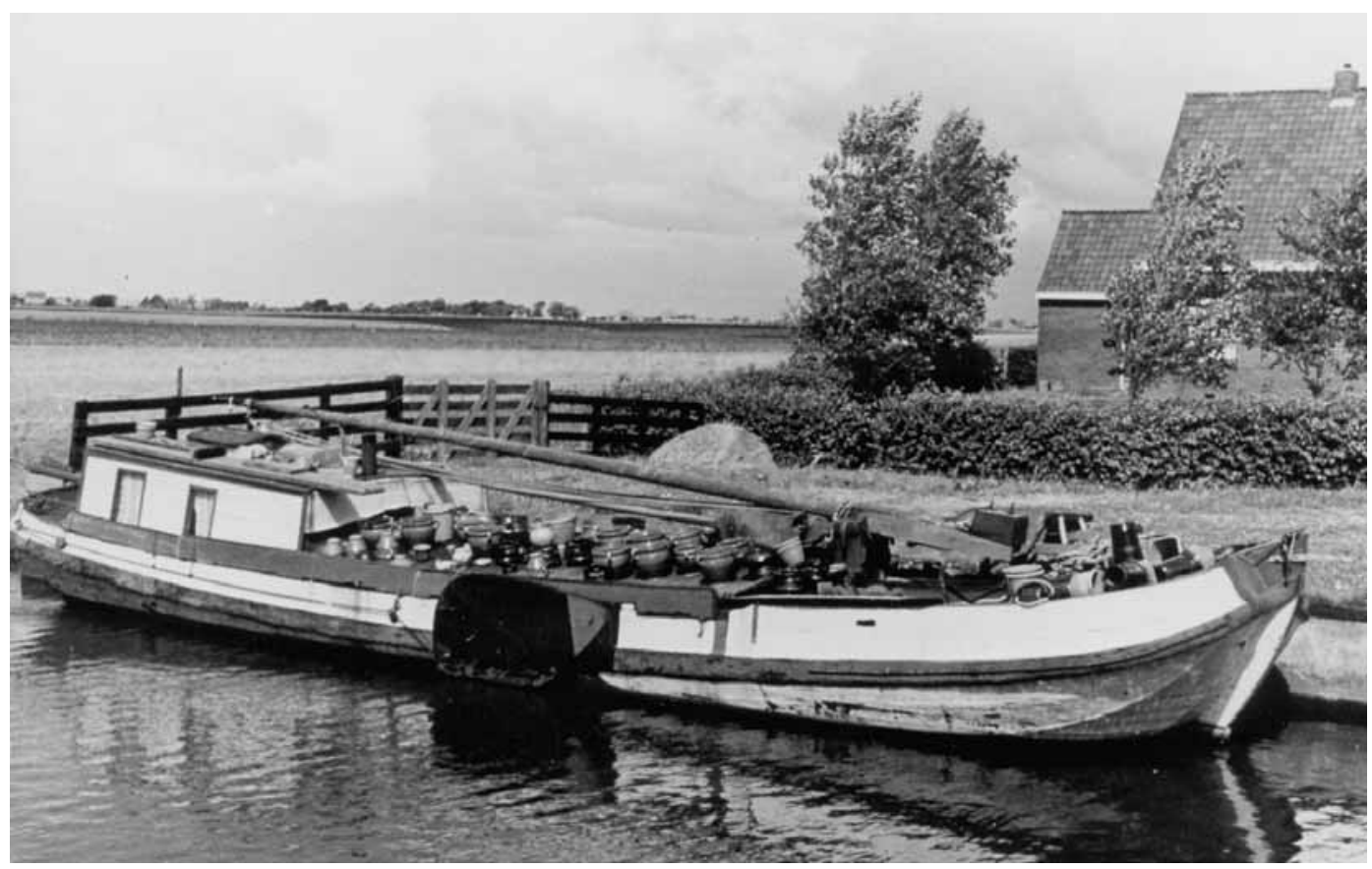

Potschip voor vervoer binnen Nederland. De foto werd gemaakt in 1943 bij Workum. Steengoed werd tot in de twintigste eeuw vervoerd in dit soort schepen. Nederlands Openluchtmuseum AA 151855 
De kruiken werden in de negentiende eeuw vooral benut voor mineraalwater. Aan het einde van de negentiende eeuw nam de belangstelling voor Westerwalder steengoed als emballage voor mineraalwater af en werd het vervangen door glazen flessen. In deze periode kwam de gewoonte in zwang om extra koolzuur aan mineraalwater toe te voegen. Glazen flessen bleken beter in staat deze verhoogde hoeveelheid koolzuur vast te houden. Bovendien waren ze gemakkelijker te reinigen en was beter te zien of ze schoon waren. ${ }^{29}$ De steengoed voorraadpotten werden gedeeltelijk vervangen door glazen Weckpotten. Als cache-pots - buitenbloempot - bleven ze nog wel in zwang.

\section{Wetgeving}

De handelsmogelijkheden van de Westerwalders werden niet alleen beïnvloed door verschuivingen in de vraag, maar ook door veranderingen in de Nassause wetgeving. Het Westerwald kende een lange traditie van zogenaamde Landgängerei; de term waarmee de trekhandel werd aangeduid. Omdat gevreesd werd dat die Landgängerei tot bedelarij zou leiden, vooral wanneer zij in familieverband plaatsvond, werden er beperkingen opgelegd. Vrouwen speelden in de trekhandel een belangrijke rol en zelfs kinderen gingen mee op reis. De wettelijke beperkingen richtten zich overwegend tegen de trek van vrouwen en kinderen. In de zeventiende en vooral de achttiende eeuw werd door bestuurders voortdurend geklaagd over bedelaars die zich voordeden als kramers. Om aan de vermeende uitwassen paal en perk te stellen en echte handelaars te onderscheiden van de bedelaars, werden stelsels van reispassen en vergunningen ingevoerd en werd het venten door vrouwen en kinderen verboden.

In 1811 werd bepaald dat een gehuwde handelaar slechts één van zijn zonen mocht meenemen, die bovendien de school ontgroeid moest zijn, hetgeen betekende dat hij ouder dan veertien jaar moest zijn. ${ }^{30}$ Deze regel werd door de handelaren geregeld overtreden. Werden ze betrapt, dan voerden ze aan dat ze niet wisten dat het meenemen van schoolkinderen verboden was, of ze zeiden dat het kind hen was nagelopen, zoals een van hen verklaarde voor het gerecht.

Es war mir allerdings verboten, mein schulpflichtiges Kind Georg auf den Hausierhandel mitzunehmen. Das Kind war mir aber nachgelaufen, und ich konnte es nicht mehr zurückschicken! ${ }^{31}$

Sommige handelaren namen echter niet alleen hun eigen kinderen mee, maar ook kinderen van anderen, die door de ouders aan hen verhuurd werden. ${ }^{32}$ Dit duidt erop dat de kinderen niet alleen om emotionele redenen werden meegenomen. De kindhandelaren waren een echte hulp en bron van inkomsten voor de volwassenen.

Gehuwde landgangers mochten hun vrouw niet meenemen, maar wel meiden en knechts. Ongehuwde landgangers mochten geen meiden meenemen. In de jaren dertig van de negentiende eeuw, na de aansluiting bij het Tolverbond, werd het verbod op het 
meereizen van vrouwen opgeheven, waarna het aandeel van de vrouwen in deze handel opnieuw belangrijk werd.

Terwijl er beperkingen waren op de seizoensmatige migratie van vrouwen, werd permanente migratie van vrouwen in principe door de Nassause overheid vanaf 1816 wel toegestaan. Voor mannen was dat slechts geoorloofd voorzover ze ouder waren dan 23 jaar en zich niet onttrokken hadden aan de dienstplicht. ${ }^{33}$ Een gedeelte van de jonge mannen kan tijdelijke migratie hebben voorgewend om niet aan de leeftijdsgrens van 23 jaar gebonden te zijn.

In 1867, na de aansluiting bij Pruisen, moesten inwoners van Nassau een 'Gewerbeschein zum Hausieren' hebben. Deze ventvergunningen waren niet voor alle producten verplicht, maar wel voor het steengoed. Het Gewerbeschein mocht alleen worden afgegeven in de eigen woonplaats en de landgangers mochten niet ziek zijn en liefst niet ouder dan dertig.

Auch soll in der Regel Leuten unter dreissig Jahren nicht erlaubt werden, ein Gewerbe im Umherziehen zu betreiben; es wäre denn, das das Gewerbe eine förmliche Erlernung erforderte und doch nicht wohl auf eine andere Weise als im Umherziehen betrieben werden könnte. ${ }^{34}$

Jonge handelaren mochten dus alleen meereizen als de overheid ervan kon worden overtuigd dat de handel alleen al doende kon worden geleerd.

In de jaren twintig van de negentiende eeuw kwamen er talloze verzoeken van landgangers om in weerwil van de wetgeving toch hun vrouw te mogen meenemen. Ze voerden aan dat de vrouwen voor de uitoefening van het bedrijf onontbeerlijk waren. Vijf Baumbacher landgangers gaven te kennen dat ze in hun standplaatsen in Amsterdam, Rotterdam en Breda woningen hadden, net als in Baumbach. Ze hadden er dus een vaste woonplaats. De vrouwen, zo zeiden zij, kwamen hun woningen niet uit, behalve op marktdagen, wanneer er veel te verdienen viel. In eerste instantie werden verzoeken ingewilligd indien er (nog) geen kinderen waren. Vervolgens kreeg men ook toestemming, wanneer kon worden aangetoond dat er voor de kinderen gedurende de ongeveer negen maanden dat de handelaren van huis waren, goede opvang was geregeld. Bij latere toestemmingen werd hieraan toegevoegd dat het jongste kind ouder dan één jaar moest zijn. Drie verzoeken, waarbij kinderen twee, vier en zes maanden oud waren, werden afgewezen. Deze kinderen waren te jong om te worden meegenomen op reis en ook te jong om van hun moeder te worden gescheiden, aldus de motivering van de afwijzing.

Kinderen werden veelvuldig in de dorpen achtergelaten. Voor opvang moest per kind een kostgeld worden betaald van 20 tot 25 Nassause guldens ( 21 tot 27 Nederlandse guldens). Indien schoolplichtige kinderen werden meegenomen op reis, verzuimden zij binnen een jaar wel tot tweehonderd dagen school. Er werd dan een boete opgelegd van ongeveer twintig Nassause guldens. De boetes wegens schoolverzuim waren lager dan het kostgeld dat voor de kinderen moest worden betaald. Wanneer de landgangers 
dat bedrag niet konden betalen, werd bij de eerste overtreding de helft van het bedrag kwijtgescholden en kon de rest worden afgelost met tien dagen wegarbeid. ${ }^{35}$ In dat geval waren de boetes dus uiterst gering en het meenemen van de kinderen was daardoor aantrekkelijk. De mogelijkheden om kinderen bij anderen onder te brengen waren bovendien beperkt. In dorpen als Ransbach en Baumbach, waar het merendeel van de trekhandelaren vandaan kwam, was gedurende het handelsseizoen de helft van de inwoners op reis. De dorpen waren uitgestorven en veel huizen waren afgesloten. ${ }^{36}$

In weerwil van de regelgeving gingen veel vrouwen en kinderen zonder toestemming mee op reis. Leraren meldden trouw het schoolverzuim van kinderen, soms jaren achtereen, waarna de boetes voor sommige gezinnen waren opgelopen tot honderden Nassause guldens. ${ }^{37}$ Dit motiveerde ongetwijfeld enkele Westerwalders om maar helemaal niet meer naar hun geboortestreek terug te keren. Midden vorige eeuw werden de regels versoepeld en kregen landgangers alsnog toestemming hun schoolplichtige kinderen mee op reis te nemen. ${ }^{38}$

\section{Het migratiepatroon}

De Westerwalders gingen aanvankelijk seizoensmatig naar Nederland. Het handelsseizoen viel in de zomer. De waren werden aan het begin van de negentiende eeuw per schip over de Rijn vervoerd, maar de schare handelaren liep ieder voorjaar, uitgerust met roggebrood, tien tot twaalf dagen naar het gezegende Nederland, om in de herfst met geld en vaak ook, zo klaagde Plenge uit naam van de Westerwalders die waren achtergebleven, met kwaadaardige koortsen terug te komen. ${ }^{39}$ Men liep zo'n acht tot tien uur per dag.

In november kwamen de handelaren terug naar het Westerwald. Met Kerstmis waren de dorpen overvol, waarna men in maart weer afreisde..$^{40}$ De handelaren brachten niet alleen koortsen mee uit verre oorden, maar ook zeden en gebruiken en een 'sonst kaum festzustellende Geselligkeit'. ${ }^{41}$ Uit Nederland kwam bijvoorbeeld modieuze kleding en koffie. Koffie werd in het Westerwald aan het einde van de negentiende eeuw veel meer geconsumeerd dan in omliggende streken en dit werd toegeschreven aan de contacten met Nederland.

De trekhandelaren brachten ook geld in het Westerwald. Volgens Plenge waren er in de jaren veertig van de negentiende eeuw ondernemers die jaarlijks negenhonderd Nassause guldens baar geld thuis brachten, twintig pond koffie, twintig pond rijst en honderd sigaren. Spaarzame handelaren konden geachte burgers worden met aanzienlijk grondbezit. Een knecht kreeg in de jaren veertig 10 tot 30 thaler ( 15 tot 45 gulden) in het eerste jaar en als de handel goed was, 30 tot 60 thaler ( 45 tot 90 gulden), een paar schoenen, een paar zolen en een kiel. Grote handelaren betrokken aan het einde van de negentiende eeuw per jaar 36 wagons Kannenbäckerware voor 36.000 mark (17.0oo gulden). ${ }^{42}$ 
Enkele Westerwalder handelaren lieten aanzienlijke erfenissen na. ${ }^{43}$ Er waren kleinere Westerwalder handelaren die in hun geboortestreek huizen en een kapel bouwden. ${ }^{44}$ De Westerwalders lijken, zoals verderop ook nog zal blijken, hun kapitaal eerder daar dan in Utrecht te hebben besteed. ${ }^{45}$

Een plaatselijke verordening in Baumbach van omstreeks 1800, onderdeel van maatregelen ter beteugeling van de concurrentie onder de pottenbakkers, bepaalde dat de handelaren hun goederen niet mochten ontvangen voor eind maart. Zodra de handelaren voorzien waren, vertrokken ze, soms reeds voor Pasen. Daarom verzette de priester van Ransbach en Baumbach de verplichte Paasbiecht naar voren. ${ }^{46}$

In 1834 gingen uit het Ambt Selters, waarin Ransbach lag, achthonderd personen als groot- en kleinhandelaren naar Nederland. In 1849 gingen er uit het naburige Ambt Montabaur driehonderd. In de jaren vijftig en zestig bereikte de steengoedhandel een hoogtepunt. In 1861 werd het aantal uit Nassau naar Nederland gaande handelaren in steengoed, tezamen met muzikanten, en handelaren in vruchten, op achttienhonderd geschat. In het voorjaar zaten honderden mensen bij het daartoe bestemde kantoor in Ambt Selters op hun reispas te wachten. ${ }^{47}$ Hierna nam de migratie aanzienlijk af. Aan het einde van de negentiende eeuw gingen er jaarlijks nog slechts ongeveer vijftig landgangers uit het Westerwald naar Nederland en België. Zeventien van hen handelden in steengoed. Behalve door een afname in de vraag, werd deze verminderde migratie ook veroorzaakt door het feit dat Westerwalders dichter bij huis werk konden vinden. ${ }^{48}$ Bovendien had een aantal migranten zich blijvend in Nederland gevestigd. Het seizoensmatig op en neer reizen kwam ten einde.

\section{Vreemde ende uytheemsche personen, die dagelycx met hare kannen alhier ter merkt komen}

De migratie van Westerwalders naar Nederland dateerde reeds van vóór de negentiende eeuw. Aanwijzingen voor deze trek in de achttiende eeuw vinden we in Duitse bronnen. In het Synodal-Protokollbuch der Pfarrarei Ransbach werd op 12 november 1782 melding gemaakt van de beboeting van Johann Forh en Anna Katharina Günther 'wegen getriebenen Unzucht, als daß vor der Kopulation ein uneheliches Kind gezeugt haben. ${ }^{49}$ Het kind werd geboren in Nederland. Het paar werd bestraft met een boete van '2 Goldgulden'. In 1786 werd besloten een kerkelijke collecte 'erst vorzunehmen wenn die in den Niederlande Handlende zurückgekommen' waren. Pas dan zou de collecte immers voldoende opbrengen..$^{50}$

De handel in Westerwalder potten op Utrecht kende een lange geschiedenis. In de elfde eeuw werd reeds melding gemaakt van invoer van 'aardewerk' uit het Rijngebied of Keulen. Pogingen tot wering van handelaren weerspiegelen hun activiteiten. Op 17 februari 1617 vaardigde het Marsliedengilde van Utrecht een ordonnantie uit op verzoek van de gezamenlijke kannenverkopers van de stad en gericht 
tegen vreemde ende uytheemsche personen, die dagelycx met hare kannen [...] alhier ter merkt komen. [...] De Raad der Stad Utrecht interdiceert by deesen wel scherpelyck, allen vreemden en uytheemsche personen, geen burgers of ingesetenen deser Stad wesende, van nu voortaan [...] kannen, kruyken, potten, [...] ende diergelyke, wes daar aankleeft, binnen deser Stad ende Vrijheyden van dien, te venten of verkopen, uyt scheepen ofte van wagens, nochte by der straaten, ofte huysen, ofte anders, dan alleenlyk op vrye jaarmerkten, ende op vrydag ende saturdag in elcken weecke, om als dan daar naar mede voor te staan op Sinte Marie-plaatse, ende anders nergens, op poene van ses gulden [...]..$^{1}$

In een notariële akte van 17 februari 1756 vinden we opnieuw een aanwijzing voor hun aanwezigheid. In die akte protesteerde ene Hendrik Hooft tegen het niet voldoen van een wisselbrief à 600 gulden door Willem Bisdom, 'Ceuls schipper' in de 'Ceulse pottewinkel' in de Mariastraat. De wissel was opgesteld te Keulen op 13 februari en getekend door Joan Hendrik Zaun. ${ }^{52}$

In 1759 vaardigde het marsliedengilde, waaronder de handelaren in aardewerk, dissen, kannen, kruiken en potten ressorteerden, een verordening uit die bepaalde dat

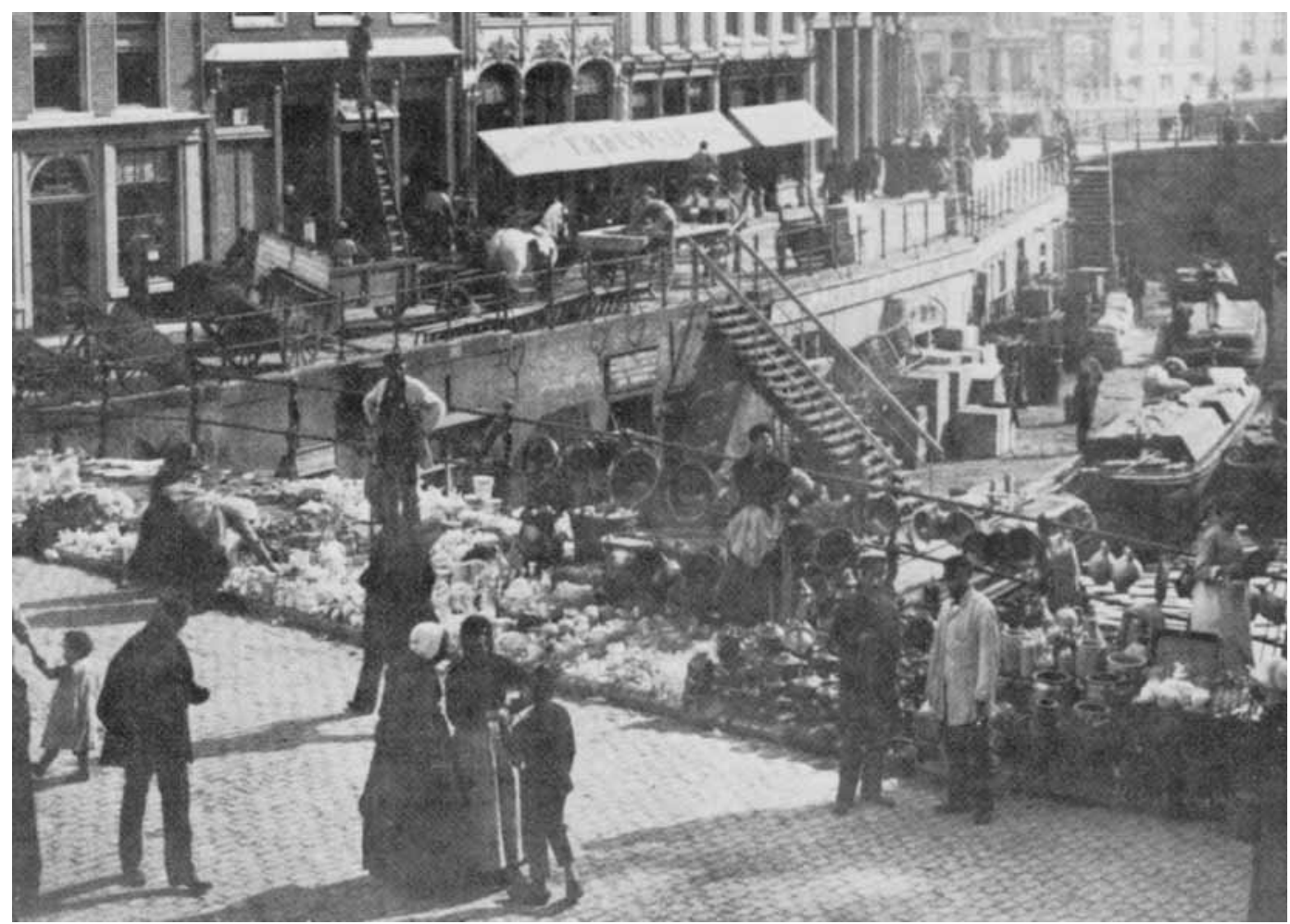


niemand deze waren mocht verkopen zonder lid van het gilde te zijn, het gildengeld te hebben voldaan en het bewijs van burgerschap te hebben getoond. Mensen die van buiten kwamen, en die goederen wilden verkopen die onder het gilde behoorden, mochten dat alleen en gros doen aan winkeliers. 'Niemant mag de waaren van dit Gildt langs de straaten veil dragen. En is alleen des Saturdags en op de Jaarmarkt gepermitteerd daar mede voor te staan.' Bij overtreding van deze regel werden hoge boetes opgelegd. De pottenmarkt bleek te zijn verplaatst van de Mariaplaats naar de Bakkerbrug. ${ }^{53}$

In 1820 werd gemeld in het 'Reglement van orde en instructie voor de marktmeester', dat de pottenmarkt, als vanouds, gehouden zou worden tussen de Vinkenburgsteeg en de Jansbrug aan de balie der (Oude) Gracht O.Z. In het midden van de negentiende eeuw floreerde zij. Behalve het stuk van de Vinkenburgsteeg tot de Jansbrug, besloeg de markt ook de Oudegracht tussen de Bakkerbrug en de Bezembrug. Volgens het Reglement van 23 augustus 1831 werd 'voor ene pottenkraam 5 cents marktgeld betaald. Zij hebben echter uitstellingen ter breedte van 7 a 9 ellen [ 5 tot 6,5 meter]. ${ }^{54}$ De marktmeester vond het marktgeld voor 'uitstellingen' van deze omvang te laag. Aan het einde van de negentiende eeuw, nam de pottenmarkt in betekenis af en in 1892 werd zij een klein onderdeel van de algemene warenmarkt op de Neude. ${ }^{55}$

Vreemde kooplieden mochten in de achttiende eeuw alleen verkopen aan de leden van het gilde nadat ze, tegen betaling, een briefje met permissie hadden gehaald bij het gilde. Het gilde stelde dan de winkeliers van hun komst in kennis. De toestemming gold voor maximaal twee dagen. Herbergiers waren verplicht het gilde op de hoogte te brengen van de komst van de vreemde kooplieden. ${ }^{56}$

De achttiende-eeuwse gildenbepalingen betekenden, dat de Westerwalder handelaren in deze periode in de stad alleen als groothandelaren konden functioneren. De Westerwalders lijken niet te zijn toegetreden tot het Utrechtse Marsliedengilde. In het register van namen van gildenbroeders en -zusters - ongeveer de helft van de leden is vrouw - komen geen Westerwalders voor. ${ }^{57}$ Het eveneens ontbreken van Westerwalders in de lijst van nieuwe burgers van de stad, lijkt daarmee in overeenstemming, gezien het feit dat lidmaatschap van het gilde was voorbehouden aan burgers. Het feit dat de Westerwalders katholiek waren, sloot hen van burgerschap en gildenlidmaatschap uit. Op deze regel werden, zoals we eerder zagen, uitzonderingen gemaakt voor 'nuttige en nodige roomschen'. De Westerwalders waren dat klaarblijkelijk niet, of ze hadden geen belangstelling voor burger- en gildenlidmaatschap. Op het platteland konden ze hun waren mogelijk wel rechtstreeks afzetten. Het gilde verbood weliswaar ook het 'omloopen op het platte land', maar de controle was daar minder scherp..$^{58}$ De gildenbeperkingen waren de reden dat de Westerwalders in Utrecht niet in de stad, maar net buiten de stadsmuren woonden. De opheffing van de gilden leidde tot een uitbreiding van de mogelijkheden voor de Westerwalder handelaren, maar maakte geen einde aan deze ruimtelijke segregatie.

Westerwalders worden vóór de achttiende eeuw niet als groep genoemd door Rommes. ${ }^{59}$ Hij wijst weliswaar op een toename van de immigratie uit Nassau, maar de Westerwalder steengoedhandelaren treden niet als groep naar voren. Hiervoor zijn twee 
verklaringen. De eerste verklaring ligt bij de door hem gebruikte bronnen, waarin katholieken - en de Westerwalders waren dat zonder uitzondering - ondervertegenwoordigd zijn. De tweede reden is, dat er vóór 1800 weliswaar Westerwalder handelaren in Utrecht waren, maar dat de grootschalige immigratie van deze groep inderdaad dateerde van na 1800 .

Dat juist Utrecht belangrijk was voor de pottenhandel, kwam door de ligging van deze stad. Grote Rijnschepen, die gewoonlijk Keulenaars werden genoemd, konden tot in Utrecht komen, maar daar moesten de ladingen in kleinere vaartuigen worden overgeladen, om naar bijvoorbeeld Amsterdam te kunnen worden vervoerd. ${ }^{60}$ Voor Utrecht was deze situatie voordelig. Vanaf 1807 was er een speciaal ingericht veer, het 'Keulscheveer' genoemd, waar de overlading onder toezicht van door het gemeentebestuur aangewezen commissarissen plaatsvond. Amsterdam was met deze situatie minder gelukkig en ijverde voor een verbetering van de waterverbinding. Die kwam er in 1824 en werd aangeduid als de 'Keulschevaart'. Amsterdam had nu weliswaar een rechtstreekse verbinding met de Rijn voor grote schepen, maar door het slechte beheer, vooral door de stad Utrecht, liep de vaardiepte reeds snel terug. Pas toen de vaart onder beheer van de provincie kwam, verbeterde het onderhoud. Een definitieve verbetering kwam er pas in 1892, toen het Merwedekanaal werd geopend. Dit viel samen met het einde van de Westerwalder gemeenschap in Utrecht, maar dat uiteenvallen kan niet alleen daaraan worden toegeschreven.

\section{Omlopers in Keulse potten}

Vanaf 1806 kunnen we voor gegevens over Westerwalders in Utrecht gebruik maken van de registers van patentbelasting. In Utrecht werd in 1806 een afzonderlijk patentregister voor deze handelaren aangelegd. Dit register, waarin volgens het opschrift 'vreemde ketelboeters en anderen met koopwaar rondgaande' werden ingeschreven, telt 135 namen. Onder deze patentplichtigen waren 4 ketellappers, 7 kooplieden met linnen en lijnwaden, 1 scharenslijper, 3 strohoedenverkopers, 1 handelaar in manufacturen, 1 Franse winkelwarenverkoper en maar liefst 99 'omlopers met Keulse potten en pannen'. ${ }^{61}$

De 99 patenten aan 'kooplieden in aardewerk' in het Utrechtse register werden uitgegeven aan 59 mannen en 40 vrouwen. ${ }^{62}$ De 'kramers in aardewerk' in de patentregisters woonden zonder uitzondering in de Utrechtse buitenwijk K. Op basis van de Utrechtse volkstellings- en latere bevolkingsregisters, kan worden vastgesteld dat de leden van deze groep aan het einde van de achttiende eeuw in het herkomstgebied werden geboren. Hun oudere kinderen werden eveneens in het herkomstgebied geboren, terwijl de latere kinderen na ongeveer 1810 in Utrecht ter wereld kwamen.

Aanwijzingen voor een eerdere aanwezigheid van Westerwalders in deze wijk ontbreken. In de manualen van de Honderdste Penning uit 1793 komen geen Westerwalders voor in de Gansstraat in de wijk Tolsteeg. ${ }^{63}$ In 1802 vroeg Melchior Stein uit Rans- 
bach, die ook voorkomt in het patentregister van 1806, recht van inwoning in de stad aan. ${ }^{64} \mathrm{Hij}$ is de enige die dit recht verwierf voordat het werd afgeschaft.

In totaal telde de groep - mannen, vrouwen en kinderen tezamen - in 1806 ongeveer tweehonderd personen. Deze groep ontstond aan het begin van de negentiende eeuw, door een poging om de beperkingen op familiemigratie te omzeilen, en van de verwarring van de Napoleontische periode gebruik te maken om naar Utrecht te reizen en zich daar permanent te vestigen.

In 1810 werd er een extra belasting geheven in het kader waarvan een nieuwe lijst patentschuldige kramers werd opgesteld. ${ }^{65}$ Deze lijst telt 22 namen van Westerwalder handelaars; 21 mannen en 1 vrouw. De beperking op het meereizen van vrouwen, die hierboven werd genoemd, had kennelijk succes. Elf mensen van de lijst van 1810 komen ook voor op de lijst van 1806. Slechts de helft van de mensen was dus beide keren in Utrecht. In 1831 werd er een register aangelegd van patentschuldige kramers en ondernemers in publieke vermakelijkheden. ${ }^{66}$ In totaal werden er 434 patenten uitgegeven, waarvan 31 aan 'kramers in aardewerk'; zes vrouwen en 25 mannen. Zes kramers kwamen reeds voor op de lijst van 1806 . Opnieuw blijkt hier het nog weinig stabiele karakter van de gemeenschap. Alle 'kramers in aardewerk' in het register van 1831 zijn zogenaamde vreemde kramers. Dit betekent dat ze niet alleen afkomstig waren uit het buitenland, maar ook daar woonden. In de eerdere lijsten werd geen herkomstplaats vermeld. Tussen april 1844 en april 1845 werden er in Utrecht 683 patenten uitgegeven aan patentschuldige kramers, waarvan 26 aan 'kramers in aardewerk'; 14 mannen en 12 vrouwen. Dit waren ook weer allemaal zogenaamde vreemde kramers. In het belastingjaar 1850-51 was het aantal patentschuldige kramers verminderd tot 468, waaronder twaalf vreemde 'kramers in aardewerk': zes mannen en zes vrouwen. ${ }^{67}$ De patentregisters zijn echter in deze periode een minder geschikte bron geworden voor de schatting van het aantal kramers. Er werd namelijk veelvuldig geklaagd dat de patentbelasting op grote schaal werd ontdoken, vooral door vreemde kramers. ${ }^{68}$ Het bevolkingsregister van 1849-1859 laat dan ook zien dat er inmiddels veel meer Westerwalders in de stad waren.

Ofschoon het gebied waaruit de handelaren kwamen zich in de negentiende eeuw uitbreidde, bleef de handel in handen van een beperkt aantal families. ${ }^{69}$ Dit blijkt reeds uit de Utrechtse lijst van 1806: negentien namen komen meerdere keren voor (dit betreft 63 personen). In totaal omvat de lijst 55 verschillende familienamen. Elf namen komen twee keer voor, en enkele namen, zoals Jäger ( 7 keer) en Korzilius ( 6 keer) veel vaker. Huwelijken tussen de kramers onderling waren regel. Halverwege de vorige eeuw komen dezelfde namen steeds terug bij huwelijken, zij het in allerlei spellingsvarianten: Gerhards, Stein, Koch, Cesar, Henkes, Jäger, Fohr, Geelhart, Kalb, Litschert, Böckling, Wälter, Klein, Wolf, Gunther, Selbach, Korzilius en Krüft. Er werd vrijwel niet buiten de groep getrouwd. Aan het einde van de negentiende eeuw werd dit patroon doorbroken. Opvallend is echter dat, toen er aan het einde van de negentiende eeuw gehuwd werd met mensen die niet in het herkomstgebied noch in Utrecht waren geboren, het in meerdere gevallen gaat om mensen die geboren zijn in bijvoorbeeld 
Den Bosch, Amsterdam, Helmond of Den Haag, maar die wat hun naam betreft overduidelijk behoren tot de Westerwalders.

De immigranten waren aanvankelijk vooral jongvolwassenen, zoals in 1834 in Utrecht Johannes, Maria en Margaretha Kalb, die respectievelijk 16, 18 en 25 jaar oud waren. In het Utrechtse bevolkingsregister vinden we aanwijzingen voor het in Nassau achterlaten van kinderen. Het echtpaar Geelhart-Fohr was bijvoorbeeld in 1840 in Utrecht in het gezelschap van hun in Utrecht geboren, acht maanden oude dochter Maria-Anna, maar zonder de zes jaar oude Jacob, die hen tien jaar later wel vergezelde. Voorts waren er handelaren die het ene jaar wel en het andere jaar niet in gezelschap van hun vrouw reisden, en een enkele keer een getrouwde vrouw zonder haar man, maar met een aantal meiden. Het achterlaten van partners en kinderen leidde ertoe dat er een sterke band bleef bestaan met het herkomstgebied.

De Westerwalders waren opvallend aanwezig in de vroege patentregisters, maar niet in de volkstellingsregisters van 1829 en $1839 .^{70}$ In de volkstellingsregisters werden alleen mensen geregistreerd die hun wettelijke domicilie in Utrecht hadden. Westerwalders die hun domicilie niet in Utrecht hadden, komen niet in deze registers voor, maar dat betekent niet dat ze niet in de stad waren. De Duitser Leonart Letschert woonde bijvoorbeeld volgens het register van de patentbelasting van 1844 in de Utrechtse wijk K. In 1840, 1841 en 1844 werden, volgens de geboorteregisters, in deze wijk zijn kinderen geboren. In 1849 overleed zijn vrouw Anna Jäger er, getuige het overlijdensregister. In 1854 en 1855 werd in de kerkboeken van de H. Martinusparochie, die met wijk K overlapte, aangetekend dat de familie Letschert in Utrecht haar Pasen had gehouden. Dit betekent dat de familieleden met Pasen daar te biecht waren geweest een van de minimumverplichtingen waaraan een katholiek moest voldoen. In tal van Utrechtse bronnen heeft de familie Letschert sporen nagelaten, maar in de volkstellingsregisters van 1839 en 1849 en de bevolkingsregisters van 1850-1859 en 1860-1869 komt ze niet voor. Pas bij de volkstelling van 1869 werd de familie Letschert voor het eerst in het bevolkingsregister ingeschreven. Voor dat register gold dat niet langer het wettelijk domicilie, maar de werkelijke woonplaats grondslag voor registratie was.

De familie Letschert was niet de enige Westerwalder familie waarvoor deze onderregistratie gold. Johan Hummerich betaalde in 1831 en 1844 in Utrecht belasting als patentplichtige kramer, wonend in wijk K. In 1837 en in 1842 werden zijn twee dochters in Utrecht geboren. ${ }^{71}$ Op het adres in wijk K, waar de familie volgens de geboorteakten van deze kinderen zou moeten wonen, stond de familie echter niet in het volkstellingregister van 1840. De familie stond ook niet elders in de wijk ingeschreven. In 1852 werd in de kerkboeken van de H. Martinusparochie aangetekend dat de familie Hummerich in Utrecht haar Pasen had gehouden. De familie Hummerich komt echter, net als de familie Letschert, niet voor in het bevolkingsregister van 1850-1859. Het is mogelijk dat de families Hummerich en Letschert slechts een gedeelte van het jaar in Utrecht waren en in de wintermaanden afreisden naar hun geboortestreek. Duidelijk is wel dat de families Hummerich en Letschert meer dan twintig jaar lang meestentijds in Utrecht woonden, zonder te worden geregistreerd als inwoner van deze stad. 
Tot 1860, zo blijkt uit het bevolkingsregister, kwamen seizoensmigratie en permanente vestiging in Utrecht naast elkaar voor. Lang niet alle migranten keerden terug naar het Westerwald. In 1854 vertrok driekwart van de Westerwalders in het najaar uit Utrecht; twee jaar later slechts de helft en twee jaar daarna opnieuw driekwart. Een kwart tot de helft van de Westerwalders overwinterde dus in Utrecht. In het Utrechtse volkstellingsregister van 1840 wordt ook naar de seizoensmigratie verwezen. Bij het echtpaar Jäger-Koch werd bijvoorbeeld aangetekend: 'zijn alhier voor pottenkopers, des winters vertrekken naar Duitschland en betalen hier alleen patent ineens.' Een soortgelijke mededeling is in het volkstellingsregister te vinden bij Frans Vugt: 'Is voor het zomersaisoen, van november tot maart na zijn geboorteplaats.'

Aantekeningen betreffende tijdelijke afwezigheid zijn in de vrij betrouwbare latere bevolkingsregisters afwezig. Nieuwe migranten kwamen er nog wel. In 1870 trok bijvoorbeeld bij de familie Krüft het echtpaar Peter Hölzmann en Anna Fritz in, beiden geboren in 1834 en komende uit Duitsland. Seizoensmigratie kwam in 1870 nog voor, zij het op beperkte schaal. Na 1860 nam de seizoensmigratie af en werden de kinderen, getuige de inschrijvingen in het bevolkingsregister, alleen nog in Utrecht geboren.

Opvallend en typerend is de opstelling van de Westerwalders na de invoering van de Vreemdelingenwet van 1849. Toen werd in Utrecht een register aangelegd van vreemdelingen die meer dan zes jaar in Utrecht hadden gewoond en die derhalve, op grond van artikel 8 van het Burgerlijk Wetboek van 1838, het recht hadden gelijkstelling met Nederlanders aan te vragen. Gelijkgestelden vielen, zoals gezegd, niet onder de Vreemdelingenwet. Klaarblijkelijk verwachtte het Utrechtse gemeentebestuur dat een groot aantal mensen van dit recht gebruik zou maken. Het vuistdikke register dat werd aangelegd bood ruimte aan 1890 inschrijvingen. Feitelijk bleef het aantal inschrijvingen beperkt tot 48. Opmerkelijk is dat 33 inschrijvingen betrekking hadden op Westerwalders. Dit waren zowel alleenstaanden als echtparen. Bij de inschrijvingen werd steeds dezelfde formule gebruikt:

De directeur van policie verklaart dat Joseph Jaeger, van beroep koopman in aardewerk, geboren te Ransbach in het Hertogdam Nassau, thans woonachtig te dezer stede buiten de Tolsteegbarriere in de Ganssteeg wijk K no 222 met zijne huisvrouw Elisabeth Koch genoegzaam is gelegitimeerd om binnen dit Rijk te worden toegelaten en van den 23 maart 1843 tot heden en derhalve sedert meer dan zes jaren onafgebroken te dezer stede heeft gewoond, en dat dezelve alzoo bevoegd is om bij het Bestuur dezer stad ingevolge Art. 8 van het Burgerlijke Wetboek de verklaring af te leggen van zijn voornemen, om zich binnen het Koningrijk te blijven vestigen. ${ }^{72}$

Gedeeltelijk reflecteert het grote aantal inschrijvingen van Westerwalders hun aandeel in de Duitse migratie naar Utrecht. De inschrijvingen geven echter ook blijk van de angst van de Westerwalders dat ze, na een als tijdelijk bedoeld bezoek aan Nassau, niet meer tot Nederland zouden worden toegelaten. ${ }^{73}$ De wens tot gelijkstelling was ook ge- 
koppeld aan hun economische positie. De Vreemdelingenwet stelde immers als eis dat een vreemdeling voldoende middelen van bestaan had. De Westerwalders voldeden niet allemaal aan dit criterium. Als laatste was ook de patentbelasting belangrijk, die vreemde kramers zwaarder belastte.

\section{De klompenparochie}

Opmerkelijk is dat de Westerwalders zich in Utrecht vestigden in één buurtje en niet verspreid over de stad woonden. ${ }^{74} \mathrm{Ze}$ woonden in een gedeelte van wijk K, rondom de Gansstraat, buiten de singels die de Utrechtse binnenstad omsloten. De Westerwalders verhuisden tot het laatste decennium van de negentiende eeuw frequent binnen deze buurt, maar slechts zelden daarbuiten. Pas toen begonnen de leden van de groep zich te verspreiden over andere wijken, vooral naar de nieuwbouwwijken I en M.

De Westerwalders bevolkten slechts een klein deel van de vrij uitgestrekte wijk K. Elders in de wijk woonden hoveniers met hun knechten en meiden. Verder waren er schippers en scheepstimmerlieden, en arbeiders die werkzaam waren op de steen-, pannen- en tegelbakkerijen die verder van de stad af aan de Vaartse Rijn lagen. Er was een scheiding tussen de kramers enerzijds en de andere wijkbewoners anderzijds. De hoveniers en schippers woonden ten westen van de Vaartse Rijn en meer naar het zuiden.

Van Rijnsoever, chroniqueur van de gedeeltelijk met wijk K samenvallende $\mathrm{H}$. Martinusparochie, gaf een beschrijving van de wijk. In de wijk stond een oude villa, Rotsoord genaamd, die was gebouwd in 1700. In het begin van de negentiende eeuw stond deze villa leeg en nam een excentrieke vrijgezel er zijn intrek, die allerlei proefjes deed, onder meer met een elektriseermachine.

Dit [...] heeft waarschijnlijk de stof geleverd voor allerlei fantastische verhalen en geschiedenissen die zich in deze omgeving zouden hebben afgespeeld, wat nog begunstigd werd door de zwervende Duitsers, die zich om de handel hier aan de Helling vestigden, aangezien zij als vreemdelingen niet in de stad mochten wonen. 's Avonds zongen zij hun volksliedjes aan de waterkant vóór zij zich terugtrokken in hun woonschuiten of in de Stijfselsteeg waar de kern der duitse kolonie woonde. ${ }^{75}$

Van Rijnsoevers opmerking over het verbod voor vreemdelingen om in de stad te wonen, slaat duidelijk op een eerdere periode. In de negentiende eeuw was er van een dergelijk verbod geen sprake. Waarschijnlijk bestond er reeds vóór 1800 een kleine gemeenschap. Die zou dan vergelijkbaar zijn met de joodse gemeenschap aan de andere kant van de stad Utrecht, bij Maarssen, waar joden zich vestigden omdat hen de toegang tot de stad werd geweigerd.

De Duitsers in wijk K vormden een gemeenschap apart. 
Dit gaf een mengeling van mensen waar gelukzoekers en zwervers de hoofdgroep van uitmaakten. Niet alleen kwam dit tot uiting in hun kleding maar ook in hun taal, die platter en slordiger was dan die der overige Utrechtenaren. ${ }^{76}$

Het buurtje van wijk K waar de Westerwalders zich concentreerden, bestond uit ongeveer 180 huizen met 272 bewoners. Volgens de volkstelling van 1849 woonden er in dat jaar in wijk K 72 mensen die in Duitsland geboren waren. Daarnaast woonden er in het buurtje nog nakomelingen van de reeds genoemde tweehonderd eerdere Duitse migranten. Tussen 1849 en 1870 kwamen er nog zo'n honderd Duitse nieuwkomers bij. In de tweede helft van de negentiende eeuw, bestond de gemeenschap in wijk K dus uit wat we nu eerste-, tweede- en derde-generatie migranten noemen. Door de sterke endogamie zijn scheidslijnen tussen de verschillende generaties moeilijk te trekken. Immigranten die behoorden tot de tweede of derde generatie, trouwden met mensen die zich recent in Utrecht hadden gevestigd en dus tot een eerste generatie behoorden.

De keuze van de kramers voor wijk K was niet onlogisch, daar de wijk gunstig gesitueerd was voor de aanvoer van handelswaar over de Rijn. Zoals gebruikelijk bij toe-

Kaart 9.2 Woonbuurt van de Westerwalders in wijk K.

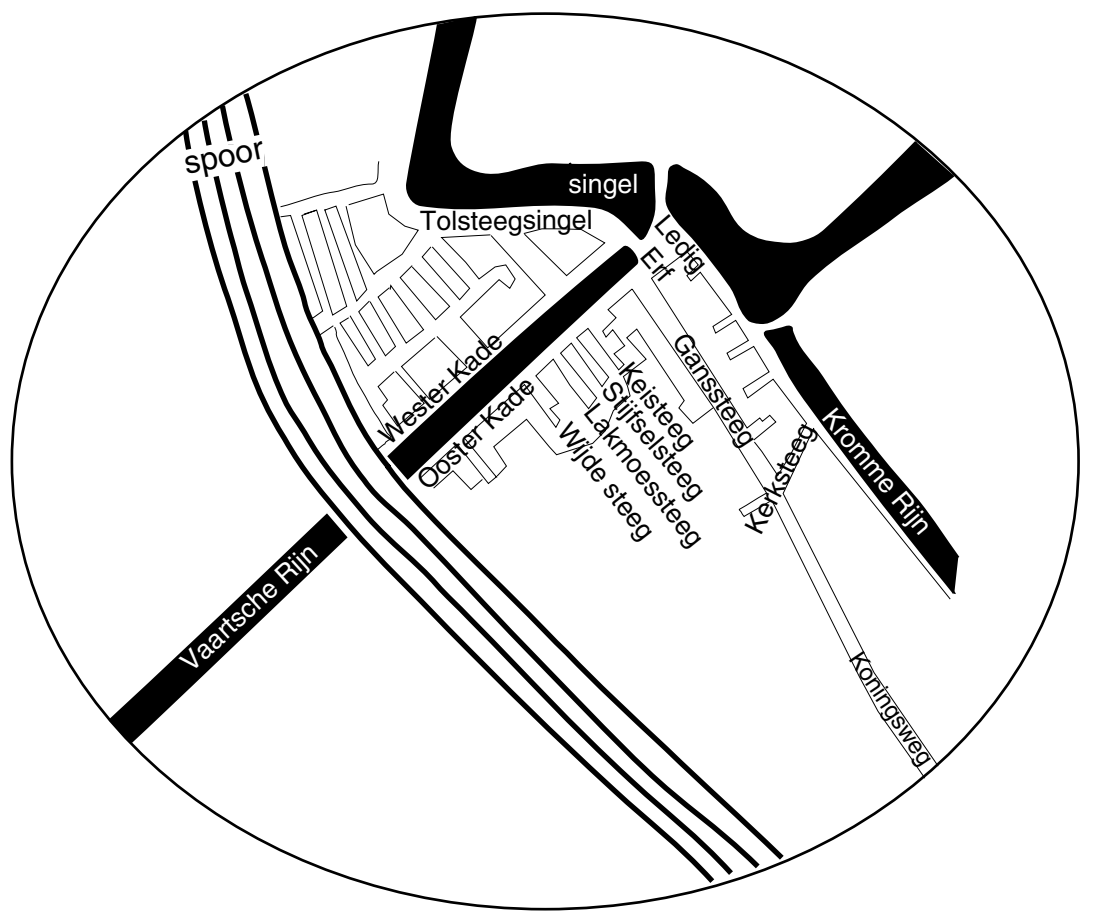

Het buurtje werd door spoorwegen en water gescheiden van de rest van de wijk. 
gangswegen tot een stad, waren er aan de stadskant van wijk K logementen en herbergen. Dit was echter niet waar de Westerwalders hun verblijf hielden. Zij bewoonden de huizen in de sloppen en stegen rond de Ganssteeg, waarbij op de erven pakhuizen waren gebouwd. Er woonden ook enkele Westerwalders op hun schepen. De pakhuizen leken niet op die in het negentiende-eeuwse Amsterdam. In dit buurtje waren het schuurachtige gebouwen van slechts één verdieping, zonder ramen en met een brede toegangsdeur waardoor een kar naar binnen kon rijden.

De buurt rondom de Ganssteeg was reeds aan het begin van de negentiende eeuw tamelijk dichtbevolkt. In de loop van de eeuw groeide de bevolking nog meer en werd de situatie niet beter. De wijk werd door de cholera-epidemie van 1866 zwaar getroffen. Verhoudingsgewijs vielen hier de meeste choleraslachtoffers. ${ }^{77}$ Door de medicus Snellen werd dit gedeelte van de stad in 1868, in een voordracht over Utrechtse achterbuurten, getypeerd als een 'aaneengeschakelde reeks van blinde stegen, hofjes en sloppen, die voor een groot deel niet aan de eischen der hygiëne voldeden. ${ }^{78}$ De weduwe Koch, bijvoorbeeld, woonde midden vorige eeuw met haar zes kinderen, op het adres Wijdesteeg $47 \mathrm{e}$. Samen met tien andere huisjes, lag haar woning aan een plaatsje zonder naam, van tweeënhalve meter breed. De woningen en het plaatsje vormden een nauw zijslop van het slop de Wijdesteeg, te bereiken door een gangetje, waar slechts één persoon tegelijk doorheen kon. Het plaatsje was volledig afgesloten, met een schutting aan de kant van het gangetje, twee rijtjes huizen tegenover elkaar en aan het eind een pakhuis. De woningen waren zeer klein en vervallen, en bevatten slechts een vertrek met een zoldertje. De vloer lag onder straatniveau. De elf woningen deelden samen een privaat. ${ }^{79}$ Mensen die er niets te zoeken hadden, kwamen er ook niet.

Een gedeelte van de Westerwalders in wijk $\mathrm{K}$ woonde bij elkaar in een groot gebouw, dat de Ark werd genoemd. In het gebouw huurden de Westerwalder families elk een of twee kamers. Deze vorm van huisvesting was voor het negentiende-eeuwse Utrecht zeer ongebruikelijk.

In de Ark van Noë was alles vertegenwoordigd, vandaar dat men deze kazernewoning in de Ganssteeg 'de Ark' noemde. Allerlei slag mensen woonden in deze huizen waaronder ook veel Duitsers, die gelijk hun landgenoten op de Helling, handelden in aarden potten en kruiken. Daarmee trokken zij stad en dorp in. ${ }^{80}$

De Westerwalders hadden de huizen die ze in wijk K bewoonden niet in hun bezit. Tussen 1842 en 1850 werd, in verband met het beheer van de buurtlasten, een lijst opgesteld van de eigenaren van dit deel van wijk $\mathrm{K}$. Op deze lijst komen geen Westerwalders voor. ${ }^{81}$ Onderzoek in het kadastraal archief bevestigt de constatering op basis van de buurtlastenlijst: Westerwalders waren in de eerste helft van de negentiende eeuw niet de eigenaren van de panden in dit deel van de wijk. ${ }^{82}$ De Utrechtse elite was dat evenmin. Perceel A 107 was bijvoorbeeld in 1832 oorspronkelijk in bezit van hovenier IJsbrand de Vreede. Later in de eeuw en na verschillende opsplitsingen van het perceel, ging zijn bezit onder meer over op de metselaar Christiaan Wiesman en de timmerman 
Petrus van Leeuwen. De beroepen van de andere eigenaars in dit buurtje geven een indicatie van de sociale klasse waartoe ze behoorden: koopman in vis, 'vaarman', landbouwer, melkverkoper, winkelier, koopman in brandstoffen, hovenierster, tapper, logementhouder, koopvrouw, scheepmaker, klompenmaker en klepperman. De eigenaars van de huizen in dit armoedige deel van de stad, behoorden duidelijk niet tot de hoogste sociale klassen. De huizen bleven evenmin steeds in handen van dezelfde mensen: het aantal overdrachten in deze buurt was enorm groot. De huizen en percelen kwamen dus veelvuldig op de markt en waren, naar de beroepen van hun nieuwe eigenaars te oordelen, niet bijzonder duur. Westerwalders kochten deze panden echter niet. Op deze regel was slechts één uitzondering. In 1875 werd de koopvrouw Catharina Letschert genoemd als mede-eigenaar van perceel A 59 (K 192). Catharina Letschert ook gespeld als Katharina Litzert - werd in 1837 geboren in Nassau. Ze kwam reeds enkele jaren later naar Utrecht met haar ouders, die beiden werden ingeschreven als kooplui in aardewerk. In 1864 trouwde ze met Carolus Mertens, een koopman uit het Belgische Turnhout. De bruidegom, zo vermeldt de huwelijksakte, kon niet schrijven. Catharina Letschert zette een zwierige handtekening. Catharina Letschert's mede-eigenaar van het pand was haar man Charles Mertens. De Westerwalders kochten, zoals eerder opgemerkt, wel bezit in het Westerwald. Wellicht zagen ze hun verblijf in Utrecht toch vooral als tijdelijk en verwierven ze daarom geen eigendom.

De huizen die de Westerwalders bewoonden waren armoedig, zo blijkt ook uit het woningonderzoek, dat in 1902-1904 werd gehouden in verband met de Woningwet. Het merendeel van de huizen in dit buurtje werd kort na dat onderzoek gesloopt. Vrijwel alle woningen werden als zeer slecht aangemerkt. Het pand Gansstraat 55 deelde een privaat met twee andere woningen. Het huis werd geplaagd door vocht, stank van het privaat, onvoldoende licht en ongedierte. Nummer 24 in dezelfde straat was nog geen vier meter breed en zesenhalve meter diep en bestond uit één kamer. De woning deelde een privaat met vijf andere woningen, en dat privaat stond 25 meter van de woning verwijderd. De afwatering vond plaats op de openbare straat.

Wijk K was halverwege de vorige eeuw een overwegend katholieke wijk; 70 procent van de bewoners was katholiek, terwijl dit percentage voor de stad Utrecht als geheel lager lag. Wijk K behoorde oorspronkelijk tot de parochie Achter de Twijnstraat en na 1855 tot de H. Martinusparochie. De parochie omvatte wijk K en het armere gedeelte van de binnenstadswijk B. In het binnenstadsgedeelte kwam na 1855 de parochiekerk. Voor die tijd was er door de bewoners van wijk K gekerkt in een eenvoudig pand in hun eigen wijk, buiten de singels. De pastoor woonde ook toen al binnen de singels. De parochie van de $\mathrm{H}$. Martinus werd een klompenparochie genoemd; een duidelijke verwijzing naar de armoede van de bewoners.

Omdat de handelaren tot het eind van de negentiende eeuw in de armoedige wijk K bleven wonen, lijkt het alsof hun handel niet bijzonder winstgevend was. Dit is in tegenspraak met Plenge's beschrijving. Er zijn verschillende mogelijke verklaringen voor dit verschil. Plenge spreekt om te beginnen over enkele succesvolle handelaren. Naast hen was er een groot aantal kleinere handelaren die veel minder inkomsten hadden. 
Door toeval zouden dan de enkele rijke handelaren geen deel uitmaken van dit onderzoek, bijvoorbeeld omdat ze niet in Utrecht woonden. Waarschijnlijker is dat de handelaren, zoals Plenge ook opmerkte, de neiging hadden hun successen te overdrijven. Mogelijk waren de inkomsten uit de handel niet zo heel groot. Een andere verklaring zou kunnen zijn dat de Westerwalders nog lang geld naar hun geboortedorp bleven sturen, met het doel daar indien mogelijk grond te kopen en een huis te laten bouwen. ${ }^{83}$ In Utrecht leefden ze sober. Onder de Westerwalder handelaren in Nederland, waren in ieder geval wel mensen die in hun geboortedorp grond bezaten. In 1845 werd er een lijst opgesteld van grondeigenaren in Ransbach, in verband met het betalen van grondbelasting. De lijst telde 205 namen; 52 mensen konden de lijst niet ondertekenen omdat ze in Holland op handelsreis waren. ${ }^{84}$

De gehechtheid aan wijk K zou in die gevallen geen teken van armoede hoeven te zijn, maar een gevolg van spaarzaamheid en gerichtheid op het land van herkomst. Indien dit ook meer in het algemeen de reden was dat Westerwalders in hun buurt bleven wonen, dan heeft dat waarschijnlijk op tweeërlei manieren hun integratie belemmerd. Ten eerste bleef, door het bezit in het Westerwald of de wens daar bezit te hebben, de emotionele band met de herkomststreek sterk. Ten tweede kwamen de Westerwalders in Utrecht niet los van hun buurtje, waar ze toch vooral met streekgenoten woonden, zodat er althans in de woonomgeving weinig contacten waren met anderen. Een reden voor hun gehechtheid aan wijk K kan voorts zijn geweest dat het stadsdeel weliswaar armoedig was, maar ook goed over water bereikbaar, hetgeen de aanvoer van handelswaar vergemakkelijkte. Bovendien waren er pakhuizen waar de goederen konden worden opgeslagen.

\section{Johann Kalb VIII}

Westerwalder migranten in Utrecht trouwden vooral binnen de eigen groep, hetgeen de groepscohesie zowel weerspiegelde als versterkte. De Westerwalders zetten een huwelijkspatroon voort dat ze reeds vóór hun migratie hadden gekend. Westerwalders die in hun geboortestreek waren achtergebleven, trouwden eveneens merendeels met partners uit het eigen dorp. De effecten van dit huwelijkspatroon worden gereflecteerd in de namen. Westerwalders hadden een voorkeur voor bepaalde voornamen of combinaties van namen. Zo waren er meerdere mensen met de drie voornamen Peter Modest Valentin. Meer gebruikelijke combinaties, als Johann Peter en Anna Maria, kwamen ook veelvuldig voor. Gecombineerd met de gewoonte van trouwen binnen de eigen groep betekende dit, dat er veel mensen waren met dezelfde voor- en achternaam en met ook nog eens ouders met dezelfde naam. Dit maakte het moeilijk naamgenoten van elkaar te onderscheiden. In officiële stukken, zoals testamenten, werd dit probleem opgelost door aan de persoonsnaam een Romeins cijfer toe te voegen. Johann Peter Kalb I l luidde dan de officiële aanduiding. In het Herzoglich Nassauisches allgemeines Intelligenzblatt, een blad dat vergelijkbaar was met het Nederlandse Algemeen Politie- 
blad, werden mensen aangeduid als Johann Peter Hummerich 3r (dritter) of Johann Letschert $4 \mathrm{r}$ (vierter). De Romeinse cijfers werden in Nederlandse bronnen wel overgenomen. In het Rotterdamse reis- en verblijfpassenregister komen we Johann Peter Kalb tegen met het bijvoegsel ir. ${ }^{85}$ Zijn collega Johann Kalb kreeg in dit register de toevoeging VIII. ${ }^{86}$

De hechte groep Westerwalders bleef ongeveer honderd jaar intact. Aan het einde van de negentiende eeuw ging het handelsmonopolie verloren, hield de migratie uit het afstotingsgebied op en werd er buiten de buurt gewoond en gehuwd. De Westerwalders keerden toen niet op grote schaal terug naar hun geboortestreek, maar bleven in Utrecht. Van huwelijken binnen de groep of concentratie binnen een wijk of een beroep was niet langer sprake. Na een eeuwlang te hebben bestaan als een zeer herkenbare groep, is het opmerkelijk hoe snel de groep aan het einde van de negentiende eeuw uiteen viel.

Aan het einde van de negentiende eeuw had, volgens Plenge, een groot aantal van de handelaren in Nederland winkels in aardewerk en porselein. Voor Utrecht wordt dit niet bevestigd. Als beroep vermelden de vroege bevolkingsregisters meestal koopman of -vrouw, vooral omstreeks 1850 nog veelal met de toevoeging 'in aardewerk' of 'in potten'. Later wordt er vaker alleen koopman of -vrouw geschreven. Aan het einde van de negentiende eeuw kwam er een grotere diversiteit aan beroepen. Anna Kleudgen zette in 1871 de handel voort na de dood van haar man. Haar dochter Margaretha werd koopvrouw, en trouwde een lampenist, die vervolgens ook koopman werd. Aan het eind van de eeuw werd deze continuïteit doorbroken. Margaretha's man, inmiddels de vijftig gepasseerd, werd knecht aan de blindeninrichting. Hun dochters werden meid, de zoon bediende. Opvallend is dat de zoon in 1904 als bediende of sjouwerman voor vier jaar naar Duisburg ging, om vervolgens als granietwerker terug te keren. De vermelding winkelier of winkelierster werd bij de leden van de groep aan het einde van de negentiende eeuw niet aangetroffen. Mogelijk maakten enkelen wel een overgang naar de gevestigde winkelstand, maar bleven zij genoteerd staan als kooplieden. ${ }^{87}$

\section{Pottenbakkers}

Utrecht was tot de negentiende eeuw een belangrijk pottenbakkerscentrum. Pottenbakkers waren in eerdere tijdvakken vanwege brandgevaar uit de stad geweerd en vestigden zich aanvankelijk omstreeks 1300 ten noorden van de stad, op de Weerd langs de Vecht. ${ }^{88}$ In de veertiende eeuw was hier sprake van een bloeiende aardewerkindustrie. ${ }^{89}$ In de veertiende en vijftiende eeuw waren er aan de Oudenoord op een zo grote schaal pottenbakkers actief, dat de historicus Van Vliet spreekt van een Middeleeuws industrieterrein..$^{90}$ In de vijftiende eeuw waren plavuizen een belangrijk handelsproduct voor de stad. ${ }^{11}$ In de negentiende eeuw vinden we op deze plek ook nog pottenbakkers. In wijk K, aan de zuidkant van de stad, vinden we slechts enkele pottenbakkers en verder steen- en pannenbakkerijen. De arbeiders van deze fabrieken vormden een arme 
bevolkingsgroep. Toen Tolsteeg in 1823 bij Utrecht werd gevoegd, werden expliciet van armenzorg door de stadsaalmoezenierskamer uitgesloten 'vreemde werklieden in steenbakkerijen of dergelijke trafieken, voor eenen tijd of saisoen werk hebbende. ${ }^{92}$

Pottenbakkers uit het Westerwald emigreerden ook naar elders. Zo vroegen in 1793 enkele Westerwalder pottenbakkers aan het gemeentebestuur van Pressath in Beieren toestemming om een pottenbakkerij te mogen beginnen. De reden voor hun verzoek was dat ze de oorlogsonrust in hun streek van herkomst willen ontvluchten. Twee aspirant-ondernemers hadden een kapitaal van achtduizend Nassause guldens. In hun herkomstdorp stelden ze twintig mensen te werk. Ze waren voornemens kruiken en flessen te maken van lokaal gewonnen klei. Het gemeentebestuur vroeg garantie dat de kleigraverij het bos niet zou beschadigen. Bezwaar tegen de industrie was er verder niet, omdat er geen reeds bestaande bedrijfstak concurrentie werd aangedaan. De migratie naar Beieren was slechts een van de vele voorbeelden voor emigratie van pottenbakkers. Ze gingen onder meer naar Luxemburg en de Elzas. Westerwalder pottenbakkers gingen ook naar Amerika. Johann Wilhelm Corcilius begon in 1728 in Manhattan in New York een steengoedbakkerij in de traditie van het Westerwald. De pottenbakkerij kende tot 1849 een bloeiend bestaan, maar verviel daarna. ${ }^{93}$

De emigratie van pottenbakkers werd in de achttiende eeuw bevorderd door een streng toegepaste regel van het pottenbakkersgilde, waarin werd bepaald dat slechts de oudste zoon van een pottenbakker zich als zelfstandige pottenbakker mocht vestigen. De andere zonen, die geen zin hadden om als knecht in het bedrijf van hun broer te werken, zwermden uit en stichtten pottenbakkerskolonies in allerlei delen van Duitsland, Frankrijk, België en Rusland. Als Nederlandse plaats van bestemming wordt, niet geheel verbazend, Gouda genoemd. ${ }^{94}$ De vraag ligt dan ook voor de hand of Westerwalder pottenbakkers naar Utrecht gingen, waar ze immers handelaren uit hun geboortestreek konden treffen.

Er waren wel enkele Westerwalders die in Utrecht genoteerd werden als pottenbakker, maar het waren er maar weinig. Om precies te zijn twee: Jan-Willem Stuber en Jacobus Beiler. De pottenbakker Johannes Lorijn werd in Nederland geboren, maar was een zoon van de Westerwalder pottenbakker Jelles Lorijn. ${ }^{95}$ Hun bedrijven waren gevestigd in de buurt van de andere pottenbakkerijen in wijk K. Utrecht telde in 1849 in totaal 150 pottenbakkers. De Westerwalders waren binnen die groep onbelangrijk.

\section{Spelend op een harmonica}

In tal van bronnen vinden we aanwijzingen voor de aanwezigheid van Westerwalders in verschillende Nederlandse plaatsen. Het gemeentebestuur van Appingedam maakte in 1832 in zijn correspondentie met de gouverneur van de provincie melding van een groot aantal marskramers dat elk voorjaar met 'aardewerk' uit Nassau kwam om 'ongestoord in dit rijk te kunnen rondzwerven en liefdegiften van de inwoners te kunnen opzamelen'. ${ }^{96}$ De producten die ze verkochten waren goedkoop. De kramers kregen 
kost en inwoning in ruil voor hun handelswaar. Ze vroegen ook om nachtverblijf, maar veroorzaakten volgens de burgemeester van Appingedam weinig overlast.

In het Algemeen Politieblad werd in de jaren van 1852 tot 1855 melding gemaakt van 36 uitzettingen van Westerwalders, die in totaal betrekking hadden op 47 personen. ${ }^{97}$ Het merendeel van de uitzettingen (30) vond plaats in de eerste twee jaar. Sommige uitzettingen betroffen groepen. Een aantal mensen werd meerdere keren uitgezet; zo werd Frederik Zwart in twee jaar tijd vijf maal uitgewezen wegens landloperij. Hij was daarbij drie maal in gezelschap van wat in de bron werd genoemd zijn 'bijzit' Catharina Wirth, geboren in Wirscheid in Nassau. Zij was ongehuwd, maar werd vergezeld door haar twee onechte kinderen van 10 en 2 jaar, waarvan de oudste liep te spelen op een harmonica. $^{98}$

Herhaalde uitzetting was niet ongebruikelijk, maar het kwam ook voor dat mensen werden uitgezet en later toch weer toegelaten. Dit overkwam bijvoorbeeld Peter Modest Valentin Heinz. Hij werd in 1852 uitgezet wegens gebrek aan middelen van bestaan. ${ }^{99}$ Een jaar later werden zijn middelen van bestaan wel voldoende geacht en had hij geldige papieren. Hij kreeg een reis- en verblijfpas in Amsterdam. ${ }^{100}$ Hij nam zijn intrek in een logement in de Warmoesstraat en vertrok vandaar twee maanden later naar Gouda. ${ }^{101}$ Ook het omgekeerde kwam voor. Geertrude Wolf kreeg in februari 1852 een reis- en verblijfpas uitgereikt in Den Bosch. $\mathrm{Na} 20$ mei verzuimde ze de pas te verlengen, zoals werd voorgeschreven door de Vreemdelingenwet. Haar handel in 'aardewerk' verviel 'kennelijk', zo staat in het Politieblad, en Wolf werd op 14 juli bij Nijmegen over de grens gezet. ${ }^{102}$ Haar collega, de pottenkramer Johann Kroth werd reeds op verschillende plaatsen aan de grens geweigerd. 'Hij gaf voor herwaarts gekomen te zijn om negotie te doen, maar was geheel ontbloot van geld. ${ }^{103}$ Uiteindelijk bereikte hij toch Bolsward, waar hij echter werd opgepakt en op dertig december 1854 via Sneek over de grens gezet.

In het Politieblad worden Roermond, Venlo, Zwolle, Boxmeer, Den Briel, Heerlen, Haarlem, Zutphen, Delfshaven, Ravenstein, Rotterdam, Neede, Leeuwarden, Den Bosch, Breda, Deventer, Gennep, Mierlo, Kampen en Bolsward genoemd, als plaatsen van waaruit Westerwalders werden verwijderd. Slechts één keer komen we Utrecht tegen. De vijftienjarige Johan Wingerden was in 1852 met een 'vaartuig met aardewerk' uit Duitsland in Utrecht aangekomen. Hij was even aan wal gegaan en toen was zijn schip zonder hem met onbekende bestemming verder gevaren. Hij had geen papieren en geen middelen van bestaan en werd uitgezet via Haarlem. ${ }^{104}$

Johan Hebgen werd, net als Johan Wingerden, min of meer in Nederland achtergelaten. Deze twintigjarige handelaar, die opgepakt werd in Delfshaven, had echter wel reispapieren. Hij sprak Hoogduits en Nederlands, en had de hele zomer voor de Duitse handelaar Kasper Bouman met potten en pannen te koop gelopen. Bouman had hem echter achtergelaten en nu was hij zonder middelen van bestaan. Op 7 december werd hij opgezonden naar Rotterdam en vandaar uitgezet. ${ }^{105}$

De Westerwalders vallen in het Politieblad op omdat ze in groepen reisden. In juni 1853 werd de gehuwde Anna Maria Hemmerlé uitgewezen, die reisde zonder haar man, 
maar in het gezelschap van haar drie kinderen van 8,4 en 1 jaar. ${ }^{106}$ In juni 1853 werden wegens gebrek aan middelen van bestaan uitgewezen Pieter, Christiaan, Catharina, Johan en Margaretha Pfenning (respectievelijk 42, 24, 42, 17 en 22 jaar oud) en vijf kinderen van 12, 8, 5, 4 en 2 jaar. ${ }^{107}$ De groep van tien mensen valt op in het Algemeen Politieblad door zowel de samenstelling als de omvang. Behalve bij de Westerwalder handelaren, komt het reizen in familiegroepen in het midden van de negentiende eeuw alleen voor bij muzikanten en bij wat omschreven wordt als 'gevaarlijke en vagebonderende troepen'. ${ }^{108}$ De enige andere uitzondering in het Politieblad zijn handelaren in rood krijt. Deze handelaren kwamen volgens het politieblad uit België. ${ }^{109}$

De verwijdering van Johann Adam Schmidt, geboren in 1824 in Witgert in 1852 en uitgeleid via Brielle, was opvallend door de aanvullende informatie die erbij werd gegeven. Hij werd door de rechtbank van Brielle tot drie maanden gevangenisstraf veroordeeld wegens diefstal.

Deze vreemdeling, wiens ouders zich veelal te Dordrecht ophouden, is door geheel Zuidholland bekend, als gewoon met potten en pannen aldaar rond te reizen. Hij is onvoorzien van legitimatie-papieren, was sedert eenige tijd buiten voldoende middelen van bestaan en reeds armlastig geworden. Hij is gehuwd met Krijntje Mosselman die uit hoofde der van hem ondergane mishandelingen, zich van hem heeft verwijderd en wier tegenwoordig verblijf onbekend is. Hij is een zeer gevaarlijk, aan het misbruik van sterke drank overgegeven persoon en zal vermoedelijk geene poging onbeproefd laten om weder het land binnen te komen. ${ }^{110}$

Opvallend is dat als zijn beroep wordt vermeld dat hij 'inlandsch' kramer is in potten en pannen. Gewoonlijk werd de term 'inlandsch' gereserveerd voor kramers die in het bevolkingsregister waren ingeschreven. Het merendeel van de uitgezette Westerwalders werd 'vreemd' kramer genoemd. Zijn ouders in Dordrecht, zijn Nederlandse vrouw en zijn bekendheid in heel Zuid-Holland duiden op een regelmatig of langjarig verblijf.

\section{Doopbriefjes}

De Westerwalders vormden in Utrecht een opvallende en numeriek belangrijke groep. Deze handelaren reisden echter, zo blijkt uit Ransbacher bronnen, beslist niet alleen naar Utrecht. In het parochie-archief van Ransbach bevinden zich talloze in het Latijn gestelde briefjes, waarmee katholieke geestelijken in Nederland hun collega in Ransbach op de hoogte brachten van de doop van een kind dat tijdens de handelsreis werd geboren. Zo liet de priester Petrus van der Beck, van de katholieke kerk in de Rotterdamse Leeuwenstraat, de pastoor van Ransbach weten dat op 21 augustus 1816 was geboren en de volgende dag gedoopt Joannes, wettelijke zoon van Petrus Corcelius en 
Elisabeth Kalb, woonachtig te Ransbach. De getuigen waren Joannes Petrus Rijgheld en Anna Maria Kalb, beiden uit Ransbach. ${ }^{111}$

Behalve Utrecht werden op deze doopbriefjes plaatsen als Alkmaar, Rotterdam, Hoorn, het Brabantse Lith, Zwolle en Delft genoemd. Een enkele keer wordt er ook een in het Nederlands gesteld extract uit de geboorteregisters van de burgerlijke stand aangetroffen. In het overlijdensregister van Ransbach werden mensen ingeschreven die op de handelsreis overleden waren. Zo komen we in het Ransbacher overlijdensregister van 1876 Johann Korzilius tegen, die op 21 juli 1818 in Utrecht werd geboren en daar stierf in $1876 .{ }^{112}$ Rotterdam, Haarlem, Dordrecht, Zaandam en Middelburg komen ook in de overlijdensregisters voor.

Nederlandse plaatsen van bestemming vinden we voorts op de zogenaamde Bürgerliste, die in Baumbach-Ransbach werden bijgehouden. Op deze lijsten werden mensen ingeschreven, op het moment dat ze als burger van deze twee plaatsen werden opgenomen. De lijsten vermelden naam, geboorteplaats en -datum, datum van opname in de lijst, en de datum waarop iemand door dood of 'Entlassung' werd afgevoerd. Entlassung duidt aan dat iemand de plaats blijvend had verlaten. Helaas wordt bij veel mensen slechts 'nach Holland' vermeld, zonder specifieke plaatsaanduiding. Plaatsen die wel genoemd worden zijn Den Haag, Amsterdam, Rotterdam en Den Bosch.

\section{Amsterdam, Delft en andere plaatsen}

'Vreemde omlopers in potten' komen in deze periode voor in patentregisters van andere Nederlandse steden. In het Rotterdamse register van 1806 , dat een veelvoud aan namen van het Utrechtse bevat, werden dertig van deze handelaars ingeschreven. ${ }^{113}$ Utrecht was uitzonderlijk, omdat hier voor de handelaren een apart register werd aangelegd. In Rotterdam, Delft en Den Bosch werden de 'vreemde rondlopers met potten' niet in een afzonderlijk register opgenomen. Hun aantal was er dan ook kleiner. Het Delftse patentregister van 1809-1811 telt acht Westerwalders; drie mannen en vijf vrouwen. $^{114}$

In hoeverre was de opmerkelijke concentratie van Westerwalders een Utrechts verschijnsel? In verschillende plaatsen vinden we in de bevolkingsregisters aanwijzingen voor hun aanwezigheid. Zo vinden we in Den Bosch in 1850 op de Breedhaven enkele Westerwalders, waaronder de broers Carel en Pieter Litschert. Pieter Litschert werd in 1819 in Ransbach geboren en overleed in 1899 in Den Bosch. Hij trouwde in 1845 in Ransbach, maar kwam aanvankelijk zonder zijn vrouw naar Den Bosch. In 1867 liet hij zich naturaliseren. In het Bossche patentregister van 1816 vinden we verder een handjevol andere Westerwalders. In Rotterdam vinden we enkele Westerwalders op de Regter Rottekade. Dordrecht was een belangrijke plaats voor de Westerwalder handelaren, omdat daar goederen van binnenschepen op zeeschepen werden overgeslagen. Er wordt daar melding gemaakt van Westerwalders op de zogenaamde Pottenkade. Tanja 
Balkema vond, bij haar onderzoek naar immigratie in Gouda, een groep Westerwalders die geconcentreerd in twee straten woonden - de Korte en Lange Groenendaal. ${ }^{115}$ Voor twee steden, Amsterdam en Delft, beschikken we over meer systematische informatie, zodat een echte vergelijking met Utrecht mogelijk is.

Gerard de Punder en Louk Pöckling hebben het Amsterdamse register van reis- en verblijfspassen tussen 1849 en 1880 doorgewerkt op zoek naar Westerwalders. ${ }^{116}$ De Punder telde in 184923 Westerwalders in dit register. In 1854 was dat aantal opgelopen tot 69. Van deze inschrijvingen betrof het in 22 gevallen een nieuwe inschrijving; 51 Westerwalders vertrokken, twaalf lieten hun pas verlengen, terwijl van zes Westerwalders onbekend is of ze vertrokken of bleven. Het jaar daarop was het cijfer min of meer gelijk, maar daarna liep het terug tot één in $1880 .{ }^{117}$ In totaal werden er tussen 1849 en 1870 in het Amsterdamse register van reis- en verblijfspassen 253 Westerwalders ingeschreven.

De registers van reis- en verblijfpassen vermelden het adres waar de vreemdeling zich vestigde. Veel van de in het register vermelde adressen lagen op Roeterseiland in de Amsterdamse wijk W. Vergelijking met het Amsterdamse bevolkingsregister leerde dat we hier, net als rondom de Gansstraat in Utrecht, een concentratie van Westerwalders aantroffen. Roeterseiland was een stadsdeel tussen de latere Plantage Muidergracht,

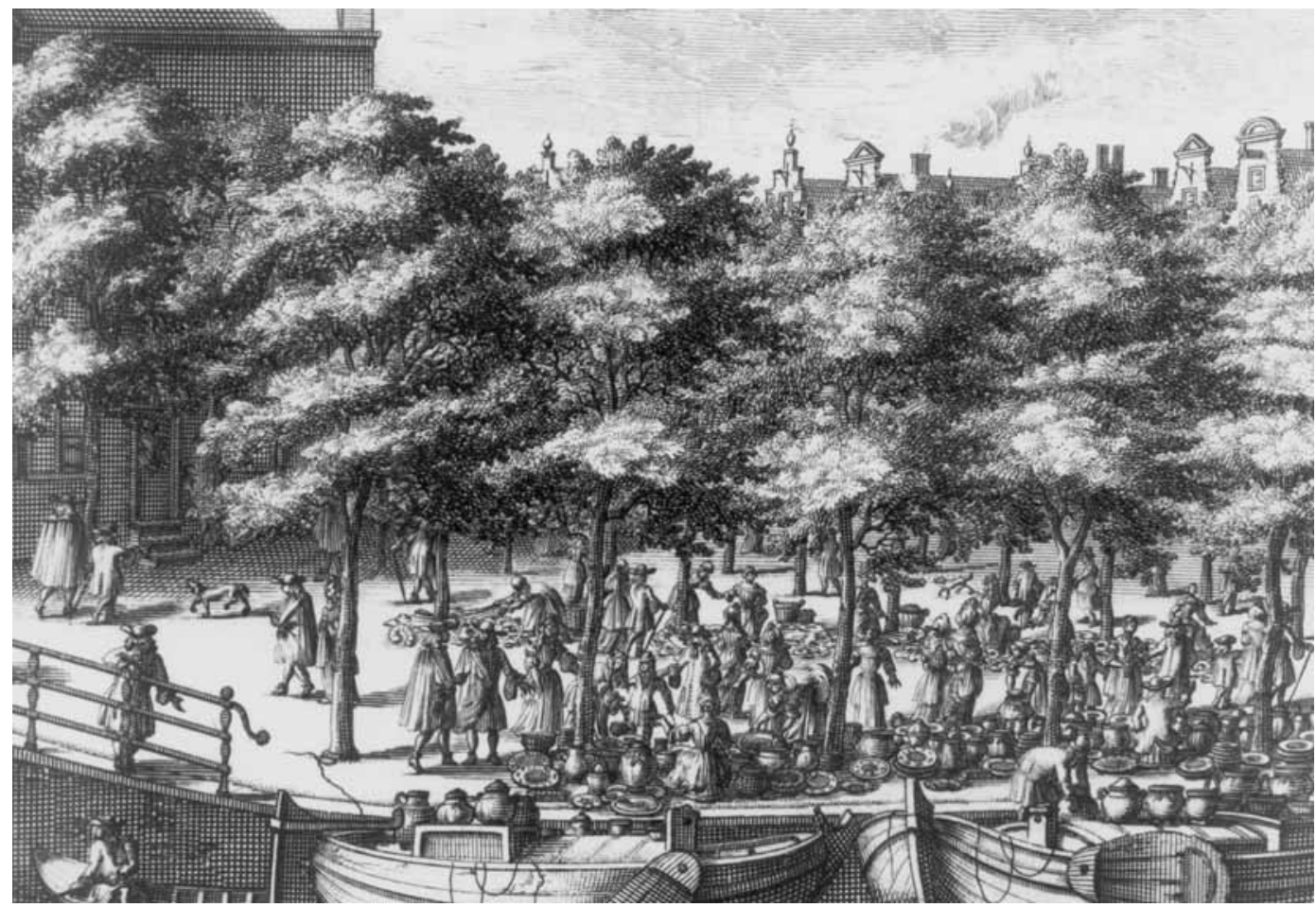

De potmarkt op de Noordermarkt in Amsterdam in 1693.

Nederlands Openluchtmuseum AA 88706. 
Nieuwe Achtergracht, Weesperplein en Sarphatistraat. In de zeventiende eeuw bezat Hendrick Roeters de erven in dit buurtje en verpachtte ze aan brandewijnbrouwerijen. In de negentiende eeuw behield de buurt een bedrijfskarakter. De bewoners van Roeterseiland waren katholiek, terwijl in de omliggende straten juist opvallend veel Portugese joden woonden. Evenals in Utrecht, woonden de Westerwalders in Amsterdam in een groot aantal, dicht bij elkaar gelegen, afzonderlijke panden. In tegenstelling tot de Utrechtse groep, huisde een gedeelte van hen in Amsterdam echter ook in logementen. Verder woonde een deel in hun vaartuigen, die waren afgemeerd in de Achtergracht bij het Weesperplein.

Behalve in het register van reis- en verblijfspassen, waren er nog meer Westerwalders in Amsterdam. In dit register werden immers alleen mensen ingeschreven, die in het kader van de Vreemdelingenwet een reis- en verblijfpas moesten aanvragen. Die wet gold, zoals gezegd, niet voor vreemdelingen die met Nederlanders gelijkgesteld waren in het kader van art. 8 van het Burgerlijk Wetboek, en voor mannelijke vreemdelingen die met een Nederlandse vrouw getrouwd waren en met haar in Nederland geboren kinderen hadden. Bovendien gold de wet niet voor vrouwelijke vreemdelingen die met een Nederlandse man getrouwd waren, en die bijgevolg de Nederlandse nationaliteit hadden. Hoe het aantal vreemdelingen in het register van reis- en verblijfpassen zich verhield tot het aantal in het bevolkingsregister, is zonder verder on-

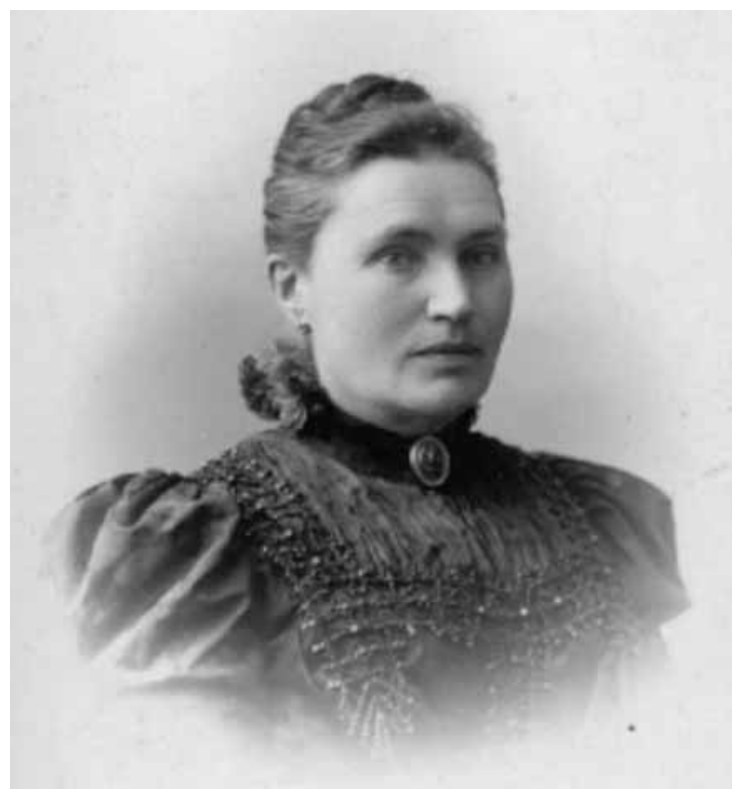

De Westerwalder koopvrouw Maria Catharina Corzilius werd geboren in 1839 in Ransbach en overleed in 1914 in Amsterdam. Ze was een dochter van de pottenbakker Peter Corzilius, die tevens burgemeester van Baumbach was. In 1865 trouwde zij met de handelaar August Fuchs. 
derzoek niet duidelijk. Aangenomen mag echter worden, dat de 253 mensen die om een reis- en verblijfpas vroegen slechts een deel vormden van de gemeenschap van Westerwalders. ${ }^{118}$

Amsterdam kende, net als Utrecht, een afzonderlijke pottenmarkt. Tot 1830 hadden de Westerwalders een legplaats voor hun schepen aan de Kloveniersburgwal, waar de pottenmarkt werd gehouden. ${ }^{119}$ Als het kermis was stalden de pottentrienen, volgens Van Maurik, hun waren uit op de Keizersgracht en op de Westermarkt. De straat stond dan vol met allerlei Keulse potten, schotels, kannen, kruiken, kommen, bloempotten en ander keukengerei. De waar werd aangevoerd met schepen die in de gracht lagen. De schipper of baas bemoeide zich alleen met het varen, en niet met de handel. ${ }^{120}$

Enkele van de Amsterdamse Westerwalders, zoals August Fuchs, groeiden uit tot grote ondernemers.

In Delft konden in verschillende bronnen - vreemdelingenregister, bevolkingsregister en patentregister - 42 Westerwalders worden getraceerd. De Delftse Westerwalders concentreerden zich rond de 'Stadsherberg Buyten', gelegen buiten de Ketelpoort aan het Zuideinde. De herberg was in 1819 in het bezit van het echtpaar Jacob van der Gaag en Heijltje Dorresteijn,

Het Delftse Zuideinde had in de eerste helft van de negentiende eeuw een bedrijfsmatig karakter. De Stadsherberg Buyten stond op de hoek van het Zuideinde en de latere Crommelinlaan, en keek uit over de Kolk in de Schie. Het Zuideinde was de los-

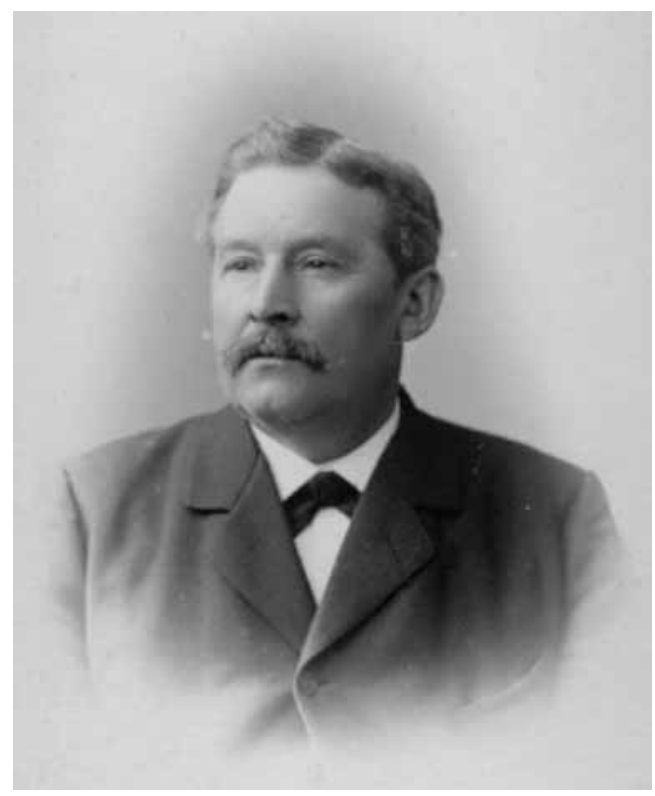

August Heinrich Fuchs, rijnschipper en importeur van steengoed, werd geboren in 1839 in Baumbach en overleed in 1914 in Amsterdam. In 1897 kreeg de familie de Nederlandse nationaliteit.

Privé-bezit Jules Huf. 
plaats voor de van ver komende, onregelmatig varende, grote schepen. Hier werden de goederen op kleinere schepen overgeladen. Het was de plaats waar elk uur een beurtveer uit Rotterdam afmeerde, en het was de ligplaats voor de buitenveren die op verderweg gelegen bestemmingen voeren.

Achter de smalle strook bebouwing aan het Zuideinde, die al dateerde van vóór de negentiende eeuw, lagen weilanden, blekersvelden en tuinen, die grotendeels eigendom waren van Jacob van der Gaag. Hij was niet alleen eigenaar van de Stadsherberg, maar ook van belendende percelen. Zijn bezit was van grote omvang en besloeg het hele gebied achter de herberg tot aan de in 1847 aangelegde spoorlijn en enkele percelen voorbij dit spoor. ${ }^{121}$

Het bezit van Van der Gaag omvatte in 1828 in totaal 23 percelen. Behalve de weilanden, tuinen en blekersvelden, behoorden hiertoe ook negen huizen met erven. Later in de eeuw, zo leerde onderzoek in kadastrale bronnen, nam het aantal percelen en huizen toe, omdat percelen werden opgesplitst en volgebouwd. Familieleden van Van der Gaag hadden verderop aan het Zuideinde eveneens bezit waarmee hetzelfde gebeurde. Tussen en vooral achter de bestaande bebouwing kwamen gangen, poorten en sloppen. ${ }^{122}$ Het nummer 171 kreeg hierdoor zo'n veertig toevoegsels.

In 1828 woonden Jacob van der Gaag en Heijltje Dorresteijn op het Zuideinde nummer 173. Van der Gaag stond in het bevolkingsregister te boek als kastelein en voerman. In 1861 woonde Van der Gaag nog steeds op dit adres, nu met zijn tweede vrouw Maria Duveldorp. Van der Gaag was, volgens het bevolkingsregister van 1861, jager van schuiten. Naast Van der Gaag, op nummer 172, woonden in 1861 de kramer Petrus Kalb en zijn vrouw Maria Geelhart, beiden geboren in Ransbach in het Westerwald. ${ }^{123}$ Op nummer 171-l woonden de koopman Philip Lahnstein en Anna Schwanderlapp, geboren in Ehringshausen in het Westerwald. Op nummer 171-lf woonden de aardewerkkramer Pieter Lahnstein en zijn vrouw Catharina Holsgen. ${ }^{124}$ Ze waren geboren in het Westerwaldse Ehringshausen en Meudt. De opsomming van Westerwalders kan schier eindeloos worden uitgebreid voor de andere panden aan het Zuideinde. In vrijwel elke woning vinden we één of meerdere Westerwalders. Opvallend op het Zuideinde zijn nog op nummer 152-a de aardewerkkramer Johannes Lamb, geboren in Nassau, en zijn vrouw Maria van der Gaag, een nichtje van de herbergier. De Westerwalders op het Zuideinde waren niet alleen buren van de herbergier, maar hadden ook een familieband met hem. Hierin verschilden deze Westerwalders van hun streekgenoten in Utrecht.

De Westerwalder bewoning van het Zuideinde dateerde al van voor 1861. Reeds in het volkstellingsregister van 1828 vinden we Westerwalders op het Zuideinde. Niet al deze migranten woonden echter permanent in Nederland. Het op en neer reizen van de migranten wordt weerspiegeld in het feit dat opeenvolgende kinderen, net als in het Utrechtse geval, afwisselend in Nederland en in het Westerwald werden geboren.

Omstreeks het midden van de negentiende eeuw breidde de groep Delftse Westerwalders zich aanzienlijk uit, gelijktijdig met de bebouwing op het Zuideinde. De Westerwalders kwamen vooral te wonen in de gangen, poorten en sloppen. In het Delftse 
Vreemdelingenregister uit die tijd staat bij meerdere Westerwalders vermeld 'in een eigen huis op het Zuideinde'. ${ }^{125}$ In kadastrale gegevens zijn zij echter niet als eigenaars van deze panden terug te vinden. Mogelijk werd met de omschrijving bedoeld dat zij de woningen als huurders permanent tot hun beschikking hadden, en niet bij anderen of in logementen tijdelijk onderdak vonden. In het midden van de vorige eeuw woonden vrijwel alle Delftse Westerwalders op het Zuideinde. De migranten die in de tweede eeuwhelft naar Delft kwamen voegden zich bij de reeds gevestigde groep op het Zuideinde.

In hoeverre zijn de groepen Westerwalders in andere plaatsen te vergelijken met de Utrechtse groep? Onderscheid bestond er waar het gaat om de herkomstplaatsen van de verschillende gemeenschappen van Westerwalders. In Utrecht kwamen de Westerwalders voor een groot deel uit wat de kern van het herkomstgebied zou kunnen worden genoemd: de dorpen Ransbach en Baumbach. De Westerwalders in Amsterdam kwamen zowel uit deze kern als uit daarbuiten gelegen plaatsen. Westerwalders in Delft kwamen uit het zuidoostelijke gedeelte van het afstotingsgebied, terwijl bijvoorbeeld de Westerwalders in Zwolle overwegend uit de buurt van Sessenhausen kwamen. In Maastricht vinden we Westerwalders uit Höhr, een dorp dat meer bevolkt werd door pottenbakkers dan door handelaren. Mogelijk betrof het hier dan ook handelende producenten of gewoon pottenbakkers. Opvallend is dat de uitgezette Westerwalders die

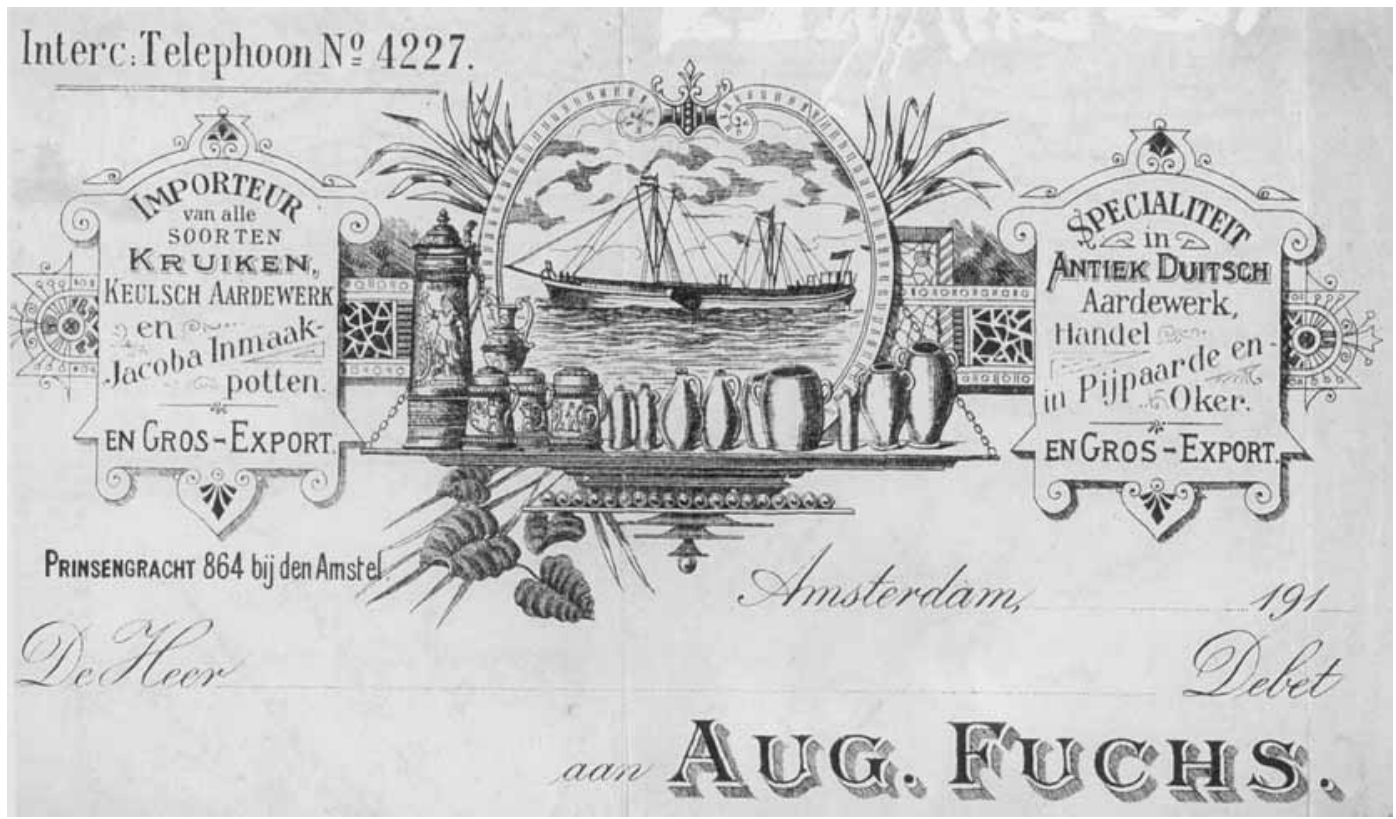

Briefhoofd van de firma Aug. Fuchs met daarop de Rijnaak Rijn en Amstel en een gedeelte van het assortiment. 
in het Algemeen Politieblad voorkomen vooral uit de periferie van de herkomststreek kwamen en niet uit het kerngebied. Ze werden niet uitgezet uit Utrecht. Wellicht ging het hier om handelaren die, omdat ze niet tot de kerngroep behoorden, genoegen moesten nemen met de afzetgebieden die de eerdere handelaren hadden laten liggen, met als gevolg een grotere kans op falen.

Het reispatroon van de Westerwalders, waarbij uit een bepaald dorp, of uit een groep dorpen, gereisd werd op één Nederlandse stad, werd in het midden van de negentiende eeuw bestendigd door het Duitse vergunningenstelsel. Sommige Westerwalder trekhandelaren kregen reispapieren uitgereikt van de burgemeester van hun geboortedorp met daarop een vaste, voorgeschreven reisroute. ${ }^{126}$

Een verschil tussen de steden bestaat waar het gaat om de aard en omvang van de handel. ${ }^{127}$ In Delft breidde Petrus Bender, een zoon van Catharine Geelhart, de steengoedhandel van zijn moeder uit en begon hij een winkel. Aan het einde van de negentiende eeuw bezat de familie Bender drie winkelpanden in Delft. Er is nog steeds een winkel van de familie Bender in Delft, die aardewerk, kristal, glas en porselein verkoopt. ${ }^{128}$ In Amsterdam vinden we na 1866 de groothandel van August Fuchs. Hij was eigenaar van een groot Rijnschip met de naam Rijn en Amstel (zie afbeelding op vorige pagina).

Het opvallendste verschil tussen de gemeenschappen in de uiteenlopende plaatsen is hun omvang. De Westerwalder gemeenschap in Utrecht was, zowel absoluut als in verhouding tot het totaal aantal Duitse immigranten, veel groter dan de Amsterdamse. In Delft was de Westerwalder gemeenschap en het aandeel van de Westerwalder handelaren in het register van reis- en verblijfpassen groot genoeg om op te vallen, maar hoe de groep zich getalsmatig verhield tot de totale Duitse immigratie is zonder verder onderzoek niet duidelijk. ${ }^{129}$

Een opvallende overeenkomst tussen de verschillende Westerwalder gemeenschappen is hun ligging: de Westerwalders woonden in buurten die goed over water bereikbaar waren. De aanvoer van hun handelsgoederen over water kan deze voorkeur verklaren. Een overeenkomst bestond er ook waar het ging om het karakter van de buurt: we vinden de Westerwalders in wat we de mindere buurten zouden kunnen noemen. Verschil is er bij de verklaring van het ontstaan van deze buurten: in Utrecht kan een eerder weren van de vreemde handelaren de keuze voor een buurt buiten de stadsgrenzen verklaren. In andere steden lagen de buurten waar de Westerwalders woonden ook aan de randen van de stad, maar de verklaring daarvoor was niet steeds gelijk.

De Westerwalder gemeenschap in Utrecht was opvallend in omvang en continuïteit. Het laatste kan mogelijk uit het eerste worden verklaard. De Westerwalders in andere plaatsen kwamen uit andere delen van het Westerwald - meer uit de periferie dan uit het centrum - en maakten in tegenstelling tot de Utrechtse Westerwalders wel de overgang naar het winkelbedrijf. 


\section{Handelaren uit Sauerland}

Er was één groep in Utrecht die een opvallende gelijkenis vertoonde met de Westerwalders; de handelaren uit Sauerland. De Sauerlanders kwamen uit Oberkirchen, Westfeld, Nordenau, Gleidorf en Obersorpe. Dit zijn dorpen in ambt Smallenberg in het bergachtige gedeelte van Sauerland (zie kaart 9.3). ${ }^{130}$ Net als het Westerwald was dit een belangrijke herkomststreek van trekhandelaren. ${ }^{131}$ In deze bergachtige streek werden houten gebruiksartikelen gemaakt. In de loop van de negentiende eeuw liep deze nijverheid terug. Houten speelgoed bleef echter een belangrijk exportproduct. Andere producten van emaille, blik en aardewerk verdrongen deels de houten artikelen, mede omdat het hout duurder werd. De Sauerlanders gingen hierop gedeeltelijk over op de

Kaart 9.3 Herkomststreek van de handelaren uit Sauerland.

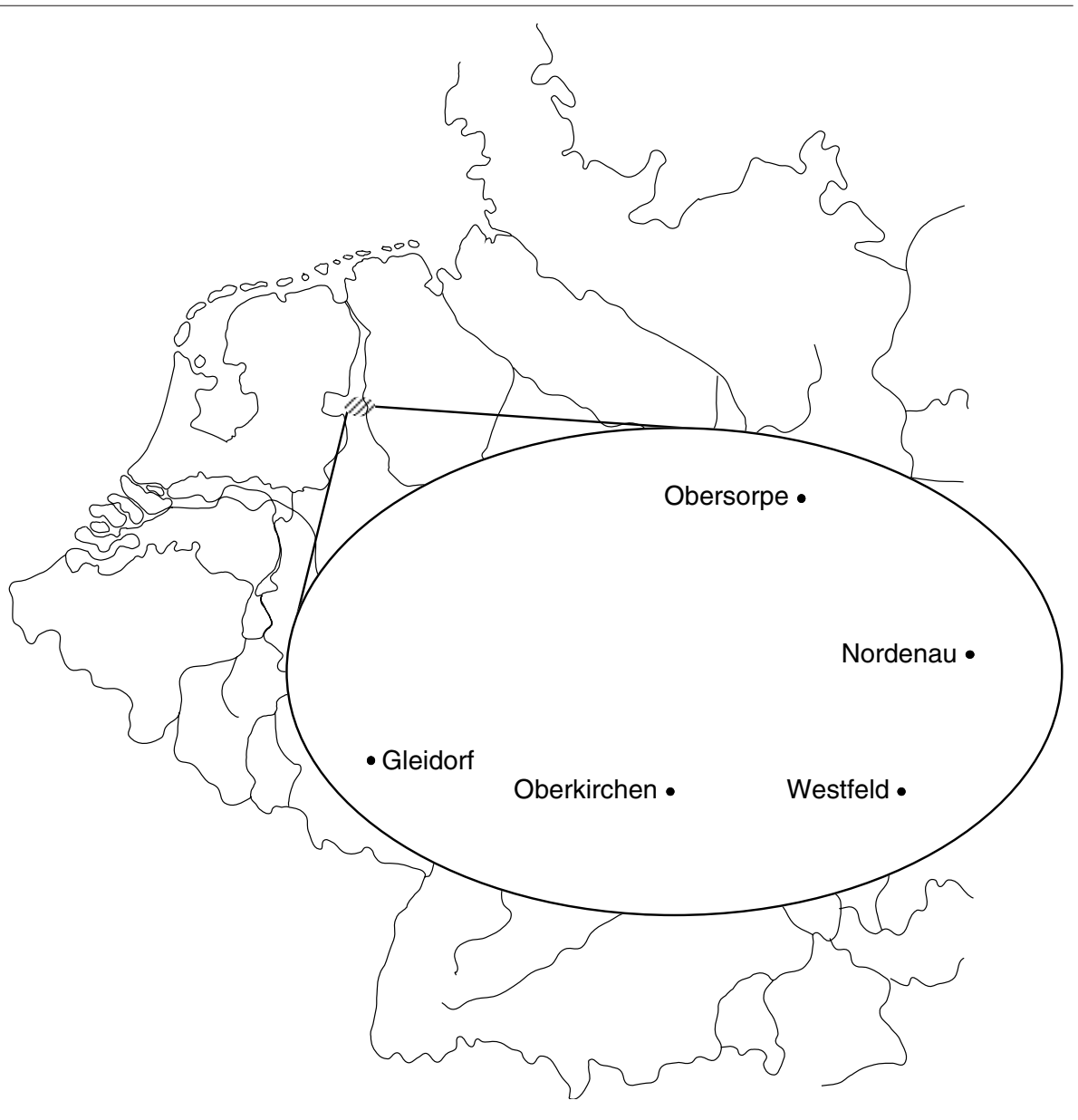


handel in textiel en zemen. De handel in ijzerwaren, zoals zeisen, scharen en messen, nam eveneens in betekenis toe. ${ }^{132}$ In de tweede helft van de negentiende eeuw werd de productie van gebreide goederen, zoals kousen en ondergoed, belangrijk. In die periode werden er in deze streek 720.000 paar kousen per jaar geproduceerd. In deze bedrijfstak werkten ongeveer driehonderd mensen op geavanceerde breimachines. Aan het einde van de negentiende eeuw zakte de bedrijfstak in door concurrentie uit Engeland. ${ }^{133}$

De Sauerlandse trekhandelaren gingen, net als de Westerwalders, niet alleen naar Nederland, maar ook naar allerlei delen van Duitsland en andere Europese landen. De trekhandelaren werkten in compagnieën en sloegen hun goederen op in depots in het land of de streek waarin ze handelden. De verschillende compagnieën verkavelden onderling het afzetgebied, zoals de Westerwalders dat deden. Deze verkaveling was gekoppeld aan herkomstdorpen, zodat mensen uit bepaalde dorpen in het afzetgebied een monopoliepositie hadden. We zien hier een duidelijke overeenkomst met de manier waarop de Westerwalders de markt verdeeld hadden. De handelaren in houtwaren, onder meer uit Nordenau, gingen merendeels naar Nederland, terwijl de zeisverkopers meer naar Noord-Frankrijk en België gingen. ${ }^{134}$

Aan het einde van de negentiende eeuw stelden bestuurders van het Amt Schmallenberg een bericht op over de handel in Nederland.

Der Hausierhandel in Holland ist bekanntlich für die Eingesessenen der Gemeinde Oberkirchen schon seit 50 Jahren eine Lebensfrage. Wenn das Geschäft auch mit jedem Jahr slechter wird, weil fast in jedem Dorfe ein stehendes Handelsgeschäft entstanden, auch geborene Holländer vielfach Hausierer geworden sind, so muß der Handel doch in Ermangelung etwas besseren festgehalten werden, weil der Boden die Bewohner nicht ernähren kann. ${ }^{135}$

Voor Oberkirchen was de handel een essentieel onderdeel van het bestaan; de bodem kon de bevolking immers niet voeden. Nu het slecht ging moesten de handelaren proberen hun positie vast te houden. Het bericht vervolgde:

Die Handelsleute haben jedoch im großen und ganzen hier ihr Heimatrecht bewahrt. Förmlich ausgewandert sind nur sehr wenige, und solche sind dann auch in Holland verblieben, da sie sich dort verheiratet und ein stehendes Geschäft gegründet haben. ${ }^{136}$

Een deel van de Sauerlanders bleef dus, getuige het citaat, permanent in Nederland.

In Utrecht bestond de groep handelaren uit Sauerland uit 34 mannen en vrouwen. Ze woonden overwegend in de binnenstadswijk D en in wijk K. Op de Westerkade in wijk K woonden voorts vier broers Frisse uit Nordenau in het ambt Smallenberg. In 1850 woonden op het Voor Clarenburg in wijk D vier handelaren uit Sauerland. De drie oudsten waren gehuwd, maar hun vrouwen waren niet meegereisd naar Utrecht. Bij hen in woonde een Nederlandse dienstbode. Pas later voegden de Duitse echtgenotes 
zich bij hun mannen in Utrecht. Vrouwen kwamen bovendien uit Sauerland naar Utrecht om met een hier reeds gevestigde handelaar te trouwen. Gevestigde handelaren reisden regelmatig naar Sauerland. In vier gevallen werd aangetekend in het bevolkingsregister dat één van de Sauerlandse handelaren tijdens een handelsreis was overleden in de geboortestreek.

In het bevolkingsregister worden de Sauerlanders omschreven als handelaren. Soms wordt daarbij vermeld 'in houtwaren' of 'in borstelwerk', veelal werd echter met alleen de term handelaar volstaan. De patentregisters zijn op dit punt informatiever dan de bevolkingsregisters. Frans Padberg ventte bijvoorbeeld, volgens de patentregisters, in kleinere gemeenten met een mars en op de Utrechtse markt met hout en ijzerwaren, mandjes, galanterieën en zeemleder ter waarde van 48 gulden. ${ }^{137}$ Frans Padberg werd in het patentregister ingeschreven als vreemd kramer. ${ }^{138}$ Dit betekent dat hij niet in het Utrechtse bevolkingsregister voorkwam. Hetzelfde gold voor zijn collega's en streekgenoten Evert en Hendrik Hoffman die ventten met marsen met een vergelijkbare inhoud. ${ }^{139} \mathrm{Zij}$ werden in het patentregister ingeschreven op de adressen van hun dorpsgenoten wat er op duidt dat zij daar tijdelijk onderdak hadden gevonden.

Op basis van advertenties krijgen we een beeld van de producten waarin de gevestigde Sauerlanders handelden. Hun assortiment kwam overeen met dat van hun ambulante collega's. De Gebr. Frisse in de Bakkersteeg 305 noemden zich in 1884 een 'van ouds bekend messenmagazijn'. Hier was 'voorhanden alle soorten van tafel-, dessert-, voorsnijmessen, scheermessen, groote soortering scharen, nieuwzilveren lepels en vorken, damestassen en portemonais, eau de cologne, zeep enz enz. ${ }^{140}$ De firma Padberg werd in het adresboek van 1880-1881 omschreven als 'een hand. in duitsche koopw.' ${ }^{141}$ In 1903-1904 heette zijn winkel een 'Grossier in huishoudelijke artikelen'. ${ }^{142}$ De Sauerlanders lijken in hun ondernemingen vrij succesvol te zijn geweest. In latere jaren hadden zij Nederlandse winkelmeisjes in dienst.

De Sauerlanders vertoonden, zoals duidelijk mag zijn, overeenkomsten met de Westerwalders. Het belangrijkste verschil is de omvang van hun groep. Een tiental Sauerlanders, die bovendien een breed productenpakket aanboden, waren waarschijnlijk ruim voldoende om aan de Utrechtse vraag naar ijzerwaren, zemen, bestek en houten speelgoed te voldoen. Evenzo zou een tiental Westerwalders hebben kunnen voorzien in de vraag naar steengoed. De Utrechtse groep Westerwalders was echter vele malen groter dan op basis van de vraag naar hun specialistische product zou mogen worden verwacht. Dit geldt ook als we rekening houden met de uitbreiding van het assortiment van de Westerwalder handelaren later in de negentiende eeuw. Op het bredere afzetgebied was de concurrentie immers ook groter.

\section{Tot besluit}

De Westerwalder handelaren profiteerden van de band die zij hadden met de producenten in hun herkomstgebied. Zij konden hun handelswaar betrekken tegen gunstige 
voorwaarden. ${ }^{143} \mathrm{Zij}$ haalden relatieve voordelen uit de toegang tot en de kennis van een specifieke markt. Gunstige handelsvoorwaarden werden gecombineerd met het rekruteren van medewerkers in de herkomststreek, die bereid waren tegen lagere dan de gangbare lonen te werken. ${ }^{144}$ Omdat zowel mannen als vrouwen in de niche werkzaam waren, ontstond er een hechte band tussen de groep en de economische sector. ${ }^{145}$ De geringe sociale contacten van de Westerwalders, zoals die tot uitdrukking kwamen in hun afwezigheid in sociale organisaties, wijzen op het in zichzelf gekeerde karakter van de groep.

Heel belangrijk in het geval van de Westerwalders was een factor waaraan in de nichevormingstheorie tot op heden geen aandacht is besteed. De omvang van de groep oversteeg op een gegeven moment de mogelijkheden van de markt. De verklaring hiervoor lig in de interactie tussen het proces van nichevorming en dat van groepsvorming. De Westerwalder gemeenschap zelf, en niet de handelsmogelijkheden van de stad, bepaalde uiteindelijk de omvang van de groep en de continuïteit. Juist het bestaan van een gemeenschap van Westerwalders in Utrecht, maakte deze stad als vestigingsplaats voor andere Westerwalders aantrekkelijk. Toen de gemeenschap eenmaal een bepaalde omvang had bereikt, groeide zij onafhankelijk van de economische mogelijkheden van de stad en onafhankelijk van de draagkracht van de niche. Nichevorming lag aan de basis van het proces van groepsvorming, maar uiteindelijk ontwikkelde het proces van groepsvorming een eigen dynamiek. Een tiental migranten is niet voldoende om dat proces in gang te zetten. De tweehonderd Westerwalders die aan het begin van de negentiende eeuw in Utrecht neerstreken, waren dat wel. Daarin ligt het verschil met andere groepen. 


\section{0 'Een eeuw van illusie en zinbegoocheling' Winkeliers en hun personeel}

Wij leven in een eeuw van illusie en zinbegoocheling. Gisteren avond was van het nieuwe gebouw, hetwelk de heer Sinkel op de Oude Gracht heeft doen daarstellen, niets te zien dan het bovengedeelte, en heden morgen is alles open en gestoffeerd.

De opening van de Utrechtse winkel van Sinkel in 1839 baarde opzien. In de Amsterdamse Avondbode van woensdag 8 mei 1839 verscheen een artikel over de opening van de winkel. Deze krant publiceerde gewoonlijk, behalve de prijzen van handelsartikelen, slechts stukjes over bezoeken die leden van het koninklijk huis aflegden. Het artikel over de opening was om deze reden uitzonderlijk, maar de winkel zelf rechtvaardigde die belangstelling.

Op de plaats, waar vroeger het zoogenaamde Kranengasthuis stond, dat ook voor eene militaire kazerne diende, en doorgaans een vuil en onaangenaam gezigt aanbood, is nu, binnen den korten tijd van twee jaren, een winkel-paleis gebouwd, zoo als Frankrijk noch Engeland er een toonen kunnen. Elk staat verbaasd en opgetogen bij het aanschouwen van een zoo schoon geheel. ${ }^{2}$

In jubelende bewoordingen werd de inrichting van de nieuwe winkel beschreven en werden het inzicht en de smaak van Sinkel geprezen. Sinkels winkel was groter en mooier dan wat er tot dan toe bestond in Nederland.

De bocht die de Oudegracht maakt tussen Stadhuisbrug en Bakkerbrug werd, in de eeuw die volgde, volgebouwd met de grote en moderne ondernemingen van andere Duitse immigranten. Op dit stuk van de gracht - het voornaamste en meest centrale gedeelte van de stad - waren gevestigd de winkels van Sinkel, Peek \& Cloppenburg, Maseland, Van der Sandt \& co, F. Brümmer, Wille, A.H. Schlüter, Hoyng, A. Heck en later Vroom \& Dreesmann (zie kaart 10.1 en de foto op de volgende pagina). In een toeristische gids uit 1889 werd dit stuk gracht aangemerkt als één van de attracties van de stad.

Amsterdam, Rotterdam, noch Den Haag kunnen op zulke schoone magazijnen wijzen $[. .$.$] een onafgebroken reeks ruime, helverlichte, moderne winkels, ter-$ wijl daartussen een dichte volksdrom zich al voorwaarts beweegt. ${ }^{3}$ 
Utrecht mocht dan trots zijn op het aaneengesloten lint van helverlichte winkels, maar concentraties van Duitse winkeliers waren er ook in andere steden: de Hoogstraat en de Kipstraat in Rotterdam, de Gedempte Gracht en Boekhorststraat in Den Haag, de Haarlemmerstraat in Leiden en de Nieuwendijk en Hoogstraat in Amsterdam. ${ }^{4}$ In Utrecht meende men echter dat het aantal winkels groter was en dat de winkels zelf mooier waren, niet helemaal ten onrechte, gezien de concentratie van winkels aan de Oudegracht.

De overheersing door Duitse ondernemers van dit stuk van de Oudegracht kan niet simpelweg in een cijfer worden uitgedrukt, omdat in de kelders aan de werven en in de kleine, oudere pandjes die nog tussen de grote nieuwe winkels stonden, kleinere winkeliers en ambachtslieden woonden. Naar oppervlakte overheersten de nieuwe Duitse zaken dit stuk gracht echter volledig. Ze domineerden ook de verkoop van gemaakte kleding. Winkeliers in gemaakte kleding worden in de volkstellingen niet als categorie onderscheiden; in de Adresboeken komen ze wel als afzonderlijke groep voor. In het Adresboek van 1879 worden 105 handelaren in gemaakte kleding genoemd; elf daarvan

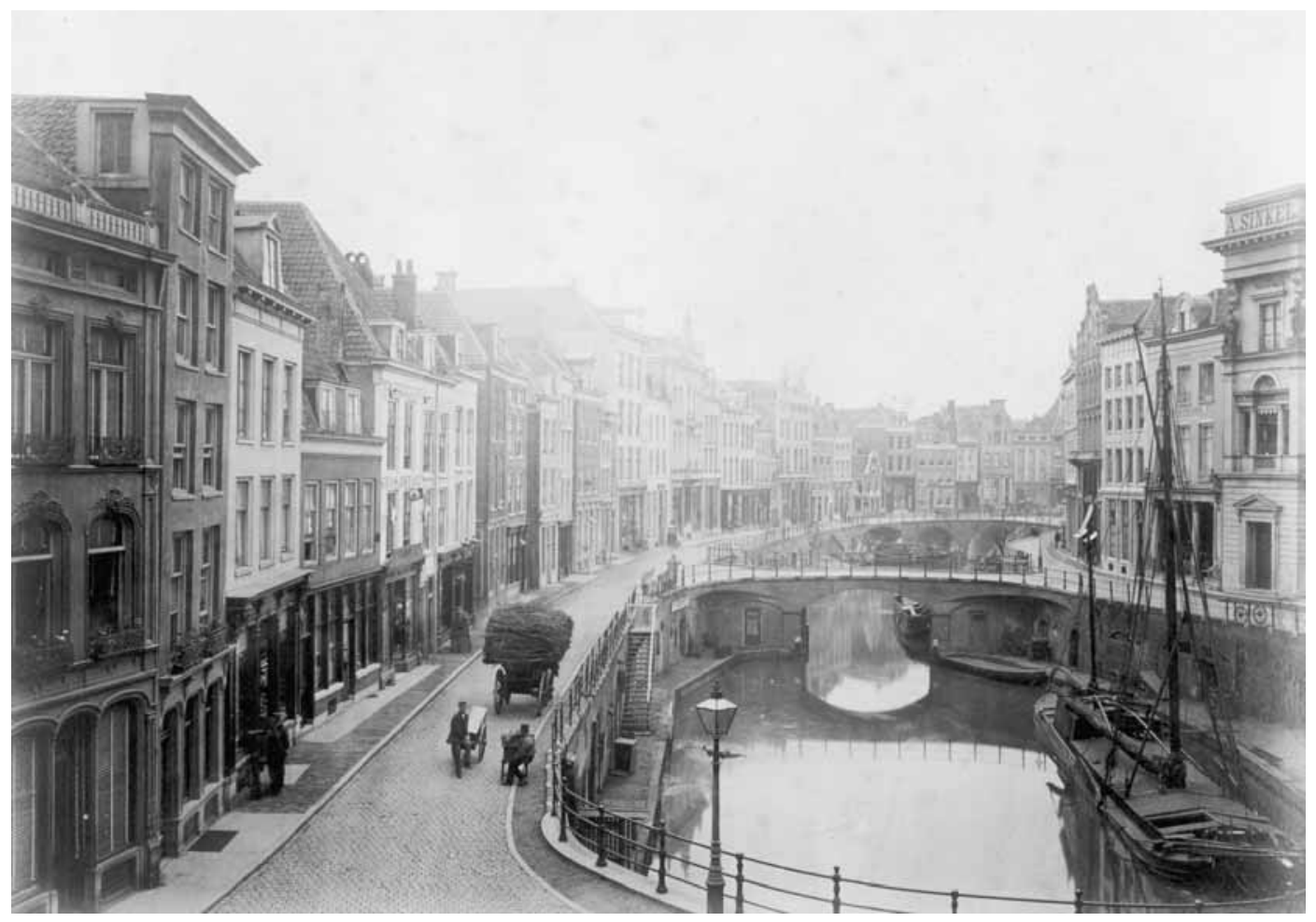

Bocht in de Oudegracht in 1878 met rechts een klein stukje van de Winkel van Sinkel. Van de panden aan de linkerkant van de gracht was een groot deel in Duitse handen; met de bocht mee onder meer: A.H. Schlüter (later Vroom \& Dreesmann), Wille, Maseland, Hoyng, A\&B Bohlen, Van der Sandt \& co, Peek \& Cloppenburg, F. Brümmer, Schräder \& Kauling en A. Heck. 
waren Duits: gebr. Abelmann, A. \& B. Bohlen, gez. Buhrs, A. Heck, firma A. Maseland, Peek \& Cloppenburg, Van der Sandt \& co, firma A.H. Schlüter, J.B. Schröder, A. Sinkel en B. Steinhoff. ${ }^{5}$ Met deze opsomming wordt echter een verkeerd beeld gegeven van het aandeel van de Duitse winkeliers, omdat hun zaken vele malen groter waren dan die van hun Nederlandse tegenvoeters.

Er waren tussen 1849 en 1879 in Utrecht 206 Duitse immigranten (157 mannen en 49 vrouwen) die tot de categorie winkeliers en hun personeel kunnen worden gerekend. De namen van sommigen van deze winkeliers, zoals Sinkel, Peek \& Cloppenburg, Kreymborg, Hunkemöller, C\&A, V\&D en Lampe, hebben ook nu nog een bekende klank. Daarnaast waren er andere bedrijven, die nu niet meer bestaan en daarom vergeten zijn.

In de eerste helft van de negentiende eeuw waren winkeliers als Sinkel, Van der Sandt \& co en Maseland in Utrecht actief. Zij werden in de tweede helft van de negentiende eeuw gevolgd door een nieuwe lichting, waarvan Peek \& Cloppenburg de belangrijkste was. Deze nieuwe winkeliers kwamen uit een groter afstotingsgebied dan de eersten. In de tweede helft van de negentiende eeuw breidde de herkomststreek zich uit naar het oosten, zuiden en noorden, maar niet naar het westen, waar de rivier de Eems de grens bleef vormen. Als laatste kwamen de winkeliers die omstreeks 1900 of nog later

Kaart 10.1 Bocht in de Oude Gracht met een gedeelte van de panden van de Duitse winkeliers.

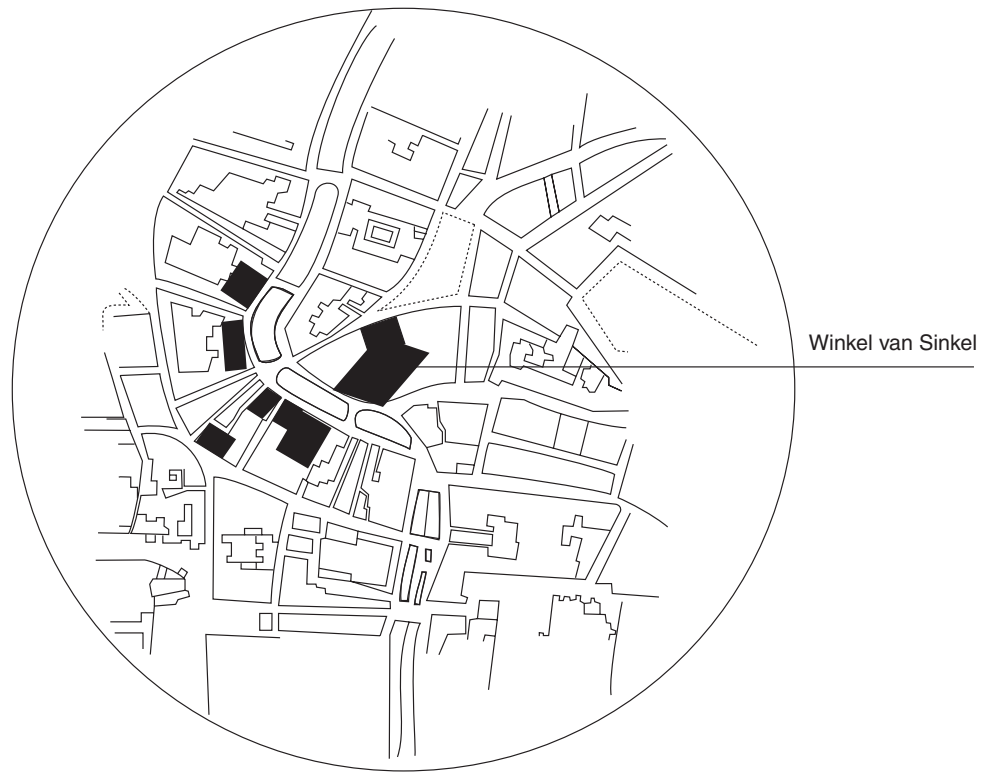

De Winkel van Sinkel was veruit het grootst en lag aan de voorzijde aan de Oudegracht en de achterzijde aan de Neude. 
in Utrecht actief werden. De Utrechtse vestiging van Vroom \& Dreesmann werd geopend in 1898. C\&A kreeg pas een vestiging in Utrecht na 1900. Leden van deze derde lichting waren vóór deze tijd reeds elders in Nederland actief, maar hun activiteiten breidden zich pas in een latere periode naar Utrecht uit. ${ }^{6}$

De winkeliers kwamen uit een groot, diffuus herkomstgebied. Uit deze zelfde streek kwamen ook andere Duitse immigranten naar Utrecht, die niet tot groep winkeliers kunnen worden gerekend. De herkomststreek van de Duitse winkeliers was veel minder compact dat die van de Westerwalders (zie kaart 10.2).

De Duitse winkeliers hadden een aantal dingen met elkaar gemeen: ze kwamen uit dezelfde streek in Duitsland, waren merendeels katholiek en het waren innovatieve ondernemers. Samen met hun personeel vormden ze een opvallende en numeriek belangrijke groep onder de Duitse immigranten in het negentiende-eeuwse Utrecht.

Kaart 10.2 Herkomststreek van de winkeliers.

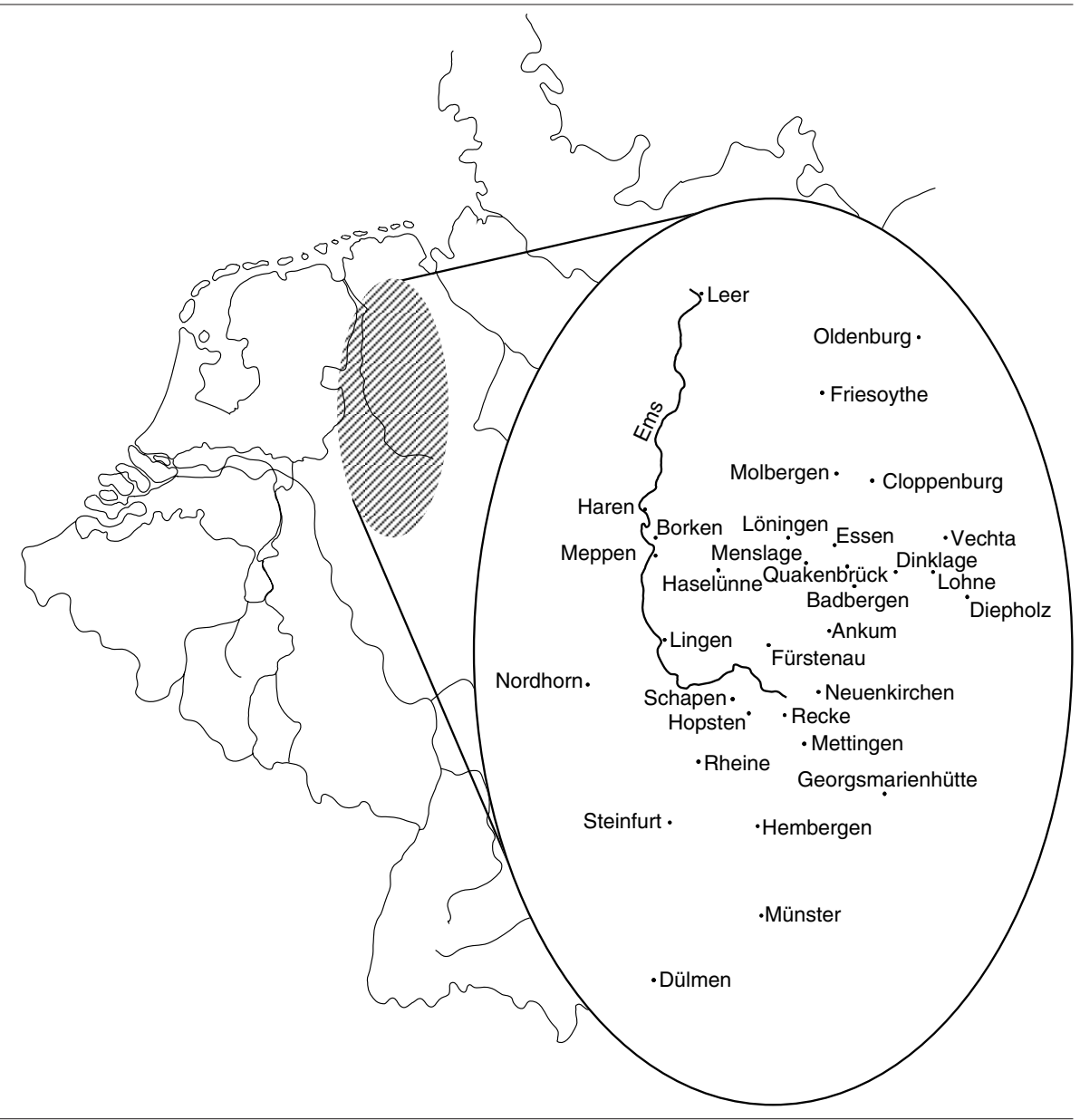


Twintig procent van de Duitse immigranten kan tot deze groep worden gerekend. Hun aandeel binnen de Duitse migrantenpopulatie was vooral zo omvangrijk door het grote verloop onder het personeel. De winkeliers hadden kosthuizen waarin ze hun personeel onderbrachten. Het grote verloop lijkt, oppervlakkig beschouwd, tegen het concept van groepsvorming te spreken. De Amerikaanse sociologen Fairlie en Meyer hebben groepsvorming en nichevorming echter juist in verband gebracht met een groot verloop onder de in de niche werkende arbeidskrachten. ${ }^{7}$ Het verloop creëerde een transfer of sector-specific human capital. Door een groot verloop van arbeidskrachten binnen de sector werden ideeën verspreid, in een zich steeds uitdijende groep, over hoe de sector georganiseerd en geleid moest worden. De arbeidskrachten werkten voor een groot aantal verschillende werkgevers, maar die behoorden wel allemaal tot dezelfde groep. Juist door het rondreizen versterkte het winkelpersoneel de band tussen de werkgevers. Bovendien werd een gedeelte van het mannelijke winkelpersoneel na verloop van tijd zelf winkelier. Ze werden dan collega's van mensen met wie ze eerder in een van de kosthuizen van de winkels hadden gewoond, of voor wie ze hadden gewerkt.

Wat vooral opvalt bij de winkeliers waren de familiebanden. Deze verwevenheid maakt een beschrijving van de groep niet eenvoudig. ${ }^{8}$ De relaties tussen de verschillende families zijn zo veelvuldig en ingewikkeld, dat ze niet snel in de gebruikelijke genealogische overzichten te vatten zijn. Huwelijken tussen (achter)neven en (achter)nichten, en tussen zwagers en schoonzussen waren gangbaar. Opvallend is, dat de huwelijken binnen deze groep niet alleen werden gesloten door de eerste generatie nieuwkomers, maar ook, of eigenlijk beter gezegd vooral tussen de leden van de zogenaamde tweede en derde generatie. Huwelijksbanden overlapten daarbij tot ver in de twintigste eeuw veelvuldig met zakelijke contacten.

\section{Tödden: continuïteit en discontinü̈teit}

De Duitse winkeliers, die in Utrecht en andere Nederlandse steden actief waren, kwamen deels voort uit families van Duitse trekhandelaren. ${ }^{9}$ Onder de trekhandelaren waren bepaalde namen gangbaar, zoals Moormann, Veerkamp, Lampe en Cloppenburg, die ook voorkwamen onder de latere winkeliers. De groepsvorming onder de winkeliers kan in zekere zin worden beschouwd als een continuering van het proces dat reeds met de handelaren was begonnen. Naast continuïteit was er echter tegelijkertijd sprake van discontinuïteit.

De winkeliers konden hun oorsprong terugvoeren op trekhandelaren die werden aangeduid met de naam Tödden en die reeds vóór 1800 veelvuldig in Nederland handel dreven. ${ }^{10}$ De oorspronkelijke Tödden kwamen uit de dorpen Lengerich, Bakum, Thuine, Freren, Beesten, Plantlünne, Ibbenbüren, Brochterbeck en vooral uit Schapen, Hopsten, Recke en Mettingen. Deze dorpen liggen ongeveer vijftig kilometer van de Nederlandse grens, ten oosten van de rivier de Ems. De herkomststreek vormde geen 
staatkundige eenheid. Oldenburg, Hannover en Pruisen zwaaiden tegelijkertijd of opeenvolgend de scepter over delen ervan. ${ }^{11}$ Naast het graafschap Lingen, maakten ook delen van Tecklenburg er deel van uit. Behalve specifieke plaatsnamen, gaven migranten ook grotere geografische eenheden als herkomstplaats op, zoals Oldenburg, Hannover en Münster. Door deze aanduidingen lijkt het afstotingsgebied groter dan het feitelijk was. De migranten kwamen niet uit heel Hannover, maar slechts uit een deel ervan.

De trekhandelaren die uit deze streek kwamen, waren vrijwel allemaal katholiek, maar dat gold niet voor de bevolking van het afstotingsgebied als geheel. Binnen het afstotingsgebied waren er wel dorpen waarvan de bevolking als geheel katholiek was, zoals Hopsten.

De Tödden handelden in producten die niet in de streek zelf werden voortgebracht. Ze kochten hun goederen op tal van plaatsen en verkochten die elders weer. Tussentijds werden de goederen opgeslagen in pakhuizen in Schapen en Hopsten. De handelaren kochten en verkochten textiel en stof, gemaakte goederen zoals mutsen, kousen en omslagdoeken, ijzerwaren, messen en fournituren. ${ }^{12}$ Naast de talloze pakdragers die met deze goederen rondgingen, waren er enkele groothandelaren. Tot de groothandelaren behoorden onder meer de families Ten Brink en Moormann uit Mettingen. Deze families en enkele andere, beheersten tientallen jaren de groothandel in deze streek. ${ }^{13}$ Ten Brink ging als handelshuis in 1812 ten onder. ${ }^{14}$

Bij de Tödden gingen alleen mannen op handelsreis en niet hele families, zoals bij de Westerwalders. Ze waren negen, tien of elf maanden onderweg. De Tödden zetten hun goederen af in alle delen van Europa, maar het zwaartepunt van de handel lag in Nederland en in Noordduitse gebieden. Als gevolg van beperkingen elders, nam omstreeks 1750 de handel op Nederland toe. Opmerkelijk is dat Utrecht vóór de negentiende eeuw geen belangrijk afzetgebied lijkt te zijn geweest. Groningen, Friesland en Holland waren dat wel. In Friesland vinden we de eerste Tödden die zich blijvend in Nederland vestigden. Omstreeks 1770 werd in Leeuwarden de eis gesteld dat vreemde handelaren burgerrecht zouden verwerven en belasting betalen; gevolg was dat tussen 1771 en 1774 veertien Tödden, merendeels uit Mettingen, het burgerrecht van Leeuwarden ontvingen. ${ }^{15}$

De Duitse immigranten die in Utrecht hun grote winkels openden, waren zelden nakomelingen van reeds in Nederland gevestigde trekhandelaren, maar nieuwe immigranten uit de inmiddels sterk uitgedijde herkomststreek van de Tödden. Ze stamden lang niet allemaal af van de eerdere nieuwkomers. De recente nieuwkomers verschilden bovendien van hun voorgangers, omdat hun migratie uit zowel mannen als vrouwen bestond. Dat gold voor de Duitse winkeliers zelf, die met hun vrouwen en kinderen kwamen, en voor het winkelpersoneel, dat uit alleenstaande mannen en vrouwen bestond. ${ }^{16}$ De winkeliers waren, net als de eerdere handelaren, overwegend katholiek. 


\section{De familie Veerkamp; representanten van de oude Töddenhandel}

In Utrecht vinden we enkele sporen van de oudere Töddenhandelaren. Als voorbeeld kan de familie Veerkamp worden genoemd, die door huwelijk verbonden was met de familie Sinkel. Veerkamp was een gangbare Töddennaam. In het midden van de negentiende eeuw had Catharine Veerkamp, geboren in 1819 in Hopsten, een winkel in garen en band op de Utrechtse Neude. Opvallend is dat het hier om een vrouw gaat, terwijl de oude Töddenhandel overwegend door mannen werd gedreven. Het was een kleine onderneming. ${ }^{17}$ Catharine Veerkamp deelde haar huis met haar man, haar broer Victor Veerkamp en later ook met Johan Veerkamp. ${ }^{18}$ Verder waren er aanvankelijk ook twee vrouwen uit hetzelfde afstotingsgebied, die op het adres van Catharina Veerkamp ingeschreven werden als bedienden. Later was er een zestal winkelbedienden -

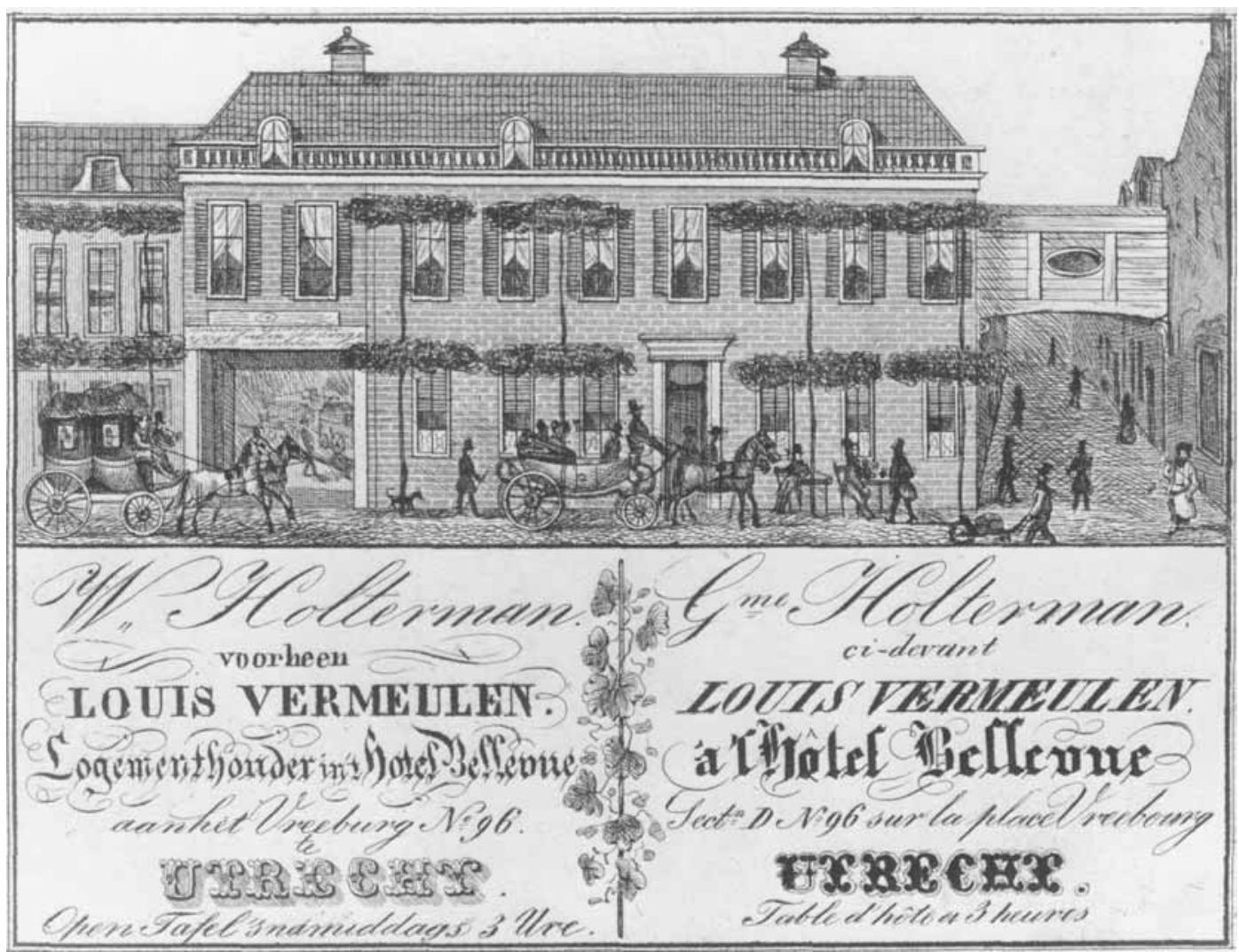

Logement Holterman of Hotel Bellevue aan het Vredenburg in 1860. Mathias Veerkamp, een handelaar in manufacturen afkomstig uit een oud Töddengeslacht, werd niet de grondlegger van een van de grote, moderne winkels, maar nam een bestaand logement over.

P.W. van de Weijer, Het Utrechts Archief C.38.580. 
die er niet gelijktijdig werkten - en waarvan er een uit het afstotingsgebied kwam. Johan Veerkamp werd later bakkersknecht.

Behalve de winkel van Catharine Veerkamp, was er aan de Oudegracht het bedrijf van Mathias Veerkamp en zijn in Culemborg geboren vrouw Hendrika Holterman. ${ }^{19}$ Mathias Veerkamp werd in 1859 ingeschreven in het bevolkingsregister op vertoon van een reis- en verblijfpas. Voor zijn komst naar Utrecht had hij in Amsterdam gewoond, bij de lakenkoopman Ferdinand Veerkamp aan de Nieuwendijk. ${ }^{20}$ In Utrecht was Mathias Veerkamp niet lang werkzaam als handelaar. In 1860 werd hij vermeld als logementhouder op het Vredenburg; het logement stond bekend als de firma Holterman \& co, en werd in eerdere jaren door zijn schoonfamilie gedreven. In de periode 18801889 werden op dit adres 25 bedienden ingeschreven. Gewoonlijk werkten er vier of vijf bedienden tegelijk. Slechts een van de bedienden - de kelner Felix Evers die in 1864 was geboren in Hopsten - kwam uit het afstotingsgebied. In 1882 overleed Hendrika Holterman. Het enige kind van de familie Veerkamp-Holterman was reeds eerder overleden en in 1884 ging Mathias Veerkamp terug naar Hopsten.

Het is opvallend dat de ondernemingen van de familie Veerkamp in Utrecht niet uitgroeiden tot grootschaligere bedrijven. Zoals we zullen zien, was zo'n geleidelijke groei ook niet gebruikelijk. De ondernemingen van de nieuwe Duitse immigranten waren van meet af aan grootschalig.

De opkomst van de gevestigde Duitse winkelstand betekende niet het einde van de ambulante Duitse handelaren in textiel en kleding. Met grote regelmaat bleven ze tot aan het einde van de hier beschreven periode naar Utrecht komen. Ze kondigden hun komst aan in de lokale krant. De ambulante handelaren kwamen echter, althans volgens de advertenties, niet uit de traditionele herkomststreek van de Tödden, maar uit grote steden als Keulen, Berlijn en Hamburg. Kleinschalig waren hun ondernemingen allerminst. In 1878 liet A. Kober uit Keulen weten dat hij voor de tweede maal in Utrecht was met zijn 'uitstalling'. Hij gebruikte de 'benedenzaal van de wed. Esselink' op het Wed als tijdelijk verkooplokaal. Hij verkocht herenkleding en gaf in zijn advertentie een opsomming van wat hij meebracht, onder meer 2500 broeken en vesten en 3000 colberts. Verkoop geschiedde tegen vaste prijzen en duurde van woensdag 22 mei tot vrijdag 7 juni. ${ }^{21}$

\section{Vernieuwende ondernemers}

De grote Duitse winkeliers verschilden niet alleen van de Tödden, maar ook van hun Nederlandse collega's. In 1849 waren er in Nederland ongeveer 60.000 winkels. ${ }^{22}$ De Duitse winkeliers vormden op dit totale aantal slechts een kleine minderheid. Zij bewogen zich echter binnen hun eigen afgescheiden marktsegment en onderscheidden zich van hun Nederlandse vakgenoten. ${ }^{23}$ De Duitse winkeliers hadden, in tegenstelling tot hun Nederlandse collega's, grote en moderne ondernemingen. Ze introduceerden nieuwe verkooptechnieken, in de vorm van vaste lage prijzen in plaats van het gebrui- 
kelijke onderhandelen. Hun winkels hadden grote, goedverlichte etalages en kenden een vrije toegang zonder koopdwang, waardoor klanten die een winkel betraden zich niet meer verplicht voelden iets te kopen. De klanten kregen van de Duitse winkeliers geen krediet en werden niet bediend door de eigenaar of eigenares. Ze konden echter wel vrij tussen de waren rondlopen, ze bekijken en aanraken, en ze hoefden niet meer te vragen naar de prijs. De winst haalde de winkelier uit een grotere omzet. ${ }^{24}$ De opening van de grote Duitse zaken leidde tot het ontstaan van het winkelen als vrijetijdsbesteding; mensen gingen niet meer naar een winkel alleen maar om iets te kopen, maar ook om te kijken en om gezien te worden. ${ }^{25}$ In een periode van twintig jaar veranderden de Duitse winkeliers de winkelpraktijk, en het aanzien van de Nederlandse binnensteden.

De Duitse winkeliers verkochten niet allemaal hetzelfde assortiment. De Winkel van Sinkel had een breed productenpakket, terwijl Peek \& Cloppenburg zich toelegde op de verkoop van confectie voor heren en jongens. De latere damesmodezaken, zoals Lampe en C\&A, ontwikkelden zich uit de mantelmagazijnen, waar aanvankelijk slechts damesmantels werden verkocht. De winkeliers waren slechts in beperkte mate elkaars concurrenten. Zij verkochten manufacturen (stoffen), gemaakte kleding, fournituren (hulpproducten zoals knopen en voeringstof), galanterieën of zogenaamde korte waren (afgeleid van het Duitse woord Kurzwaren, waarmee onder meer ondergoed en kousen werden bedoeld).

De Duitse winkeliers verschilden van hun Nederlandse collega's, omdat ze op zeer grote schaal adverteerden in lokale kranten. Op basis van deze krantenadvertenties krijgen we een goed beeld van het assortiment en de wisselingen daarin. De Duitse winkeliers kwamen, in tegenstelling tot anderen, elk seizoen met iets nieuws. In het najaar werd de komst van de wintercollectie aangekondigd. Daarna volgde de 'cadeautijd'. Aan het begin van het nieuwe kalenderjaar was er eerst de uitverkoop van het wintergoed en dan de verkoop van het witte goed, zoals tafel- en bedlinnen, ondergoed en kinderkleding. In februari volgden handschoenen, in maart de nieuwigheden van het seizoen, in april de japonnen, in mei de zomercollectie en in juni de uitverkoop van het zomergoed. ${ }^{26}$ De Duitse winkeliers introduceerden het lokartikel als verkoopmiddel. ${ }^{27}$ Een kinderhemdje in de kleinste maat werd onder de inkoopprijs aangeboden, in de hoop dat het winkelende publiek gelijktijdig de grotere en duurder geprijsde hemden zou aanschaffen.

De nieuwe zaken verschilden voorts van de oudere winkels, doordat ze werkten met het filiaalstelsel. De grote Duitse kledingzaken openden vestigingen in tal van Nederlandse steden en tegen het einde van de negentiende eeuw ook buiten Nederland. Gedeeltelijk werden deze vertakkingen gecreëerd om zonen, neven, broers en zwagers de mogelijkheid te geven een eigen onderneming te beginnen. ${ }^{28}$ 


\section{Grote werkgevers}

De nieuwe winkels van de Duitsers waren merendeels grootschaliger van opzet dan de Nederlandse en vereisten derhalve een forse investering. Bovendien werkten de Duitse winkels met veel personeel, terwijl de oudere Nederlandse winkels vaak door slechts familieleden draaiende werden gehouden. Doordat de winkels werkten met veel personeel, ontstond er ook een scheiding tussen personeel en eigenaar, alle pogingen van de eigenaren om een paternalistische sfeer te creëren ten spijt. ${ }^{29}$ De arbeidsvoorwaarden voor de talrijke winkelbedienden in het grootwinkelbedrijf waren niet goed. Over de precieze arbeidsvoorwaarden is weinig bekend, omdat winkels niet tot werkplaatsen werden gerekend en derhalve buiten onderzoek van de overheid vielen. In 1915 werd aangenomen dat de lonen van het zogenaamde interne winkelpersoneel vrijwel nihil waren; ze kregen slechts kost en inwoning. ${ }^{30}$ In sommige winkels gold een leertijd van drie jaar, waarin vrijwel niets werd verdiend en waarin de leerling pakjes moest bezorgen, stof afnemen en opruimen. ${ }^{31}$ In de bevolkingsregisters worden de winkelbedienden soms ook vermeld als 'volontair', wat impliceert dat hun verdiensten gering waren. De werktijden waren lang. Winkels waren open van 's morgens acht tot 's avonds tien en 's zaterdags nog langer. Op zondag waren ook veel winkels open. Na sluitingstijd moesten winkels worden opgeruimd en etalages ingericht. ${ }^{32}$ Het winkelpersoneel was gedeeltelijk intern. Dit kon betekenen dat ze bij de eigenaar van de winkel inwoonden. In de meeste gevallen betekende het internenstelsel echter dat het winkelpersoneel werd ondergebracht in kosthuizen naast of boven de winkels. De vrijheid van het interne personeel werd zeer beperkt. Na sluitingstijd moest ook nog voor alles toestemming aan de baas worden gevraagd. Patroons vreesden verlies van hun vrouwelijke klandizie als het winkelpersoneel zich in zedelijk opzicht afkeurenswaardig gedroeg. Onderzoekers hebben zich erover verwonderd dat meisjes desondanks liever winkelmeisje dan dienstbode werden. Het beroep van winkeljuffrouw had echter meer aanzien dan dat van dienstbode. ${ }^{33}$

De internaten boden niet alleen kost en inwoning, maar soms ook vermaak. Het internaat van Vroom \& Dreesmann had bijvoorbeeld een eigen toneelvereniging. ${ }^{34}$ Het winkelpersoneel hoefde de schaarse vrije tijd niet eens buiten het internaat door te brengen.

In 1890 werkten er in de Winkel van Sinkel in Utrecht zestig mensen, plus twaalf mensen in de aangrenzende tapijtafdeling; allen waren intern. Jules Moor, die in 1890 in de winkel werkte en er zijn opleiding kreeg, vertelde bijna vijftig jaar later over het interne stelsel:

Dat moest, tot de chefs toe. Om tien uur werd de zaak gesloten en dan moesten we meteen naar bed, tenminste dat dachten ze! Want vaak genoeg gingen we van de tapijtenafdeeling den kelder door en dan door de poort de Ganzenmarkt op en dan naar de zaak van Fevre [...] om een potje bier te drinken. Meestal 
waren we toch weer vroeg thuis, want rare sprongen konden we met ons salaris niet maken. ${ }^{35}$

Het loon was toen zestig tot honderdvijftig gulden per jaar, met vrije kost en inwoning. Het personeel moest om acht uur 's morgens in de zaak zijn. Op zaterdag was dat een uur vroeger. Men werkte tot twaalf uur; dan werd er in twee ploegen warm gegeten. Thee werd gedronken om vier uur en het souper was van half negen tot half tien in de avond. Nieuwelingen in het internaat werden ingehaald met een vat bier en een installatierite. Daarna behoorden ze echt tot het personeel, maar veelal - gezien het grote verloop - niet voor lang.

Naast het nieuwe verschijnsel van het talrijke en deels intern wonende personeel, betekende de komst van de grote winkels ook het ontstaan van een nieuwe beroepsgroep van winkelklerken, zaakwaarnemers, magazijnhouders en handelsreizigers. Dit was een groep die tussen de eigenaar en het bedienende personeel in kwam te staan.

Het personeel van de grote 'Duitse' winkels bestond niet alleen uit Duitsers, maar zij hadden wel een belangrijk aandeel in het personeel. Bovendien werkten Duitse winkelbedienden zonder uitzondering voor Duitse ondernemingen; bij Nederlandse ondernemingen vonden ze geen emplooi. Dit hoeft niet te betekenen dat Duitse winkelbedienden werden achtergesteld; de Nederlandse winkels werkten veelal zonder personeel, met uitzondering van de eigen familieleden. De Duitse winkeliers hadden behalve Duitse bedienden ook Nederlands personeel in dienst, naast enkele Fransen, Belgen en Britten. Hoe groot het aandeel van het Duitse personeel was, was afhankelijk van het aantal jaren dat een onderneming bestond. Hoe langer de winkel bestond, des te geringer het aandeel van de Duitse personeelsleden. Bij de beschrijving van de afzonderlijke bedrijven zal dit punt nader worden geïllustreerd.

\section{De Winkel van Sinkel}

De Winkel van Sinkel behoorde tot oudere zaken, dat wil zeggen de zaken die er reeds waren in de eerste helft van de negentiende eeuw. Deze winkel kan onmiskenbaar in verband worden gebracht met de trekhandelaren. Ofschoon er eerdere voorbeelden waren waarbij handelaren overgingen tot de winkelstand, vooral in Friesland, vormde de opening van de Winkel van Sinkel een opmerkelijk breekpunt. De grootschaligheid en het succes van Sinkels onderneming waren bepalend voor de weg die de latere Duitse immigranten insloegen.

Michael Anton Sinkel werd geboren in Cranpendorf-Cloppenburg in het graafschap Oldenburg. Aan het begin van de negentiende eeuw trad hij toe tot de Töddencompagnie van Ten Brink en Moormann, de twee internationaal opererende stoffenkooplieden uit Mettingen. ${ }^{36}$ Sinkel kwam in 1806 naar Amsterdam. In 1822 opende hij daar een winkel aan de Nieuwendijk en trouwde met Agnes ten Brink (1787-1859). Zij was de weduwe van de rijke Mettingse koopman Joseph Moormann. ${ }^{37}$ Sinkel beperkte 


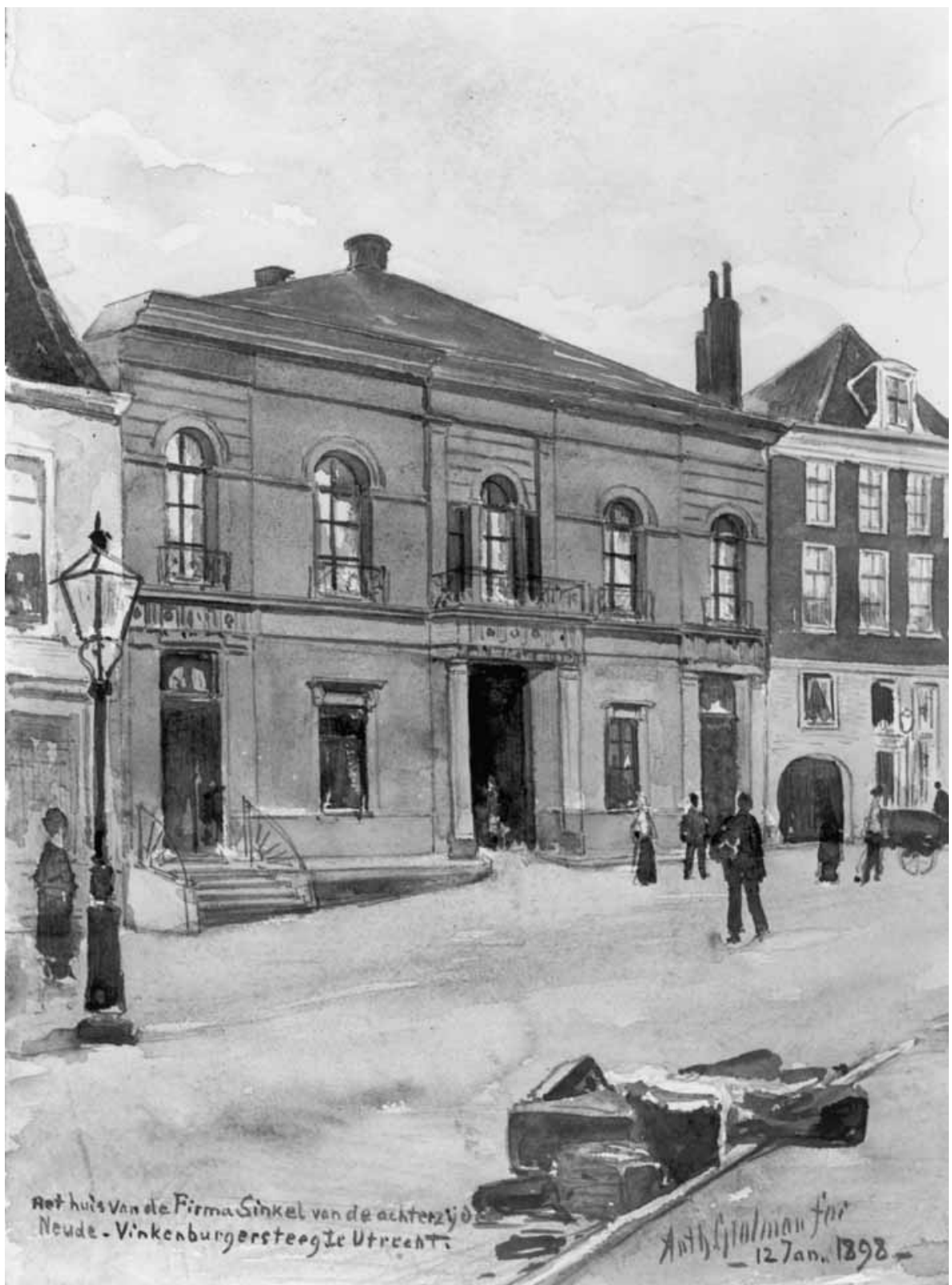

Achterzijde van de Winkel van Sinkel aan de Vinkenburgstraat en de Neude in 1898. De Winkel van Sinkel lag aan de voorzijde aan de Oudegracht bij de Stadhuisbrug.

Aquarel A. Grolman. Het Utrechts Archief C1573. 
zijn activiteiten niet tot Amsterdam. In 1824 werd de eerste Utrechtse vestiging geopend, die later zou worden vervangen door het pand dat bij de opening zoveel opzien baarde. In 1827 volgde de Winkel van Sinkel in Leeuwarden, die Anton Sinkel exploiteerde met zijn broers Joseph en Hermann..$^{38}$ Daarna kwamen er winkels in Leiden, Sneek, Rotterdam en Alkmaar.

In 1824 had Sinkel het eeuwenoude pand Het Houten Been gekocht aan de Oudegracht bij het stadhuis. Deze Utrechtse vestiging werd aanvankelijk beheerd door Eduard Moormann, een stiefzoon van Anton Sinkel. Na onenigheid met zijn stiefvader vertrok Moormann naar Nederlands-Indië, waar hij een handelshuis met suiker-, koffie- en rubberplantages opzette. ${ }^{39}$ Anton Sinkel verwierf in 1836 voor 24.000 gulden de bebouwing naast Het Houten Been, bestaande uit het voormalige Barbaragasthuis en het Laurentiusgasthuis. ${ }^{40}$ Nadat beide gebouwen waren gesloopt, verrees hier een monumentaal winkelpand, waarvan de voorgevel versierd werd met vier kolossale gietijzeren vrouwenbeelden. Bij het optakelen van deze beelden, uit boten die in de Oudegracht lagen, stortte de oude stadskraan uit 1402 in elkaar, daarmee op symbolische wijze het einde markerend van een tijdvak van kleinhandel. De kraan werd niet opnieuw opgebouwd.

In de Utrechtsche Courant werd de nieuwe 'paleis-winkel' gedetailleerd beschreven: de vier gigantische ijzeren beelden bij de ingang, de vloeren van blauw en wit marmer, ingelegd met koper en kasten en deuren van goudgebronsd, kunstig bewerkt ijzer. De zaal was 50 bij 100 voet groot (ongeveer 15 bij 30 meter) met daarboven, zonder enige ondersteuning, een gaanderij, 'men kan dit niet aanzien zonder daarbij aan de majestueuse paleizen en hangende tuinen der antieken te denken.' De betimmeringen waren 'van gepolitourd Amerikaans esdoorn- en maghonijhout; het stucadoor- en beeldhouwwerk, onverschillig, of men hetzelve op een afstand of van nabij beziet, getuigt evenzeer, dat hier theorie en praktijk uitmuntend hebben zamengewerkt.' Vanuit de zaal had men door een bewerkte glazen deur uitzicht op een tuin die uitkwam op de stal en het koetshuis aan de Neude. Naast de tuindeuren waren aan weerszijden enorme spiegels geplaatst. ${ }^{41}$

In 1848 overleed Anton Sinkel. Hij had geen kinderen, en liet zijn bedrijf ter waarde van 1,4 miljoen gulden na aan zijn petekind Anton Povel, zijn neef Bernard Sinkel en Joseph Veerkamp, een zoon van de zuster van zijn vrouw. ${ }^{42}$ De kinderen van zijn vrouw uit haar eerste huwelijk, met wie Sinkel niet op goede voet stond, kregen geen aandeel in de zaak. In 1852 zette de inmiddels tot Nederlander genaturaliseerde Povel de onderneming alleen voort. ${ }^{43}$

De katholieke Anton Povel (1796-1875) werd geboren in het Duitse Greven. ${ }^{44}$ Aanvankelijk was hij verbonden aan de Töddencompagnie Von Lohe, Povel en Verhage. Dit was een onderneming die onder meer in Groningen in textiel handelde. Onder Povels leiding begon de Winkel van Sinkel in 1860 met de verkoop van uit Duitsland ingevoerde herenconfectie. ${ }^{45}$ In de Winkel van Sinkel werd echter veel meer verkocht dan manufacturen en kleding; er was een breed assortiment woningartikelen zoals gordijnen en tapijten. Reeds onder Sinkels leiding was de winkel eerder een warenhuis dan 
een kledingzaak. Sinkel was daarmee een heel vroege voorloper van dit winkeltype. Pas in 1852 werd in Parijs Au Bon Marché geopend. ${ }^{46}$ In 1885 maakten in Duitsland Tiets en Wertheim van hun garen- en bandwinkels warenhuizen. Het warenhuis ontstond uit een mengeling van de winkelpassages, zoals die er waren in Parijs, en de kleinere bazaars die in eerdere tijdvakken op het platteland hadden bestaan. De bazaars waren op hun beurt geïnspireerd op de pakhuisverkoop. De pakhuizen van de Tödden zouden voor dit winkeltype model hebben kunnen staan. Sinkel was met zijn grote bedrijf en brede assortiment in ieder geval onmiskenbaar een pionier.

Ofschoon Sinkel van aanvang af een zeer divers productenpakket voerde, werd het pas een zaak waar alles te koop was, nadat in 1880 in Amsterdam het assortiment van een overgenomen apotheek in de collectie werd opgenomen. Pas toen kwamen er, naast 'hoeden en petten en dameskorsetten', ook 'drop om te snoepen en pillen om te poepen'. ${ }^{47}$

Naast winkels die de naam Sinkel droegen, opende Povel ook depots onder de naam De Vlijt, die door derden werden geëxploiteerd en waar onder meer garen en band, mutsen en schorten werden verkocht. ${ }^{48}$ In 1910 werd de Winkel van Sinkel geliquideerd. In het Utrechtse pand kwam de bank Vlaer en Kol en aan het eind van de twintigste eeuw een horecagelegenheid met opnieuw de naam Winkel van Sinkel. De aangrenzende tapijtzaak werd verkocht aan de Duitser Schumacher, die er een bioscoop in vestigde die er nu nog zit.

\section{Het kosthuis van Sinkel}

In de periode 1850-1859 werd het perceel van de Winkel van Sinkel in het bevolkingsregister aangeduid met nummer $\mathrm{G}$ 11/15. ${ }^{49}$ Reeds bij de aanleg van het bevolkingsregister werden voor dit pand meerdere pagina's uitgetrokken, waarmee geanticipeerd werd op het grote verloop onder het personeel. De omvang van het personeel en het verloop dateerden reeds van voor de introductie van het bevolkingsregister in 1850. Personeelsomvang en -verloop waren echter nog groter dan verwacht, zodat inschrijvingen op talloze vervolgpagina's achter in het register noodzakelijk waren. Een tweede kosthuis van Sinkel stond om de hoek van de winkel op de Ganzenmarkt. Dit was minder groot en is minder lang gebruikt dan het interne kosthuis van de winkel.

De Winkel van Sinkel in Utrecht stelde Duits personeel te werk, maar in de tweede helft van de negentiende eeuw was het personeel niet meer volledig Duits. Sinkel had mannen en vrouwen in dienst. Een kwart van het personeel bestond uit vrouwen, die in het bevolkingsregister met winkeljuffrouw en met modiste werden aangeduid. De modistes, die kleding en hoeden maakten, zullen niet in de winkel hebben gewerkt, maar in de daarbij horende ateliers. In de periode van 1860 tot 1879 werden er 238 mensen ingeschreven op het adres van het kosthuis van de winkel. Er was overlap met het personeel van andere grote winkelbedrijven, zoals Peek \& Cloppenburg. Dezelfde Duitse immigranten woonden afwisselend in de verschillende kosthuizen. Bovendien duiken 
mensen, die als winkelbediende in Utrecht stonden ingeschreven, veelvuldig op in andere steden, zoals Amsterdam en Rotterdam.

In de Winkel van Sinkel in Utrecht was de dagelijkse leiding in handen van Joseph Stuckenborg, die in 1823 werd geboren in Dinklage en in 1853 uit Amsterdam naar Utrecht kwam..$^{50}$ Onder zijn leiding had het personeel een sterk Duitse inslag. Tussen 1850 en 1859 werden 38 Duitse winkelbediendes ingeschreven op het adres van de winkel. Zij waren allen katholiek en kwamen vrijwel allemaal uit Oldenburg.

Na de dood van Stuckenborg in 1875, kwam de Utrechtse Winkel van Sinkel onder leiding van H.L.P. Povel, een zoon van Anton Povel, geboren in Amsterdam. Hij was getrouwd met een Franse vrouw en zijn kinderen waren in Engeland geboren. Bij hem zien we het migratiegedrag dat zo typerend was voor de zogenaamde tweede generatie winkeliers. Zij woonden afwisselend in de grote steden van Europa en daarbuiten. Onder de leiding van de tweede generatie Povel, nam het Duitse karakter van het bedrijf snel af.

Onder het personeel van Sinkel waren verschillende mensen die later zelf een modezaak of manufacturenhuis openden. Bij Sinkel in Utrecht werkte bijvoorbeeld August Taphorn, die later een zwager werd van Willem Vroom en Anton Dreesmann (alledrie trouwden met dochters van de familie Tombrock-Theissling). ${ }^{51}$ August Taphorn werd in 1854 in Essen in Oldenburg geboren, als zoon van Gerhard Taphorn en Luise Niermann. Hij ging naar Amsterdam, waar hij in 1879 een winkel in manufacturen had in de Anjelierenstraat. Hij werkte samen met zijn zwagers Vroom en Dreesmann, ging met hen geen associatie aan, maar kocht wel goederen van hen. Hij keerde uiteindelijk terug naar zijn geboortedorp, waar hij in 1925 overleed. Kinderen van August Taphorn en Anna Tombrock trouwden met medewerkers en firmanten van Vroom \& Dreesmann..$^{2}$

Het kosthuis van Sinkel was een kweekvijver voor de latere Duitse ondernemers in deze bedrijfstak. Bij andere ondernemingen werden binnen het bedrijf ook opvolgers opgeleid. Het verschil meet andere winkels was echter de schaal waarop dit bij Sinkel gebeurde. De omvang en het verloop van het personeel versterkten het kweekvijvereffect.

\section{Maseland: uit de kweekvijver van Sinkel}

Uit de kweekvijver van Sinkel kwam de firma Maseland op de Oudegracht voort. Maseland had zich in 1824 in Utrecht gevestigd als agent van Sinkel..$^{53}$ Albertus Maseland werd in 1796 geboren in Enschede uit Oldenburgse ouders. Zijn firma had ook ondernemingen in Deventer en Aarlanderveen. ${ }^{54}$ Hij overleed in 1866 . Bij de winkel van Maseland was een kosthuis, net als bij de Winkel van Sinkel. Tussen 1850 en 1859 woonden er zeventig kostgangers. Van hen kwamen er tien uit Oldenburg; alle kostgangers waren katholiek.

Na de dood van Albertus Maseland, werd de firma onder dezelfde naam voortgezet door de Duitser Johan Wehrij die in 1817 in Dinklage was geboren. Hij was getrouwd met Maselands dochter Johanna, geboren in Utrecht in 1826. Hun oudste drie kinderen 
waren geboren in Parijs en de jongste drie in Eaubonne. In 1878 werd de firma voortgezet door de comparanten Johanna Maseland, Johan Wehrij en Grasveld. ${ }^{55}$ Grasveld werd in Utrecht geboren als zoon van een Nederlandse vader en een Oldenburgse moeder. Wehrij woonde met zijn familie slechts kort in Utrecht. In 1873 werd hij ingeschreven, komende uit Frankfurt am Main. ${ }^{56}$ Een half jaar later vertrok de familie naar Amsterdam. De dagelijkse gang van zaken werd overgelaten aan een zaakgelastigde. Onder leiding van Wehrij werd het 'Duitse' karakter van de onderneming versterkt. Tot 1879 waren tien van de twaalf kostgangers geboren in Oldenburg. Allen waren katholiek.

Het kosthuis van de firma Maseland werd op zijn beurt, net als dat van de Winkel van Sinkel, een kweekvijver voor latere ondernemers in deze sector. Onder het personeel vinden we bijvoorbeeld Gustav Schlatmann. ${ }^{57}$ Deze werd in 1852 in Neuenkirchen geboren als zoon van Zacharias Schlatmann en Justine Hofstée; zijn levensgeschiedenis is kenmerkend voor de groep winkeliers. ${ }^{58}$ Zacharias Schlatmann reisde als handelaar naar Nederland, maar zijn vrouw en kinderen bleven in Duitsland achter. Na de dood van hun ouders in 1866 en 1867, werden de wezen Schlatmann een voor een naar familie in Nederland gestuurd. Gustav Schlatmann ging in de leer bij Maseland en nam toen de manufacturenzaak van Withof over aan de Vischmarkt in Leiden. Hij trouwde met Agnes Brüning en was door huwelijksbanden verbonden met de familie Dreesmann. ${ }^{59}$ Vier van de zes kinderen Schlatmann begonnen een manufacturenzaak en allen trouwden binnen de kring van Duitse handelaren. Gustav Schlatmann ging met zijn boers en zwagers een firma aan onder de naam De Faam, met een kapitaal van 350.000 gulden en winkels in Leiden, Haarlem, Woerden en Schoonhoven. Schlatmann kende het internenstelsel van dichtbij.

Er waren altijd "jongelui" intern, vaak niet zozeer bedienden dan wel zoons van familie of zakenrelaties, waarbij de tweede categorie de eerste insloot. In de allereerste jaren sliepen deze leerlingen wel onder te toonbank. ${ }^{60}$

\section{Van der Sandt \& co}

Derde in de rij oudere winkels was de firma Van der Sandt \& co. ${ }^{61}$ Deze firma werd opgericht door Gerardus van der Sandt en Paula Moormann, beiden uit Oldenburg. Van der Sandt werd op 19 april 1868 genaturaliseerd tot Nederlander. Hij was net als Sinkel verwant aan de handelaren Moormann en Ten Brink.

Van der Sandt had een groot aantal Duitse winkelbedienden, maar zijn personeel kwam niet exclusief uit Oldenburg. Aan het einde van de negentiende eeuw had de firma Van der Sandt \& co naast Duits winkelpersoneel, ook Duitse klerken en zaakgelastigden. Een Duitse vrouw hield toezicht op het atelier. ${ }^{62}$

Van der Sandt \& co verkocht gemaakte kleding, maar ook tal van andere artikelen, waarvan in wekelijks herhaalde advertenties een opsomming werd gegeven. 
Tafelkleeden in alle soorten en genres. Tafelloopers met deviezen. Antimacassers en tablets met broderies, nachtzakken met deviezen, geparfumeerde artikelen, werktaschjes in satijn en velours, speldenkussens, toiletkussens, naaldenboekjes, visiteboekjes, garde-mouchoiers, garde-gants, zakdoeken in etuis. Ruches in etuis, kanten lafaieres en fichus, handschoenen voor bals en soirees, avonddoeken en sorlies, Yersey-Talles (avondkleuren) tricot-costumes voor meisjes en jongens, kappers en hoedjes gevoerde zijde- en glace handschoenen pelterijgen in groote verscheidenheid. ${ }^{63}$

De onderneming van Van der Sandt \& co deed het niet slecht. Van der Sandt behoorde tot de hoogst aangeslagenen in de stedelijke belasting. ${ }^{64}$ Op de lijst met 57 hoogst aangeslagenen, die de Utrechtse krant in 1878 publiceerde, was Van der Sandt de enige die buiten Nederland was geboren.

In 1888 werd de firma Van der Sandt voortgezet door Ferdinand Theissing, geboren in 1843 in het Duitse Münster. Hij trouwde met Maria Josepha Moormann, die in 1852 in Londen werd geboren. $\mathrm{Zij}$ was een dochter van Eduard Moormann en Gesina Krans. ${ }^{65}$ Eduard Moormann was op zijn beurt de eerdergenoemde stiefzoon van Anton Sinkel. Zoals gezegd waren de banden tussen de verschillende winkeliers ingewikkeld en talrijk. Chef bij de firma Van der Sandt werd de Duitser Gerhard Sluijter. ${ }^{66}$

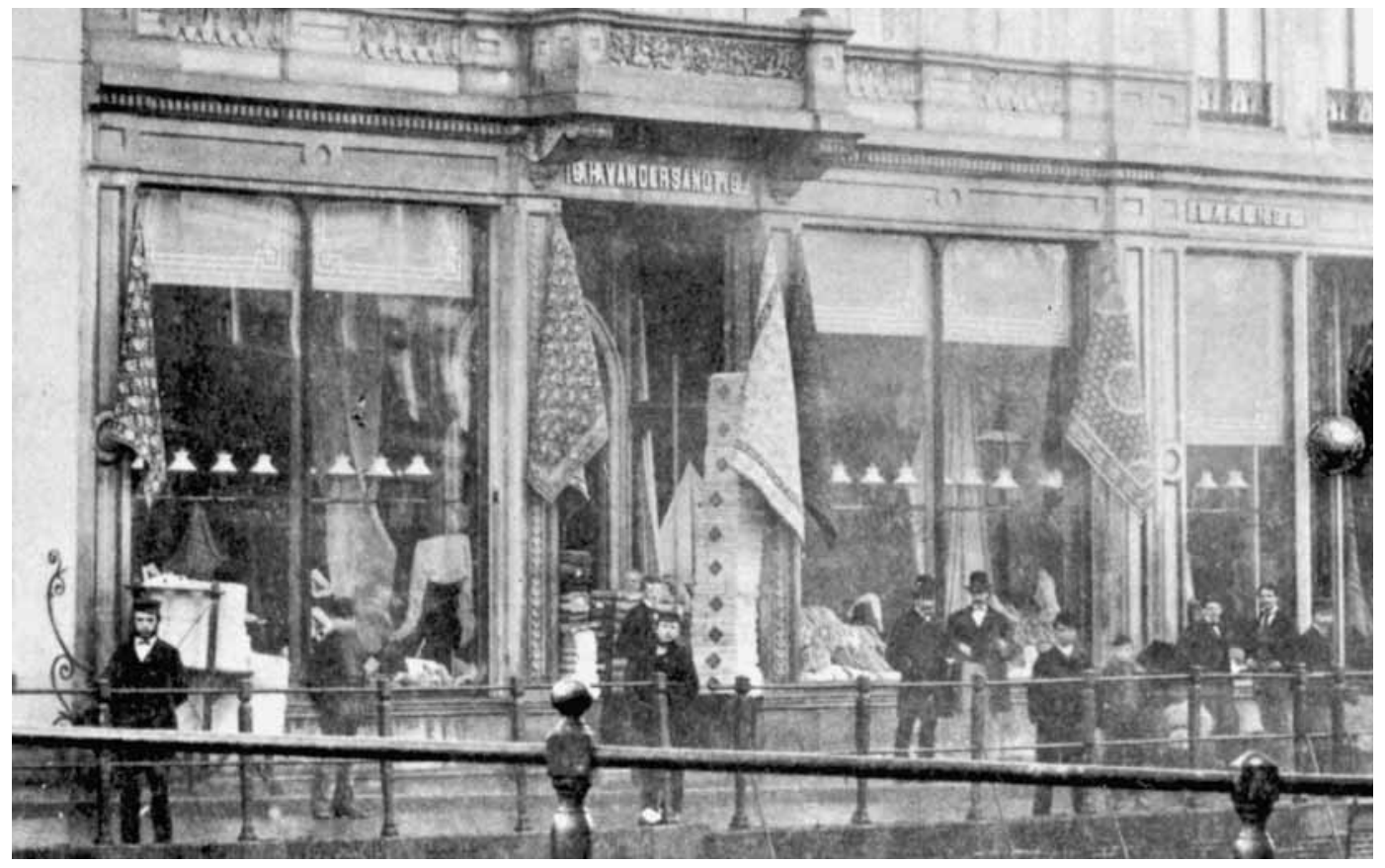

Winkel van G.H. van der Sandt en co in 1877 aan de Oudegracht. Van der Sandt behoorde tot de rijkste inwoners van Utrecht.

Foto C. Marcussen. Het Utrechts Archief C. 5129. 


\section{Peek \& Cloppenburg}

Peek \& Cloppenburg was de belangrijkste van de Duitse winkels in de tweede helft van de negentiende eeuw. In 1869 gingen in Rotterdam Peek en Cloppenburg een vennootschap aan. Beide vennoten woonden toen in Rotterdam. Peek werd in de akte een agent genoemd en Cloppenburg een handelsbediende. ${ }^{67}$ Peek (1845-1907) werd geboren in Grönheim als zoon van een boer, Cloppenburg (1844-1922) kwam uit een kostersgeslacht te Altenoythe. Geen van beiden stamde rechtstreeks af van de eerdere trekhandelaren.

Op 2 januari 1870 verscheen er een advertentie in het Rotterdamsch Nieuwsblad, waarin bekend werd gemaakt dat Peek en Cloppenburg een vennootschap waren aangegaan 'ten doel hebbende den handel in Manufacturen en Lakens. ${ }^{68}$ Het kapitaal bedroeg 4500 gulden, gedeeltelijk geleend van de zussen van Peek. ${ }^{69}$ In 1899 was het kapitaal van deze firma drie miljoen gulden; alle aandelen waren in handen van de beide families. In 1899 werd Peek \& Cloppenburg een naamloze vennootschap. De zetel van de firma werd verplaatst naar Utrecht. Doel van de firma was 'de vervaardiging van Heeren- en kinderkleeding alsmede den handel en gros en en detail in Heeren en kinderkleeding, stoffen en aanverwante artikelen zijnde eene voortzetting der zaken tot dus ver door de firma Peek en Cloppenburg gedreven in verschillende plaatsen zonder evenwel tot die plaatsen beperkt te zijn indien het bestuur goedvindt daartoe ook andere plaatsen binnen of buiten Nederland aan te wijzen'.

Peek \& Cloppenburg begon in een winkelhuis aan de Hoogstraat in Rotterdam met de verkoop van stoffen. Het Utrechtse filiaal werd geopend in 1870, daarna volgden filialen in Leiden en Den Haag (1882), Amsterdam (1885), Groningen (1889), Haarlem (1891), Leeuwarden en Breda (1892), Arnhem (1895) en Nijmegen (1898)..$^{70}$ In 1901 werden Peek \& Cloppenburg-winkels geopend in Düsseldorf en Berlijn, en in 1911 in Hamburg. ${ }^{71}$ De Duitse ondernemingen waren slechts losjes verbonden met het Nederlandse bedrijf.

Reeds spoedig na de opening van de eerste winkel, werden een coupeur en enige kleermakers aangetrokken en werd begonnen met de verkoop van gemaakte heren- en jongenskleding. Peek \& Cloppenburg liet coupeurs en kleermakers in eigen ateliers werken en liet confectie maken door thuiswerkers. Er waren ateliers in Rotterdam, Utrecht en Groningen. Omstreeks 1900 verkochten zeventien winkels, die niet onder de naam Peek \& Cloppenburg opereerden, uitsluitend goederen van Peek \& Cloppenburg. Met de elf eigen winkels betekende dat, dat het bedrijf 28 afzetpunten had. In deze grootschalige eigen kledingproductie verschilde Peek \& Cloppenburg van de oudere Duitse ondernemingen.

Uit het grootboek van het filiaal Utrecht, dat tussen 1884 en 1886 werd bijgehouden, is op te maken met wie de firma Peek \& Cloppenburg zaken deed. ${ }^{72}$ Het merendeel van de inschrijvingen betrof de levering van stoffen voor de ateliers, en de levering van gemaakte kleding. Uit het overzicht blijkt dat beide leveringen zeer groot waren. Hierin weerspiegelen zich de omvangrijke productie en verkoop. Bovendien blijkt uit deze ad- 
ministratie dat lang niet alle kleding die door Peek \& Cloppenburg werd verkocht, ook binnen de eigen ateliers werd gemaakt. In de lijst komen bekende namen voor van grote textielfabrikanten in het zuiden van Nederland, zoals Pieter van Dooren in Tilburg. Daarnaast waren er veelvuldige handelscontacten met Engeland en incidentele met Frankrijk, België, Oostenrijk en Denemarken. Opvallend is dat veruit het grootste aantal transacties plaatsvond met Duitse bedrijven. De regelmatige reizen van Peek naar Duitsland bevestigen dit. Peek lijkt van zijn kennis van de Duitse markt te hebben geprofiteerd. Peek \& Cloppenburg kocht bij Duitse fabrikanten van gemaakte kostuums zoals bij Bender \& Garthmann in Frankfurt am Main. In het grootboek worden 135 Duitse bedrijven genoemd, verspreid over alle delen van Duitsland. Peek \& Cloppenburg deed niet alleen zaken met katholieke leveranciers, maar ook veelvuldig met joodse producenten.

Johan Peek werd in 1870 ingeschreven in het Utrechtse bevolkingsregister, komende uit Grönheim in Oldenburg met zijn Duitse vrouw. ${ }^{73}$ Cloppenburg bleef in Rotterdam. In zijn winkel op de Oudegracht had Peek aanvankelijk vier winkelbedienden, die net als hij uit Oldenburg kwamen. Peek begon in Utrecht met de verkoop van stoffen. Al snel kwamen daar kant en klare accessoires bij: handschoenen, stropdassen, kragen en boorden, sokken en kousen, sjaals en ondergoed. Vervolgens ging de winkel over tot de productie van confectiekleding. De kleding werd gedeeltelijk gemaakt in een atelier boven de winkel. In 1882 had Peek \& Cloppenburg zeven coupeurs in dienst, terwijl 136 kleermakers werkzaam waren als thuiswerkers. ${ }^{74}$ Daaronder waren vrijwel geen Duitsers.

Er werden zomerstoffen verkocht voor 'confectie op maat' en een grote sortering gemaakte 'heeren- en jongeheeren- en kinderkleedingstukken (solied en uitsluitend eigengemaakt)'. ${ }^{75}$ De ateliers van Peek \& Cloppenburg makten ook confectiekleding voor een tweede winkel die Peek \& Cloppenburg in 1880 opende in Utrecht: De Stad Parijs, op de hoek van de Bakkersteeg en de Steenweg (Heilige weg).$^{76}$ Het verband tussen beide ondernemingen van Peek \& Cloppenburg werd zorgvuldig geheim gehouden. De ondernemers vreesden namelijk dat de mindere kwaliteit van de kleding die werd verkocht in De Stad Parijs - en die werd gemaakt in de ateliers van Peek \& Cloppenburg - de goede naam van de hoofdvestiging zou bederven. In het atelier in Utrecht werd ook kleding gemaakt, die door andere winkels in en buiten Utrecht, werkend onder hun eigen naam, werd verkocht. Het Utrechtse atelier maakte ook confectie voor de vestigingen in Den Haag en Leiden. Omstreeks 1900 verdwenen de Utrechtse productiebedrijven en werd de productie geconcentreerd in Rotterdam. ${ }^{77}$

Bij beide winkels van Peek \& Cloppenburg in Utrecht was er een kosthuis boven de winkel. In deze huizen woonden zo'n tien winkelbedienden tegelijk, allemaal katholieke mannen, afkomstig uit Oldenburg. Het verloop onder de winkelbedienden was groot; in een periode van tien jaar passeerden meer dan honderd winkelbedienden de beide huizen. Er was overlap tussen beide huizen; immigranten woonden afwisselend in het ene en het andere kosthuis. De helft van deze Duitse immigranten kwam direct uit Oldenburg; de andere helft had reeds eerder in andere steden in Nederland ge- 
woond, bij andere winkels van Peek \& Cloppenburg, of bij vergelijkbare bedrijven. De dagelijkse leiding in de kosthuizen was in handen van een oudere Duitse huishoudster, Bernardina Wilting. ${ }^{78}$

Net als bij Maseland en Sinkel, zien we ook onder het personeel van Peek \& Cloppenburg de stichters van andere ondernemingen in deze sector. Het kosthuis van Peek \& Cloppenburg vervulde dus ook weer een functie als kweekvijver. Anton en Franz Kreymborg werkten voor Peek \& Cloppenburg, en ook Hunkemöller - later grondlegger van het gelijknamige lingeriehuis - komen we onder het personeel tegen. ${ }^{79}$

Anton Kreymborg werkte aanvankelijk in 1882 voor de firma Van der Sandt \& co. Hij werd geboren in 1863 in Lohne in Oldenburg. In het Utrechtse bevolkingsregister werd hij ingeschreven als winkelbediende komend uit Amsterdam. ${ }^{80} \mathrm{Na}$ zijn verblijf bij Van der Sandt \& co, ging hij in 1888 naar De Stad Parijs van Peek \& Cloppenburg. Bij hem voegde zich Franz Kreymborg, geboren in 1864 in Lohne. Zij werden gevolgd door de broer Gerard en Bernard Kreymborg. ${ }^{81}$ Gehard stond genoteerd als chef, Franz als reiziger. In 1889 ging Gerard Kreymborg naar Groningen. ${ }^{82}$

Anton Kreymborg werd medefirmant van de firma Peek \& Cloppenburg, voor de vestigingen in Groningen en Leeuwarden. Zijn inbreng in de vennootschap werd voldaan door inhoudingen op zijn salaris en tantièmes. ${ }^{83}$ In 1900 wilde Kreymborg aandeelhouder worden binnen de nieuwe structuur van Peek \& Cloppenburg. Toen dat werd geweigerd stapte hij uit de onderneming, begon zijn eigen bedrijf en zette ateliers op die onder meer leverden aan C\&A. ${ }^{84}$

\section{Hoyng, Schlüter en Bohlen}

Tot nu toe zijn de grotere en meer bekende zaken beschreven. ${ }^{85}$ Op de Oudegracht zaten ook enkele winkels die enigszins afweken van het hier beschreven beeld. Het ging tot nog toe steeds om katholieke winkeliers in manufacturen en kleding, en grootschalige ondernemingen met katholiek, deels Duits personeel uit dezelfde herkomststreek als de werkgever. Voor de bedrijven van Hoyng, Schlüter en Bohlen gold dat niet helemaal. De geschiedenis van deze bedrijven laat zien welke variatie er mogelijk was en welke verschuivingen er in de loop der tijd plaatsvonden.

Carl Hoyng werd geboren in 1837 in Vechta in Oldenburg en was katholiek. ${ }^{86} \mathrm{Hij}$ kwam uit dezelfde streek als de andere grote winkeliers op dit deel van de gracht. Hoyng verkocht echter geen kleding en manufacturen, maar huishoudelijke artikelen, zoals glas, porselein en pendules. De afwijking van het gangbare assortiment was het voornaamste verschil. Hoyng woonde aanvankelijk - in 1855 - net als veel van de andere grote winkeliers in het kosthuis van Sinkel op de Ganzenmarkt. Hij vertrok uit Utrecht en keerde in 1866 vanuit Amsterdam terug. Kort daarop trouwde hij met Anna Wille uit Lingen in Hannover en na haar dood met Carolina Nierman uit Vechta in Oldenburg. Evenals de andere winkeliers trouwde hij dus met vrouwen die uit zijn geboortestreek kwamen. Carl Hoyng kreeg veertien kinderen. Via zijn huwelijk met 
Anna Wille was hij verwant aan de andere Duitse winkeliers op de Oudegracht. Heinrich Wille, ${ }^{87}$ een broer van Anna, kwam ook naar Utrecht en nam in 1897 de reeds bestaande lakenwinkel van het Nederlandse echtpaar Van Geel en Fievez dite de Chalines aan de Stadhuisbrug over. Dit was een van de weinige winkels op dit gedeelte van de gracht, die op dat moment nog niet in Duitse handen was. Kenmerkend is dat Heinrich Wille en zijn broer Friederich aanvankelijk werkten als winkelbedienden voor Van der Sandt.

Opmerkelijk aan de winkel van Hoyng is, dat de zaak achtereenvolgens op verschillende plaatsen in de stad gevestigd was, om uiteindelijk ook in de befaamde bocht van de Oudegracht te eindigen. Hoyng schoof dus in letterlijke zin op naar de plek waar zijn streekgenoten een niche bezetten. Net als de andere winkeliers had hij een groot aantal personeelsleden in dienst, maar slechts een klein deel ervan kwam uit zijn geboortestreek. Daarin verschilde hij dus van zijn collega's. Zijn personeelsleden waren weer wel allemaal katholiek.

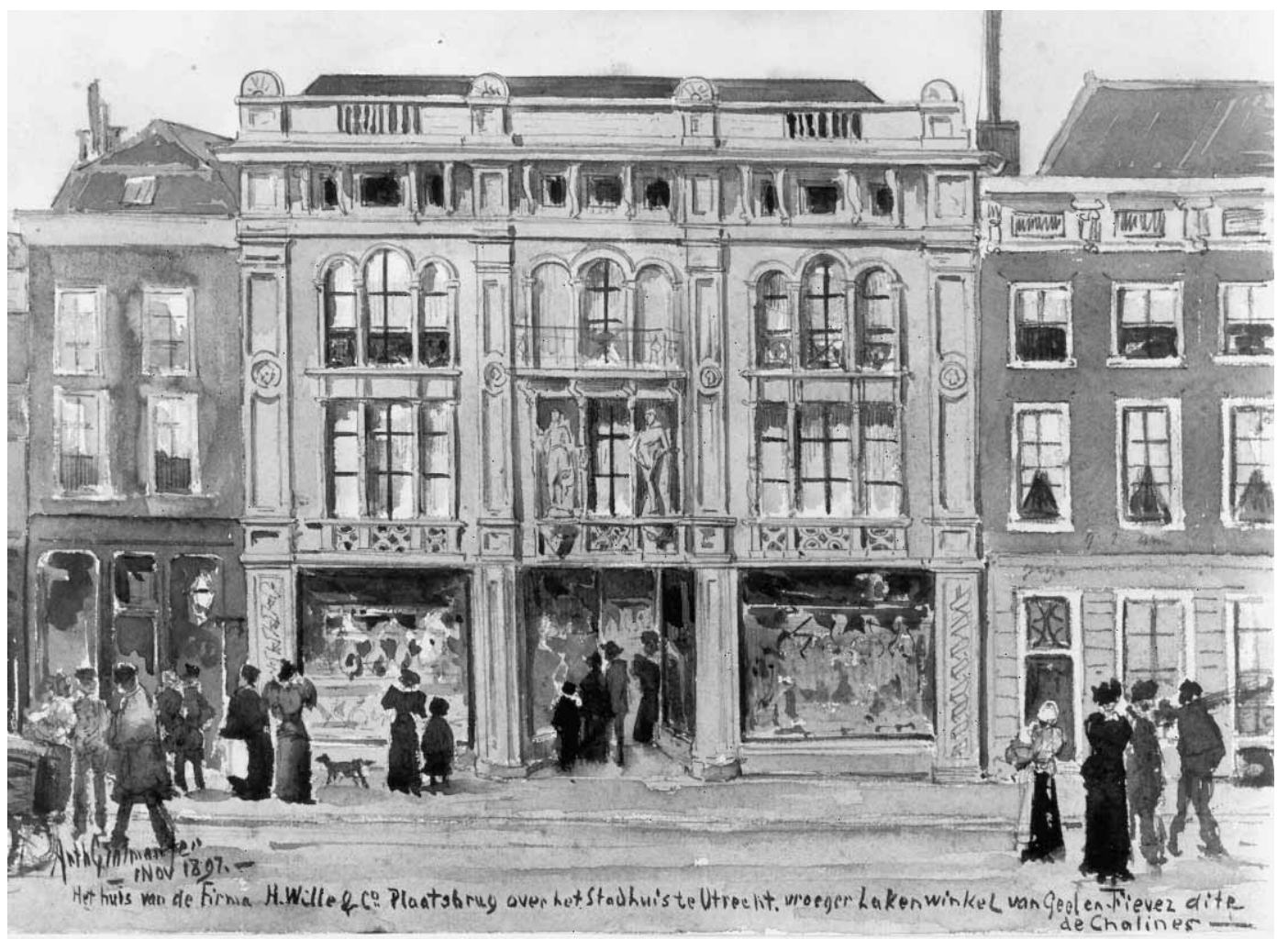

Winkel van Wille aan de Oudegracht tegenover het stadhuis. Heinrich Wille nam in 1897 de reeds bestaande lakenwinkel van het Nederlandse echtpaar Van Geel en Fievez dite de Chalines aan de Stadhuisbrug over. Dit was een van de weinige winkels op dit gedeelte van de gracht, die op dat moment nog niet in Duitse handen was. Aquarel van A. Grolman. 


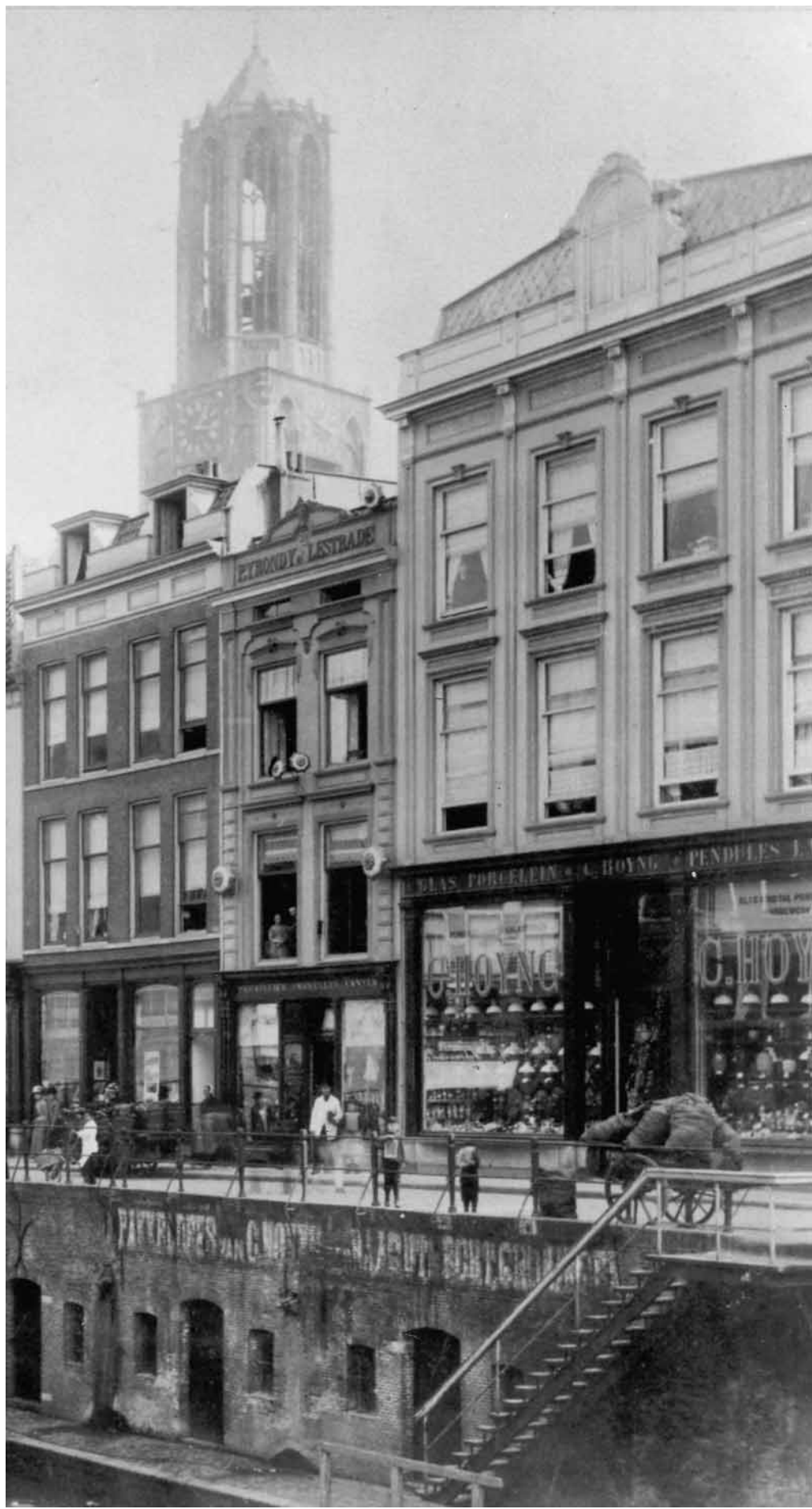

Winkel van Hoyng aan de Oudegracht in 1890 (rechts). Hoyng verkocht in tegenstelling tot de andere Duitse winkeliers op de Oudegracht geen kleding of manufacturen, maar huishoudelijke artikelen, zoals glas, porselein en pendules.

Het Utrechts Archief TA O-Gr. (B-S). 
Carolina Nierman zette het bedrijf voort na de dood van haar man in 1896. Opvallend is het migratiegedrag van de kinderen Hoyng. Ze verhuisden omstreeks 1900 niet alleen naar Vechta in Oldenburg, maar ook naar Hamburg, Engeland en Zuid-Afrika. ${ }^{88}$ Deze mobiliteit was kenmerkend voor de volwassen kinderen van de grote Duitse winkeliers.

Hoyng maakte, net als de eerdergenoemde firma's, deel uit van het netwerk van de winkeliers. De onderneming nam, evenals Vroom \& Dreesmann, financieel deel in de firma Peek \& Cloppenburg, toen die in 1900 werd omgevormd tot een naamloze vennootschap. De familie Hoyng werd vervolgens ook door huwelijksbanden met Peek \& Cloppenburg verbonden. ${ }^{89}$

Een winkel die meer van het algemene patroon afweek is Schlüter \& co, eveneens op de Oudegracht. ${ }^{90}$ Schlüter stelde namelijk slechts vrouwen tewerk, die bovendien allemaal Nederlands waren en protestant. Schlüter voerde, getuige de veelvuldige advertenties in de krant, wel eenzelfde assortiment als de andere Duitse winkeliers. ${ }^{91}$

August Herman Schlüter - geboren in het Oostfriese Embden in 1822 - had aan de Oudegracht op de Stadhuisbrug, tegenover Sinkel, een winkel vergelijkbaar met die van de andere Duitse winkeliers; hij kwam echter niet uit dezelfde herkomststreek en was luthers. Hij dreef de winkel met zijn broer Heinrich David Schlüter en zijn partner Heinrich David Hennings. ${ }^{92}$ Onder Schlüters personeel van ongeveer tien personen, waren drie Duitsers, die luthers waren en ook afkomstig uit Oostfriesland. Schlüter was gehuwd, maar had geen kinderen. Hij werd opgevolgd door Wilhelm August Niemann uit Langforden en deze op zijn beurt door Reinhard Dreesmann, in 1871 geboren in Haselünne in Hannover. Onder de 32 personeelsleden van Dreesmann waren twee Duitsers; zijn gehele personeel was katholiek. Uiteindelijk kwam door de overname door Reinhard Dreesmann, ook het perceel van Schlüter in handen van de katholieke Duitse winkeliers die dit deel van de Oudegracht overheersten.

Als laatste ogenschijnlijke uitzondering kan de firma A\&B Bohlen worden genoemd. Ook deze winkel zat op de Oudegracht. ${ }^{93}$ Anton Bohlen - geboren in 1824 te Larrelt in Hannover - werkte aanvankelijk in 1850 voor de winkelier Eilard Plagge. ${ }^{94}$ Zowel Bohlen als Plagge kwamen uit de hier beschreven herkomststreek van de winkeliers. Bohlen was echter, in tegenstelling tot de andere winkeliers, calvinistisch; Plagge was luthers. Het aandeel van de Duitsers onder het personeel van deze firma's was veel geringer dan bij hun collega's.

Plagge had met zijn Nederlandse vrouw een winkel in manufacturen op de Oudegracht. In de winkel werkten in de periode 1850-1859 tien personeelsleden, maar behalve Bohlen waren dit geen Duitsers. Bohlen trouwde in 1853 met Anna Maria Schroder - geboren in Utrecht in 1825 - en werd vermeld als koopman. Hij nam de winkel van Plagge over, samen met zijn broer. In de periode 1860-1879 werkten er in de winkel 62 mensen, op één na allemaal Nederlanders. Behalve winkelpersoneel waren er ook modistes, wat erop duidt dat Bohlen confectie in eigen beheer liet maken. In 1880 werd 
de firma omschreven in het Adresboek als confection pour dames. In 1880-1889 waren er 37 personeelsleden, waaronder vier Duitsers. ${ }^{95}$

Het algemene beeld was: grootschalig, handelend in manufacturen en kleding, gesitueerd in de bocht van de Oudegracht, katholiek en met Duits katholiek personeel dat woonde in een kosthuis van de winkel. De kern van de winkeliers vormde een hechte gemeenschap, verbonden door veelvuldige huwelijksbanden. Om die kern heen bevonden zich echter winkeliers die op bepaalde punten van het algemene beeld afweken, en er op bepaalde punten mee overeenkwamen. We herkennen hier het beeld van een groep zoals dat is geschetst in de inleiding: duidelijkheid waar het gaat om de kern van de groep, maar vervaging en een geleidelijke overgang aan de randen.

\section{De kweekvijvers}

De kosthuizen die als kweekvijver fungeerden, speelden in de groepsvorming van de winkeliers een cruciale rol. Door het grote verloop onder het personeel, werden in een zich steeds uitdijende groep ideeën verspreid over hoe de sector georganiseerd en geleid moest worden. Personeel van de bedrijven van Sinkel, Maseland en Van der Sandt begon later voor zichzelf. De kweekvijvers versterkten de niche en maakten deze groter. Tegelijkertijd versterkten ze de samenhang binnen de groep.

De zonen van verwanten en zakenrelaties werkten voor niets en sliepen onder de toonbank. Hun beloning bestond uit de mogelijkheid die ze kregen om te leren hoe ze in de toekomst een eigen bedrijf moesten leiden, en uit financiële steun bij de start van zo'n onderneming. De winst voor de werkgever was, dat hij een loyale en goedkope arbeidskracht had en, na de start van het nieuwe bedrijf, een afzetpunt voor de productie van de eigen ateliers. Waarschijnlijk werd niet aan alle personeelsleden deze mogelijkheid geboden, maar slechts aan getalenteerde mannen die een (familie)band met de bedrijfseigenaar hadden. Hiermee kwamen de vele onderlinge huwelijken niet alleen voort uit contact, maar kunnen ze ook worden gezien als een mogelijkheid om de samenhang binnen de groep te behouden en vergroten.

De overstap van bediende naar zelfstandig winkelier werd alleen gemaakt door het mannelijke winkelpersoneel; de talrijke winkeljuffrouwen werden later geen zelfstandige winkeliersters. Evenmin werden zij de echtgenotes van de voormalige mannelijke winkelbedienden. De winkeljuffrouwen vertrokken - net als een groot deel van hun mannelijke tegenhangers - na verloop van tijd naar elders of maakten de overstap naar een dienstbodebestaan. Bernhardina Krans kwam bijvoorbeeld in 1869 als winkeljuffrouw uit Duitsland en ging werken bij Sinkel. ${ }^{96}$ Reeds twee maanden later ging ze werken als dienstbode bij een Nederlands-Chileense familie op de Biltstraat. Drie maanden daarna vertrok ze weer uit de stad. Voor de vrouwen waren de kosthuizen, met het paternalistische toezicht, een relatief veilige omgeving voor hun eerste kennismaking met de nieuwe stad. Hierdoor waren ze voor hen aantrekkelijk. 


\section{Inlands fabrikaat}

In 1876 hielden boze winkeliers in Londen een demonstratie voor de winkel van William Whiteley. Whiteley noemde zich een universal provider en zijn winkel was hard op weg zich te ontwikkelen tot het eerste grote Engelse warenhuis waar alles te koop was, zoals dat gold voor de Winkel van Sinkel enkele decennia eerder. Zijn kleinere collegawinkeliers zagen Whiteleys assortimentsuitbreiding met lede ogen aan en organiseerden een demonstratie. Ze klaagden over valse concurrentie en broodroof, en trokken onder begeleiding van ketelmuziek aan zijn winkel voorbij. ${ }^{97}$

De Utrechtse kranten meldden geen vergelijkbare uitingen van ongenoegen. Dat is opmerkelijk, omdat een dergelijk protest gecombineerd had kunnen worden met antiDuitse en antikatholieke sentimenten. In het Londense geval ontbrak die mogelijkheid; Whiteley was niet Duits en niet katholiek. Bovendien was er in Londen sprake van een enkele winkel, terwijl het in Utrecht ging om de overheersing van het meest centrale deel van de binnenstad. Slechts één aantijging kwam ik in Utrecht tegen: de Utrechtse manufacturier Van Genderen adverteerde in 1851 voor zijn 'Depot van inlandsche machinaal gebreide goederen' met de opmerking:

In bovenstaande Depôt, in welke Fabrijk alleen Nederlanders werkzaam zijn, zijn verkrijgbaar gesteld alle soorten van onderkleederen voor mannen, vrouwen en kinderen, ook gemaakte Mans-bovenbroeken, Kinderjurkjes, Slaapmutsen in vele soorten, tot zeer geringe prijzen. [...] Geene rondventers, onder welke naam ook, loopen met goederen van het Inlandsche fabrikaat langs de huizen..$^{8}$

Van Genderen zette zich af tegen zijn Duitse concurrenten. Bovendien noemde hij nadrukkelijk de rondventers, in de hoop zijn concurrenten met dit minderwaardige beroep te identificeren.

Het protest tegen Whiteley werd ontketend toen deze, naast zijn zakdoeken, biefstuk te koop aan bood. De grote winkeliers in de Domstad breidden hun assortiment weliswaar naar alle kanten uit, maar onthielden zich van de verkoop van voedingsmiddelen en lokten daarom minder protest uit.

Een tweede verklaring voor het uitblijven van protest lag mogelijk in de advertentie-inkomsten van kranten. Hun advertentiekolommen werden goeddeels gevuld met reclames van de grote Duitse winkeliers (zie afbeelding op de volgende pagina). De kranten zullen er geen behoefte aan hebben gehad om, door het aanwakkeren van een hetze tegen de grote winkeliers, hun kip met de gouden eieren te slachten.

De laatste en meest waarschijnlijke reden voor het uitblijven van protest was, dat de, zoals gezegd, grote winkels een attractie waren, waarvan de kleinere winkeliers meeprofiteerden. Het ontstaan van grote winkels betekende de opkomst van het winkelen als een nieuw tijdverdrijf. Winkelen trok mensen van buiten naar de stad. Een verbetering van het vervoer droeg daaraan bij. Kleine winkeliers profiteerden net zo goed van deze nieuwe ontwikkeling. De grote, geillumineerde winkelpaleizen waren de voor- 


\section{A. H. SCHL̈̈TER \& Co.}

hebben de Eer, de ontvangst te berichten van de nieuwste Modellen

Voorjaars- en Zomer-Mantels, MA I TI I I ES

Châles en Doeken, Robes, ROBES de chambre, PEIGNOItS en ROKKEN, eene prachitige collectie

\section{Zwarte Iyonsche Zijde, \\ eene ruine kenze van de sleuwste}

FRANSCHE, DUITSCHE on ENGEISOHE DAPONSTIOFFEN, OXFORDS, PERCALS en verdere NOUVEAUTES,

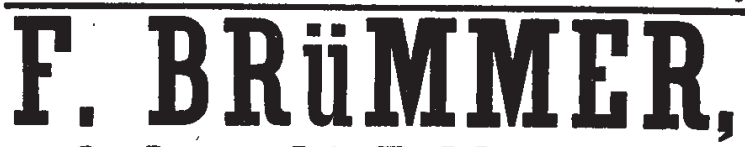

Dudegracht, Bakkerbrugs, heeft reer groote keus in:

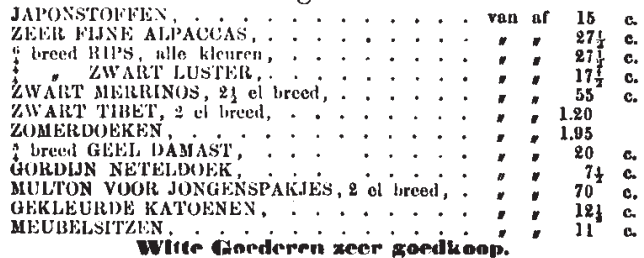

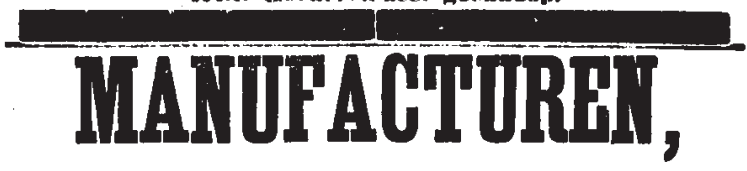

A. HECK,

Oude Grucht. Hoek Drieharingsteeg. G ROO'T E

Driemaandelijksche Opruiming

VAN

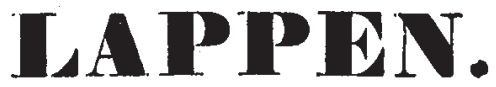

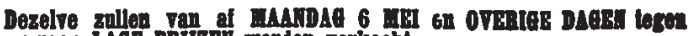

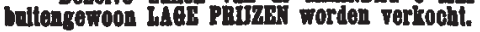

$$
\text { (1) T } \mathbf{N} \boldsymbol{N} \mathbf{N} \mathbf{N}
$$

ecne groote sortecring
Gedeelte van een pagina uit het Utrechtsch Provinciaal en Stedelijk Dagblad van 5-5-1878 met advertenties van de Duitse winkeliers Schlüter, Brümmer en Heck. De advertentiekolommen van de Utrechtse kranten werden voornamelijk gevuld door de Duitse winkeliers. 
naamste attractie, maar de kleine winkeliers hadden ook baat bij deze nieuwe vorm van vermaak.

Opvallend is dat de grote Duitse winkeliers hun zaken merendeels dreven onder hun eigen Duitse familienaam en ze niet voorzagen van een fantasienaam. Namen als De Vlijt en De Zon waren uitzonderingen. Als de winkeliers hun Duitse oorsprong hadden willen ontkennen, waren fantasienamen een voor de hand liggende keuze geweest. Daarvoor kozen de winkeliers niet, maar in hun krantenadvertenties benadrukten ze hun Duitse oorsprong evenmin. De advertenties waren doorspekt met Franse frases. De winkels werden aangeduid als Maison à Rotterdam of Maison à Utrecht. 'Grandes Maisons de Confection et Confection sur mesure pour hommes et enfants' is te lezen in een advertentie uit 1878 (zie advertentie op deze pagina). ${ }^{99}$ In 1885 adverteerde Peek \& Cloppenburg dat zij een grote keuze voorradig hadden in gemaakte kledingstukken, zoals 'demisaisons, winterjassen, jacquets, colberts, pantalons en costumes'. De firma voegde eraan toe: 'Deze artikelen zijn uitsluitend op onze ateliers, onder directie van onze Franse coupeurs vervaardigd. ${ }^{100}$ In 1884 adverteerde het bedrijf: 'Wij berigten bij deze, dat onze coupeur Mr. Kintzelé, van Parijs is geretourneerd, voorzien van de nieuwste modellen voor het aanstaande saizoen. ${ }^{\text {,101 }}$ Kintzelé komt niet in het bevolkingsregister voor, dus is het niet te controleren of hij Frans was of niet. Kintzelé komt wel voor op de loonlijsten van Peek \& Cloppenburg, dus een fictieve figuur was hij niet. Het bedrijf probeerde zich eerder als Frans dan als Duits te profileren. Uit een associatie met Franse mode was immers meer winst te behalen dan met Duitse confectie.

\section{Tot besluit}

De Duitse winkeliers vormden een herkenbare groep binnen de Utrechtse samenleving; ze woonden meestal geconcentreerd, kwamen uit eenzelfde herkomstgebied, trouwden veelvuldig onderling en behoorden tot hetzelfde geloof. Aan de randen tra-

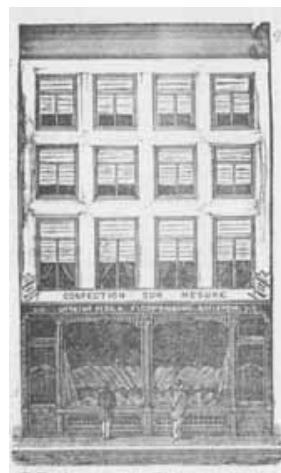

\section{Grandes Maisons de Confection} et Confection sur mesure pour hommes el enfants.
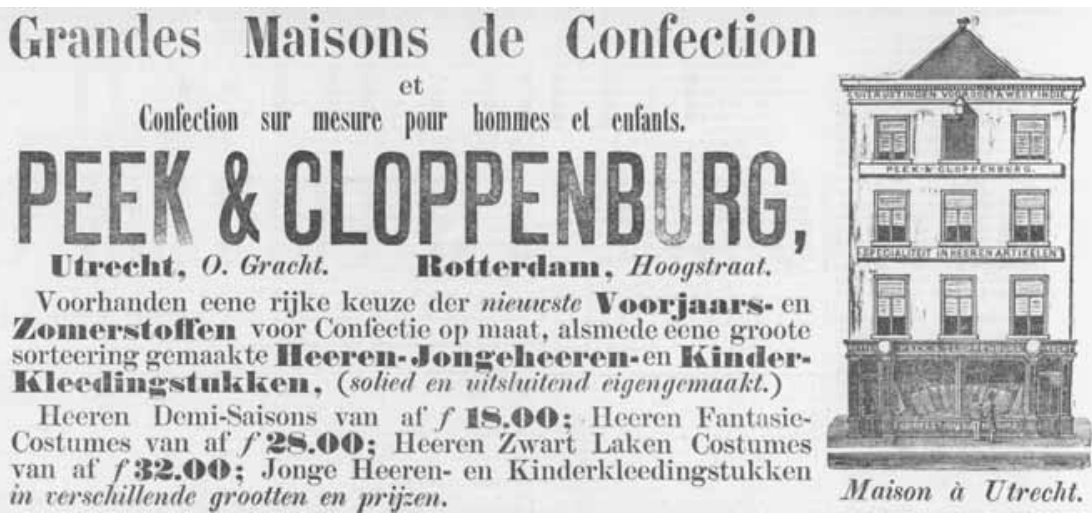

Reclame van Peek \& Cloppenburg in het Utrechtsch Provinciaal en Stedelijk Dagblad van 26-4-1878. 
den variaties op en vervaagde de groep. De winkeliers kenden vooral een sterke onderlinge verzwagering. Opmerkelijk aan de groep Duitse winkeliers en hun personeel is voorts, dat zowel de groep als de herkomststreek in de tweede helft van de negentiende eeuw fors uitdijde.

Bij de Münsterlandse winkeliers en hun personeel, herkennen we in het sterke verloop onder het personeel de transfer of sector-specific human capital, waardoor de niche werd versterkt en gecontinueerd. ${ }^{102}$ Het personeel vormde een zeer mobiele groep, maar dezelfde winkelbedienden kwamen elkaar op tal van plaatsen tegen. De groep was daarom minder aan een plaats gebonden, maar hing toch sterk samen. Eenmaal winkelier geworden, hadden de voormalige bedienden in veel steden contacten.

De grote winkeliers waren niet alleen verkopers van gemaakte kleding, ze waren gedeeltelijk ook producenten van textiel. De textielindustrie werd gekenmerkt door een zeer arbeidsintensief karakter, met slechts beperkte mogelijkheden om door technologische vernieuwingen op arbeidskosten te besparen. Mogelijkheden voor goedkope productie moesten dus worden gevonden in het aanstellen van goedkope arbeidskrachten. Mogelijk waren de kleermakers die voor Peek \& Cloppenburg werkten wel goedkope arbeidskrachten, maar het was in dit geval niet een gedeelde regionale oorsprong die de kledingfabrikant toegang verschafte tot een reservoir van goedkoop personeel. De grote winkeliers vonden hun voordeel in goedkoop winkelpersoneel en niet in goedkope kleermakers.

Het aanvankelijke succes van de winkeliers was het derde punt van belang - naast het verloop van het personeel en de geringe kosten - dat invloed had op de interactie tussen niche- en groepsvorming. Dit succes trok andere, nieuwe immigranten aan, die zich op deze sector wilden of konden toeleggen. Door dit opschuiven naar de niche breidden de groep en de niche zich uit. 


\section{1 'Eene Geldersche keukemeid'}

\section{Vijlenkappers, stukadoors, dienstbodes, spoorbeambten en studenten}

In de Utrechtsche Courant van 1838 verzocht een Duitse dienstbode om werk (zie advertentie op deze pagina). ${ }^{1}$ De 'Geldersche keukemeid', die de advertentie plaatste was niet atypisch. In de tweede helft van de negentiende eeuw kwamen de meeste Duitse dienstbodes in Utrecht uit Kleefsland, ze waren katholiek en voor dienstbodes relatief oud. De advertentie is opmerkelijk omdat de vrouw zich gelijktijdig identificeerde als Gelders en als Duits. Een verklaring hiervoor is dat een aanzienlijk deel van het oorspronkelijke oude Gelderland later bij Duitsland hoorde. Het gaat om het gebied rond de stad Geldern, ten noorden van Venlo. Hier werd tot 1830-1840 officieel in het Nederlands gepreekt. Het is goed mogelijk dat men zich daar tot die tijd ook Gelders bleef noemen. De aanduiding 'Geldersche dienstmeid', zo blijkt uit andere advertenties, heeft echter niet zozeer betrekking op een geografisch gebied, als wel op een type dienstbode: een dienstbode die van het platteland kwam (en niet uit de stad) en daarom gewend was aan hard werken.

In dit hoofdstuk worden de dienstbodes besproken, samen met nog vier andere groepen: vijlenkappers, stukadoors, spoorbeambten en studenten. De Westerwalder potverkopers en de Münsterlandse winkeliers vormden groepen die bestonden uit mannen en vrouwen. Niches die mogelijkheden boden aan zowel mannen als vrouwen vertoonden grote samenhang en continuïteit en versterkten de interactie tussen

\section{(84) ** Eene Geldersche KEUKEMEID; Duitscher "van gebooite en van de Roomsche Gods- dienst, van goede getuigen toorzien, kunnendo goed Koken, Braden en Bahken, op eon Duitschen kagchel, 30 jaren oud, zağ zich gaarne geplanist, hoe eerder hoo liever; in eene fatsoenclijke dienst onverschillig waar, maar in geen Logernent of dergelijke Huizen. Te bevragen an het Bureat dezer Courant.}

Advertentie waarin een 'Geldersche keukemeid' om werk vraagt in de Utrechtsche Courant van 8-1-1838. De dienstbode identificeerde zich gelijktijdig als Duits en Gelders. 
groeps- en nichevorming; vrouwen en mannen werkten immers samen. Bovendien maakten migrantengroepen die uit mannen en vrouwen bestonden, huwelijken binnen de eigen groep mogelijk. Hierdoor werd die integratie vertraagd. Om te toetsen in hoeverre deze beweringen kloppen, wordt hier gekeken naar vijlenkappers, stukadoors, dienstbodes, spoorbeambten en studenten; groepen die bestonden uit mannen of vrouwen. De vijf groepen kunnen worden afgezet op een denkbeeldig continuüm. De vijlenkappers bevinden zich aan de ene kant van het continuüm en vertonen de grootste samenhang: ze woonden min of meer geconcentreerd, kwamen uit een beperkte herkomststreek en waren allemaal luthers. Voor de stukadoors gold dit alles ook, behalve dat zij minder geconcentreerd woonden. Dienstbodes kenden wel een beperkt herkomstgebied en waren allen katholiek, maar binnen Utrecht woonden ze niet geconcentreerd. Spoorbeambten en studenten kwamen uit een grote regio en hadden geen gemeenschappelijk geloof. Ze woonden over de hele stad verspreid.

In tabel 11.1 wordt een overzicht gegeven van het aantal Duitse immigranten dat in deze beroepsgroepen werkzaam was, en het totaal aantal mensen dat volgens de volkstellingen in deze sectoren werkte.

\section{Vijlenkappers}

Vijlmakers of vijlenkappers vormen, historisch gezien, een relatief onbekende groep waarover slechts weinig literatuur is. Het aantal vijlenkappers in Nederland was niet bijzonder groot. Bij de beroepstelling van 1889 werden voor heel Nederland 96 vijlenkappers geteld. ${ }^{2}$ Vijlenkappers werkten niet alleen in Utrecht, maar ook in andere ste-

Tabel 11.1 Vijlenkappers, stukadoors, dienstbodes, spoorbeambten en studenten.

\begin{tabular}{lrrr}
\hline & $\begin{array}{c}\text { Duitsers werkzaam } \\
\text { in hele periode }\end{array}$ & \multicolumn{2}{c}{$\begin{array}{c}\text { totaal aantal mensen } \\
\text { in beroepentelling }\end{array}$} \\
\hline vijlenkappers & $1849-1879$ & 1849 & 1889 \\
stukadoors & $37(100)$ & n.v. & 10 \\
dienstbodes & $25(65)$ & 44 & 143 \\
spoorbeambten & 90 & 2576 & 3659 \\
studenten & 75 & 61 & 929 \\
\hline
\end{tabular}

Opmerkingen n.v. = niet vermeld als afzonderlijke categorie in de volkstellingen

Bij stukadoors gaat het in de volkstellingen om stukadoors en witters. De Duitse immigranten werden echter in de bevolkingsregisters nooit als witter ingeschreven, wat overigens niet betekent dat ze niet als zodanig werkten. Voor cijfers tussen haakjes zie toelichting bij de bespreking van de afzonderlijke groepen.

Bron Bestand van Duitsers in Utrecht en volkstellingen 1849 en 1889. 
den. In het Rotterdamse vreemdelingenregister werd in 1880 bijvoorbeeld Eduard Walther de Groote ingeschreven. Hij was zestien jaar en kwam net als de Utrechtse vijlenkappers uit de Remscheidregio. Hij reisde via Dordrecht terug naar Duitsland. ${ }^{3}$

De econoom Everwijn noemde in zijn beschrijving van handel en nijverheid in $\mathrm{Ne}$ derland uit 1912, behalve voor Utrecht, ook vijlenfabrieken of vijlenkapperijen in Amsterdam (2), Delft (3), Heerenveen (1) en Rotterdam (3). ${ }^{4}$ Niet alle vijlenkappers in Nederland waren van Duitse oorsprong; er waren ook Engelse bedrijven. In $1848 \mathrm{kwam}$ de Engelse vijlenkapper G.H. Watson naar Rotterdam. Hij opende in 1850 zijn bedrijf aan de Zwaanhals bij de Rotte en werd daarmee de oprichter van Watson's vijlenfabriek. ${ }^{5}$

In Utrecht waren tussen 1849 en 1879 eenendertig Duitse mannen en zes vrouwen, die direct tot de groep vijlenkappers gerekend kunnen worden. Dit cijfer geeft echter een enigszins vertekend beeld. De vijlenkappers werkten met een groot aantal hulpkrachten, die met hun een hechte ploeg vormden. Een vijl ging door vijftien tot twintig paar handen, voordat hij klaar was. De hulpkrachten werden echter in beroepstellingen en bevolkingsregisters genoteerd als arbeider, werkman, smid(sknecht) of metselaar (voor de bouw van de ovens). In hun beroepsbeschrijving komt hun band met de vijlenkappers niet tot uitdrukking. De hulpkrachten zijn tot de groep van de vijlenkappers gerekend, omdat ze uit dezelfde dorpen kwamen, bij hen in huis woonden en als getuigen optraden in geboorteakten. De precieze omvang van de groep is onbekend, maar naar mijn schatting behoorden in Utrecht ongeveer honderd mensen tot deze groep. Duitse immigranten overheersten de bedrijfstak volledig. In het Adresboek van 1879-188o komen zes vijlenkappers voor; allemaal zijn ze tot de Duitse groep te rekenen.

De niche van de vijlenkapper steunde vooral op de aard van het product. Vijlen werden in de tweede helft van de negentiende eeuw op grote schaal gebruikt onder meer door goud- en zilversmeden, horlogemakers, paraplumakers, beeldhouwers en schrijnwerkers, slotenmakers, geweermakers, kopersmeden, draadtrekkers, messenmakers, naalden- en speldenmakers, orgel- en pianobouwers, tandartsen, instrumentmakers, pijpenmakers, klokkenmakers, schoenmakers, spiegelmakers en hoefsmeden. In tuchthuizen, of rasphuizen, werden grove vijlen gebruikt voor het raspen van verfhout. ${ }^{6}$ Het merendeel van de vijlen werd gebruikt voor metaalbewerking, maar er waren ook vijlen voor hout, steen en baleinen (voor korsetten en paraplu's). Elke beroepsgroep had tientallen vijlen nodig in verschillende formaten en modellen. Er waren ronde, halfronde, vlakke, driehoekige, vierkante en mes- of snijvijlen en zogenaamde rattenstaartjes. Elke vijl kon dan ook nog eens geleverd worden in zeven hardheden merkwaardigerwijs onderscheiden met termen die doen denken aan suiker, zoals zoet en basterd. Vijlenmakers werkten op voorraad en op bestelling.

In Utrecht zal vanuit de metaalindustrie, de werkplaats van het spoor en de universiteit relatief veel vraag zijn geweest naar vijlen. De Duitse vijlenmakers - gewoonlijk in negentiende-eeuwse bronnen aangeduid als vijlenkappers - die in Utrecht actief waren, hebben echter net als hun collega's in Duitsland, ook voor de bovenregionale of 
nationale markt gewerkt. De centrale ligging van de stad bood daarvoor een ideale uitvalsbasis.

De Duitse vijlenkappers in Utrecht kwamen uit de buurt van Remscheid. In Duitse streken kende de productie van vijlen een lange traditie. Otto Dick schreef in 1925 een uitgebreide studie over de Duitse vijlenkapperij. ${ }^{7}$ Vijlenkappers waren in eerdere tijdvakken te vinden in slechts enkele Duitse streken. In tegenstelling tot andere beroepen, bleef de productie beperkt tot een handvol plaatsen. Dit duidt erop dat de vijlenkappers ook vroeger reeds werkten voor een bovenregionale markt. Vijlen werden gemaakt in Nürnberg, in de nabijheid van Schmalkalden, Remscheid en Zwickau. Tussen de verschillende productiecentra bestond een taakverdeling. Nürnberg legde zich bij-

Kaart 11.1 Herkomststreek van de vijlenkappers.

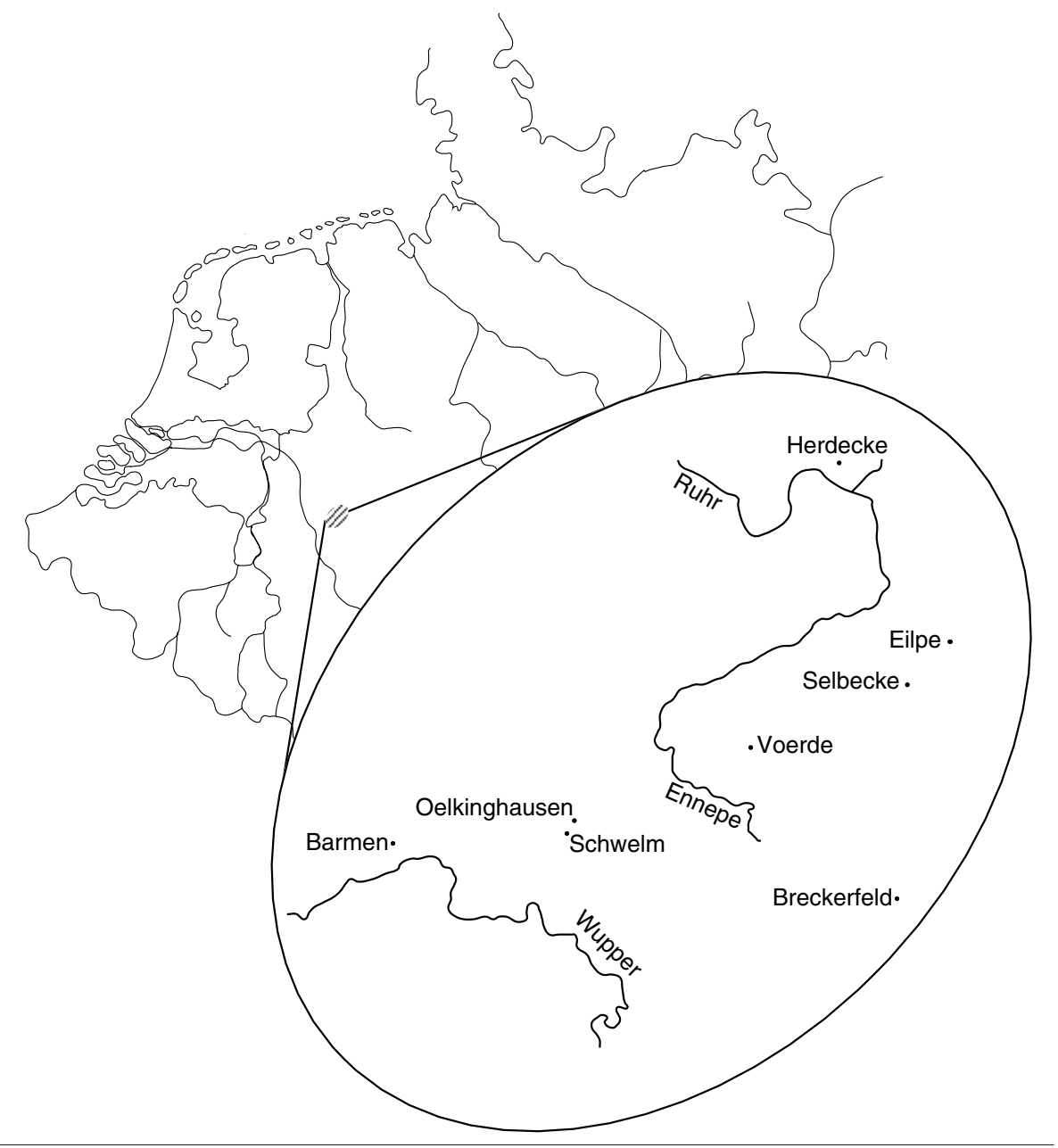


voorbeeld toe op de productie van de zogenaamde roomvijlen, die gebruikt werden door slotenmakers. ${ }^{8}$ De marktverdeling vrijwaarde de Duitse vijlenkappers mogelijk van onderlinge concurrentie, maar niet van buitenlandse. Aan het einde van de achttiende eeuw werd in Duitsland veelvuldig geklaagd over ijzerkramers die Engelse waar verkochten en daarmee Duitse vijlenkappers benadeelden. ${ }^{9}$

De regio rond Remscheid, waar de 'Utrechtse' vijlenkappers vandaan kwamen, ligt in het grensgebied tussen het Bergische Land en het Graafschap Mark, ten zuiden van de Ruhrstad Hagen. Een gedeelte van dit gebied stond bekend als het Ennepedal of het zeismakersdal. De Utrechtse vijlenkappers kwamen overwegend uit de plaatsen Schwelm en Barmen en uit enkele kleinere plaatsen daar in de buurt (zie kaart 11.1).

Wanneer de vijlenkapperij in deze streek een aanvang heeft genomen, is niet duidelijk. In het nabijgelegen Solingen werden reeds vroeg zwaarden en messen gemaakt. Deze industrie bereikte een omvang van aanzien in de twaalfde eeuw, ofschoon er ook reeds in de vijfde eeuw zwaarden werden gemaakt. In de vijftiende eeuw werden in de buurt van Remscheid in ieder geval vijlen geproduceerd. ${ }^{10}$ In het midden van de achttiende eeuw werden hier 150 meestervijlmakers geteld.

De productie van vijlen in deze streek vond tot 1850 plaats in de vorm van huisindustrie. Fabrikanten hadden inrichtingen voor het smeden en harden van de vijlen. Het slijpen, in vorm trekken en kappen van de vijlen werd echter in de huisindustrie gedaan. In de negentiende eeuw werden talloze pogingen ondernomen om het vijlenkappen te mechaniseren. Geen van deze initiatieven had succes. De handkappers verzetten zich tegen de introductie van de machines, omdat ze broodroof vreesden. Probleem met de machines was dat ze niet sneller werkten dan de handkappers, terwijl de eindproducten van mindere kwaliteit waren. Pas in 1890 deden de eerste goede kapmachines hun intrede. Daarna nam het aantal handkappers in snel tempo af. In de omgeving van Remscheid, waar het kappen als huisindustrie bestond, bleef het handmatig kappen langer belangrijk. ${ }^{11}$ Het geringe succes van de mechanisatie van het vijlenkappen leidde tot een grote samenhang binnen de groep.

Fabrikanten legden zich toe op het smeden en harden van vijlen. ${ }^{12}$ De vijlenkappers kregen staven geleverd die grofweg de vorm van een vijl hadden. Ze kwamen in paren, met de uiteinden aan elkaar op de plaats van het toekomstige handvat. De vijlen werden door de kappers naar de waterslijpkotten gebracht, daar geslepen en vervolgens weer opgehaald. Als door het slijpen een glad oppervlak was verkregen, kon er worden gekapt. De vijlenkappers moesten de vijlen eerst inkorten tot een bepaalde lengte en vervolgens in de juiste vorm slaan. Voor zijn werk had een vijlenkapper een aambeeld nodig met kapriemen, beitel, hamers, een slijpsteen, een hardingsoven en een hardingsvat. ${ }^{13}$ Bij het kappen werd elke inkeping afzonderlijk met een beitel gemaakt. De beitel sprong na de eerste harde slag met een lichte terugslag nogmaals tegen de vijl, waardoor een typerend ritme ontstond, dat door de vogels in de Remscheidregio werd geïmiteerd.

Bij het bewerken van de vijlen kwam veel stof vrij, met als gevolg dat vijlenkappers reeds op jonge leeftijd aan stoflongen overleden. ${ }^{14}$ De leertijd voor het vijlenkappen 
werd op vier tot zes jaar geschat. Of de leertijd werkelijk zo lang moest zijn, is niet helemaal duidelijk. In Engeland werden jongens van tien tot twaalf jaar aan het vijlenkappen gezet. Dit lijkt erop te duiden dat de lange leertijd meer met de afscherming van het vak te maken had dan met de tijd die nodig was om de vaardigheid te verwerven. ${ }^{15}$ De kappers werkten zelfstandig, maar wel met meerdere hulpen. Na het kappen brachten ze de vijlen terug naar de fabriek, waar ze gehard, gepoetst en gereedgemaakt werden.

De streek waar de 'Utrechtse' vijlenkappers vandaan kwamen, was dicht bevolkt en bebouwd. In de zeventiende eeuw werd er vanuit deze streek reeds veel handel gedreven op Vlaanderen, Nederland en Frankrijk. ${ }^{16}$ Een reiziger door de streek merkte in 1823 op:

In den Sitten und Gebräuchen der Einwohner bemerkt man eine auffallende Ähnlichkeit mit denen der Holländer, mit welchen durch den Handel fast alle hiesige Häuser in Verbindung stehen. Überall herrscht ein hoher Grad von Reinlichkeit: selbst unbewohnte Zimmer werden wöchentlich 2 mal gewaschen. ${ }^{17}$

De vijlenkappers vormden in de Remscheidregio een zeer gesloten groep. Het beroep ging gewoonlijk over van vader op zoon. Familiebanden waren belangrijk. Er waren veel huwelijken tussen slijpersdochters en slijperszonen. De saamhorigheid van de groep had echter ook een keerzijde. Van slijpers die personeel van buiten de eigen groep aanstelden werd het slijpkot platgebrand. ${ }^{18}$

In Utrecht woonden de vijlenkappers in de betere straten van de stad. Alle vijlenkappers in Utrecht waren luthers. In Utrecht trouwden ze vooral met geloofsgenoten.

Kleinschaligheid en afwezigheid van mechanisatie, leidden ertoe dat de Utrechtse vijlenkapperijen niet voorkwamen in gemeenteverslagen of verslagen van de Kamer van Koophandel. In deze verslagen werden bedrijven vermeld die ofwel beschikten over een stoommachine, ofwel meer dan twintig arbeiders hadden, of beide. Vijlenkapperijen vielen niet in deze categorieën.

De vijlenkappers in Utrecht kwamen vrijwel allemaal als alleengaande mannen. Er was een belangrijke uitzondering. Maria Plett kwam tussen 1842 en 1848 uit Schwelm, met haar echtgenoot en twee kinderen. ${ }^{19}$ Haar echtgenoot werd genoteerd als een vijlenkapper. Hij stierf kort na de komst van de familie naar Utrecht, waarna zijn vrouw werd ingeschreven als vijlenkapster. Ze had meerdere, inwonende, vijlenkappers en hulpkrachten in dienst. Na enige tijd hertrouwde ze met een typograaf, die net als zij uit Schwelm kwam. Na dit tweede huwelijk verliet ze het bedrijf. Haar dochter trouwde met een smid en haar zoon werd klerk bij het spoor. Het bedrijf werd voortgezet door haar broer Johannes Plett. Hij werd aanvankelijk ingeschreven in het bevolkingsregister als vijlenkapper en later als vijlenfabrikant. Zijn zoon en kleinzoon zetten het bedrijf voort. Enkele werknemers van de firma Plett begonnen naderhand voor zichzelf met een vijlenkapperij.

De vijlenkappers vormden binnen Utrecht een groep met een duidelijke samenhang. Ze woonden geconcentreerd, kwamen uit een klein hecht afstotingsgebied en 
hadden hun geloof gemeen. De migratie bestond overwegend uit mannen; uit de herkomstdorpen kwamen bijna geen vrouwen. De Duitse vijlenkappers trouwden buiten de eigen groep en keerden niet naar hun herkomststreek terug om daar te trouwen. De samenhang binnen de groep werd bevorderd door het specialistische product dat de vijlenkappers maakten, de vaardigheden die voor de productie waren vereist en het geringe succes van pogingen om de bedrijfstak te mechaniseren.

\section{Stukadoors}

De Duitse stukadoors in Utrecht kwamen - net als die in andere Nederlandse plaatsen - als trekarbeiders uit Oldenburg. ${ }^{20}$ 'Die Entstehungszeit dieser Wanderarbeiter liegt im Dunkeln', schreef Johannes Tack in $1902 .^{21}$ Er waren volgens deze auteur geen bewijsstukken waarmee het begin van hun trek gedateerd kon worden. Hij nam aan dat ze er reeds waren aan het begin van de negentiende eeuw. Jan Lucassen vond echter van deze groep nog geen sporen in 1811. Hun migratie naar Nederland dateert derhalve waarschijnlijk van na die tijd. ${ }^{22}$

In de tijd dat Tack schreef, was de trek van de stukadoors vrijwel opgehouden omdat er dichter bij huis werkgelegenheid was. Belangrijker was, volgens hem, dat er in Nederland ook meer concurrentie was ontstaan. Er werd meer dan voorheen met olieverf gewerkt, waarmee bijvoorbeeld patronen van imitatiemarmer op de muren werden gemaakt en ook behang werd meer gebruikt. Bovendien hadden enkele stukadoors die oorspronkelijk uit Oldenburg kwamen, zich blijvend in Nederland gevestigd. Aanvankelijk werkten deze Duitse meesters nog met Duitse gezellen; geleidelijk namen ze ook Nederlandse knechts in dienst. Volgens Tack werkten omstreeks 1902 nog enkele Oldenburgse stukadoors in Amsterdam, maar 'steht die Kunstfertigkeit dieser Leute nicht mehr auf der früheren Höhe'. ${ }^{23}$ Ze waren afgezakt naar het niveau van de witters. Dit beeld komt niet helemaal overeen met wat de Duitse onderzoeker Sahner schreef over de jaren twintig van de twintigste eeuw. Volgens hem waren toen in ieder geval de meeste stukadoors in Friesland nog Duits. In 1920 werden nog 3000 Duitse stukadoors gevraagd, die door de weinige Nederlandse collega's niet als een bedreiging werden aangemerkt. Twee jaar later probeerden de Nederlandse stukadoors hun Duitse collega's te weren, in de hoop zo de lonen te verhogen. De georganiseerde ondernemers stelden zich daartegen teweer. ${ }^{24}$ Sahner ziet in het beroep van de stukadoor een langere Duitse traditie dan Tack.

De migratie van stukadoors naar Amsterdam was omvangrijker dan die naar Utrecht. In 1850 waren er in Amsterdam 174 Oldenburgse stukadoors, twee jaar later waren er $189 .{ }^{25}$ In 1868 was het cijfer min of meer gehalveerd en vervolgens daalde het naar 10 in $1874 .{ }^{26}$ De stukadoors kwamen gewoonlijk tussen half maart en eind april en vertokken tussen eind juni en november. 
Binnen het vak van stukadoor vonden verschuivingen plaats. In de achttiende eeuw maakten stukadoors uit de hand wand- en plafondversieringen. In een Amsterdams rapport uit 1898 werd geschreven:

Wat het plafondwerk betreft, behoorde dit vak eenmaal tot de kunstvakken. De tijden echter, waarin door den stukadoor die schoone plafonds werden vervaardigd, welke wij in oude huizen nog kunnen bewonderen, zijn sedert lang voorbij. Het maken van onze tegenwoordige zooveel eenvoudiger plafonds is niet eenmaal geheel zijn werk. De modellen daarvoor toch worden op de stukadoorswerkplaats thans door speciale modelmakers of beeldhouwers vervaardigd of van buiten ingevoerd. En de taak van den stukadoor op de werkplaats bepaalt zich tot het maken van gietvormen en afgietsels. In de lateren tijd heeft de algemeene neiging tot goedkoopere productie hem gedeeltelijk ook dat werk uit handen genomen: want zoo goed als alle ornamenten voor den eigenbouw betrekt men thans uit de fabriek. ${ }^{27}$

De achttiende-eeuwse stukadoors, die de prachtige wand- en plafondversieringen hadden gemaakt die in dit Amsterdamse rapport worden beschreven, waren geen Oldenburgers. Hun migratie dateerde immers van een latere periode. Waarschijnlijk waren het Italianen.

In de negentiende eeuw werden gipsen ornamenten in werkplaatsen gegoten en kreeg de stukadoor de taak deze afgietsels aan elkaar te passen zonder al te veel zichtbare naden. Aan het einde van de negentiende eeuw veranderde de mode en verdwenen de wand- en plafondversieringen, waarna de stukadoors alleen nog gladde oppervlakken hoefden te pleisteren. Deze verandering van smaak leidde ertoe dat stukadoors minder werk kregen. ${ }^{28}$

Ook in het stukadoorsvak doet zich het verschijnsel voor, dat in eenzelfde vak twee categorieën van werklieden bestaan, die in bekwaamheid, positie en opleiding verschillen. De stukadoors in de revolutiebouw behoeven eene zeer geringe opleiding. ${ }^{29}$

Het stukadoorsvak werd tegen het einde van de negentiende eeuw minder seizoensgebonden. 'En houdt dan soms het werk in den nieuwbouw's winters op, dan kunnen nog op de werkplaats ornamenten in voorraad worden gemaakt. ${ }^{30}$

Omstreeks 1870 was er door de revolutiebouw veel vraag naar stukadoors. Voor Amsterdam werd opgemerkt:

Oudergewoonte kwamen nog geruimen tijd, wanneer te bouwen viel, metselaars en stukadoors jaarlijks bij den aanvang van het seizoen vooral uit NoordBrabant en de aan Nederland grenzende Duitsche provincies naar Amsterdam 
en verlieten de stad weder tegen het najaar, om op het platte land van het oververdiende geld den winter door te brengen. ${ }^{31}$

Een aanhoudende vraag naar metselaars en stukadoors leidde er echter toe dat deze seizoensmigranten zich permanent in Amsterdam vestigden.

Toen nu de stadsuitbreiding bleef aanhouden, hebben zich vele van die werklieden voor goed te Amsterdam gevestigd. Anderen vonden in de verbeterde toestanden en de verlevendiging van den bouw in hun geboorteplaats aanleiding om niet meer naar Amsterdam te komen. In den laatsten tijd heeft deze jaarlijksche trek zoo goed als geheel opgehouden. ${ }^{32}$

Utrecht kende in de tweede helft van de negentiende eeuw, net als Amsterdam, een grote vraag naar stukadoors. In het Provinciaal Verslag werd in 1862 over Utrecht geschreven:

De Stukadoors genieten nog steeds hooger loon dan andere werklieden, niettegenstaande de kunst en oefening, die vroeger in dit vak gevorderd werk, thans onnoodig is geworden, en de aan te brengen ornamenten naar buitenlandsche modellen gegoten worden. ${ }^{33}$

Klachten waren er echter ook.

Het ambacht van Stucadoor is niet vooruitgegaan, hoofdzakelijk ten gevolge van het toenemend gebruik van voorwerpen van terra cotta in allerlei gegoten ornamenten, die op vlak werk worden aangebracht. ${ }^{34}$

Slecht ging het echter niet.

Stukadoors hadden onafgebroken werk. Het merendeel der modellen en ornamenten wordt van elders, voornamelijk uit België, ingevoerd, daar bekwame modelmakers bij ons niet aanwezig zijn; voor het ontwerpen van een fraai ornament is meer kennis, ondervinding, smaak en kunstgevoel noodig, dan men bij onze gewone werklieden vindt; bij niet te nauwe prijsbepaling maakt men echter zeer goede lijst- en compartimentwerken. ${ }^{35}$

Jelle van Lottum telde in Utrecht, in de periode 1829-1839, 29 Duitse stukadoors. Daarnaast waren er drie Italiaanse, en een stukadoor uit Italiaanssprekend Zwitserland. ${ }^{36}$ Tussen 1849 en 1879 vinden we in Utrecht 25 Duitse stukadoors. Er is dus sprake van een vrij grote continuïteit wanneer het gaat om de omvang van de groep. Van de 25 Duitse stukadoors trouwden er vijf met een Duitse vrouw en negen met een niet-Duitse, de 
overigen trouwden niet. Vrijwel alle stukadoors waren luthers; hetzelfde gold voor hun Duitse partners, maar de niet-Duitse partners waren calvinistisch.

De Duitse stukadoors in Utrecht kwamen uit het Groothertogdom Oldenburg uit de dorpen Littel, Wardenburg, Rödenbeck, Dingstede, Grossenkneten en Döhlen. Dit waren kleine, dicht bij elkaar gelegen plaatsen ten zuiden van de stad Oldenburg. ${ }^{37}$ Daarnaast waren er stukadoors die tijdelijk in Utrecht verbleven en niet in het bevolkingsregister werden ingeschreven. De stukadoorsbaas Abeling noemde in 1876 een aantal van veertig tijdelijk aanwezige Duitse stukadoors. ${ }^{38}$

In de volkstelling van 1849 komen in totaal 44 stukadoors voor; in de telling van 1889 zo'n honderd meer. Duitsers waren getalsmatig in vergelijking met dit totaal geen onbetekenende groep. Hierbij moeten twee kanttekeningen worden gemaakt. Ten eerste omvat het cijfer van de volkstelling ook witters. Aangezien Duitse stukadoors in de bevolkingsregisters nooit als witters worden genoteerd, betekent dit dat het overwicht van de Duitse stukadoors nog groter is dan het in eerste instantie lijkt. Een tweede, belangrijkere kanttekening is, dat de 'Nederlandse' stukadoors gedeeltelijk van Duitse origine waren. Dit gold bijvoorbeeld voor de lutherse weduwe Neuhaus, die met haar kinderen een stukadoorsbedrijf op het Oudkerkhof had. Neuhaus en haar kinderen waren in Nederland geboren, maar haar man, Johan Neuhaus, kwam oorspronkelijk uit Oldenburg. Deze Nederlandse stukadoors stonden dus dicht bij de Oldenburgse groep.

De Duitse en Nederlandse stukadoors werkten samen. In het Adresboek van 1850 komen zeven stukadoors voor. Zoals eerder opgemerkt gaat het in deze bron slechts om werkgevers en zelfstandigen. Twee van hen waren Duits, Heidenreich en Lüschen. Heidenreich nam samen met een van de Nederlandse stukadoors uit het Adresboek Overklieft - het bedrijf van de weduwe Neuhaus over. ${ }^{39}$

Er waren tussen de stukadoors ook andere banden. Johan Heidenreich - geboren in 1806 in Oldenburg - had zijn bedrijf op het Oudmunsterkerkhof in wijk F. Hij was getrouwd met Geertruida Bakkenes. ${ }^{40}$ Hun kinderen werden geboren in Utrecht tussen 1839 en 1851 . Nadat Johan Heidenreich in 1861 was overleden, werd zijn weduwe in het Adresboek vermeld als stukadoorster. Behalve Johan, woonde in Utrecht ook nog Gerhard Heidenreich. ${ }^{41}$ Niet alleen Johan Heidenreich huwde met een meisje Bakkenes, maar ook de Oldenburgse stukadoor Johan Garms; hij trouwde met Catharina Bakkenes. ${ }^{42}$ De Oldenburgse stukadoor Christiaan Lüschen vond een tijdlang onderdak bij haar vader, de timmerman Otto Bakkenes, geboren in Driebergen.

Een belangrijke stukadoor in Utrecht was de Duitser Johan Abeling. Hij werd in 1824 geboren in Rödenbeck in Oldenburg; hij trouwde met Catharina IJperlaan en na haar dood in 1865 met Jacoba Hogerhout. ${ }^{43}$ Zijn zes kinderen werden tussen 1852 en 1862 in Utrecht geboren. Abeling was luthers, zijn vrouwen hervormd. De kinderen werden ook als hervormd in het bevolkingsregister ingeschreven. Aanvankelijk was zijn bedrijf gevestigd op het Vredenburg in Utrecht, later verhuisde het achtereenvolgens naar de Hoogjacobijnenstraat in wijk $\mathrm{H}$, de Nauwewatersteeg in wijk C en het Predikherenkerkhof in wijk $\mathrm{H}$. Abeling werd in de bevolkingsregisters vermeld als stukadoor en stukadoorsbaas. Een broer van Johan Abeling - Herman - woonde ook in 
Utrecht, eerst bij zijn broer en later zelfstandig met zijn gezin. Hij gaf toen onderdak aan andere stukadoors uit Oldenburg. Het bedrijf van Johan Abeling kende van de Utrechtse stukadoorsbedrijven de grootste continuïteit. In 1886 ging Johan Abeling met zijn zoon Herman een vennootschap aan. ${ }^{44}$ Onder de andere stukadoorsondernemingen was het verloop groter.

De stukadoors Christiaan en Johan Diederick Lüschen woonden in 1850 op 't Hoogt. ${ }^{45}$ Christiaan Lüschen ging in 1853 naar de Mijlpoort in wijk C en vervolgens vinden we hem als kostganger bij Otto Bakkenes. Johan Diederick Lüschen ging naar Arnhem. In dezelfde periode vinden we in Utrecht nog een stukadoor met de naam Lüschen: Johann Heinrich. ${ }^{46}$ Hij woonde op de Predikherenstraat in wijk H. Hij trouwde met Jannigje Veldhuizen, ${ }^{47}$ een naaister die in 1851 uit Driebergen was gekomen met twee buitenechtelijke kinderen. Nog in hetzelfde jaar werd zoon Christiaan geboren en vertrok het hele gezin naar Soest. Jannigje Veldhuizen en haar twee eerste kinderen stonden genoteerd als hervormd, zoon Christiaan als luthers.

In de Donderstraat in wijk D vonden twee Oldenburgse stukadoors - Knoop en Eilers - onderdak bij de Duitse tapper Johannes Schröder. ${ }^{48}$ Schröder hield een kosthuis voor mannen; het merendeel van zijn kostgangers was Nederlands. De Nederlandse steenhouwer Matheus Pau dreef ook een kosthuis voor mannen, waar drie Oldenburgse en enkele Nederlandse stukadoors onderdak vonden. ${ }^{49}$

De stukadoor Johan Hollmann kwam naar Utrecht met zijn vrouw en zijn in Oldenburg geboren zoons Ludwig en Carel. ${ }^{50}$ Hij was de enige stukadoor die in familieverband migreerde. De latere kinderen werden geboren in Amersfoort. In 1866 werd zijn dochter Emma in Utrecht geboren. De familie woonde op de Weerdsingel in wijk M. In 1869 vertrok Hollmann zonder zijn familie naar Leeuwarden. Zijn vrouw en kinderen bleven nog enkele jaren in Utrecht. Zijn vrouw werd niet genoteerd als verlaten vrouw; bij haar inschrijving werd vermeld daar haar man in Leeuwarden woonde. In 1873 verhuisde de rest van de familie daarheen.

De Duitse stukadoors vormden, zoals blijkt uit deze gedetailleerde beschrijvingen, een groep met enige samenhang. Ze kwamen uit een kleine herkomststreek. Tussen hen bestonden veelvuldige (familie)banden. Binnen de stad Utrecht woonden de stukadoors verspreid, zij het dat er wel concentraties zijn aan te wijzen rond bepaalde werkgevers en kosthuizen. Opvallend is dat zij bijna allemaal met Nederlandse vrouwen trouwden. Het netwerk van de stukadoors was, net als het netwerk van de winkeliers, gedeeltelijk een netwerk van familieleden. Verschil met de winkeliers was, dat de stukadoors vrijwel allemaal met een niet-Duitse vrouw trouwden. De vrouwen waren merendeels hervormd en niet, zoals bij de vijlenkappers, luthers. Nederlandse en Duitse stukadoors hadden hechte banden met elkaar, waarbij gold dat een gedeelte van de Nederlandse stukadoors feitelijk van Duitse origine was. 


\section{Dienstbodes}

Er waren in Utrecht tussen 1849 en 1879 negentig Duitse dienstbodes. Daarmee hadden deze vrouwen slechts een klein aandeel in het totaal aantal dienstbodes; in 1849 werden in totaal 2.576 dienstbodes geteld. Bij de telling in 1889 waren er ruim duizend meer: 3.659. De negentig Duitse dienstbodes vallen daarbij in het niet. Dienstbodewerk was in de negentiende eeuw in Nederland geen niche van immigranten, zoals het dat wel was in de vs. ${ }^{51}$ Duitse dienstbodes hadden in de tweede helft van de negentiende eeuw in Nederland niet speciaal een goede naam. In de Verenigde Staten was dat wel het geval en gold de Duitse dienstbode als ijverig en hardwerkend. ${ }^{52}$ In Amerikaanse kranten werd in deze periode veelvuldig nadrukkelijk gevraagd om een Duitse dienstbode.

In de advertentie, waarmee dit hoofdstuk opende, werden weliswaar de gangbare kenmerken van Duitse dienstbodes in Utrecht samengevat, maar de advertentie zelf is uitzonderlijk. In de lokale Utrechtse krant werd veelvuldig geadverteerd, zowel door mensen die een dienstbode zochten, als door dienstbodes die zichzelf aanboden. De vragers hadden echter, getuige de advertenties, een voorkeur voor een protestantse dienstbode, terwijl de aanbieders geen geloof vermeldden of verklaarden protestants te zijn. Als uitzondering op deze regel vinden we in latere periodes verspreid wel enkele advertenties waarin gericht om een katholieke dienstbode werd gevraagd. In de krant van 17 maart 1871 was, bijvoorbeeld, te lezen: 'Met Mei wordt tegen goed loon gevraagd eene Roomsch-Cath. Dienstbode, die flink werken en een burgerpot koken kan. ${ }^{53}$ Opvallend is dat hier net als in de advertentie van de 'Geldersche' keukenmeid uit 1838 de vaardigheden op kookgebied worden genoemd. Gewoonlijk ontbrak deze eis in advertenties. De nadrukkelijke vermelding van het geloof in de advertenties, zowel door de vragers als de aanbieders, betekent dat de markt van dienstbodes in dit opzicht gesegmenteerd was. De signatuur van de krant kan in dit geval de inhoud van de advertenties overigens wel hebben beïnvloed..$^{54}$ De Utrechtsche Courant had een protestantse signatuur. In het katholieke blad De Tijd vinden we meer advertenties voor katholiek personeel.

Van de Duitse dienstbodes waren er 37 reeds vóór 1850 aanwezig of kwamen tussen 1850 en 1859 . Zij werden geboren tussen 1788 en 1838 ; het merendeel van hen werd geboren tussen 1816 en 1822 en was dus in dit tijdvak tussen de 28 en 43 jaar oud. In de periode 1860-1879 kwamen er 53 nieuwe dienstbodes bij. Zij werden geboren tussen 1807 en 1862; het merendeel tussen 1842 en $1850 .^{55} \mathrm{Zij}$ waren dus iets jonger dan de eerdere nieuwkomers (18 tot 37 jaar). Duitse dienstbodes waren gemiddeld ouder dan hun niet-Duitse collega's.

Duitse dienstbodes kwamen terecht in alle delen van de stad, maar - niet erg opvallend - vooral in de betere wijken F en G. In de wijken D, H en I waren ze ook goed vertegenwoordigd. In de slechtere wijken B, C, E en K waren veel minder Duitse dienstbodes. Er is enige overlap tussen Duitse winkelmeisjes die in de grote zaken werkten en dienstbodes. Enkele vrouwen die bijvoorbeeld eerst voor de winkel van Sinkel werkten, 
werden naderhand dienstbode. Uit niets blijkt een uitstroom naar de geregistreerde prostitutie (die wel verondersteld is). ${ }^{56}$

Het dienstbodewerk in Nederland verschilde van dit werk in Duitsland. ${ }^{57}$ In meerdere Duitse streken waren dienstbodes nog onderworpen aan reeds lang bestaande, strenge regels, de zogenaamde Gesindeordnungen. ${ }^{58}$ Volgens deze regelgeving mochten ze door hun werkgeefster bestraft worden en konden ze om tal van redenen worden ontslagen. Er waren geen regels die hun gezondheid beschermden, of waarin werd bepaald hoeveel zij te eten moesten krijgen en welke voorzieningen er moesten zijn voor hun huisvesting. Wanneer een dienstbode zonder toestemming haar werkgeefster verliet, kon ze worden teruggebracht door de politie. De politie hield een administratie bij, Dienstbücher genoemd, waarin namen van werkgevers en opmerkingen over het gedrag van de dienstbode werden genoteerd. De Dienstbücher maakten het moeilijk om al te frequent van werkgever te wisselen. Werk als dienstbode in Nederland was voor Duitse vrouwen door het ontbreken van Gesindeordnungen en Dienstbücher ongetwijfeld aantrekkelijk.

Dienstbodewerk bood aan immigrantes een aantal voordelen. De dienstbodes kwamen terecht in wat gezien kon worden als een beschermde omgeving. Het was een manier om snel met taal en gewoonten van de ontvangende samenleving bekend te raken. Als een nadeel kan worden gezien dat dienstbodes vrij geïsoleerd werkten. Ze woonden verspreid over de stad en hadden weinig vrije tijd.

De Duitse dienstbodes in Utrecht kwamen overwegend uit een streek nabij de Duits-Nederlandse grens (zie kaart 11.2). Het merendeel van de bewoners van deze streek was katholiek. De streek was een semi-enclave in geografische zin, die zowel in het westen als in het noorden aan Nederland grensde. Uit deze streek kwamen vrijwel alle Duitse dienstbodes die in de periode van 1849 tot 1879 in Utrecht werkten. Deze geconcentreerde herkomst kan verklaard worden uit een oudere migratietraditie. Utrecht kende sinds de overgang naar het protestantisme in 1655 een beperking op de vestiging van katholieke immigranten. In de loop der tijd werd deze beperking voor binnenlandse immigranten versoepeld - zo er al ooit strak de hand aan was gehouden maar voor buitenlandse immigranten werd ze gedeeltelijk gehandhaafd. Uitzonderingen waren echter mogelijk en werden ruimhartig toegepast. Vanwege de grote vraag werd een uitzondering gemaakt voor katholieke Duitse dienstbodes. ${ }^{59}$ De migratietraditie die zo ontstond, zette zich voort in de negentiende eeuw. Het gevolg was dat, terwijl in de negentiende eeuw vrijwel alle Duitse dienstbodes, en daarmee 27 procent van alle Duitse vrouwelijke immigranten in Utrecht voor wie een beroep vermeld wordt, uit deze streek kwamen, slechts acht procent van de ongeveer duizend Duitse mannelijke immigranten uit dit gebied afkomstig was.

Duitse dienstbodes die naar Utrecht kwamen, moesten daar een werkgever zien te vinden. In het begin van de negentiende eeuw werd in oktober op de Neude de zogenaamde Jutjesdag gehouden. Op deze dag verzamelden zich op dit plein vrouwen van buiten de stad. Zij hielden een takje in hun hand, dat werd afgebroken als ze een 
dienstje hadden gevonden. ${ }^{60}$ In de tweede helft van de negentiende eeuw bestond deze dienstbodemarkt echter niet meer. ${ }^{61}$

Dienstbodes konden ook werk vinden via zogenaamde besteedsters of bezorgsters van dienstbodes. ${ }^{62}$ In Utrecht waren er in 1849 zeven besteedsters. Dat aantal nam toe naar twaalf in 1859, om vervolgens af te nemen tot elf in 1869 en opnieuw zeven in 1879. De ondernemingen van de besteedsters kenden een grote continuïteit. Sommige bleven twintig tot dertig jaar bestaan. De besteedsters gaven, getuige de inschrijvingen in het bevolkingsregister, geen onderdak in hun eigen woning aan dienstbodes.

Vóór 1870 kwam het overgrote deel van de besteedsters uit de stad Utrecht (14 van de 20). Na 1870 kwamen drie van de veertien besteedsters uit de stad. Van de zeven besteedsters die Utrecht telde in 1849, waren zes protestant en een katholiek. De besteed-

Kaart 11.2 Herkomststreek van de dienstbodes.

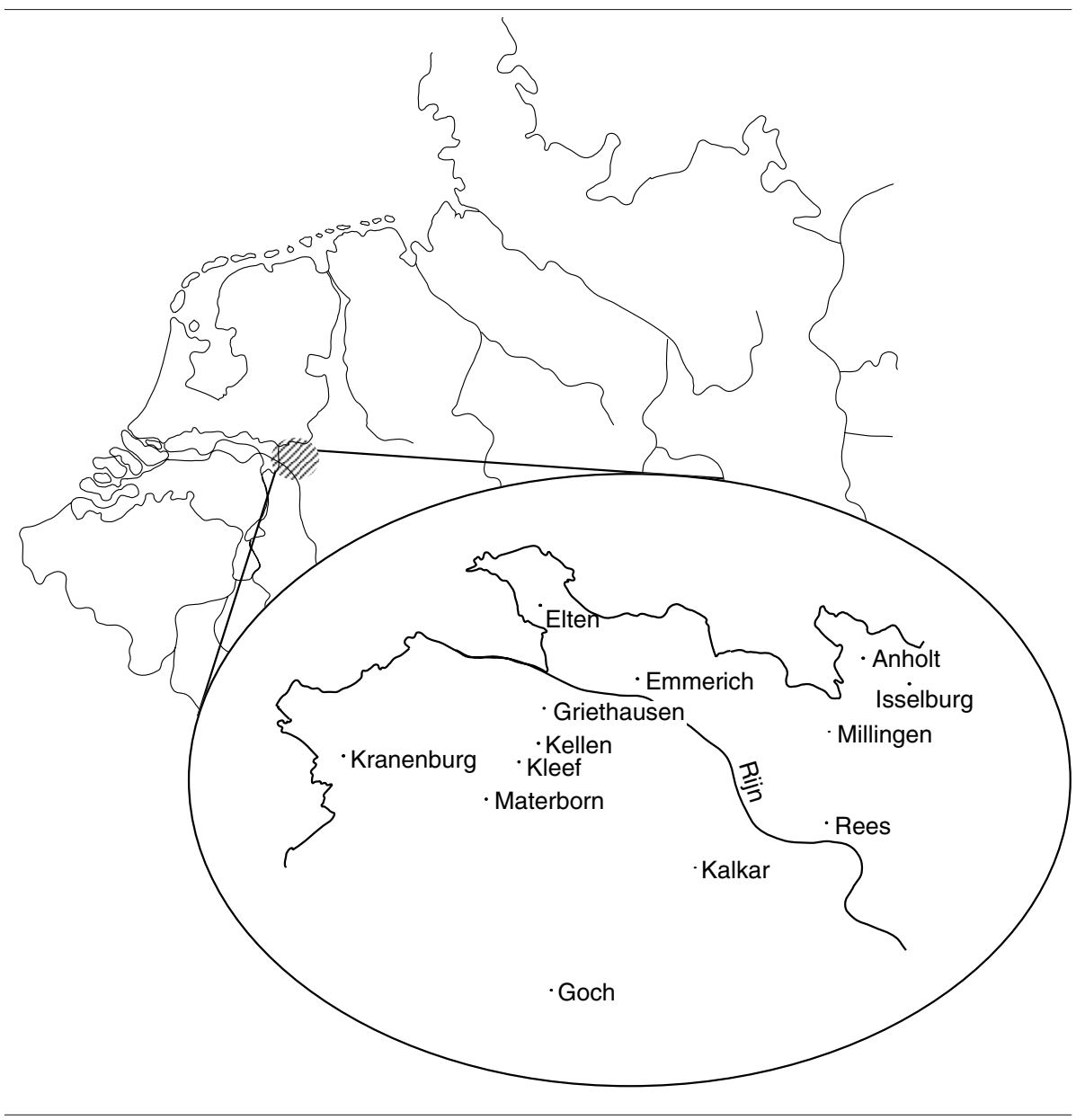


sters waren te vinden in alle delen van de stad (in 1868-1869 in de wijken B, D, E, G, H en I en in 1879-1880 in A, C, D, G en H).

Er was slechts één Duitse vrouw onder de besteedsters; Wilhelmina Betmann. ${ }^{63} \mathrm{Zij}$ woonde op 't Jansdam in het centrum van de stad en was getrouwd met de Rotterdammer Hendricus Niemeyer. Ze moet tussen 1822 en 1848 naar Utrecht zijn gekomen. Haar oudste dochter werd in 1822 in Emmerich geboren; haar jongste dochter in 1848 in Utrecht. Wilhelmina Betmann werd zelf geboren in Emmerich en dus in dezelfde streek als waar het merendeel van de dienstbodes in Utrecht vandaan kwam. De dienstbodes waren echter merendeels katholiek, terwijl Betmann protestants was.

Wilhelmina Betmann-Niemeyer komt maar één jaar voor in het Adresboek als besteedster (1872-1873). In het bevolkingsregister werd bij haar geen beroep vermeld. Noch het ontbreken van een beroepsvermelding in het bevolkingsregister, noch de eenmalige vermelding in het Adresboek, sluiten uit dat ze het beroep van besteedster veel langer heeft uitgeoefend. Mogelijk was het werk voor haar slechts een nevenbezigheid en wellicht wisten haar klanten haar ook wel te vinden zonder de reclame van het Adresboek. Behalve Wilhelmina Betmann-Niemeyer was er nog een besteedster met een 'Duitse' band: Dina Weevers, geboren in Utrecht en wonende aan de Oudegracht, was gehuwd met de koperslager Hugo Wanting, geboren in Oldenburg in Duitsland. ${ }^{64}$ Zij kwam langer voor in de Adresboeken.

De besteedsters maakten in de tweede helft van de negentiende eeuw een zekere professionalisering door. In het midden van de negentiende eeuw werd door de besteedsters niet in de lokale krant geadverteerd. Omstreeks 1880 verschijnen er advertenties van meer professionele bemiddelingsbureaus.

Dienstboden!!! Zonder onkosten kan men overal tegen hoog loon buiten de stad, flinke Diensten bekomen. HEEREN!! DAMES!! Behoeven in geen geval, van af heden gelden vooruit te betalen, ter verkrijging van Dienstboden, uitgenomen Dagmeiden. Adres Maatschappij De Vraagbaak, Verbreede Viesteeg, C 170 bovenhuis. De Directie A.H de Kreek \& co. ${ }^{65}$

$\mathrm{Na} 1870$ werden de krantenadvertenties belangrijker voor de bemiddeling van dienstboden. ${ }^{66}$ Afschaffing van het krantenzegel in 1867 , leidde tot daling van de prijs van de krant. Een advertentie kostte aan het einde van de negentiende eeuw een kwartje. De afname van het aantal besteedsters viel samen met een toename van het aantal krantenadvertenties. In 1850 werden er in de Utrechtsche Provinciale en Stadscourant 23 advertenties geplaatst waarin een dienstbode werd gevraagd en twaalf waarin een dienstbode zich aanbood. Tien jaar later waren er 103 vragers en 27 aanbieders en in 1870 was dit cijfer opgelopen tot 542 vragers en 148 aanbieders. Weer tien jaar later was het aantal vragers meer dan zesduizend, waartegenover bijna drieduizend meisjes stonden die zich aanboden als dienstbode. De advertenties hadden de bemiddeling van besteedsters vrijwel overbodig gemaakt. ${ }^{67}$ 
De Duitse dienstbodes kunnen worden vergeleken met hun Utrechtse collega's. Ze verschilden, zoals gezegd, van de Utrechtse dienstbodes in leeftijd. De jongste Utrechtse dienstbodes waren veertien jaar; de Duitse waren over het algemeen ouder. Utrechtse dienstbodes bleven gewoonlijk een jaar, maar ook wel korter bij hun werkgever. Onder de Utrechtse dienstbodes waren vrouwen die binnen enkele jaren in tientallen huizen hadden gewerkt. Vertrek naar buiten de stad was ongebruikelijk. De Duitse dienstbodes waren trouwer aan hun werkgever. Als voorbeeld kan Maria Gronwal worden genoemd. ${ }^{68} \mathrm{Zij}$ werd in 1811 geboren in Friesoythe in Oldenburg. In Utrecht werkte ze meer dan dertig jaar voor de chique familie Van Tuijl van Serooskerken.

Een deel van de Duitse dienstbodes ging terug naar de streek van herkomst. Het merendeel bleef echter in Utrecht of reisde door naar een andere Nederlandse bestemming. Duitse dienstbodes trouwden veelal met Nederlandse mannen. Geen van de Duitse dienstbodes in de Domstad trouwde met een Duitse partner. Een groot deel van de dienstbodes (8o procent) bleef ongehuwd.

\section{Beambten bij het spoor}

De spoorwegen waren een belangrijke werkgever in Utrecht en naarmate de tweede eeuwhelft vorderde, werd het aantal mensen dat voor het spoor werkte steeds groter. De Duitsers die bij het spoor werkten zijn interessant omdat zij, in tegenstelling tot de eerder besproken sigarenmakers, wel gebruik maakten van de nieuwe mogelijkheden die de sterk expanderende sector bood.

In totaal waren er in de periode van 1849 tot 187975 Duitse mannen die voor de spoorwegen werkten. Opmerkelijk is dat slechts twee Duitse immigranten dat deden als ketelmaker. In Amerikaanse studies wordt het beroep van ketelmaker genoemd als een Duits specialisme. In Utrechtse kranten werd wel om ketelmakers gevraagd, ${ }^{69}$ maar het aanbod van Nederlanders was kennelijk groot genoeg om in deze vraag te voorzien, of Duitse immigranten hadden voor dit werk geen belangstelling. Onder het spoorwegpersoneel vinden we slechts enkele oud-militairen. Een overstap naar werk bij de spoorwegen, die volgens de literatuur een voorkeur zouden hebben gehad voor het aanstellen van oud-militairen, ${ }^{70}$ kwam slechts één keer voor.

Van de 75 Duitse immigranten die bij het spoor werkten, werden er 41 in het bevolkingsregister omschreven als 'beambte bij het spoor', dertien als machinist en zes als conducteur. Volgens de officiële rangorde die bij de spoorwegen werd gehanteerd, behoorden ook machinisten en conducteurs tot de groep beambten. Dit betekent dat vrijwel de hele groep tot de beambten kan worden gerekend. Beambten vormden het zogenaamde middenkader bij de spoorwegen. Zij werden onderscheiden van de ambtenaren, die de topfuncties in het bedrijf bekleedden. Beambten waren het geschoolde personeel uit de operationele dienst en het lagere administratieve personeel. ${ }^{71}$ Bij de volkstelling van 1849 werden in totaal 61 mannen geteld als beambten bij het spoor. Dit aantal nam vervolgens snel toe. 
Van de 75 Duitsers die in Utrecht bij het spoor werkten, waren er volgens het bevolkingsregister 39 in dienst van de Nederlandsche Rhijnspoorwegmaatschappij (NRS). Waarschijnlijk was ook een deel van de overige Duitsers, bij wie geen werkgever werd vermeld, in dienst van deze maatschappij. De NRs, die voornamelijk met Engels kapitaal werd opgezet, legde de lijn aan die van Amsterdam over Utrecht naar Arnhem liep en die werd uitgebreid met zijtakken van Utrecht naar Rotterdam en van Arnhem naar Emmerich. ${ }^{72}$ Vanuit Emmerich reden de treinen met de Cöln-Mindener Eisenbahn door naar Keulen. ${ }^{73}$ In 1860 was dit de belangrijkste Nederlandse spoorverbinding. De NRS specialiseerde zich in doorgaand vervoer naar Duitsland. Het is dus niet zo verbazend dat deze maatschappij Duits personeel aanstelde.

Aan het einde van de hier onderzochte periode zien we ook enkele Duitse immigranten die, volgens het bevolkingsregister, werkzaam waren bij De Nederlandsche Centraalspoorweg Maatschappij (NCS) en de Maatschappij tot Exploitatie van Staatsspoorwegen (ss). In 1880 hadden alledrie de maatschappijen hun hoofdkantoren in Utrecht.

De sterke Duitse invloed op het spoor had een weerslag op de regelgeving. In 1865 maakte de Maatschappij tot Exploitatie van Staatsspoorwegen algemene bepalingen voor het personeel. ${ }^{74}$ Gedeeltelijk werden deze zowel in het Duits als in het Nederlands gesteld. Opmerkelijk is welke regels in beide talen werden gegeven en welke alleen in het Nederlands. De regels voor de stationschefs waren alleen in het Nederlands en dat gold ook voor de regels voor alle functies die te maken hadden met de behandeling van goederen en materieel. Zowel in het Duits als het Nederlands waren er regels voor hoofdconducteurs, conducteurs, opzichters (bahnmeister), wegwachters en hulpwachters (bahnwärter), wisselwachters op de stations, machinisten, leerling-machinisten en stokers. Dat waren klaarblijkelijk de beroepen waarin Duitse immigranten werkten.

Bij de Nrs bekleedde de Duitser Christiaan Herman Schanze een hoge positie. Hij was ingenieur-werktuigkundige. Schanze werd in 1812 geboren in Leipzig. Hij was luthers en vestigde zich in 1843 in Utrecht. ${ }^{75}$ In 1856 vertrok hij naar Leiden. De migratie van de andere Duitse spoorwegbeambten kan waarschijnlijk niet aan contacten met Schanze worden toegeschreven. De Duitsers bij het spoor kwamen niet uit Leipzig, noch waren ze allemaal luthers. De enige andere spoorbeambte uit Leipzig was Gotlieb Julius Schanze, een broer van Christiaan Herman. ${ }^{76}$ Hij werd in 1817 in Leipzig geboren en werkte als machinist voor de NRs. Hij overleed in 1850 in Utrecht op 33-jarige leeftijd.

De Duitse medewerkers van de spoorwegen hadden geen gemeenschappelijke regionale herkomst. Emmerich was met zeven vermeldingen de geboorteplaats die het meest voorkwam. Andere spoorwegmedewerkers kwamen uit plaatsen als Kleef, Wesel, Düsseldorf of Bentheim. Hiermee kwam het merendeel wel uit de grensstreek, maar er waren ook enkele immigranten die van verder weg kwamen, onder meer uit Berlijn en München.

Het spoorwegpersoneel woonde verspreid over Utrecht, zij het iets meer in de nieuwere wijken en met een kleine concentratie in de nabij het station gelegen Amsterdam- 
sestraatweg en omliggende straten. Ongehuwde spoorwegmedewerkers woonden nogal eens in bij gehuwde collega's. Verder vonden ongehuwde mannen onderdak in kosthuizen. Spoorwegpersoneel verhuisde veelvuldig, omdat het door de spoorwegmaatschappij van de ene naar de andere plaats werd overgeplaatst. Dit migratiepatroon had zijn weerslag op het huwelijksgedrag. Er waren dertien Nederlandse spoorwegmedewerkers die met een Duitse vrouw getrouwd waren. Er waren ook twaalf Nederlandse echtparen, waarvan de man bij het spoor werkte, die kinderen kregen in de tijd dat ze in Duitsland woonden. Opmerkelijk is dat de spoorwegbeambten niet alleen relatief veel tussen plaatsen verhuisden, maar ook binnen de stad. Het is onduidelijk wat de reden voor deze verhuizingen binnen de stad was. Het Nederlandse spoorwegpersoneel vertoonde eenzelfde opvallend migratiepatroon.

De Duitse beambten waren niet de enige vreemdelingen bij het spoor; er waren ook enkele Britse ingenieurs. Zij werkten in een andere deelsector van het spoorwegbedrijf dan hun Duitse collega's. Zij woonden in die delen van de wijken L, M en C die aan het stationscomplex grensden. De Britse ingenieurs kwamen naar Utrecht nadat een aanvang was gemaakt met constructie van de spoorwegen in 1843. Hun migratie was geenszins tijdelijk; de ingenieurs die in de jaren zestig kwamen, waren er ook nog in de jaren tachtig. Er kwamen in de tussenliggende jaren ook enkele nieuwe ingenieurs bij. Zo vestigde zich in 1880 bijvoorbeeld de Britse ingenieur Robert Wright uit Hull, met zijn vrouw, kinderen en Engelse dienstbode, op de nieuw aangelegde Stationsstraat in wijk L. De Britse ingenieurs kwamen met hun in Engeland geboren vrouwen, kinderen en dienstpersoneel.

\section{Studenten en hoogleraren}

De Utrechtse universiteit trok studenten en medewerkers van elders. Dat was ook reeds vóór de negentiende eeuw het geval. Het verblijf van studenten was niet minder tijdelijk dan dat van tal van andere immigranten. Net als bij de dienstbodes of het winkelpersoneel, bleef een groot deel van de studenten slechts enkele jaren in de stad, om na verloop van tijd naar elders te vertrekken. Vreemde studenten waren niet in alle studierichtingen gelijkelijk vertegenwoordigd. Er was een duidelijke oververtegenwoordiging van vreemdelingen onder de theologiestudenten. De theologie-opleiding binnen de Utrechtse universiteit was van oudsher belangrijk. De Utrechtse universiteit trok meer buitenlandse studenten dan de Leidse of de Groningse. In de periode van 1849 tot 1879 waren er in Utrecht 6o Duitse studenten. In vergelijking met de 314 studenten die in 1849 in totaal werden geteld, is de omvang van deze groep gering. Het aantal vreemde studenten in Utrecht was wel groter dan dat in andere universiteitsteden. In het midden van de negentiende eeuw telde Utrecht zeven procent buitenlandse studenten, tegen Groningen vijf en Leiden twee. ${ }^{77}$

De studenten kwamen uit alle delen van Duitsland naar Utrecht. Eén student was joods en zeven waren katholiek; de overigen waren protestants (luthers, calvinistisch, 
waals en hernhutter). Veruit het grootste deel van de Duitse studenten studeerde, net als de andere vreemde studenten, theologie. Onder de theologiestudenten was sprake van een lichte oververtegenwoordiging van studenten uit de Pfalz. Voor deze studenten was er in Utrecht een beurs beschikbaar, het zogenaamde Bernhardinum. Deze beurs stoelde op het fonds dat voc-gouverneur Daniel Bernhards ten behoeve van studenten had gesticht. ${ }^{78}$ De 15 tot 20 Duitse theologiestudenten uit de Pfalz, die omstreeks 1880 in Utrecht woonden, hielden, samen met een handvol Hongaarse of Zevenburgse studenten, in de maanden februari en maart in de Pieterskerk kerkdiensten in het Duits die echter slechts weinig werden bezocht. ${ }^{79}$

De Duitse theologiestudenten gingen, zo blijkt uit de bevolkingsregisters en uit de studentenalmanakken, voor een groot deel terug naar Duitsland. In de almanakken werd in een afzonderlijke rubriek gemeld wie naar Duitsland was vertrokken om daar predikant te worden. Zo vertrokken in $1861 \mathrm{~F}$. Metzlar en in $1863 \mathrm{~W}$. Weiffenbach en F. Weiffenbach. ${ }^{80}$

De Duitse studenten woonden vrijwel allemaal in het centrum van de stad, net als de overige studenten. Er kunnen ook enkele 'Duitse' studentenhuizen worden aangewezen. De Utrechtse stukadoor Jacobus Mackay in de Looierstraat, bood bijvoorbeeld omstreeks 1900 onderdak aan dertien Duitse theologiestudenten. ${ }^{81}$

Naast de studenten waren er ook Duitse hoogleraren. Duitse wetenschappers waren in andere tijden en plaatsen geen ongebruikelijk fenomeen. ${ }^{82}$ In het midden van de negentiende eeuw kampte Nederland met een tekort aan wetenschappers. Daarom werd er ten aanzien van hen een uitzondering gemaakt waar het ging om de 'benoembaarheid tot landsbediening'. In de Grondwet werd bepaald dat 'iedere Nederlander tot elke landsbediening benoembaar is' en 'Geen vreemdeling is hiertoe benoembaar, dan volgens de bepalingen der wet.' In 1857 werd bij wet bepaald voor welke 'landsbediening' vreemdelingen wel benoembaar mochten zijn. Hieronder vielen onder meer consul-generaal, ambtenaren bij de telegraaf, stoomwerktuigen, mijnwezen en 's Rijks entrepot, stempelsnijders bij de munt, graveurs bij de topografische dienst van het Departement van Oorlog en hoogleraren. ${ }^{83}$ Vreemdelingen waren ook benoembaar tot leraren en beambten bij instellingen van onderwijs, kunst of wetenschap. In 1852 verwachtte Thorbecke nog dat de noodzaak voor het benoemen van vreemden niet lang zou blijven bestaan.

[...] de noodzakelijkheid of wenschelijkheid om naar vreemdelingen uit te zien zal steeds verminderen. Onder leiding van vreemden zullen zich onderwijzers vormen, die voor geene vreemden meer zullen behoeven onder te doen; kunsten en wetenschappen zullen hier te lande beoefenaars vinden, die op geene mindere hoogte staan dan de vroeger daarin uitmuntende vreemdeling. ${ }^{84}$

De verwachtingen van Thorbecke werden echter gelogenstraft. Meer dan twintig jaar later, omstreeks 1876, was er volgens de historicus De Coninck sprake van een 'professorennood' en zaten de vier Nederlandse universiteiten om personeel verlegen. Dit 
probleem werd, net als in de jaren ervoor, opgelost door professoren, privaat-docenten en assistenten in Duitsland te werven. ${ }^{85}$

In Utrecht zien we de Duitse professoren en andere medewerkers pas helemaal aan het einde van de hier beschreven periode hun entree maken. Later zouden er meer volgen. ${ }^{86}$ Tussen 1849 en 1879 waren er echter slechts drie Duitse hoogleraren. ${ }^{87}$ De Duitser J.H. Hisgen werd in 1878 benoemd tot privaat-docent in de Hoogduitse taal en letterkunde aan de Universiteit. ${ }^{88}$ Daarvóór was hij sinds 1847 lector aan de universiteit in de Hoogduitse taal geweest. Naast Hisgen waren er geen andere privaat-docenten of lectoren in het Duits. ${ }^{89}$ Hisgen was voorts leraar Duits op het stedelijk gymnasium en op de technische school van zijn landgenoot Grothe aan de Ganzenmarkt.90

De Duitse hoogleraar Frederik Miquel uit 'Nieuwenhuis' (Neuenhausen) in het graafschap Bentheim, werd naar Utrecht gehaald als hoogleraar botanie en landhuishoudkunde. $^{91}$ F.A.W. Miquel vervulde deze functie van 1859 tot 1871 . Hij had in Groningen gestudeerd, werd vervolgens lector in natuurlijke historie en geneesmiddelen-

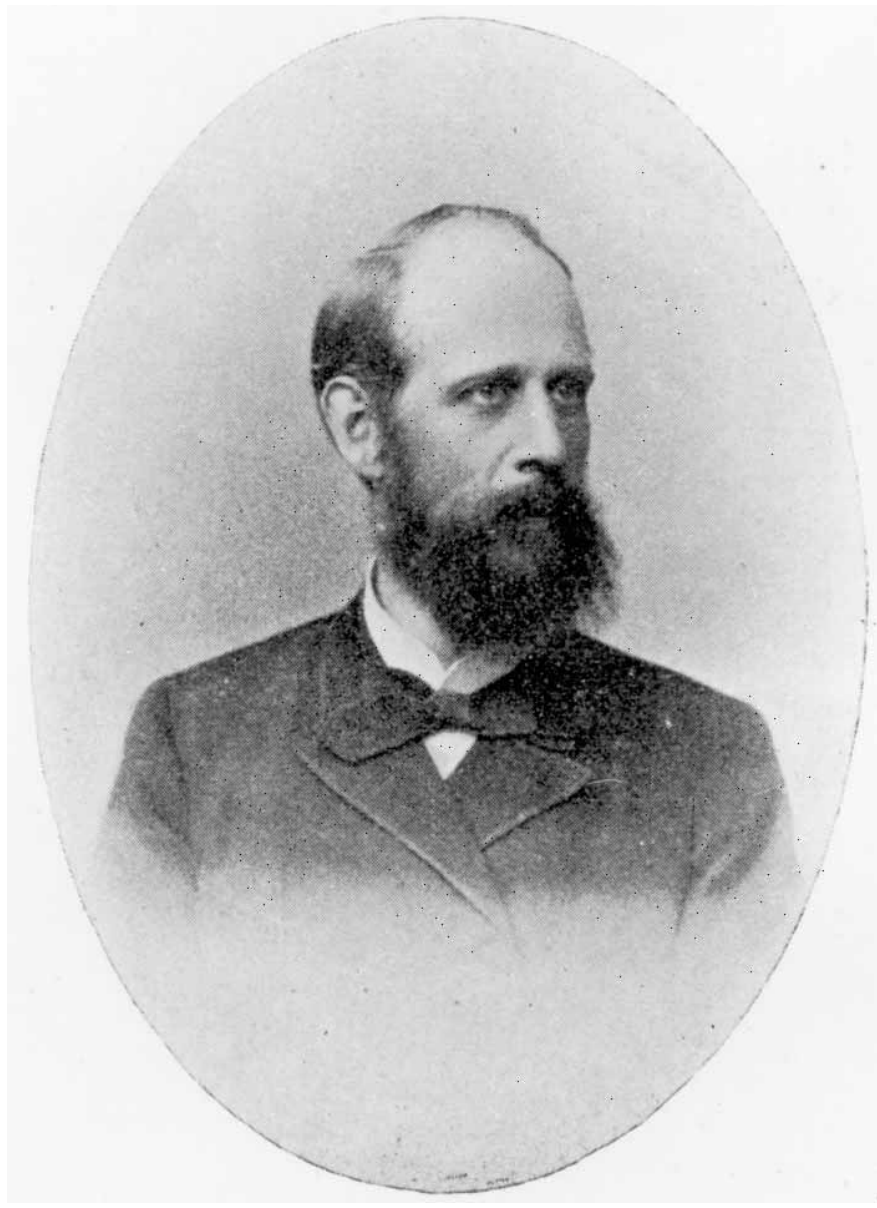

Professor Carl Ernst Arthur Wichmann. Het Utrechts Archief C.50.350. 
leer aan de klinische school in Rotterdam (1835) en daarna in 1846 professor in de botanie aan het Amsterdamsche Athenaeum. In 1859 werd hij hoogleraar aan de Utrechtse faculteit wis- en natuurkunde.

Twee bekende Duitse professoren waren Carl Wichmann en Theodor Engelmann. Carl Ernst Arthur Wichmann werd geboren in 1851 in Glückstadt aan de Elbe in een familie van walvisvaarders. ${ }^{92}$ In maart 1879 werd hij benoemd tot hoogleraar in de geologie te Utrecht en in augustus van dat jaar trouwde hij met Johanna Zeise uit het Duitse Altona. Hij ondernam twee grote reizen naar Nederlands-Indië, in 1888-1889 en in 1902-1903. ${ }^{93}$ In 1916 scheidde het echtpaar. De familie Wichmann was sterk op Duitsland georiënteerd. ${ }^{94}$

Theodor Engelmann werd geboren in Leipzig in 1843, als zoon van een wetenschappelijk uitgever. ${ }^{95}$ Hij kwam naar Utrecht in 1869 . Daarvoor studeerde hij medicijnen in Jena, Leipzig, Heidelberg en Göttingen. De toen reeds zeer befaamde Utrechtse hoogleraar F.C. Donders, haalde hem naar Utrecht en zette hem reeds spoedig in bij het onderwijs. Dat ging Engelmann aanvankelijk niet gemakkelijk af. Hij schreef aan een Duitse collega:

Meine ohnehin nicht geläufige Zunge findet in der holländischen Sprache eine neue erschwerende Umstand für die mündliche Mittheilungen. Zum Glück sprechen die meisten und verstehen alle Studenten hier Deutsch; doch denke ich in einigen Wochen nur auf Holländisch zu krächzen um zu röcheln. ${ }^{96}$

In juni 1869 trouwde Engelmann in Utrecht met het enige kind van professor Donders. Hij werd vervolgens in 1877 benoemd tot hoogleraar aan het 'physisch laboratorium' en volgde in 1884 zijn schoonvader op. De dochter van Donders overleed reeds kort na het huwelijk, bij de geboorte van een tweeling in 1870. Daarop trok Engelmanns zus Louise bij hem en zijn kinderen in. Engelmann hertrouwde in 1874 met de Duitse pianiste Emma Vick Brandes (1843-1940). Het jaar daarvoor leerde hij reeds de componist Johannes Brahms kennen. Die ontmoeting was het begin van een periode van twintig jaar waarin het echtpaar Engelmann huiskamerconcerten organiseerde in hun Utrechtse woning en waar Duitse muzikanten, componisten en wetenschappers van naam hun opwachting maakten. Bij deze concerten waren soms wel tweehonderd gasten aanwezig. De concerten waren een trefpunt voor Duitsers en mensen met bewondering voor de Duitse cultuur, taal en wetenschap. Religieuze en politieke verschillen waren ondergeschikt. De opbrengst van de concerten gebruikte Engelmann ter financiering van het Ooglijdersgasthuis. De familie ging uiteindelijk in 1897 terug naar Duitsland, omdat Emma Vick Brandes heimwee had. Engelmann kreeg een aanstelling in Berlijn en overleed in 1909. ${ }^{97}$

De Duitse intellectuele invloed op de Utrechtse medische faculteit was groot. ${ }^{98}$ Dat riep wel enige weerstand op. In 1890 werd de Duitser Friedrich Salzer benoemd als opvolger voor de scheidende hoogleraar L.C. van Goudoever. ${ }^{99}$ Van Goudoever was daarmee niet gelukkig. 
Zeer tegen mijn zin was de nominatie voor mijn opvolger opgemaakt. Er schijnt hier langzamerhand een Duitsche medische faculteit te moeten komen. Lieten zich die Heeren nog maar naturaliseren, maar zij zijn en blijven Duitschers. ${ }^{100}$

De student F. Wierdels maakte ook bezwaar tegen de benoeming van Salzer. Duitsland zou beslist niet de beste krachten aan Nederland afstaan. Het was een

droevig testimonium paupertatis, wanneer het buitenland weer zoo goed moet wezen om in de hand, die wij ophouden, de aalmoes van een Duitsch of Oostenrijksch professor te laten glijden. ${ }^{101}$

Niet iedereen deelde de bezwaren. Uit Duitsland kwamen niet de gevestigde hoogleraren die 'beweibt und bekindert' waren en die niet meer de elasticiteit hadden om een nieuwe taal te leren of zich aan een vreemd land aan te passen, maar jonge, nog ongehuwde talenten. De Utrechtse student P. Bierens de Haan was tegen het voortrekken van buitenlanders bij benoemingen, maar

voor Duitschers echter, zooals de meeste vreemdelingen-professoren zijn, bestaat geen bezwaar, daar zij zich in enkele jaren het Nederlandsch volledig machtig kunnen maken en daarenboven de meeste wetenschappelijke boeken in het Duitsch geschreven zijn. ${ }^{102}$

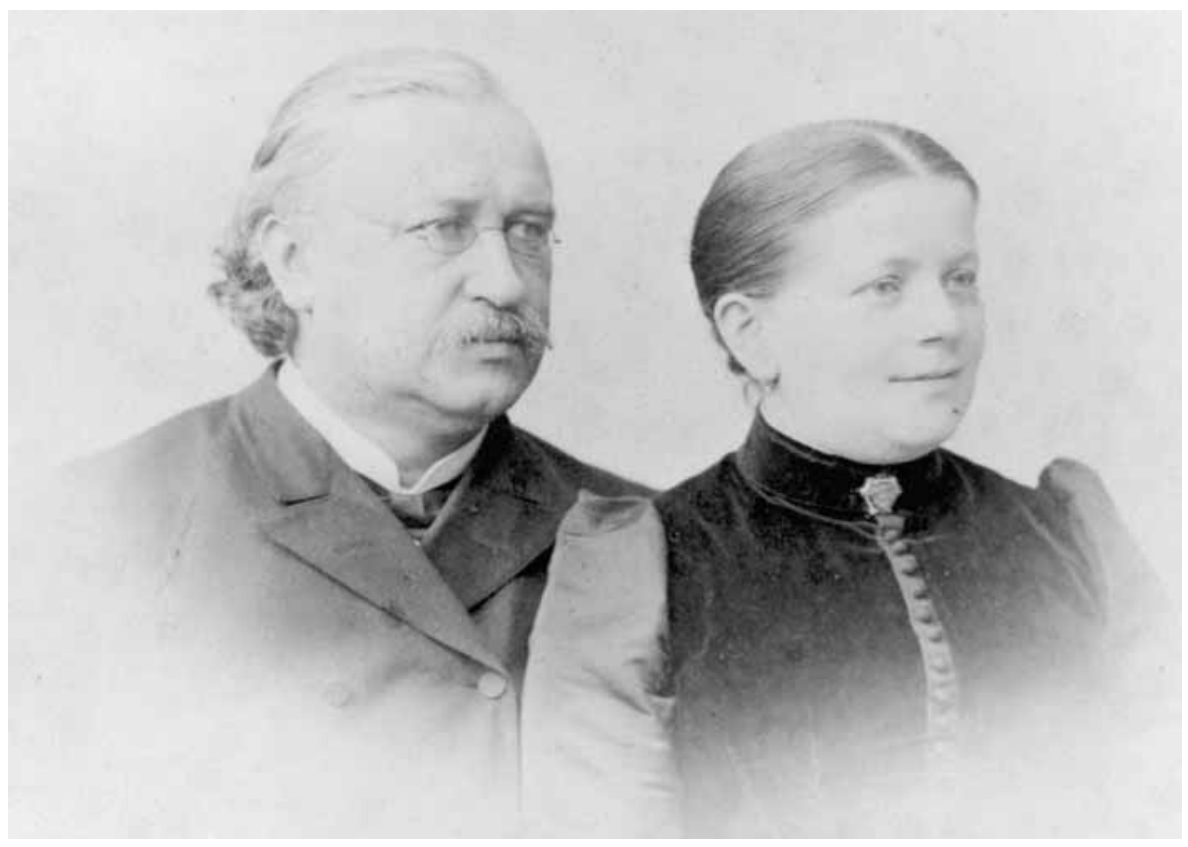




\section{Tot besluit}

De hier gepresenteerde groepen hebben met elkaar gemeen dat het ging om meer dan een handvol Duitse immigranten. De groepen waren echter minder omvangrijk dan die van de Westerwalders en winkeliers. Zijn hier beschreven omdat ze, in tegenstelling tot de andere twee groepen, bestonden uit of alleen mannen of alleen vrouwen. Voor hun huwelijksgedrag had dat gevolgen. De meeste Duitse migranten die tot deze groepen behoorden, trouwden buiten de eigen groep. De vijlenkappers en stukadoors vormden desondanks vrij herkenbare groepen, waar het gaat om geconcentreerde bewoning en het verband tussen herkomststreek en concentratie in beroepen. De stukadoors vielen op dit punt op, omdat ze weliswaar niet met Duitse vrouwen trouwden, maar wel met vrouwen binnen een beperkte groep. Voor de vijlenkappers gold dat minder. Zij trouwden echter, in tegenstelling tot de stukadoors, weer overwegend met geloofsgenoten. Stukadoors en vijlenkappers hadden met elkaar gemeen dat hun beroep in hoge mate erfelijk was: zonen en kleinzonen van stukadoors en vijlenkappers werden stukadoors en vijlenkappers.

De groepen verschillen waar het gaat om de hechtheid van hun afstotingsgebied. Studenten en spoorbeambten kenden geen gemeenschappelijke herkomststreek; vijlenkappers, stukadoors en dienstbodes wel. Deze laatste drie groepen hebben - bijna logisch gezien de religieuze geografische verdeling in Duitsland - met elkaar gemeen dat ze ook hun geloof deelden. De vijlenkappers en stukadoors waren luthers, de dienstbodes vrijwel allemaal katholiek.

Niet alle groepen kenden een geconcentreerde bewoning binnen de stad Utrecht. De dienstbodes woonden verspreid over de stad, zij het iets meer in de betere wijken. Hun verspreiding werd vooral bepaald door hun beroep. De studenten woonden in de binnenstad, maar daarbinnen woonden ze verspreid. Pas tegen het einde van de negentiende eeuw is er een 'Duits' studentenhuis aan te wijzen. De stukadoors woonden gedeeltelijk in de buurt van hun werkgever. De vijlenkappers vertoonden, waar het gaat om een geconcentreerde bewoning, de meeste samenhang. Ze woonden bij hun werkgever of in de nabijheid van de bedrijven waar ze werkten. Die bedrijven lagen meer geconcentreerd dan die van de stukadoors.

De vijlenkappers vormden reeds vóór hun migratie een hechte groep. De specialistische vaardigheden die hun beroep vereiste en de geringe technologische vernieuwingen, maakten het mogelijk de verhouding tussen baas en knecht over te planten van het ene land naar het andere. Waar het gaat om theorieën omtrent groepsvorming, kunnen we op dit punt aanhaken bij het concept van de inheritable economic base. ${ }^{103}$ Juist in omstandigheden zoals die golden voor de vijlenkappers, was het mogelijk deze erfelijke economische basis, en de daarmee samenhangende arbeidsverhoudingen, te verplaatsen. De kenmerken van het beroep maakten het mogelijk om deze vaste verhoudingen te behouden en dat schiep een band tussen de leden van de groep.

Groepen die hun beroep deelden en die bestonden uit zowel mannen als vrouwen, vertoonden een grotere samenhang en continuïteit dan groepen waarvoor dit niet 
gold. In dit hoofdstuk werd deze stelling gedeeltelijk bevestigd. Migranten die alleen hun beroep gemeen hadden, kenden slechts een zeer geringe samenhang als groep. Dit gold voor de spoorbeambten en de studenten. Migranten die naast een beroep, een geografische herkomst en geloof deelden, vertoonden meer samenhang. Dit gold wel voor de vijlenkappers en de stukadoors, maar niet voor de dienstbodes. Bij de dienstbodes maakte hun beroep het samenwonen binnen de stad onmogelijk. 


\section{2 'Door Hongaarsche zon verbruind'}

\section{Een multiculturele samenleving}

Tussen 1850 en 1859 woonden er in Utrecht een smidsknecht uit Siberië, een pijpendopmaker uit Krakau in Polen, een 'professor in de lithografie' uit Alexandrië, een apotheker uit het Deense Christiaansfeld, een vioolbouwer uit Warschau, een schout bij nacht uit het Spaanse Malaga en een Griekse muntwerker. Samen met Henkiffy Mazina en Livezaa Lakja, een Mohammedaans echtpaar uit Japan, waren zij enkelen van de immigranten uit ver weg gelegen oorden, die gedurende enige tijd in Utrecht woonden. ${ }^{1}$ Daarnaast waren er mensen uit verre landen die tijdelijk in Utrecht hun opwachting maakten. Op 16 juli 1859 hield Fr. Rappo uit St. Petersburg gedurende drie dagen een vertoning van zijn 'tableaux vivants'. Zijn tent telde 140 zitplaatsen. ${ }^{2}$ Rappo kwam voor de grote kermis die in juli werd gehouden en die veel vreemdelingen trok, zoals een groep Hongaren in klederdracht en 'door Hongaarsche zon verbruind' die tijdens de kermisdagen een concert gaf. $^{3}$

Vreemde handelaren zijn over het algemeen redelijk in de bronnen terug te vinden. Zij moesten immers patentbelasting betalen en komen daarom voor in de patentregisters. Voor hen was het bovendien belangrijk dat de stadsbevolking van hun komst op de hoogte was en dus adverteerden ze veelvuldig in de lokale Utrechtse krant. Gevestigde vreemde handelaren deden dat eveneens. De Franse ondernemers bedienden zich daarbij meestal van het Frans. In de Utrechtsche Provinciale en Stadscourant van 28 november 1851 prees de Franse kapper Labbé zijn salon in de Choorstraat aan. 'A l'honneur de prévenir qu'il vient d'ouvrir un grand et comfortable salon pour la coupe des cheveux et la coiffure.' Labbé maakte volgens een nieuw systeem en tegen redelijke prijzen 'perruques, tours et toupets remarquables par leur légereté, leur solidité et leur naturel parfait. ${ }^{4}$ Labbé hoopte ongetwijfeld dat zijn maandelijks herhaalde Franse advertentie zijn redelijk geprijsde pruiken een achtenswaardig of chique aanzien zou geven. 'Mad. Duvalle de Paris' hoopte iets vergelijkbaars toen ze in hetzelfde jaar in het Frans adverteerde voor haar tijdelijke verkoop van lingerie: 'a l'honneur de prevenir les Dames qu'elle vient d'arriver en cette ville avec un joli assortiment de nouveautés en fait de Lingerie, Broderies et Dentelles en tous genres, et aux prix les plus raisonables.' Ze had haar handel uitgepakt in het Hotel Lion d'Or op het Oudkerkhof, alwaar ze drie of vier dagen zou blijven. ${ }^{5}$

Franse boekverkopers, die in andere landen niet onbelangrijk waren als ambulante handelaren, ${ }^{6}$ komen we in Utrechtse advertenties niet tegen. Uit een ingezonden brief, die in 1839 in de krant verscheen, weten we echter dat ze er wel degelijk waren. 
Mijnheer de Redacteur!

Het zal $U$ en anderen zeker onbekend zijn, dat vreemde Boekhandelaren, hier ter stede uitgepakt, aan $\mathrm{HH}$. studenten de onkiesche boeken van Franschen oorsprong, aanbieden, die nergens anders toe dienen, dan om de zeden te bederven, de driften op te wekken, en de gezondheid te ondermijnen. ${ }^{7}$

\section{Jutphaas, Zuilen, Maarssen, De Bilt en Zeist}

De buitenlandse migranten, die in dit hoofdstuk worden beschreven, waren wel opvallend in de Utrechtse samenleving, maar de binnenlandse migranten waren veel talrijker.

In 1875 kwam de dienstbode Hendrika Gadellaa uit haar geboorteplaats Zeist naar Utrecht. Ze werkte iets meer dan een jaar in deze stad en keerde toen terug naar Zeist. Hendrika Gadellaa was een van de vele binnenlandse immigranten die enige tijd in Utrecht woonden. Dienstbodes uit Zeist en uit andere buurgemeenten als Zuilen, Jutphaas, De Bilt of Maarssen, vormden samen met de palfreniers en de stal- en dienstknechten uit deze plaatsen, een belangrijk deel van de Utrechtse immigrantenpopulatie.

Binnenlandse migratie was in Utrecht, zoals in alle Nederlandse steden, veel omvangrijker dan de buitenlandse. ${ }^{8}$ In 1849 woonden er in Utrecht, volgens de volkstelling, 1.555 mannen en 2.337 vrouwen die buiten de stad Utrecht, maar binnen de provincie waren geboren. Nog eens 3.947 mannen en 5.182 vrouwen waren geboren buiten de provincie, maar binnen Nederland. Deze dertienduizend binnenlandse immigran-

Figuur 12.1 Vestiging en vertrek in Utrecht 1852-1900.

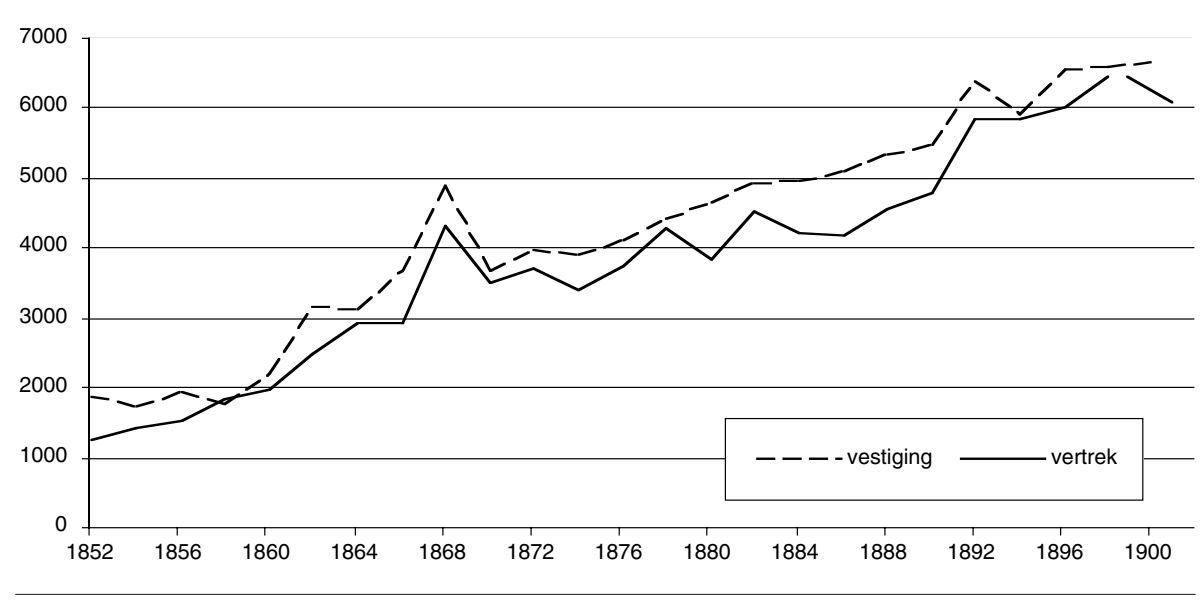

Bron Gemeenteverslagen Utrecht 1852-1900. 
ten vormden gezamenlijk meer dan een kwart van de Utrechtse stadsbevolking (de totale bevolking telde in 184947.781 mensen). Vrouwen, zowel van binnen als van buiten de provincie, waren onder deze immigranten in de meerderheid ( 58 procent).

In 1849 vestigden zich volgens de officiële cijfers 1.338 mensen in Utrecht en vertrokken er 1.693. In 1849 was het aantal vertrekkers groot in vergelijking met de daaropvolgende jaren. Gewoonlijk overtrof het aantal nieuwkomers het aantal vertrekkers. In 1859 werden er bijvoorbeeld 1.950 mensen geteld die zich in Utrecht vestigden, tegen 1.775 mensen die vertrokken. Zowel het aantal vertrekkers als het aantal nieuwkomers nam tussen 1850 en 1900 fors toe. In 1899 waren er 7.462 nieuwkomers en 7.134 vertrekkers (zie figuur 12.1). Amsterdam en Utrecht hadden in de periode 1850-1859 een vestigingsoverschot van 4,5 procent. In Haarlem en Dordrecht was het vestigingsoverschot min of meer gelijk (4,3 en 4,7 procent). Alleen Rotterdam had een hoger vestigingsoverschot (11,7 procent). ${ }^{9}$

Van de totale Utrechtse bevolking overschreed zeven procent in 1849 de gemeentegrens om van woonplaats te veranderen. De mobiliteit in verhouding tot de bevolking, ook wel de relatieve mobiliteit genoemd, was in dat jaar niet uitzonderlijk groot; ${ }^{10}$ het cijfer schommelde in de tweede helft van de negentiende eeuw tussen zeven en dertien procent. ${ }^{11}$ De relatieve mobiliteit van de Domstad was daarmee groter dan die van Amsterdam of Rotterdam.

Het migratiecijfer werd beïnvloed door de verhuizingen van rijke of adellijke families, die hun traditie van 's zomers buiten en 's winters binnen de stad wonen in stand hielden. Met hun grote gezinnen en talrijke bedienden, hadden zij een niet onbetekenend aandeel in de totale migratie. Verder verhuisden ook het spoorwegpersoneel en de studenten veelvuldig. Een deel van de migratie bestond uit families die seizoensmatig op en neer gingen tussen Utrecht en de steenbakkerijen net buiten de stadsgrens. In de wintermaanden woonden de steenbakkers in de stad, gedeeltelijk in wijk K, in de zomermaanden woonden ze bij de steenbakkerijen in het aangrenzende Jutphaas. ${ }^{12}$ Het migratiegedrag van de steenbakkers wordt weerspiegeld in de geboorteplaatsen van hun kinderen. De vijf kinderen van Gerrit van Galensloot en Maria van der Linden werden bijvoorbeeld tussen 1860 en 1875 geboren in achtereenvolgens Utrecht, Jutphaas, Vianen, opnieuw Jutphaas en Utrecht. ${ }^{13}$ De steenbakkers, die bekend stonden als een zeer mobiele bevolkingsgroep, ${ }^{14}$ migreerden ook wel naar verderweg gelegen fabrieken in Nederland en daarbuiten. In de jaren 1870 woonde er bijvoorbeeld tijdelijk een steenbakkersfamilie Van Beek in een keet aan de Croeselaan. De kinderen van deze familie werden tussen 1862 en 1873 geboren in Duisburg, Ruhrort en Antwerpen. ${ }^{15}$ In Ruhrort bevond zich een Nederlandse kolonie van steenbakkers, die daar in de zomermaanden werk vond en gehuisvest werd in keten op een drassig stuk grond bij de rivier. $^{16}$

Concentraties van binnenlandse immigranten in bepaalde wijken, laten zich niet eenvoudig vaststellen. Direct opvallend is slechts een concentratie van Friezen in de relatief goede wijk F. De historicus Pim Kooij vond voor Groningen, dat immigranten uit de omliggende gemeenten zich concentreerden in de aan hun gemeente grenzende 
stadswijken. In Utrecht zien we dat alleen voor de migranten uit Jutphaas. Voor de andere buurgemeenten lijkt dit niet op te gaan.

\section{Strohoedenmakers en andere Belgische immigranten}

Belgen vormden na Duitsers de grootste groep vreemdelingen in Utrecht: bij de volkstelling in 1849 waren er 225. Bij de Belgische immigranten was het aantal mannen en vrouwen niet gelijk; vrouwen waren met zestig procent in de meerderheid. Uit het bevolkingsregister blijkt dat veel Belgische vrouwen gehuwd waren met niet-Belgische mannen. De groep als geheel vertoonde dus een relatief grote exogamie. De Belgische immigranten waren wel vrijwel allemaal katholiek. Ze kwamen niet uit één herkomstgebied. Een deel ( 57 procent) van de Belgische immigranten kwam uit de grotere steden; 15 procent uit Antwerpen, 10 procent uit Brussel en 9 procent uit Namen. Gent en Luik waren goed voor ieder 8 procent, Brugge voor 4 en IJperen voor 3 procent. De overige 43 procent kwam uit tal van kleinere plaatsen in België.

Belgische immigranten werkten in een groot aantal verschillende beroepen. Onder de mannen waren nogal wat gepensioneerde ambtenaren en verder zien we beroepen als schrijnwerker, luitenant, kuiper, kleermaker, commies stedelijke belasting, koopman in eieren, werkman, hoogleraar, huisonderwijzer en schermmeester. Onder de vrouwen waren enkele winkeliersters en dienstbodes. Belgische immigranten woonden in alle delen van de stad en hadden met de Duitse immigranten gemeen dat ze niet één groep vormden.

Opmerkelijk onder de Belgische immigranten in Utrecht, waren de strohoedenmakers. Dit is een groep die we ook in andere steden tegenkomen. Door recent onderzoek van Annemarie Cottaar en Leo Lucassen, weten we meer over hen. ${ }^{17}$ De strohoedenmakers kwamen uit de Belgische provincies Luik en Limburg in de grensstreek langs de rivier de Jeker en dan vooral uit de plaatsen Glons, Roclenge, Bassenge en Wonck. Reeds in de zeventiende en achttiende eeuw gingen van hieruit strohoedenmakers naar Londen. In de negentiende eeuw trokken zij seizoensmatig naar Frankrijk, Duitsland, Nederland en andere delen van België. Volgens Cottaar en Lucassen bestond de migratie van strohoedenmakers overwegend uit mannen. Vrouwen bleven in het Jekerdal achter. De strohoedenmakers hielden bezit aan in hun geboortestreek, of verwierven dat na hun tijdelijke verblijf elders. De meer permanent in Nederland verblijvende strohoedenfabrikanten trokken seizoensarbeiders uit hun geboortestreek aan. Zij kwamen tussen januari en maart en keerden aan het begin van de zomer naar hun geboortestreek terug. In de periode tussen 1850 en 1875 kwamen er jaarlijks tachtig tot honderd naar steden als Amsterdam, Rotterdam en Den Haag. Zij vervaardigden nieuwe strohoeden, waarbij ze gebruik maakten van stroken die in het Jekerdal waren gevlochten. Verder fristen ze ook hoedjes van het vorige seizoen op, door ze schoon te maken en te voorzien van nieuwe stroken, linten, gedroogde bloemen en borduursels. De strohoedenwinkels waren in de betere straten van het stadscentrum te vinden. De hoeden wer- 
den op grote schaal gedragen; zij tooiden de hoofden van slagersknechts, studenten en schoolmeisjes.

De strohoedenmakers vormden in Utrecht ongeveer tien procent van het aantal Belgen. ${ }^{18}$ In het Adresboek van 1860-1861 worden negen strohoedenmakers genoemd. Alle negen behoorden tot de groep die haar wortels vind in het Jekerdal, maar ze waren niet allemaal zelf in die streek geboren. De migratie van strohoedenmakers uit het Jekerdal naar Utrecht dateerde reeds van voor 1800. In 1749 werd Arnoldus Gielson als nieuwe burger van de stad Utrecht ingeschreven. Hij kwam uit 'Gain bij Maestricht' en had als beroep 'strooijehoedenwinkeldoende'. In 1786 werd hij gevolgd door Pascal Frenai, een strohoedenmaker uit 'Brusglons tussen Maastricht en Luik' die naar Utrecht kwam met zijn zonen Arnoldus, Johan en Matthijs. ${ }^{19}$

De Utrechtse strohoedenfabrikanten woonden, net als de strohoedenmakers elders, in het stadscentrum. Op de Oudegracht was gevestigd Henri Rosfary, die in 1811 in Glons werd geboren. ${ }^{20}$ Hij was getrouwd met de Utrechtse Alida Klaassen, bij wie als beroep hoedenmaakster werd vermeld. Op de Choorstraat zat het bedrijf van de strohoedenfabrikant Wierck Corbersier. Deze weduwenaar werd in 1792 in Wonck geboren. Getuige de geboortedata van zijn kinderen, was hij in ieder geval reeds in 1822 in Utrecht. ${ }^{21}$ Corbersier had een groot aantal dienstbodes, winkeljuffrouwen en modistes in dienst, waaronder één Duitse. De overigen waren Nederlands. Bij hem woonde slechts één strohoedenmakersknecht, Francois Dessart uit Wonck. Op Lijnmarkt 35 was gevestigd de strohoedenfabrikant Eustache Frenay (ook wel geschreven Eustachius Frenaij). Hij was geboren in 1813 in Roclenge en gehuwd met Marie Jeanne Baurieux, eveneens uit Roclenge. Bij hen in huis woonde hun neef Pierre Baurieux, die geboren was in Den Haag. Verder woonden er de Belgische strohoedenmaker Arnoldus Renier en acht Nederlandse dienstbodes. ${ }^{22}$ Strohoedenmakers vinden we ook op Lijnmarkt 7o, waar de weduwnaar Victor Mouillard en zijn zonen woonden. ${ }^{23}$ Mouillard was in 1798 in Luik geboren, zijn zonen in de jaren 1840 in Glons. Mouillard en zonen woonden zo'n vijf jaar in Utrecht en vertrokken toen naar Luik.

In de Bakkersteeg, een zijstraat van de Oudegracht, woonde de strohoedenfabrikant Arnoldus Mathot. Hij kwam in 1862 uit Wonck, maar was hier waarschijnlijk reeds eerder geweest, daar zijn zoon reeds voor die tijd in Utrecht was geboren. ${ }^{24} \mathrm{Hij}$ was gehuwd met de Utrechtse Allegonda van Dillen.

Op de Springweg was gevestigd strohoedenfabrikant Pierre Watrin. Dit was het enige bedrijf dat enigszins buiten het stadscentrum lag. Watrin was in 1840 geboren in het Belgische Glons en gehuwd met de in Utrecht geboren Augustine Coulembier. Zijn oudste kind werd in Utrecht geboren in $1869 .{ }^{25}$ Frenaij, Corbersier, Mathot en Beaurieux zijn namen die in andere plaatsen ook gangbaar zijn onder strohoedenmakers uit het Jekerdal.

In Amsterdam en andere plaatsen vonden Cottaar en Lucassen veel tijdelijke strohoedenmakers. In het Utrechtse bevolkingsregister werden zij niet in grote aantallen ingeschreven. Dit kan op drie dingen wijzen. Ten eerste kunnen zij zijn ingeschreven in het (verloren) vreemdelingenregister. Ten tweede kan het zijn dat de seizoensmatige 
migratie naar Utrecht niet zo groot was als die naar andere Nederlandse steden. Utrechtse strohoedenverkopers zouden hun waren uit bijvoorbeeld Amsterdam kunnen hebben betrokken. Het feit dat de Belgen uit het Jekerdal in Utrecht genoteerd werden als fabrikanten en niet als winkeliers, makt deze verklaring echter minder waarschijnlijk. Als laatste kunnen de Utrechtse strohoedenfabrikanten gebruik hebben gemaakt voor Nederlands personeel. De inwonende dienstbodes en modistes wijzen in die richting.

De strohoedenmakers vertoonden overeenkomsten met de Westerwalders: geconcentreerde bewoning, een regiogebonden specialistisch product, een klein herkomstgebied, de band die via handelsbetrekkingen met de herkomststreek in stand werd gehouden en het naast elkaar bestaan van seizoensmigratie en permanente migratie. Een gedeelte van de strohoedenmakers in Utrecht migreerde, zoals hierboven werd beschreven, in familieverband. Op dit punt lijken ze af te wijken van het beeld zoals dat is geschetst door Cottaar en Lucassen. De mannen die alleen migreerden, huwden veelal met niet-Belgische vrouwen.

\section{Lestrade en Yrondy, Franse paraplumakers uit de Auvergne}

In de achttiende eeuw werd, door Franse ketellappers en scharenslijpers, herhaaldelijk een akte van indemniteit overlegd. De ketellapper Antoine Baille uit de Auvergne in Frankrijk, deed dat in 1786 en zijn collega Jean Corsa in $1777 .{ }^{26}$ Tussen 1775 en 1781 overlegden in totaal vijf Franse scharenslijpers in Utrecht een akte van indemniteit. ${ }^{27}$ In de tweede helft van de negentiende eeuw zien we echter geen ketellappers en scharenslijpers meer. In het midden van de negentiende eeuw was er wel een handjevol Franse kappers. Ook zij kenden achttiende-eeuwse voorlopers. ${ }^{28}$ In negentiende eeuw vallen de Franse kappers echter in het niet bij de 93 kappers die de stad Utrecht in 1849 in totaal telde. ${ }^{29}$

De grootste groep onder de Franse immigranten in de negentiende eeuw, werd gevormd door de paraplumakers uit de Auvergne. Zij overheersten in Utrecht het parapluvak. De paraplumakers die in de negentiende eeuw in Utrecht actief waren, kenden achttiende-eeuwse voorlopers. In 1789 overlegde de Fransman François Drie een akte van indemniteit. ${ }^{30}$ Nakomelingen van Drie waren in de negentiende eeuw in Utrecht nog steeds in het parapluvak werkzaam. In 1793 verwierf de paraplumaker Pierre Alia uit 'Valmousin' in Frankrijk het burgerrecht in Utrecht. Met Valmousin werd mogelijk St. Martin-Valmeroux bedoeld, dat ligt in de streek waar de negentiende-eeuwse paraplumakers vandaan kwamen. ${ }^{31}$ In andere steden zijn er aanwijzingen voor de aanwezigheid van paraplumakers die later in Utrecht actief waren. In 1787 makkten Pierre en Joseph Lestrade via een advertentie in een Amsterdamse krant 'aan alle Heeren en Dames en 't Publiek bekend, dat zij fabriceeren allerhande soorten van parapluis en parasols. ${ }^{32}$

De migratie van handelaren uit de Auvergne - niet alleen parapluverkopers dateerde reeds van voor de negentiende eeuw. ${ }^{33}$ Aanvankelijk reisden zij naar andere de- 
len van Frankrijk en naar Spanje. ${ }^{34}$ Omstreeks 1811 verlegden ze hun werkterrein naar België en Noord-Frankrijk. ${ }^{35}$ De Auvergnats, zoals zij werden genoemd, behielden volgens Jan Lucassen lange tijd een band met hun geboortegrond. ${ }^{36}$ In beschrijvingen van migratie uit de Auvergne worden de parapluhandelaren slechts sporadisch genoemd. ${ }^{37}$ Onduidelijk is of de vroege parapluverkopers handelden in producten die zij zelf maakten, die ze betrokken uit hun herkomststreek, of die ze kochten van tussenhandelaren.

Omstreeks 1800 zijn er meer gegevens voor Nederland en (het latere) België. In de Archives Departementales van Aurillac in de Auvergne wordt een lijst bewaard, met namen van mensen die in de periode van januari 1796 tot maart 1806 een paspoort aanvroegen om naar Nederlandse of Belgische plaatsen te reizen. ${ }^{38}$ Het ging om mannen tussen 14 en 62 jaar. Ze reisden te voet en legden per dag zo'n dertig kilometer af. Hun campagne duurde gewoonlijk vijftien maanden, maar kon ook uitlopen tot enkele jaren. Behalve parapluverkopers waren er onder de aanvragers ook ketellappers, koperslagers en mensen die werden omschreven met de meer algemene term handelaar. Als bestemming hadden ze verschillende Nederlandse steden.

De migratie van parapluverkopers breidde zich in de negentiende eeuw uit, met een toename van de vraag. Paraplu's komen reeds voor op afbeeldingen uit de Oudheid. In Aziatische landen werden parasols met bamboe ribben en een papieren bespanning eveneens reeds ver vóór de negentiende eeuw gebruikt. In de negentiende eeuw kwam de paraplu echter sterk in zwang in Europa en werd ongekend populair.

In deze branche moet onderscheid gemaakt worden tussen nieuwe en tweedehands paraplu's, en tussen paraplumakers en parapluverkopers. Paraplu's werden veelvuldig gerepareerd en bij de komst van het volgende seizoen overtrokken met nieuwe zijde. Opkopers kochten oude paraplu's, overtrokken ze en verkochten ze weer. Handel in tweedehands paraplu's was een veel voorkomend beroep onder ambulante handelaren. Paraplu's werden, behalve door Franse handelaren, ook verkocht door mensen uit andere streken.

Naast de tweedehands handel waren er winkels waar nieuwe paraplu's werden verkocht. In Utrecht hielden deze winkels zich ook bezig met de fabricage van paraplu's. De Utrechtse productie lijkt een bovenregionale functie te hebben vervuld. In latere tijdvakken bestelden ambulante handelaren hun paraplu's bij fabrikanten in deze stad. $^{39}$

Utrecht telde in 1849 volgens de volkstelling tien 'regenschermmakers'. In het Adresboek van 1860-1861 komen zeven 'parapluimakers' voor, allen gevestigd in het centrum van de stad. Twee paraplumakers met Frans klinkende namen, Rolin en Goudeau, waren in Nederland geboren (in de jaren 1820). Mogelijk waren ze nakomelingen van Franse immigranten die eerder naar Nederland waren gekomen. De families Rolin en Goudeau waren door huwelijksbanden met de Franse paraplumakers verbonden.

De Franse paraplumakers in Utrecht waren vrijwel allemaal geboren in de $\mathrm{Au}-$ vergne. Uitzondering waren enkele paraplumakers uit Parijs. Mogelijk waren zij nakomelingen van Auvergnats die in een eerdere fase naar Parijs waren gegaan. De Auvergnats kwamen vooral uit de plaats Chaussenac. Anderen kwamen uit de nabijgele- 
gen plaatsen Ally, Cros-de-Montvert, St.-Martin-Cantalès, Bassignac-le-Haut, Crandelles, St.-Santin-de-Maurs en Brageac. Dit zijn kleine plaatsen, grotendeels gelegen ten noordwesten van Aurillac.

De belangrijkste Franse paraplufabrikanten in Utrecht waren Yrondy en Lestrade. Beiden hadden inwonende Franse paraplumakers in dienst. Tussen de twee families bestond een band. In de periode van 1850 tot 1859 woonden Louis Yrondy en Christophe Lestrade in hetzelfde pand op de Oudegracht in Wijk D. Bij hen in huis woonden ook Pierre Yrondy en zijn Franse vrouw Maria Perier en hun in Nederland geboren kinderen. Verder woonden er Michael Yrondy en zijn in Leiden geboren vrouw Elisabeth Goudeau. Dit laatste gezin had zich hier in 1851 uit Leiden gevestigd. In 1855 ging deze familie naar Parijs; Louis Yrondy was hen enkele maanden eerder voorgegaan. Christophe Lestrade ging naar Groningen.

Yrondy adverteerde met grote regelmaat in de Utrechtse krant. Hij noemde zijn bedrijf een fabriek, maar verkocht, getuige de advertentie, niet alleen eigen fabrikaat.

De ondergeteekenden berigten het publiek, dat zij ontvangen hebben eene groote collectie van eene nieuwe soort van wandelstokken en badines. Men vindt bij hen ook een groot assortiment van parapluiën, en Zijden van verschillende kleur, om Parapluiën te overtrekken, zoo dat ze nieuw schijnen. Zij repareren alle voorwerpen in hun vak. ${ }^{40}$

Yrondy verkocht zijn paraplu's en aanverwante artikelen aanvankelijk ook op de markt, maar hield daar in latere jaren mee op. Per advertentie liet hij kopers binnen en buiten de stad weten 'dat zij wederom dit jaar niet met eene kraam op de Kermis, zoo als vroeger, zullen zijn uitgepakt. ${ }^{41}$ In latere jaren werd de kermisverkoop klaarblijkelijk gestaakt.

Yrondy's grootste concurrent Lestrade was gevestigd op de dichtbij Yrondy's fabriek gelegen Choorstraat 19 in wijk E. Gerrit en Antoine Lestrade, mogelijk broers van de reeds genoemde Christophe, adverteerden net als Yrondy veelvuldig voor hun 'Parapluies en parasols' ${ }^{42}$

Bij Gerrit Lestrade en zijn vrouw Susanna Arnal woonden in de periode 1860 tot 1879 vijftien andere mensen: een Belgische paraplumaker, twee Nederlanders met Franse namen en elf Fransen. Een van de Nederlanders heette Jean Martinot. Hij werd in 1860 in Rotterdam geboren. Martinot was waarschijnlijk een nakomeling van Anthony of Antoine Martinot, twee Fransen die respectievelijk in 1771 en 1797 een akte van indemniteit overlegden. ${ }^{43}$ De paraplumakers waren allemaal mannen en vrijwel allemaal katholiek. De enige inwonende vrouw die niet tot het huishouden behoorde, was een Duitse dienstbode.

In de periode 1860-1879 werd de zaak Yrondy gedreven door de broers Louis en Pierre en hun neven Odon en Emile, allen uit Chaussenac. Louis en Pierre waren gehuwd, maar hun vrouwen woonden, getuige de inschrijving in het bevolkingsregister, in Frankrijk. Behalve de vier paraplumakers woonde op dit adres een groot aantal 
Winkel van Lestrade en Yrondy aan de Oude-

gracht in 1878. Op de gevel is te lezen

'Fabrication Français'. De gevel is versierd met bonte paraplu's.

Foto G.L. Mulder. Het Utrechts Archief C.4619.

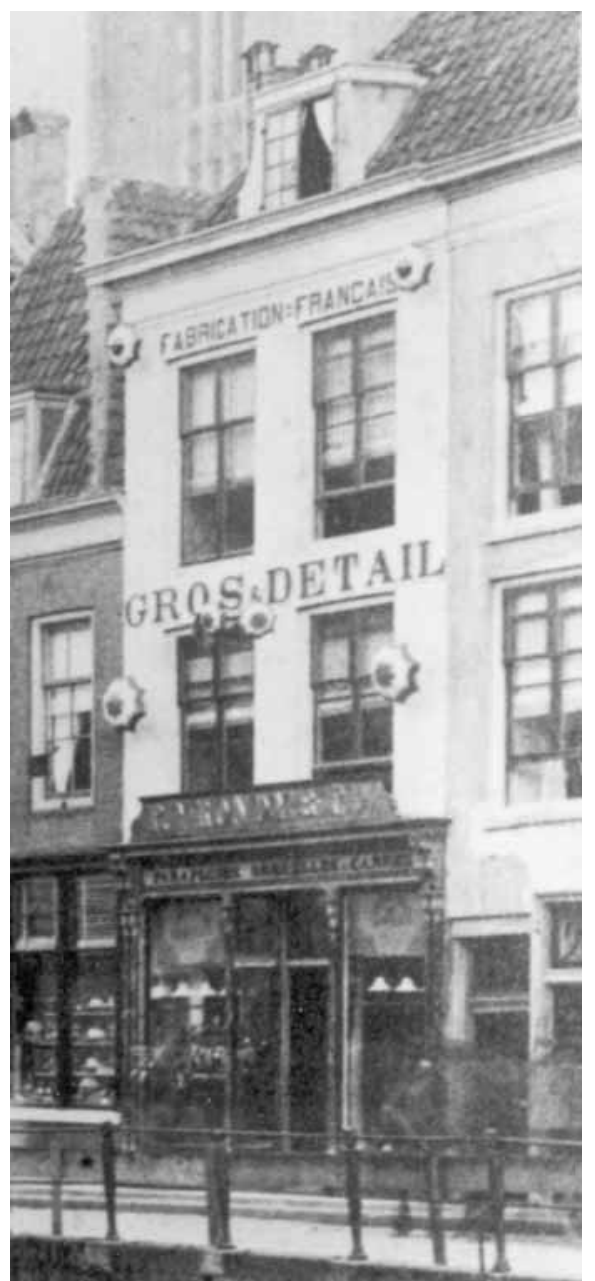

\section{FABRICATION FRANGAISE DE PARAPLUIIS, ete. MOUVEAUTE DE PARASOLS.

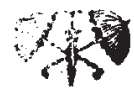

P. L. YROVDY en UZET, Oudegracht over Simkel $\mathbf{7}$ 39,

* Wij nemen de vrijheid hiermede onzen geëerden begunstigers kennis te geven, da ons nieuw MACAZIJN geopend is.

Het zal ons'streven zijn, door ruimte van keuze van alle tot ons vak behoorende artikelen, goede kwaliteit, civiele prijzen en prompte soliede bediening het vertrouwen, steeds 200 ruimschoots genoten, ook in het vervolg waardig te mogen blijven.

Advertentie van de parapluverkopers Yrondy en Lizet in het Utrechtsch Provinciaal en Stedelijk Dagblad van 23-4-1866. 
dienstbodes, allemaal Nederlandse. We zien op dit punt een overeenkomst met de strohoedenmakers. Mogelijk werden deze vrouwen bij de parapluproductie ingezet.

Odon en Louis Yrondy gingen in 1874 en 1875 terug naar Frankrijk. De andere bewoners waren reeds eerder vertrokken. De firma ging verder onder de naam LestradeYrondy. Leon Lestrade dreef de zaak met zijn vrouw Justine Yrondy, een dochter van Pierre Yrondy. Onder aan de gevel kwam in hardsteen het opschrift 'Fabrication Français', dat er nog steeds staat. Behalve Nederlandse dienstbodes, woonden er bij hen opnieuw twee Franse paraplumakers. De firma Lestrade bleef tot het einde van de negentiende eeuw Frans personeel aantrekken, dat veelvuldig op en neer reisde tussen de winkel-fabrieken van hun Franse patroons. Camille Rentier woonde bijvoorbeeld in 1879 twee maanden bij Leon Lestrade. Hij kwam uit Leeuwarden en vertrok naar Amsterdam. ${ }^{44}$

Er bestond een band tussen de Franse paraplumakers en de Westerwalder pottenhandelaren. Behalve in potten, handelden de Westerwalders incidenteel ook in paraplu's. Een van de Westerwalders was door familiebanden met de Franse paraplufamilies verbonden. In 1848 beviel de Westerwalder koopvrouw Elisabeth Weber buitenechtelijk van een zoon die zij de naam François gaf. Getuige bij de aangifte van deze geboorte was Louis Yrondy. Uit het geboorteregister van de Martinusparochie blijkt, dat de vader Antoine Martin was, een regenschermmaker geboren in Brageac. Antoine Martin en Elisabeth Weber trouwden later met elkaar. De Westerwalder koopman in paraplu's Peter Weber, geboren in Ransbach en broer van Elisabeth, woonde jarenlang bij de familie Yrondy in huis. Hij woonde later ook bij Antoine Martin en zijn gezin in Amsterdam.

Bij de parapluverkopers en -handelaren zijn er opvallende overeenkomsten met de eerder beschreven groepen: compacte herkomststreek, specialisatie in een bepaalde bedrijfstak en geconcentreerde bewoning. De Franse paraplumakers lijken niet te hebben gehandeld in producten die speciaal in hun herkomststreek werden gemaakt. Hierin kwamen ze overeen met de Duitse winkeliers. In het rondreizen van de jongere paraplumakers tussen de winkels in verschillende steden, zien we parallellen met de Duitse winkelbedienden.

\section{Italiaanse schoorsteenvegers en pleistergieters}

De Heer Romualdo Galliri heeft de eer het geachte publiek deze stad te berigten, dat hij voor de eerste maal in Holland uit Italië aangekomen zijnde, zijn fraai kunstkabinet ter bezigtiging zal aanbieden, hetwelk hij bereids bezig is op te zetten op het Vreeburg, de derde tent van af de Schouwburg. De affiches zullen in breedvoeriger verslag treden. ${ }^{45}$

Galliri was een tijdelijke, Italiaanse immigrant in Utrecht. De permanente Italiaanse immigranten in Utrecht kwamen merendeels uit Noord-Italië en vormden één groep 
met de immigranten uit het aangrenzende Zwitserland. Het waren vooral pleistergieters en de schoorsteenvegers. Utrecht week op dit punt niet af van andere Nederlandse steden. $^{46}$

De vestiging van Italiaanse schoorsteenvegers dateerde reeds uit de zestiende eeuw. ${ }^{47}$ Binnen korte tijd wisten de Italianen de branche te overheersen en zij bleven dit doen tot de Tweede Wereldoorlog. ${ }^{48}$ De reden voor deze snelle verovering lag in een verandering in het bouwen, die in de loop van de zeventiende eeuw plaats had. ${ }^{49}$ De houten huizen maakten plaats voor stenen gebouwen van meerdere verdiepingen, met lange, smalle schoorstenen.

Italiaanse schoorsteenvegers maakten gebruik van de arbeid van jonge Italiaanse knechts. Zij kropen overigens niet in de schoorstenen, zoals wel is verondersteld: die waren daarvoor te smal. ${ }^{50}$ De voorkeur voor jonge knechts stoelde op het feit dat zij goedkope arbeidskrachten waren. De schoorsteenvegers en hun knechts kwamen uit Piemonte in Italië en uit de aangrenzende Tessiner Alpen in Zwitserland, waar ook Italiaans gesproken wordt.

In Den Haag werd het monopolie van de Italiaanse schoorsteenvegers reeds omstreeks 1860 aangetast. De Italianen verloren hun positie, omdat ze niet langer gebruik konden maken van goedkope arbeidskrachten, vanwege beperkingen op de kinderarbeid. Hierdoor raakten ze het voordeel kwijt dat ze ten opzichte van Nederlandse ondernemers in deze sector hadden gehad. Bovendien liep na 1860 het aanbod van goedkope arbeidskrachten terug, door migratie vanuit Italië naar Amerika en Australië. ${ }^{1}$

In Utrecht was de teruggang van een latere datum. Een belangrijke werkgever in Utrecht was de Italiaanse schoorsteenveger Rocco Simonis, die was geboren in wat in het huwelijksregister de vlek St. Maria Maggiore wordt genoemd. Simonis was niet de eerste Italiaanse schoorsteenveger in Utrecht. Aan het begin van de negentiende eeuw komen in de geboorteregisters bijvoorbeeld de Italiaanse schoorsteenveger Carlo Andrioli voor, die getrouwd was met de Utrechtse breister Maria de Beer, en zijn collega Johannes Rusconi met zijn vrouw Gijsberta Steenbeek.

Simonis had zijn bedrijf op de Korte Smeestraat. Hij was getrouwd met de Italiaanse Wilhelmina Rensen. Hun oudste kind was in 1836 in Zutphen geboren, de latere kinderen tussen 1839 en 1850 in Utrecht. In 1866 overleed zijn eerste vrouw en hertrouwde hij met Duitse dienstbode Maria Hoenselaar. Bij Simonis in huis woonden zeventien andere Italiaanse en Zwitserse schoorsteenvegers, die waarschijnlijk bij hem in dienst waren. In het naastgelegen pand woonden nog meer Italiaanse en Zwitserse schoorsteenvegers, die mogelijk ook voor hem werkten. De beide huishoudens tezamen telden slechts een vrouw, Maria Hoenselaar. De schoorsteenvegers kwamen onder meer uit Albogna, Druogno en Buttogno. Deze plaatsen liggen, samen met de vlek St. Maria Maggiore, aan de rivier de Melezzo. Deze rivier loopt ten noorden van het Lago Maggiore van Domodossola in Italië naar Locarno in Zwitserland en mondt bij Locarno in het meer uit.

De schoorsteenvegers in Utrecht kunnen worden opgesplitst in twee groepen: jongens van elf en twaalf jaar en mannen van omstreeks veertig. De jonge schoorsteenve- 
gers kwamen rechtstreeks uit Italië, de ouderen hadden veelal reeds elders in Nederland gewoond. Jonge en oudere schoorsteenvegers reisden op en neer tussen Nederlandse steden. Zo overlappen de namen van de 'Utrechtse' Italianen gedeeltelijk met de 'Amsterdamse' van de antropologen Bovenkerk en Ruland en de 'Haagse' van Annemarie Cottaar. Francesco del Sasso, die in 1876 voor Simonis in Utrecht werkte, komt ook voor in het Leidse onderzoek van Gerard van der Harst en Leo Lucassen. ${ }^{52}$ In Utrecht werkten in het schoorsteenvegersvak ook Nederlandse en Duitse schoorsteenvegers. In 1879 waren er in Utrecht volgens het Adresboek dertien schoorsteenvegerbedrijven, waarvan iets minder dan de helft Italiaans was.

De Italiaanse pleistergieters, naast de schoorsteenvegers de enige andere belangrijke groep, overheersten daarentegen het vak volledig. In 1849 werden er in Utrecht zes pleistergieters geteld; allemaal Italianen. In het Adresboek van 1879 kwamen twee pleistergietersbazen voor; Jos Antoniettie jr. en A. Bertorelli.

Italiaanse pleistergieters waren er in Utrecht reeds vóór 1800. In de achttiende eeuw waren, volgens Heering, veel stukadoors Italiaans. ${ }^{53}$ Rommes vond echter in die periode nog geen Italiaanse stukadoors in Utrecht. ${ }^{54}$ Wel waren er reeds Italiaanse pleistergieters. In 1799 overlegde Johannes Schavinie, een 'beeldenmaker van pleister' uit Intra bij Turijn in Utrecht een akte van indemniteit. ${ }^{55}$

Aan het begin van de negentiende eeuw vinden we wel enkele Italiaanse stukadoors in Utrecht. In 1818 werd in Utrecht Magdalena Barberini geboren, dochter van de Italiaanse stukadoor Franciscus Barberini. ${ }^{56}$ In de negentiende eeuw veranderde het karakter van het stukadoorsvak en werden Duitse immigranten belangrijker. De Italianen gingen zich toeleggen op het gipswerken, wat als een afgeleide van het kunstige stucwerk uit de achttiende eeuw kan worden beschouwd. De gipswerkers goten gipsen ornamenten in mallen, die vervolgens door Duitse en Nederlandse stukadoors op gladde wanden werden bevestigd.

In de negentiende eeuw was op de Lijnmarkt in wijk E gevestigd het zogenaamde Pleister-magazijn van de Italiaan L. Guisti. ${ }^{57}$ Hij kwam uit Lucca, de herkomststreek van de Italiaanse gipsenbeeldenverkopers. ${ }^{58}$ Bij Guisti in huis woonden aanvankelijk twee pleistergieters later vijf. De twee eerste pleistergieters kwamen niet uit Lucca, maar uit Parma; de andere drie waren Nederlanders. In 1857 vertrok Guisti naar Amsterdam, maar kwam reeds spoedig terug naar Utrecht. Hij werkte zich op tot beeldenfabrikant. In 1851 liet hij zijn geëerd publiek weten dat er bij hem een 'gelijkende buste van Z.M. den Koning Willem in ' te koop was, 'zijnde de eenigste die in Holland zich bevindt'. . $^{9}$

Naast Guisti was er Jos Antoniettie, die adverteerde met 'Artistieke beelden, groepen en bustes in elfenbein, masse en geïmiteerd terracotta, tevens een grote collectie Engelsche Biscuit etagiere-artikelen, Coog Mernim Busten enz. Alles zeer geschikt voor St. Nicolaas-cadeaux ${ }^{60}{ }^{60}$ Guisti onderhield banden met Italianen die werkzaam waren in andere beroepen. Als getuigen bij zijn huwelijk traden op de Italiaanse kunsthandelaar Bartholomeus Tessaro en de Italiaanse koopman Baptist Antonioli, naast de Zwitserse koopman Bernardus Fochetti en de Nederlandse beeldhouwer Johannes Rijn- 
hout. ${ }^{61}$ De Italiaan Bartholomeus Tessaro had met zijn landgenoot Carmelli een kunsthandel aan de Oudegracht en was geboren in Puve Fisena in Italië. ${ }^{62}$ In het Frans lieten ze via krantenadvertenties de 'amateurs du beau chant' weten dat er een mogelijkheid was om via hun zaak in te schrijven op 'des leçons dans l'art du chant, invite tous les amateurs de la musique vocale'. ${ }^{63}$

De tweede getuige bij Guisti's huwelijk, Fochetti, kwam uit Brionne in Zwitserland. Hij woonde met zijn zonen vlakbij Guisti op de Lijnmarkt. Fochetti verkocht barometers, thermometers, toneelkijkers, brillen en lorgnetten, en messen en scharen. ${ }^{64}$ Het maken van barometers was een Italiaans-Zwitsers specialisme. ${ }^{65}$

Italiaanse terrazzowerkers, die later in de eeuw belangrijk zouden worden, vinden we in dit tijdvak nog niet in Utrecht. Opmerkelijk is in dat verband de advertentie van A. de Morie uit 1876. Hij maakte reclame met

Duitsche Mozaïk-vloeren voor kerken, scholen, vestibule's, gangen, portalen, keukens, trottoirs enz. Om dezelver constructie billijker te leggen als Engelsche; voor de levering, alsook legging, beveelt de ondergeteekende zich minzaam aan. Staatkaarten en monsters in Natura ten zijnen huize te bezigtigen A. de Morie, mr. Metselaar. Achter de Tweijenstaat B. $93 .{ }^{66}$

De Morie was Nederlands en noemde de vloeren, die later Italiaans zouden heetten, Duits.

De Italiaanse immigranten vormden, evenmin als de andere immigranten één groep. Bij de Italianen waren de schoorsteenvegers in aantal het belangrijkst. Opnieuw zien we bij hen overeenkomsten met andere groepen immigranten: het binnen Nederland rondreizen van de jongere arbeidskrachten, het regiogebonden specialisme en de beperkte herkomststreek. De migratie van schoorsteenvegers betrof vooral mannen en exogamie was regel.

\section{Tiroler handelaren in gemsleren handschoenen}

Ter gelegenheid van de kermis van 1851 stond Karl Wimpissenger uit Tirol met zijn kraam op het Janskerkhof in Utrecht. Hij verkocht

echte handschoenen van Tyrol en ook fijne gemslederen broeken, borstrokken, beddenlakens en bretels allen tot de minst mogelijke prijzen. ${ }^{67}$

Gemsleren handschoenen werden ook verkocht door Bischofer.

F. Bischofer uit Tyrol, wonende in de Kalverstraat no 226 te Amsterdam, heeft de eer zijne geachte begunstigers en het geëerde publiek te berigten dat hij alhier gearriveerd is, en staat op het St. Janskerkhof, met een assortement der fijnste 
Tyroler Gemslederen, Parijser Privat en Jouvin Handschoenen, fijne Gemslere onderbroeken, borstrokken en beddenlakens alsmede Bretels in soorten. ${ }^{68}$

Deze handschoenhandelaren kwamen uit het Zillertal in Tirol. ${ }^{69}$ Handschoenen waren een statussymbool voordat ze in de negentiende eeuw een massaproduct werden. Aan het einde van de achttiende eeuw waren het vooral de glacéhandschoenen, van glanzend leer, die furore maakten. Het waren deze handschoenen waarin de Zillertaler handelaren zich specialiseerden. Tiroler handschoenen werden reeds in de zeventiende eeuw buiten Tirol verkocht. Aan het einde van de achttiende eeuw werden vele duizenden paren buiten deze streek afgezet. In 1840 werden in het productiecentrum Innichen jaarlijks alleen al 84.00o paar handschoenen gemaakt. De handschoenen gingen naar Duitsland, Italië en Spanje. Of ze allemaal van gemsleer waren is niet duidelijk.

Tiroler handelaren verkochten aanvankelijk slechts handschoenen uit Tirol, maar op het hoogtepunt van de vraag, in het midden van de negentiende eeuw, verhandelden ze ook handschoenen die ze elders inkochten..$^{70}$ Nadruk op het Tiroler karakter van hun waar bleef echter bestaan. Daarvoor waren twee redenen. Ten eerste was er de goede naam van de Tiroler handschoenen. Ten tweede waren er verordeningen in bepaalde delen van Duitsland, die het rondventen door vreemdelingen alleen toestonden wanneer het ook om vreemde waar ging. De handelaren afficheerden zich soms als fabrikanten, omdat in bepaalde delen van Duitsland slechts het venten met zelf geproduceerde waren was toegestaan. ${ }^{71}$

Handschoenen werden uitgevent en op markten verkocht. De handelaren hadden later ook zogenaamde Wanderlager, tijdelijke winkels waarin ze, in het seizoen, hun handel afzetten. De handel in handschoenen was seizoensgebonden. De meeste handschoenen werden - misschien enigszins verbazend - in de zomer verkocht. De Wanderlager waren een tussenvorm tussen straathandel en een vast winkelpand.

Franz Bischofer, die in 1851 de Utrechtse kermis bezocht, was in 1839 uit Stumm met zijn familie naar Amsterdam gemigreerd, waar hij een lederwarenwinkel begon. ${ }^{72} \mathrm{Ze}$ ventig jaar eerder, in 1781, maakte de Zillertaler handschoenenhandelaar Peter Prosch reeds een rondreis, waarbij hij onder meer Aken, Luik, Brussel, Oostende, Gent, Antwerpen, Mechelen en uiteindelijk Maastricht aandeed. In 1844, 1846 en 1849 werden er tezamen acht passen in het Zilllertal afgegeven voor een reis naar Nederland. Vooral leden van de familie Laimböck concentreerden zich op Nederland. Frans Laimböck reisde naar Amsterdam, Rotterdam en Den Haag. Zijn nakomelingen bezochten markten in Breda, Delft, Groningen en Haarlem. Ze dreven seizoensmatige handel in Scheveningen en hadden winkels in Amsterdam, Rotterdam, Den Haag, Arnhem en Nijmegen. Ze maakten de overstap van handschoenhandel naar -productie en stichtten een fabriek in Heemstede. ${ }^{73}$ Laimböck is nu nog een bekend handschoenenmerk.

Bij de handschoenhandelaren zien we opnieuw overeenkomsten met eerder beschreven groepen. Vooral het regiogebonden specialisme treedt op de voorgrond. In het geval van de handschoenverkopers kan echter moeilijk van groepsvorming worden 
gesproken. Het ging om een handjevol handelaren, die de Utrechtse kermissen bezochten als onderdeel van hun rondreis door Nederland.

\section{Kapenaars en andere vreemde studenten}

In Utrecht studeerden, naast de Duitsers, ook een aantal andere vreemdelingen. Het belangrijkst waren de Hongaren en de zogenaamde Kapenaars. In eerdere periodes was het aantal Hongaarse studenten in Utrecht groter geweest dan in de negentiende eeuw. In 1722 waren er zoveel Hongaarse studenten, dat zij eigen godsdienstoefeningen hielden in wat de Hongaarse kerk werd genoemd. ${ }^{74}$

De Kapenaars, zoals de studenten uit Kaap de Goede Hoop werden genoemd, studeerden in Utrecht zonder uitzondering theologie. Vóór 1812 waren de Kapenaars vooral juristen in spe geweest. $\mathrm{Na} 1813$ nam het aantal Kaapse theologiestudenten toe, om in 1859 een hoogtepunt te bereiken. Daarna nam het aantal drastisch af omdat in Stellenbosch in Zuid-Afrika een eigen predikantenopleiding werd opgericht.

Onder de Kapenaars waren kinderen van Nederlandse immigranten, die in eerdere tijdvakken naar Zuid-Afrika waren vertrokken. Er waren echter ook studenten met Schotse en Duitse ouders of grootouders. De studenten van Schotse en Duitse origine volgden in Utrecht eerst cursussen Nederlands. ${ }^{75}$ In 1859, op het hoogtepunt van de Kaapse immigratie, richtten de Kapenaars ook een eigen leesgezelschap op, 'Colonia' genaamd, dat twee jaar heeft bestaan. ${ }^{76}$ De Kapenaars woonden niet allemaal in hetzelfde huis, maar om vier uur aten ze wel gezamenlijk warm in hetzelfde eethuis.

De Kaapse studenten vormden een groep apart van de andere studenten. Servaas Hofmeyr uit Kaapstad schreef naar huis dat hij van de vierhonderd studenten er slechts twee of drie kende 'want wij Kaapenaren die met onze 11ve zijn houden geen gemeenschap met de anderen uit vrees dat zij ons zullen vervoeren. ${ }^{77}$ De Kapenaars zagen zichzelf als meer orthodox dan de overige theologiestudenten in Utrecht.

De Kaapse studenten vertoonden overeenkomst met hun Duitse tegenhangers: ze verschilden onderling wat betreft hun geografische achtergrond, studeerden allemaal theologie en woonden verspreid over de stad. Ze verschilden van de Duitse studenten in het bewuste isolement dat ze lijken te hebben gezocht.

\section{West- en Oost-Indië}

In alle delen van de stad woonden mensen die geboren waren in Nederlands Oost- en West-Indië. Volgens de volkstelling van 1849 woonden in Utrecht 71 mannen en 60 vrouwen die in de koloniën geboren waren. Deze immigranten vormden een mobiele groep. In het hele tijdvak 1850-1859 woonden er in Utrecht in totaal 333 mensen die in de koloniën waren geboren. Deze immigranten kwamen zowel uit Oost- als uit WestIndië. Immigranten uit Batavia waren het best vertegenwoordigd. Immigranten uit 
Nederlands-Indië waren niet gelijkelijk over de verschillende delen van de stad verdeeld. Concentraties waren er in de wijken A en $\mathrm{H}$ en in iets mindere mate in C. Opvallend veel immigranten uit de koloniën woonden in wijk I. In de periode 1860-1879 nam het aantal koloniale immigranten in deze vrij goede nieuwbouwwijk nog verder toe.

Bij de immigranten uit Nederlands-Indië ging het merendeels om kinderen van Nederlandse ouders, geboren in de koloniën, zoals bijvoorbeeld Roelof de Bruyn (geboren in Tiel) en Johanna de Wit (geboren in Delft). Zij kwamen uit Nederlands OostIndië met hun op Padang geboren zoon Jan en hun dochter Johanna, die op zee werd geboren. Naast deze kinderen van Nederlandse ouders, waren er ook vrij veel kinderen die in de koloniën geboren waren uit niet-Nederlandse Europese ouders, waaronder nogal wat Duitsers.

Behalve in familieverband migreerden ook alleenlopende kinderen uit de koloniën naar Utrecht, om daar hun opleiding te krijgen of te voltooien. Bij de Haagse onderwijzer Polderman woonden behalve zijn op Celebes geboren zoon Louis, de negenjarige Wilhelm Bakkers en de achtjarige Maria Nagel. Deze kinderen waren geboren op Celebes en Java en werden in het bevolkingsregister omschreven als pupillen van Polderman. $^{78}$

De immigranten uit Oost- en West-Indië brachten dienstpersoneel mee. Bij dit dienstpersoneel werden voor- en achternaam, geboortedatum en -plaats in de bevolkingsregisters zeer onvolledig ingevuld. Een Hongaarse man kwam bijvoorbeeld met zijn op Java geboren vrouw en kinderen uit Nederlands-Indië, vergezeld door een Javaanse bediende bij wie als achternaam Mira werd vermeld, maar waarbij geen voornaam en geboortedatum werd ingevuld. ${ }^{79}$ Wel werd aangegeven dat ze katholiek was en dat haar verblijf tijdelijk was. ${ }^{80}$ Een familie die eveneens uit Java kwam, bracht de Mohammedaanse 'Javaanse meid' Seima mee. ${ }^{81}$ Verder was er nog de 'kindermeid' Fredja. ${ }^{82}$ Een familie uit Ambon werd vergezeld door een bediende die slechts de naam Parris droeg. ${ }^{83}$ De Utrechtse zendeling Johannes van Hasselt keerde terug uit Nieuw Guinea, samen met zijn Duitse vrouw Carolina Mundt, hun in Nieuw Guinea geboren kinderen en twee andere in Nieuw Guinea geboren personen. Door het ontbreken van een geboortedatum is niet duidelijk of dit kinderen waren of volwassenen. Een van hen was een vrouw die Candace werd genoemd en die in het bevolkingsregister werd omschreven als 'inboorling van Nieuw Guinea'. ${ }^{84}$

Opvallend onder de immigranten in Utrecht, is een groep van enkele tientallen mensen die geboren waren in de koloniën Berbice en Demerara. Dit waren koloniën die in de zeventiende en achttiende eeuw op de noordelijke kust van Zuid-Amerika door Nederlanders waren gesticht, en die aan het einde van de achttiende eeuw feitelijk en aan het begin van de negentiende eeuw ook formeel in Britse handen kwamen. Ze gingen vervolgens op in Brits Guyana. ${ }^{85}$ De overgang van de koloniën van Nederlandse in Britse handen, was waarschijnlijk aanleiding voor een gedeelte van de nakomelingen van de oorspronkelijke zeventiende- en achttiende-eeuwse migranten, om naar Nederland te gaan. 
Bij de migranten uit de Nederlandse koloniën overheerst de diversiteit. Het meest opmerkelijke kenmerk is de diversiteit waar het gaat om regionale herkomst. Een gedeelte van de immigranten uit de koloniën was in Nederland geboren, of had ouders die daar waren geboren. Er waren echter ook immigranten die in Nederlands-Indië waren geboren uit Duitse of Britse ouders of uit inlandse ouders. De immigranten uit Nederlands-Indië hadden weinig met elkaar gemeen. Ze woonden niet geconcentreerd en trouwden niet veelvuldig onderling. Wat ze met elkaar gemeen hadden, was de tijdelijkheid van hun verblijf in Utrecht en het feit dat ze merendeels werkten of gewerkt hadden voor het Nederlandse leger.

\section{Tot besluit}

In de beschrijving van de Duitse immigrantenpopulatie in Utrecht schuilt een zeker gevaar, omdat die benadering het onmogelijk maakt om aan te geven of het gedrag van deze immigranten verklaard wordt uit de kenmerken van de immigranten - hun culturele bagage - of uit de kenmerken van de stad. Nancy Green pleit daarom voor het gebruik van het zogenaamde convergente model, naast het divergente model. ${ }^{86}$ In het divergente model, zoals dat is toegepast in de vorige hoofdstukken, werd een groep bekeken in verschillende plaatsen en tijden. Bij het convergente model wordt niet een groep, maar een plaats - de stad Utrecht in dit geval - als uitgangspunt en constante genomen. De variabelen zijn nu de immigranten met een wisselende achtergrond. Deze opzet maakt het mogelijk om de factoren die gelieerd zijn aan de kansen en mogelijkheden van de stad, te scheiden van de factoren die betrekking hebben op de immigranten zelf. In hoeverre kan de positie van immigranten in de samenleving worden verklaard uit kenmerken van die samenleving waarin ze terecht kwamen, en in hoeverre uit kenmerken van de immigranten zelf?

De plaats die andere immigranten innamen in de Utrechtse samenleving, bepaalde mede de plaats van de Duitse immigranten. Deze wisselwerking tussen verschillende immigranten is omschreven als een stoelendans of de opvolgings- of successietheorie. ${ }^{87}$ Migranten streden om een plek op een beperkt aantal 'stoelen'. In die zin vormden de andere immigranten een onderdeel van de kansenstructuur waarmee Duitse immigranten werden geconfronteerd. Immigranten met een uiteenlopende achtergrond voerden echter niet alleen een symbolische stoelendans op. Een betere metafoor is wellicht die van de kralenketting, waarbij de plaats van de kraal aan de ketting verandert doordat er meer kralen worden aangeregen. Door de komst van 'nieuwe' immigranten, kwamen de 'oude' nieuwkomers dichter bij de gevestigden te staan. Kwamen er langere tijd geen nieuwe immigranten, dan kon de positie van de immigranten zich consolideren. Dit vastroesten op een bepaalde plek, versterkte de band tussen immigranten, omdat klasse of economische en sociale positie lange tijd samenvielen met etnische verbondenheid, gedefinieerd als een gedeelde geografische herkomst. 
Kunnen de andere immigranten worden gezien als concurrenten van de Duitse nieuwkomers? Streden groepen immigranten om dezelfde plaatsen binnen de Utrechtse samenleving en veranderde door de komst van 'nieuwe' nieuwkomers de plaats van Duitse immigranten? Er kwamen in de tweede helft van de negentiende eeuw geen grote groepen migranten naar Utrecht, die in zekere zin Duitse immigranten opvolgden, zoals dat wordt gesuggereerd in de successiethese. Er was sowieso geen sprake van opeenvolgende migratiebewegingen, maar van parallelle. Van concurrentie, bijvoorbeeld op eenzelfde arbeidsmarkt, is niets te merken. De niet-Duitse migranten naar de Domstad bewogen zich binnen hun eigen gescheiden economische sectoren.

Tussen de Duitse immigranten en anderen bestaan opvallende parallellen. Voor de andere immigranten gold, net als voor hun Duitse tegenhangers, dat zij zich niet tot één groep formeerden. Groepsvorming deed zich bij de andere immigranten, net zoals bij de Duitse, voor binnen de migrantenpopulatie. De groepsvorming beperkte zich bovendien, net als bij de Duitse nieuwkomers, tot een gedeelte van de immigranten. Van de Belgische immigranten was in Utrecht bijvoorbeeld slechts tien procent in het strohoedenbedrijf werkzaam.

Waar zich groepsvorming voordeed, speelde regiogebonden specialisme een rol. Concentraties in beroepen en concentraties in bewoning vielen samen met een gedeelde regionale herkomst. Endogamie was minder belangrijk. Groepen konden blijven voortbestaan ondanks een relatief sterke exogamie, zoals dat gold voor de schoorsteenvegers, die in de negentiende eeuw een herkenbare groep bleven vormen, ondanks hun exogamie. 


\section{Interactieve groepsformatie}

\section{Samenvatting en conclusie}

Groepsvorming langs etnische lijnen is tot inzet van dit boek gemaakt, omdat het een actueel onderwerp van discussie is. Groepsvorming werd bestudeerd aan de hand van de Duitse immigranten die eeuwenlang - tot de Tweede Wereldoorlog - de grootste groep vreemdelingen in Nederland vormden. Het doel van het onderzoek was meer greep te krijgen op het proces van groepsvorming, door de belangrijkste groep immigranten uit de negentiende eeuw over een langere periode te bestuderen. De Duitse immigranten hebben met de hedendaagse gemeen, dat ze gedurende langere tijd en druppelsgewijs naar Nederland kwamen. Net als de hedendaagse immigranten, die komen in het kader van gezinsvorming of -hereniging, waren zij numeriek gezien belangrijker dan vluchtelingen. In historisch onderzoek en in de hedendaagse discussie, gaat de belangstelling echter eenzijdig uit naar vluchtelingen. Juist over de getalsmatig belangrijkste groep nieuwkomers in Nederland, was tot op heden nog relatief weinig bekend. Dat is niet alleen een historische lacune, maar het vertroebelt ook ons inzicht in het belangrijke proces van groepsvorming.

Groepsvorming is in dit boek opgevat als een sociale constructie en als tegenhanger van integratie. Groepsvorming en integratie zijn onderdelen van het vestigingsproces van immigranten. In het inleidende hoofdstuk is onderscheid gemaakt tussen de factoren die aan groepsvorming langs etnische lijnen ten grondslag liggen en de factoren waarin die groepsvorming een uitdrukking vindt. Grondslagen voor de vorming van een collectieve etnische identiteit zijn (vermeende) gemeenschappelijke oorsprong, afstamming of geschiedenis. Religie, taal en fysiek voorkomen zijn daaraan gerelateerd en dragen tegelijkertijd bij aan de vorming van een collectieve identiteit. De factoren waarin collectieve identiteit een uitdrukking vindt, zijn endogamie, geconcentreerde bewoning, concentratie in beroepen en concentraties in verenigingen (waaronder kerkelijke activiteiten). Omdat etniciteit is gedefinieerd als een sociale constructie waarvan de invulling afhankelijk is van context en contact, is ook de (vermeende) gemeenschappelijkheid onderwerp van die constructie. Wanneer mensen trouwen, wonen, werken en sociaal verkeren met andere mensen met wie ze een nationale of regionale herkomst, een geloof of een taal delen, wordt aangenomen dat die gemeenschappelijkheid de basis vormt voor en uitdrukking is van een collectieve identiteit.

Groepsvorming is op het praktische niveau gedefinieerd als het samenvallen van wonen, trouwen, werken en sociaal verkeer met gedeelde nationale of regionale oorsprong, geloof of taal. Daarbij is het onmogelijk om aan deze definitie percentages te verbinden. Er kan niet worden gezegd dat er sprake is van groepsvorming, wanneer een 
bepaald percentage immigranten bijvoorbeeld binnen de eigen groep trouwt. Duidelijkheid bestaat er slechts aan de uiteinden van het spectrum waar samen wonen, werken, trouwen en sociaal verkeer overduidelijk wel of niet samenvallen met een gedeelde regionale herkomst, afstamming of geschiedenis.

De stad Utrecht, die als casus werd gekozen, behoorde tot de grote steden van Nederland. Utrecht kan niet worden aangemerkt als een doorsnee Nederlandse stad, maar hetzelfde geldt voor alle alternatieve keuzes. Omdat Utrecht niet een extreem grote stad is, was het mogelijk om het bevolkingsregister over een periode van dertig jaar in zijn geheel door te nemen. Dit is weliswaar een arbeidsintensieve benadering, maar het geeft wel het meest volledige beeld van alle vreemdelingen die meer dan drie maanden in Utrecht woonden.

Het bestuderen van één groep immigranten in één stad, in dit geval Duitsers in Utrecht, maakt het onmogelijk om te bepalen of hetgeen Duitse immigranten in Utrecht deden - woongedrag, huwelijksgedrag, verdeling over beroepen en deelname aan het sociaal verkeer - verklaard moet worden vanuit kenmerken van de groep, of vanuit kenmerken van de ontvangende samenleving. Daarom is gekozen voor een divergente benadering. Duitse immigranten in Utrecht werden vergeleken met die in andere steden en andere tijdvakken. Groepsvorming deed zich in het Utrechtse geval vooral voor binnen de Duitse migrantenpopulatie. Om op dat proces meer greep te krijgen, zijn de verschillende groepen Duitse migranten, die binnen de Duitse immigrantenpopulatie ontstonden, naast elkaar geplaatst. In een parallelle convergente benadering, werd bovendien bekeken wat andere immigranten in hetzelfde tijdvak in Utrecht deden. Tot slot werden Duitse immigranten vergeleken met de autochtone Utrechtse bevolking.

Het verloop van het vestigingsproces van immigranten - tussen groepsvorming en integratie - werd bepaald door de kansenstructuur van hun nieuwe omgeving. Onderdeel van die kansenstructuur waren wetgeving en vreemdelingenbeleid, beeldvorming en de economische en sociale mogelijkheden die de stad Utrecht bood.

Wettelijk waren er slechts weinig beperkingen voor vreemdelingen. Het belangrijkst was de Vreemdelingenwet van 1849 . De werking van die wet verslapte na verloop van enige jaren. Gevolg was dat veel vreemdelingen golden als niet officieel toegelaten. Zij konden over de grens worden gezet wanneer ze onvoldoende middelen van bestaan hadden, hetgeen aan het licht kwam wanneer zij onderstand aanvroegen. Hierin ligt het voornaamste gevolg van de wet. Het merendeel van de vreemdelingen gold na een aantal jaren als niet toegelaten vreemdelingen en kon dus in principe over de grens worden gezet. Voor vreemdelingen die in hun onderhoud konden voorzien, was die dreiging gering, maar voor armere vreemdelingen was ze groter.

Beeldvorming laat zich niet eenvoudig reconstrueren. Uit het gepresenteerde materiaal komt echter wel een samenhangend beeld naar voren. Dit beeld bestond ondanks het feit dat de Duitse immigranten geen eenvormige groep vormden en er geen eenvormige samenleving was waarin een beeld kon worden geconstrueerd. Lokale omstan- 
digheden en diversiteit binnen de groep Duitsers, hadden hun weerslag op de beeldvorming. De beeldvorming omtrent Duitse immigranten kende desondanks een relatief grote continuïteit, waarbij de vreemdelingen vooral werden afgeschilderd als armoedig. Nadruk op armoede is echter een universeel element in beeldvorming omtrent nieuwkomers. De beeldvorming was gevoelig voor ontwikkelingen binnen en buiten de Nederlandse grenzen. In 1849 werd er, gezien het pauperisme en de revolutiedreiging, vooral gesproken over het gevaar dat grote groepen armlastigen en woelzieken naar Nederland zouden komen. Tijdens het hoogtepunt van de Aprilbeweging, werd de nadruk gelegd op het feit dat het katholieke volksdeel werd versterkt door de komst van katholieke Duitsers. Antipapistische en anti-Duitse gevoelens raakten vermengd. Door de Duitse militaire successen in de oorlogen van 1866 en 1870, verschoof die beeldvorming van armoedig, lomp, ruw en ongemanierd gedeeltelijk naar gezagsgetrouw, opgevoed in de 'kazerne-philosophie', met een nadruk op plichtsbesef en orde. Tegelijkertijd was er een zekere bewondering voor de Duitse prestaties, die echter ook weer werd gemengd met angst voor annexatie van Nederland door Duitsland.

Duitse immigranten vormden niet één groep binnen de Utrechtse samenleving. Groepsvorming - afgemeten aan de indicatoren wonen, werken, trouwen en sociaal verkeer - deed zich veeleer voor binnen de Duitse immigrantenpopulatie. In twee gevallen was de groepsvorming daarbij het meest herkenbaar: bij de Westerwalders en bij de Münsterlandse winkeliers. Andere studies naar groepsvorming hebben vaak populaties tot onderwerp, die homogeen zijn waar het gaat om geloof of sociale positie. Dat heeft tot een zekere eenzijdigheid in de analyse van groepsvorming geleid. Groepsvorming binnen migrantenpopulaties was waarschijnlijk veel gebruikelijker dan de uitkomsten van die onderzoeken doen geloven.

De migratie van Duitsers naar Utrecht kende een lange traditie. Duitse nieuwkomers kwamen uit alle delen van Duitsland, maar daarbinnen zijn wel geconcentreerde herkomstgebieden aan te wijzen.

De verdeling tussen het aantal Duitse mannen en vrouwen was in de Domstad min of meer gelijk. Protestanten en katholieken hadden een gelijk aandeel. Jongvolwassenen waren onder de migranten oververtegenwoordigd. Kinderen en bejaarden waren ondervertegenwoordigd. Het migratiepatroon van de Duitse immigranten wordt gekenmerkt door een zoekende beweging, waarbij pas na verloop van een relatief lange tijd een vaste bestemming werd gevonden.

Duitse immigranten concentreerden zich niet in een bepaald deel van de stad, maar binnen de stad kunnen wel enkele wijken worden aangewezen waarin verhoudingsgewijs veel Duitse immigranten woonden.

Wanneer Duitse immigranten buiten hun eigen groep trouwden, trouwden ze met andere - binnenlandse of buitenlandse - migranten en slechts beperkt met mensen die geboren waren in Utrecht. De Duitse immigranten waren, gemeten naar hun huwelijksgedrag, slecht geïntegreerd in de Utrechtse samenleving. Binnen de groep als geheel bestonden echter grote verschillen. De endogamie was het grootst bij de Westerwalders en de winkeliers en het kleinst bij de stukadoors, vijlenkappers en dienstbodes. 
Klasse, regionale herkomst en religie vormden de scheidslijnen tussen Duitse organisaties, maar Duitse immigranten vonden toch ook een plaats in Nederlandse organisaties. Organisaties waren niet in gelijke mate voor alle Duitse immigranten toegankelijk. De organisaties die door Duitsers werden opgezet, waren relatief open organisaties waarvan reeds spoedig niet-Duitsers lid werden. Het opmerkelijkst was het ontbreken van Westerwalders in de verenigingen. Duidelijk is dat ze, als ze zich organiseerden, dat afzonderlijk van andere Duitse immigranten deden. Het ontbreken van de Westerwalders in de verschillende organisaties, kan in verband worden gebracht met klasse: de Westerwalders vormden het armere deel van de Duitse immigrantenpopulatie. Rijkere vreemdelingen en immigranten die behoorden tot de middenklasse, vonden wel een plaats in organisaties of waren mede-initiatiefnemers ervan. Armere immigranten hadden die mogelijkheid niet. Gezien in dit licht is een gebrekkige integratie, waar het gaat om sociaal verkeer, vooral een klassenfenomeen.

Duitse immigranten werkten in een lange reeks beroepen. In een groot aantal beroepen was slechts een handjevol Duitsers werkzaam. Er waren echter ook beroepen waarin veel Duitsers werkten. De Westerwalder steengoedverkopers en de Münsterlandse winkeliers waren het meest talrijk. Concentratie in beroepen, gewoonlijk aangeduid als economische nichevorming, was een verschijnsel dat zich frequent voordeed en voordoet onder immigranten. De culturele bagage en het gat in de markt, worden in de gangbare theorieën gezien als de belangrijkste verklaringen voor die nichevorming. De divergente benadering die in dit boek werd gevolgd, toonde echter aan dat de beide verklaringen slechts beperkte geldigheid hebben.

Wanneer de Duitse populatie als geheel in ogenschouw wordt genomen, is het vooral de versnippering of heterogeniteit die in het oog springt. De Duitse immigranten vormden niet één groep in de Utrechtse samenleving. Duits-zijn mag dan voor de Nederlandse publieke opinie betekenis hebben gehad, het was voor de 'Duitsers' geen basis voor een collectieve identiteit; het was niet zo dat alle Duitse immigranten samenwoonden in bepaalde wijken, zich concentreerden in bepaalde beroepen, onderling huwden, of samenklonterden in bepaalde verenigingen.

Groepsvorming deed zich voor binnen de Duitse immigrantenpopulatie. Welke factoren droegen nu bij aan het ontstaan van groepen? Negentiende-eeuws nationalisme heeft ons denken over etniciteit beïnvloed. In onderzoek naar etniciteit wordt nationaliteit aangemerkt als samenbindend element. Waar dat evident onjuist is, wordt geloof naar voren geschoven als bepalende factor.

In dit onderzoek is duidelijk dat gedeelde religie geen basis was voor groepsvorming. Studies waarin aan gedeelde religie een belangrijke verklarende rol wordt toebedeeld, hebben vaak een homogeen religieuze groep als onderwerp. Duitse immigranten in Utrecht vormden geen homogeen religieuze gemeenschap en bieden dus de mogelijkheid om de verklarende waarde van religie als samenbindend element te toetsen. Lutherse immigranten vormden geen groep waar het ging om wonen, werken of trouwen. Ze waren zelfs niet allemaal lid van de Utrechtse lutherse kerk, terwijl omgekeerd het lutherse kerkbestuur en de lidmaten merendeels niet-Duits waren. De katholieke 
Westerwalders hadden niets gemeenschappelijk met de eveneens katholieke winkeliers aan de Oudegracht.

Gedeelde nationale herkomst vormde evenmin een basis voor groepsvorming. Een gemeenschappelijke Duitse oorsprong schiep overduidelijk geen band. Een gedeelde regionale oorsprong in beperktere zin was echter ook niet in alle gevallen voldoende basis voor groepsvorming. Immigranten uit Elberfeld waren er bijvoorbeeld wel in Utrecht, maar zij hadden niets met elkaar gemeen.

Taal was evenmin het brandpunt waaromheen Duitse immigranten zich groepeerden. Er waren geen initiatieven voor het oprichten van een Duitse krant, een Duitse school of een Duits theater. Slechts het zingen in het Duits lijkt een band te hebben geschapen. De zangverenigingen waren echter geen exclusief Duitse organisaties, doch meer algemene organisaties die openstonden voor Duitse en niet-Duitse zangers.

Groepsvorming deed zich wel voor waar een gedeelde regionale herkomst samenviel met concentratie in beroepen. Endogamie en geconcentreerde bewoning konden dat versterken, maar moeten toch vooral als afgeleide van dit samenvallen worden gezien. Groepsvorming was het sterkst bij de Westerwalders, waar sprake was van gedeelde regionale herkomst en concentratie in hetzelfde beroep, endogamie en geconcentreerde bewoning. De niche van de Westerwalders bood mogelijkheden aan mannen en vrouwen en de migratie uit het Westerwald bestond gedeeltelijk uit hele gezinnen, hetgeen de groepsvorming versterkte.

Regionale specialisatie in een bepaald product leidde niet per definitie tot nichevorming onder immigranten uit die streek. Voor het specialistische product moest ook een relatief grote markt bestaan, zodat een groot aantal mensen zich met de handel kon bezighouden. Waar een enkele handelaar aan een specifieke, maar zeer beperkte vraag kon voldoen, ontstond geen niche en geen groep. Het specialistische product is dus onvoldoende voorwaarde voor nichevorming. Het is zelfs geen noodzakelijke voorwaarde, zoals het voorbeeld van de winkeliers laat zien. De niche van de winkeliers stoelde niet op de toegang tot een specialistisch product, maar op de beschikbaarheid van goedkope en loyale arbeidskrachten.

Groepsvorming onder migranten was dus vooral gerelateerd aan economische nichevorming. Tussen beide processen bestaat een wisselwerking. Groepsvorming en nichevorming zijn elkaar versterkende processen. Mensen die aanvankelijk niet in het zogenaamde ge-etniseerde beroep werkzaam waren, maar die om een of andere reden wel tot de groep gerekend (kunnen) worden, schuiven, in geval van succes, door naar deze sector. ${ }^{1}$ Wanneer nichevorming succesvol blijkt, volgen geen willekeurige immigranten, maar mensen die zich op dezelfde sector kunnen of willen toeleggen. Dit betekent dat een immigrantengemeenschap in eerste instantie een grotere beroepsdiversiteit kan kennen, die na verloop van tijd plaats maakt voor beroepsspecialisatie. ${ }^{2}$ Door dit opschuiven naar de niche, breidt de groep waarop de niche stoelt zich uit en verstevigen de banden binnen de groep. Dit is een cruciaal punt waarop de processen van groeps- en nichevorming elkaar raken. Groepsvorming en nichevorming waren niet alleen elkaar versterkende processen. De interactie tussen groepsvorming en nichevor- 
ming kan sterker worden gesteld: de niche bepaalde veel meer de groep, dan de groep de niche. Kenmerken van de niche bepaalden de termen van inclusie en exclusie. De mogelijkheden van de niche bepaalden de aard, het verloop en de continuïteit van het groepsvormingsproces. De interactie tussen groeps- en nichevorming, hier aangeduid als interactieve groepsformatie, ${ }^{3}$ kende vier fases:

1 Bij een succesvolle niche schuiven mensen naar die niche op, die aanvankelijk niet tot de groep behoorden. De pottenhandelaren kwamen aanvankelijk uit Ransbach en Baumbach. Toen de handel succesvol bleek, kwamen daar andere handelaren uit het Westerwald bij. Hetzelfde zien we bij de winkeliers. Dit is feitelijk de eerste fase van de nichevorming. Sommige groepen, zoals de Sauerlanders, ontgroeiden deze fase niet. Zij bleven steken bij een handjevol handelaren, zonder dat feitelijk gesproken kan worden van nichevorming. Pas bij succes ontstaat er een niche. Door dat succes begint zich een groep te formeren. Succes hoeft overigens niet per se welvaart te impliceren. Het duidt veeleer op het bestaan en de groei van mogelijkheden.

2 Na een periode van succes volgt een fase van afsluiting. De groep moet worden afgebakend om potentiële nieuwkomers en concurrenten te weren: wie horen er tot de groep: mensen uit Baumbach en Ransbach, Westerwalders, katholieke Westerwalders of Nassauers?

3 Na verloop van tijd kan de niche vervallen, bijvoorbeeld door veranderingen in de vraag, technologische ontwikkelingen of een einde aan de aanvoer van goedkope arbeidskrachten. Welke factor prevaleert, wordt bepaald door het karakter van de niche. Wanneer de niche uiteenvalt, valt ook de groep uiteen. In geen van de historische voorbeelden schuift de groep op naar een volgende niche. Nichevorming leidt niet tot een permanente groepsvorming; het is slechts een tijdelijke fase.

4 De laatste en belangrijkste stap is, dat de groep de niche feitelijk ontgroeit. Het groepsvormingsproces ontwikkelt op dat moment een eigen dynamiek. Niet langer bepalen de mogelijkheden binnen de niche, of zelfs nieuwe mogelijkheden buiten de niche het verdere proces, maar het bestaan van de groep zelf. Het bestaan van een relatief grote groep immigranten, trekt nieuwe immigranten aan met min of meer dezelfde achtergrond, zonder dat daarvoor noodzakelijkerwijs een economische basis bestaat. Het proces van groepsvorming haalt het proces van nichevorming in feite - symbolisch gezien - in. Indien er door een succesvol proces van nichevorming op een gegeven moment een groep is ontstaan, ontwikkelt het groepsvormingsproces een eigen dynamiek, los van de nichevorming. Dat zien we bij de twee grootste groepen Duitse immigranten.

Of de interactieve groeps- en nichevorming, zoals die hier is beschreven, zich voordeed en in welke sectoren die zich voordeed, was sterk afhankelijk van lokale mogelijkheden en zelfs van toeval. Een succesvolle immigrant of een groepje mensen dat toevallig ergens terechtkwam, kon aan het begin van het interactieve proces van groeps- en nichevorming staan. Het vrij plotseling wegvallen van mogelijkheden op de ene plaats, kan 
het begin zijn van het proces wanneer het toevallig samenvalt met het ontstaan van mogelijkheden op een andere plaats. ${ }^{4}$

Tussen het Europese onproblematische assimilatieperspectief en het Amerikaanse eeuwige etniciteitsperspectief, blijkt een derde weg te bestaan. In de eerste benadering wordt teveel nadruk gelegd op het resultaat en in de tweede wordt het proces teveel verabsoluteerd. In de tussenvariant, zoals hier beschreven, is groepsvorming een tijdelijk fenomeen van de middenlange termijn. Die groepsvorming is sterk verbonden met concentratie in beroepen, een verschijnsel dat onder migranten veelvuldig is geconstateerd, maar niet echt is verklaard, behalve door verwijzingen naar vage begrippen als een gemeenschappelijke band. De wisselwerking tussen nichevorming en groepsvorming, zo bleek hier, was het belangrijkst. Deze constatering is van belang in het licht van de actuele discussie omtrent groepsvorming en de pendant integratie. Bij hedendaagse pogingen de integratie te bevorderen, gaat het om de overname van culturele normen en waarden, om een verspreiding van immigranten over woonwijken en scholen, en om het ontmoedigen van endogamie. Voor concentratie in beroepen of economische sectoren, hier aangemerkt als de voornaamste factor in het proces van groepsvorming, is de minste belangstelling in het integratiedebat. De uitkomsten van dit onderzoek geven aan dat die aandacht er wel zou moeten zijn. 



\section{Noten}

\section{VOORWOORD}

1 De Duitsers in het buurpand zijn niet de enige Duitsers die in Nederland komen werken. Zie De Volkskrant 'Duitsers werken graag in Nederland', 25-5-2000, 1.

\section{INLEIDING}

1 Iñaki Oñorbe Genovesi, 'Partij? Nu meer een bende', De Volkskrant 10 september 2001.

2 Utrechtsche Courant 10 mei 1839.

3 Jan Hein Furnée, “'Om te winkelen, zoo als dat in de residentie heet". Consumptiecultuur en stedelijke ruimte in Den Haag, 1850-1890', Jaarboek voor Vrouwengeschiedenis 22 (2002) 28-55.

4 A.J. Dekker, 'De opkomst van kerstboom en kerstviering in Nederland (ca. 18351880)', Volkskundig bulletin 8, 2 (1982) 129179.

5 Aspecten van de Duitse immigratie in de negentiende eeuw en eerder zijn reeds beschreven. Belangrijk zijn: J. Lucassen, Naar de kusten van de Noordzee. Trekarbeid in Europees perspectief, 1600-1900 (Gouda 1984); Piet Lourens en Jan Lucassen, Arbeidswanderung und berufliche Spezialisierung. Die lippischen Ziegler im 18. und 19. Jarhhundert (Osnabrück 1999); H. Oberpenning, Migration und Fernhandel im "Tödden-System". Wanderhändler aus dem nördlichen Münsterland im mittleren und nördlichen Europa (Osnabrück 1996); Leo Lucassen, 'Het einde van een migratieregime: buitenlanders in Holland gedu- rende de 19e eeuw', Historisch Tijdschrift Holland (2001) 190-211; R. Rommes, Oost, west, Utrecht best? Driehonderd jaar migratie en immigranten in de stad Utrecht (begin 16e - begin 19e eeuw) (Utrecht 1998); R. Rommes, 'Lutherse immigranten in Utrecht tijdens de Republiek', in: Marjolein 't Hart, Jan Lucassen en Henk Smal (red.), Nieuwe Nederlanders. Vestiging van immigranten door de eeuwen heen (Amsterdam 1996); D.E.A. Faber en R.N.J. Rommes, 'Op weg naar stabiliteit', in: R.E. de Bruin, P.D. 't Hart, A.J. van den Hoven van Genderen, A. Pietersma (red.), 'Een paradijs vol weelde'. Geschiedenis van de stad Utrecht (Utrecht 2000) 251-314; Bram van den Hoven van Genderen en Ronald Rommes, 'Rijk en talrijk. Beschouwingen over de omvang van de Utrechtse bevolking tussen circa 1300 en het begin van de 17e eeuw', Jaarboek Oud-Utrecht (1995) 5387; Jelle-Jaap van Lottum, Nieuwkomers in Nederland in de eerste helft van de 19e eeuw. Een onderzoek op basis van de volkstellingen in Utrecht van 1829 en 1839 (Ongepubliceerde doctoraalscriptie vu 2002, aanwezig op Het Utrechts Archief). Zie verder ook: Gerard van der Harst en Leo Lucassen (met medewerking van Annette van Rijn), Nieuw in Leiden. Plaats en betekenis van vreemdelingen in een Hollandse stad 1918-1955 (Leiden 1998); Annemarie Cottaar, Ik had een neef in Den Haag. Nieuwkomers in de twintigste eeuw (Zwolle 1998); Barbara Henkes, Heimat in Holland. Duitse dienstmeisjes 1920-1950 (Amsterdam 1995); A. Eiynck e.a. (red.), Werken over de grens. 350 jaar geld verdie- 
nen in het buitenland (Assen 1993). Zie ook mijn publicaties waarin voorlopige uitkomsten van dit onderzoek werden gepresenteerd: M. Schrover, 'Omlopers in Keulse potten en pottentrienen uit het Westerwald', in: M. 't Hart, J. Lucassen en H. Smal (red.) Nieuwe Nederlanders. Vestiging van immigranten door de eeuwen heen (Amsterdam 1996) 101-120; Marlou Schrover, 'Groepsvorming onder Duitse aardewerkhandelaren in 19e-eeuws Holland en Utrecht', Historisch tijdschrift Holland nr.2 (1998) 94-112; Marlou Schrover, 'German communities in nineteenthcentury Utrecht: Factors influencing the settlement process' IMIS-Beiträge. 14 (2000) 45-74; Schrover, 'Potverkopers, vijlenkappers, stukadoors en winkeliers', Nichevorming onder Duitse migranten in de negentiende-eeuwse stad Utrecht', Tijdschrift voor Sociale Geschiedenis (2000) 281-305.

6 Een uitzondering is: Heinz Schmitz, 'Discriminatie of integratie van Duitsers in het negentiende-eeuwse Rotterdam? Een verkenning', in: Paul van de Laar, Thimo de Nijs, Johan Okkema, Albert Oosthoek (red.), Vier eeuwen migratie. Bestemming Rotterdam (Rotterdam 1998) 124-145.

7 Stanley Nadel, Little Germany: ethnicity, religion, and class in New York City, 184580 (Urbana en Chicago 1990); Panikos Panayi, German immigrants in Britain during the 19th century 1815-1914 (Oxford en Washington 1995); Robert Paul McCaffery, Islands of Deutschtum. GermanAmericans in Manchester, New Hampshire and Lawrence, Massachusetts, 1870-1942 (New York 1996); Gesa Snell, Deutsche Immigranten in Kopenhagen 1800-1870. Eine Minderheit zwischen Akzeptanz und Ablehnung (Münster 1999).

8 Zie bijvoorbeeld: Schmitz, 'Discriminatie of integratie', 132-133.

9 L.J. Rogier, Katholieke herleving. Geschiedenis van katholiek Nederland sinds 1853 (Den Haag 1962) 267.
10 Geciteerd in McCaffery, Islands of Deutschtum, 2.

11 Eberhard Reichmann, La Vern J. Rippley en Jörg Nagler, 'Introduction', in: Eberhard Reichmann, LaVern J. Rippley en Jörg Nagler (red.), Emigration and settlement patterns of German communities in North America (Indianapolis 1995) ixxvi, ix.

12 McCaffery, Islands of Deutschtum, 3.

13 Brief van F. Richert, 10 januari 2002.

14 Zie behalve de studies van Panayi, Snell, McCafferry en Nadel ook: Barbara Henkes, 'Gedeeld Duits-zijn aan de Maas. Gevestigd Deutschtum en Duitse nieuwkomers in de jaren 1900-1940', in: Van de Laar e.a. (red.), Vier eeuwen migratie, 218239.

15 McCaffery, Islands of Deutschtum, 2.

16 Jan Lucassen en Leo Lucassen, 'Migration, migration history, history. Old paradigms and new perspectives', in: Jan Lucassen en Leo Lucassen (red.), Migration, migration history, history: old paradigms and new perspectives (Bern enz. 1997) 57-72, 69.

17 Ewa Morawska, 'The sociology and historiography of immigration', in: Virginia Yans-McLaughlin, Immigration reconsidered. History, sociology, and politics (New York/Oxford 1990) 187-240, 189; J. Lucassen en R. Penninx, Nieuwkomers, nakomelingen, Nederlanders. Immigranten in Nederland 1550-1993 (Amsterdam 1994) 118-119 en 170.

18 Lucassen en Penninx, Nieuwkomers, 101. Uitzonderingen waren joden en zigeuners.

19 Morawska, 'The sociology and historiography of immigration', 189.

20 Het Volkskrant Magazine 20-10-2001, 50.

21 Lucassen en Penninx, Nieuwkomers, 102.

22 Bob Carter, Marci Green en Rick Halpern, 'Immigration policy and the racialization of migrant labour: the construction of national identities in the USA and Britain', Ethnic and Racial Studies (januari 1996) Vol. 19 nr 1, 135-157; George E. Pozzetta, 'Introduction', in: George E. Pozzetta 
(red.), Assimilation, acculturation and social mobility (New York en Londen 1991), V-X.

23 F. Barth (red.), Ethnic groups and boundaries. The social organization of cultural difference (Londen 1969); Maykel Verkuyten, Etnische identiteit. Theoretische en empirische benaderingen (Amsterdam 1999) 4.

24 Nadel, Little Germany, 5, noemt in zijn boek enkele zeldzame voorbeelden waarbij historici wel dit idee hebben opgepakt.

25 Sonya Salamon, Prairie patrimony: family, farming and community in the Midwest (Chapel Hill 1992) 6; Pernille Larsen, 'Hebben Nederlanders dan geen cultuur? Een beschouwing over Nederlands onderzoek naar 'etnisch ondernemerschap', Immigrantenstudies (1995) nr. 1, 30-38.

26 Geertje Mak, 'Verschil als uitgangspunt. Een inbreng van vrouwenstudies op het terrein van (lokale) migratiegeschiedenis', Tijdschrift voor Sociale Geschiedenis (2000) 343-362; Sawitri Saharso, Jan en alleman. Etnische jeugd over etnische identiteit, discriminatie en vriendschap (Utrecht 1992).

27 Marlou Schrover, 'Wie zijn wij? Vrouwen, eten en etniciteit', Voeden en Opvoeden, Jaarboek voor Vrouwengeschiedenis 19 (1999) 115-144.

28 J. Rath, Minorisering: de sociale constructie van 'etnische minderheden' (Utrecht 1991) 37; Nadel, Little Germany, 6.

29 John Hutchinson en Anthony D. Smith (red.), Ethnicity (Oxford/New York 1996).

30 Edna Bonacich en John Modell, The economic basis of ethnic solidarity. Small business in the Japanese American community (Berkeley 1980).

31 Verkuyten, Etnische identiteit, 12.

32 Peter Ratcliffe, 'Conceptualizing "race", ethnicity and nation: towards a comparative perspective.' in: Peter Ratcliffe (red), "Race", ethnicity and nation. International perspectives on social conflict (Londen 1994) 6.
33 J.S. Phinney, 'Ethnic identity in adolescents and adults: review of research', Psychological Bulletin (1990) nr. 108, 499-514.

34 Lucassen en Penninx, Nieuwkomers; E. Bonacich, 'A theory of middlemen minorities', American Sociological Review (1973) 38 (5) 583-594.

35 J. H. Jackson, 'Migration in Duisburg, 1867-1890. Occupational and familial contexts', Journal of Urban History ( 3 mei 1982) vol. 8, 235-270.

36 Remieg Aerts en Henk te Velde, 'De taal van het nationaal besef, 1848-1940', in: N.C.F. van Sas (red.), Vaderland. Een geschiedenis van de vijftiende eeuw tot 1940 (Amsterdam 1999) 391-454, 392.

37 Aets en Te Velde, 'De taal van het nationaal besef, 404 .

38 Marlou Schrover, 'Memory and identity of Dutch caravan travellers', Oral History (voorjaar 1990) 41-43; Anthony D. Smith, 'Chosen peoples: why ethnic groups survive', Ethnic and Racial Studies (juli 1992) Vol. 15, nr. 3, 436-456; Leo Lucassen, 'En men noemde hen zigeuners'. De geschiedenis van Kaldarasch, Ursari, Lowara en Sinti in Nederland: 1750-1944 (Amsterdam/Den Haag 1990); Verkuyten, Etnische identiteit, 44.

39 Verkuyten Etnische identiteit, 44.

40 Anne Woollett, Harriette Marshall, Paula Nicolson en Neelam Dosanjh, 'Asian women's ethnic identity: the impact of gender and context in the accounts of women bringing up children in East London', in: Kum-Kum Bhavnani en Ann Phoenix (red.), Shifting identities shifting racisms. A feminism \& Psychology Reader (Londen/Thousand Oaks/New Delhi 1994) 119-132; Verkuyten, Etnische identiteit, 28.

41 Koen Vlassenroot, 'Sociale en politieke functies van etniciteit. Verkenning en operationalisering van een begrippenkader', Tijdschrift voor sociale wetenschappen (1997) 42 nr. 4, 385-407, 392. 
42 Vlassenroot, Sociale en politieke functies van etniciteit', 385-407.

43 Vergelijk: Panayi, German immigrants; Nadel, Little Germany; Snell, Deutsche Immigranten in Kopenhagen; McCaffery, Islands of Deutschtum; Georg Fertig, Migration from the German-speaking parts of central Europe, 1600-180o: estimates and explanations (Berlijn 1991); Reichmann, Rippley en Nagler (red.), Emigration and settlement patterns of German communities; Walter D. Kamphoefner, The Westfalians. From Germany to Missouri (Princeton 1987). Zie voor een recent overzicht van migratie van Duitsers: Peter Marschalck, 'Einführung', in: Peter Marschalck (red.), Europa als Wanderungsziel. Ansiedlung und Integration von Deutschen im 19. Jahrhundert. IMIS-Beiträge 14/200 (Osnabrück 2000).

44 Panayi, German immigrants; Snell, Deutsche Immigranten in Kopenhagen; Nadel, Little Germany; en Henkes, 'Gedeeld Duits-zijn aan de Maas'.

45 Rinus Penninx, Raster en Mozaiek. Uitgangspunten voor onderzoek naar internationale migratie, etnische processen en sociale ongelijkheid (Amsterdam 1994) 5; Lucassen en Penninx, Nieuwkomers, 99111; Marita Krauss, 'Integration und Akkulturation. Eine methodische Annäherung an ein vielschichtiges Phänomen', in: Mathias Beer, Martin Kintzinger, Marita Krauss (red.), Migration und Integration. Aufnahme und eingliederung im Historischen Wandel (Stuttgart 1997) 11-25.

46 Krauss, 'Integration und Akkulturation'; John W. Berry, 'Psychology of acculturation. Understanding individuals moving between cultures', in: Richard W. Brislin (red.), Applied cross-cultural psychology (Cross-cultural research and methodology series vol 14) (Newbury Park/Londen/ New Delhi 1990) 232-253.

47 Rinus Penninx en Boris Slijper, Voor elkaar? Integratie, vrijwilligerswerk en organisaties van migranten (Amsterdam 1999).
48 Donald M. MacRaild, Culture, conflict and migration. The Irish in Victorian Cumbria (Liverpool 1998) 2.

49 Het interview met Camel El Makrini, december 2000, werd afgenomen door Jeroen Brouwer, student geschiedenis u U 2000.

50 Patricia Boscia-Mulè, Authentic ethnicities. The interaction of ideology, gender power, and class in the Italian-American experience (Westport, Connecticut en Londen 1999) 4.

51 Verkuyten, Etnische identiteit, 121.

52 Rob Kroes, The persistence of ethnicity, Dutch Calvinist pioneers in Amsterdam, Montana (Urbana/Chicago 1992) 7. Bij de bespreking van deze variabelen in de afzonderlijke hoofdstukken wordt verwezen naar de relevante literatuur.

53 Anne Aengenvoort, Migration - Siedlungsbildung - Akkulturation. Die Auswanderung Nordwestdeutscher nach Ohio, 18301914 (Stuttgart 1999) 252.

54 Boscia-Mulè, Authentic ethnicities, 18-19.

55 Lucassen en Penninx, Nieuwkomers, 102.

56 Milton M. Gordon, Assimilation in American life. The role of race, religion and national origins (New York 1964).

57 Voor een uitgebreide bespreking van de literatuur op dit punt zie: Marlou Schrover, 'Maria en Rocco. Gemengde huwelijken en integratie in de negentiende eeuw', Gaan \& Staan, Jaarboek voor Vrouwengeschiedenis 21 (Amsterdam 2001) 81-101.

58 Erna Hooghiemstra, 'Voor de keuze: Een specifieke of algemene blik op partnerkeuze van immigranten', Immigrantenstudies (2000) nr. 4, 209-228, 220.

59 Rosemarie Buikema, 'Someday, somehow, somewhere. Interetnische relaties in West Side Story en Jungle Fever', Migrantenstudies (2000) nr. 4 260-274, 261.

60 Hooghiemstra, 'Voor de keuze', 209-228.

61 De Amerikaanse sociologen Vosburgh en Juliani geven in hun vergelijkende studie talloze voorbeelden hiervan: Miriam G. 
Vosburgh en Richard N. Juliani, 'Contrasts in ethnic family patterns: the Irish and the Italians', Journal of comparative family studies (1990) vol. XxI, nr. 2, 267286. Zie voor Nederland bijvoorbeeld: Van der Harst en Lucassen, Nieuw in Leiden; Cottaar, Ik had een neef in Den Haag, waar het gaat over Italianen.

62 Zie voor een overzicht op dit punt: Marlou Schrover, 'Potverkopers, vijlenkappers, stukadoors en winkeliers. Nichevorming onder Duitse migranten in de negentiende-eeuwse stad Utrecht', Tijdschrift voor Sociale Geschiedenis (2000) 281-305; Marlou Schrover, 'Immigrant business and niche formation in a historical perspective. The Netherlands in the nineteenth century', Journal of Ethnic and Migration Studies (april 2001) vol. 27 .no. 295-311.

63 Charles Tilly, 'Transplanted network', in: Virginia Yans-McLaughlin (red.), Immigration reconsidered. History, sociology, and politics (New York/Oxford 1990) 79-95, 92.

64 R. Waldinger, Still the promised city? African-Americans and new immigrants in postindustrial New York (Cambridge MA/Londen 1996).

65 Hans Vermeulen, Etnische groepen en grenzen. Surinamers, Chinezen en Turken (Weesp 1984) 24. Vermeulen ontleende dit begrip aan: M. Hechter, 'Group formation and the cultural division of labor', American Journal of Sociology (1978) nr. 84, 293318.

66 Dik van Arkel, 'De groei van het antiJoodse stereotype. Een poging tot een hypothetisch-deductieve werkwijze in historisch onderzoek', Tijdschrift voor Sociale Geschiedenis (1984) 34-70.

67 Ruby Jo Reeves Kennedy, 'Single or triple melting pot? Intermarriage trends in New Haven, 1870-1950', American Journal of Sociology LVII, 56-59, 58.

68 Kroes, The persistence of ethnicity, 9.

69 Zie ook Pim Kooij, Groningen 1870-1914. Sociale verandering en economische ontwik- keling in een regionaal centrum (Groningen 1987) 17-20.

70 Ewa Morawska, Insecure prosperity. Smalltown jews in industrial America, 1890-1940 (Princeton 1996); Waldinger, Still the promised city?; Leo Lucassen en Floris Vermeulen, Immigranten en lokale arbeidsmarkt. Vreemdelingen in Den Haag, Leiden, Deventer en Alkmaar (1920-1940) (CGM working paper, Amsterdam 1999).

71 In totaal werden voor deze steekproef 957 mensen getrokken. Dit aantal werd gekozen op basis van prognoses omtrent het aantal mensen dat in latere huwelijksakten zou kunnen worden teruggevonden. Als beginjaar is niet 1810 genomen, maar 1812, omdat voor de eerste twee jaren de geboorteakten niet beschikbaar waren. Oorspronkelijk werd voor de steekproef een percentage van 0,75 van het aantal geboorten genomen in Utrecht tussen 1812 en 1835. Vervolgens werd een oversample genomen om het cijfer van $957 \mathrm{vol}$ te maken. Daarna werd door HSN-medewerkers opgezocht of de mensen uit deze steekproef teruggevonden konden worden in de Utrechtse huwelijksregisters. Zie voor de HSN onder meer: Kees Mandemakers, 'De Historische Steekproef van de Nederlandse Bevolking', in: Kees Mandemakers en Onno Boonstra (red.), De levensloop van de Utrechtse bevolking in de 19de eeuw (Assen 1995) 157-162; Kees Mandemakers, 'Het HsN-bestand van de provincie Utrecht', in: Mandemakers en Boonstra (red.), De levensloop van de Utrechtse bevolking, 163-175.

72 Hiervoor werd gebruik gemaakt van materiaal dat uit een eerder onderzoek beschikbaar was. Richard Loontjens, Peter Vuijst en Marlou Schrover, Op zoek naar de wortels der marginaliteit. Vijftig Utrechtse families ten tijde van de industrialisatie (1850-1920) (Ongepubliceerde doctoraalscriptie Geschiedenis Universiteit Utrecht 1985, aanwezig op Het Utrechts Archief). Deze gegevens hadden 
betrekking op mensen die gedurende de extreem koude winters van 1853-54 en 1854-55 een extra vorm van bedeling kregen. Voor deze winterbedeling kwamen mensen in aanmerking die geen reguliere armenzorg kregen. Vierduizend hoofden van huishoudens, ongeveer eenderde van de Utrechtse bevolking, kregen deze bedeling. Idee achter de keuze voor deze tweede groep als controlegroep was dat zij bestond uit mensen die min of meer een homogene sociale klasse vormden; ze werden niet-permanent bedeeld, maar kwamen in uitzonderlijke omstandigheden, zoals lang aanhoudende extreme kou, wel in moeilijkheden. Uit deze groep werd een steekproef getrokken en er werd geselecteerd op het geboortecohort 1810-1835. Dit resulteerde in een groep van 168 families. Vrijwel alle winterbedeelden waren in Utrecht geboren. Geboorte in Utrecht was echter geen voorwaarde voor bedeling.

73 Nancy L. Green, 'The comparative method and poststructural structuralism: new perspectives for migration studies', in: Jan Lucassen en Leo Lucassen (red.), Migration, migration history, history: old paradigms and new perspectives (Bern 1997) 57-72, 70.

74 Green, 'The comparative method', 69.

75 Panayi, German immigrants in Britain; Nadel, Little Germany; Snell, Deutsche Immigranten in Kopenhagen.

76 I. Light en S. Karageorgis, 'The ethnic economy', in: Smelser en Swedberg (red.), The handbook of economic sociology (Princeton 1994) 647-670, 663.

77 Green, 'The comparative method', 68.

\section{VREEMDELINGENWETGEVING}

1 Nationaal Archief (NA, voorheen ARA) Ministerie van Justitie, 1813-1876, 2.09.01, 5181 Toelating en uitzetting van vreemdelingen (vreemdelingenwet) 1849-1876.
2 NA, Ministerie van Justitie, 1813-1876, 2.09.01 5181 Toelating en uitzetting van vreemdelingen (vreemdelingenwet) 18491876. Brief van de 'directeur van policie te Amsterdam' 3-10-1850 aan de Minister van Justitie. Waar in de tekst namen worden genoemd, wordt de spellingsvariant gebruikt die in de bronnen het meest voorkwam, en niet de meest Duits-klinkende variant. Namen werden in bronnen op tal van manieren gespeld. In de database zijn alle spellingsvarianten opgenomen.

3 Met dank aan Corrie van Eijl en Ronald Rommes voor hun commentaar op eerdere versies van dit hoofdstuk. Voor dit hoofdstuk is onder meer gebruik gemaakt van: Eric Heijs, Van vreemdeling tot Nederlander (Amsterdam 1995); L. Lucassen, "'Het paspoort als edelste deel van een mens." Een aanzet tot een sociale geschiedenis van het Nederlandse vreemdelingenbeleid', Holland. Regionaal historisch tijdschrift 27 (1995) 265-285; Marij Leenders, Ongenode gasten. Van traditioneel asielrecht naar immigratiebeleid 18151938 (Hilversum 1993); C.A. Groenendijk, Op weg naar een Nederlandse paspoortwet (Deventer 1973); R. Tjin, 'Nederlandse paspoorten. De politiek van reizen en identificatie van personen', Amsterdams Sociologisch Tijdschrift, 17 (1990) 74-100; A. Cottaar, J. Lucassen en L. Lucassen, Van over de grens. Gids voor lokaal historisch onderzoek naar immigratie in Nederland (Utrecht 1998); Lucassen en Vermeulen, Immigranten en lokale arbeidsmarkt; Ronald Rommes en Marlou Schrover, Grensverleggers. Gids voor lokaal historisch onderzoek naar migratie in de provincie Utrecht (Utrecht 2001); Corrie van Eijl en Marlou Schrover, 'Vreemde landlopers. Het Nederlandse vreemdelingenbeleid tussen 1800 en 1940', Jaarboek Centraal Bureau voor Genealogie deel 55 (2001) 161180; Corrie van Eijl en Marlou Schrover, 'Inleiding', in: Marlou Schrover (red.), 
Bronnen betreffende de registratie van vreemdelingen in Nederland in de negentiende en twintigste eeuw. Broncommentaar 5 (Den Haag 2002) 7-33.

4 In een volgend hoofdstuk wordt op de kenmerken van een migrantenpopulatie nader ingegaan.

5 Rommes Oost, west, Utrecht best?, 50.

6 Faber en Rommes, 'Op weg naar stabiliteit', 251-314, 305.

7 Het Utrechts Archief (huA), 86 BA 1 gilden 56, Publicatie van Vroedschap 27-11738.

8 Rommes, Oost, west, Utrecht best?, 42. Utrecht was niet uitzonderlijk in dit beleid. In Nijmegen, Arnhem, Zwolle en Zutphen golden vergelijkbare beperkingen. B. Panhuysen, Maatwerk. Kleermakers, naaisters, oudkleerkopers en de gilden (1500-1800) (Amsterdam 2000) 83-86; Maarten Prak, Republikeinse veelheid, democratisch enkelvoud. Sociale verandering in het Revolutietijdvak 's-Hertogenbosch 1770-1820 (Nijmegen 1999) 36; P. Lourens en J. Lucassen, " "Zunftlandschaften" in den Niederlanden und im benachbarten Deutschland', in: W. Reininghaus (red.), Zunftlandschaften in Deutschland und den Niederlanden im Vergleich (Münster 2000) 11-43.

9 R. Rommes, 'Duitse immigratie in Utrecht vanaf de zestiende tot de achttiende eeuw', in: K. Davids, M. 't Hart, H. Kleijer, J. Lucassen (red.), De Republiek tussen zee en vasteland. Buitenlandse invloeden op cultuur, economie en politiek in Nederland 1580-1800 (Leuven/Apeldoorn 1995) 169-188, 169.

10 Rommes, Oost, west, Utrecht best?

11 Tussen 1795 en 1815 vonden er veel veranderingen plaats, maar deze veranderingen zijn vanwege hun tijdelijke karaker in het kader van dit verhaal minder relevant en worden daarom buiten beschouwing gelaten.
12 Cottaar, Lucassen en Lucassen, Van over de grens, 38; Lucassen en Vermeulen, Immigranten en lokale arbeidsmarkt.

13 Met dank aan Corrie van Eijl die mij op deze regelgeving heeft gewezen.

14 Zitting van den 8ste maart. Ix Beraadsl. over de regeling en beperking der uitoefening van het regt van Vereeniging en Vergadering. Bijblad Handelingen Tweede Kamer 18-9-1854 tot 23-8-1855, 587-598, 589.

15 Wet van 28-7-1850, Staatsblad nr. 44.

16 De Gemeentestem 25-6-1862, nr. 560, 4.

17 Slechts 0,1 procent van de in Nederland wonende Duitsers liet zich in de tweede helft van de negentiende eeuw naturaliseren. Heijs, Van vreemdeling tot Nederlander, 85. Zie voor berekening van dit percentage aldaar.

18 Heijs, Van vreemdeling tot Nederlander, 87. Onduidelijk is hoeveel procent van de naturalisaties kosteloos waren.

19 Schmitz, 'Discriminatie of integratie', 124145.

20 NA, Ministerie van Justitie, 1813-1876, 2.09.01, 4917 bestrijding van landloperij en bedelarij 1815-1829. Stukken betreffende de uitlevering van Pruissische deserteurs en de wederzijds genomen maatregelen omtrent het wegzenden van landlopers en andere dergelijke lieden. Brief van 23-5$1818 \mathrm{nr} .350$ en brief van 14-1-1819 nr. 84 .

21 HUA, Archief provinciaal bestuur, Notulen van de vergadering van gedeputeerde staten met bijlagen, 668, 1847 mei.

22 HUA, Archief provinciaal bestuur, Notulen van de vergadering van gedeputeerde staten met bijlagen, 6681847 mei.

23 HUA, Archief provinciaal bestuur, Notulen van de vergadering van gedeputeerde staten met bijlagen, 668, 1847 mei. 5-51847.

24 HUA, Archief provinciaal bestuur, Notulen van de vergadering van gedeputeerde staten met bijlagen, Nr. 674 30-11-1847 bijlage 32 Signalement opgemaakt 8-111847. 
25 Correspondentie Buitenlandse Zaken onder meer gedateerd 2-8-1843, 12-7-1843, 312-1844, 11-1-1843. Verzameld en bewerkt in: C.W. van Santen, Het internationale recht in Nederlands buitenlands beleid (een onderzoek in het archief van het ministerie van buitenlandse zaken) (Den Haag 1953) 820-821.

26 Geheime brief 22-4-1848 in archief Buitenlandse Zaken, aangehaald in: Van Santen, Het internationale recht, 823 .

27 Louk Pöckling en Marlou Schrover, 'Registers van verstrekte en geweigerde reisen verblijfpassen (1849-1923)', in: Marlou Schrover (red.), Bronnen betreffende de registratie van vreemdelingen in Nederland in de negentiende en twintigste eeuw. Broncommentaren 5 (Den Haag 2002) 35-68.

28 Staatsblad no 39 wet van 13 den augustus 1849 tot regeling der toelating en uitzetting van vreemdelingen.

29 Pöckling en Schrover, Registers van verstrekte en geweigerde reis- en verblijfpassen; Zie ook: De Gemeentestem 9-12-1878 nr. 1419, 1-2.

30 Lucassen, Naar de kusten van de Noordzee, 111-117; Lucassen, En men noemde hen zigeuners, 33 .

31 Bijvoegsel tot het Staatsblad 1862 circulaire no. 121, 252. Afschaffing verplicht tonen paspoort 26-4-1862.

32 Bijvoegsel tot het Staatsblad 1861 no. 131, 256. Missive van Minister van Justitie 295-1861.

33 Bijvoegsel tot het Staatsblad 1861 no. 139, 267.

34 'Vreeemdelingen-wet', Weekbl. V.h. Regt 25-5-1871; gereproduceerd in De Gemeentestem 29-5-1871 nr. 1026, 2.

35 De Gemeentestem 12-7-1875, nr. 1241, 1.

36 NA, Ministerie van Justitie, 1813-1876, 2.09.01 5190, Toelating en uitzetting van vreemdelingen (vreemdelingenwet) 18491876.

37 Met dank aan Corrie van Eijl.

38 Verslag over de verrigtingen aangaande het Armbestuur over 1854, onderdeel van Rege- ringsverslag, Handelingen Tweede Kamer 1855-1856, 874 .

39 M.P. Bossenbroek, Volk voor Indië. De werving van Europese militairen voor de Nederlandse koloniale dienst 1814-1909 (Amsterdam 1992) 189.

40 NA, Ministerie van Justitie, 1813-1876, 2.09.01 5181 Toelating en uitzetting van vreemdelingen (vreemdelingenwet) 18491876.

41 Verslag over de verrigtingen aangaande het Armbestuur over 1854, onderdeel van Regeringsverslag, Handelingen Tweede Kamer 1855-1856, 874.

42 Idem.

43 HUA, Archief provinciaal bestuur 79, 7545 stukken betreffende de zorg voor armlastige vreemdelingen 1848-1849.

44 HUA, Stadsarchief (sA) SA V 719 29-3-1856 Brief aan Burgemeester en wethouders betreft werking gedurende afgelopen jaar der wet van 13-8-1849 staatsblad 39 houdende regelingen van de toelating en uitzetting der vreemdelingen.

45 Verslag over de verrigtingen aangaande het Armbestuur over 1856, onderdeel van Regeringsverslag, Handelingen Tweede Kamer 1857-1858, 858.

46 Marco H.D. van Leeuwen, Bijstand in Amsterdam, ca. 1800-1850. Armenzorg als beheersings- en overlevingsstrategie (Utrecht 1990) 94.

47 HUA, Archief provinciaal bestuur 79, 7545 stukken betreffende de zorg voor armlastige vreemdelingen 1848-1849.

48 Idem.

49 Idem.

50 Idem.

51 HUA, Archief provinciaal bestuur 79, Notulen en bijlagen 668 mei 1847 Brief van de Minister van Binnenlandse Zaken aan Heren Gedeputeerde Staten der Provincie Utrecht 29-4-1847.

52 HUA, Archief provinciaal bestuur 79, Notulen en bijlagen 668 mei 1847 BenW van Utrecht aan Gedeputeerde Staten der Provincie 18-5-1847. 
53 HUA, Archief provinciaal bestuur 79, 7545 stukken betreffende de zorg voor armlastige vreemdelingen 1848-1849.

54 Annemarie Cottaar, Kooplui, kermisklanten en andere woonwagenbewoners. Groepsvorming en beleid 1870-1945 (Amsterdam 1996) 138.

55 HUA, Archief provinciaal bestuur 79, Jaarverslag Provinciaal Bestuur 1813-1920, Inv. nr. 213, Verslag over 1861, 236.

56 Cottaar, Kooplui, kermisklanten en andere woonwagenbewoners, 141.

57 De Gemeentestem 28-4-1856 nr. 239, 4.

\section{BeEldvorming}

1 J. Huizinga, Cultuur-historische verkenningen (Haarlem 1929) 188.

2 Theo Meder, Vertelcultuur in Waterland. De volksverhalen uit de collectie Bakker in hun context (ca. 1900) (Amsterdam 2001) 151. De Poepengrappen gingen volgens Meder gedeeltelijk terug op een in 1827 anoniem verschenen anti-Duits schotschrift: Hans Hannekemaaijers's kluchtige lotgevallen en ontmoetingen op zijne reis naar en door Holland. Dat werd mogelijk geschreven door Maarten Douwes Teenstra 1795-1864 (in 1978 herdrukt). Dezelfde grappen komen echter ook reeds voor in zeventiende- en achttiende-eeuwse kluchten.

3 Meder, Vertelcultuur in Waterland, 231.

4 Justus van Maurik, Toen ik nog jong was (Amsterdam 1901) 55.

5 Utrechtsch Provinciaal en Stedelijk Dagblad 4-6-1892.

6 Utrechtsch Provinciaal en Stedelijk Dagblad 15-6-1892.

7 Utrechtsche Provinciale en Stadscourant 229-1851 advertentienummer 5786 .

8 Utrechtsche Provinciale en Stadscourant 1912-1851.

9 Utrechtsche Provinciale en Stadscourant 187-1851 advertentienummer 5239.
10 Utrechtsche Provinciale en Stadscourant 1912-1851.

11 Conrad Busken Huet, Lidewijde (oorspronkelijke uitgave Amsterdam 1868, hier geciteerd uit de herdruk Utrecht/Amsterdam 1981) 156.

12 Huizinga, Cultuur-historische verkenningen, 143.

13 Het navolgende stuk stoelt op het verslag dat Hermann Bauer zestig jaar later (in 1913) schreef. Een Nederlandse bewerking van een gedeelte van dit verslag door Annelies Krekel-Aalberse verscheen als: 'Utrecht in 1853 Het begin van de Utrechtse zilverindustrie', Maandblad Oud Utrecht (november/december 1996) 124-128. Ik wil Annelies Krekel-Aalberse heel hartelijk bedanken voor het ter beschikking stellen van het originele document, dat zich bevindt in het (nog niet overgedragen) archief van de zilverfabriek Van Kempen en Begeer. Hermann Bauer werd geboren in Abstatt in 1833 en overleed in Schwäbisch Gmünd in 1919.

14 In deze en volgende noten wordt steeds de eerste pagina van het bevolkingsregister genoemd, waarop een bepaalde migrant wordt genoemd. Vanaf dat adres is de migrant eenvoudig verder te volgen. Bevolkingsregister 1850-1859, Oudegracht 67, fiche 156, vel 83. Frederik Geuer en Emilie Jaeger uit Elberfeld en Unna.

15 Hermann noemt Gustav steeds 'Freund Gustav'. Volgens Annelies Krekel was het een neef van Hermann. Volgens het bevolkingsregister werd Gustav in 1830 in Heilbronn in Würtemberg geboren. Volgens zijn huwelijksakte was hij het buitenechtelijk kind van Caroline Bauer. Bevolkingsregister 1850-1859, wijk C, Oudegracht 77, fiche 102, vel 77; huwelijksakte 409 5-12-1855.

16 Krekel-Aalberse 'Utrecht in 1853 Het begin van de Utrechtse zilverindustrie', 124-128. In 1858 verhuisde de fabriek van Van Kempen met vijftig personeelsleden naar Voorschoten. Gustav Bauer bleef na het 
vertrek van Hermann nog enkele jaren bij Van Kempen werken. Kort voor de verhuizing naar Voorschoten verliet hij deze onderneming. In 1857 richtte hij samen met S. en J. van Lier de fabriek Van Lier en Bauer op, gevestigd op het Domkerkhof. In 1868 werd dit bedrijf overgenomen door C.J. Begeer. Gustav Bauer trouwde in 1855 in Utrecht met de Vlaamse Adelaïda Stengel. Onduidelijk is of dit dezelfde vrouw was door wie hij eerder bekoord was en welke relatie zo ijverig door haar familie en kennissen was bevorderd. Hij en zijn vrouw kregen zeven kinderen. Bevolkingsregister 1860-1869, F Domkerkhof 293, fiche 386, vel 549. Na de overname van zijn bedrijf door Begeer verhuisde hij met zijn familie naar Duitsland waar hij docent aan een kunstacademie werd.

17 Otto Brües, Das Mädchen von Utrecht. Erzählung (Berlijn 1933). De roman speelt in de negentiende eeuw, maar werd geschreven in de jaren dertig van de twintigste eeuw.

18 P. Groen, 't Grunneger Zangbouk. Tweede druk van Oude en Nieuwe Groninger Liederen (Winschoten 1958) 76. Het Lied heet de Nijsverteller en is uit 1823 .

19 Van Maurik, Toen ik nog jong was, 9.

20 W. A. Ornée, De 'Mof' in de Nederlandse blij- en kluchtspelen uit de 17e en 18e eeuw (Groningen 1970) 12.

21 Willem van Iependaal, Onder de pannen. Belevenissen in hotel Stoot-je-hoofd-niet, de lijmkit van Moeke Mullemans (Bussum z.j.) 125 .

22 Norbert Elias en John L. Scotson, De gevestigden en de buitenstaanders. Een studie van de spanningen en machtsverhoudingen tussen twee arbeidersbuurten (Utrecht en Antwerpen 1976) 20.

23 Meder, Vertelcultuur in Waterland, 151.

24 Zie voorbeelden bij het lemma Westfaalsch in Woordenboek der Nederlandsche taal.

25 Van Dale, Groot Woordenboek der Nederlandse taal, onder lemma 'sauger'.
26 Alex van Nancy, De nomaden van Nederland. Onthullingen uit het leven der rondreizende kooplieden, alias venters en bedelaars (Geertruidenberg 1902) 7.

27 Van Nancy, De nomaden van Nederland, 21.

28 Zie bijvoorbeeld de verwijzingen onder het lemma Mof in het Woordenboek der Nederlandsche taal, negende deel (Leiden 1913) 990.

29 Lucassen en Penninx, Nieuwkomers, 122, alwaar wordt verwezen naar deze editie van het Woordenboek.

30 Van Maurik, Toen ik nog jong was, 34.

31 Ornée, De 'Mof' in de Nederlandse blij- en kluchtspelen; Leo Lucassen, 'Poepen, Knoeten, Mieren en Moffen. Beeldvorming over Duitse immigranten en trekarbeiders in zeventiende- en achttiendeeeuwse kluchten', in: Vreemd gespuis (Amsterdam 1987) 29-38; H. MertensWestphalen, 'De Duitsers en de Hollandganger in kluchten uit de 17e en 18e eeuw', in: A. Eiynck e.a. (red.), Werken over de grens. 350 jaar geld verdienen in het buitenland (Assen 1993) 52-59; Lucassen en Penninx, Nieuwkomers, 118-199.

32 Lucassen, 'Poepen, Knoeten, Mieren en Moffen', 29-37.

33 Ornée. De 'Mof in de Nederlandse blij- en kluchtspelen; 9; Lucassen, 'Poepen, Knoeten, Mieren en Moffen', 29-38.

34 L.J. Rogier en N. de Rooy, In vrijheid herboren. Katholiek Nederland 1853-1953 (Den Haag 1953) 300-301; J.W.C. van Campen, 'De Handelsfirma Trip 1820-189o, volgens familieaantekeningen medegedeeld', Oud Utrecht (1958) 115-141, 120.

35 Van Campen, 'De Handelsfirma Trip, 120.

36 Utrecht tussen Pruis en Francoos 1780-180o. Uit de papieren van tijdgenoot C.J. Nagtglas, aangevuld door F. Nagtglas, opnieuw uitgegeven met aantekeningen van $d r$. A. van Hulzen (Utrecht 1975) 58.

37 Utrecht tussen Pruis en Francoos, 62-63.

38 Rogier, Katholieke herleving, 263.

39 Rogier, Katholieke herleving, 265-266. 
40 Rogier, Katholieke herleving, 267. Thorbecke's moeder kwam uit Osnabrück evenals zijn grootvader van vaderszijde.

41 Rogier, Katholieke herleving, 267.

42 Karmela Liebkind, 'The identity of a minority', International journal of multilingual and multicultural development (1989) 47-57, 53.

43 Johannes Tack, Die Hollandgänger in Hannover und Oldenburg. Ein Beitrag zur Geschichte der Arbeiter-Wanderung (Leipzig 1902) 173.

44 Aangehaald in: Johan Frieswijk, Om een beter leven. Strijd en organisatie van de land-, veen- en zuivelarbeiders in het noorden van Nederland (1850-1914) (Leeuwarden 1989) 56.

45 Van Maurik, Toen ik nog jong was, 32.

46 Leonie van Nierop, De bevolkingsbeweging der Nederlandsche stad (Amsterdam 1905) 111.

47 Van Nierop, De bevolkingsbeweging der Nederlandsche stad, 111.

48 Handelingen Tweede Kamer, zitting 18 juli $1849,628$.

49 Regeling van de toelating en uitzetting van vreemdelingen en van de algemeene voorwaarden hunner uitlevering (Verslag van de Commissie van Rapporteurs). Bijlage Handelingen van de Tweede Kamer der Staten Generaal 1849, 41-45, 42.

50 Idem.

51 Handelingen Tweede Kamer, zitting 18 juli $1849,626$.

52 Handelingen Tweede Kamer, zitting 18 juli 1849, 633, Van Zuijlen van Nijvelt (spreekt voor Gelderland).

53 Handelingen Tweede Kamer, zitting 18 juli 1849, 631, Kamerlid Sloet tot Oldhuis.

54 Handelingen Tweede Kamer, zitting 19 juli 1849, 643, Kamerlid De Man (Nijmegen).

55 Handelingen Tweede Kamer, zitting 18 juli 1849, 631, Kamerlid Sloet tot Oldhuis.

56 Handelingen Tweede Kamer, zitting 19 juli 1849, 641.

57 Handelingen Tweede Kamer, zitting 18 juli $1849,638$.
58 Handelingen Tweede Kamer, zitting 18 juli $1849,638$.

59 Regeling van de toelating en uitzetting van vreemdelingen en van de algemeene voorwaarden hunner uitlevering (Verslag van de Commissie van Rapporteurs). Bijlage Handelingen van de Tweede Kamer der Staten Generaal 1849, 41-45, 42.

60 Handelingen Tweede Kamer, zitting 18 juli $1849,628$.

61 Handelingen Tweede Kamer, zitting 18 juli 1849, 634, verwoord door Van Heiden Reinestein.

62 Regeling van de toelating en uitzetting van vreemdelingen en van de algemeene voorwaarden hunner uitlevering (Verslag van de Commissie van Rapporteurs). Bijlage Handelingen van de Tweede Kamer der Staten Generaal 1849, 41-45, 42.

63 Handelingen Tweede Kamer, zitting 18 juli 1849, 626, Kamerlid Costerus.

64 Handelingen Tweede Kamer, zitting 18 juli 1849, 634, Kamerlid Van Heiden Reinestein.

65 J.C. Boogman, Rondom 1848. De politieke ontwikkeling van Nederland 1840-1858 (Bussum 1978) 53.

66 P. Albers, Geschiedenis van het herstel der hierarchie in Nederland (2 delen Nijmegen 1903-1904); C.B. Wels, 'Kanttekeningen bij 'Schrikbeeld van een staatsgreep in 1853', Bijdragen en Mededelingen voor de geschiedenis der Nederlanden XV II (1963) 70-77; J.H. von Santen, 'Politiek leven in de stad Utrecht rond het midden van de negentiende eeuw (1840-1860)', Jaarboek Oud Utrecht (1985) 110-165.

67 Een stemgeregtigde, De zogenaamde geheime genootschappen der protestanten in Nederland verdedigd. Zestal brieven aan den Nederlandschen kiezer (Amsterdam 1853) 17.

68 De Waakzaamheid, Prot. Courant 6-41853, geciteerd in: Albers, Geschiedenis van het herstel der hierarchie, deel II, 346; zie ook: P.J.A. van Meegeren, 'Katholiek Utrecht in de tweede helft van de 
19e eeuw', Utrechtse Historische Cahiers jaargang 8 (Utrecht 1987) nr. 3/4, 15 en 20.

69 Albers, Geschiedenis van het herstel der hierarchie, deel II, 348 .

70 Een stemgeregtigde, De zogenaamde geheime genootschappen, 61.

71 L.J. Rogier, Schrikbeeld van een staatsgreep in 1853 (Amsterdam 1959) 242.

72 Toespraak eener Protestantsche Christin aan hare landgenooten (Den Haag 1853) 46; geciteerd in Albers, Geschiedenis van het herstel der hierarchie, deel II, 347.

73 De groote kwestie van den dag. Wat deze en gene al zoo dacht, sprak en deed (Utrecht 1853) 5-6. Geciteerd in Albers, Geschiedenis van het herstel der hierarchie, deel II 348.

74 Niet iedereen legde het verband tussen anti-Duitse en antikatholieke gevoelens. De Utrechtse hoogleraar G.W. Vreede vond de term Aprilbeweging volledig overdreven. Vreede was beslist geen aanhanger van Thorbecke en stond weinig sympathiek tegenover Duitsland. Van antikatholieke sentimenten merken we echter bij hem niets, evenmin als van een koppeling met de Aprilbeweging. Levensschets van $G$.W. Vreede naar zijn eigen handschrift uitgegeven (Leiden 1883).

75 Deze klacht was afkomstig van de Groningse afdeling van Unitas. Het standpunt werd door de andere afdelingen gedeeld. Citaat wordt aangehaald in: Hein Klemann, "Unitas" Georganiseerd antipapisme in Nederland in het midden van de vorige eeuw. 1842-1853 (Ongepubliceerde scriptie geschiedenis vu Amstelveen 1982, te raadplegen Nederlands documentatiecentrum voor het Protestantisme).

76 Aangehaald in Klemann, "Unitas".

77 Rogier, Katholieke herleving, 266.

78 S.J. van den Bergh, Een dichtbundel voor mijn vaderland (Haarlem 1851) 129-135.

79 J.C. Boogman, Nederland en de Duitse Bond 1815-1851 (Groningen 1955).

80 Deze constructie was onderdeel van het eindverdrag tussen Nederland en België, waarbij de afscheiding van België definitief werd geregeld.

81 J.C. Boogman, Rondom 1848. De politieke ontwikkeling van Nederland 1840-1858 (Bussum 1978) 63-71.

82 Boogman, Rondom 1848, 23.

83 Utrecht tussen Pruis en Francoos, 76.

84 Utrechtsche Courant, 30 december 1839.

85 Zitting van den 8ste maart. Ix Beraadslaging over de regeling en beperking der uitoefening van het regt van Vereeniging en Vergadering. Bijblad Handelingen Tweede Kamer 18-9-1854 tot 23-8-1855, 587598, 589 .

86 Handelingen Tweede Kamer 1855-56, bijlagen 184ste vel, 723, Voorlopig Verslag der Commissie van Rapporteurs. Uiteindelijk werd in de Lager-onderwijswet van 1857 bepaald dat vreemde onderwijzers, behalve bewijzen van bekwaamheid en zedelijkheid, toestemming van de Nederlandse regering moesten hebben. In 1863 bepaalde de Minister van Binnenlandse Zaken bovendien dat vreemdelingen een examen moesten afleggen, waarna hen een bewijs van bekwaamheid werd verstrekt. Tot 1863 mochten vreemde leraren ook reeds werken voor dat examen. De Gemeentestem 4-5-1863 nr. 605, 2.

87 W. Bevaart, De Nederlandse defensie (18391874) (Den Haag 1993) 489.

88 Anne Doedens, Nederland en de FransDuitse oorlog. Enige aspecten van de buitenlandse politiek en de binnenlandse verhoudingen van ons land omstreeks het jaar 1870 (Zeist 1973).

89 Bevaart, De Nederlandse defensie, 470; G. Umbgrove, Neerlands roeping (Arnhem 1871) 16-17.

90 Opvallend is dat in Denemarken in 1864, bij de strijd om Sleeswijk en Holstein, ook voorgesteld werd om het onderricht in Duits op Deense scholen af te schaffen. Snell, Deutsche Immigranten in Kopenhagen, 214.

91 Umbgrove, Neerlands roeping, 15.

92 Umbgrove, Neerlands roeping, 42. 
93 Umbgrove, Neerlands roeping, 16.

94 C.W. Opzoomer, De Bonapartes en het recht van Duitschland ook na Sedan. Redevoering ter opening der akademische lessen (Amsterdam 1871) 101.

95 Doedens, Nederland en de Frans-Duitse oorlog, 144.

96 Opzoomer, De Bonapartes en het recht van Duitschland, 23-24.

97 Panayi, German immigrants in Britain.

98 Opzoomer, De Bonapartes en het recht van Duitschland, 24.

99 Opzoomer, De Bonapartes en het recht van Duitschland, 27.

100 Pieter de Coninck, Een les uit Pruisen.

Nederland en de Kulturkampf, 1870-1880 (Leiden 1998) 148-149; Doedens, Nederland en de Frans-Duitse oorlog, 167-176.

101 Jochem van Ondere, Pijpenfabrikant en ouderling te Gouda, Mijn bezoek aan Bismarck in den zomer van 1875 (Deventer 1876). De Coninck, Een les uit Pruisen, besteedde eerder in zijn boek aandacht aan dit werk. Jochem van Ondere was een pseudoniem van de classicus A.J. Vitringa (1827-1901).

102 Van Ondere, Mijn bezoek aan Bismarck, 1. 103 Van Ondere, Mijn bezoek aan Bismarck, 49.

104 Van Ondere, Mijn bezoek aan Bismarck, 102.

105 Van Ondere, Mijn bezoek aan Bismarck, 103.

106 'Het oorlogsgevaar. Op, Mannen van het Vredebond!' in: Utrechtsche Courant 8 mei 1875. Herdrukt in: Hoofdartikelen van wijlen professor Vreede, overgedrukt uit het Utrechtsche Dagblad 1869-1880 (Leiden 1906) 227-228.

107 Idem.

108 'Onverzoenlijkheid van regeringsbeginselen. Pruissen - Nederland en België', Utrechtsche Dagblad 9-5-1875. Herdrukt in: Hoofdartikelen van wijlen professor Vreede, overgedrukt uit het Utrechtsche Dagblad 1869-1880 (Leiden 1906) 229-231.
109 Utrechtsch Provinciaal en Stedelijk Dagblad, 19-1-1875.

110 Utrechtsch Provinciaal en Stedelijk Dagblad, 19-1-1875.

111 De Coninck Een les uit Pruisen, 152; Bevaart, De Nederlandse defensie, 477.

112 Huizinga Cultuur-historische verkenningen, 151.

11317 november 1872 Rochussen, gezant te Berlijn aan Minister Gericke van Herwijnen, in: J. Woltring, Bescheiden betreffende de buitenlandse politiek van Nederland 1848-1919, tweede periode 1871-1898, eerste deel 1871-1874 (Den Haag 1962) RGP 107, nr. 302, 426-428.

114 Aantekening van de Minister van Justitie De Vries, in: Woltring, Bescheiden betreffende de buitenlandse politiek, 429-430.

115 Utrechtsche Provinciale en Stedelijke Courant, 4-2-1884.

116 Bijlagen Handelingen Tweede Kamer 1891$1892 \mathrm{nr} .130,3,3$.

117 Bijlagen Handelingen Tweede Kamer 18911892 nr. 130, 5, 17.

118 Bijlagen Handelingen Tweede Kamer 18911892 nr. 130 4, 9.

119 Panayi, German immigrants in Britain, 201-251.

120 Leopold Katscher, 'German life in London', Nineteenth Century (1887) 12, 740. Geciteerd in Panayi, German immigrants in Britain, 224.

121 Snell, Deutsche Immigranten in Kopenhagen, 219.

122 Snell, Deutsche Immigranten in Kopenhagen, 231.

123 Panayi, German immigrants in Britain, 232, 239.

124 Meder, Vertelcultuur in Waterland, 151.

125 Lucassen, En men noemde hen zigeuners, 236.

126 Zie ook: A. Wennemann, Arbeit im Norden. Die Italiener im Rheinland und Westfalen des späten 19. und frühen 20. Jahrhunderts (Osnabrück 1996). 


\section{Registratie, OMVANG, HERKOMST EN VESTIGING}

1 Het bevolkingsregister is reeds veelvuldig gebruikt bij historisch onderzoek. Zie voor een uitgebreide literatuurverwijzing op dit punt: Marlou Schrover, 'Registratie van vreemdelingen in het bevolkingsregister (1850-1920)', in: Marlou Schrover (red.), Bronnen betreffende de registratie van vreemdelingen in Nederland in de negentiende en twintigste eeuw. Broncommentaren 5 (Den Haag 2002) 93-111, 109.

2 De Gemeentestem 2-9-1921, 3649.

3 Idem.

$4 \quad$ NRC van 23 april 1893.

5 Handelingen Tweede Kamer 1-8-1893 uitspraak van Rutgers van Rozenburg, 1676.

6 Handelingen Tweede Kamer 3-8-1893 uitspraak Heemskerk, 1724.

7 Zie voor Utrecht bijvoorbeeld bevolkingsregister 1860-1879, wijk M, fiche 704, vel 481 of register $1900-1910 \mathrm{dl} 2$ 290-548, wijk 4, Amsterdamsestraatweg, vel 493-499, 1890-1900, dl 13, 2995-3244-46.

8 In vestigings- en vertrekregisters - zogenaamde hulpregisters van de bevolkingsregisters - werd opgetekend wie zich in een plaats vestigde of eruit vertrok. Mensen die ingeschreven werden in deze registers, werden ook ingeschreven in de bevolkingsregisters. Registers van vestiging en vertrek kunnen wel worden gebruikt voor het in kaart brengen van migratiebewegingen, maar niet voor het traceren van vreemdelingen, omdat ze slechts plaats van herkomst of bestemming vermelden en geen nationaliteit of geboorteplaats.

9 Schrover, 'Registratie van vreemdelingen in het bevolkingsregister (1850-1920)', 93111.

10 De Gemeentestem 30-9-1889, nr. 1983, 3-4.

11 H.A. Wijne, De wet op het regt van patent uit een handels- en staathuishoudkundig oogpunt beschouwd (Groningen 1853); P.M.M. Klep, A. Lansink en W.F.M Ter- wisscha van Scheltinga, De registers van patentplichtigen 1805-1893. Broncommentaren II (Den Haag 1987).

12 Met dank aan Corrie van Eijl, die mij op dit onderscheid heeft gewezen.

13 HUA, stadsarchief 4, 5/250/9, patentregister 1859/60; bevolkingsregister 1850-1860, fiche 178 , wijk D, 507, vel 719 .

14 Zie voor een uitgebreide beschrijving van de vreemdelingenregisters: Louk Pöckling en Marlou Schrover, 'Registers van verstrekte en geweigerde reis- en verblijfpassen (1849-1923)', in: Marlou Schrover (red.), Bronnen betreffende de registratie van vreemdelingen in Nederland in de negentiende en twintigste eeuw. Broncommentaren 5 (Den Haag 2002) 35-68.

15 Idem.

16 De bevolkingsregisters vermelden wel de datum van naturalisatie, veelal met het nummer van het Staatsblad waarin de naturalisatie bekend werd gemaakt.

17 Bijlagen Handelingen Tweede Kamer 18911892 nr. 130, 5, 20.

18 De zogenaamde relationele database waarin de gegevens zijn opgeslagen, bestaat uit drie samenhangende delen. Het hoofdbestand bestaat uit bevolkingsregistergegevens met 5177 records, met binnen ieder record 1103 velden. Met deze database in verband staan een databestand met 'namen' waarin 3774 records en een bestand met 3157 records waarin de gegevens over de kinderen zijn opgeslagen (het aantal velden in deze bestanden is gezien het relationele karakter van de database in principe ook 1103). De database werd ontworpen met het programma Filemaker pro.

19 In het bevolkingsregister staan voor elk huis of zelfstandig huisdeel voor elke bewoner de volgende twintig gegevens genoteerd: volgnummer, datum van inschrijving, achternaam, voornamen, geslacht, relatie tot het gezinshoofd, geboortedatum en -plaats, burgerlijke staat, datum van wijziging daarin, geloof, 
beroep met in de latere delen de vermelding zelfstandige beroepsuitoefening (h) of loondienst (o), datum van vestiging, vorige woonplaats, datum van vertrek, nieuwe woonplaats, overlijdensdatum en in de vroege delen een aantekening of het een woon- ( $w$ ) of verblijfplaats (v) betrof. De bevolkingsregisters vermelden ook de datum van naturalisatie, veelal met het nummer van het Staatsblad waarin de naturalisatie bekend werd gemaakt. In de marges van het bevolkingsregisterblad werden aantekeningen geplaatst over het wettelijk domicilie, wanneer dit afweek van de werkelijke woonplaats. Er werden voorts opmerkingen opgenomen over de datum en plaats waar een reis- en verblijfpas was afgegeven en door wie een pas was afgegeven.

20 Kamphoefner, The Westfalians, 8.

21 Onderzoek in andere plaatsen, zoals Gouda, heeft inmiddels aangetoond dat deze plaatsnaamverwarring niet tot Utrecht beperkt was. Zie de uitkomsten van een werkgroep die in het jaar 19992000 gegeven werd door Jan Lucassen, naar gegevens zoals die voorkomen in de volkstellingsregisters van 1830 en 1840 in Gouda, Utrecht, Watergraafsmeer en Rotterdam. Voor Gouda: A.J. van Zoelen, Nieuwkomers in de eerste helft van de negentiende eeuw (onderzoeksverslag v Amsterdam 2000); L. Pöckling geeft ook een voorbeeld van plaatnaamverwarring. Een migrant uit Marienhausen werd in het bevolkingsregister ingeschreven als geboren in Haringhuizen. L. Pöckling, Vestiging, groepsvorming en integratie van de Westerwalders in Amsterdam in de negentiende eeuw (Onuitgegeven scriptie Open Universiteit Nederland, cultuurwetenschappen) (Amsterdam 2001) 16. Jelle van Lottum heeft laten zien dat de plaatsnaamverwarring ook in het begin van de negentiende eeuw in Utrecht voorkwam. Jelle-Jaap van Lottum, Nieuwkomers in Nederland in de eerste helft van de 19e eeuw. Een onderzoek op basis van de volkstellingen in Utrecht van 1829 en 1839 (Ongepubliceerde doctoraalscriptie vu 2002, aanwezig op Het Utrechts Archief) 37.

22 Rommes, Oost, west, Utrecht best?

23 Faber en Rommes, 'Op weg naar stabiliteit', 251-314, 301.

24 Rommes, Oost, west, Utrecht best?, 89.

25 Rommes, Oost, west, Utrecht best?, 69.

26 Rommes Oost, west, Utrecht best?, 107.

27 Rommes, Oost, west, Utrecht best?; S. Hart, Geschrift en getal. Een keuze uit de demografisch-economisch-en sociaal-historische studiën op grond van Amsterdamse en Zaanse archivalia, 1600-1800 (Dordrecht 1976) 115-182.

28 In de Hollandse steden was de huwelijksregistratie overigens beter dan in Utrecht.

29 Rommes, Oost, west, Utrecht best?, 46-59.

30 Kamphoefner, The Westfalians, 35.

31 La Vern J. Rippley en Robert J. Paulson, German-Bohemians. The quiet immigrants (New Ulm 1995).

32 Fiets- en wandelkaarten boden soms uitkomst.

33 Opvallend is dat de Deense volkstellingen vergelijkbare problemen kenden: Snell, Deutsche Immigranten in Kopenhagen, 86.

34 Bij het hoofdstuk over de beroepsstructuur en bij de beschrijving van enkele afzonderlijke groepen wordt hier nader op ingegaan.

35 Rogier, Katholieke herleving, 265-266.

36 P. D. 't Hart, Utrecht en de cholera 18321910 (Utrecht 1990) 66.

37 P. Kooij, 'Stad en platteland', in: F.L. van Holthoorn (red.), De Nederlandse samenleving sinds 1815. Wording en samenhang (Assen/Maastricht 1985) 93-113, 95.

38 't Hart, Utrecht en de cholera, 302.

39 't Hart, Utrecht en de cholera, 303.

40 D. Bosschaert, De stad Utrecht als medisch ontwikkelingsgebied (Utrecht 1969) 76-77.

41 Uitkomsten van de volkstelling 1849.

42 Verslag van de Vereeniging tot Verbetering der Volksgezondheid. Mededeeling op de 
eerste algemeene vergadering gehouden den 9den augustus 1866. L. van Vuuren, Rapport betreffend een onderzoek naar de sociaal economische struktuur van een gebied in de provincie Utrecht, omvattende Utrecht als centrumgemeente en negen randgemeenten (Utrecht 1937).

43 J.P. Fockema Andrea, 'De stad Utrecht omstreeks 1823', Jaarboekje Oud-Utrecht (1924) 28-39; Van den Hoven van Genderen en Rommes, 'Rijk en talrijk', 53-87, 61.

44 A. van Hulzen, Utrecht en het verkeer 18501910 (Baarn 1987) 7-15.

45 Carl Denig, Utrecht van ancien régime tot nieuwe tijd. De bewoning van de Utrechtse binnenstad in haar ruimtelijke structuur, 1793-1891 (Utrecht 1995) 59-60.

46 't Hart, Utrecht en de cholera, 67.

47 Richard Loontjens, Marlou Schrover en Peter Vuijst, Op zoek naar de wortels der marginaliteit. Vijftig Utrechtse families ten tijde van de industrialisatie (18501920) (Ongepubliceerde doctoraalscriptie UU 1985 aanwezig op Het Utrechts Archief); zie ook: HUA, Stadsarchief IV, 1172-1173; Marlou Schrover en Peter Vuijst, 'Familiereconstructies en bevolkingsregister', in: Corrie van Eijl e.a. (red.), Hoe krijg ik mijn bronnen aan de praat? (Utrecht 1990) 34-53.

48 H.J. Broers, Utrecht. Historische wandelingen (Utrecht 1908) 296.

49 Van Meegeren, 'Katholiek Utrecht in de tweede helft van de 19e eeuw', 25.

50 L. F. Jens, Criminaliteit te Utrecht in verband met familie en wijk (Utrecht zj) 26.

51 A.C. de Vooys, De trek van de plattelandsbevolking in Nederland. Bijdrage tot de kennis van de sociale mobiliteit en de horizontale migratie van de plattelandsbevolking (Groningen en Den Haag 1932) 165167.

52 Jens, Criminaliteit te Utrecht, 28.

53 Jens, Criminaliteit te Utrecht, 29.

54 Broers, Utrecht. Historische wandelingen, 105.
55 Aaron S. Fogleman, 'Immigration, German immigration and 18th-century America', in: Eberhard Reichmann, La Vern J. Rippley en Jörg Nagler (red.), Emigration and settlement patterns of German communities in North America (Indianapolis 1995) 3-22, 11.

56 McCaffery, Islands of Deutschtum, 5.

57 Van Maurik, Toen ik nog jong was, 59.

58 Wilhelm Sahner, Katholische und Evangelische Seelsorge des Deutschtums in Holland. Kirchliche und kulturelle Gliederung (Emsdetten 1950) 181.

59 Zie het hoofdstuk over de Westerwalders. 60 Verschillen in de zorgvuldigheid van de wijkmeesters bestonden er ook in eerdere tijdvakken. Zie Jelle-Jaap van Lottum, Nieuwkomers in Nederland in de eerste helft van de 19e eeuw. De wijkmeester van wijk $\mathrm{G}$ voegde bij de volkstellingen van 1829 en 1839 in geen enkel geval een regioaanduiding aan de geboorteplaats toe, terwijl wijkmeesters van andere wijken dat wel deden.

\section{MigratiepatroON, LEEFTIJDSOPBOUW EN RELEGIE}

1 Maria Leijting werd in 1814 geboren in Kleef, Theodorus Reintjes werd geboren in Emmerik in 1806. Bevolkingsregister 1850-1859, wijk E, fiche 187, Haverstraat 117 , vel 162 .

2 Hij werd in 1827 geboren in Utrecht. Bevolkingsregister 186o-1879, wijk E, fiche 348, Boterstraat 306, vel 668 .

3 HUA, Rijksarchief, toegang 182 arrondissementsrechtbank, 656 akte 261 13-5-1879 84.

4 Adelheid Leijting werd in 1844 geboren in Kleef. Bevolkingsregister 1860-1879, wijk L, fiche 644, Nieuwe weg/Moreelse laan 168 , vel 842 .

5 Hij werd in 1815 geboren in Utrecht. Bevolkingsregister 1860-1879, wijk E, fiche 358, Mariaplaats 448b, vel 954. 
6 De huwelijksakte werd in Kleef opgesteld en vandaar opgestuurd en door de Utrechtse burgerlijke stand verwerkt. HUA, huwelijksakte 218, 2-7-1869.

7 Paul-André Rosental, Les sentiers invisibles. Espace, familles et migrations dans la France du 19e siècle (Parijs 1999) en Jose C. Moya, Cousins and strangers. Spanish immigrants in Buenos Aires, 1850-1930 (Berkeley 1998), gebruikten bij hun onderzoek huwelijksgetuigen voor de reconstructie van netwerken. Voor Utrecht is deze bron minder geschikt, omdat veelvuldig gebruik gemaakt werd van zogenaamde stadhuisgetuigen. Dit waren vier mannen, waaronder de klerk en de bode van het stadhuis, die bij vrijwel elk huwelijk als getuigen optraden. Niet in elke Nederlandse plaats werd in dezelfde mate van stadhuisgetuigen gebruik gemaakt en niet alle religieuze groepen maakten er in dezelfde mate gebruik van; bij katholieken waren ze meer gangbaar dan bij protestanten. In Utrecht werd tachtig procent van alle huwelijken gesloten met stadhuisgetuigen. Hiermee is deze bron voor het reconstrueren van netwerken vrijwel ongeschikt. De twee getuigen die optraden bij het opmaken van geboorteakten, bieden meer informatie over netwerken. In Utrecht werd slechts tien procent van alle geboorteakten opgemaakt in de aanwezigheid van stadhuisgetuigen. In de overige negentig procent van de gevallen mogen we aannemen dat de getuigen behoorden tot het netwerk van de ouders van de nieuwgeborene. Getuigen bij de doop van het kind in de kerk zijn eveneens een bron van aanvullende informatie. De informatie in de doopregisters is echter minder uitgebreid dan in de geboorteakten van de burgerlijke stand. Bij de katholieke doopgetuigen werden in Utrecht wel namen vermeld, maar geen beroepen of adressen. Zie ook: Snell, Deutsche Immigranten in Kopenhagen, 235.
8 Johanna werd in 1847 geboren in Kleef. Bevolkingsregister 1860-1879, wijk E, fiche 358, Mariaplaats 448b, vel 954 .

9 G. Jansen, De verhouding tussen joden en niet-joden in de stad Utrecht in de periode 1789-1824 (Ongepubliceerde doctoraalscriptie Geschiedenis Universiteit Utrecht 1986) 40.

10 Joden waren tot het einde van de achttiende eeuw uit Utrecht geweerd. Toen zij zich er wel mochten vestigen, verplichtten de Utrechtse bestuurders hen een woning te kiezen binnen de stadswallen en niet in de voorsteden. Opvallend is dat er ook in de tweede helft van de negentiende eeuw vrijwel geen joden buiten de singels woonden, zelfs niet toen die wijken na 1860 sterk groeiden. De joodse gemeenschap bleef de hele negentiende eeuw van geringe omvang. Jansen, De verhouding tussen joden en niet-joden, 43.

11 R.E. de Bruin, Burgers op het kussen. Volkssoevereiniteit en bestuurssamenstelling in de stad Utrecht, 1795-1813 (Zutphen 1986) 179.

12 Van Meegeren, 'Katholiek Utrecht in de tweede helft van de 19e eeuw', 23; zie ook S.T. Buwalda, 'Voor godsdienst, vaderland en Oranje. Het verzet van Utrechtse protestanten tegen de liberale staatsinrichting en het herstel van de bisschoppelijke hiërarchie (1840-1853)', Jaarboek Oud Utrecht (2000) 103-124. Volgens historicus Renger de Bruin verklaarde de relatieve toename van het aantal katholieken in de eerste helft van de negentiende eeuw mede het antipapisme dat de Domstad in het midden van de negentiende eeuw kenmerkte. R.E. de Bruin, 'Stilte na de storm. Utrecht in de eerste helft van de negentiende eeuw', Bijdragen en Mededelingen betreffende de Geschiedenis der Nederlanden, 101 (1986) 510-528, 521-522. Waarschijnlijk stoelde het antipapisme meer op een vermeende groei van de katholieke bevolking, dan de geringe reële toename. 
13 Van Meegeren, 'Katholiek Utrecht in de tweede helft van de 19e eeuw', 24.

14 Utrechtsche Courant 8 mei 1854. Ook aangehaald in Van Meegeren, 'Katholiek Utrecht in de tweede helft van de 19e eeuw', 1 .

15 De directeur-generaal van de R.K. eredienst schreef dit in 1849 aan Willem II; aangehaald in Van Meegeren, 'Katholiek Utrecht in de tweede helft van de 19e eeuw', 3 .

16 Utrecht wijkt op dit punt af van andere grote steden, zoals New York en Londen, waar een groot deel van de Duitse immigranten joods was. Panayi, German immigrants in Britain; Nadel, Little Germany.

17 In de bronnen worden calvinisten aangeduid met de term reformierten en ook wel als hervormd.

18 Rommes, Oost, west, Utrecht best?, 190.

19 P.G. Witsen Geysbeek (red.), Algemeen noodwendig woordenboek der zamenleving (Amsterdam 1836-1861), Lemma Westfalen.

20 Utrechtsch Provinciaal en Stedelijk Dagblad 14-1-1875.

21 Utrechtsche Courant 18 december 1839.

22 HUA, Archief Provinciaal bestuur 79, Notulen en bijlagen 668 augustus 1847. Bijlage 37 Brief Burgemeester en Wethouders van Utrecht 11-8-1847 aan Gedeputeerde Staten.

23 HUA, Archief van Provinciaal bestuur 79, Notulen en bijlagen 668 augustus 1847 Bijlage 37 Brief van Burgemeester en Wethouders aan Gedeputeerde Staten 3-41847.

24 Kamphoefner, The Westfalians; Charles Tilly, 'Migration in modern European history', in: William H. McNeill (red.), Human migration. Patterns and policies (Bloomington 1978) 48-72; Tilly, 'Transplanted network', 79-95.

25 Johannes Fischer werd in 1823 geboren in Aken; Margaretha Klosch in 1830 in Eppenich. Bevolkingsregister 1860-1879, wijk M, fiche 695, Gruttersdijk 126g, vel 240.
26 Georg Frétropp werd in 1832 geboren in Anhalt Cothen en Maria Huebsch in 1832 Diekirch in Luxemburg, Bevolkingsregister 1860-1879, wijk K, fiche 573, Oosterkade 15, vel 21.

27 HUA, Overlijdensakte 998, 18-3-1871.

28 HUA, Gestichtsregister 1870-1879 G 305; gestichten en schippers 622, 1870-1880, I 330, vel 181.

29 Utrechts Provinciaal en Stedelijk Dagblad 17-3-1871.

30 Alberta Agtenberg werd in 1822 geboren in Utrecht. Bevolkingsregister 1850-1859 wijk D, fiche 162, Vreeburg 166, vel 235.

31 Hij werd in 1826 geboren in Zoelmond. Bevolkingsregister 1860-1879, wijk C, fiche 167, Van Stockumpoort 373h, vel 743.

32 Tilly, 'Transplanted network', 79-95, 88.

33 Oscar Handlin, The uprooted (Boston 1973).

34 Kamphoefner, The Westfalians, 70.

35 Esselman komt ook voor in het bestand dat Kasja Weenink aanlegde van Duitse immigranten in Rotterdam, als onderdeel van het pionierproject 'Immigratie naar Nederland 1860-1960'. Dit project wordt afgerond door Henk Delger, Universiteit van Amsterdam. HUA, Bevolkingsregister 1860-1879, wijk G, fiche 413, Oudegracht 11/15, vel 478 .

36 Kamphoefner, The Westfalians, 70.

37 Bevolkingsregister 1860-1879, fiche 1, wijk A, Oude Gracht 2, vel 3.

38 De genealoog Ben Rigter maakte een reconstructie van het leven van zijn familie, waarop de hier volgende beschrijving stoelt. Ben Rigter, De Kermisfamilie Wagner-Wagenaar. Genealogisch manuscript. Met dank voor het ter beschikking stellen van dit materiaal.

39 Den Toom heeft de reis van Witte gereconstrueerd, op basis van het dagboek dat deze tijdens zijn reis bijhield. T.W.F. den Toom, De orgelmakers Witte. Een bijdrage tot de geschiedenis van de orgelbouw in Nederland in de tweede helft van de negentiende eeuw (Utrecht 1997). 
40 Den Toom, De orgelmakers Witte, 25.

41 Bevolkingsregister 1850-1859, fiche 352, wijk M, Bemuurde Weerd OZ 92, vel 143.

42 Bevolkingsregister 1880-1889, fiche 182, wijk D, Oudegracht Weerdzijde 54/56 32 en 34, vel 64 .

43 Bevolkingsregister 1860-1879, fiche 286, wijk D, Oudegracht 54, vel 76.

\section{HUWELIJKSGEDRAG}

1 Van Ondere, Mijn bezoek aan Bismarck.

2 Van Ondere, Mijn bezoek aan Bismarck, 110.

3 Van Ondere, Mijn bezoek aan Bismarck, 113.

4 Van Ondere, Mijn bezoek aan Bismarck, 114.

5 Van Ondere, Mijn bezoek aan Bismarck, 115.

6 Zoals de in een eerder hoofdstuk genoemde Adelheid Leijting en Herman Wormer.

7 Schrover, 'Maria en Rocco', 81-101.

8 Hondius heeft de betekenissen geïnventariseerd, die in de loop van de twintigste eeuw aan het begrip 'gemengd huwelijk' zijn gegeven. Dienke Hondius, Gemengde huwelijken, gemengde gevoelens. Aanvaarding en ontwijking van etnisch en religieus verschil sinds 1945 (Den Haag 1999); zie ook: Rosemarie Buikema, 'Someday, somehow, somewhere. Interetnische relaties in West Side Story en Jungle Fever', Immigrantenstudies (2000) nr. 4, 260-274.

9 Glenda Riley, Building and breaking families in the American west (Albuquerque 1996).

10 Zie voor literatuur op dit punt: Hooghiemstra, 'Voor de keuze', 211.

11 Peter M. Blau, Inequality and heterogeneity; a primitive theory of social structure (New York 1977).

12 Walter D. Kamphoefner, 'Paths of urbanization: St. Louis in 1860', in: Eberhard Reichmann, La Vern J. Rippley en Jörg
Nagler (red.), Emigration and settlement patterns of German communities in North America (Indianapolis 1995) 258-272, 264.

13 Lauren Ann Kattner, 'Land and marriage: German regional reflections in four Texas towns, 1845-1860', in: Eberhard Reichmann, La Vern J. Rippley en Jörg Nagler (red.), Emigration and settlement patterns of German communities in North America (Indianapolis 1995) 237-257, 237.

14 Kattner, 'Land and marriage', 240.

15 Edna Bonacich en John Modell, The economic basis of ethnic solidarity. Small business in the Japanese American community (Berkeley/Los Angeles 1980); Howard Aldrich, John Cater, Trevor Jones, David McEvoy en Paul Velleman, 'Ethnic residential concentration and the protected market hypothesis', Social Forces 63 (4 juni 1985) 996-1009.

16 Light en Karageorgis, 'The ethnic economy', 647-670.

17 Riley, Building and breaking families in the American west.

18 Herman Diederiks, Een stad in verval. Amsterdam omstreeks 180o, demografisch, economisch, ruimtelijk (Amsterdam 1982) $35,68,102$.

19 P. 't Hart, De stad Utrecht en haar inwoners. Een onderzoek naar samenhangen tussen sociaal-economische ontwikkelingen en de demografische geschiedenis van de stad Utrecht 1771-1825 (Utrecht 1983) 114.

20 De Coninck, Een les uit Pruisen, 14.

21 Aan de kwestie werd in 1839 in verschillende kranten bij herhaling aandacht besteed. Zie bijvoorbeeld de artikelen in de Avondbode van dat jaar.

22 De Coninck, Een les uit Pruisen, 114.

23 Idem.

24 Monika Blaschke, 'No way but out: German women in Mecklenburg', in: Christiane Harzig (red.), Peasant maids - city women. From the European countryside to urban America (Ithaca en Londen 1997) 25-56, 40-41. 
25 Utrechtsch Provinciaal en Stedelijk Dagblad 15-5-1892.

26 Diederiks, Een stad in verval, 76; Rommes Oost, west, Utrecht best?, 190.

27 Bevolkingsregister 1850-1859, fiche 250, wijk G, Zonstraat 468, vel. 541.

28 Bevolkingsregister 1860-1879, fiche 655, wijk L, Stationstraat 1641, vel 1140.

29 Jacobus Smits werd geboren in Haaften in 1828. Bevolkingsregister 1860-1879, wijk L, Stationsstraat 1641, fiche 655, vel 1140.

30 F. van Poppel, Trouwen in Nederland. Een historisch-demografische studie van de $19 e$ en vroeg-20e eeuw (Wageningen 1992) 275.

31 Ik heb 425 huwelijken van de Duitse immigranten, die tussen 1849 en 1879 in Utrecht woonden en die tussen 1810 en 1835 waren geboren, vergeleken met de 450 huwelijken die gesloten werden binnen de beide controlegroepen ( 268 binnen de HSN-controlegroep en 182 binnen de groep winterbedeelden). HSN-controlegroep: van de 268 huwelijken waren er 35 (dertien procent) waarbij het een tweede huwelijk was voor de man en 29 (elf procent) waarbij het een tweede huwelijk was voor de vrouw. Bij slechts twee huwelijken trouwde een van beide partners voor de derde keer. Van de 168 huwelijken in de controlegroep der winterbedeelden, waren er zeventien tweede huwelijken en vijf derde (dertien procent was dus geen eerste huwelijk).

32 De mediaan voor de Duitse vrouwen was 28 tegen 25 bij de gecombineerde controlegroepen; voor Duitse mannen was deze 29 tegen 24 bij de controles. Bij het gemiddelde zijn de verschillen groter dan bij de mediaan, vanwege enkele uitschieters naar boven.

33 In de HSN-controlegroep zitten zestien bruiden en vier bruidegoms, die jonger zijn dan twintig jaar. Zulke jonge echtelieden ontbreken onder de Duitse immigranten. Onder de winterbedeelden waren zulke lage leeftijden echter ook minder gebruikelijk. Er waren slechts vijf vrouwen onder de twintig en geen enkele man.

34 Bevolkingsregister 1860-1879, fiche 82, wijk B, Twijestraat 216, vel 343 .

35 A.C. de Vooys, Het huwelijkspatroon in Nederland in het midden der 19de eeuw toegelicht aan een onderzoek in Utrecht. Mededeling no.1 van de afdeling Historische Geografie (Utrecht 1965) 3.

36 Maria Haagen werd geboren in Utrecht in 1843. Bevolkingsregister 1870-1879, wijk C, fiche 250, Wijde Watersteeg 500, vel 1087.

37 Martiena Haagen werd in 1816 geboren in Utrecht.

38 Hondius, Gemengde huwelijken, 53-10o.

39 Van Poppel, Trouwen in Nederland, 551. Door een andere manier van berekenen zijn de percentages van Van Poppel niet simpelweg te vergelijken met de hier genoemde percentages.

40 Van Poppel, Trouwen in Nederland, 474. Er werden in die periode in Utrecht 16.500 huwelijken gesloten.

41 Bij de HSN-controlegroep eindigden van de 268 huwelijken er twee in een scheiding (minder dan een procent). Van de 168 huwelijken van winterbedeelden eindigde er geen een in scheiding en maar één in verlating.

42 Het gaat om huwelijken van immigranten die geboren werden tussen 1810 en 1835 : 255 huwelijken.

43 Catharina Klauer werd geboren in Ellenhausen in 1827. Bevolkingsregister 18601879, wijk B, fiche 91, Schutterstraat 301f, vel 604 .

44 Bevolkingsregister 1860-1879, wijk I, fiche 509, Cingel 217 b 2, vel 626. Geboorteakte 1446 20-11-1849.

45 Bevolkingsregister 1860-1879, wijk C, fiche 171 , St. Jacobspoort $412 \mathrm{~s}$, vel 860. Geboorteakte 471, 7-4-1840, geboorteakte 41, 8-11843, geboorteakte 1282 26-9-1845, geboorteakte $1359,14-12-1847$, huwelijksakte 287 , 8-12-1847.

46 Hans Sterk, 'Buitenechtelijke geboorten in Utrecht 1775-1825. Een historisch-demo- 
grafish onderzoek.' Tijdschrift voor Sociale Geschiedenis (1987) 1-32.

47 Bij de 268 huwelijken in de HSN-controlegroep was in 24 gevallen sprake van erkenning van een of meer voorechtelijk geboren kinderen (negen procent). Bij twee van deze huwelijken werden twee kinderen erkend; bij de overige één. Bij de 168 huwelijken in de groep winterbedeelden, werden bij twaalf huwelijken kinderen erkend (zeven procent). Bij tien huwelijken ging het om één kind, bij twee huwelijken om twee kinderen. Eén van deze twee huwelijken was dat van de Duitse schoenmaker Groen, die ook in het bestand Duitse immigranten voorkomt.

48 Bevolkingsregister 1850-1859, wijk $\mathrm{H}$, Pauwsteeg 184, vel 281.

49 Sterk, 'Buitenechtelijke geboorten in Utrecht' 1-32.

50 Hondius, Gemengde huwelijken, 53-100.

51 Blau, Inequality and heterogeneity.

\section{Organisaties}

1 Milena Veenis, Kartoffeln, Kuchen und Asado. Over de verborgen keuken van Duitsers in Argentinië (Amsterdam 1995) 24.

2 Count E. Armfelt, 'German London', in: George R. Sims (red.), Living London, vol. 3 (Londen 1903), geciteerd in Panayi, German immigrants in Britain, 184.

3 Dorothee Schneider, 'The German bakers of New York city: between ethnic particularism and working-class consciousness', in: Camille Guerin-Gonzales en Carl Strikwerda (red.), The politics of immigrant workers. Labor activism and migration in the world economy since 1830 (New York en Londen 1993) 49-70, 49; McCaffery, Islands of Deutschtum, 5 .

4 McCaffery, Islands of Deutschtum, 155.

5 Henkes, 'Gedeeld Duits-zijn aan de Maas', 218-239; Panayi, German immigrants in Britain.

6 McCaffery, Islands of Deutschtum.
7 Sahner, Katholische und Evangelische Seelsorge, 1.

8 Er waren organisaties, vooral in de sfeer van liefdadigheid en armenzorg, waar de Utrechtse elite in het bestuur zat. Dezelfde bestuurders en leden komen we tegen bij veel van deze organisaties. Hieronder waren ook enkele Duitsers en dan vooral de winkelier G.H. van der Sandt. Hij was bijvoorbeeld lid van de Choleracommissie. Statuten van de Vereeniging genaamd de Cholera Commissie te Utrecht opgericht in 1866 (Utrecht 1874) 17.

9 Utrechtsche studentenalmanak 1862 (Utrecht 1861).

10 De Avondbode, algemeen nieuwsblad voor staatkunde, handel, nijverheid, landbouw, kunsten en wetenschappen, 29 maart 1839.

11 De Avondbode donderdag 4 april.

12 De Avondbode maandag 8 april.

13 Zie voor een uitgebreidere theoretische beschouwing: Rinus Penninx en Marlou Schrover, Bastion of bindmiddel? Organisaties van immigranten in historisch perspectief (Amsterdam 2001).

14 Utrechtsch Provinciaal en Stedelijk Dagblad 4-1-1878.

15 Utrechtsch Provinciaal en Stedelijk Dagblad 12-1-1878.

16 Utrechtsch Provinciaal en Stedelijk Dagblad 16-1-1875.

17 Vergelijk op dit punt bijvoorbeeld de veel grotere Duitse gemeenschappen in Londen, New York en Chicago. Zie behalve Panayi en Nadel ook Hartmut Keil, 'Die deutsche Amerikaeinwanderung im städtisch-industriellen Kontext; das Beispiel Chicago 1880-1910', in: Klaus Bade (red.), Auswanderer - Wanderarbeiter - Gastarbeiter. Bevölkerung, Arbeitsmarkt und Wanderung in Deutschland seit Mitte des 19. Jahrhunderts. Band 1 (Ostfildern 1984) 378-405.

18 Snell, Deutsche Immigranten in Kopenhagen, 217.

19 Nadel Little Germany, 1. 
20 Keil, 'Die deutsche Amerikaeinwanderung'.

21 Voor Rotterdam Henkes, 'Gedeeld Duitszijn', 218-239.

22 McCaffery, Islands of Deutschtum, 40.

23 Vergelijk Peter Clark, British clubs and societies 1580-180o. The origins of an associational world (Oxford 200o).

24 Utrechtsch Provinciaal en Stedelijk Dagblad 15-5-1892.

25 Jens, Criminaliteit te Utrecht.

26 Geciteerd in: T.H.G. Verhoeven, 'Stedelijk leven in een stroomversnelling', in: R.E. de Bruin, P.D. 't Hart, A.J. van den Hoven van Genderen, A. Pietersma (red.), 'Een paradijs vol weelde'. Geschiedenis van de stad Utrecht (Utrecht 2000) 375-434, 389.

27 Zie bijvoorbeeld de Utrechtsche provinciale en stads almanak voor het jaar 1861 (Utrecht 1861) waarin de namen van alle bestuurders worden opgesomd.

28 Morawska, 'The sociology and historiography of immigration', 187-240, 215.

29 Jan Erik Burger en Peter Berntsen, 'De Duitse immigratie naar Amsterdam in de 19e eeuw', Ons Amsterdam (maart 1986) nr. 3, 60-64, 61.

30 P. D. 't Hart, Stakers en onruststokers in de Domstad. Uit de beginjaren van de arbeidersbeweging en socialisme in Utrecht tussen 1870 en 1895 (Utrecht 1996).

31 HUA, Losse aanwinsten toegang 802, 1854, Jaarverslag der Utrechtsche Winkeliersvereeniging.

32 Hij werd geboren in 1767 in Saksen Gotha. Bevolkingsregister 1850-1859 wijk C, fiche 101, Oudegracht 30, vel 37. Utrechtsche provinciale en stads almanak voor het jaar 1861 (Utrecht 1861) 181.

33 Garardo Jorge Ojeda-Ebert, Deutsche Einwanderung und Herausbildung der Chilenischen Nation (1846-1920) (München 1984) 99.

34 Ojeda-Ebert, Deutsche Einwanderung und Herausbildung der Chilenischen Nation, 100.
35 Hij werd geboren in Kluppelenburg. Bevolkingsregister 1850-1859, wijk E, fiche 185, Oudegracht 90, 91, vel 117. A. Scheffer, Herinnering aan het veertigjarig bestaan der Handels-societeit te Utrecht, 1852-1892 (Utrecht 1892).

36 Von Santen, 'Politiek leven in de stad Utrecht', 110-165, 145.

37 A.H. Laseur, Na vijftig jaren. De handelsSocieteit te Utrecht 1852-1902 (Utrecht 1902).

38 Laseur, Na vijftig jaren.

39 Idem.

40 Schrover, 'Wie zijn wij?, 115-144.

41 Geciteerd in McCaffery, Islands of Deutschtum, 53.

42 Nellie van Vulpen, 'Vermaak in Utrecht (1850-1880). Publiekswerving door de Utrechtse Schouwburg en de koffiehuizen', Jaarboek Oud-Utrecht (1995) 119-138.

43 Adresboek voor de stad Utrecht 1879.

44 Utrechtsche Provinciale en stads almanak voor het jaar 1861 (Utrecht 1861) 59.

45 Mönzert werd geboren in 1829 in Lobenstein. Bevolkingsregister 1860-1879, wijk G, fiche 412, Neude 55, vel 434.

46 Rapp werd in 1836 in Baiersbronn in Württemberg geboren. Rapp was getrouwd met de Duitse Adeline Osberghaus. Na haar dood hertrouwde hij met de Nederlandse Anna Ebling. Bevolkingsregister 1860-1879, wijk G, fiche 407, Lange Jansstraat 193, vel 310.

47 Johanna Wurlitzer werd geboren in 1840, net als haar man in Lobenstein. Bevolkingsregister 1860-1879, wijk G, fiche 412, Neude 55, vel 434.

48 Utrechtsch Provinciaal en Stedelijk Dagblad 2-5-1878.

49 Mönzert, die inmiddels weduwnaar was geworden, verhuisde met zijn zoon naar de Voorstraat, waar hij een nieuw koffiehuis begon. Hij hertrouwde met de Nederlandse Johanna Gestel. Johanna Gestel werd geboren in Gouda in 1853. Bevolkingsregister 1870-1879, wijk C, fiche 212, Oudegracht 30, vel 38. In 1897 over- 
leed Mönzert op 67-jarige leeftijd. Gestel zette het café voort, nog steeds met gedeeltelijk Duits personeel.

50 Franz Sturm werd geboren in Elberfeld in 1854 en Maria Louise Kunde in Zanow in 1853. Bevolkingsregister 1880-1889, wijk H, fiche 334, Voorstraat 543 / 23, vel 984.

51 Catharina Wahl uit Bonn en Maria Kautsch uit Ehrenfeld. Bevolkingsregister 1880-1889, wijk H, fiche 334, Voorstraat 543 / 23, vel 984 .

52 Hij overleed in Utrecht in 1883. Bevolkingsregister 1850-1859, wijk D, fiche 175, Donkerstraat 453, vel 625. Zie ook Van Meegeren, 'Katholiek Utrecht in de tweede helft van de 19e eeuw', 64 .

53 Door katholieke Poolse immigranten in Chicago werd de onmogelijkheid om in de landstaal te biechten aangemerkt als een belangrijk gemis. Joseph John Parot, Polish Catholics in Chicago, 1850-1920. A religious history (Illinois 1981) 21.

54 McCaffery, Islands of Deutschtum, 58-59.

55 H. van Woerden, De familie Schlatmann. Geschiedenis van een Tjoddengeslacht (Oegstgeest 1953) 39.

56 Bettina Goldberg, 'Cultural change in Milwaukee's German Evangelical Lutheran congregations of the Missouri Synod, 1850-1930', in: Eberhard Reichmann, La Vern J. Rippley en Jörg Nagler (red.), Emigration and settlement patterns of German communities in North America (Indianapolis 1995) 115-129, 116.

57 Ontwikkelingen binnen de lutherse Kerk zijn door Ronald Rommes uitgebreid beschreven. Rommes, Oost, west, Utrecht best?, 195; Rommes, 'Lutherse immigranten in Utrecht tijdens de Republiek', 35-54.

58 Rommes, 'Lutherse immigranten', 50; Opvallend is dat een vergelijkbare strijd in het midden van de negentiende eeuw ook gevoerd werd in Kopenhagen. Snell, Deutsche Immigranten in Kopenhagen, 158.

59 Jaap Vogel, 'Duitse predikant in opspraak. Hieronymus Durer: zijn geloof, zijn ker- kenraad en zijn 'dienstmaagd”, Haarlem Jaarboek 1999 (Haarlem 2000) 21-50.

60 Rommes, 'Lutherse immigranten', 47.

61 Rommes, Oost, west, Utrecht best? 196.

62 Sahner, Katholische und Evangelische Seelsorge, 159.

63 C.Ch.G. Visser, De Lutheranen in Nederland. Tussen katholicisme en calvinisme 1566 tot heden (Dieren 1983) 114.

64 Aangehaald in: Visser, Luthersen in Utrecht, 26

65 Wolgang Grams, 'The North German Lutheran Church in Cincinnati: an “Osnabrück" congregation (1838)', in: Eberhard Reichmann, La Vern J. Rippley en Jörg Nagler (red.), Emigration and settlement patterns of German communities in North America (Indianapolis 1995) 7990, 81.

66 Grams, 'The North German Lutheran Church in Cincinnati', 79-90; zie ook: Otto Holzapfel, Religiöse Identität und Gesangbuch. Zur Ideologiegeschichte deutschsprachiger Einwanderer in den USA und die Auseinandersetzung um das 'richtige' Gesangbuch (Bern 1998).

67 Utrechtsche provinciale en stads almanak voor het jaar 1861 (Utrecht 1861) 131.

68 Adresboek 1899-1900, 456.

69 HUA, Register schippers en gestichten.

70 Volkstelling 1849.

71 Deze informatie is ontleend aan de zogenaamde Reisepredigt, met dank aan Jan Lucassen voor inzage in dit manuscript.

72 Bericht van Heinrich Otto Rathmann aan den Central-Ausschuß für die Innere Mission. Werkgroep Reisepredigt, Jan Lucassen, IISG, met dank voor inzage.

73 Idem.

74 Utrechtsch Provinciaal en Stedelijk Dagblad 1 juli 1876.

75 De Marnixzaal bestaat nog en is onderdeel van de muziekschool aan het Domplein.

76 Bericht van Heinrich Otto Rathmann aan den Central-Ausschuß für die Innere Mission, Werkgroep Reisepredigt, Jan Lucassen, IISG. 
77 Bericht van Werner Droß aan den Central-Ausschuß für die Innere mission 1880. Werkgroep Reisepredigt, Jan Lucassen, IISG.

$78 \mathrm{HAU}$, Archief Gustaaf Adolfvereniging, toegang 492. Tijdschrift: Gustaaf-Adolf Tafereelen en berigten uit de Geschiedenis der Protestantsche kerk in onze dagen, 1870, 137.

79 HAU, Archief Gustaaf Adolfvereniging, toegang 492, 1. Notulen van het hoofdbestuur 1853-1931.

$80 \mathrm{HAU}$, Archief Gustaaf Adolfvereniging toegang 492,1 . Notulen van het hoofdbestuur 1853-1931, Notulen van de vergadering van 24 july 1854 .

81 HUA, Archief Gustaaf Adolfvereniging, toegang 492, 1. Notulen september 1854. Ingekomen brief van den Heer Stephanie namens de Central-Vorstand van de GAS waarin hij zijn leedwezen betuigt over de zelfstandige vorming onser G.A.v.

82 HUA, Archief Gustaaf Adolfvereniging, toegang 492, 1. Notulen 3-8-1854.

83 HUA, Archief Gustaaf Adolfvereniging, toegang 492, 1. Notulen 13-7-1867 brief van Leiden aan Leipzig.

84 HUA, Archief Gustaaf Adolfvereniging, toegang 492,1 . Notulen van vergadering $2-$ 7-1867.

$85 \mathrm{HUA}$, Archief Gustaaf Adolfvereniging, toegang 492, 49, Tafereelen en berigten uit de Geschiedenis der Protestantsche kerk in onze dagen 1882, 24.

86 HUA, Archief Gustaaf Adolfvereniging, toegang 492, 49, Tafereelen en berigten $1882,26$.

87 HUA, Archief Gustaaf Adolfvereniging, toegang 492, 49, Tafereelen en berigten 1882, 25.

88 HUA, Archief Gustaaf Adolfvereniging, toegang 492, 49, Tafereelen en berigten $1870,86$.

89 HUA, Archief Gustaaf Adolfvereniging toegang 492, 49, Tafereelen en berigten 1874,3 .
90 Carl Euler, Het universele karakter der Gustaaf-Adolfvereeniging en hare uitbreiding in Nederland (Haarlem 1854).

91 Kerkelijke Courant, nr. 39. Geciteerd in: Conrad Busken Huet, De Nederlandsche Gustaaf-Adolfvereeniging en hare bestrijding (Haarlem 1854) 19-20.

92 Kerkelijke Courant, nr. 39. Geciteerd in: Busken Huet, De Nederlandsche GustaafAdolfvereeniging, 20.

93 Mgr. G.W. van Heukelum was oprichter en directeur van het Aartsbisschoppelijk museum te Utrecht en later pastoor te Jutphaas.

94 Rogier en De Rooy, In vrijheid herboren, 403.

95 H.P.R. Rosenberg, De 19de-eeuwse kerkelijke bouwkunst in Nederland (Den Haag 1972) 53 .

96 Gerard Brom, Herleving van de kerkelijke kunst in katholiek Nederland (Leiden 1933) 231.

97 A.J. Looijenga, De Utrechtse school in de neogotiek. De voorgeschiedenis en het Sint Bernulphusgilde (zp 1991) 344.

98 Brom, Herleving van de kerkelijke kunst, 208.

99 'Moet ik't geloof der vaadren melden / Dat Neerlands trouwe zonen hecht / Aan d'eedlen van Westfalens velden / En met den Rijn hen samenvlecht?' Gedicht van Leo van Heemstede ter ere van het Bernulphusgilde, geciteerd in Brom, Herleving van de kerkelijke kunst, 226.

100 Brom, Herleving van de kerkelijke kunst, 235.

101 Rogier, Katholieke herleving, 227.

102 Rosenberg, De 19de-eeuwse kerkelijke bouwkunst, 51.

103 De Nederlander Blom was relatief onbelangrijk en wordt hier verder buiten beschouwing gelaten.

104 Rosenberg, De 19de-eeuwse kerkelijke bouwkunst, 109; Brom, Herleving van de kerkelijke kunst, 322.

105 Friedrich Mengelberg was de vader van beeldhouwer en glazenier Otto Mengel- 
berg en dirigent Willem Mengelberg. Bevolkingsregister 1860-1879, wijk G, fiche 405, Hoogt 161, vel 255. Rosenberg, De 19de-eeuwse kerkelijke bouwkunst, 103. 106 Rogier, Katholieke herleving, 227.

107 Brom, Herleving van de kerkelijke kunst, 263.

108 Gemeenteverslag 1890.

109 Gemeenteverslag 1892.

110 Gemeenteverslag 1893.

111 Gemeenteverslag 1895.

112 Gemeenteverslag 1897.

113 Brom, Herleving van de kerkelijke kunst,

114 Bevolkingsregister wijk K, fiche 584, straatnaam niet ingevuld, 196, vel 342.

115 Brom, Herleving van de kerkelijke kunst, 269, 278.

116 Gemeenteverslag 1897.

117 Brom, Herleving van de kerkelijke kunst, 241.

118 Brom, Herleving van de kerkelijke kunst, 213, 269, 311.

119 J.D.C. van Dokkum, 'Een episode uit het Utrechtse kunstleven in het einde der 19de en het begin der 2oste eeuw', Jaarboekje Oud-Utrecht (1937) 97-137.

120 Van Dokkum, 'Een episode uit het Utrechtse kunstleven'.

121 Van Dokkum, 'Een episode uit het Utrechtse kunstleven', 106.

122 Hein Mol, Memoires van een havenarbeider. Van aantekeningen en een nawoord voorzien door Tony Jansen en Jacques Giele (Nijmegen 1980) 80.

$123 \mathrm{Mol}$, Memoires van een havenarbeider, 81 .

124 Panayi, German immigrants in Britain, 126.

125 H.J. Zomerdijk, Het muziekleven in Noord-Brabant 1850-1914 (Tilburg 1982) 81. 126 Snell, Deutsche Immigranten in Kopenhagen, 75.

127 Elisabeth Reintjes werd geboren in Kleef in 1801 . Ze was katholiek. Bevolkingsregister 1850-1859, wijk F, Oud Munsterkerkhof 221, vel 348 .
128 Monique Dirven, 'Het gemeentelijk cultuurbeleid in de negentiende eeuw', Jaarboek Oud-Utrecht (1995) 95-118.

129 J.D.C. van Dokkum, 'De Utrechtsche toonkunstafdeeling in haar ontwikkelingsjaren (uit oude notulen en verslagen)', Jaarboekje Oud Utrecht(1933) 122-194.

130 Kufferath kreeg na een veertigjarige loopbaan in Utrecht een conflict en ging naar Wiesbaden, waar hij in 1864 overleed.

131 J. du Saar, 'Het Collegium Musicum Ultrajectum in de laatste honderd jaar', Jaarboekje Oud-Utrecht (1941) 74-132.

132 Rahr studeerde waarschijnlijk niet af. In de studentenalmanakken werd zijn afstuderen in ieder geval niet vermeld. Voor theologiestudenten was dat niet ongebruikelijk. Bevolkingsregister 1850-1859, wijk D, fiche 156, Oudegracht 55.

133 HUA, archief muziekhandel Rahr te Utrecht en Arnhem 1838-1952, toegang 79; Utrechtsch Provinciaal en Stedelijk Dagblad 22-9-1851.

134 Utrechtsch Provinciaal en Stedelijk Dagblad 15-5-1892.

135 HUA, stadsarchief 4 1859/60 5/250/9 D 4 register patentplichtige kramers 15 maart 1860 en D 16/17 12 maart 1860.

136 Philip V. Bohlman, "'Still, they were all Germans in town" - music in the multireligious German-American community', in: Eberhard Reichmann, La Vern J. Rippley en Jörg Nagler (red.), Emigration and settlement patterns of German communities in North America (Indianapolis 1995) 275293, 288.

137 Geciteerd in: Panayi, German immigrants in Britain, 184.

138 Snell, Deutsche Immigranten in Kopenhagen, 198.

139 Herman von der Dunk, Der Deutsche Vormärz und Belgien 1830/48 (Wiesbaden 1966) 317-330.

140 Geciteerd in Von der Dunk, Der Deutsche Vormärz, 321.

141 Snell, Deutsche Immigranten in Kopenhagen, 198, 202. 
142 Jozef Vos, 'Nationale kunst en lokale sociabiliteit: de Nederlandse mannenzangverenigingen in de negentiende eeuw', Bijdragen en Mededelingen betreffende de Geschiedenis der Nederlanden. 112e jrg. nr.3 (1997) 364-381.

143 Van Dokkum, 'De Utrechtsche toonkunstafdeeling', 122-194, 146.

144 HUA, Losse aanwinsten 802, 1164-1165, Utrechtse Liedertafel Aurora, Naamlijst der leden 1854.

145 HU A, Koninklijke Utrechtse Mannenzangvereniging, archief nr. 734, 71-73.

146 Utrechtsch Provinciaal en Stedelijk Dagblad 9-3-1878.

147 G.J. van Rijnsoever. Sint Maarten in de Tolsteeg. Geschiedenis van de Sint Martinusparochie te Utrecht (Utrecht 1947) 127-128.

148 Deze kerk had een koor, maar een ledenlijst is er niet van bewaard gebleven voor deze periode.

149 Wilhelm Franz Fohr, Aus der Geschichte Ransbachs (onuitgegeven typescript Ransbach 1943) 60.

150 Hij zette zijn herinneringen aan zijn Utrechtse studententijd op papier. Geschichte eines Offiziers. Lebenserinnerungen von Carl Anton Wilhelm Grafen von Wedel, Berlin 1897, gereproduceerd als 'Een ontgroeningspartij te Utrecht 1809 ', Bijlage xxi van W.C.A. van Vredenburgh, Schets van eene geschiedenis van het Utrechtsche studentenleven (Utrecht 1914) 239-255.

151 De studentenalmanakken geven de namen van alle studenten. De namen van studenten die geen lid waren van het corps werden gemerkt met een sterretje.

152 W.J.B. Serfontein, Suid-Afrikaners in Utrecht 1762-1954 (Utrecht 1954) 43.

153 Utrechtsche studentenalmanak 1862 (Utrecht 1861).

154 Van Vredenburgh, Schets van eene geschiedenis van het Utrechtsche studentenleven, 173.
155 Zie de studies van Panayi, Nadel, McCaffery en Snell, 190.

156 Nadel, Little Germany, 119-120; Jörg Nagler, 'Frontier socialism: the founding of New Ulm, Minnesota, by German workers and Freethinkers', in: Eberhard Reichmann, La Vern J. Rippley en Jörg Nagler (red.), Emigration and settlement patterns of German communities in North America (Indianapolis 1995) 178-192, 180181.

157 McCaffery, Islands of Deutschtum, 70. 158 Studentenvereniging Olympia met 153 leden, Nemea voor officieren en burgers met 29 leden, 'In bello propugnaculum, in pace, ornamentum, een studentenvereniging met 12 leden, Isthmia (27 leden), De Vereeniging (16 leden) en Jong Sparta (een jongelingenvereniging met 101 leden). Utrechtsche provinciale en stads almanak voor het jaar 1861 (Utrecht 1861). In latere jaren kwamen daar nog andere verenigingen bij, zoals de Gymnastiek Ver. Bato. Utrechtsch Provinciaal en Stedelijk Dagblad 1-1-1875.

159 Pascal Delheye, 'Carl Euler (1809-1882): Een Duitse turnapologeet in Brussel', Sportimonium (2001) 2, 25-33.

160 Hij werd geboren in Züsch bij Trier als zoon van Friedrich Euler en Dorothee Arendt. Hij trouwde met Fanny Anhut. Delheye, 'Carl Euler', 33.

161 Van Vredenburgh, Schets van eene geschiedenis van het Utrechtsche studentenleven, 161.

162 Utrechtsch Provinciaal en Stedelijk Dagblad 16-5-1878; Schulze werd geboren in 1825 in Landau in Waldeck en was luthers, zie bijvoorbeeld Bevolkingsregister 1850-1859, wijk H, Breedstraat 405, fiche 277, vel 579 .

163 Cleveland and its Germans (Cleveland Ohio 1998) 42. Vertaling uit het Duits van: Cleveland und sein Deutschtum (Cleveland Ohio 1897-98).

164 Ueber Land und Meer, Fliegende Blätter, Illustrierte Zeitung, Schorer's Familienblatt, Gartenlaube, Deutsche Rundschau en Vom 
Fels und Meer. J.A.F. Janzen, 'Van allerlei slag. De lotgevallen van een typisch Utrechts leesgezelschap', Oud Utrecht (1975) 131-160, 136, 140.

165 J.M.H.J. Hemels, Op de bres voor de pers. De strijd voor de klassieke persvrijheid (Assen 1969).

166 Aengenvoort, Migration - Siedlungsbildung-Akkulturation, 267.

167 Snell, Deutsche Immigranten in Kopenhagen.

168 Henkes, 'Gedeeld Duits-zijn aan de Maas'.

169 Verhoeven, 'Stedelijk leven in een stroomversnelling', 375-434, 416.

170 R. Reinsma, 'Het onderwijs in de provincie Utrecht tussen 1830 en 1850 volgens de rapporten van de hoofdinspecteur Wijnbeek', Jaarboekje Oud Utrecht (1964) 57-116, 62 .

171 HUA, stadsarchief 4, 982. Opgaven der wijkmeesters van de niet schoolgaande kinderen in hun wijken. 1861, $\mathrm{x}$ kinderen die de school verzuimen.

172 Idem.

173 Philip Ermann werd geboren in Senden in Munster 1816. Bevolkingsregister 18501859, wijk F, Achter de Dom 292, fiche 223, vel 428; Bevolkingsregister 1850-1859 A Nieuwegracht 825 fiche 35 vel 1017, bevolkingsregister 1860-1879 B Jufferstraat 601 fiche 114, vel 1295; bevolkingsregister 18801889, Jufferstraat / Springweg, wijk B 601, fiche 88, vel 1099. Zie voor advertenties van Ermann: Utrechtsche Provinciale en Stadscourant 5786 en 22-9-1851 Utrechtsch Provinciaal en Stedelijk Dagblad 8-5-1878.

174 Diderik Grothe werd geboren in Herscheid in 1806 . Zie ook Utrechtsche provinciale en stads almanak voor het jaar 1861 (Utrecht 1861) 202. Bevolkingsregister 1850-1859, wijk G, fiche 231, Ganzenmarkt 4 , vel 7 .

175 Utrechtsch Provinciaal en Stedelijk Dagblad 17-11-1851.

176 Utrechtsche provinciale en stads almanak voor het jaar 1861 (Utrecht 1861) 204 en 207.
177 Opmerkelijk in dit verband is dat de Duitse historicus Martin Schumacher voor de eerste helft van de negentiende eeuw heeft vastgesteld dat Duitse, katholieke handelaren uit Westfalen en het Rijnland hun in Duitsland geboren en getogen kinderen naar Charlier in Luik op kostschool stuurden, waar ze onderwijs kregen in handelsvakken, Duits, Frans en Nederlands. Martin Schumacher, Auslandsreisen Deutscher Unternehmer 17501851 unter besonderer Berücksichtigung von Rheinland und Westfalen (Keulen 1968) 69.

$178 \mathrm{Zij}$ werd in 1843 geboren in Rhede en was luthers. Bevolkingsregister 1860-1879, wijk G, fiche 417, Kromme Nieuwegracht 364, vel 596.

179 Panayi, German immigrants in Britain, 135. 180 Panayi, German immigrants in Britain, 136. 181 Snell, Deutsche Immigranten in Kopenhagen, 62.

182 Greddy Huisman, Tussen salon en souterrain. Gouvernantes in Nederland 1800-1940 (Amsterdam 2000).

183 Huisman, Tussen salon en souterrain, 84. 184 Bevolkingsregister 1860-1879, wijk H , fiche 473, vel 1155 .

185 Utrechtsche Provinciale en Stadscourant 2411-1851.

186 Adresboek 1911-12, 662.

187 Sahner, Katholische und Evangelische Seelsorge, 84 .

188 Idem.

189 Henkes, 'Gedeeld Duits-zijn aan de Maas'. 190 Boudien de Vries, 'Onder ons? Vrouwen en verenigingen in de negentiende-eeuwse stad', Jaarboek voor Vrouwengeschiedenis 22 (2002) 97-125.

191 Henkes, 'Gedeeld Duits-zijn aan de Maas', 218-239; Panayi, German immigrants in Britain. 


\section{Beroepsstructuur}

1 Op het кммг in De Bilt zijn lijsten te raadplegen met daarop onder meer de temperaturen. Van die lijsten is gebruik gemaakt voor dit overzicht.

2 Utrechtsche Provinciale- en Stadscourant 23-12-1855.

3 Handelingen Tweede Kamer, zitting 18 juli $1849,626$.

4 Handelingen Tweede Kamer, zitting 18 juli 1849,628 .

5 HUA, gemeentelijk jaarverslag 1863.

6 't Hart, Stakers en onruststokers; Verhoeven, 'Stedelijk leven in een stroomversnelling', 392.

7 Zie voor de stad Utrecht onder meer: 't Hart, De stad Utrecht en haar inwoners, 9, 41; J.J.A. de Beer, 'Beroepskeuze, levensstandaard en lichamelijke ontwikkeling. De kleine sigarenmaker in Utrecht, ca. 1850', Tijdschrift voor Sociale Geschiedenis (1993) 216-235, 225; 't Hart, Utrecht en de cholera; Denig, Utrecht van ancien régime tot nieuwe tijd; Jan Brugman, Hans Buiter en Kaj van Vliet, Markten in Utrecht van de vroege middeleeuwen tot $n u$ (Utrecht 1995); Verhoeven, 'Stedelijk leven in een stroomversnelling', 392; I. Vijlbrief, Van anti-aristocratie tot democratie. Een bijdrage tot de politieke en sociale geschiedenis der stad Utrecht (Amsterdam 1950); Bosschaert, De stad Utrecht als medisch ontwikkelingsgebied.

8 J.E.A.L Struick, Utrecht door de eeuwen heen (Utrecht/Antwerpen 1968) 55.

9 't Hart, Utrecht en de cholera, 71.

10 HUA, stadsarchief 4, toegang 704, 1236. Verslagen van de algemene marktmeester betreffende de verschillende markten in Utrecht over 1850/51, 1851 en 1854 met bijlagen; W.H. Vermooten, 'Schets van de geschiedenis van het Utrechtsche marktwezen in de 19e eeuw', Oud Utrecht (1933) 157-194.
11 HUA, Archief Provinciaal Bestuur, Toegang 79, Jaarverslag Provinciaal Bestuur 1813-1920, 213, Verslag over 1861, 435.

12 Idem, 214, Verslag over 1862, 432.

13 Idem, 216, Verslag over 1862, 431.

14 Idem, 214, Verslag over 1862, 432.

15 Idem, 216, Verslag over 1862, 431.

16 Idem, 213, Verslag over 1861, 435.

17 Idem, 216, Verslag over 1862, 431.

18 A.H.M. van Schaik, 'Een nieuwe heer en een andere leer', in: R.E. de Bruin, P.D. 't Hart, A.J. van den Hoven van Genderen, A. Pietersma (red.), 'Een paradijs vol weelde'. Geschiedenis van de stad Utrecht (Utrecht 2000) 191-250, 230.

19 Faber en Rommes, 'Op weg naar stabiliteit', 251-314, 268.

20 Vijlbrief, Van anti-aristocratie tot democratie, 152.

21 Faber en Rommes, 'Op weg naar stabiliteit', 302; Vijlbrief, Van anti-aristocratie tot democratie, 152.

22 Larsen, 'Hebben Nederlanders dan geen cultuur?', 34; Anneke H. van Otterloo, Eten en eetlust in Nederland 1840-1990. Een historisch-sociologische studie (Amsterdam 1990) 227.

23 Handschoenverkopers uit Tirol: Kurt Brenner, Der Zillertaler Wanderhandel im. 18. Und 19. Jahrhundert (Innsbrück 1964); zeisverkopers uit Sauerland: Peter Höher, Heimat und Fremde. Wanderhändler der oberen Sauerlandes (Münster 1985).

24 Strohoedenmakers: Annemarie Cottaar en Leo Lucassen, 'Naar de laatste Parijse mode. Strohoedenmakers uit het Jekerdal in Nederland 1750-1900', in: Ad Knotter en Willibrord Rutten (red.), Studies over de sociaal-economische geschiedenis van Limburg XLVI (Maastricht 2001) 45-82; tichelbakkers: Lourens en Lucassen, Arbeitswanderung und berufliche Spezialisierung; gouvernantes: Huisman, Tussen salon en souterrain.

25 Jan Lucassen, 'Beschouwingen over seizoensgebonden trekarbeid naar het westen van Nederland, ca. 1600 - ca. 180o', 
Tijdschrift voor Sociale Geschiedenis (1982) 327-358, 348; Ad Knotter en Jan Luiten van Zanden, 'Immigratie en arbeidsmarkt te Amsterdam in de $17 \mathrm{e}$ eeuw', Tijdschrift voor Sociale Geschiedenis (1987) 403-430, 410, 425;. Ad Knotter, 'Vreemdelingen in Amsterdam in de 17e eeuw: groepsvorming, arbeid en ondernemerschap', Historisch Tijdschrift Holland 27 (1995) 219-235, 229; Leo Lucassen en Boudien de Vries, 'Leiden als middelpunt van een Westeuropees textiel-migratie-systeem, 1586-1650, Tijdschrift voor Sociale Geschiedenis (1996) 138-167.

26 De Tijd 21-4-1954.

27 Zie de studies van Snell, Nadel en Panayi.

28 Burger en Berntsen, 'De Duitse migratie naar Amsterdam', 60-64, 62.

29 Panayi, German immigrants in Britain, 120, 134.

30 Zie voor een overzicht op dit punt: Schrover, 'Potverkopers, vijlenkappers, stukadoors en winkeliers, 281-305; Schrover, 'Immigrant business and niche formation in a historical perspective'.

31 A. Portes, 'The informal economy and its paradoxes', in: N.J. Smelser en R. Swedberg (red.), The handbook of economic sociology (Princeton 1994) 426-449.

32 H.J.J. Wubben, "Chineezen en ander Aziatisch ongedierte". Lotgevallen van Chinese immigranten in Nederland, 1911-1940 (Amsterdam 1986) 55.

33 Geciteerd in Wubben, "Chineezen en ander Aziatisch ongedierte", 126.

34 Rath, Minorisering, 37, 51.

35 P.H. Wilken, Entrepreneurship. A comparative historical study (Norwood 1979); A. Stepick, 'Community growth versus simply surviving: the informal sectors of Cubans and Haitians in Miami', in: M. Estellie Smith (red.), Perspectives on the informal economy; monographs in Economic anthropology no. 8 (Lanham 1990) 183-205.

36 K.S. Chin, I. Yoon en D. Smith, 'Immigrant small business and international economic linkage: a case of the Korean wig business in Los Angeles, 1968-1977', International Migration Review (1996) vol. xxx, no 2, 485-510; Marlou Schrover, 'Wie zijn wij?'

37 Schrover, 'Omlopers in Keulse potten', 101-120; Chin, Yoon en Smith, 'Immigrant small business', 485-510.

38 Portes, 'The informal economy and its paradoxes', 437.

39 Light en Karageorgis, 'The ethnic economy', 647-670, 663.

40 Emilio Reyneri, 'The role of the underground economy in irregular migration to Italy: cause or effect?' Journal of Ethnic and Migration Studies (1998) vol. 24 nr. 2, 313-331.

41 Tony Waters, 'Towards a theory of ethnic identity and migration: the formation of ethnic enclaves by migrant Germans in Russia and North America', International Migration Review (1995) vol 29 no. 2, 515544; Frank Bovenkerk, Anne Eijken en Wiesje Bovenkerk-Teerink, Italiaans ijs. De opmerkelijke historie van de Italiaans ijsbereiders in Nederland (Amsterdam 1983) 180.

42 Robert W. Fairlie en Bruce D. Meyer, 'Ethnic and racial self-employment differences and possible explanations', The Journal of Human Resources (1996) 31-4, 757-793.

43 Waldinger, Still the promised city?, 21-25, 302-304.

44 Jimmy M. Sanders en Victor Nee, 'Limits of ethnic solidarity in the enclave economy', American Sociological Review (1987) vol 52, 745-767.

45 Multatuli, Max Havelaar of de koffieveilingen der Nederlandse Handelsmaatschappij (oorspronkelijk 186o, herdruk Utrecht 1988) 16-17.

46 Nadel, Little Germany, 67.

47 Terwijl er wel 47 klerken in de volkstelling van 1849 voorkomen.

48 Nadel Little Germany, 67. 
49 R.E. de Bruin, 'Regenten en revolutionairen', in: R.E. de Bruin, P.D. 't Hart, A.J. van den Hoven van Genderen, A. Pietersma (red.), 'Een paradijs vol weelde'.

Geschiedenis van de stad Utrecht (Utrecht 2000) 315-374, 326.

50 Rommes, Oost, west, Utrecht best?, 164.

51 Nadel, Little Germany, 72.

52 T. Landré, De groote bedrijven in Nederland. Het bierbrouwerijbedrijf (Amsterdam 1926) 31.

53 Johannes Boddé (geboren in 1801 in Borkum in Westfalen, katholiek) werkte als bierbrouwersknecht en Friedrick Bartmann (geboren in 1807 in Warmsen ambt Diepenau in Hannover, luthers) als bierbrouwer. Boddé, bevolkingsregister 18501859, wijk D, fiche 75, Lange Rosendaal 440 434W, vel 6868 684. Bartman, bevolkingsregister 1850-1859, wijk A, fiche 44, Keukenstraat 1031, vel 1271.

54 Geboren in Bielefeld, 1786, luthers. Bevolkingsregister 1850-1859 wijk B, fiche 73, Suikerstraat 420j, vel 637 .

55 Geboren in Zschopau - ten zuiden van Chemnitz - 1847, hersteld, luthers. Bevolkingsregister 1860-1879, wijk L, fiche 667, Leidscheweg 135d, vel 1341.

56 Rommes Oost, west, Utrecht best?, 164.

57 Geboren in Demming in Pruisisch Pommeren bij Stettin, 1794, luthers. Bevolkingsregister 1850-1859, wijk C, fiche 129, Nauwe Waatersteeg 511, vel 858.

58 Geboren in Kranenburg, 1840, katholiek. Bevolkingsregister 1860-1879, wijk $\mathrm{H}$, Hoog Jacobijnestraat 39, vel 72.

59 Rommes, Oost, west, Utrecht best?, 163.

60 Rommes, Oost, west, Utrecht best?

61 Snell, Deutsche Immigranten in Kopenhagen, 53 en 75.

62 De Utrechtse hoogleraar G.W. Vreede liet wel enige kritische geluiden horen. G.W. Vreede, Onze volksgeest voor en na de grondwetherziening van 1848. Teekenen des tijds. Eischen van het oogenblik (Utrecht 1870).
63 De registratie van militairen week enigszins af van die van de rest van de bevolking. Tussen 1862 en 1877 werd een gedeelte van het militaire personeel wel in de bevolkingsregisters ingeschreven en een gedeelte niet. Na 1877 werd de gehele administratie in de kazernes verzorgd en verdwenen alle militairen uit de reguliere bevolkingsregisters. Op basis van de cijfers voor de jaren dat militairen wel geregistreerd werden, kan worden gezegd dat voor de jaren 1860-1879 maximaal 28 Duitse immigranten die tot categorie militairen behoorden aan het totaal moeten worden toegevoegd. Van deze militairen kennen we echter de namen niet. Zie voor een overzicht van wie wel en wie niet werd ingeschreven: Schrover, 'Registratie van vreemdelingen in het bevolkingsregister (1850-1920)'.

64 H. van Amersfoort, Koning en kanton. De Nederlandse staat en het einde van de Zwiterse krijgsdienst hier te lande 1814-1829 (Den Haag 1988) 97-107.

65 Van Campen, 'De Handelsfirma Trip', 115-141, 120.

66 Walter D. Kamphoefner, 'At the crossroads of economic development: background factors affecting emigration from nineteenth-century Germany', in: Ira A. Glazier en Luigi De Rosa (red.) Migration across time and nations. Population mobility in historical contexts (New York en Londen 1986) 174-201, 186.

67 De belangrijksten waren Bernardus Bunte (Harsewinkel 1781 katholiek), Johann Heinrich Bunte (Bramsche 1787 luthers) en Julius Sambler (Essen 1826 luthers). Daarnaast waren er anderen die slechts kort in Utrecht hun verblijf hielden, zoals Jacob Lukschwerdt (Bodenburg 1817 luthers), Hermanus Reincke (1798 Klanhorst katholiek), Andreas Gothel (Mannheim 1834 katholiek), Henrich van Rossum (1845 Kleef geloof weggevallen) en Wilhelm Welleshaus (Borbeck 1860 luthers). Bernardus Bunte: bevolkingsre- 
gister 1850-1859, wijk G, fiche 246, Minnebroederstraat 307, vel 405; Johan Heinrich Bunte, bevolkingsregister 1850-1859, wijk A, fiche 28, Groenesteeg 671, vel 807; Sambler, bevolkingsregister 1860-1879 wijk M, fiche 761, Koekkoeksteeg 390 L, vel 2010; Lukschwerdt, bevolkingsregister 18501859, wijk C, Nauwe Watersteeg 528, vel 908; Reincke bevolkingsregister 1850-1850, wijk F, fiche 216, Vischmarkt 127, vel 191; Gothel, bevolkingsregister 1850-1859, wijk D, fiche 159, Vreeburg 1160, vel 165; Van Rossum, bevolkingsregister 1860-1879, wijk G, fiche 416, Drift 328, vel 553; Welleshaus, bevolkingsregister 1860-1879, wijk G, fiche 433, Muntstraat 396/7 vel 1028.

68 Een uitzondering was Bernard Meesing (Havixbeck 1853 katholiek). Hij kwam in 1873 in huis bij de Nederlandse horlogemaker Rieke, waar hij enkele weken later op 20-jarige leeftijd overleed. Bevolkingsregister 1860-1879, wijk D, fiche 301, Bakkersteeg 299, vel 508.

69 Panayi, German immigrants in Britain, 131.

70 Snell, Deutsche Immigranten in Kopenhagen.

71 Lucassen, 'Het einde van een migratieregime'.

72 Snell, Deutsche Immigranten in Kopenhagen, 57, zie ook 195.

73 Adresboek 1868-69. De metselaars uit het adresboek zijn opgezocht in het bevolkingsregister om te achterhalen wat hun geboorteplaats is.

74 Onder de 268 bruidegoms in de HSN-controlegroep zijn zestien hoveniers (zes procent).

75 J.W.M. Sickmann, T. Joustra-Schumacher, A. Fontijn en H. Ruhe, 'Van Heuerleute en warmoezeniers', in: De Boerenwetering. Wonen, werken en vermaak langs een eeuwenoude waterweg (Uitgave Vereniging Historisch Amstelveen. Amstelveense Historische Reeks no. 2 1995) 61-68.

76 Gemeentearchief Rotterdam, Handelingen gemeenteraad 1882 144, aangehaald in: Nelleke Manneke, 'Reactie van Rotter- damse burgers op de migratie rond 1900.' In: Paul van de Laar, Thimo de Nijs, Johan Okkema en Albert Oosthoek, Vier eeuwen migratie. Bestemming Rotterdam (Rotterdam 1998) 172-187.

77 Coby van der Wurf-Bodt, Van lichte wiven tot gevallen vrouwen. Prostitutie in Utrecht vanaf de late middeleeuwen tot het einde van de negentiende eeuw (Utrecht 1988) 192-193.

78 Leenders, Ongenode gasten, 118.

79 Martin Bossenbroek en Jan H. Kompagnie, Het mysterie van de verdwenen bordelen. Prostitutie in Nederland in de negentiende eeuw (Amsterdam 1998) 93.

80 Van der Wurf-Bodt, Van lichte wiven tot gevallen vrouwen, 56 .

81 Data over prostitutie zijn verzameld door Hans Sterk. Hans Sterk, "Rondom de Galekopsteeg.' 1858-1885. Enige aspecten van de prostitutie te Utrecht', Tijdschrift voor Sociale Geschiedenis (1983) 79-107. Hans Sterk heeft zijn basismateriaal aan mij afgestaan, waarvoor mijn dank.

82 P.D. 't Hart, 'Het onbespreekbare besproken. Het Utrechtse gemeentebestuur en de prostitutiekwestie, 1850-1900', Jaarboek Oud Utrecht 1993, 147-180; Bossenbroek en Kompagnie, Het mysterie van de verdwenen bordelen, 101.

83 P.J. Andriessen, Iets anders. Bevattende een beschrijving van de provincien Zuid-Holland en Utrecht (Deventer 1871) 77.

84 Woordenboek der Nederlandsche taal. Zevende deel, eerste druk (Leiden 1923) 2111.

85 Staatscommissie over de werkloosheid (ingesteld bij koninklijk besluit van 30 juli 1909 no 42) IV Verslag van de derde subcommissie (Den Haag 1913) 38. Hierin wordt geciteerd uit het Rapport van een gemeentelijke commissie over den toestand in het hotel- en cafébedrijf te Amsterdam uit 1907.

86 In 1910 had deze bond wereldwijd 10.000 leden verdeeld over 180 afdelingen. In Amsterdam telde de bond toen 35 leden. 
"Union Ganymed" Deutscher KellnerBund, te Erfurt, Directie van den arbeid, Adresboek van de werklieden-organisaties in Nederland Den Haag 1910, 188.

87 Zie ook Panayi, German immigrants in Britain, 193.

88 Staatscommissie over de werkloosheid, 88.

89 Struick, Utrecht door de eeuwen heen, 317.

90 Bevolkingsregister 1860-1879 L 152 e, blad $943,562,748,750$ en 1809. Biehme werd geboren in 1859 in Maagdenburg, Krumbing in 1857 in Hannover en Hoffman in 1854 in Marnburg.

91 Bosschaert, De stad Utrecht als medisch ontwikkelingsgebied, 98-99.

92 De Beer, 'Beroepskeuze, levensstandaard en lichamelijke ontwikkeling', 227; K.E. Sluyterman, Ondernemen in sigaren. Analyse van bedrijfsbeleid in vijf Nederlandse sigarenfabrieken in de perioden 1856-1865 en 1925-1934 (Tilburg 1983) 109; Gertjan de Groot, Fabricage van verschillen. Mannenwerk, vrouwenwerk in de Nederlandse industrie (1850-1940) (Amsterdam 2001).

93 Sluyterman, Ondernemen in sigaren, 147.

94 Sluyterman. Ondernemen in sigaren, 151, 154 en 166.

95 F. Nas, Sigaren uit Dieren. Over sigaren, sigarenfabrikanten, sigarenmakers, sigarenverkopers en tabak (Bilthoven 1993) 32; Sluyterman, Ondernemen in sigaren, 70 en 145-148.

96 Dit was in 1826 in Kampen de Duitser Lehmkuhl uit Bremen. Sluyterman, Ondernemen in sigaren, 17.

97 Nadel 72.

98 Hij werd geboren in Düsseldorf in 1838 en was katholiek. Bevolkingsregister 18601879, fiche 658, wijk L, Lekstraat 407, vel 1206.

99 Hij werd eveneens geboren in Düsseldorf in 1847 en was katholiek. Bevolkingsregister 1860-1879, fiche 658, wijk L, Lekstraat 407, vel 1206.

100 De Vooys, De trek van de plattelandsbevolking, 165.
101 Waldinger, Still the promised city?; Hondius, Gemengde huwelijken. 17.

102 E. 'Hoe de fotografie in Utrecht kwam', Maandblad Oud-Utrecht 1934, 26-29.

103 Irma van Bommel, 'De fotografie', in: J.W.L. Hilkhuijsen (red.), De stad Delft. Cultuur en maatschappij van 1813 tot 1914 (Delft 1992) 289-302.

104 Het migratiegedrag van de Franse fotografen kan gereconstrueerd worden aan de hand van de advertenties die ze veelvuldig in dagbladen lieten opnemen. De fotografiehistoricus Steven Wachlin heeft de krantenadvertenties op deze manier gebruikt. S. Wachlin, 'Fotografen - een overzicht', in: J.W.L. Hilkhuijsen (red.), De stad Delft. Cultuur en maatschappij van 1813 tot 1914 (Delft 1992), 303-310. Wachlin heeft een zeer uitgebreide verzameling aangelegd van krantenadvertenties van fotografen, geboren voor 1880 . Verder heeft hij op basis van de bevolkingsregisters een bestand gemaakt van alle fotografen die in Nederland in de negentiende eeuw actief waren. Ik dank hier Steven Wachlin voor inzage in zijn archief.

105 Steven Wachlin en Hans Rooseboom, 'Parijzenaar of Amsterdammer', Nieuwsbrief Nederlands fotogenootschap, nr. 17 Fotografen in Amsterdam, maart 1997, 15-16.

$106 \mathrm{E}$. 'Hoe de fotografie in Utrecht kwam, vervolg', Maandblad Oud-Utrecht 1934, 66-69.

107 E. 'Hoe de fotografie in Utrecht kwam, vervolg, 66-69.

108 Van Bommel, 'De fotografie', 289-302, 302.

109 Robbert van Venetië en Annet Zondervan, 'Friedrich Julius von Kolkow', in: Ingeborg Th. Leijerzapf (red.), Geschiedenis van de Nederlandse fotografie (Amsterdam 1984/2000) 16, 1-15, 4; Henk Wierst, Photographieën \& dynastieën: beroepsfotografie in Groningen 1842-1940 (Bedum 2000).

110 Schatting op basis van de gegevens van Steven Wachlin. Met dank voor de inzage. 
111 Leijerzapf (red.), Geschiedenis van de Nederlandse fotografie.

112 E. 'Hoe de fotografie in Utrecht kwam', 26-29; E. 'Hoe de fotografie in Utrecht kwam, vervolg'; Utrechtsche Provinciale en Stadscourant 17-9-1851 advertentie nummer 5723; Utrechtsche Provinciale en Stadscourant 3-9-1851.

113 Deutmann werd geboren in 1809 in Dorsten; Wachlin, 'Fotografen - een overzicht', 303-310. 304.

$114 \mathrm{E}$. 'Hoe de fotografie in Utrecht kwam, vervolg', 60.

115 Bevolkingsregister 1850-1859, fiche 275, wijk $\mathrm{H}$, Breedstraat 355, vel 515.

116 Hij trouwde met de protestantse Antonia van der Velden. Tussen 1859 en 1864 werden in Utrecht hun vijf kinderen geboren. Bevolkingsregister 1860-1879, fiche 456, wijk $\mathrm{H}$, Breedstraat 355, vel 667 .

117 Bevolkingsregister 1860-1879, fiche 63, wijk A, Brigittestraat 1139, vel 1811 .

118 In 1866 trouwde hij met de Utrechtse katholieke Hendrikje van Engelen, die reeds een zevenjarige buitenechtelijke zoon had. Er werden nog vijf kinderen geboren. De kinderen werden als Nederlands Hervormd ingeschreven, behalve de jongste en enige dochter die als luthers vermeld staat.

119 Protestants en geboren in 1845 . Hij trouwde met de Rotterdamse Henrietta Margadant. In 1874 kreeg dit echtpaar de tweeling Sara en Maria, gevolgd door nog drie kinderen tussen 1875 en 1878 . Bevolkingsregister 1860-1879, fiche 620, wijk L, Bij het Leidsche Veer 50, vel 250.

$120 \mathrm{HUA}$, Archief arrondissementsrechtbank, toegang 182,656 acte 558 4-2-1879. Wilhelm Mannebach werd in 1849 geboren in Brugbrohl.

121 Bevolkingsregister 1870-1879, fiche 214, wijk C, Potterstraat 103, vel 139.

122 Hij werd geboren in Oberhausen in 1839. Bevolkingsregister 1860-1879, fiche 419, wijk G, Zonstraat 401, vel 646.
123 Hans Rooseboom, 'Wegner \& Mottu', in: Ingeborg Th. Leijerzapf (red.), Geschiedenis van de Nederlandse fotografie (Amsterdam 1984/2000) nr. 25, april 1995. Ludwig Wegner werd in 1816 in Frankenthal in Duitsland geboren. Pierre Mottu werd in 1840 in Parijs geboren.

124 Het was eerst gevestigd aan de Leidseweg L 153 en later op de Hamburgerstraat F 237. Wegner woonde in München, Wenen, Luzern en Zürich voordat hij in 1849 naar Amsterdam kwam. In 1862 associeerde hij zich met Mottu. Twee jaar daarna overleed hij. Toen het filiaal in Utrecht werd geopend, was Wegner reeds dood.

125 Max Büttinghausen werd in 1847 in Urdenbach bij Düsseldorf geboren. In 1873 kwam Max Büttinghausen naar Amsterdam. Vijf jaar later werd hij gevolgd door zijn neef Joseph Büttinghausen. Op het Amsterdamse Spui bouwde de firma het indrukwekkende gebouw Helios. De firma had ook een atelier in het Duitse Godesberg. Max Büttinghausen hield ook anderszins banden met Duitsland. Zijn vrouw was Duitse, zijn kinderen gingen in Duitsland op kostschool en Max Büttinghausen reisde regelmatig naar Duitsland. Anja Krabben, 'Max en Ernst Büttinghausen', in: Ingeborg Th. Leijerzapf (red.), Geschiedenis van de Nederlandse fotografie (Amsterdam 1984/2000) nr. 20, april 1993. 126 Bevolkingsregister 1880-1889, fiche 578, wijk L, Catharijnesingel 70, 280.

127 Hij vestigde zich in wijk $\mathrm{C}$ en trouwde met de in Gorinchem geboren weduwe Teuntje van Baalen. Hij was 29 jaar, zijn vrouw 38. Teuntje van Baalen was tapster en had twee kinderen uit haar eerdere huwelijk. Het echtpaar kreeg nog twee kinderen, waarvan de eerste binnen twee maanden na het huwelijk. In 1860 woonde het gezin op het Lauwerecht in wijk M. Behalve de kinderen van zijn vrouw uit het eerste huwelijk en hun kinderen uit het tweede huwelijk, maakten ook de 
vader van Teuntje van Baalen en haar schoonzus uit haar eerste huwelijk met haar kinderen deel uit van het huishouden. De vader van Rencker was landbouwer. Bevolkingsregister 1850-1859, fiche 353, wijk M, Bemuurde Weerd oz 110, vel 177.

128 J.G. Hibbeln, Wilhelm Hibbeln. De glasmof. Hoe een Duitse emigrant in de vorige eeuw vanuit Amterdam-Oost een zakenimperium stichtte (Utrecht 1995).

129 Van der Woude, Leeuwarden 1850-1914, 114-117.

130 Bevolkingsregister 1860-1879, fiche 753 , wijk M, Lauwerecht 189, vel 1779.

131 Bevolkingsregister 1860-1879, fiche 555, wijk I, Maliesingel 328 9, vel 1957.

$132 \mathrm{HUA}$, Archief arrondissementsrechtbank, toegang 182, 656 akte 549, 21-9-1878.

133 Bevolkingsregister 1860-1879, fiche 590, wijk K, Ganssteeg 256 niet kom, 485; bevolkingsregister 1860-1879, fiche 605, wijk K, Ganssteeg 260 I, vel 821.

134 Gemeenteverslag 1880.

135 J.C.A. Everwijn, Beschrijving van handel en nijverheid in Nederland (Den Haag 1912) 383.

136 H UA, Archief arrondissementsrechtbank, toegang 182,656 akte 776 - 624 22-12-188o 23-11.

137 Plannen om in het nieuwe pand een wasserij te vestigen, werden afgewezen door de gemeente, na klachten van omwonenden die vreesden voor vervuiling van het water. Uiteindelijk begon A. de Kievit in het pand een houtzagerij. Gemeenteverslag 1882.

138 H.A.M. Snelders, De geschiedenis van de scheikunde in Nederland. Van alchemie tot chemie en chemische industrie rond 1900 (Delft 1993) 161.

139 E. Homburg, 'Zwavelzuur', in: E. Homburg e.a. (red.), Chemische techniek in Nederland in de negentiende eeuw (Zutphen 1994) 37-60, 53.

140 Volgens Panayi,German Immigrants, 73, werd hij geboren in 1839 . Volgens de inschrijvingen in het Utrechtse bevolkingsregister in 1835. Zie ook: J. M. Cohen, The life of Ludwig Mond (Londen 1956).

141 Homburg, 'Zwavelzuur', 58.

142 Hij woonde in wijk M Hoogelanden 214, register 1860-1879 fiche 702, vel 446 en wijk M Weerdsingel 409c, register 18601879 fiche 730 vel 1239 .

143 Frederika Loewenthal werd geboren in Keulen in 1847. Het echtpaar trouwde niet in Utrecht.

144 Panayi, German Immigrants, 73 en 142. Panayi noemt 1862 als het jaar waarin hij naar Engeland ging. Waarschijnlijk was dat tijdelijk, want 1865-1866 woonde hij in ieder geval in Utrecht.

145 E. Homburg, 'Een bedrijfstak in verandering', in: E. Homburg e.a. (red.), Chemische techniek in Nederland in de negentiende eeuw (Zutphen 1994) 115-126, 124.

146 We weten meer over Bätz en Witte, en de migratie van Duitse orgelbouwers, door de onderzoeken van Gerard Oost en T.W.F. den Toom. Gerard Oost, De orgelmakers Bätz (1739-1849). Een eeuw orgelbouw in Nederland (Utrecht 1975); Den Toom, De orgelmakers Witte.

147 Oost, De orgelmakers Bätz, 17.

148 Bevolkingsregister 1850-1859, fiche 156, wijk D, Oudegracht 56, vel 69.

149 Den Toom, De orgelmakers Witte, 25. 150 Hans van der Harst, 'De orgelmakers Witte en hun tijdgenoten', in: T.W.F. den Toom (red.) De orgelmakers Witte (Gorinchem 1978) 4-15.

151 Oost, De orgelmakers Bätz, 48. 152 Oost, De orgelmakers Bätz, 51.

153 Den Toom, De orgelmakers Witte, 49. 154 Den Toom, De orgelmakers Witte, 53. 155 Oost, De orgelmakers Bätz, 55 en 57. 156 Den Toom, De orgelmakers Witte, 67. 157 Jaarverslag Gemeente Utrecht 1852. 158 Bevolkingsregister 1850-1859, fiche 363, wijk M, Lauwerecht 266, vel 463.

159 Knotter, Economische transformatie en stedelijke arbeidsmarkt. 
160 Burger en Berntsen, 'De Duitse migratie naar Amsterdam', 62.

161 Van Maurik, Toen ik nog jong was, 32.

162 Panayi, German immigrants in Britain, 131.

163 Snell, Deutsche Immigranten in Kopenhagen, 102, 105.

164 Snell, Deutsche Immigranten in Kopenhagen, 105.

165 Schneider 'The German bakers of New York city', 50

166 Zoals Peter Heppelman uit Lipperode (1843 hervormd) en Ludwig Brandt uit Rosenthal (1827 luthers). Bevolkingsregister 1860-1879, fiche 718, wijk M, Bemuurde Weerd 456, vel 913.

167 Rommes, Oost, west, Utrecht best?, 154 en 164.

168 Heitz, Philip Florens, geb. te Duitsland, luthers, 'een bakker', (inwoning), Beschikking: 30 april 1792, HUA, S.A. II, 386, De bakker Hutz, ook gespeld als Heitz Christiaan (geboren in Bielefeld in 1796 en luthers), die in de we in de negentiende-eeuwse bronnen tegenkomen, was een zoon van deze bakker.

169 Van Lottum Nieuwkomers in Nederland, 98.

170 Van Lottum, Nieuwkomers in Nederland, 100 en 102.

171 Van Lottum, Nieuwkomers in Nederland, 122.

172 Hendrikus Gerritzen register 1850-1859, wijk H Oudegracht 14, fiche 258, vel 17. Gerritzen werd geboren in Elten in 1817 en was katholiek.

173 Knotter en Van Zanden, 'Immigratie en arbeidsmarkt te Amsterdam', 412.

174 Zie op dit punt ook: Bovenkerk, Eijken en Bovenkerk-Teerink, Italiaans ijs, 180.

175 Utrechtsch Provinciaal en Stedelijk Dagblad 23-5-1878.

176 In 1849 waren er immers op een bevolking van 50.000284 bakkers. Uitgaande van een gemiddelde gezinsgrootte van vijf.

177 Nancy L. Green, Ready-to-wear and readyto-work. A century of industry and immi- grants in Paris and New York (Durham en Londen 1997) 78.

178 P. Werbner, 'From rags to riches: Manchester Pakistanis in the textile trade' New Community, 1980, viII vol 1/2.

179 Snell, 98.

180 Snell, 105.

181 Knotter, Economische transformatie en stedelijke arbeidsmarkt; Jan Boersma en Ivo Kuypers, 'En toen kwam het kapitaal ...' Een onderzoek naar segmenteringsprocessen op de Amsterdamse arbeidsmarkt voor de kledingindustrie, 1850-1920 (Ongepubliceerde doctoraalscriptie Universiteit Utrecht 1988) 85.

182 Knotter, Economische transformatie, 148.

18322 procent kwam uit de Noordelijke Nederlanden en slechts 21 procent uit Amsterdam zelf. B. Panhuysen, Maatwerk. Kleermakers, naaisters, oudkleerkopers en de gilden (1500-1800) (Amsterdam 2000) 163-164. In Amsterdam was in 1642 het onderscheid in intreegeld voor de geboren poorters en vreemdelingen opgeheven.

184 Everwijn, Beschrijving van handel en nijverheid in Nederland, 380.

185 Rommes, Oost, west, Utrecht best?, 163. 186 Bevolkingsregister 1850-1859 wijk $\mathrm{H}$ fiche 260.

187 Bevolkingsregister 1850-1859 wijk $\mathrm{H}$ fiche 259 vel 31.

188 Bevolkingsregister 1850-1859 wijk D fiche 155 vel 47.

189 HUA, Archief Provinciaal Bestuur, Toegang 79 Jaarverslag Provinciaal Bestuur 1813-1920, 213, Verslag over 1861, 435.

190 Utrechtsch Provinciaal en Stedelijk Dagblad 19-5-1878.

191 Panayi, German immigrants in Britain; Nadel, Little Germany.

192 Utrechtsche Provinciale en Stadscourant 2212-1851.

193 Morawska, Insecure prosperity; Waldinger, Still the promised city? Zie ook: Lucassen en Vermeulen, Immigranten en lokale arbeidsmarkt. 
194 Zie voor dat laatste punt: Lucassen en Vermeulen, 37.

\section{WesterwaLders}

1 Van Maurik, Toen ik nog jong was, 31; zie ook Johann Plenge, Westerwälder Hausierer und Landgänger (Leipzig 1898) 39.

2 Van Maurik, Toen ik nog jong was, 31; Plenge, Westerwälder Hausierer, 39.

3 J. van Lennep, Romantische werken, derde deel. Ferdinand Huyck (Rotterdam 1856) 171.

4 Louis Couperus, De boeken der kleine zielen. Eerste deel (Amsterdam 1901) 169.

5 Zie voor de verhalen de Verhalenbank van het Meertensinstituut onder het trefwoord 'pot'.

6 J. de Kleyn, Volksaardewerk in Nederland 1600-190o (Zeist 1965) 30-31; J. de Kleyn, 'Pottenverkopers, kiepkerels en andere rondtrekkende lieden', Bijdragen en mededelingen van het Rijksmuseum voor Volkskunde 'Het Nederlands Openluchtmuseum' 24e jrg, (1961) nr.2, 39-43.

7 Van Campen, 'De Handelsfirma Trip', 115-141, 120.

8 Plenge, Westerwälder Hausierer.

9 W.H. Struck, Die Auswanderung aus dem Herzogtum Nassau (1806-1866) (Wiesbaden 1966) 17.

10 Struck, Die Auswanderung, 20.

11 Struck Die Auswanderung, 48.

12 Kamphoefner, The Westfalian, 73. Texas was op dat moment een onafhankelijke staat. In 1845 sloot de staat zich aan bij de vs, maar het Duits werd erkend als gerechtstaal. Zie ook Terry G. Jordan, German seeds in Texas soil. Immigrant farmers in nineteenth-century Texas (Austin 1966).

13 F. Baaden, Landgänger. Botschafter des Kannenbäckerlande. (Ransbach-Baumbach 1993) 12; Alleen de katholieke Westerwalders ventten en niet de protestantse. Plenge verklaarde dit uit de armoede bij de katholieken vanwege een grotere omvang van de gezinnen. Opvallend is, zoals Lucassen heeft opgemerkt, dat kramerij in het algemeen een katholiek verschijnsel lijkt te zijn geweest. Er waren natuurlijk wel protestantse en joodse handelaren, maar bij de aan een bepaald afstotingsgebied gekoppelde handel lijken katholieke handelaren overheersend te zijn. Lucassen, Naar de kusten van de Noordzee, 116.

14 De Kleyn, Volksaardewerk in Nederland 1600-190o (Zeist 1965); A. Wegener, Ochtrup, ein Heimatbuch (zp, zj) 204, 216.

15 Hier vinden we slechts een migrant uit Ochtrup en die werkte als bediende in de winkel van Sinkel.

16 De Kleyn, Volksaardewerk in Nederland, 40.

17 De Kleyn, Volksaardewerk in Nederland, 76.

18 Plenge, Westerwälder Hausierer, 5.

19 H. Fries, Kurrimurri. Erinnerungen an die Kannenbäcker in Höhr-Grenzhausen (Höhr-Grenzhausen 1993).

20 Herzoglich Nassauisches allgemeines Intelligenzblatt 1854, 10, 18, 22, 31, 115, 134, 146, 167 en 197.

21 Gisela Reineking-Von Bock, 'Steinzeug Nachahmung, Nachbildung oder Fälschung?', Keramos 49 (1971) 3-66.

22 Baaden, Landgänger, 21.

23 Hendrik Jacob Keuning, 'De economischgeografische achtergrond van de Rijnvaart voor 1870', Physisch-en Economisch-Geografische beschouwingen over de Rijn als Europese rivier. Vriendenboek aangeboden aan prof. W.E. Boerman (Rotterdam 1948) 32-60; Henricus Cornelis Wilhelmus Roemen, 'De ontwikkeling na 1870', in: Physich-en Economisch-Geografische beschouwingen over de Rijn als Europese rivier. Vriendenboek aangeboden aan prof. W.E. Boerman (Rotterdam 1948) 61-88.

24 Plenge,Westerwälder Hausierer, 204.

25 Idem. 
26 A. van der Meulen en P. Smeele, 'Oosterhout als pottenbakkerscentrum in de negentiende en twintigste eeuw', Antiek, tijdschrift voor liefhebbers en kenners van oude kunst en kunstnijverheid, 24e jaargang (1989/90) deel 1 2-23, deel 2 63-87.

27 Hessisches Hauptstaatsarchive Wiesbaden W 21114334 Gewerbekonsessionen in Ambt Selters 1, 1861.

28 Adri van der Meulen en Paul Smeele bezitten een omvangrijke collectie van dit gemerkte aardewerk. Ik wil hen bedanken voor inzage in deze collectie en de uitvoerige toelichting.

29 P. Zwaal, Frisdranken in Nederland (Rotterdam 1993) 31.

30 Hessisches Haupstaatsarchive Wiesbaden w 241-345; Baaden, 13.

31 Baaden, Landgänger, 30.

32 Baaden, Landgänger, 28.

33 Struck, Die Auswanderung, 9.

34 Herzoglich Nassauisches allgemeines Intelligenzblatt jaar 1867, Bijlage 259.

35 Hessisches Haupstaatsarchive Wiesbaden w 241-345; Baaden, 26.

36 Baaden, Landgänger, 8.

37 Hessisches Haupstaatsarchive Wiesbaden w 241-345.

38 Hessisches Haupstaatsarchive Wiesbaden w 241-413.

39 Ibidem, 107 en 110.

40 Plenge, Westerwälder Hausierer, 190.

41 Wilhelm Franz Fohr, Aus der Geschichte Ransbachs (onuitgegeven typescript Ransbach 1943) 45.

42 Plenge, 114.

43 Hessisches Haupstaatsarchive Wiesbaden w 241-757/25 en w 241-757/1.

44 Hessisches Haupstaatsarchive Wiesbaden w 241-2657 en 1655.

45 De 'Utrechtse' Westerwalders schonken hun kapitaal niet aan de H. Martinusparochie waartoe zij behoorden. In het archief van deze parochie zit wel een map met schenkingen, maar de Westerwalders komen daar niet in voor. HUA, Archief archieven van de in 1855 opgerichte R.K.
Parochies in de stad Utrecht $822-5 \mathrm{H}$.

Martinus, 128, erfenissen en schenkingen.

46 Plenge, Westerwälder Hausierer, 190.

47 Plenge, 111.

48 Plenge, 45.

49 Synodal-Protokollbuch der Pfarrerei Ransbag 12-11-1782.

50 Synodal-Protokollbuch der Pfarrerei Ransbag 1786.

51 Groot Placaatboek vervattende alle de placaten, ordonnantien en edicten der edele mogende heeren staten 's lands van Utrecht mitsgaders van de ed. Groot achtb. Heeren borgemeesteren en vroedschap der stad Utrecht tot het jaar 1728 ingesloten (Utrecht 1729) III boek XVI, 781.

52 De akte was opgesteld bij notaris Dirk Oskamp, Notarieel Archief U188 a 018 (aktenummer 14). Met dank aan Ronald Rommes voor deze informatie.

53 Jan Brugman, Hans Buiter en Kaj van Vliet, Markten in Utrecht van de vroege middeleeuwen tot nu (Utrecht 1995) 17, 26, 31 en 47.

54 HUA, stadsarchief 4, 1236, toegang $704 \mathrm{~N}$, blz 24, Verslagen van de algemene marktmeester betreffende de verschillende markten in Utrecht over 1850/51, 1851 en 1854.

55 Opvallend is dat de potmarkt in Amsterdam als afzonderlijke markt ook verdween in de tweede helft van de negentiende eeuw. In 1845-1846 werd de markt nog als afzonderlijke markt genoemd, later niet meer. Jac. van de Kar, De geschiedenis van de markt- en straathandel (Amsterdam/ Antwerpen 1982) 22.

56 HUA, 86 BA 1, Gilden, 63 en 56.

57 HUA, 86 BA 1, Gilden, 58, Register van de namen der aangenomen leden van het marslieden gild 17-24-1798.

58 HUA, 86 BA 1, Gilden, 56.

59 Rommes, Oost, west, Utrecht best?

60 J. Vink, Utrecht's Rijnverbinding in den loop der eeuwen, Maandblad Oud-Utrecht (1928) 89-96. 
61 HUA, archief 1795-1813, no. 40. Alphabetisch register van afgegeven patenten aan vreemde ketelboeters en kooplieden in aardewerk 1806.

62 Idem.

63 HUA, stadsbestuur 2, 2051; 702-6, buitenwijken. Dit onderzoek in het manuaal van de honderdste penning werd verricht door Ronald Rommes, waarvoor mijn dank.

64 HUA, S.A. II, inv.nr. 386, Beschikking: 12 aug. 1802.

65 HUA, Stadsarchief III, stedelijke besturen 1808-1813, no. 626 Patenten voor rondventers van aardewerk afgegeven in verschillende steden, doch allen te Utrecht van omslagzegel voorzien op 30 april 1810.

66 HUA, Archief gemeente 1814-1851, no. 250 Register van patentschuldige kramers 1831-1850/51.

67 Idem.

68 Zie voor de patentregisters als bron in Utrecht: 't Hart, De stad Utrecht en haar inwoners, 33 .

69 't Hart, De stad Utrecht en haar inwoners, 115.

70 Het register van 1829 telde slechts vijf Westerwalders. In 1839 werden er reeds dertig Westerwalders ingeschreven in het volkstellingsregister van wijk $\mathrm{K}$.

71 Geboorteakte 956 28-7-1842, adres K 66, patentregister $1831 \mathrm{~K} \mathrm{64}$, patentregister $1844 \mathrm{~K} 67$. Het is niet onwaarschijnlijk dat het hier steeds om hetzelfde adres gaat. Hernummering en verkeerde registratie kwamen veelvuldig voor.

$72 \mathrm{HUA}$, stadsarchief iv $26^{*} 2$, register van vreemdelingen die meer dan zes jaar in Utrecht hebben gewoond en derhalve op grond van artikel 8 van het Burgerlijk Wetboek het recht hebben zich blijvend in Nederland te vestigen met verklaringen van de directeur van politie te Utrecht 1849-1856.

73 Pöckling maakt ook melding van de aanvragen van gelijkstelling door Westerwalders. Het precieze aantal is bij hem niet helemaal duidelijk. In ieder geval vroegen dertien leden van de eerste generatie van de zogenaamde 'Roetersgroep' de gelijkstelling aan. Daarnaast waren er andere verzoeken. Het totaal is niet vermeld. Pöckling, Vestiging, groepsvorming en integratie van de Westerwalders in Amsterdam.

74 De aanwezigheid van Westerwalders in Amsterdam en Delft werd met behulp van bevolkingsregister, patentregister en vreemdelingenregister systematisch onderzocht. Schrover, 'Groepsvorming', 94-112. Dezelfde bronnen werden gebruikt voor een minder systematisch onderzoek in Maastricht, Den Bosch en Zwolle. Een onderzoek langs dezelfde lijn in Haarlem leverde geen resultaat op. De aanwezigheid van Westerwalders in Gouda is beschreven in Tanja Balkema, Migratie naar Gouda 1850-1914 (ongepubliceerde doctoraalscriptie geschiedenis Universiteit Utrecht 2001). In Duitse bronnen zijn er aanwijzingen voor Westerwalders in Gorinchem, Dordrecht, Purmerend, Alkmaar, Culemborg, Hoorn, Den Bosch, Boekel, Maaseik, Arnhem en Lith.

75 G.J. van Rijnsoever. Sint Maarten in de Tolsteeg. Geschiedenis van de Sint Martinusparochie te Utrecht (Utrecht 1947) 127-128.

76 Van Rijnsoever Sint Maarten in de Tolsteeg.

77 't Hart, Utrecht en de cholera 1832-1910, 304.

78 H. Snellen, Voordracht over Utrecht's achterbuurten, gehouden op de Alg. Vergadering van de Ned. Vereeniging tot Verbetering der Volksgezondheid, 25 februari 1868. Geciteerd in: L.F. Jens, Criminaliteit te Utrecht in verband met familie en wijk (Utrecht zj) 21.

79 F.E. Vos, Onderzoekingen over de choleraepidemie van 1866 gemeente Utrecht (Alphen aan de Rijn 1867) 84-85.

80 Van Rijnsoever, Sint Maarten in de Tolsteeg, 128. 
81 HUA, SA iv 816 stukken betreffende het beheer van de buurtlasten in de omgeving van de Westerkade 1842-1850 in toegang $704 \mathrm{i}-\mathrm{j}$.

82 In het archief van het kadaster van Utrecht, aanwezig op het kadaster, werden alle eigenaars opgezocht van de panden in deze buurt. Vanwege de veelvuldige splitsing van percelen was dit een zeer arbeidsintensief onderzoek, waarbij mijn vader Frans Schrover, die vijftig jaar bij het kadaster werkte, mij behulpzaam was. Waarvoor mijn dank.

83 Plenge, 112.

84 Fohr, Aus der Geschichte Ransbachs, 46.

85 Gemeentearchief Rotterdam (GAR), Vreemdelingenregister 3376 28-11-1876 tot 7-10-1882 nr. 1339, 5-4-1879.

86 GAR, Vreemdelingen register 3376 28-111876 tot 7-10-1882 nr. 2026, 14-4-188o.

87 De grondleggers van het hedendaagse Utrechtse servieshuis Mobach waren van Duitse oorsprong, maar het waren geen Westerwalders. Ze woonden ook enige tijd in wijk $\mathrm{K}$, maar vestigden zich daar pas in de jaren negentig vanuit Bolsward. Vandaar loopt de lijn terug naar Duitsland, maar niet naar Nassau. De naam Mobach kwam niet voor in het namenbestand van dit onderzoek. Als geloof vermeldt het bevolkingsregister gereformeerd. Overigens stelt Rosa Werf, 'Mobach Pottenbakkers - seit 1895 in Utrecht', Keramische Zeitschrift, jrg. 33 nr. 3 (1981) 173, dat de familie wel vanuit het Westerwald naar Nederland kwam. Ze geeft echter niet aan wanneer die migratie dan zou hebben plaats gevonden, noch waarheen de familie ging.

88 K. van Vliet, 'De stad van de burgers', in: R.E. de Bruin, P.D. 't Hart, A.J. van den Hoven van Genderen, A. Pietersma (red.), 'Een paradijs vol weelde'. Geschiedenis van de stad Utrecht (Utrecht 2000) 73-113, 97.

89 A.J. van den Hoven van Genderen, 'Op het toppunt van macht', in: R.E. de Bruin, P.D. 't Hart, A.J. van den Hoven van Gen- deren, A. Pietersma (red.), 'Een paradijs vol weelde'. Geschiedenis van de stad Utrecht (Utrecht 2000) 113-191, 138.

90 Kaj van Vliet, 'Middeleeuws Utrecht: een markt in ontwikkeling', in: Jan Brugman, Hans Buiter en Kaj van Vliet, Markten in Utrecht van de vroege middeleeuwen tot $n u$ (Utrecht 1995) 8-43, 31.

91 van den Hoven van Genderen, 'Op het toppunt van macht', 173.

92 J.P. Fockema Andrea, 'De stad Utrecht omstreeks 1823', Jaarboekje Oud-Utrecht 1924, 28-39, 32.

93 Franz Baaden, Chronik der Gemeinde Mogendorf 1385-1985 (Mogendorf 1985) 158-166.

94 Franz Baaden, 'Die Töpferregion Westerwald. Ein geschichtlicher Überblick über das Kannenbäckerland und seine Ausstrahlungen', in: Dieter Rolfes (red.), Keramikmuseum Westerwald. Deutsche Sammlung für historische und zeitgenössische Keramik (Höhr-Grenzhausen zj) niet gepagineerd.

95 Zie ook: Adri van der Meulen en Paul Smeele, De IJsel, Doesburg 1841-1969. Portret van een Gelderse pottenbakkerij (Doesburg 1999) 12, 56.

96 V.C. Sleebe, In termen van fatsoen. Sociale controle in het Groningse kleigebied 17701914 (Groningen 1994) 394.

97 Zie bijvoorbeeld Algemeen Politieblad Maart 1853 Rotterdam 120; Algemeen Politieblad Juli 1852 Brielle 492; Algemeen Politieblad Juni 1853 Neede 263; Algemeen Politieblad Oktober 1852 Haarlem 637; Algemeen Politieblad Juni 1853 Kampen 430; Algemeen Politieblad 1852 Venlo 233; Algemeen Politieblad Juni 1853 Breda 344. Zie voor gebruik van het Algemeen Politieblad in historisch onderzoek: Corrie van Eijl, 'Registratie van vreemdelingen in het Algemeen Politieblad (1852-1947)', in: Marlou Schrover (red.), Bronnen betreffende de registratie van vreemdelingen in Nederland in de negentiende en twintigste 
eeuw. Broncommentaar 5 (Den Haag 2002) 71-91.

98 Algemeen Politieblad 1852 Venlo 233.

99 Algemeen Politieblad 1852489.

100 Algemeen Politieblad 1853, bekendmaking.

101 Gemeentearchief Amsterdam (GAA), archief gemeentepolitie 5225, 871-975 register reis- en verblijfpassen.

102 Algemeen Politieblad 1853 Den Bosch. 103 Algemeen Politieblad 1855 Bolsward. 104 Algemeen Politieblad 1852 Haarlem. 105 Algemeen Politieblad 1852 Delfshaven. 106 Algemeen Politieblad Juni 1853 Kampen 430.

107 Algemeen Politieblad Juni 1853 Breda 344. 108 Algemeen Politieblad, jaren vijftig en zestig. Zie ook: Leo Lucassen, En men noemde hen zigeuners... De geschiedenis van Kaldarasch, Ursari, Lowara en Sinti in Nederland (1750-1944) (Amsterdam 1990) 361.

109 Wie precies deze handelaren waren is niet duidelijk. Het krijt moet, gezien het regelmatig voorkomen van deze handelaren, een product zijn geweest met een redelijk grote afzetmarkt. Onwaarschijnlijk is daarom dat het bijvoorbeeld om tekenkrijt ging. Het kan zijn dat met rood krijt de fijne vettige zandaarde werd bedoeld die ook wel Brusselse aarde of Brussels zand werd genoemd, welke rood van kleur was en als schuurmiddel werd gebruikt. Mogelijk waren dit toch ook Westerwalders of nakomelingen daarvan. Toen de vraag naar steengoed verslapte, gingen de Westerwalder handelaren een poetsmiddel verkopen dat wonderkrijt of Weens krijt heette en dat als schuurmiddel diende. Wellicht was dit hetzelfde als het rode krijt. Algemeen Politieblad; Lucassen, En men noemde hen zigeuners, 361.

110 Algemeen Politieblad 1852.

111 Geboorteregister Pfarrerei Ransbach 1816 in bezit van Franz Baaden, Ransbach.

112 Overlijdensregister Ransbach in bezit Franz Baaden, Ransbach.
113 GAR, Oudstadsarchief, 4243-4245 index op de kohieren van het Patentrecht 180-1808.

114 Gemeentearchief (GA) Delft, stadsarchief 2e afd., 92 Patentregister 1809-1811.

115 Balkema, Migratie naar Gouda 1850-1914, 44.

116 In Amsterdam kon geen gebruik worden gemaakt van patentregisters. Uitgangspunt voor het Amsterdamse onderzoek, dat diende als aanvulling en controle op het Utrechtse, waren de gegevens van een onderzoek dat Gerard de Punder in 1986 heeft gedaan naar de Westerwalders in Amsterdam in de tweede helft van de negentiende eeuw. Gerard de Punder was zo vriendelijk om mij het basismateriaal van zijn onderzoek ter beschikking te stellen. Waarvoor mijn hartelijke dank. Zie ook: Pöckling, Vestiging, groepsvorming en integratie van de Westerwalders in Amsterdam.

117 GAA, Register van reis- en verblijfpassen 1849-1922, 5225/871-975. Het materiaal van De Punder werd door mij ingevoerd in de datebase en aangevuld met gegevens uit bevolkingsregister. Pöckling geeft in zijn onderzoek iets andere cijfers voor de verschillende jaren, omdat hij uitgaat van een andere definitie van de groep.

118 Het onderzoek van Pöckling geeft op dit punt geen uitsluitsel.

119 Pöckling, 33.

120 Van Maurik, Toen ik nog jong was, 31. 121 Naar de herbergier werd het in de spoorweggeschiedenis befaamde Laantje van Van der Gaag genoemd. D. Wijbenga, 'Zorg voor armen en wezen', in: I.V.T. Spaander en R.A. de Leeuw (red.), De stad Delft, cultuur en maatschappij van 1667 tot 1813 (Delft 1982) 89.

122 GA Delft, kadastrale gegevens.

123 De naam Geelhart wordt, zoals heel veel andere Duitse namen, niet in alle bronnen hetzelfde gespeld. Geelhart wordt bijvoorbeeld ook als Keelhart geschreven. 
124 Mogelijk waren Pieter en Philip familie van elkaar. Op basis van het Delftse materiaal is dat echter niet vast te stellen.

125 GA Delft, Vreemdelingenregister, politiearchief, 980, 1859-1863.

126 Algemeen Politieblad Juni 1853 Neede 263.

127 Pöckling noemt meer handelaren die een overstap maakten naar het gevestigde winkelbedrijf. Het gaat daarbij ook om activiteiten in een andere sector, zoals de parapluhandel.

128 M.B. Chotkowski, 750 jaar migratie naar Delft. Onderzoek en bronnenoverzicht (Leiden 1996) 67-68.

129 Chotkowski 63-67. Het register van reisen verblijfpassen vermeldde dertien Westerwalders. In totaal werden er tussen 1859 en 1913152 passen uitgereikt. Het merendeel werd uitgereikt tussen 1859 en 1866.

130 Klaas Padberg Evenboer, 'Padberg (I) (kwartierstaat)', Nederlandse Genealogieën Deel 9 Koninklijk Nederlandsch Genootschap voor Geslacht- en wapenkunde (Den Haag 1989) 55-63.

131 We weten meer over deze groep handelaren door het werk van de Duitse historicus Peter Höher. Peter Höher, Heimat und Fremde. Wanderhändler der oberen Sauerlandes (Münster 1985).

132 Höher, Heimat und Fremde, 49, 84 en 99. 133 A. Bruns, Gericht und Kirchspiel Oberkirchen. Beiträge zur Geschichte der Stadt Schmallenberg (Schmallenberg 1981) 445 en 447.

134 Höher, 150-151.

135 Geciteerd in Bruns, 382.

136 Geciteerd in Bruns, 382-383.

137 HUA, stadsarchief 4 inv nr. 5/250/9, patentregister patentplichtige kramers 1859/60.

138 Idem. Frans Padberg k 16 vreemd kramer ventende in gemeenten van de $6 \mathrm{e}$ rang en op de markt alhier hout en ijzerwaren mandjes galanterien zeemleder enz. f 48 mars klio en 11 tarief $B$ gecontroleerd klasse 9 en 12 B.
139 Idem. Hendrik Hoffman k 16 vreemd kramer ventende in gemeenten van de 1e tot de 6 rang, en op de markt alhier hout en ijzerwaren, mandjes, galanterien zeemleder enz f 25 mars klasse 10 en 11 tarief B; patentregister patentplichtige kramers 1859/6o. Evert Hoffman k 16 vreemd kramer, ventende in gemeenten 4 tot $6 \mathrm{e}$ rang, en op de markt alhier, hout- en ijzerwaren mandjes, galanterien, zeemleder, enz f 25 mars klasse 10 en 13 tarief B.

140 Utrechtsch Provinciaal en Stedelijk Dagblad 1884.

141 Adresboek 1880-1881 Firma gebr Padberg, Oudegr Vollerbr B 195.

142 Adresboek 1903-1904 A. Padberg Grossier in huishoudelijke artikelen Oudegr. 7 (Volderbr) $206 \mathrm{~T} 380$ [het laatste cijfer is een telefoonnummer]

143 M. Schrover, 'Omlopers in Keulse potten en pottentrienen uit het Westerwald', 101120; Chin, Yoon en Smith, 485-510.

144 Portes, 'The informal economy and its paradoxes', 437.

145 I. Light en S. Karageorgis, 'The ethnic economy', in: Smelser en Swedberg (reds.), The handbook of economic sociology, 647-670, 663.

\section{WiNKELIERS EN HUN PERSONEEL}

1 De Avondbode, algemeen nieuwsblad voor staatkunde, handel, nijverheid, landbouw, kunsten en wetenschappen, woensdag 8 mei 1839.

2 De Avondbode, woensdag 8 mei 1839.

3 Geciteerd in: z.n., 'Winkelen in Utrecht omstreeks 1900', Maandblad Oud Utrecht (1963) 70-81.

4 E. Elias, Drie-kwart honderd jaren met eer, met naald, met garen. Een boekje, uitgegeven door de $n v$ Herenkledingfabriek $v / h$ gebrs. Levie te Groningen, ter gelegenheid van haar vijf-en-zeventig jarig bestaan (Groningen 1955) 12; Schmitz, 'Discriminatie of integratie van Duitsers in het 
negentiende-eeuwse Rotterdam?, 124-145, 129.

5 Adresboek Utrecht 1879.

6 Een lid van de familie Brenninkmeijer was overigens wel reeds voor 1900 in Utrecht actief. In 1898 kwam Julius Brenninkmeijer naar Utrecht, een in 1858 in Mettingen geboren neef van Clemens en August Brenninkmeijer, de stichters van het C\&A-concern. Hij was op allerlei manieren met de andere winkeliers verzwagerd. Zo was hij getrouwd met Emma Schröder, terwijl zijn schoonmoeder als eigennaam Lampe had. Julius Brenninkmeijer dreef zijn zaak aan de Oudegracht onder de naam Schröder \& Brenninkmeijer. Deze onderneming sloot zich in het begin van de twintigste eeuw aan bij het Lampe-concern. Bevolkingsregister 1900-1912, fiche 284, wijk 2, Oude Gracht (Weerdzijde) 28, vel 2875. Miellet, 215; zie ook Roger Miellet en Marieke Voorn, Winkelen in weelde. Warenhuizen in WestEuropa 1860-2000 (Zutphen 2001).

7 Robert W. Fairlie en Bruce D. Meyer, 'Ethnic and racial self-employment differences and possible explanations', The Journal of Human Resources (1996) 31-4, 757-793.

8 N.A. Hamers heeft een genealogie samengesteld van de families die verbonden waren met Vroom \& Dreesmann. N.A. Hamers, Samenvatting van de genealogieën der geslachten verbonden met het concern Vroom \& Dreesmann (Nijmegen 1967).

9 Oberpenning, Migration und Fernhandel, 116,300 .

10 Door het zeer gedegen werk van de Duitse historica Oberpenning, weten we meer over deze groep. Uit het onderzoek van Oberpenning is gebleken dat trekarbeiders en trekhandelaren twee gescheiden groepen vormden. Oberpenning, Migration und Fernhandel. Wolff-Gerzon legt, bij de beschrijving van het begin van de manufacturenhandel, de oorsprong van deze sector bij de rondreizende trekarbeider, die behalve zijn arbeidskracht ook een stuk linnen of textiel meebracht. WolffGerzon, 'Au Bonheur des Dames', 31. De bedrijven van deze groep migranten worden in uiteenlopende studies veelvuldig min of meer terloops genoemd. In 1986 schreef Roger Miellet dat er aan de geschiedenis van deze groep tot dat moment weinig systematische aandacht was besteed. R. Miellet, 'Westfaalse ondernemers en de opkomst van het Nederlandse grootwinkelbedrijf tot circa 1920', Jaarboek van de Geschiedenis van Bedrijf en Techniek 3 (1986) 135-157, 150. Miellets boek uit 1992 heeft hierin sindsdien verbetering gebracht. Roger Miellet, Honderd jaar grootwinkelbedrijf in Nederland (Zwolle 1992). De nadruk van Miellets werk ligt echter op de periode na 1900.

11 Hamers, Samenvatting, 9. Oberpenning, Migration und Fernhandel, 112.

13 Oberpenning, 116.

14 Wilfried Pott, Westfaalse handelaren vestigen zich in Nederland. De families Sinkel, Moormann en Ten Brink op buitenplaatsen in Hilversum (Hilversum 2000) 15. Oberpenning, 128, 139, 141-144, 149, 293. 16 Mogelijk waren er naast de recente migranten ook anderen, die bijvoorbeeld in Friesland werden geboren als kinderen of kleinkinderen van de eerdere generatie nieuwkomers. Wellicht werkten zij ook als personeel in bijvoorbeeld de Winkel van Sinkel, en maakten bijgevolg als tweede of derde generatie migranten deel uit van dezelfde groep als hun collega's die rechtstreeks uit het afstotingsgebied kwamen. In het kader van dit onderzoek is echter niet de afkomst van het Nederlandse winkelpersoneel nagetrokken, zodat deze veronderstelling niet kan worden onderbouwd.

17 In 1850 trouwde Catharine Veerkamp met Hendrikus van Hulst (Maarssen 1823). In 1854 overleed Van Hulst op 31-jarige leef- 
tijd. Bevolkingsregister 1850-1859, fiche 234, wijk G, Neude 77, vel 97.

18 Victor Veerkamp werd geboren in Hopsten in 1820, John Veerkamp werd in 1846 in Hopsten geboren. Bevolkingsregister 1850-1859, fiche 234, wijk G, Neude 77, vel 97.

19 Mathias Veerkamp werd in 1825 in Hopsten geboren, Hendrika Holterman werd geboren in Culemborg in 1823. Bevolkingsregister 1850-1859, fiche 155, wijk D, Oudegracht 41, vel 51. De vader van Mathias Veerkamp was lakenkoopman in Amsterdam. Bevolkingsregister Amsterdam 1849, 1-209 en 1234-1253/229, wijk H 1, Nieuwendijk 26/37, vel 59.

20 Ferdinand Veerkamp werd in 1819 geboren in Hopsten.

21 Utrechtsch Provinciaal en Stedelijk Dagblad 25-5-1878.

22 Miellet, Honderd jaar grootwinkelbedrijf, 16.

23 Zie ook: A.C.R. Dreesmann, Evolutie en expansie. Een onderzoek naar de samenhang van vorm, functie en prijspolitiek in de detailhandel, inzonderheid bij het grootbedrijf (Leiden 1963) 399.

24 Dreesmann, Evolutie en expansie, 400.

25 Furnée, "Om te winkelen, zoo als dat in de residentie heet", 28-55.

26 Zie ook: F. van der Goes, Grootkapitaal en kleinhandel. Bijdrage tot kennis van de middenstandspolitiek (Amsterdam 1902) 48-49.

27 H.Ph. Hondelink, 'Vroom en Dreesmann, de oprichters en hun onderneming 1887 1912', Jaarboek van de geschiedenis voor Bedrijf en Techniek (1992) 159-184, 168.

28 Hondelink, 'Vroom en Dreesmann', 169.

29 Dreesmann, 629.

30 Jeanne de Bruijn, Haar werk. Vrouwenarbeid en arbeidssociologie in historisch en emancipatorisch perspectief (Amsterdam 1989) 97.

31 Wolf-Gerzon, 65.

32 Wolf-Gerzon, 65.

33 De Bruijn, Haar werk, 97.
34 Miellet en Vroon, Winkelen in weelde, 233.

35 Utrechtsch Dagblad 4-8-1936.

36 Miellet, 38.

37 De dochter van Agnes uit haar eerste huwelijk, Elisa, trouwde met fabrikantkoopman James Barge uit Manchester. Kinderen uit dit huwelijk trouwden met leden van de familie Dreesmann.

38 R.E. van der Woude, Leeuwarden 18501914. De modernisering van een provinciehoofdstad (Groningen 1994) 136.

39 Pott, Westfaalse handelaren, 31.

40 H.J. Broers, Utrecht. Historische wandelingen (Utrecht 1908) 48.

41 Utrechtsche Courant 10 mei 1839.

42 Agnes Moormann had wel kinderen uit haar eerste huwelijk, maar Sinkel stond met hen niet op vriendelijke voet. Pott, 19.

43 Miellet, 40.

44 Bevolkingsregister Amsterdam 1849, 1-209 en 1234-1253/229, wijk H 1, Water 41/136, vel 30 .

45 Miellet, 'Westfaalse ondernemers en de opkomst van het Nederlandse grootwinkelbedrijf tot circa 1920', 135-157, 141.

46 A. Wolff-Gerzon, "Au Bonheur des Dames". Uit het Nederlandse kledingbedrijf van de laatste honderd jaar (Amsterdam 1949) 22. De Amerikaanse, Engelse en Duitse warenhuizen waren van nog later datum. Zie Dreesmann, 400.

47 Wolff-Gerzon, 29.

48 Miellet, Honderd jaar grootwinkelbedrijf, 41.

49 Bevolkingsregister 1850-1859, fiche 231, wijk G, Oudegracht 11/15, vel 19.

50 Bevolkingsregister 1860-1879, fiche 397, wijk G, Oudegracht 11/15, vel 17.

51 Bevolkingsregiser 1860-1879, fiche 397, wijk G, Oudegracht 11/15, vel 16.

52 Hamers, 51.

53 Bevolkingsregister 1850-1859, fiche 156, wijk D, Oudegracht 62, vel 77. Everard E. Gewin, 'Vóor een eeuw', Jaarboekje OudUtrecht (1926) 168-176, 173. 
54 Hammer-Stroeve vermeldt in haar boek ook een Maselandwinkel in Enschede. In advertenties van de Utrechtse vestiging werd echter niet aan een winkel in Enschede gerefereerd. Mogelijk was de Enschedese zaak van latere datum. Uit het boek van Hammer-Stroeve blijkt dat Maseland zowel confectie als mode op maat maakte en dat laatste voor de betere stand. Tina Hammer-Stroeve, Familiezoet. Vrouwen in een ondernemerselite, Enschede 1800-1940 (Zutphen 2001) 114.

55 HUA, toegang 182 Arrondissementsrechtbank inventarisnummer, 656 akte 547 138-1878.

56 Bevolkingsregister 1860-1879, fiche 302, wijk $\mathrm{D}$, straatnaam niet ingevuld (Oudegracht) 61/62, vel 519 .

57 Bevolkingsregister 1860-1879, fiche 287, wijk D, Oudegracht 62, vel 90.

58 H. van Woerden, De familie Schlatmann. Geschiedenis van een Tjoddengeslacht (Oegstgeest 1953) 32.

59 Hamers, Samenvatting, 105.

60 Van Woerden, De familie Schlatmann, 32.

61 Bevolkingsregister 1850-1859, fiche 235, wijk G, Neude 106, vel 136; Bevolkingsregister 1860-1879, fiche 286, wijk D, Oudegracht 54/55, vel 74 .

62 Bevolkingsregister 1860-1879, fiche 286, wijk D, Oudegracht 54, vel 76; Bevolkingsregister 1900-1912, fiche 285, wijk 2, Oudegracht Weerdzijde 32, vel 2882.

63 Utrechtsch Provinciaal en Stedelijk Dagblad 2-12-1884.

64 G.H. van der Sandt werd in 1878 aangeslagen voor 182 gulden grondbelasting, 473 personele belasting en 464 patentrecht. Utrechtsch Provinciaal en Stedelijk Dagblad 26-4-1878. Zie ook: T.H.G. Verhoeven, 'Stedelijk leven in een stroomversnelling (1851-1917)', in: R.E. de Bruin, P.D. 't Hart, A.J. van den Hoven van Genderen, A. Pietersma (red.), 'Een paradijs vol weelde'. Geschiedenis van de stad Utrecht (Utrecht 2000) $375-433,385$.
65 Gesina Krans was getrouwd met Jan Houtsager, maar verliet hem en ging met Moormann naar Londen. In Londen kreeg dit paar drie kinderen, voordat de scheiding van Houtsager en het huwelijk met Moormann waren geregeld. Pott, 4041.

66 Bevolkingsregister 1900-1912, fiche 284, wijk 2, Oudegracht Weerdzijde 32, vel 2879.

67 Gemeentearchief Den Haag (GADH), Archief Peek en Cloppenburg, nr. 1. Oprichtingsakte 22-12-1869.

68 F.M. Stavast, Peek en Cloppenburg 18691961. Inventaris van de archieven van Peek en Cloppenburg en Maatschappij "De Dam" tot exploitatie van onroerende goederen NV en van de stukkken afkomstig van de familie Peek en H.A.A. Cloppenburg, VII Inleiding.

69 HUA, toegang 182, Arrondissementsrechtbank, 659 24-10-1899.

70 Miellet, Honderd jaar grootwinkelbedrijf, 144 .

71 Miellet, 151.

72 GADH, Archief Peek en Cloppenburg, nr. 19. Grootboek van het filiaal Utrecht 18841886.

73 Bevolkingsregister 1860-1879, fiche 398, wijk G, Oude Gracht, 29, vel 40.

74 Miellet, 144.

75 Utrechtsch Provinciaal en Stedelijk Dagblad 26-4-1878.

76 Bevolkingsregister 1880-1889, fiche 196, wijk D, Steenweg (Heiligeweg) 320/85 en 85 bis, vel 495 .

77 In 1926 werd er een confectiefabriek geopend in Rotterdam, waar 600 vrouwen werkten Miellet, 145.

78 Bevolkingsregister 1880-1889, fiche 196, wijk D, Steenweg (Heiligeweg) 320/85 en 85 bis, vel 495 . Zie ook hoofdstuk 5.

79 Wilhelm Hunkemöller werd geboren in Warendorf. Bevolkingsregister 1860-1879, fiche 370, wijk F, Oude Kerkhof 57, vel 110. 
80 Bevolkingsregister 1880-1889, fiche 182, wijk D, Oudegracht Weerdzijde 54/56, 32 en 34 .

81 Bevolkingsregister 1890-1899, fiche 118, wijk G, Oudegracht Weerdzijde 33, vel 3498.

82 Bevolkingsregister 1880-1889, fiche 196, wijk D, Steenweg (Heiligeweg) 320/85 en 85bid, vel 495 .

83 Miellet, 146.

84 Het Kreymborgconcern werd pas in 1904 opgericht in Maastricht. Voor die tijd waren er echter reeds afzonderlijke Kreymborgwinkels. In 1891 werd een Kreymborgzaak geopend in Den Bosch door Gerhard Kreymborg. Gerhard Kreymborg opende een tweede zaak in Middelburg in 1894, gevolgd door winkels in Venlo in 1900 en Eindhoven in 1908. Toen hij in 1911 overleed, werd zijn zaak bij het concern van zijn broer Anton gevoegd. F.L. Jansen, Kledinghandel in transitie. Een eeuw detailverkoop te 's-Hertogenbosch. Oorsprong en ontwikkeling van het familiebedrijf 'A.F. Jansen' 1889-1987 (Tilburg 1991) 109. De Kreymborgvestiging in Utrecht werd pas na de Eerste Wereldoorlog geopend.

85 Er waren nog meer Duitse zaken op de Oudegracht. August Heck had zijn onderneming op de hoek van de Oudegracht en de Drieharingensteeg. Heck was katholiek en geboren in Meppen in 1845. Hij werkte aanvankelijk als reiziger voor Van der Sandt \& co. Bevolkingsregister 1860-1879, Oudegracht, wijk D, 54, fiche 286, vel 76 . Op de Oudegracht zat verder ook de manufactuursfirma Schräder \& Kauling. zie ook HUA, toegang 182, Arrondissementsrechtbank inventarisnummer, 656 akte 268 16-5-1879. Kauling werkte eerst als bediende in de Winkel van Sinkel. Als laatste had Johan Schröder zijn winkel op de Oudegracht. Hij was geboren in Steinfurt in Oldenburg en was katholiek. De zussen Antonetta en Euphemia Buhrs uit Neuenkirchen dreven een winkel op de
Twijnstraat in het verlengde van de Oudegracht. Zij hadden geen inwonend winkelpersoneel. De naam Buhrs is opmerkelijk, omdat Anton Dreesmann aanvankelijk, bij zijn komst naar Nederland, intern was bij de familie Albert Buhrs in Amsterdam. Miellet en Voorn, 225. Jozef Abelmann uit Riesenbeck had met twee broers en een vierde man uit zijn geboortedorp een winkel op de Steenweg. Later had hij met zijn vrouw een manufactuurwinkel op de Potterstraat. Daar had hij wel enkele inwonende winkeljuffrouwen, maar geen van hen was Duits. Op de Choorstraat in wijk E vinden we Hermanus Meijer uit Cloppenburg in Oldenburg. Hij kwam wel uit dezelfde herkomststreek als de andere winkeliers, maar was calvinistisch.

86 Bevolkingsregister 1850-1859, fiche 231, wijk G, Ganzenmarkt 10, vel 18; Bevolkingsregister 1860-1879, fiche 302, wijk D, geen straatnaam ingevuld (Oudegracht) 21-23, vel 517.

$87 \mathrm{Hij}$ werd geboren in Lingen in Hannover in 1857.

88 Bevolkingsregister 1900-1912, fiche 284, wijk 2, Oude Gracht (Weerdzijde) 12 bis, vel 2860 .

89 Miellet, 150. In 1988 nam Blokker de toen als enige overgebleven winkel van firma Hoyng over en verkreeg daarmee het recht op het voeren van de handelsnaam (Miellet, 312). Hoyng bestaat nu nog als onderneming in glas, porselein en aardewerk in verschillende Nederlandse plaatsen, zoals Nieuwegein, Zeist en Maastricht. In Utrecht is er geen vestiging.

90 Bevolkingsregister 1850-1859, fiche 154, wijk D, Over het Stadhuis 25, vel 28.

91 Zie advertenties in het Utrechtsch Provinciaal en Stedelijk Dagblad van 5-2-1884, 48-1851, 7-10-1851.

92 HUA, toegang 182 Arrondissementsrechtbank inventarisnummer, 656 akte 660 171-1882. Heinrich David Hennings was luthers en geboren in Embden. Bevol- 
kingsregister 1850-1859, fiche 154, wijk D, Over het Stadhuis 25, vel 28.

93 Bevolkingsregister 1850-1859, fiche 156, wijk D, Oudegracht 57, vel 71; Bevolkingsregister 1860-1879, fiche 286, wijk D, Oudegracht 57, vel 81.

94 Plagge werd geboren in Borken in Oldenburg. Bevolkingsregister 1850-1859, fiche 156, wijk D, Oudegracht 57, vel 71.

95 Het echtpaar Bohlen kreeg zes kinderen, waarvan er een als kind en drie als jongvolwassenen overleden. Anna Maria Schroder overleed in 1870 (bijna 40 jaar oud). Na de dood van zijn vrouw ging Bohlen op de Maliebaan wonen en werd vermeld als koopman. De winkel bleef op de Oudegracht gevestigd.

96 Bevolkingsregister 1860-1879, fiche 412, wijk G, Oude Gracht 11/15, vel 435.

97 Erika Diane Rappaport, Shopping for pleasure. Women in the making of London's West End (Princeton 2000) 16.

98 Utrechtsche Provinciale en Stadscourant 257-1851 advertentienummer 5293.

99 Utrechtsch Provinciaal en Stedelijk Dagblad 26-4-1878.

100 Miellet, 143.

101 Miellet, 143.

102 Fairlie en Meyer, 'Ethnic and racial selfemployment differences and possible explanations', 757-793.

\section{VIJLENKAPPERS, STUKADOORS, DIENSTBODES, SPOORBEAMBTEN EN STUDENTEN}

1 In de Utrechtsche Courant van woensdag 10 januari 1838, advertentie nr 83 .

2 Uitkomsten der beroepstelling in het koninkrijk der Nederlanden op den een en dertigsten december 1889 (Den Haag 1894).

3 GAR, Vreemdelingenregister 3376 28-111876 tot 7-10-1882 nr. 1642.

4 J.C.A. Everwijn, Beschrijving van handel en nijverheid in Nederland (Den Haag 1912) 102.
5100 jaar Sandford vijlen (Rotterdam 1961).

6 Otto Dick, Die Feile und ihre Entwicklungsgeschichte (Berlijn 1925) 56, 64.

7 Dick, Die Feile und ihre Entwicklungsgeschichte.

8 Dick 23-29, 62.

9 Dick, 65.

10 Dick, 31-32.

11 Dick, 33, 81, 171.

12 Beeton's dictionary of industries and commerce (Londen z.j. (1880)) 142.

13 Dick, 54.

14 Dick, 171-175, 185-190.

15 Dick, 203, 72, 215.

16 Hans Hardenberg, Die Fachsprache der bergischen Eisen- und Stahlwarenindustrie (Bonn 1940) 11.

17 Holger Becker, 'Christian Gottlieb Daniel Steins Bericht über das Bergische Land anläßlich seiner Reise nach den vorzüglichsten Haupstädten von MittelEuropa (1823)', in: Jürgen Reulecke en Burkhard Dietz, Mit Kutsche, Dampfroß, Schwebebahn. Reisen im Bergische Land II (1750-1910) (Neustadt/Aisch 1984) 128.

18 Hardenberg. 11-25. 73.

19 Bevolkingsregister 1850-1859, fiche 352, wijk M, Bemuurde Weerd oz. 92, vel 143.

20 Aan deze groep is voor Amsterdam aandacht besteed door Knotter, Economische transformatie en stedelijke arbeidsmarkt, 46, 101, 111, 317; Ad Knotter, 'Stedelijke economie en arbeidsmarkt. Amsterdam in de eerste helft van de negentiende eeuw', BMGN (1986) 551-580; Lucassen, Naar de kusten van de Noordzee, 98.

21 Johannes Tack, Die Hollandgänger in Hannover und Oldenburg. Ein Beitrag zur Geschichte der Arbeiter-Wanderung (Leipzig 1902) 116.

22 Lucassen, Naar de kusten van de Noordzee, 98.

23 Tack, Die Hollandgänger, 117.

24 Sahner, Katholische und Evangelische Seelsorge, 16. 
25 Leo Lucassen, 'Het einde van een migratieregime: buitenlanders in Holland gedurende de 19e eeuw', Historisch Tijdschrift Holland (2001) 190-211; Pöckling, Vestiging, groepsvorming en integratie van de Westerwalders in Amsterdam in de negentiende eeuw.

26 Pöckling, 7.

27 De toestanden der werklieden in de bouwbedrijven te Amsterdam. Rapport uitgebracht door de commissie van onderzoek benoemd door de gemeenteraad in zijn vergadering van 30 juni 1897 (Amsterdam 1898) 21.

28 Staatscommissie over de werkloosheid (ingesteld bij koninklijk besluit van 30 juli 1909 no 42) II Verslag van de eerste sub-commissie (Den Haag 1913) 16, 34.

29 De toestanden der werklieden in de bouwbedrijven te Amsterdam, 21.

30 Idem, 22.

31 Idem, 13.

32 Idem, 13.

33 HUA, toegang 79 Provinciaal Bestuur Jaarverslag Provinciaal Bestuur 1813-1920, 214, Verslag over 1862, 432.

34 Idem, 215, Verslag over 1862, 461.

35 Idem, 216, Verslag over 1862, 431.

36 Van Lottum, Nieuwkomers in Nederland, 79.

37 Vergelijk Knotter, Economische transformatie en stedelijke arbeidsmarkt, 317.

38 Bericht von Heinrich Otto Rathmann an den Central-Ausschuß für die Innere Mission. Werkgroep Reisepredigt, Jan Lucassen, IISG.

39 Utrechtsche Courant woensdag 28 februari 1838.

40 Bakkenes werd geboren in Nijkerk in 1805. Bevolkingsregister 1850-1859, fiche 221, wijk F, Oud Munster kerkhof 222, vel 349.

41 Gerhard Heidenreich werd geboren in 1821 in Oldenburg. Bevolkingsregister 1880-1889 fiche 252, wijk F, Oude Gracht Tolsteegzijde 168/23, vel 283 .

42 Johan Garms werd in 1829 geboren in Oldenburg. Catharina Bakkenes werd in
1822 in Driebergen geboren. Bevolkingsregister 1860-1879, fiche 294, wijk D, Achter Clarenburg 171, vel 315.

43 Catharina IJperlaan werd geboren in Utrecht in 1827 en Jacoba Hogerhout werd geboren in Montfoort in 1827. Bevolkingsregister 1850-1859, fiche 106, wijk C, Vreeburg 154, vel 190.

44 HUA, toegang 182,656 , akte $258-769$ 17-31886.

45 Christiaan Lüschen werd geboren in Littel in Oldenburg in 1807 en Johan Diederick Lüschen in Littel in Oldenburg in 1829.

46 Johann Heinrich werd in 1823 geboren in Littel. Bevolkingsregister 1850-1859, fiche 126, wijk C, Mijlpoort 451f, vel 767; Bevolkingsregister 1850-1859, fiche 239, wijk G, Hoogt 164, vel 240.

$47 \mathrm{Zij}$ werd in 1815 geboren in Driebergen.

48 Bevolkingsregister 1850-1859, fiche 175, wijk D, Donkerstraat 453, vel 625.

49 Matheus Pau werd in 1816 geboren in Woerden. Bevolkingsregister 1860-1879, fiche 193, wijk C, Varkenmarkt 715, vel 1555 .

50 Johan Hollmann werd geboren in Wardenburg in 1823, Ludwig en Carel werden geboren in 1847 en 1851. Bevolkingsregister 1860-1879, fiche 731, wijk M, Weerdsingel 614I, vel 1273 .

51 Joy K. Lintelman, 'Making service serve themselves: immigrant women and domestic service in North America, 18501920', in: Dirk Hoerder en Jörg Nagler (red.), People in transit, German migrations in comparative perspective. 1820-1930 (Cambridge 1995) 249-265.

52 Silke Wehner-Franco, Deutsche Dienstmädchen in Amerika 1850-1914 (Münster/New York 1994) 110.

53 Utrechtsch Provinciaal en Stedelijk Dagblad 17-3-1871.

54 De krant was gematigd antipapistisch.

55 Mediaan voor de eerste groep 1820, voor de tweede 1845 .

56 Coby van der Wurf-Bodt, Van lichte wiven tot gevallen vrouwen. Prostitutie in Utrecht 
vanaf de late middeleeuwen tot het einde van de negentiende eeuw (Utrecht 1988).

57 Silke Wehner, 'German domestic servants in America, 1850-1914: a new look at German immigrants women's experiences', in: Dirk Hoerder en Jörg Nagler (red), People in transit, German migrations in comparative perspective. 1820-1930 (Cambridge 1995) 267-293.

58 Klaus Tenfelde, 'Dienstmädchengeschichten. Strukturelle Aspekte im 19. und 20. Jahrhundert', Zeitschrift für Unternehmensgeschichte Beiheft 35; Hans Pohl en Wilhelm Treue, Die Frau in der deutschen Wirtschaft (Wiesbaden 1985) 105-119.

59 Rommes, Oost, west, Utrecht best?

60 Jan Brugman, Hans Buiter en Kaj van Vliet, Markten in Utrecht van de vroege middeleeuwen tot nu (Utrecht 1995) 75.

61 P.J. Andriessen, Iets anders. Bevattende een beschrijving van de provincien Zuid-Holland en Utrecht (Deventer 1871) 158.

62 Zie ook: Anke de Jong, Honderd jaar 'besteden' in Utrecht. Een onderzoek naar hen, die in de periode 1830-1930 bemiddelden op de dienstboden-arbeidsmarkt (Kandidaatsscriptie Sociale en economische geschiedenis Rijksuniversiteit Utrecht 1983. Aanwezig op het Utrechts Archief).

$63 \mathrm{Zij}$ werd geboren in 1802. Bevolkingsregister 1850-1859, fiche 246, wijk G, st. Jansdam 319, vel 426.

64 Bevolkingsregister 1850-1859, wijk A, Oude Gracht 68, vel 76 .

65 Utrechtsch Provinciaal en Stedelijk Dagblad 8-5-1878.

66 De Jong, Honderd jaar 'besteden' in Utrecht, 40.

67 Bernard Gewin, Arbeidsbeurzen (Utrecht 1898) 281-283.

68 Bevolkingsregister 1850-1859, fiche 39, wijk A, Nieuwegracht 926, vel 1132.

69 Utrechtsch Provinciaal en Stedelijk Dagblad 5-2-1884.

70 P.W.N.W. Dehing, '... Eene soort van dynastie van spoorwegbeambten'. Arbeids- markt en spoorwegen in Nederland, 18751914 (Hilversum 1989) 46.

71 Dehing, '... Eene soort van dynastie van spoorwegbeambten', 43.

72 Willem van den Broeke, Financiën en financiers van de Nederlandse spoorwegen 1837-1890 (Zwolle 1985) 64.

73 A.J. Veenendaal, De ijzeren weg in een land vol water. Beknopte geschiedenis van de spoorwegen in Nederland 1834-1958 (Amsterdam 1998) 50.

74 Algemeene bepalingen voor het personeel in dienst bij de Maatschappij tot Exploitatie van Staatsspoorwegen. Allgemeine Bestimmungen für die Angestellten der Gesellschaft für den Betrieb von StaatsEisenbahnen (zp 1865). Met dank aan A.J. Veenendaal die mij op dit reglement attendeerde en zijn exemplaar aan mij uitleende.

75 HUA, stadsarchief 4, stadsarchief, $26^{*} 2$, register van vreemdelingen die meer dan zes jaar in Utrecht hebben gewoond en derhalve op grond van artikel 8 van het Burgerlijk Wetboek het recht hebben zich blijvend in Nederland te vestigen met verklaringen van de directeur van politie te Utrecht 1849-1856; Bevolkingsregister 1850-1859, fiche 231, wijk G, Oudegracht 21, vel 27.

76 Bevolkingsregister 1850-1859, fiche 165 , wijk D, Elisabethstraat 247, vel 342; Overlijdensakte 6-1-1850, nr. 247.

77 Koos Wingelaar, Studeren in de negentiende eeuw. Een onderzoek naar het hoger onderwijs en met name naar de studenten aan de Utrechtse universiteit in de periode 1815-1877, Utrechtse Historische Cahiers jaargang 10 (1989) nr. 1/2, 64.

78 Daniel Bernhards werd geboren in Frankenthal in 1676 en overleed in Utrecht in 1761. Reispredigt. Met dank aan Jan Lucassen, die mij inzage verleende in het manuscript van deze uitgave.

79 Bericht von Werner Droß an den CentralAusschuß für die Innere Mission 1880. 
Werkgroep Reisepredigt, Jan Lucassen, IISG.

80 Utrechtsche studentenalmanak 1862 (Utrecht 1861); Utrechtsche studentenalmanak 1864 (Utrecht 1863).

81 Bevolkingsregister 1900-1910, bl. 2166, deel 8 1974-2288, wijk vi, Looierstraat 9 bis.

82 Zie het werk van Snell, Rommes, Panayi.

83 Ontwerp van wet tot regeling der benoembaarheid van vreemdelingen tot landsbediening. Handelingen Tweede Kamer 1856-1857, bijlagen 1171-1173.

84 G. J. Hooykaas en F.J.P. Santegoeds (red.), De briefwisseling van J.R. Thorbecke (Den Haag 1996) Brief van Thorbecke aan de Minister van Buitenlandse Zaken 4-7-1852, 394-395.

85 De Coninck, Een les uit Pruisen, 151.

86 G.W. Kernkamp, 'De Utrechtsche hoogeschool van 1815 tot 1877 ', in: J.P. Fockema Andreae e.a. (red.), De Utrechtsche Universiteit 1815-1936 (Utrecht 1936); J.P. Fockema Andreae, 'het beheer der universiteit sinds 1877 ', in: idem.

87 Vergelijking met de Utrechtsche studentenalmanakken over deze periode leert dat dit ook werkelijk alle Duitse hoogleraren waren. In de almanakken worden adressen vermeld van studenten en medewerkers. Hieruit blijkt dat er geen hoogleraren net buiten de stadsgrens woonden.

88 Hij werd geboren in Emmerich in 1812. Bevolkingsregister 1850-1859, fiche 220, wijk F, Wed 216, vel 345; Utrechtsch Provinciaal en Stedelijk Dagblad 12-1-1878.

89 Utrechtsche provinciale en stads almanak voor het jaar 1861 (Utrecht 1861) 88.

90 Utrechtsche provinciale en stads almanak voor het jaar 1861 (Utrecht 1861) 171, 202.

91 Bevolkingsregister 1850-1859, fiche 34, wijk A, Nieuwegracht 802, vel 987 .

92 Bevolkingsregister 1860-1879, fiche 466, wijk H, Bagijne kade 324, vel 959.

93 J. Lorié, Levensschets van Dr. C.E.A. Wichmann, aangeboden ter gelegenheid van zijn veertigjarig jubileum als hoogleraar te Utrecht (Amsterdam 1919); Carl Wich- mann was de vader van juriste en publiciste Clara Wichmann, die in 1885 tijdens een vakantie in het huis van haar grootouders te Hamburg werd geboren en die in 1922 in Utrecht overleed. Hij was ook de vader van schrijver, beeldend kunstenaar en activist Erich Wichman (die zijn naam met één ' $n$ ' spelde), die in 1890 in Utrecht werd geboren. Erich Wichman ging in Duitsland op kostschool. In 1927 richtte hij de fascistenbeweging 'De Bezem' op. Hij overleed in 1929. F. Vogelzang, 'Clara Wichmann (1885-1922) Maatschappijhervormster', in: J. Aalbers e.a. (red.), Utrechtse biografieën. Levensbeschrijvingen van bekende en onbekende Utrechters 3 (Amsterdam/Utrecht 1996) 202-209; M. Stafleu, 'Erich Wichman (1890-1929) Kunstenaar, activist en bohémien', in: J. Aalbers e.a. (red.), Utrechtse biografieën. Levensbeschrijvingen van bekende en onbekende Utrechters 1 (Amsterdam/Utrecht 1994) 197-201.

94 Vogelzang, 'Clara Wichmann (1885-1922)

Maatschappijhervormster', 202-209.

95 Bevolkingsregister 1860-1879, fiche 417, wijk G, Kromme Nieuwe Gracht 357, vel 588.

96 Willem Veltheer, Heelkunde te Utrecht. Op het breukvlak van twee eeuwen (Utrecht 1989) 46. Veltheer citeert uit een brief van Engelmann aan Albert von Bezold in particulier bezit.

97 F.L. Meijler, 'Introduction', in: Th.W. Engelmann, professor of physiology, Utrecht (1889-1897). Some papers and his bibliography with an introduction by Dr. Frits $L$. Meijler and a forword (in Dutch) by Dr. Dirk Durrer (Amsterdam 1984) ix-Xv. 98 Veltheer, Heelkunde te Utrecht, 59.

99 Friedrich Adelbert Salzer werd in 1858 in Wenen geboren. 100 Veltheer, Heelkunde te Utrecht, 46. 101 Veltheer, Heelkunde te Utrecht, 61. 102 Veltheer, Heelkunde te Utrecht, 62. Veltheer citeert uit het studentenblad Minerva, 'Benoeming', 1890. 
103 Zie op dit punt ook: Bovenkerk, Eijken en Bovenkerk-Teerink, Italiaans ijs, 180.

\section{Een multiculturele SAMENLEVING}

1 Bevolkingsregister 1850-1859, wijk I, fiche 302, wijk I, fiche 166 ii; Bevolkingsregister 1860-1879, wijk I, fiche 142.

2 HUA, stadsarchief V, 246 Registers der patenten over de twaalf wijken der stad 1851-1864 en 1875-1894, Patentregister 1859/60.

3 Utrechtsche Provinciale en Stadscourant 147-1851.

4 Utrechtsche Provinciale en Stadscourant 28 november 1851.

5 Utrechtsche Provinciale en Stadscourant 311-1851, 6170.

6 Fontaine, Laurence, History of pedlars in Europe (Cambridge 1996).

7 Utrechtsche Courant 30 december 1839.

8 Zie ook: Jan Kok, 'Komen en gaan. Migratiepatronen in de provincie Utrecht', in: Kees Mandemakers en Onno Boonstra (red.), De levensloop van de Utrechtse bevolking in de 19de eeuw (Assen 1995) 128156.

9 Leonie van Nierop, De bevolkingsbeweging der Nederlandsche stad (Amsterdam 1905) 125.

10 Pim Kooij, Groningen 1870-1914. Sociale verandering en economische ontwikkeling in een regionaal centrum (Groningen 1987).

11 Op basis van 't Hart, De stad Utrecht en haar inwoners, 297-299.

12 Frans van Besouw, Migratie tussen Utrecht en Jutphaas 1850-1900 (ongepubliceerde doctoraalscriptie Geschiedenis UU 1988) 71.

13 Gerrit van Galensloot werd geboren in 1841 in Utrecht en Maria van der Linden in 1839 in Jutphaas. Bevolkingsregister, 1860-1879, deel 1/370/214, wijk K, Hoog Rovarschedijk 141, vel 225.

14 G.B. Jansen, Baksteenfabricage in Nederland 1850-1920 (Zutphen 1987).
15 Bevolkingsregister 1860-1879, wijk L, 236, fiche 639, vel 769 .

16 Stadsarchiv Duisburg: Holländerverzeichnissen, onderdeel van de bevolkingsregistratie.

17 Annemarie Cottaar en Leo Lucassen, 'Naar de laatste Parijse mode. Strohoedenmakers uit het Jekerdal in Nederland 1750-190o', in: Ad Knotter en Willibrord Rutten (red.), Studies over de soiciaaleconomische geschiedenis van Limburg XLVI (Maastricht 2001) 45-82.

18 In de volkstelling van 1849 zijn de strohoedenmakers samengevoegd met de hoeden- en pettenmakers. Op basis hiervan kan niet worden vastgesteld of er van overheersing van deze sector door Belgen sprake was.

19 Overzicht van mensen die tussen 1701 en 1797 het burgerrecht in Utrecht verwierven, aanwezig op Het Utrechts Archief. Met dank aan Ronald Rommes.

20 Bevolkingsregister 1850-1859, wijk G, 17, fiche 231, vel 21.

21 Bevolkingsregister 1850-1859, wijk E, fiche 324, vel 15 .

22 Bevolkingsregister 1850-1859, wijk E, fiche 325 , vel 52, fiche 183 , vel 47 .

23 Bevolkingsregister 1860-1879, wijk E, fiche 327, vel 119.

24 Bevolkingsregister 1860-1879, wijk D, fiche 305, vel 577.

25 Bevolkingsregister 1860-1879, wijk E, fiche 329, vel 178 .

26 HUA, S.A. II, 386, Beschikking: 24 april 1786, Baille, Antoine, geb. 'Auvergne in Vrankrijk', rooms, 'een keetellapper'; Beschikking: 24 maart 1777, Corsa, Jean, geb. 'Vrankrijk', rooms, 'een keetellapper'. Ontleend aan: H. Tigelaar, Index van namen van personen: - die zich na overlegging van een akte van indemniteit te Utrecht gevestigd hebben, - die te Utrecht om het recht van inwoning verzocht hebben 1726 - 1811 (1812) Gemeentelijke Archiefdienst Utrecht (Utrecht 1991). 
27 HUA, S.A. II, 386, Beschikking: 30 jan. 1775, Beise, Anthony, geb. Frankrijk, rooms, 'een scheersliep'; Beschikking: 25 mei 1778, Brun, le, Pierre, geb. te 'Vrankrijk', 'messen en schaarenslijper'; Beschikking: 28 okt. 1776, Papon, Jean, geb. in 'Vrankrijk', rooms 'een messe- en schaarenslijper'; Beschikking: 27 dec. 1781, Rievos, Jean Pierre, geb. in 'Vrankrijk', rooms, 'scharenslijper'; Beschikking: 24 maart 1777, Dilpet, Leendert, geb. te 'Vrankrijk', 'schareslijper'. Ontleend aan: $\mathrm{H}$. Tigelaar, Index van namen van personen.

28 Snell maakt ook melding van Franse kappers in Kopenhagen, 135. Ook daar vormden ze geen belangriike beroepsgroep.

29 HUA, S.A. II, 386, Beschikking: 8 nov. 1779, Chouet, Jan Philippe, geb. te Parijs, rooms, 'paruykemaker en friseur'; Beschikking: 8 mei 1775, Verdigny, Louis, 'paruykemaker', met zijn vrouw Jeanne Tessain. Ontleend aan: Tigelaar, Index van namen van personen.

30 HUA, S.A. II, inv. nr. 386, Beschikking: 14 april 1789, Drie, Francois, geb. te 'Vrankrijk'. Ontleend aan: Tigelaar, Index van namen van personen.

31 Overzicht van mensen die tussen 1701 en 1797 het burgerrecht in Utrecht verwierven, aanwezig op Het Utrechts Archief.

32 Geciteerd in Lestrade, 3.

33 Jan Lucassen, 336; J. Mertens, Handel en wandel van de Teuten in Duitse gewesten (Lommel 1995) 277.

34 Laurence Fontaine, History of pedlars in Europe (Cambridge 1996) 181.

35 Lucassen, Naar de kusten van de Noordzee, 114.

36 Lucassen, Naar de kusten van de Noordzee, 226.

37 Lucassen, Naar de kusten van de Noordzee, 114, 192-193, 223, 323; Oberpenning noemt in haar overzicht van Europese trekhandelaars-systemen de parapluverkopers niet. Oberpenning, Migration und Fernhandel im “Tödden-System", 70-74; Abel Poitri- neau bespreekt wel de handelaren uit de Auvergne en noemt daarbij tal van artikelen, maar maakt geen melding van paraplu's. Abel Poitrineau, 'Les Colporteurs d'autrefois en France', in: Wilfried Reininghaus (red.), Wanderhandel in Europa. Beiträge zur wissenschaftlichen Tagung in Ibbenburen, Mettingen, Recke und Hopsten vom 9-11. Oktober 1992 (Dortmund 1993) 73-80; Mertens noemt hen wel. Mertens, Handel en wandel, 277.

38 Lestrade, 'Ketellappers, koperslagers en paraplumakers uit Auvergne', 1-4. Lestrade verwijst naar de lijst in het archief van Aurillac.

39 Annemarie Cottaar vermeldt dat ambulante handelaren in paraplu's nieuwe exemplaren bestelden in Utrecht, bij de firma Sinke. Deze firma werd genoemd door een van de geïnterviewden. Welke firma dat is, is onduidelijk. Annemarie Cottaar, Kooplui, kermisklanten en andere woonwagenbewoners. Groepsvorming en beleid 1870-1945 (Amsterdam 1996) 92.

40 Utrechtsche Provinciale en Stadscourant 229-1851 nr. 5787.

41 Utrechtsche Provinciale en Stadscourant 287-1851 nr. 5317; Utrechtsche Provinciale en Stadscourant 26-9-1851 nr. 5803.

42 Utrechtsche Provinciale en Stadscourant 269-1851 nr. 5803.

43 HUA, S.A. II, 386: Beschikking: 8 april 1771 en Beschikking: 17 jan. 1797. Ontleend aan:. Tigelaar, Index van namen van personen.

44 Camille Rentier werd geboren in Cros-deMontvert in 1844. Bevolkingsregister 18601879, fiche 285, wijk D, Oude Gracht 39, vel 49.

45 Utrechtsche Provinciale en Stadscourant 167-1851 nr. 5200.

46 Snell noemt ook Italiaanse pleistergieters in Kopenhagen in het midden van de negentiende eeuw, 135. Ze maakt geen melding van schoorsteenvegers.

47 Aart Heering, 'Italianen in Nederland', in: A.H. Huussen, W.E. Krul en E.Ch.L. van 
der Vliet (red.), Vreemdelingen. Ongewenst en onbemind (Groningen 1991) 15-20; R. Rommes, 'Café Italien', Oud-Utrecht. Tijdschrift voor de geschiedenis van de stad en provincie Utrecht (1998) 71, 86-87.

48 Frank Bovenkerk en Loes Ruland, 'Italiaanse schoorsteenvegers in Amsterdam', Ons Amsterdam jrg. 38, nr.1, 1986, 23-26.

49 J.W.M. Kors en M.J.G. Kors, 'Italiaanse schoorsteenvegers in Den Haag. De familie Andreoli', Jaarboek van het Centraal Bureau voor Genealogie en het iconographisch bureau. Deel 46 (Den Haag 1992) 178-207, 181.

50 Kors en Kors, Italiaanse schoorsteenvegers, 183 .

51 Kors en Kors, Italiaanse schoorsteenvegers, 195.

52 Van der Harst en Lucassen, 106; Het veelvuldig op en neer reizen van schoorsteenvegers tussen verschillende Nederlandse steden is ook vastgesteld door Kors en Kors, 'Italiaanse schoorsteenvegers in Nederland', 178-207.

53 Heering, Italianen in Nederland, 15.

54 Rommes, Oost, West, Utrecht best?.

55 HUA, S.A. II, 386, Beschikking: 19 april 1779. Ontleend aan: Tigelaar, Index van namen.

56 HSN Steekproef geboorte 11-12-1818, Geboorteakte 989 11-12-1818.

57 Bevolkingsregister 1850-1859, wijk E, fiche 183, vel 30. De advertentie vermeldt Lijnmarkt 36. Het bevolkingsregister 31. Waarschijnlijk is de nummering veranderd. Luigi Guisti werd in 1818 in Lucca in Toscane geboren. Hij trouwde in 1849 in Utrecht met de Haagse Margaretha Mansveldt. Hun kinderen werden in Utrecht geboren tussen 1848 en 1854. Bij het huwelijk werd de voorechtelijk geboren dochter Maria Louisa geëcht. De nog een jaar eerder geboren dochter Louisa Dommica was toen reeds overleden.

58 Lucassen, Naar de kusten van de Noordzee, 143-144.
59 Utrechtsche Provinciale en Stadscourant 610-1851 advertentienummer 5888.

60 Utrechtsche Provinciale en Stadscourant 2311-1884.

61 Huwelijksakte 421 5-12-1849.

62 Utrechtsche Provinciale en Stadscourant 1211-1851 advertentienummer 6279.

63 Utrechtsche Provinciale en Stadscourant 2910-1851 advertentienummer 6131.

64 Later P.J. Fochettie Oudegracht A 36 tussen wees- en smeebrug. Utrechtsche Provinciale en Stadscourant 24-11-1884.

65 Heering, 15.

66 Utrechtsche Provinciale en Stadscourant 25 juni 1876.

67 Utrechtsche Provinciale en Stadscourant 187-1851 advertentienummer 5227.

68 Utrechtsche Provinciale en Stadscourant 257-1851 advertentienummer 5292.

69 Kurt Brenner, Die Zillertaler Wanderhandel im 18. Und 19. Jahrhundert (Inssbruck 1964).

70 Brenner, Die Zillertaler Wanderhandel, 133.

71 Brenner, 134.

72 Brenner, 248

73 Brenner, 249.

74 Boven de zuidzijde van de pandhof van de Domkerk. D.E.A. Faber en R.N.J. Rommes, 'Op weg naar stabiliteit', in: R.E. de Bruin, P.D. 't Hart, A.J. van den Hoven van Genderen, A. Pietersma (red.), 'Een paradijs vol weelde'. Geschiedenis van de stad Utrecht (Utrecht 2000) 251-314, 308.

75 W.J.B. Serfontein, Suid-Afrikaners in Utrecht 1762-1954 (Utrecht 1954), 54.

76 Serfontein, Suid-Afrikaners in Utrecht, 52.

77 Serfontein, 50.

78 Bevolkingsregister 1860-1879, wijk K, Singel 326b/37, fiche 595, vel 610 .

79 Bevolkingsregister 1860-1869, wijk M, fiche 744, vel 1554 .

80 Bevolkingsregister 1860-1869, wijk M, fiche 751, vel 1745 .

81 Bevolkingsregister 1850-1859, wijk I, 6-8, wijk G.

82 Bevolkingsregister 1850-1859, wijk I, fiche 304. 
83 Bevolkingsregister 1860-1869, wijk M, fiche 731, vel 1263.

84 Bevolkingsregister 1860-1879, wijk L, $333 \mathrm{v}$, fiche 679, vel 1784 .

85 Cornelis Ch. Goslinga, The Dutch in the Caribbean and in Surinam 1791/5-1942 (Assen/Maastricht 1990) 19.

86 Green, 'The comparative method', 57-72, 68.

87 Vergelijk: Waldinger, Still the promised city?; Hondius, Gemengde huwelijken, gemengde gevoelens, 17.

\section{Samenvatting en conclusie}

1 Zie ook: Bovenkerk, Eijken en BovenkerkTeerink, Italiaans ijs, 180 .

2 Zie op dit punt ook Lourens en Lucassen, Arbeidswanderung und berufliche Spezialisierung. De niche van de steenbakkers uit het Duitse graafschap Lippe kwam tot ontwikkeling, toen gelijktijdig de mogelijkheden in het tichelbakken toenamen en andere opties wegvielen. Lipper immigranten, die aanvankelijk ook (of vooral) in andere beroepen werkzaam waren, verschoven hun activiteiten naar het tichelwerk. De Lipper overheid bevorderde daarna het proces door een boodschapper aan te stellen, die een monopolie had in het afsluiten van contracten met Nederlandse producenten. In haar studie van de textielhandelaren uit Münsterland, heeft Oberpenning eveneens geconstateerd dat overheidsbeleid het nichevormingsproces bewust of onbewust kan bevorderen. $\mathrm{H}$.
Oberpenning, Migration und Fernhandel im 'Tödden-system'. Wanderhändler aus dem nördlichen Münsterland im mittleren und nördlichen Europa (Osnabrück 1996).

3 Vermeulen, Etnische groepen en grenzen, 24.

4 In de twee Amerikaanse textielsteden Lawrence en Manchester in New England, werkten Duitse immigranten in geschoolde beroepen in de snel expanderende textielindustrie. Zij kwamen uit slechts enkele kleinere dorpen in het zuiden van Saksen. Immigranten uit Saksen hadden maar een beperkt aandeel in de totale Duitse immigratie naar de Verenigde Staten en van de Duitse immigranten ging alleen een klein aantal naar New England. De textielindustrie van de Saksische dorpen - die een lange traditie kende - stortte in na 1870, juist op het moment dat er zich in Lawrence en Manchester veel nieuwe mogelijkheden voordeden. Deze samenloop van omstandigheden veroorzaakte over een korte periode een uitstroom van migranten uit enkele dorpen in Saksen, naar de twee textielsteden in Amerika. McCaffery, 45. In de Maastrichtse aardewerkindustrie zien we iets vergelijkbaars. Deze kwam tot ontwikkeling juist op het moment dat de aardewerkindustrie in het Belgische Andenne inzakte. Het gevolg was een korte migratiebeweging van Andenne naar Maastricht. Gertjan de Groot, Fabricage van verschillen. 



\section{Literatuurlijst}

\author{
Adresboek (Utrecht) \\ Algemeen Politieblad \\ De Avondbode, algemeen nieuwsblad voor \\ staatkunde, handel, nijverheid, landbouw, \\ kunsten en wetenschappen \\ De Gemeentestem \\ Gustaaf-Adolf, Tafereelen en berigten uit de \\ Geschiedenis der Protestantsche kerk in \\ onze dagen \\ Verslag der Handelingen van de Tweede Kamer \\ der Staten Generaal \\ Herzoglich Nassauisches allgemeines Intelli- \\ genzblatt \\ Jaarboekje Oud-Utrecht \\ Jaarboek Oud Utrecht \\ Maandblad Oud Utrecht \\ Utrechtsch Provinciaal en Stedelijk dagblad \\ Utrechtsche Courant \\ Utrechtsch Dagblad \\ Utrechtsche Provinciale en Stadscourant \\ Utrechtsche studentenalmanak \\ Utrechtsche provinciale en stads almanak voor \\ het jaar... \\ De Volkskrant
}

Adresboek van de werklieden-organisaties in Nederland (Den Haag 1910).

Aengenvoort, Anne, Migration - Siedlungsbildung - Akkulturation. Die Auswanderung Nordwestdeutscher nach Ohio, 1830-1914 (Stuttgart 1999).

Aerts, Remieg, en Henk te Velde, 'De taal van het nationaal besef, $1848-1940$ ', in: N.C.F. van Sas (red.), Vaderland. Een geschiedenis van de vijftiende eeuw tot 1940 (Amsterdam 1999) 391-454.

Albers, P., Geschiedenis van het herstel der hierarchie in de Nederlanden (2 delen Nijmegen 1903-1904).
Aldrich, Howard, John Cater, Trevor Jones, David McEvoy en Paul Velleman, 'Ethnic residential concentration and the protected market hypothesis', Social Forces 63 (4 juni 1985) 996-1009.

Algemeene bepalingen voor het personeel in dienst bij de Maatschappij tot Exploitatie van Staatsspoorwegen. Allgemeine Bestimmungen für die Angestellten der Gesellschaft für den Betrieb von Staats-Eisenbahnen (zp 1865).

Amersfoort, H. van, Koning en kanton. De Nederlandse staat en het einde van de Zwiterse krijgsdienst hier te lande 1814-1829 (Den Haag 1988).

Andriessen, P.J., Iets anders. Bevattende een beschrijving van de provinciën Zuid-Holland en Utrecht (Deventer 1871).

Arkel, Dik van, 'De groei van het anti-Joodse stereotype. Een poging tot een hypothetisch-deductieve werkwijze in historisch onderzoek', Tijdschrift voor Sociale Geschiedenis (1984) 34-70.

Baaden, Franz, Chronik der Gemeinde Mogendorf 1385-1985 (Mogendorf 1985).

Baaden, F., Landgänger. Botschafter des Kannenbäckerlandes (Ransbach-Baumbach 1993).

Baaden, Franz, 'Die Töpferregion Westerwald. Ein geschichtlicher Überblick über das Kannenbäckerland und seine Ausstrahlungen', in: Dieter Rolfes (red.), Keramikmuseum Westerwald. Deutsche Sammlung für historische und zeitgenössische Keramik (Höhr-Grenzhausen zj).

Balkema, Tanja, Migratie naar Gouda 18501914 (ongepubliceerde doctoraalscriptie geschiedenis Universiteit Utrecht 2001, 
aanwezig op het gemeentearchief in Gouda).

Barth, F., 'Introduction', in: F. Barth (red.), Ethnic groups and boundaries. The social organization of cultural difference (Londen 1969).

Becker, Holger, 'Christian Gottlieb Daniel Steins Bericht über das Bergische Land anläßlich seiner Reise nach den vorzüglichsten Haupstädten von Mittel-Europa" (1823)', in: Jürgen Reulecke en Burkhard Dietz (red.), Mit Kutsche, Dampfroß, Schwebebahn. Reisen im Bergische Land II (1750-1910) (Neustadt/ Aisch 1984).

Beer, J.J.A. de, 'Beroepskeuze, levensstandaard en lichamelijke ontwikkeling. De kleine sigarenmaker in Utrecht, ca. 1850', Tijdschrift voor Sociale Geschiedenis (1993) 216-235.

Beeton's dictionary of industries and commerce (Londen z.j./1880).

Bergh, S.J. van den, Een dichtbundel voor mijn vaderland (Haarlem 1851).

Berntsen, Peter D., Werken en wonen in vreemd Amsterdam; Duitse migranten in de hoofdstad van ons land in het jaar 1853 . Een onderzoek naar de Duitse migranten in Amsterdam in het jaar 1853 aan de hand van hun registratie in het reis- en verblijfpassenregister van de stad (ongepubliceerde doctoraalscriptie Amsterdam 1987, aanwezig in het gemeentearchief Amsterdam).

Berry, John W., 'Psychology of Acculturation. Understanding individuals moving between cultures', in: Richard W. Brislin (red.), Applied cross-cultural psychology (Cross-cultural research and methodology series vol. 14), (Newbury Park/Londen/New Delhi 1990) 232-253.

Bervoets, J.A.A., 'De registratie van militairen in Nederland en haar weerslag in de archieven, berustend bij het Algemeen Rijksarchief, Gens Nostra xx VII (1972) 368-375.

Besouw, Frans van, Migratie tussen Utrecht en Jutphaas 1850-1900 (ongepubliceerd doctoraalscriptie Geschiedenis UU 1988).
Bevaart, W., De Nederlandse defensie (18391874) (Den Haag 1993).

Blau, Peter M., Inequality and heterogeneity; a primative theory of social structure (New York 1977).

Blaschke, Monika, 'No way but out: German women in Mecklenburg', in: Christiane Harzig (red.), Peasant maids - city women. From the European countryside to urban America (Ithaca en Londen 1997) 25-56.

Boersma, Jan en Ivo Kuypers, 'En toen kwam het kapitaal...' Een onderzoek naar segmenteringsprocessen op de arbeidsmarkt voor de kledingindustrie, 1850-1920 (ongepubliceerde Doctoraalscriptie geschiedenis Universiteit Utrecht 1988).

Boersma, Jan en Ivo Kuypers, "'En toen kwam het kapitaal..." Een onderzoek naar segmenteringsprocessen op de arbeidsmarkt voor de kledingindustrie, 1850-1920', Textielhistorische Bijdragen, 33 (1993) 92-118.

Bohlman, Philip V., "'Still, they were all Germans in town" - music in the multi-religious German-American community', in: Eberhard Reichmann, La Vern J. Rippley en Jörg Nagler (red.), Emigration and settlement patterns of German communities in North America (Indianapolis 1995) 275293.

Bommel, Irma van, 'De fotografie', in: J.W.L. Hilkhuijsen (red.), De stad Delft. Cultuur en maatschappij van 1813 tot 1914 (Delft 1992) 289-302.

Bonacich, E., 'A theory of middlemen minorities', American Sociological Review, 38 (1973) (5) 583-594.

Bonacich, Edna en John Modell, The economic basis of ethnic solidarity. Small business in the Japanese American community (Berkeley 1980).

Boogman, J.C., Nederland en de Duitse Bond 1815-1851 (Groningen 1955).

Boogman, J.C., Rondom 1848. De politieke ontwikkeling van Nederland 1840-1858 (Bussum 1978).

Borne, J.C.C.F.M. van den, 'Naturalisaties in Nederland in de eerste helft van de negen- 
tiende eeuw', Jaarboek van het $C B G, 46$ (1992) 208-246.

Boscia-Mulè, Patricia, Authentic ethnicities. The interaction of ideology, gender power, and class in the Italian-American experience (Westport, Connecticut en Londen 1999).

Bosschaert, D., De stad Utrecht als medisch ontwikkelingsgebied (Utrecht 1969).

Bossenbroek, M.P., Volk voor Indië. De werving van Europese militairen voor de $\mathrm{Ne}$ derlandse koloniale dienst 1814-1909 (Amsterdam 1992).

Bossenbroek, Martin, en Jan H. Kompagnie, Het mysterie van de verdwenen bordelen. Prostitutie in Nederland in de negentiende eeuw (Amsterdam 1998).

Bovenkerk, Frank, Anne Eijken en Wiesje Bovenkerk-Teerink, Italiaans ijs. De opmerkelijke historie van de Italiaans ijsbereiders in Nederland (Amsterdam 1983).

Bovenkerk, Frank, en Loes Ruland, 'Italiaanse schoorsteenvegers in Amsterdam', Ons Amsterdam jrg. 38 (1986) nr.1., 23-26.

Bras, Hilde, 'Domestic service, migration and the social status of women at marriage. The case of a Dutch sea province, Zeeland 1820-1935', Historical Social Research, vol. 23, 1998, 3, 3-19.

Brenner, Kurt, Der Zillertaler Wanderhandel im. 18. Und 19. Jahrhundert (Innsbruck 1964).

Broeke, Willem van den, Financiën en financiers van de Nederlandse spoorwegen 18371890 (Zwolle 1985).

Broers, H.J., Utrecht Historische wandelingen (Utrecht 1908).

Brom, Gerard, Herleving van de kerkelijke kunst in katholiek Nederland (Leiden 1933).

Brugman, Jan, Hans Buiter en Kaj van Vliet, Markten in Utrecht van de vroege middeleeuwen tot nu (Utrecht 1995).

Brües, Otto, Das Mädchen von Utrecht. Erzählung (Berlijn 1933).

Bruin, R.E. de, Burgers op het kussen. Volkssoevereiniteit en bestuurssamenstelling in de stad Utrecht, 1795-1813 (Zutphen 1986).
Bruin, R.E. de, 'Stilte na de storm. Utrecht in de eerste helft van de negentiende eeuw', Bijdragen en Mededelingen betreffende de Geschiedenis der Nederlanden, 101 (1986) 510-528.

Bruin, R.E. de, P.D. 't Hart, A.J. van den Hoven van Genderen, A. Pietersma (red.), 'Een paradijs vol weelde'. Geschiedenis van de stad Utrecht (Utrecht 2000).

Bruin, R.E. de, 'Regenten en revolutionairen', in: R.E. de Bruin, P.D. 't Hart, A.J. van den Hoven van Genderen, A. Pietersma (red.), 'Een paradijs vol weelde'. Geschiedenis van de stad Utrecht (Utrecht 2000) 315374 .

Buikema, Rosemarie, 'Someday, somehow, somewhere. Interetnische relaties in West Side Story en Jungle Fever', Immigrantenstudies (2000) nr. 4, 260-274.

Bruijn, Jeanne de, Haar werk. Vrouwenarbeid en arbeidssociologie in historisch en emancipatorisch perspectief (Amsterdam 1989).

Bruns, A., Gericht und Kirchspiel Oberkirchen. Beiträge zur Geschichte der Stadt Schmallenberg (Schmallenberg 1981).

Buikema, Rosemarie, 'Someday, somehow, somewhere. Interetnische relaties in West Side Story en Jungle Fever', Migrantenstudies (2000) nr. 4 260-274.

Burger, Jan Erik, en Peter Berntsen, 'De Duitse immigratie naar Amsterdam in de 19e eeuw', Ons Amsterdam 38 (maart 1986) nr. 3, 59-64.

Busken Huet, Conrad, Lidewijde (oorspronkelijke uitgave Amsterdam 1868, Utrecht/Amsterdam 1981).

Busken Huet, Conrad, De Nederlandsche Gustaaf-Adolfvereeniging en hare bestrijding (Haarlem 1854).

Buwalda, S.T., 'Voor godsdienst, vaderland en Oranje. Het verzet van Utrechtse protestanten tegen de liberale staatsinrichting en het herstel van de bisschoppelijke hiërarchie (1840-1853)', Jaarboek Oud Utrecht (2000) 103-124.

Campen, J.W.C. van, 'De Handelsfirma Trip 1820-1890, volgens familieaantekeningen 
medegedeeld', Jaarboekje Oud Utrecht (1958) 115-141.

Carter, Bob, Marci Green en Rick Halpern, 'Immigration policy and the racialization of migrant labour: the construction of national identities in the UsA and Britain', Ethnic and Racial Studies (januari 1996) Vol. 19, nr. 1, 135-157.

Chin, K. S., I. Yoon en D. Smith, 'Immigrant small business and international economic linkage: a case of the Korean wig business in Los Angeles, 1968-1977', International Migration Review (1996) vol. xxx, no 2, 485-510.

Chotkowski, M.B., 750 jaar migratie naar Delft. Onderzoek en bronnenoverzicht (Leiden 1996).

Clark, Peter, British clubs and societies 15801800 . The origins of an associational world (Oxford 2000).

Cleveland and its Germans (Cleveland Ohio 1998).

Cohen, J. M., The life of Ludwig Mond (Londen 1956).

Coninck, Pieter de, Een les uit Pruisen. Nederland en de Kulturkampf, 1870-1880 (Leiden 1998).

Cottaar, Annemarie, Kooplui, kermisklanten en andere woonwagenbewoners. Groepsvorming en beleid 1870-1945 (Amsterdam 1996).

Cottaar, Annemarie, Ik had een neef in Den Haag. Nieuwkomers in de twintigste eeuw (Zwolle 1998).

Cottaar, A., J. Lucassen en L. Lucassen, Van over de grens. Gids voor lokaal historisch onderzoek naar immigratie in Nederland (Utrecht 1998).

Cottaar, Annemarie, en Leo Lucassen, 'Naar de laatste Parijse mode. Strohoedenmakers uit het Jekerdal in Nederland 17501900', in: Ad Knotter en Willibrord Rutten (red.), Studies over de soicaal-economische geschiedenis van Limburg XLVI (Maastricht 2001) 45-82.

Couperus, Louis, De boeken der kleine zielen. Eerste deel (Amsterdam 1901).
Dehing, P.W.N.W., '... Eene soort van dynastie van spoorwegbeambten'. Arbeidsmarkt en spoorwegen in Nederland, 1875-1914 (Hilversum 1989).

Dekker, A.J., 'De opkomst van kerstboom en kerstviering in Nederland (ca. 1835-188o)', Volkskundig bulletin 8, 2 1982, 129-179.

Delheye, Pascal, 'Carl Euler (1809-1882): Een Duitse turnapologeet in Brussel', Sportimonium (2001) 2, 25-33.

Denig, Carl, Utrecht van ancien régime tot nieuwe tijd. De bewoning van de Utrechtse binnenstad in haar ruimtelijke structuur, 1793-1891 (Utrecht 1995).

Dick, Otto, Die Feile und ihre Entwicklungsgeschichte (Berlijn 1925).

Diederiks, Herman, Een stad in verval. Amsterdam omstreeks 1800, demografisch, economisch, ruimtelijk (Amsterdam 1982).

Dijk, H. van, Rotterdam 1810-1880. Aspecten van een stedelijke samenleving (Schiedam 1976).

Dirven, Monique, 'Het gemeentelijk cultuurbeleid in de negentiende eeuw', Jaarboek Oud-Utrecht 1995 (Utrecht 1995) 95-118.

Doedens, Anne, Nederland en de Frans-Duitse oorlog. Enige aspecten van de buitenlandse politiek en de binnenlandse verhoudingen van ons land omstreeks het jaar 1870 (Zeist 1973).

Dokkum, J.D.C. van, 'Een episode uit het Utrechtse kunstleven in het einde der 19de en het begin der 2oste eeuw', Jaarboekje Oud-Utrecht (1937) 97-137.

Dokkum, J.D.C. van, 'De Utrechtsche toonkunstafdeeling in haar ontwikkelingsjaren (uit oude notulen en verslagen), Jaarboekje Oud Utrecht (1933) 122-194.

Dreesmann, A.C.R., Evolutie en expansie. Een onderzoek naar de samenhang van vorm, functie en prijspolitiek in de detailhandel, inzonderheid bij het grootbedrijf (Leiden 1963).

Dunk, Herman von der, Der Deutsche Vormärz und Belgien 1830/48 (Wiesbaden 1966).

E., 'Hoe de fotografie in Utrecht kwam', Maandblad Oud-Utrecht (1934) 26-29. 
E., 'Hoe de fotografie in Utrecht kwam' vervolg, Maandblad Oud-Utrecht (1934) 6669.

Eiynck, A. e.a. (red.), Werken over de grens. 350 jaar geld verdienen in het buitenland (Assen 1993).

Eijl, Corrie van, en Marlou Schrover, 'Vreemde landlopers. Het Nederlandse vreemdelingenbeleid tussen 1800 en 1940', Jaarboek Centraal Bureau voor Genealogie deel 55 (2001) 161-180.

Eijl, Corrie van, 'Registratie van vreemdelingen in het Algemeen Politieblad (18521947)', in: Marlou Schrover (red.), Bronnen betreffende de registratie van vreemdelingen in Nederland in de negentiende en twintigste eeuw. Broncommentaar 5 (Den Haag 2002) 71-91.

Eijl, Corrie van, en Marlou Schrover, 'Inleiding', in: Marlou Schrover (red.), Bronnen betreffende de registratie van vreemdelingen in Nederland in de negentiende en twintigste eeuw. Broncommentaar 5 (Den Haag 2002) 7-33.

Elias, E., Drie-kwart honderd jaren met eer, met naald, met garen. Een boekje, uitgegeven door de $n v$ Herenkledingfabriek $v / h$ gebrs. Levie te Groningen, ter gelegenheid van haar vijf-en-zeventig jarig bestaan (Groningen 1955).

Elias, Norbert, en John L. Scotson, De gevestigden en de buitenstaanders. Een studie van de spanningen en machtsverhoudingen tussen twee arbeidersbuurten (Utrecht en Antwerpen 1976).

Euler, Carl, Het universele karakter der Gustaaf-Adolfvereeniging en hare uitbreiding in Nederland (Haarlem 1854).

Everwijn, J.C.A., Beschrijving van handel en nijverheid in Nederland (Den Haag 1912).

Faber, D.E.A. en R.N.J. Rommes, 'Op weg naar stabiliteit', in: R.E. de Bruin, P.D. 't Hart, A.J. van den Hoven van Genderen, A. Pietersma (red.), 'Een paradijs vol weelde'. Geschiedenis van de stad Utrecht (Utrecht 2000) 251-314.

Fairlie, Robert W., en Bruce D. Meyer, 'Ethnic and racial self-employment, differ- ences and possible explanations', The Journal of Human Resources (1996) 31-4, 757-793.

Fertig, Georg. Migration from the Germanspeaking parts of central Europe, 1600-180o: estimates and explanations (Berlijn 1991).

Fockema Andrea, J.P., 'De stad Utrecht omstreeks 1823', Jaarboekje Oud-Utrecht (1924) 28-39.

Fockema Andreae, J.P., 'Het beheer der universiteit sinds 1877 ', in: J.P. Fockema Andreae e.a. (red.), De Utrechtsche Universiteit 1815-1936 (Utrecht 1936).

Fogleman, Aaron S., 'Immigration, German immigration and 18th-century America', in: Eberhard Reichmann, La Vern J. Rippley en Jörg Nagler (red.), Emigration and settlement patterns of German communities in North America (Indianapolis 1995) 3-22.

Fohr, Wilhelm Franz, Aus der Geschichte Ransbachs (onuitgegeven typescript Ransbach 1943).

Fontaine, Laurence, History of pedlars in $\mathrm{Eu}$ rope (Cambridge 1996).

Fries, H., Kurrimurri. Erinnerungen an die Kannenbäcker in Höhr-Grenzhausen (Höhr-Grenzhausen 1993).

Frieswijk, Johan, Om een beter leven. Strijd en organisatie van de land-, veen- en zuivelarbeiders in het noorden van Nederland (1850-1914) (Leeuwarden 1989).

Furnée, Jan Hein,، "'Om te winkelen, zoo als dat in de residentie heet". Consumptiecultuur en stedelijke ruimte in Den Haag, 1850-1890', Jaarboek voor Vrouwengeschiedenis 22 (2002) 28-55.

Gewin, Everard E., 'Vóor een eeuw', Jaarboekje Oud-Utrecht (1926) 168-176.

Giesberts, Robert, De singels over. Veranderingen in de ruimtelijke en sociale ordening van Utrecht in de tweede helft van de negentiende eeuw (ongepubliceerde doctoraalscriptie UU 1991).

Goes, F. van der, Grootkapitaal en kleinhandel. Bijdrage tot kennis van de middenstandspolitiek (Amsterdam 1902). 
Goldberg, Bettina, 'Cultural change in Milwaukee's German Evangelical Lutheran congregations of the Missouri Synod, 1850-1930', in: Eberhard Reichmann, La Vern J. Rippley en Jörg Nagler (red.), Emigration and settlement patterns of German communities in North America (Indianapolis 1995) 115-129.

Grams, Wolgang, 'The North German Lutheran Church in Cincinnati: an “Osnabrück" congregation (1838)', in: Eberhard Reichmann, La Vern J. Rippley en Jörg Nagler (red.), Emigration and settlement patterns of German communities in North America (Indianapolis 1995) 7990.

Green, Nancy L., 'The comparative method and poststructural structuralism: new perspectives for migration studies', in: Jan Lucassen en Leo Lucassen (red.), Migration, migration history, history: old paradigms and new perspectives (Bern 1997) 5772.

Green, Nancy L., Ready-to-wear and ready-towork. A century of industry and immigrants in Paris and New York (Durham en Londen 1997).

Groen P., 't Grunneger Zangbouk. Tweede druk van Oude en Nieuwe Groninger Liederen (Winschoten 1958).

Groenendijk, C.A., Op weg naar een Nederlandse paspoortwet (Deventer 1973).

Groot Placaatboek vervattende alle de placaten, ordonnantien en edicten der edele mogende heeren staten's lands van Utrecht mitsgaders van de ed. Groot achtb. Heeren borgemeesteren en vroedschap der stad Utrecht tot het jaar 1728 ingesloten (Utrecht 1729) III boek XVI.

Groot, Gertjan de, Fabricage van verschillen. Mannenwerk, vrouwenwerk in de Nederlandse industrie (1850-1940) (Amsterdam 2001).

Gordon, Milton M., Assimilation in American life. The role of race, religion and national origins (New York 1964).

Goslinga, Cornelis Ch., The Dutch in the Caribbean and in Surinam 1791/5-1942 (Assen/Maastricht 1990).
Hageman, R.J.B., (red.), Naturalisatiegids. Gids voor het archiefonderzoek naar naturalisatie in het Algemeen Rijksarchief (Den Haag 2000).

Hamers, N.A., Samenvatting van de genealogieën der geslachten verbonden met het concern Vroom \& Dreesmann (Nijmegen 1967).

Hammer-Stroeve, Tina, Familiezoet. Vrouwen in een ondernemerselite, Enschede 18001940 (Zutphen 2001).

Handlin, Oscar, The uprooted (Boston 1973).

Hardenberg, Hans, Die Fachsprache der Bergischen Eisen- und Stahlwarenindustrie (Bonn 1940).

Harst, Hans van der, 'De orgelmakers Witte en hun tijdgenoten', in: T.W.F. den Toom (red.) De orgelmakers Witte (Gorinchem 1978) 4-15.

Harst, Gerard van der, en Leo Lucassen (met medewerking van Annette van Rijn), Nieuw in Leiden. Plaats en betekenis van vreemdelingen in een Hollandse stad 19181955 (Leiden 1998).

Hart, S., Geschrift en getal. Een keuze uit de demografisch-, sociaal- en economischehistorische studiën, op grond van Zaanse en Amsterdamse archivalia, 1600-1800 (Dordrecht 1976).

Hart, P. D. 't , De stad Utrecht en haar inwoners. Een onderzoek naar samenhangen tussen sociaal-economische ontwikkelingen en de demografische geschiedenis van de stad Utrecht 1771-1825 (Utrecht 1983).

Hart, P. D. 't , Utrecht en de cholera 1832-1910 (Utrecht 1990).

Hart, P. D. 't , 'Het onbespreekbare besproken. Het Utrechtse gemeentebestuur en de prostitutiekwestie, 1850-1900', Jaarboek Oud Utrecht (1993) 147-180.

Hart, P. D. 't, Stakers en onruststokers in de Domstad. Uit de beginjaren van de arbeidersbeweging en socialisme in Utrecht tussen 1870 en 1895 (Utrecht 1996).

Hechter, M., 'Group formation and the cultural division of labor', American Journal of Sociology (1978) nr. 84, 293-318. 
Heering, Aart, 'Italianen in Nederland', in: A.H. Huussen, W.E. Krul en E.Ch.L. van der Vliet (red.), Vreemdelingen. Ongewenst en onbemind (Groningen 1991) 1520.

Hemels, J.M.H.J., Op de bres voor de pers. De strijd voor de klassieke persvrijheid (Assen 1969).

Henkes, Barbara, Heimat in Holland. Duitse dienstmeisjes 1920-1950 (Amsterdam 1995).

Henkes, Barbara, 'Gedeeld Duits-zijn aan de Maas. Gevestigd Deutschtum en Duitse nieuwkomers in de jaren 1900-1940', in: Van de Laar e.a. (red.), Vier eeuwen migratie, 218-239.

Heijs, Eric, Van vreemdeling tot Nederlander (Amsterdam 1995).

Hibbeln, J.G., Wilhelm Hibbeln. De glasmof. Hoe een Duitse emigrant in de vorige eeuw vanuit Amsterdam-Oost een zakenimperium stichtte (Utrecht 1995).

Höher, Peter, Heimat und Fremde. Wanderhändler der oberen Sauerlandes (Münster 1985).

Holzapfel, Otto, Religiöse Identität und Gesangbuch. Zur Ideologiegeschichte deutschsprachiger Einwanderer in den USA und die Auseinandersetzung um das 'richtige' Gesangbuch (Bern 1998).

Homburg, E., 'Zwavelzuur', in: E. Homburg e.a. (red.), Chemische techniek in Nederland in de negentiende eeuw (Zutphen 1994) 37-60.

Homburg, E., 'Een bedrijfstak in verandering', in: E. Homburg e.a. (red.), Chemische techniek in Nederland in de negentiende eeuw (Zutphen 1994) 115-126.

Hondelink, H.Ph., 'Vroom en Dreesmann, de oprichters en hun onderneming 18871912', Jaarboek van de geschiedenis voor Bedrijf en Techniek (1992) 159-184.

100 jaar Sandford vijlen (Rotterdam 1961).

Hondius, Dienke, Gemengde huwelijken, gemengde gevoelens. Aanvaarding en ontwijking van etnisch en religieus verschil sinds 1945 (Den Haag 1999).

Hoof, J.P.C.M. van, 'Enkele richtlijnen voor het verrichten van genealogisch onderzoek naar militairen, behoord hebbende tot de Nederlandse troepen te land', Gens

Nostra xxxix (1984) 249-263.

Hoofdartikelen van wijlen professor Vreede, overgedrukt uit het Utrechtsche Dagblad 1869-1880 (Leiden 1906).

Hooghiemstra, Erna, 'Voor de keuze: Een specifieke of algemene blik op partnerkeuze van immigranten', Immigrantenstudies (2000) nr. 4, 209-228.

Hooykaas, G. J., en F.J.P. Santegoeds (red.), De briefwisseling van J.R. Thorbecke (Den Haag 1996).

Hoven van Genderen, Bram van den, en Ronald Rommes, 'Rijk en talrijk. Beschouwingen over de omvang van de Utrechtse bevolking tussen circa 1300 en het begin van de 17e eeuw', Jaarboek Oud-Utrecht (1995) 53-87.

Hoven van Genderen, A.J. van den, 'Op het toppunt van macht', in: R.E. de Bruin, P.D. 't Hart, A.J. van den Hoven van Genderen, A. Pietersma (red.), 'Een paradijs vol weelde'. Geschiedenis van de stad Utrecht (Utrecht 2000) 113-191.

Huisman, Greddy, Tussen salon en souterrain. Gouvernantes in Nederland 1800-1940 (Amsterdam 2000).

Hulzen, A. van, Utrecht en het verkeer 18501910 (Baarn 1987).

Hutchinson, John en Anthony D. Smith (red.), Ethnicity (Oxford/New York 1996).

Huizinga, J., Cultuur-historische verkenningen (Haarlem 1929).

Iependaal, Willem van, Onder de pannen. Belevenissen in hotel Stoot-je-hoofd-niet, de lijmkit van Moeke Mullemans (Bussum z.j.).

Jackson, J. H., 'Migration in Duisburg, 18671890. Occupational and familial contexts', Journal of Urban History (mei 1982) vol. 8, no. 3, 235-270.

Jansen, F.L., Kledinghandel in transitie. Een eeuw detailverkoop te 's-Hertogenbosch. Oorsprong en ontwikkeling van het familiebedrijf 'A.F. Jansen' 1889-1987 (Tilburg 1991). 
Jansen, G., De verhouding tussen joden en niet-joden in de stad Utrecht in de periode 1789-1824 (Ongepubliceerde Doctoraal scriptie geschiedenis Universiteit Utrecht, 1986).

Jansen, G.B., Baksteenfabricage in Nederland 1850-1920 (Zutphen 1987).

Janzen, J.A.F., 'Van allerlei slag. De lotgevallen van een typisch Utrechts leesgezelschap', Jaarboekje Oud Utrecht (1975) 131160.

Jens, La. F., Criminaliteit te Utrecht in verband met familie en wijk (Utrecht zj).

Jobse-van Putten, Jozien, Eenvoudig maar voedzaam: cultuurgeschiedenis van de dagelijkse maaltijd in Nederland (Nijmegen 1995).

Jong, Anke de, Honderd jaar 'besteden' in Utrecht. Een onderzoek naar hen, die in de periode 1830-1930 bemiddelden op de dienstboden-arbeidsmarkt (Kandidaatsscriptie sociale en economische geschiedenis Rijksuniversiteit Utrecht 1983. Aanwezig op het Utrechts Archief).

Jordan, Terry G., German seeds in Texas soil. Immigrant farmers in nineteenth-century Texas (Austin 1966).

Kamphoefner, Walter D., The Westfalians. From Germany to Missouri (Princeton 1987).

Kamphoefner, Walter D., 'Paths of urbanization: St. Louis in 1860', in: Eberhard Reichmann, La Vern J. Rippley en Jörg Nagler (red.), Emigration and settlement patterns of German communities in North America (Indianapolis 1995) 258-272.

Kamphoefner, Walter D., 'At the crossroads of economic development: background factors affecting emigration from nineteenth-century Germany', in: Ira A. Glazier en Luigi De Rosa (red.) Migration across time and nations. Population mobility in historical contexts (New York en Londen 1986) 174-201.

Kar, Jac. van de, De geschiedenis van de markten straathandel (Amsterdam/Antwerpen 1982).
Kattner, Lauren Ann, 'Land and marriage: German regional reflections in four Texas towns, 1845-186o', in: Eberhard Reichmann, La Vern J. Rippley en Jörg Nagler (red.), Emigration and settlement patterns of German communities in North America (Indianapolis 1995) 237-257.

Keil, Hartmut, 'Die deutsche Amerikaeinwanderung im städtisch-industriellen Kontext; das Beispiel Chicago 1880-1910', in: Klaus Bade (red.), Auswanderer - Wanderarbeiter-Gastarbeiter. Bevölkerung, Arbeitsmarkt und Wanderung in Deutschland seit Mitte des 19. Jahrhunderts. Band 1 (Ostfildern 1984) 378-405.

Kernkamp, G.W., 'De Utrechtsche hoogeschool van 1815 tot 1877 ', in: J.P. Fockema Andreae e.a. (red.), De Utrechtsche Universiteit 1815-1936 (Utrecht 1936).

Keuning, Hendrik Jacob, 'De economisch-geografische achtergrond van de Rijnvaart voor 1870', in: Physisch- en EconomischGeografische beschouwingen over de Rijn als Europese rivier. Vriendenboek aangeboden aan prof. W.E. Boerman (Rotterdam 1948) 32-60.

Klemann, Hein, “Unitas” Georganiseerd antipapisme in Nederland in het midden van de vorige eeuw. 1842-1853 (Ongepubliceerde scriptie geschiedenis vu, Amstelveen 1982, te raadplegen bij het Nederlands documentatiecentrum voor het Protestantisme).

Klep, P.M.M., A. Lansink en W.F.M Terwisscha van Scheltinga, De registers van patentplichtigen 1805-1893. Broncommentaren II (Den Haag 1987).

Kleyn, J. de, Volksaardewerk in Nederland 1600-1900 (Zeist 1965).

Kleyn, J. de, 'Pottenverkopers, kiepkerels en andere rondtrekkende lieden', Bijdragen en mededelingen van het Rijksmuseum voor Volkskunde 'Het Nederlands Openluchtmuseum', 24e jrg. (1961) nr.2, 39-43.

Knotter, Ad, en Jan Luiten van Zanden, 'Immigratie en arbeidsmarkt te Amsterdam in de 17e eeuw', Tijdschrift voor Sociale Geschiedenis (1987) 403-430. 
Knotter, Ad, Economische transformatie en stedelijke arbeidsmarkt. Amsterdam in de tweede helft van de negentiende eeuw (Amsterdam 1991).

Knotter, Ad, 'Vreemdelingen in Amsterdam in de 17e eeuw: groepsvorming, arbeid en ondernemerschap', Historisch Tijdschrift Holland 27 (1995) 219-235.

Knotter, A., en A.C. Meijer (red.), 'De gemeentelijke bevolkingsregisters 1850 1920', Broncommentaren, deel 2 (Den Haag 1995) 75-116.

Kooij, P., 'Stad en platteland', in: F.L. van Holthoorn (red.), De Nederlandse samenleving sinds 1815. Wording en samenhang (Assen/Maastricht 1985) 93-113.

Kooij, Pim, Groningen 1870-1914. Sociale verandering en economische ontwikkeling in een regionaal centrum (Groningen 1987).

Kok, Jan, 'Komen en gaan. Migratiepatronen in de provincie Utrecht', in: Kees Mandemakers en Onno Boonstra (red.), De levensloop van de Utrechtse bevolking in de 19de eeuw (Assen 1995) 128-156.

Kok, Jan, 'Migratie als gezinsstrategie in Midden-Nederland, 1850-1940', in: Jan Kok, Ad Knotter, Richard Paping en Eric Vanhaute, Levensloop en levenslot: arbeidsstrategieën van gezinnen in de negentiende en twintigste eeuw (Groningen 2000) 89-145.

Kors, J.W.M., en M.J.G. Kors, 'Italiaanse schoorsteenvegers in Den Haag. De familie Andreoli', Jaarboek van het Centraal Bureau voor Genealogie en het iconographisch bureau. Deel 46 (Den Haag 1992) 178-207.

Krabben, Anja, 'Max en Ernst Büttinghausen', in: Ingeborg Th. Leijerzapf (red.), Geschiedenis van de Nederlandse fotografie (Amsterdam 1984/2000), nr. 20, (april 1993).

Krauss, Marita, 'Integration und Akkulturation. Eine methodische Annäherung an ein vielschichtiges Phänomen', in: Mathias Beer, Martin Kintzinger en Marita Krauss (red.), Migration und Integration. Aufnahme und Eingliederung im Historischen Wandel (Stuttgart 1997) 11-25.
Krekel-Aalberse, Annelies, 'Utrecht in 1853 Het begin van de Utrechtse zilverindustrie' Maandblad Oud Utrecht (november/december 1996) 124-128.

Kroes, Rob, The persistence of ethnicity, Dutch Calvinist pioneers in Amsterdam, Montana (Urbana/Chicago 1992).

Laar, Paul van de, Thimo de Nijs, Johan Okkema en Albert Oosthoek (red.), Vier eeuwen migratie. Bestemming Rotterdam (Rotterdam 1998).

Landré, T., De groote bedrijven in Nederland. Het bierbrouwerij bedrijf (Amsterdam 1926).

Laseur, A.H., Na vijftig jaren. De handelsSocieteit te Utrecht 1852-1902 (Utrecht 1902).

Larsen, Pernille, 'Hebben Nederlanders dan geen cultuur? Een beschouwing over Nederlands onderzoek naar "etnisch ondernemerschap"', Immigrantenstudies (1995) nr. 1, 30-38.

Leenders, Marij, Ongenode gasten. Van traditioneel asielrecht naar immigratiebeleid 1815-1938 (Hilversum 1993).

Leeuwen, Marco H.D. van, Bijstand in Amsterdam, ca. 1800-1850. Armenzorg als beheersings- en overlevingsstrategie (Utrecht 1990).

Leijerzapf, Ingeborg Th., (red.), Geschiedenis van de Nederlandse fotografie (Amsterdam 1984/2000).

Lennep, J. van, Romantische werken, derde deel. Ferdinand Huyck (Rotterdam 1856).

Lestrade, P.J., 'Ketellappers, koperslagers en paraplumakers uit Auvergne', Gens Nostra, 1986, 1-4.

Levensschtets van $G$.W. Vreede naar zijn eigen handschrift uitgegeven (Leiden 1883).

Liebkind, Karmela, 'The identity of a minority', International journal of multilingual and multicultural development (1989) 4757.

Light, I., en S. Karageorgis, 'The ethnic economy', in: N.J. Smelser en R. Swedberg (red.), The handbook of economic sociology (Princeton 1994) 647-670. 
Lintelman, Joy K., 'Making service serve themselves: immigrant women and domestic service in North America, 18501920', in: Dirk Hoerder en Jörg Nagler (red.), People in transit, German migrations in comparative perspective. 1820-1930 (Cambridge 1995) 249-265.

Looijenga, A.J., De Utrechtse school in de neogotiek. De voorgeschiedenis en het Sint Bernulphusgilde (zp 1991).

Loontjens, Richard, Marlou Schrover en Peter Vuijst, Op zoek naar de wortels der marginaliteit. Vijftig Utrechtse families ten tijde van de industrialisatie (1850-1920). (Ongepubliceerde doctoraalscriptie u U 1985, aanwezig op het Utrechts Archief).

Lorié, J., Levensschets van Dr. C.E.A. Wichmann, aangeboden ter gelegenheid van zijn veertigjarig jubileum als hoogleraar te Utrecht (Amsterdam 1919).

Lottum, Jelle-Jaap van, Nieuwkomers in Nederland in de eerste helft van de 19e eeuw. Een onderzoek op basis van de volkstellingen in Utrecht van 1829 en 1839 (Ongepubliceerde doctoraalscriptie vu 2002 aanwezig op Het Utrechts Archief).

Lourens, Piet en Jan Lucassen, Arbeitswanderung und berufliche Spezialisierung. Die lippischen Ziegler im 18. und 19. Jahrhundert (Osnabrück 1999).

Lourens, P., en J. Lucassen, " Zunftlandschaften" in den Niederlanden und im benachbarten Deutschland', in: W. Reininghaus (red.), Zunftlandschaften in Deutschland und den Niederlanden im Vergleich (Münster 2000) 11-43.

Lucassen, Jan, 'Beschouwingen over seizoensgebonden trekarbeid naar het westen van Nederland, ca. 1600 - ca. 180o', Tijdschrift voor Sociale Geschiedenis (1982) 327-358.

Lucassen, J., Naar de kusten van de Noordzee. Trekarbeid in Europees perspectief, 16001900 (Gouda 1984).

Lucassen, Jan, en Rinus Penninx, Nieuwkomers, nakomelingen, Nederlanders. Immigranten in Nederland 1550-1993 (Amsterdam 1994).

Lucassen, Jan en Leo Lucassen, 'Van incident tot constante factor. Een historiografisch overzicht van de migratiegeschiedenis in Nederland', in: Louise Rietbergen (sam.), Migratie en vestiging in Nederland. Bronnenoverzicht en geselecteerde bibliografie (Amsterdam 1994) 15-16.

Lucassen, J., 'Tijdelijke of permanente vestiging van Duitsers in Holland', Holland, regionaal historisch tijdschrift 27 (1995) 254-262.

Lucassen, Jan, en Leo Lucassen 'Migration, migration history, history. Old paradigms and new perspectives', in: Jan Lucassen en Leo Lucassen (red.), Migration, migration history, history: old paradigms and new perspectives (Bern 1997) 57-72, 69.

Lucassen, Jan, en Leo Lucassen (red.), Migration, migration history, history: old paradigms and new perspectives (Bern 1997).

Lucassen, Leo, 'Poepen, Knoeten, Mieren en Moffen. Beeldvorming over Duitse immigranten en trekarbeiders in zeventiendeen achttiende-eeuwse kluchten', in: Vreemd gespuis (Amsterdam 1987) 29-38.

Lucassen, Leo, En men noemde hen zigeuners... De geschiedenis van Kaldarasch, Ursari, Lowara en Sinti in Nederland, 17501945 (Amsterdam/Den Haag 1990).

Lucassen, L., "'Het paspoort als edelste deel van een mens." Een aanzet tot een sociale geschiedenis van het Nederlandse vreemdelingenbeleid', Holland. Regionaal historisch tijdschrift 27 (1995) 265-285.

Lucassen, Leo, en Boudien de Vries, 'Leiden als middelpunt van een Westeuropees textiel-migratie-systeem, 1586-1650, Tijdschrift voor Sociale Geschiedenis (1996) 138167.

Lucassen, Leo, en Floris Vermeulen, Immigranten en lokale arbeidsmarkt. Vreemdelingen in Den Haag, Leiden, Deventer en Alkmaar (1920-1940) (Amsterdam 1999).

Lucassen, Leo, 'Het einde van een migratieregime: buitenlanders in Holland gedurende de 19e eeuw', Historisch Tijdschrift Holland (2001) 190-211.

Mak, Geertje, 'Verschil als uitgangspunt. Een inbreng van vrouwenstudies op het terrein van (lokale) migratiegeschiedenis', 
Tijdschrift voor Sociale Geschiedenis (2000) nr. 4, 343-362.

Mandemakers, K. en O. Boonstra (red.), De levensloop van de Utrechtse bevolking in de 19de eeuw (Assen 1995).

Mandemakers, Kees, 'De Historische Steekproef van de Nederlandse Bevolking', in: Kees Mandemakers en Onno Boonstra (red.), De levensloop van de Utrechtse bevolking in de 19de eeuw (Assen 1995) 157162.

Mandemakers, Kees, 'Het HSN-bestand van de provincie Utrecht', in: Kees Mandemakers en Onno Boonstra (red.), De levensloop van de Utrechtse bevolking in de 19de eeuw (Assen 1995) 163-175.

Manneke, Nelleke, 'Reactie van Rotterdamse burgers op de migratie rond 1900', in: Paul van de Laar, Thimo de Nijs, Johan Okkema en Albert Oosthoek (red.), Vier eeuwen migratie. Bestemming Rotterdam (Rotterdam 1998) 172-187.

Marschalck, Peter, 'Einführung', in: Peter Marschalck (red.), Europa als Wanderungsziel. Ansiedlung und Integration von Deutschen im 19. Jahrhundert. IMISBeiträge 14/2000 (Osnabrück 2000) 7-12.

Maurik, Justus van, Toen ik nog jong was (Amsterdam 1901).

McCaffery, Robert Paul, Islands of Deutschtum. German-Americans in Manchester, New Hampshire and Lawrence, Massachussetts, 1870-1942 (New York 1996).

MacRaild, Donald M., Culture, conflict and migration. The Irish in Victorian Cumbria (Liverpool 1998).

Meder, Theo, Vertelcultuur in Waterland. De volksverhalen uit de collectie Bakker in hun context (ca. 1900) (Amsterdam 2001).

Meegeren, P.J.A. van, 'Katholiek Utrecht in de tweede helft van de 19e eeuw', Utrechtse Historische Cahiers jaargang 8 (Utrecht 1987) nr. $3 / 4$.

Meijler, F.L., 'Introduction', in: Th. W. Engelmann, professor of physiology, Utrecht (1889-1897). Some papers and his bibliography with an introduction by Dr. Frits $L$.
Meijler and a foreword (in Dutch) by Dr. Dirk Durrer (Amsterdam 1984) ix-xv.

Mertens-Westphalen, H., 'De Duitsers en de Hollandgänger in kluchten uit de 17e en 18e eeuw', in: A. Eiynck e.a. (red.), Werken over de grens. 350 jaar geld verdienen in het buitenland (Assen 1993) 52-59.

Mertens, J., Handel en wandel van de Teuten in Duitse gewesten (Lommel 1995).

Miellet, R., 'Westfaalse ondernemers en de opkomst van het Nederlandse grootwinkelbedrijf tot circa 1920', Jaarboek van de Geschiedenis van Bedrijf en Techniek 3 (1986) 135-157.

Miellet, R.L., 'Immigratie van katholieke Westfalers en de modernisering van de Nederlandse detailhandel', Tijdschrift voor Geschiedenis 100 (1987) 3, 374-393.

Miellet, R.L. Honderd jaar grootwinkelbedrijf in Nederland (Zwolle 1992).

Miellet, Roger, en Marieke Voorn, Winkelen in weelde. Warenhuizen in West-Europa 1860-2000 (Zutphen 2001).

Meulen, A. van der, en P. Smeele, 'Oosterhout als pottenbakkerscentrum in de negentiende en twintigste eeuw', Antiek, tijdschrift voor liefhebbers en kenners van oude kunst en kunstnijverheid, 24e jaargang (1989/90) deel 1 2-23, deel 2 63-87.

Meulen, Adri van der, en Paul Smeele, De IJsel, Doesburg 1841-1969. Portret van een Gelderse pottenbakkerij (Doesburg 1999).

Mol, Hein, Memoires van een havenarbeider. Van aantekeningen en een nawoord voorzien door Tony Jansen en Jacques Giele (Nijmegen 1980).

Morawska, Ewa, 'The sociology and historiography of immigration', in: Virginia Yans-McLaughlin, Immigration reconsidered. History, sociology, and politics (New York/Oxford 1990) 187-240.

Morawska, Ewa, Insecure prosperity. Smalltown Jews in industrial America, 1890-1940 (Princeton 1996).

Moya, Jose C., Cousins and strangers. Spanish immigrants in Buenos Aires, 1850-1930 (Berkeley 1998).

Mulder, K. Hannekemaaiers en kiepkerels (Haren 1971). 
Multatuli, Max Havelaar of de koffieveilingen der Nederlandse Handelsmaatschappij (oorspronkelijk 1860, herdruk Utrecht 1988).

Nadel, Stanley, Little Germany: ethnicity, religion, and class in New York City, 1845-80 (Urbana en Chicago 1990).

Nagler, Jörg, 'Frontier socialism: the founding of New Ulm, Minnesota, by German workers and Freethinkers', in: Eberhard Reichmann, La Vern J. Rippley en Jörg Nagler (red.), Emigration and settlement patterns of German communities in North America (Indianapolis 1995) 178-192.

Nas, F., Sigaren uit Dieren. Over sigaren, sigarenfabrikanten, sigarenmakers, sigarenverkopers en tabak (Bilthoven 1993).

Nancy, Alex van, De nomaden van Nederland. Onthullingen uit het leven der rondreizende kooplieden, alias venters en bedelaars (Geertruidenberg 1902).

Nierop, Leonie van, De bevolkingsbeweging der Nederlandsche stad (Amsterdam 1905).

Oberpenning, H., Migration und Fernhandel im "Tödden-System". Wanderhändler aus dem nördlichen Münsterland im mittleren und nördlichen Europa (Osnabrück 1996).

Ojeda-Ebert, Garardo Jorge, Deutsche Einwanderung und Herausbilding der Chilenischen Nation (1846-1920) (München 1984).

Ondere, Jochem van, Pijpenfabrikant en ouderling te Gouda, Mijn bezoek aan Bismarck in den zomer van 1875 (Deventer 1876).

Oost, Gerard, De orgelmakers Bätz (17391849). Een eeuw orgelbouw in Nederland (Utrecht 1975).

Opzoomer, C.W., De Bonapartes en het recht van Duitschland ook na Sedan. Redevoering ter opening der akademische lessen (Amsterdam 1871).

Ornée, W. A., De 'Mof' in de Nederlandse blijen kluchtspelen uit de 17e en 18e eeuw (Groningen 1970).

Padberg Evenboer, Klaas, 'Padberg (I) (kwartierstaat)', Nederlandse Genealogieën Deel
9 Koninklijk Nederlandsch Genootschap voor Geslacht- en wapenkunde (Den Haag 1989).

Panayi, Panikos, German immigrants in Britain during the 19th century 1815-1914 (Oxford en Washington 1995).

Panhuysen, B., Maatwerk. Kleermakers, naaisters, oudkleerkopers en de gilden (150o1800) (Amsterdam 2000).

Parot, Joseph John, Polish Catholics in Chicago, 1850-1920. A religious history (Illinois 1981).

Penninx, Rinus, Raster en Mozaïek. Uitgangspunten voor onderzoek naar internationale migratie, etnische processen en sociale ongelijkheid (Amsterdam 1994).

Penninx, Rinus, en Boris Slijper, Voor elkaar? Integratie, vrijwilligerswerk en organisaties van migranten (Amsterdam 1999).

Penninx, Rinus en Marlou Schrover, Bastion of bindmiddel? Organisaties van immigranten in historisch perspectief (Amsterdam 2001).

Phinney, J.S., 'Ethnic identity in adolescents and adults: review of research', Psychological Bulletin (1990) nr. 108, 499-514.

Plenge, Johann, Westerwälder Hausierer und Landgänger (Leipzig 1898).

Pöckling, L., Vestiging, groepsvorming en integratie van de Westerwalders in Amsterdam in de negentiende eeuw (Onuitgegeven scriptie Open Universiteit Nederland, cultuurwetenschappen Amsterdam 2001, aanwezig op het gemeentearchief Amsterdam).

Pöckling, Louk, en Marlou Schrover, 'Registers van verstrekte en geweigerde reis- en verblijfpassen (1849-1923)', in: Marlou Schrover (red.), Bronnen betreffende de registratie van vreemdelingen in Nederland in de negentiende en twintigste eeuw. Broncommentaren 5 (Den Haag 2002) 35-68.

Pohl, Hans, en Wilhelm Treue, Die Frau in der deutschen Wirtschaft (Wiesbaden 1985).

Poitrineau, Abel, 'Les Colporteurs d'autrefois en France', in: Wilfried Reininghaus (red.), Wanderhandel in Europa. Beiträge zur wissenschaftlichen Tagung in Ibbenbu- 
ren, Mettingen, Recke und Hopsten von 911. Oktober 1992 (Dortmund 1993) 73-80.

Portes, A., 'The informal economy and its paradoxes', in: N. J. Smelser en R. Swedberg (red.), The handbook of economic sociology (Princeton 1994) 426-449.

Pott, Wilfried, Westfaalse handelaren vestigen zich in Nederland. De families Sinkel, Moormann en Ten Brink op buitenplaatsen in Hilversum (Hilversum 2000).

Poppel, F. van, Trouwen in Nederland. Een historisch-demografische studie van de $19 e$ en vroeg-20e eeuw (Wageningen 1992).

Pozzetta, George E., 'Introduction', in: George E. Pozzetta (red.), Assimilation, acculturation and social mobility (New York en Londen 1991), v-x.

Prak, Maarten, Republikeinse veelheid, democratisch enkelvoud. Sociale verandering in het Revolutietijdvak's-Hertogenbosch 1770 1820 (Nijmegen 1999).

Puffelen, A.E. van, 'Deutsche Auswanderung nach Holland im 18. Jahrhundert, erläutert am Beispiel des Bergischen Landes', Zeitschrift Berg. Geschichtsverein 87 (1974/76) 51-76.

Randeraad, Nico, 'Negentiende-eeuwse bevolkingsregisters als statistische bron en middel tot sociale beheersing', Tijdschrift voor Sociale Geschiedenis (1995) 319-342.

Rappaport, Erika Diane, Shopping for pleasure. Women in the making of London's West End (Princeton 2000).

Ratcliffe, Peter, 'Conceptualizing "race", ethnicity and nation: towards a comparative perspective.' in: Peter Ratcliffe (red.), 'Race', ethnicity and nation. International perspectives on social conflict (Londen 1994).

Rath, J., Minorisering: de sociale constructie van 'etnische minderheden' (Utrecht 1991).

Reeves Kennedy, Ruby Jo, 'Single or triple melting pot? Intermarriage trends in New Haven, 1870-1950', American Journal of Sociology LVII, 56-59.

Reichmann, Eberhard, La Vern J. Rippley en Jörg Nagler, 'Introduction', in: Eberhard Reichmann, La Vern J. Rippley en Jörg
Nagler (red.), Emigration and settlement patterns of German communities in North America (Indianapolis 1995) ix-xvi.

Reineking-Von Bock, Gisela, 'Steinzeug Nachahmung, Nachbildung oder Fälschung?', Keramos 49 (1971) 3-66.

Reinsma, R., 'Het onderwijs in de provincie Utrecht tussen 1830 en 1850 volgens de rapporten van de hoofdinspecteur Wijnbeek', Jaarboekje Oud Utrecht (1964) 57116.

Rijnsoever. G.J. van, Sint Maarten in de Tolsteeg. Geschiedenis van de Sint Martinusparochie te Utrecht (Utecht 1947).

Reyneri, Emilio, 'The role of the underground economy in irregular migration to Italy: cause or effect?', Journal of Ethnic and Migration Studies (1998) vol. 24 no. 2, 313331.

Riley, Glenda, Building and breaking families in the American west (Albuquerque 1996).

Rippley, La Vern J., en Robert J. Paulson, German-Bohemians. The quiet immigrants (New Ulm 1995).

Roemen, Henricus Cornelis Wilhelmus, 'De ontwikkeling na 1870', in: Physisch- en Economisch-Geografische beschouwingen over de Rijn als Europese rivier. Vriendenboek aangeboden aan prof. W.E. Boerman (Rotterdam 1948) 61-88.

Rogier, L.J., Katholieke herleving. Geschiedenis van katholiek Nederland sinds 1853 (Den Haag 1962).

Rogier, L.J., en N. de Rooy, In vrijheid herboren. Katholiek Nederland 1853-1953 (Den Haag 1953).

Rogier, L.J., Schrikbeeld van een staatsgreep in 1853 (Amsterdam 1959).

Rommes, R., 'Lutherse immigranten in Utrecht tijdens de Republiek', in: Marjolein 't Hart, Jan Lucassen en Henk Smal (red.), Nieuwe Nederlanders. Vestiging van immigranten door de eeuwen heen.

(Amsterdam 1996), 35-54.

Rommes, R., 'Duitse immigratie in Utrecht vanaf de zestiende tot de achttiende eeuw', in: K. Davids, M. 't Hart, H. Kleijer, J. Lucassen (red.) De Republiek tussen zee en vasteland. Buitenlandse in- 
vloeden op cultuur, economie en politiek in Nederland 1580-1800 (Leuven/Apeldoorn 1995) 169-188.

Rommes, R., Oost, west, Utrecht best? Driehonderd jaar migratie en immigranten in de stad Utrecht (begin 16e - begin 19e eeuw) (Utrecht 1998).

Rommes, R., 'Café Italien', Oud-Utrecht. Tijdschrift voor de geschiedenis van de stad en provincie Utrecht 71 (1998) 86-87.

Rommes, Ronald, en Marlou Schrover, Grensverleggers. Gids voor lokaal historisch onderzoek naar migratie in de provincie Utrecht (Utrecht 2001).

Rooseboom, Hans, 'Wegner \& Mottu', in: Ingeborg Th. Leijerzapf (red.), Geschiedenis van de Nederlandse fotografie (Amsterdam 1984/2000), nr. 25, april 1995.

Rosenberg, H.P.R., De 19de-eeuwse kerkelijke bouwkunst in Nederland (Den Haag 1972).

Rosental, Paul-André, Les sentiers invisibles. Espace, familles et migations dans la France du 19e siècle (Parijs 1999).

Saar, J. du, 'Het Collegium Musicum Utrajectum in de laatste honderd jaar', Jaarboekje Oud-Utrecht 1941, 74-132.

Saharso, Sawitri, Jan en alleman. Etnische jeugd over etnische identiteit, discriminatie en vriendschap (Utrecht 1992).

Sahner, Wilhelm, Katholische und Evangelische Seelsorge des Deutschtums in Holland. Kirchliche und kulturelle Gliederung (Emsdetten 1950).

Salamon, Sonya, Prairie patrimony: family, farming and community in the Midwest (Chapel Hill 1992).

Sanders, Jimmy M. en Victor Nee, 'Limits of ethnic solidarity in the enclave economy', American Sociological Review (1987) vol 52, 745-767.

Santen, C.W. van, Het internationale recht in Nederlands buitenlands beleid (een onderzoek in het archief van het ministerie van buitenlandse zaken) (Den Haag 1953).

Santen, J.H. von, 'Politiek leven in de stad Utrecht rond het midden van de negentiende eeuw (1840-1860)', Jaarboek Oud Utrecht (1985) 110-165.
Schaik, A.H.M. van, 'Een nieuwe heer en een andere leer', in: R.E. de Bruin, P.D. 't Hart, A.J. van den Hoven van Genderen, A. Pietersma (red.), 'Een paradijs vol weelde'. Geschiedenis van de stad Utrecht (Utrecht 2000) 191-250.

Scheffer, A., Herinnering aan het veertigjarig bestaan der Handels-societeit te Utrecht, 1852-1892 (Utrecht 1892).

Schmitz, Heinz, 'Discriminatie of integratie van Duitsers in het negentiende-eeuwse Rotterdam? Een verkenning.', in: Paul van de Laar, Thimo de Nijs, Johan Okkema, Albert Oosthoek (red.), Vier eeuwen migratie. Bestemming Rotterdam (Rotterdam 1998) 124-145.

Schneider, Dorothee, 'The German bakers of New York city: between ethnic particularism and working-class consciousness', in: Camille Guerin-Gonzales en Carl Strikwerda (red.), The politics of immigrant workers. Labor activism and migration in the world economy since 1830 (New York en Londen 1993) 49-70.

Schrover, Marlou, 'Memory and identity of Dutch caravan travellers', Oral History (voorjaar 1990) 41-43.

Schrover, M., 'Omlopers in Keulse potten en pottentrienen uit het Westerwald', in: M. 't Hart, J. Lucassen en H. Smal (red.) Nieuwe Nederlanders. Vestiging van immigranten door de eeuwen heen (Amsterdam 1996) 101-120.

Schrover, Marlou, 'Groepsvorming onder Duitse aardewerkhandelaren in 19e-eeuws Holland en Utrecht', Historisch tijdschrift Holland nr.2 (1998) 94-112.

Schrover, Marlou, 'Wie zijn wij? Vrouwen, eten en etniciteit', Voeden en Opvoeden, Jaarboek voor Vrouwengeschiedenis 19 (1999) 115-144.

Schrover, Marlou, 'German communities in nineteenth-century Utrecht: Factors influencing the settlement process' IMISBeitrage. 14 (2000) 45-74.

Schrover, Marlou, 'Potverkopers, vijlenkappers, stukadoors en winkeliers. Nichevorming onder Duitse migranten in de negentiende-eeuwse stad Utrecht', Tijd- 
schrift voor Sociale Geschiedenis (2000) 281-305.

Schrover, Marlou, 'Maria en Rocco. Gemengde huwelijken en integratie in de negentiende eeuw', Gaan \& Staan, Jaarboek voor Vrouwengeschiedenis 21 (Amterdam 2001) 81-101.

Schrover, Marlou, 'Immigrant business and niche formation in a historical perspective. The Netherlands in the nineteenth century', Journal of Ethnic and Migration Studies vol. 27 (april 2001) 295-311.

Schrover, Marlou, 'Registratie van vreemdelingen in het bevolkingsregister (18501920)', in: Marlou Schrover (red.), Bronnen betreffende de registratie van vreemdelingen in Nederland in de negentiende en twintigste eeuw. Broncommentaren 5 (Den Haag 2002) 93-111.

Schrover (red.), Marlou, Bronnen betreffende de registratie van vreemdelingen in Nederland in de negentiende en twintigste eeuw. Broncommentaren 5 (Den Haag 2002).

Schumacher, Martin, Auslandsreisen Deutscher Unternehmer 1750-1851 unter besonderer Berücksichtigung von Rheinland und Westfalen (Keulen 1968).

Serfontein, W.J.B., Suid-Afrikaners in Utrecht 1762-1954 (Utrecht 1954).

Sickmann, J.W.M., T. Joustra-Schumacher, A Fontijn en H. Ruhe, 'Van Heuerleute en warmoezeniers', in: De Boerenwetering. Wonen, werken en vermaak langs een eeuwenoude waterweg (Uitgave Vereniging Historisch Amstelveen. Amstelveense Historische Reeks no. 2) (Amstelveen 1995) 61-68.

Sleebe, V.C., In termen van fatsoen. Sociale controle in het Groningse kleigebied 17701914 (Groningen 1994).

Sluyterman, K.E., Ondernemen in sigaren. Analyse van bedrijfsbeleid in vijf Nederlandse sigarenfabrieken in de perioden 1856-1865 en 1925-1934 (Tilburg 1983).

Smith, Anthony D., 'Chosen peoples: why ethnic groups survive', Ethnic and Racial Studies (juli 1992) Vol. 15, nr. 3, 436-456.

Snelders, H.A.M., De geschiedenis van de scheikunde in Nederland. Van alchemie tot chemie en chemische industrie rond 1900 (Delft 1993).

Snell, Gesa, Deutsche Immigranten in Kopenhagen 1800-1870. Eine Minderheit zwischen Akzeptanz und Ablehnung (Münster 1999).

Staatscommissie over de werkloosheid (ingesteld bij koninklijk besluit van 30 juli 1909 no 42) IV Verslag van de derde sub-commissie (Den Haag 1913).

Stafleu, M., 'Erich Wichman (1890-1929) Kunstenaar, activist en bohémien', in: J. Aalbers e.a. (red.), Utrechtse biografieën. Levensbeschrijvingen van bekende en onbekende Utrechters 1 (Amsterdam/Utrecht 1994) 197-201.

Statuten van de Vereeniging genaamd de Cholera Commissie te Utrecht opgericht in 1866 (Utrecht 1874).

Een stemgeregtigde, De zogenaamde geheime genootschappen der protestanten in Nederland verdedigd. Zestal brieven aan den $\mathrm{Ne}-$ derlandschen kiezer (Amsterdam 1853).

Stepick, A., 'Community growth versus simply surviving: the informal sectors of $\mathrm{Cu}$ bans and Haitians in Miami', in: M. Estellie Smith (red.), Perspectives on the informal economy; monographs in Economic anthropology no. 8 (Lanham 1990) 183-205.

Sterk, Hans, 'Rondom de Galekopsteeg 18581885. Enige aspecten van de prostitutie te Utrecht', Tijdschrift voor Sociale Geschiedenis (1983) 79-107.

Sterk, Hans, 'Buitenechtelijke geboorten in Utrecht 1775-1825. Een historisch-demografisch onderzoek.' Tijdschrift voor Sociale Geschiedenis (1987) 1-32.

Struck, W.H., Die Auswanderung aus dem Herzogtum Nassau (1806-1866) (Wiesbaden 1966).

Struick, J.E.A.L, Utrecht door de eeuwen heen (Utrecht/Antwerpen 1968).

Tack, Johannes, Die Hollandgänger in Hannover und Oldenburg. Ein Beitrag zur Geschichte der Arbeiter-Wanderung (Leipzig 1902).

Tenfelde, Klaus, 'Dienstmädchengeschichten. Strukturelle Aspekte im 19. und 20. 
Jahrhundert', Zeitschrift für Unternehmensgeschichte Beiheft 35 .

Tigelaar, H., Index van namen van personen: - die zich na overlegging van een akte van indemniteit te Utrecht gevestigd hebben, - die te Utrecht om het recht van inwoning verzocht hebben 1726-1811 (1812) (Gemeentelijke Archiefdienst Utrecht, Utrecht 1991).

Tilly, Charles, 'Migration in modern European history', in: William H. McNeill (red.) Human migration. Patterns and policies (Bloomington 1978) 48-72.

Tilly, Charles, 'Transplanted network', in: Virginia Yans-McLaughlin (red.), Immigration reconsidered. History, sociology, and politics (New York/Oxford 1990) 7995.

Tjin, R., 'Nederlandse paspoorten. De politiek van reizen en identificatie van personen', Amsterdams Sociologisch Tijdschrift, 17 (1990) 74-100.

De toestanden der werklieden in de bouwbedrijven te Amsterdam. Rapport uitgebracht door de commissie van onderzoek benoemd door de gemeenteraad in zijn vergadering van 30 juni 1897 (Amsterdam 1898).

Toom, T.W.F. den, De orgelmakers Witte. Een bijdrage tot de geschiedenis van de orgelbouw in Nederland in de tweede helft van de negentiende eeuw (Utrecht 1997).

Tschudi, P. von, Geschichte der deutschen Evangelischen Gemeinde im Haag (Göttingen 1932).

Umbgrove, G., Neerlands roeping (Arnhem 1871).

Utrecht tussen Pruis en Francoos 1780-180o. Uit de papieren van tijdgenoot C.J. Nagtglas, aangevuld door F. Nagtglas, opnieuw uitgegeven met aantekeningen van $d r$. A. van Hulzen (Utrecht 1975).

Veenendaal, A.J., De ijzeren weg in een land vol water. Beknopte geschiedenis van de spoorwegen in Nederland 1834-1958 (Amsterdam 1998).
Veenis, Milena, Kartoffeln, Kuchen und Asado. Over de verborgen keuken van Duitsers in Argentinië (Amsterdam 1995).

Venetië, Robbert van, en Annet Zondervan, 'Friedrich Julius von Kolkow', in: Geschiedenis van de Nederlandse fotografie, 16, 115.

Verhoeven, T.H.G., 'Stedelijk leven in een stroomversnelling', in: R.E. de Bruin, P.D. 't Hart, A.J. van den Hoven van Genderen, A. Pietersma (red.), 'Een paradijs vol weelde'. Geschiedenis van de stad Utrecht (Utrecht 2000) 375-433.

Verkuyten, Maykel, Etnische identiteit. Theoretische en empirische benaderingen (Amsterdam 1999).

Vermeulen, Hans, Etnische groepen en grenzen. Surinamers, Chinezen en Turken (Weesp 1984).

Vermooten W.H., 'Schets van de geschiedenis van het Utrechtsche marktwezen in de 19e eeuw', Jaarboekje Oud Utrecht (1933) 157194.

Verslag van de Vereeniging tot Verbetering der Volksgezondheid. Mededeeling op de eerste algemeene vergadering gehouden den 9 den augustus 1866.

Vijlbrief, I., Van anti-aristocratie tot democratie. Een bijdrage tot de politieke en sociale geschiedenis der stad Utrecht (Amsterdam 1950).

Vink, J., Utrecht's Rijnverbinding in den loop der eeuwen, Maandblad Oud-Utrecht, (1928) 89-96.

Visser, C.Ch.G., Luthersen in Utrecht. Hun komst, geschiedenis en huidige situatie (Utrecht 1963).

Vlassenroot, Koen, 'Sociale en politieke functies van etniciteit. Verkenning en operationalisering van een begrippenkader', Tijdschrift voor sociale wetenschappen (1997) 42 nr. 4, 385-407.

Vliet, Kaj van, 'Middeleeuws Utrecht: een markt in ontwikkeling', in: Jan Brugman, Hans Buiter en Kaj van Vliet, Markten in Utrecht van de vroege middeleeuwen tot $n u$ (Utrecht 1995) 8-43.

Vliet, K. van, 'De stad van de burgers', in: R.E. de Bruin, P.D. 't Hart, A.J. van den Hoven 
van Genderen, A. Pietersma (red.), 'Een paradijs vol weelde'. Geschiedenis van de stad Utrecht (Utrecht 2000) 73-113.

Vogel, Jaap, 'Duitse predikant in opspraak. Hieronymus Durer: zijn geloof, zijn kerkenraad en zijn 'dienstmaagd', Haarlem Jaarboek 1999 (Haarlem 2000) 21-50.

Vogelzang, F., 'Clara Wichmann (1885-1922) Maatschappijhervormster', in: J. Aalbers e.a. (red.) Utrechtse biografieën. Levensbeschrijvingen van bekende en onbekende Utrechters 3 (Amsterdam/Utrecht 1996) 202-209.

Vooys, A.C. de, De trek van de plattelandsbevolking in Nederland. Bijdrage tot de kennis van de sociale mobiliteit en de horizontale migratie van de plattelands bevolking (Groningen en Den Haag 1932).

Vooys, A.C. de, Het huwelijkspatroon in Nederland in het midden der 19de eeuw toegelicht aan een onderzoek in Utrecht. Mededeling no. 1 van de afdeling Historische Geografie (Utrecht 1965).

Vos, F.E., Onderzoekingen over de choleraepidemie van 1866 gemeente Utrecht (Alphen aan de Rijn 1867).

Vos, Jozef, 'Nationale kunst en lokale sociabiliteit: de Nederlandse mannenzangverenigingen in de negentiende eeuw', Bijdragen en Mededelingen betreffende de Geschiedenis der Nederlanden 112e jrg. (1997) nr. 3 , 364-381.

Vosburgh, Miriam G., en Richard N. Juliani, 'Contrasts in ethnic family patterns: the Irish and the Italians', Journal of comparative family studies, vol. Xxi (1990) nr. 2, 267-286.

Vreede, G.W., Onze volksgeest voor en na de grondwetherziening van 1848. Teekenen des tijds. Eischen van het oogenblik (Utrecht 1870).

Vredenburgh, W.C.A. van, Schets van eene geschiedenis van het Utrechtsche studentenleven (Utrecht 1914).

Vries, Boudien de, 'Onder ons? Vrouwen en verenigingen in de negentiende-eeuwse stad', Jaarboek voor Vrouwengeschiedenis 22 (2002) 97-125.
Vulpen, Nellie van, 'Vermaak in Utrecht (1850-1880). Publiekswerving door de Utrechtse Schouwburg en de koffiehuizen', Jaarboek Oud-Utrecht (1995) 119-138.

Vulsma, R.F., Burgerlijke stand en bevolkingsregister (Den Haag 1988).

Vuuren, L. van, Rapport betreffend een onderzoek naar de Sociaal Economische struktuur van een gebied in de provincie Utrecht, omvattende Utrecht als centrumgemeente en negen randgemeenten (Utrecht 1937).

Wachlin, S., 'Fotografen - een overzicht', in: J.W.L. Hilkhuijsen (red.), De stad Delft. Cultuur en maatschappij van 1813 tot 1914 (Delft 1992) 303-310.

Wachlin, Steven, en Hans Rooseboom, 'Parijzenaar of Amsterdammer', Nieuwsbrief Nederlands fotogenootschap, nr. 17 Fotografen in Amsterdam (maart 1997) 15-16.

Waldinger, R., Still the promised city? AfricanAmericans and new immigrants in postindustrial New York (Cambridge MA/Londen 1996).

Waters, Tony, 'Towards a theory of ethnic identity and migration: the formation of ethnic enclaves by migrant Germans in Russia and North America', International Migration Review (1995) vol. 29 no. 2, 515544 .

Wehner-Franco, Silke, Deutsche Dienstmädchen in Amerika 1850-1914 (Münster/New York 1994).

Wehner, Silke, 'German domestic servants in America, 1850-1914: a new look at German immigrants Women's experiences', in: Dirk Hoerder en Jörg Nagler (red.), People in transit. German migrations in comparative perspective. 1820-1930 (Cambridge 1995) 267-293.

Wegener, A., Ochtrup, ein Heimatbuch (zp, zj). Wels, C.B., 'Kanttekeningen bij "Schrikbeeld van een staatsgreep in 1853", Bijdragen en Mededelingen voor de geschiedenis der $\mathrm{Ne}$ derlanden XVII (1963) 70-77.

Wennemann, A., Arbeit im Norden. Die Italiener im Rheinland und Westfalen des späten 19. und frühen 20. Jahrhunderts (Osnabrück 1996). 
Werbner, P., 'From rags to riches: Manchester Pakistanis in the textile trade', New Community (1980) viII vol 1/2.

Werf, Rosa, 'Mobach Pottenbakkers - seit 1895 in Utrecht', Keramische Zeitschrift, jrg. 33 (1981) nr. 3.

Wierst, Henk, Photographieën \& dynastieën: beroepsfotografie in Groningen 1842-1940 (Bedum 2000).

Wijbenga, D., 'Zorg voor armen en wezen', in: I.V.T. Spaander en R.A. de Leeuw (red.), De stad Delft, cultuur en maatschappij van 1667 tot 1813 (Delft 1982).

Wijne, H.A., De wet op het regt van patent uit een handels- en staathuishoudkundig oogpunt beschouwd (Groningen 1853).

Wilken, P.H., Entrepreneurship. A comparative historical study (Norwood 1979).

Wingelaar, Koos, 'Studeren in de negentiende eeuw. Een onderzoek naar het hoger onderwijs en met name naar de studenten aan de Utrechtse universiteit in de periode 1815-1877', Utrechtse Historische Cahiers jaargang 10 (1989) nr. 1/2.

'Winkelen in Utrecht omstreeks 1900', Maandblad Oud Utrecht (1963) 70-81.

Witsen Geysbeek, P.G., (red.), Algemeen noodwendig woordenboek der zamenleving (Amsterdam 1836-1861).

Woerden, H. van, De familie Schlatmann. Geschiedenis van een Tjoddengeslacht (Oegstgeest 1953).

Wolff-Gerzon, A., 'Au Bonheur des Dames'. Uit het Nederlandse kledingbedrijf van de laatste honderd jaar (Amsterdam 1949).
Woltring, J., Bescheiden betreffende de buitenlandse politiek van Nederland 1848-1919, tweede periode 1871-1898, eerste deel 18711874 (Den Haag 1962) RGP 107, nr. 302.

Woollett, Anne, Harriette Marshall, Paula Nicolson, Neelam Dosanjh, 'Asian women's ethnic identity: the impact of gender and context in the accounts of women bringing up children in East London', in: KumKum Bhavnani en Ann Phoenix, Shifting identities, shifting racisms. A feminism \& Psychology Reader (Londen/Thousand Oaks/New Delhi 1994) 119-132.

Woude, R.E. van der, Leeuwarden 1850-1914. De modernisering van een provinciehoofdstad (Groningen 1994).

Wubben, H.J.J., 'Chineezen en ander Aziatisch ongedierte' Lotgevallen van Chinese immigranten in Nederland, 1911-1940 (Amsterdam 1986).

Wurf-Bodt, Coby van der, Van lichte wiven tot gevallen vrouwen. Prostitutie in Utrecht vanaf de late middeleeuwen tot het einde van de negentiende eeuw (Utrecht 1988).

Zoelen A.J. van, Nieuwkomers in de eerste helft van de negentiende eeuw (ongepubliceerd onderzoeksverslag vu Amsterdam 2000).

Zomerdijk, H.J., Het muziekleven in NoordBrabant 1850-1914 (Tilburg 1982).

Zwaal, P., Frisdranken in Nederland, (Rotterdam 1993). 


\section{Index}

Bij namen van immigranten is in deze index de spellingsvariant opgenomen die het meeste voorkwam in de bronnen en niet bijvoorbeeld de meest Duitsklinkende variant. Namen werden veelvuldig ook anders gespeld.

Plaatsnamen die in de tekst alleen in voorbijgaande zin worden genoemd zijn niet opgenomen in de index.

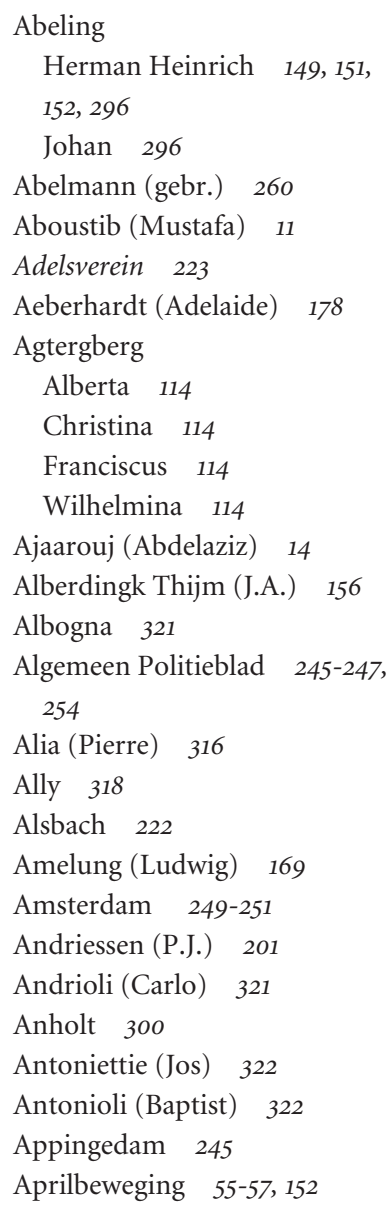

Arabische Democratische
Arbeiderspartij 11
Arends
Dirk 213
Johannes 212
Armfelt 165
Arnal (Susanna) 318
Asselijn (Thomas) 50
Association of German

Governesses in England 178

Au Bon Marché 272

Aurillac 318

Aurora $164-170,181$

Badbergen 262

Bätz \& co 210

Bätz (Johann) 210

Bahlman 56

Baille (Antoine) 316

Bakkenes

Catharina 296

Geertruida 296

Otto 296, 297

Bakkers (Wilhelm) 326

Bapretti (Camillo) 29

Barberini

Franciscus 322

Magdalena 322

Barmen 290

Barth (Frederik) 14

\author{
Bassenge 314 \\ Bassignac-le-Haut 318 \\ Balkema (Tanja) 249 \\ Bauer \\ Gustav 44 \\ Hermann 41-46 \\ Baumbach 222, 231, 232 \\ Baurieux \\ Marie Jeanne 315 \\ Pierre 315 \\ Beathmann 210 \\ Becher (Richard) 205 \\ Beck (Petrus van der) 247 \\ Beek (van) 313 \\ Beer (Maria de) 321 \\ Beesten 263 \\ Beiler (Jacobus) 245 \\ Bender (Petrus) 254 \\ Bender \& Garthmann 277 \\ Berbice 326 \\ Bergh (S.J. van den) $\quad$ 57-58 \\ Bergsteijn (Nicolaas) 132 \\ Bernhardium 305 \\ Bernhards (Daniel) 305 \\ Bernulphusgilde 156-160 \\ Bertorelli (A.) 322 \\ Besteedsters 300, 302 \\ Betmann (Wilhelmina) 301 \\ Bevolkingsregister 20, 71-79 \\ Biehme (Robert) 202
}


Bierens de Haan (P.) 308

Bierhaus (Johannes) 169

Bimermann (P.) 204

Bischofer (Franz) 323

Blankenstein 116

Blind (Jacob) 205

Blom (Gerard) 157

Bockhofen 44

Böckling 236

Böker

Gerardus 114
Johan 114
Maria Gesina 115
Maria Gertrud $\quad 114,115$

Boerenwetering 198

Bohlen 142, 168, 261, 278, 281

Anton 281

Bohlman 164

Bonhôte (Rentine) 178

Boom (Maria van) 164

Borken 262

Bornheim 116

Bossenbroek (Martin) 199, 200

Boudriat (Wilhelm) 158

Bouman (Kasper) 246

Bouter (C. de) 214

Bovenkerk (Frank) 322

Brageac 318

Braun (Wilhelm) 103

Breckerfeld 290

Breitenau 222

Brenner (Mouritz) 208

Brill (Gerard) 205

Brink (ten) 264, 269, 274

Agnes 269

Brochterbeck 263

Broers 94

Brom (Gerard) 156-160

Brüning (Agnes) 274

Bruin

Johannes de 130

Lambert de 133

Brummer (F.) 259, 260

Bruyn (Roelof de) 326

Buddenberg (Louise) 205

Büdde (Johan) 169

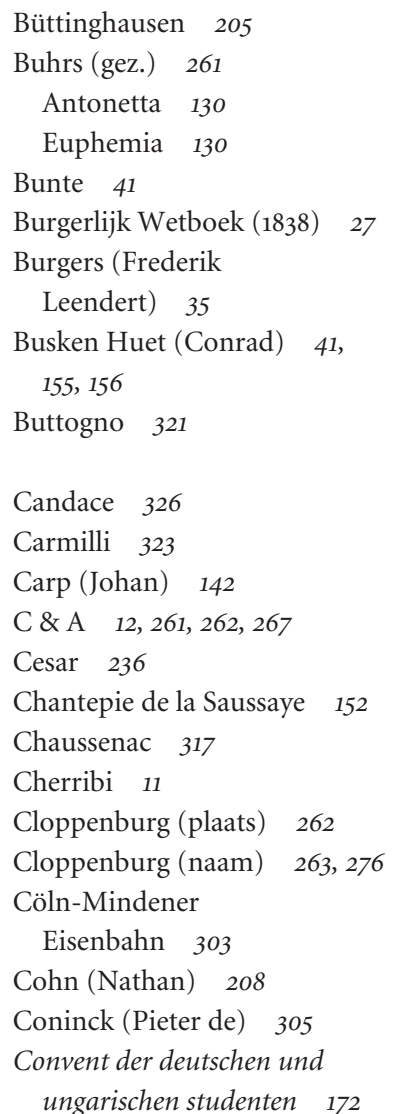

Corbesier (Wierck) 169.315

Corcilius

Joannes 247

Johann Wilhelm 245

Corsa (Jean) 316

Coster (Samuel) 48

Costerus 51, 184

Corzilius

Maria Catharina 250

Peter 250

Cottaar (Annemarie) 314-316, 322

Coulembier (Augustine) 315

Couperus (Louis) 220

Cramer (Jan Willem) 49

Crandelles 318

Cros-de-Montvert 318

Cuypers (P.J.H.) 156
Daguerre (L.J.M.) 203

Deessen 222

Delft 251-253

Demerara 326

Dernbach 222

Dassart (Francois) 315

Deutmann (F.W.) 204

Deutscher Kellner Bund Union

Ganymèd 201

Deutsche Verein zu

Utrecht 178-180

Diederiks (Herman) 125

Dienstbücher 299

Diepholz 262

Dillen (Alegonda van) 315

Dingstede 296

Dinklage 262

Döhlen 296

Dokkum (van) 161

Dolinski 215

Dombauhütte 157, 158

Domicilie van

Onderstand 34, 72

Donders (F.C.) 116, 307

Dooren (Pieter van ) 277

Dorresteijn (Heijltje) 251, 252

Dreesmann 274

Anton 273

Reinhard 281

Dresler (Joseph) $\quad 76$

Drie (Francois) 316

Dross (Werner) 152

Droste (Clemens August) 126

Drukker

Hermanus Mozes 103

Hartog Moses 103

Druogno 321

Ducaat (Stina) 132

Dülmen 262

Dunk (H. von der) 165

Duitsche Nederlandsche Stoom

Viltenhoedenfabriek 208

Duitse Bond 58, 223

Duits Tolverbond 223, 229

'Duitsland' 83-85

Duvelop (Maria) 252 
Ebenwien (Frans) 112

Ehringhausen 222, 252

Eilers (Frederik) 150, 297

Eilpe 290

Eiselen (Ernst) 173

Elberfeld 86

Elgendorf 222

Elten 300

Emmerich 300

Engelen (van) 184

Engelmann

Louise 307

Theodor 307

Erhrenbreitstein 113

Ermann (Philip) 40,177

Eschelbach 222

Ess (van) 170

Esselman (Heinrich) 117

Essen 262

Euler (Carl) 155, 173

Evers (Felix) 266

Everwijn 208, 289

Fabricius (Frederik) 170

Fairlie (Robert W.) 263

Fakkel (de) 57

Farouk (Ibrahim) 11

Finger (Theodor) 168

Fischer (Johannes) 113

Flegelskamp (Maria

Louisa) 118

Fochetti (Bernardus) 322-323

Fockink (Wijnand) 228

Fogleman (Aaron S.) 95

Fohr 236, 237

Jacob 237

Johann 232

Maria-Anna 237

Wilhem Franz 169

Fredja 326

Frenkel (Izak) 127

Frenai

Arnoldus 315

Johan 315

Matthijs 315

Pascal 315
Frenay (Eustache) 103, 168, 169, 315

Freren 263

Frétropp (Georg) 114

Fricke 148

Friesoythe 262

Frisse (Gebr.) 256, 257

Fritz (Anna) 238

Fruschel (Joana) 78

Fuchs

August 250, 251, 253, 254

Wilhelmina 113

Fürstenau 262

Gaag

Jacob van der 251, 252

Maria van der 252

Gadellaa (Hendrika) 312

Galensloot (Gerrit van) 313

Galliri (Romualdo) 320

Gantevoort (Jacob) 196

Garms (Johan) 296

Geel en Fievez dite de Chalines, van 279

Geelhart 236

Maria 252

Genderen (van) 283

Georgsmarienhütte 262

Gericke van Herwijnen 66

Gerhards 236

German-American Turner

Movement 173

Gerritzen (Hendrikus) 213

Gesindeordnungen 299

Geuer (Heinrich) 157, 160-162, 168,169

Gielson (Arnoldus) 315

Giershofen 222

Givet 114

Gladbach 222

Glazewski 169, 215

Gleidorf 255

Glons 314

Goch 300

Godefroi 51,53

Goudeau 317

Elisabeth 318
Goudoever (L.C. van) 307

Goudoever (W. van) 32, 75

Graf (Auguste) 177

Grasveld 169, 274

Green (Nancy) 22, 23, 327

Griethausen 300

Groen (Johan) 112

Gronemeijer (Carl) 170

Gronwal (Maria) 302

Groot (J. de) 208-209

Groote (Eduard Walther

de) 289

Grossenkneten 296

Grothe 208, 209

Carl 142, 168, 306

Diderik 177

Günther (Anna

Katharina) 232

Güsbacher (N.) 40

Guisti (L.) 322

Gunther 236

Gustaaf Adolf Veree-

niging $152-156,168,174$

Gustav Adolf Stiftung 152-156, 181

Haagen
Julius 168
Maria 131
Martiena 131
Hagen 291
Hahn 222
Halbisch
Jacob 129
Johanna 130
Johannes 130
Wilhelmina 130
Wilhelmus 130
Hall-Viruly (Julia van) 130
Haren 262
Harst (Gerard van der) 322
Hartenfels 222
Hasselt (Johannes van) 326
Halthausen
Theodora 111
Hendrina 111
Handels-Societeit 140,141




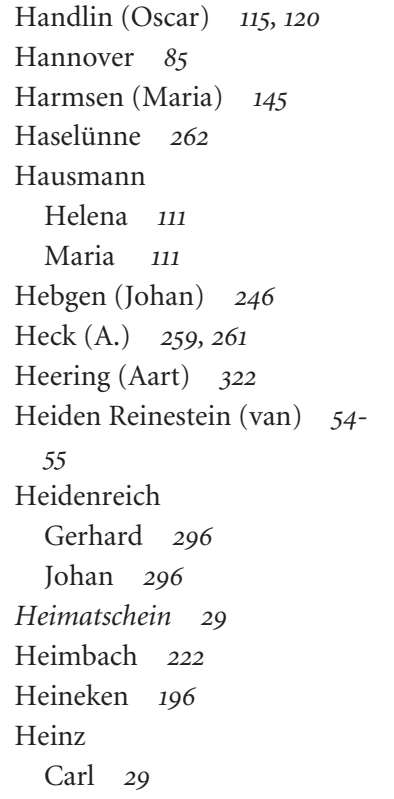

Peter Modest Valentin 246

Helferskirchen 222

Hembergen 262

Hemmerlé (Anna Maria) 246

Hengst 53

Henkes 236

Hennings (Heinrich

David) 281

Herbig (Conrad) 25

Herdecke 290

Herschbach 222

Hessink (Heinrich) 33-34

Heukelum (Gerard van) 156, 157

Heuker (Christiaan) 196

Hibbeln (Wilhelm) 207

Hillscheid 222

Hindenburg-Feier 180

Hisgen (Julius H.) 168, 169, 306

Historische Steekproef

Nederland (HSN) 22

Hofstée (Justine) 274

Höhr 222, 252

Hoenselaar (Maria) 321

Hölzmann (Peter) 238

Hollmann

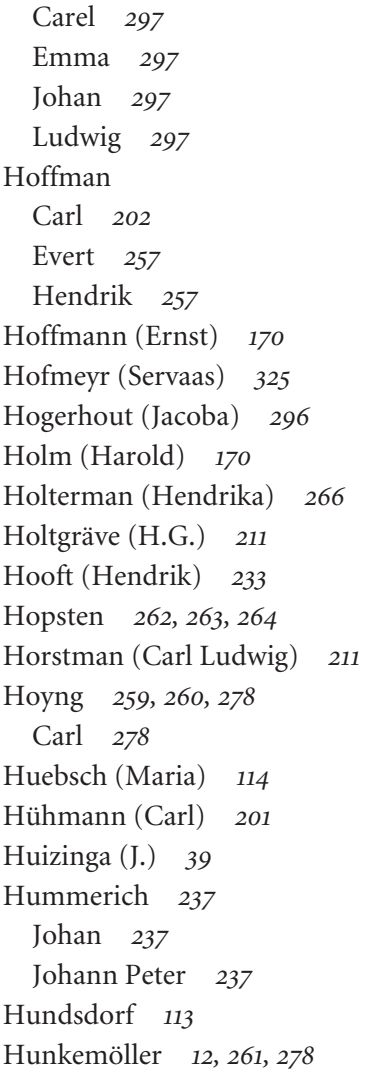

Ibbenbüren 263

IJpelaan (Catharina) 296

Innere Mission 150-152, 181

Isselburg 300

Jäger 236,238

Anna 237

Joseph 238

Jahn (Ludwig) 173

Janssen (L.J.F.) 152

Jens 94

Jutjesdag 299

Kaijser (Frederich) 168, 169, 204

Kalb 236

Anna Maria 248

Elisabeth 248

Johann 244

\author{
Johann Peter 243 \\ Johannes 237 \\ Margaretha 237 \\ Maria 237 \\ Petrus 252 \\ Kalkar 300 \\ Kalkhoff (Hendrik) 35 \\ Kammerforst 222 \\ Kamphoefner (Walter) 75, \\ 115, 117, 120
}

Karageorgis (S.) 23

Katscher (Leopold) 68

Kattner (Laura Ann) 125

Kellen 300

Kempen (van) 42

Keulschevaart 235

Keulse Kwestie 126

Keulse Veer 235

Kiek (David) 203

Kintzelé 285

Kist (F.C.) 167

Klaassen (Alida) 315

Klauer

Anna Eva 132

Catharina 132

Kleef 300

Kleefsland 85, 287, 298-302

Klein 236

Kleine (August) 168

Kleinmaischeid 222

Kleudgen

Anna 244

Margaretha 244

Klosch (Margaretha) 113

Knoop (Jan) 150, 297

Kober (A.) 266

Koch 236, 238, 241

Elisabeth 238

Johan 145

Kögel 154

Köhler (H.L.) 140

Kölnische Turnverein 173

Koenig (W.) 169

Kompagnie 199, 200

Kooij (Pim) 313

Korzilius 236

Johann 248 


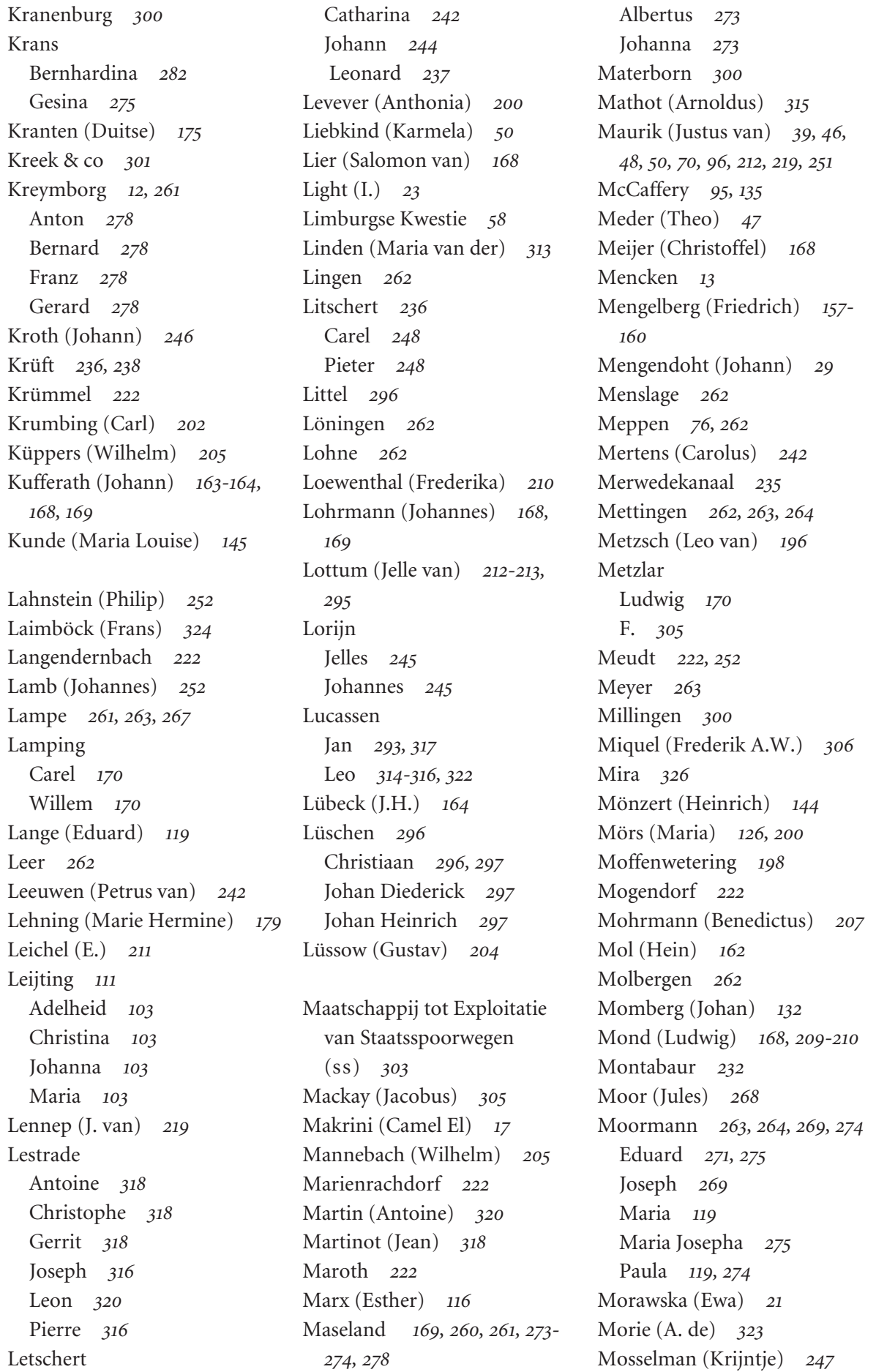




\begin{tabular}{|c|c|c|}
\hline Mouillard (Victor) 315 & Olympia 174 & Punder (Gerard de) 249 \\
\hline Muijs (Carel) 133 & Ondere (Jochem van) $62-65$, & \\
\hline Münster 262 & 121 & Quakenbrück 262 \\
\hline Münsterland $90,259-286$ & Opzoomer (C.W.) $\quad 61,63$ & \\
\hline Multatuli 195 & Osthues (Heinrich) 116 & Rahr (Henry Jacques) 142, \\
\hline Muller & Overklieft 296 & $164,168,169$ \\
\hline Amalia 118 & & Ransbach $85,117,90,169,219-$ \\
\hline Hendrik 74 & Padberg (Frans) 257 & 257 \\
\hline Mundt (Carolina) 326 & Panayi (Panikos) 22, 165 & Rapp (Johannes) 144 \\
\hline Muskens & Parris 326 & Rappo (F.) 311 \\
\hline Dorothea 111 & Patentbelasting $72-74,311$ & Ras (Maria) 133 \\
\hline Petronella 111 & Patraminski 215 & Rathmann (Heinrich \\
\hline Sibilla 111 & Patzer 169 & Otto) 151,152 \\
\hline & Pau (Matheus) 297 & Recke 262,263 \\
\hline Naber (C.F.A.) 211 & Peacock (Ludwig) 169,277 & Ree (Johannes) 200 \\
\hline Nadel (Stanley) 22, 165 & Peek (Johan) 276 & Rees 300 \\
\hline Nagel (Maria) 326 & Peek \& Cloppenburg 12,116 & Reeves Kennedy (Ruby Jo) \\
\hline Nancy (Alex van) 47 & $259,260,261,267,272,276-278$ & Reintjes \\
\hline Nassau $\quad 219-258$ & Peffer (Maria Agnes & Elisabeth 164 \\
\hline Nauort 222 & Theresia) 200 & Theodorus 103 \\
\hline Nederlandsche & Perier (Maria) 318 & Reis- en verblijfpas 30 \\
\hline Centraalspoorweg & Perrin (Esther) 178 & Remscheid 90, 291 \\
\hline Maatschappij (NCs) 303 & Pfenning & Rencker (Christiaan) 142, 149, \\
\hline Nederlandsche Rhijnspoorweg- & Catharina 247 & $197,205-208$ \\
\hline maatschappij (NRs) 303 & Christiaan 247 & Renier (Arnoldus) 315 \\
\hline Neuenkirchen 85,262 & Johan 247 & Rennert (Johanna) 129 \\
\hline Neuhaus (Johan) 296 & Margaretha 247 & Rensen (Wilhelmina) 321 \\
\hline Niekiel & Pieter 247 & Rentier (Camille) 320 \\
\hline Jacob 202 & Plagge (Eilard) 281 & Rheine 262 \\
\hline Pieter 202 & Plantlünne 263 & Ribbius Peletier 202 \\
\hline Niemann (Wilhelm & Plenge (Johann) 221, 231, 242, & Richter (Adelheid) $\quad 116$ \\
\hline August) $\quad 281$ & 243,244 & Rieges (Johan) 145 \\
\hline Nierman (Carolina) $\quad 278,281$ & Plett & Rijgheld (Joannes Petrus) \\
\hline Niermann (Luise) 273 & Maria 292 & Rijnbond 223 \\
\hline Nierop (Leonie van) $\quad 50-51$ & Johannes 292 & Rijnhout (Johannes) 322 \\
\hline Niemeyer (Hendricus) 301 & Prijs & Rijnsoever (van) 169, 239 \\
\hline Nieuwenhuis (Jacob) 148 & Angenita 114,115 & Rijsselberge (Jean) 126 \\
\hline Norden 113 & Dirk 114,115 & Rochussen 66 \\
\hline Nordenau 255,256 & Maria Gesina 114,115 & Roclenge 314 \\
\hline Nordhorn 262 & Prosch (Peter) 324 & Rödenbeck 296 \\
\hline & Proudhon (P.J.) 54 & Röhm (Catharina) $\quad 176$ \\
\hline Oberhaid 222 & Pöckling (Louk) 249 & Roeters (Hendrik) 250 \\
\hline Oberkirchen 255 & Polderman (Louis) 326 & Rogier (L.J.) $\quad 12-13,49-50,57$, \\
\hline Ober-Sorpe 255 & Pontier (Johanna) 119 & $69,90,157,158$ \\
\hline Oelkinghausen 290 & Povel & Rolin 317 \\
\hline Oldenbarneveld $\quad 178$ & Anton $169,271,273$ & Rommes (Ronald) \\
\hline Oldenburg $\quad 85,262,293-297$ & H.L.P. 273 & 234,322 \\
\hline
\end{tabular}


Roos (Friedrich

Wilhelm) 209-210

Rosenbaum (Johann) 131

Rosfary (Henri) 315

Ruhrort 313

Ruland 322

Rulfs

Anna Catharina 132

Anna Karolina 132

Rudersdorf 169

Rusconi (Johannes) 321

Sabler (Julius) 140

Sahner (Wilhelm) 135, 179180, 293

Salzer (Friedich) 307-308

Sandt, van der 117, 142, 215, 259-285

Engelbert 119

Gerardus 119, 274

Sasso (Francesco del) 322

Sauerland $85,90,255-256$

Savels (Maria) 157

Schanze

Christiaan Herman $\quad$ 142, 303

Gotlieb Julius 303

Scharzman (S.) 113

Schattenberg (Helena) 157

Schapen 262, 263, 264

Schavinie (Johannes) 322

Schirmer (Reinholt) 169

Schlatmann 146

Gustav 274

Zacharias 274

Schlüter $259,260,261,278,281$

August 142

August Herman 149, 281

Heinrich 142

Heinrich David 281

Schmallenberg 256

Schmidt (Johann Adam) 247

Schneider (Dorothee) 213

Schober (Christiaan) 140

Schräder \& Kauling 260

Schröder (J.B.) 261

Schröder (Johannes) 145, 168, 169, 297
Schröder van der Kolk 173

Schroder (Anna Maria) 281

Schumacher 272

Schultz (Theodoor) 196

Schulze (Frederik) 174

Schütter (Hermina) 130

Schütze (Mina) 112, 113

Schwanderlapp (Anna) 252

Schwelm 290

Seelberg (Georg) 74

Segbers (Bernard) 130

Seima 326

Selbach 236

Selbecke 290

Seligberger (Emma) 127

Selters 232

Sessenhausen 222, 253

Shelfish-club 160-162

Siegel (Heinrich) 207

Sigler (Georg) 158

Simonis (Rocco) 321

Sinkel 11-12, 56, 76, 117, 259285, 298

Anton 11-12, 269, 271

Bernard 271

Hermann 271

Joseph 271

Sluijter (Gerhard) 275

Smits (Jacobus) 130

Smits \& De Wolff 210

Snell (Gesa) 22

Snellen 241

Solingen 291

Spellen 118

Stad Parijs 277

St. Jean-Molenbeek 114

St. Maria Maggiore 321

St.-Martin-Cantalès 318

St.-Santin-de-Maurs 318

Steenbeek (Gijsberta) 321

Stein 236

Jospehina 160

Melchior 235

Steinfurt 262

Steinhoff (B.) 261

Steppé (Henri) 140

Stuber (Jan-Willem) 245
Stuckenborg (Joseph) 142, 168, 273

Sturm (Franz) 145

Taalgrenzen 90-91

Tack (Johannes) 50, 293

Tak van Poortvliet 72

Taphorn

August 273

Gerhard 273

Tenhalff

Wilhelmina 111

Johanna 111

Tepe (Alfred) 157, 158

Tessaro (Bartholomeus) 322

Texas Verein 223

Thiessing (Ferdinand) 119, 275

Tiets \& Wertheim 272

Thompson (Mary-Ann) 178

Thorbecke (J.R.) 55, 305

Thueré 142, 168

Thuine 263

Tombrock 273

Trip (handelsfirma) 141, 220

Trip (Hendrik) 220

Turnsperre 173

Tuijl van Serooskerken

(van) 302

Umbgrove (G.) 60

Umland (Jacob) 162, 169

U MzV (Koninklijke Utrechtse

Mannenzang-

vereeniging) 169

Union Ganymèd 201

Unitas 55

Vechta 262

Veerkamp 263, 265

Catharina 265, 266

Ferdinand 266

Johan 265, 266

Joseph 271

Mathias 168, 266

Victor 265

Veldhuizen (Jannigje) 297 


\begin{tabular}{|c|c|c|}
\hline Veltmann (Johann) 168 & Wardenburg 296 & Wirscheid 222, 246 \\
\hline Venning (Henriette) 177 & Watrin (Pierre) 315 & Wirth \\
\hline Verband deutscher Vereine in & Watson (G.H.) 289 & Catharina 246 \\
\hline den Niederlanden $\quad 180$ & Weber & L. 179 \\
\hline Verblijfsregister 72 & Elisabeth 320 & Wit (Johanna de) 326 \\
\hline Verein deutscher und ungarische & François 320 & Withof 274 \\
\hline studenten 172 & Peter 320 & Witte (Christiaan Gottlieb \\
\hline Vernède (H.J.) 168 & Wedel (Carl graaf Von) 170 & Friedrich) $119,120,142,149$, \\
\hline Veth (P.J.) 58 & Weevers (Dina) 301 & $169,210-212$ \\
\hline Vick Brandes (Emma) 307 & Wegner \& Mottu 205 & Wittgert 222,247 \\
\hline Visser \& Smits 209 & Wehrij (Johan) 273 & Wolf 236 \\
\hline Vlear \& Kol 272 & Weiffenbach & Geertrude 246 \\
\hline Vliet (K. van) 244 & W. 305 & Wolff \\
\hline Vlijt (de) $\quad 272,285$ & F. 305 & Joseph 116 \\
\hline Voerde 290 & Welters & Wolfe (Neena Mary) 19 \\
\hline Vohl (Carl) $\quad 118$ & Geertruida 132 & Wonck 314 \\
\hline Vooys (A.C. de) 94, 202 & Johanna 132 & Wormer (Herman) 103 \\
\hline Voswinkel Dorselen & Karel 132 & Wright (Robert) 304 \\
\hline (Peter) 141 & Marianne 132,133 & Wurlitzer (Johanna) 144 \\
\hline Vreede (G.W.) 65 & Werbner (P.) 215 & Wustenberg \\
\hline Vreede (IJsbrand de) 241 & Wesseling 116 & Agnes 177 \\
\hline Vreemdelingenregister $\quad 74-75$ & Westerwald $219-258$ & Friedrich $168,169,176$ \\
\hline $\begin{array}{l}\text { Vreemdelingenwet (1849) } 25 \text { - } \\
\quad 26,51-55\end{array}$ & $\begin{array}{l}\text { Westfeld } 255 \\
\text { Whiteley (William) } 283\end{array}$ & Frederick 177 \\
\hline Vroom (Willem) 273 & Wichmann (Carl Ernst & Xhaflaiere (Maria) 118 \\
\hline Vroom \& Dreesmann & Arthur) 307 & \\
\hline$(\mathrm{V} \& \mathrm{D}) \quad 12,259,260,262,268$ & Wickop (Ludwig) 179 & Yrondy \\
\hline Vugt (Frans) 238 & Wierdels (F.) 308 & Emile 318 \\
\hline & Wiesman (Christiaan) 241 & Justine 320 \\
\hline Wälter 236 & Wijken van Utrecht $\quad 93-95$ & Louis 318,320 \\
\hline Wagner & Wille 259,260 & Michael 318 \\
\hline Catharina Maria 113 & Anna 278,279 & Odon 318,320 \\
\hline Christiaan 118 & Friederich 279 & Pierre 318 \\
\hline Christina 29 & Heinrich 279 & \\
\hline Johann 118, 119 & Willem I 223 & Zaun (Joan Hendrik) 233 \\
\hline Waldinger (Richard) 18, 21, & Willem II 55 & Zillertal 324 \\
\hline 203 & Wilson (Hendrik) 103 & Zon (de) $\quad 285$ \\
\hline Waldorf (Joseph) 132 & Wilting (Bernardina) $\quad 116$ & Zürbach 222 \\
\hline Wanderbuch 29 & Wimpissenger (Karl) 323 & Zwart (Frederik) 246 \\
\hline Wanderlager 324 & Wingerden (Johan) 246 & \\
\hline Wanting (Hugo) 301 & Winterbedeelden 22 & \\
\hline
\end{tabular}

